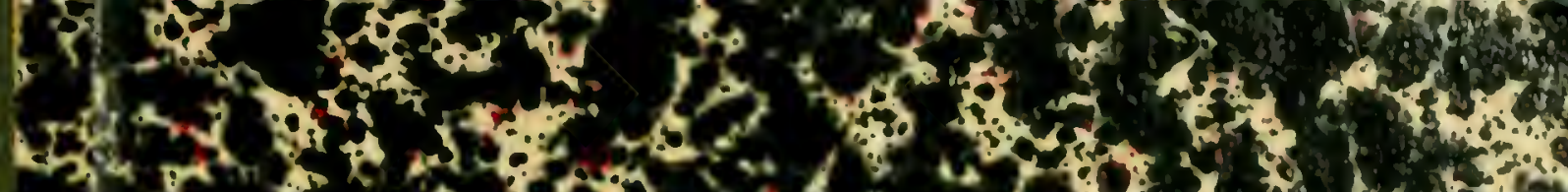

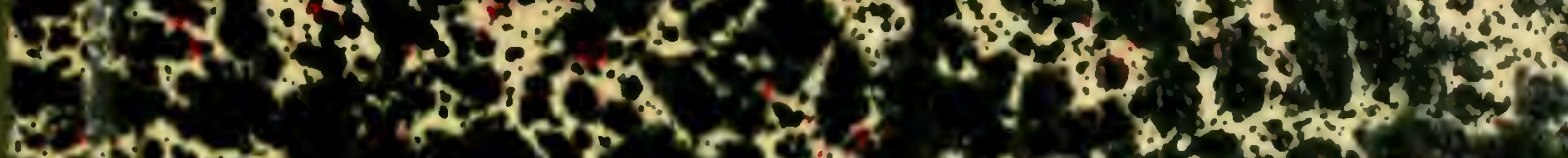
cat

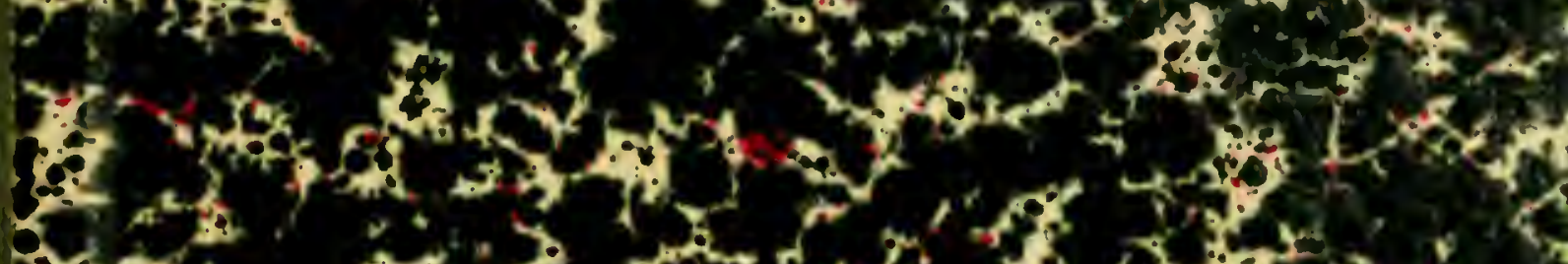

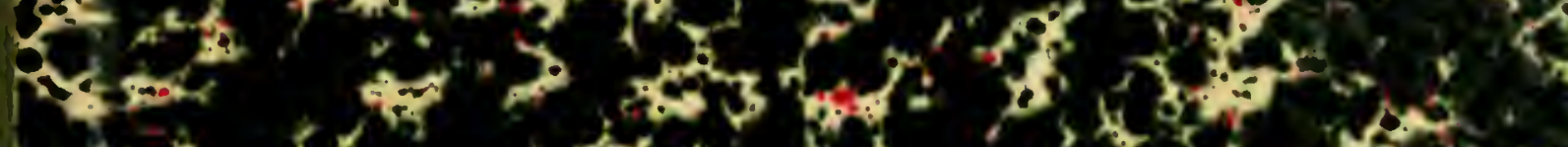

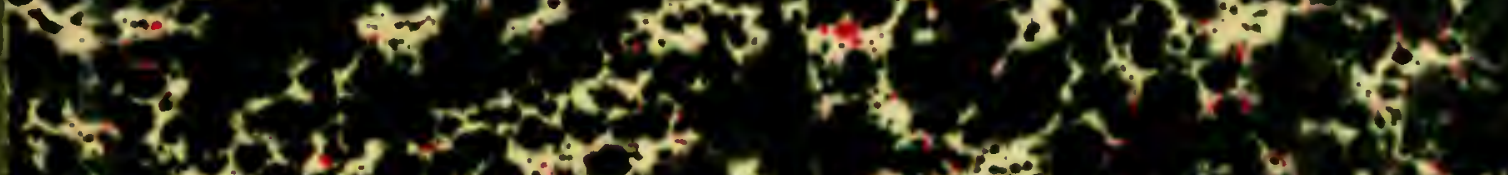

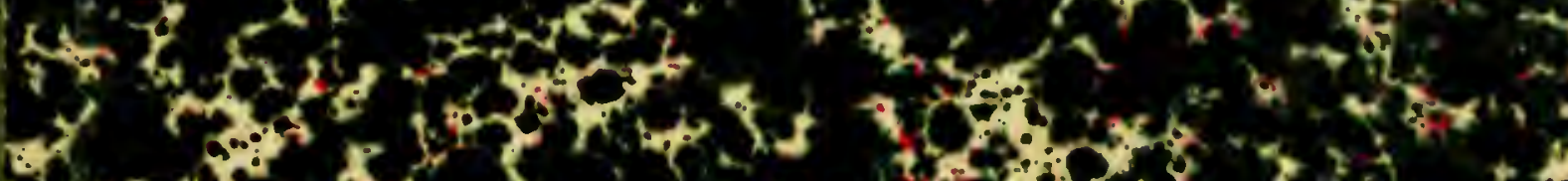

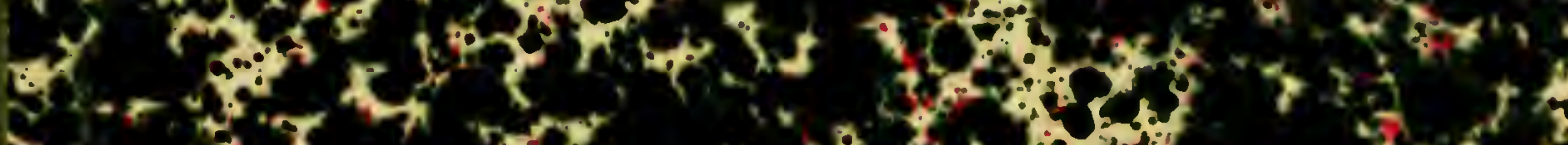
(a)

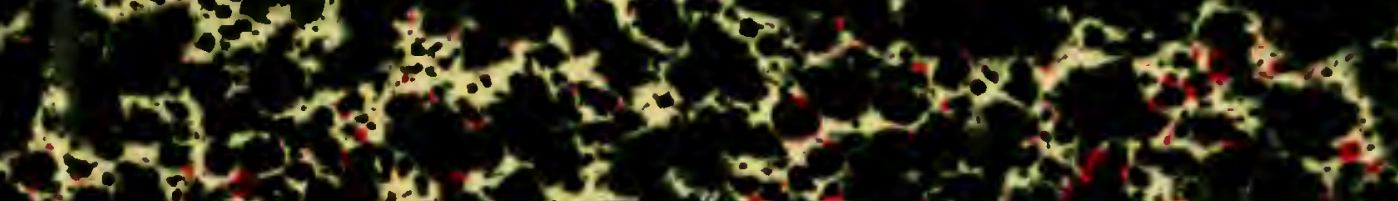

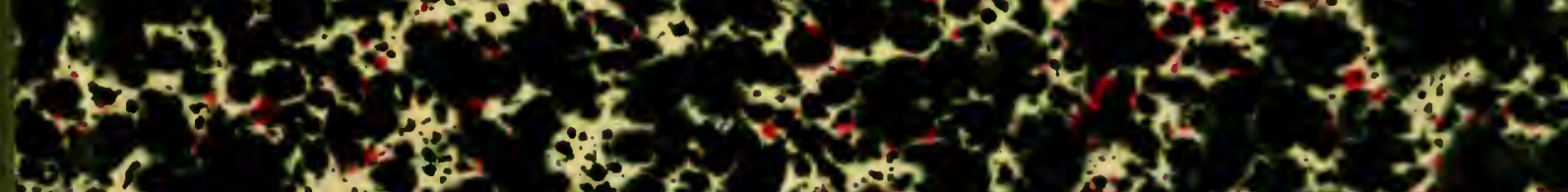

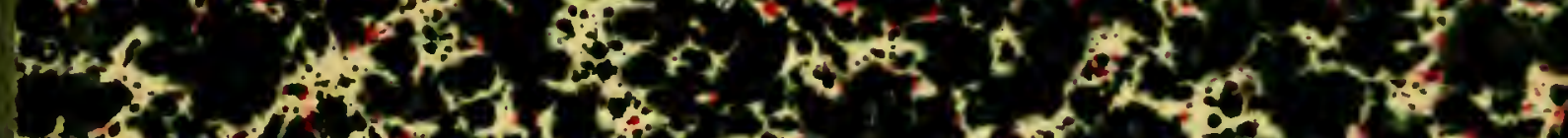

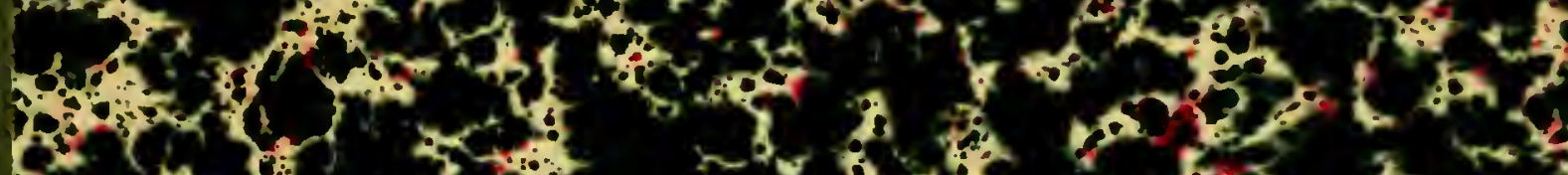
- An r 3 , d

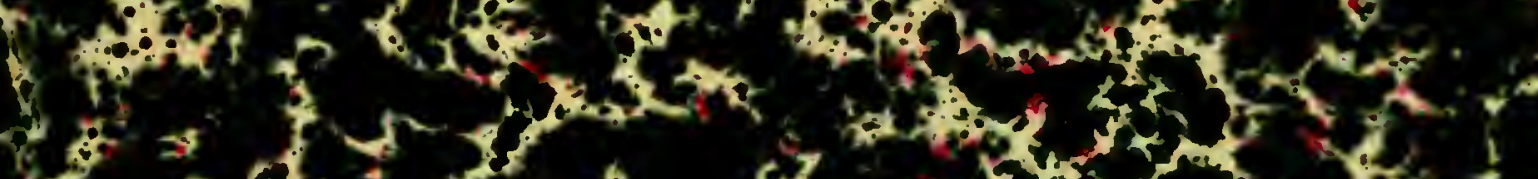

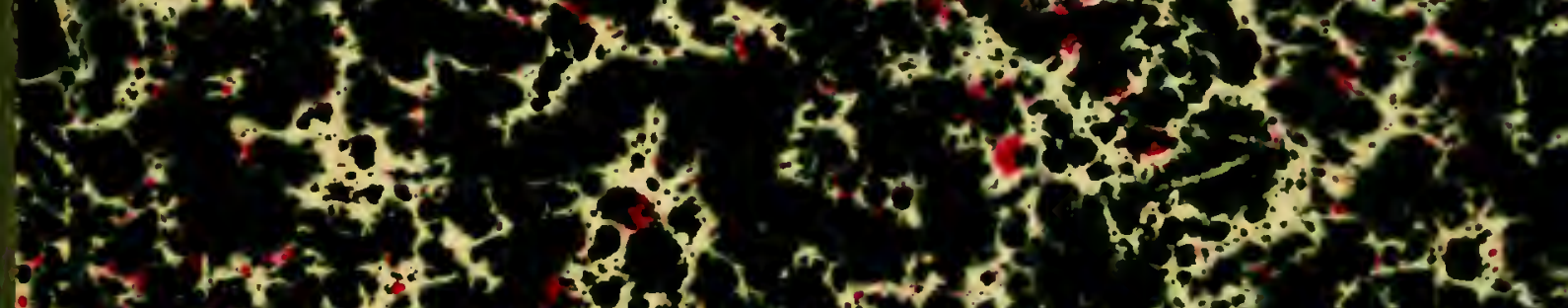

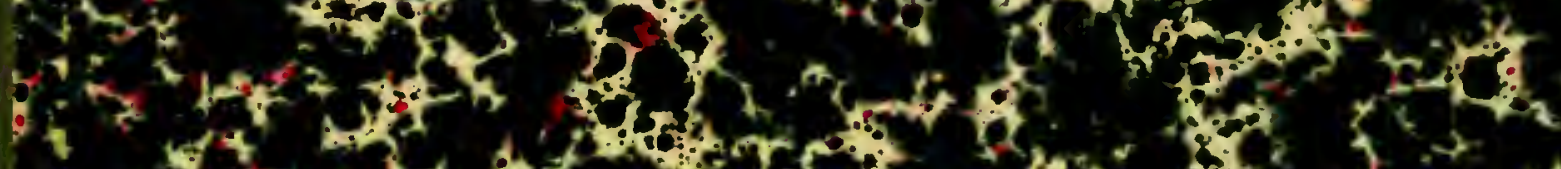

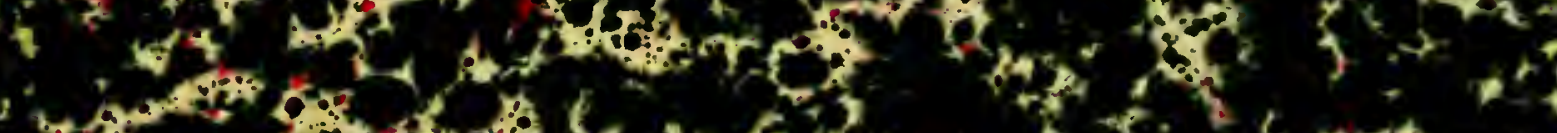
4 (3) $\therefore$ row

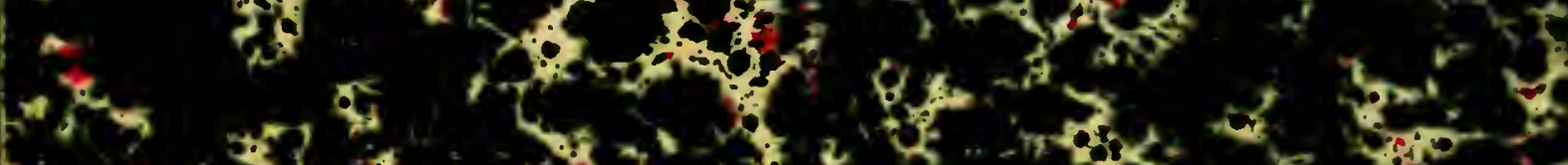
(n)

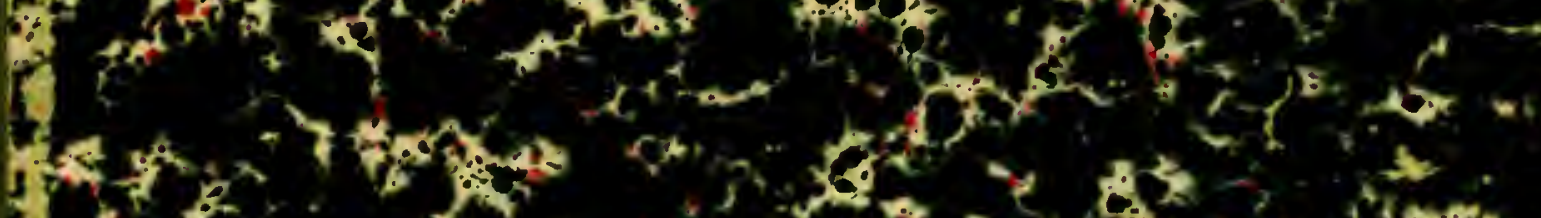
1) 1 क

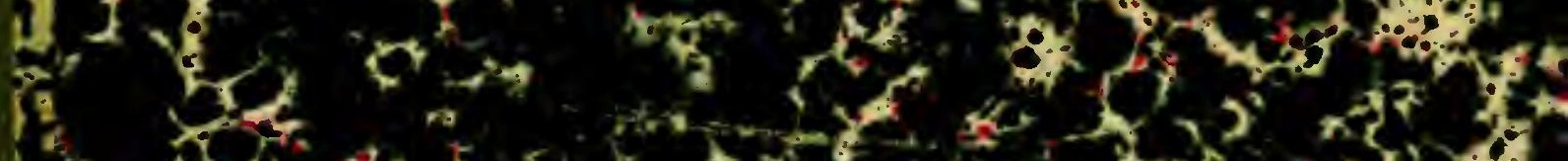

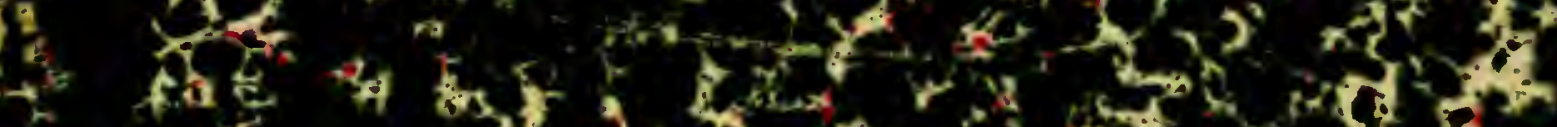

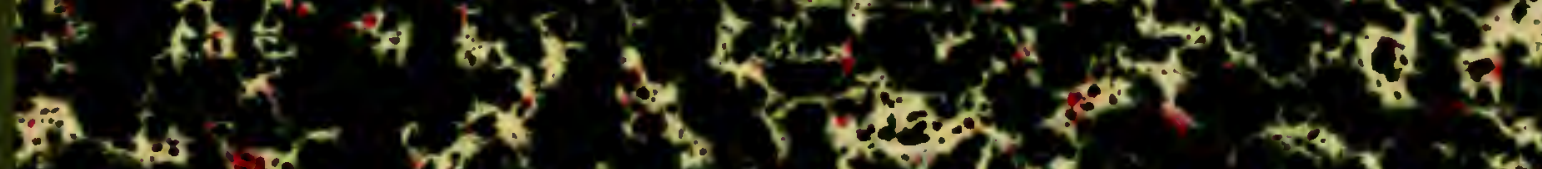

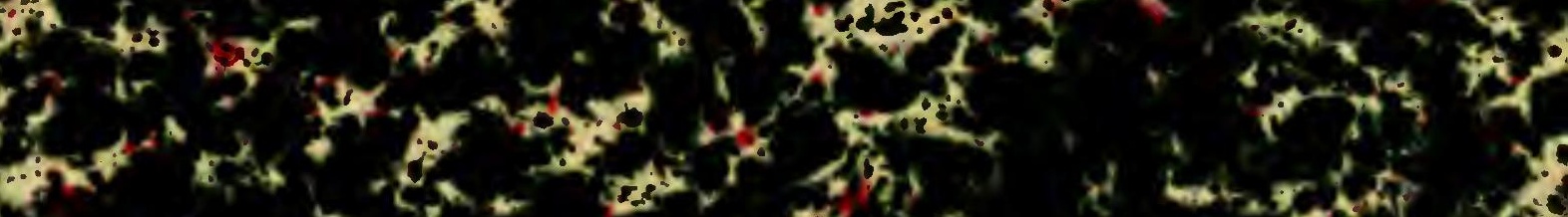

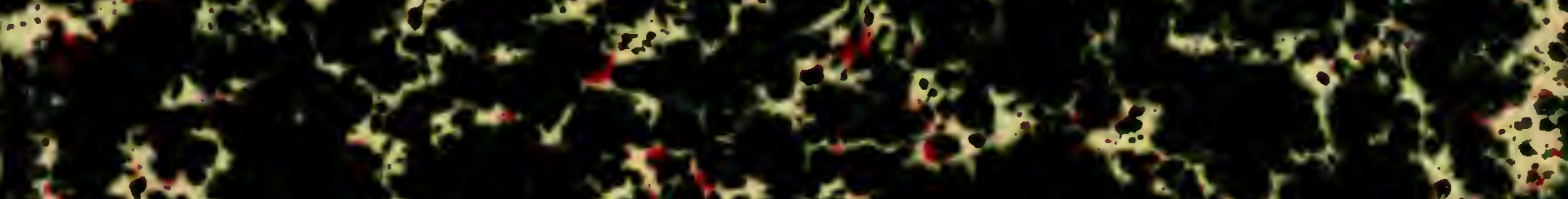

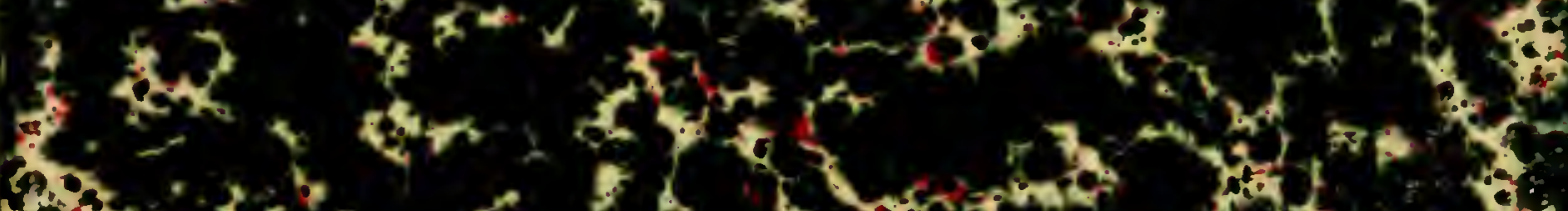

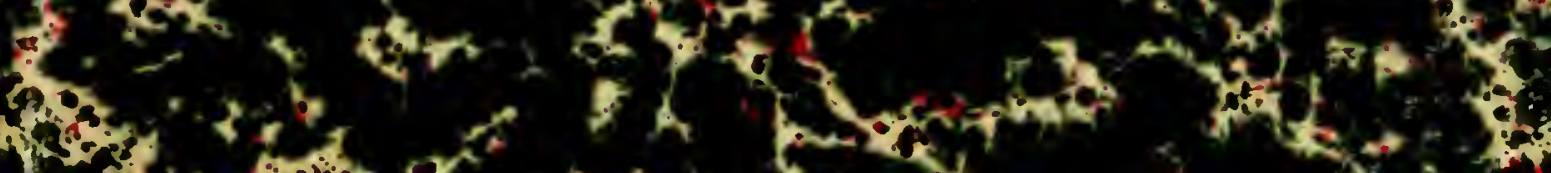





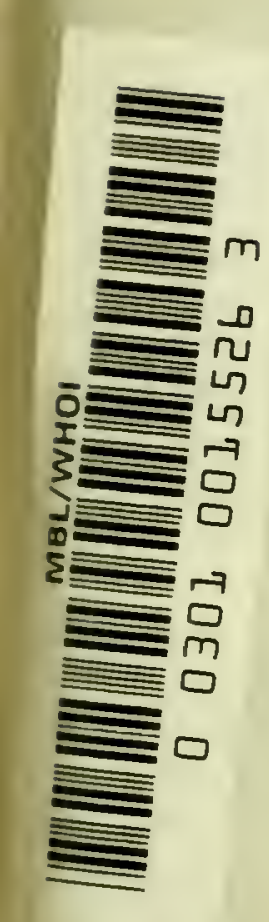






\section{НАУЧНЫЕ РЕЗУЛЬТАТЫ ОООлОГИЧЕСКОЙ ӘГСПЕДИЦІИ проф. В. А. Догепя и И. И. Сокопова}

въ Брнтансную Восточную Афрнну и Уганду въ 1914 году.

\section{Tomb 1.}

\section{SCIENTIFIC RESULTS}

OF THE

\section{ZOOLOGICAL EXPEDITION}

to British East Africa and Uganda

made by

prof. V. Dogiel and I. Sokolow

in the year 1914.

Volume I. 



\section{НАУЧНЫЕ РЕЗУЛЬТАТЫ 300ЛОГИЧЕСКОЙ วКСПЕДИЩИ}

проф. В. А. Догепя и И. И. Сокопова

въ Брнтансную Восточную Афрнку н Уганду въ 1914 году.

\section{ToMb 1.}

\section{SCIENTIFIC RESULTS}

OF THE:

\section{ZOOLOGICAL EXPEDITION}

to British East Africa and Uganda

made by

prof. V. Dogiel and I. Sokolow

in the year 1914.

Volume I. 



\section{Содернаніе 1-го тома.}

i. 1. B. L

i. Dour iel and I. Sokolow. The romte and brief description of the trivel.

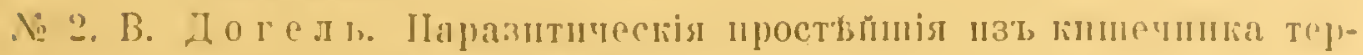
mutumz. I. Tetramitidae.

v. Douriel. On some parasitic l'jotozoa from the intestime of termites. I. Tetramitidae.

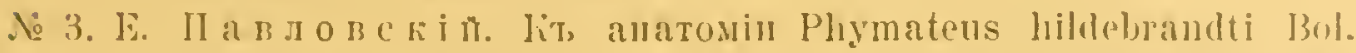

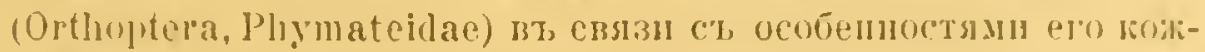
mon ceripenin.

E. Pa $w \mid$ owsk $\mathrm{w}$. On the anatomy of Phymateus hildebrandti bol. (Orthoptera, Phymateidae) in connection with the peculiarities: of its dermal secretion.

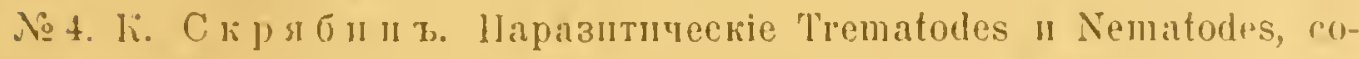
бұлниые эксиедицей проф. В. А. Догеля и II. II. Coronoma

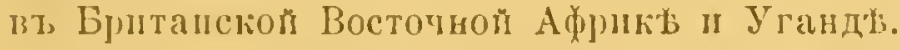

K. Scrjabin. Parasitic Trematodes and Nematodes collected hy the expedition of Plof. V. Dogiel and I. Sokolow in British East Africa.

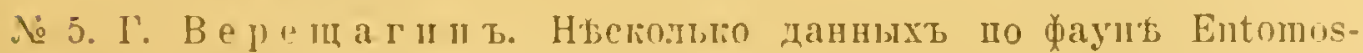
traca Центральной Африки.

G. IV erestcliagin. Some remarlis on the fauna of Entomostraca of centril Africa.

ํㅜ 6. Ф. Эггере ь. Новые и мало пзистные виды семеп̆етва

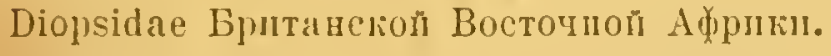

F. Eggers. On some new and incompletely known species of the family Diopsidae from British East Africa.

№ 7. Ф). Эггер с ъ. О строеніи стебельчатыхъ глазъ Diopsidae.

F. Eggers. On the structure of the stalked eyes of Diopsiclae.

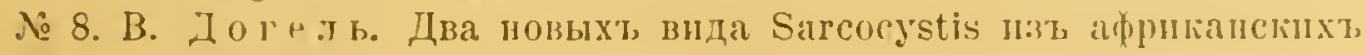
a

V. Dog iel. Two new species of Sareocystis from African Antelopes.

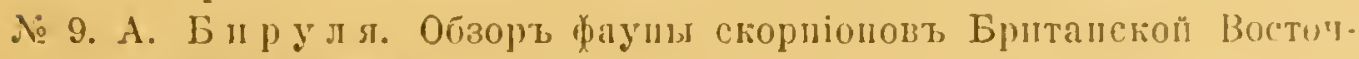
ноп A фрurки.

A. Birula. A general list of the Scorpions of British East Africa. 


\section{Отъ издателей.}

Настоящая книга представляетъ собою I-й томъ начатаго нами изданія. Все изданіе должно, по приблизительному подсчету, состоять изъ трехъ томовъ, объемомъ отъ 400-500 страницъ каждый. Второй и третій тома предполагается выпускать посльдовательно черезъ годичный промежутокъ времени. Каждый томъ будетъ содержать, въ зависимости отъ поступающаго изъ рукъ спеціалистовъ обработаннаго матеріала, 10-15 работъ, которыя будутъ печататься не въ какомъ либо систематическомъ порядкь; а въ порядкь поступленія ихъ въ редакцію.

Выпуская въ свьтъ I-й томъ „Научныхъ результатовъ" нашей пођздки, мы считаемъ пріятнымъ долгомъ выразить нашу искреннюю благодарность всђмъ ученымъ спеціалистамъ, любезно согласившимся взять на себя обработку доставленныхъ экспедиціей коллекцій, а также Физико-Математическому Факультету Императорскаго Петроградскаго Университета, оказавшему намъ нькоторую матеріальную поддержку ассигновкой на печатаніе настоящей книги 500 рублей. 


$$
\begin{aligned}
& \text { № } 1 \text {. } \\
& \text { B. ДOГEПЬИ Н. COKOПOB В. }
\end{aligned}
$$

\section{OПИСАHIE ПУTEШECTB।Я,}

$$
\text { V. DOGIEL and I. SOKOLOW. }
$$

The route and brief description of the travel,

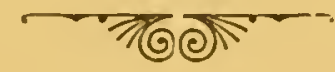





\title{
Описаніе путепествія.
}

\author{
Составлено В. А. Догелемъ и И. И. Соноловымъ. *).
}

\section{1. Путь до Момбасы. Момбаса.}

Путешествіе в"ъ Британскую Восточную Африку, результаты Котораго составляютъ предметъ настоящей книги, было выполнено нами въь 1914 г. и заняло около 6 мвсяцев’ь (съ 23 марта по 17 сентября ст. стиля). Изъ нихъ 2 мисяца ушло на дорогу, остальное же время было посвяцено научнымъ изсльдсваніямъ. Главною цвлью поћздки были наблюденія и собираніе матеріаловъ по анатоміи и эмбріологіи низшихъ, безпозвоночныхъ животныхъ. Коллектированіе позвоночныхъ и фаунистическія изсльдованія были поставлены нами на второй планъ, такъ какъ, при сравнительно скромныхъ средствахъ, имъвшихся въ нашемъ распоряженіи, мы не надъялись достигнуть въ данномъ направленіи хороших'ь результатовъ. Кромь того, нами руководило при этомъ и то соображеніе, что большинство экспедицій посвящается исключительно фаунистическимъ изсльдованіямъ, оставляя въ сторонъ добываніе анатомическаго и эмбріологическаго матеріала. Несмотря на такую тенденцію, сборы наши, какъ можно видъть изъ содержанія даннаго тома, дали матеріалъ и для ряда фаунистическихъ работъ.

Самой пожздкъ предшествовали довольно долгія подготовленія. Прежде всего необходимо было заручиться содъйствіемъ мбстныхъ властей, для чего рекомендуется обратиться заранъе въ Мини-

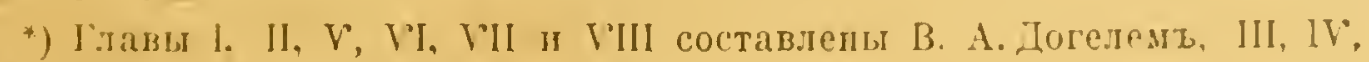
ІХ и $\mathrm{X}$ - Н. Н. Сиколовымъ. 
стерство Иностранныхъ Дълъ; посльднее сносится съ англійскимъ министерствомъ колоній, которое и поснлаетъ на мћсто извщеніе о вашемь предполагаемомь пріъздь, вамь же самимь присылаеть пропускной листь, который облегчаеть первые шаги путешественника по прибытіи в’b колонію. Как'ь этот’ы пропускной листъ. такъ и имғвндіяя у насъ рекомендаціи к'b нвкоторымъ частнымъ лицамъ, оказались крайне полезными.

Далье, билеть на пароходъ для перевзда въ главный портъ Британской Восточной Африки-Момбасу, тоже слғдуеть доставать заблаговременно. Имъется цълый рядъ пароходныхъ линій, которыми можно воспользоваться. Таковы: Union Castle Line, British Jndia Mail, Messageries Maritimes $n$ Deutsche Ost-Afrika Linie.

Мы избрали пароходъ нбмецкой компаніи, всльдствіе меньшей дороговизны пробзда на немъ.

Снаряженіе, необходимое для научной экспедиціи въ тропики, довольно громоздко. Кромъ обыкновенныхъ личныхъ вещей нужно еще имћть: приспособленія для лагерной жизни, оружіе и все, что требуется для изсльдованія и собиранія научнаго матеріала.

Къ первой рубрикъ относятся: тропическое платье и бълье, обувь, кровати и палатка. Большинство этихъ вешей мы пріобр‡ли въ Берлинъ, въ огромномъ магазинь Dingeldey und Werres. Однако, повидимому, закупки лучше производить въ Марсели, гдъ имъется много магазиновъ, снабжающихъ тропическія экспедиціи всъмъ необходимымъ. Такъ, можно. напримєръ, указать на фирму Rieffel, значительно болье дешевую, чъмъ берлинская. Относительно тропической экипировки можно узнать полезныя свђдънія у Dugmore (см. въ кониь указательлитер.).

По личному опыту мы можемъ посовътовать сльдующее. При поъздкъ на нъсколько мъсяцевъ можно удовлетвориться изъ платья тремя-четьрьмя полотняными бюлм. костюмами и бълымъ тропическимъ шлемомъ для парохода и пребыванія въ городахъ; кромь того, для повседневної носки во время экследиціи сльдуетъ имъть двђ смғны костюмовъ защитнаго цвъта. Изъ обуви для парохода лучше всего взять бълыя туфли, въ экспедиціи же 


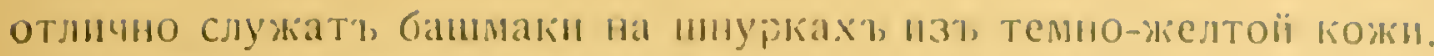

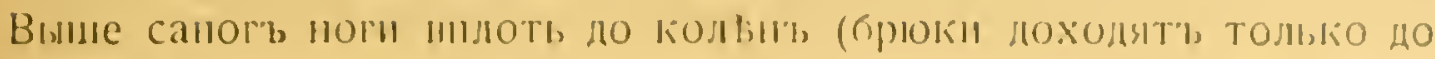

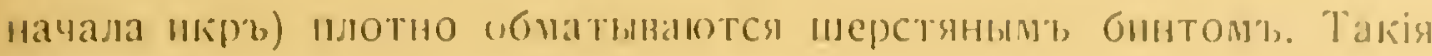

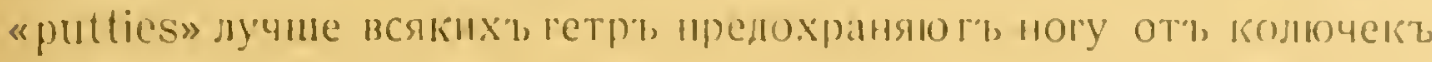

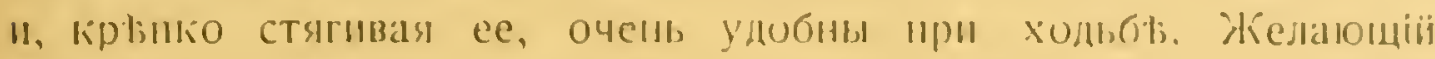

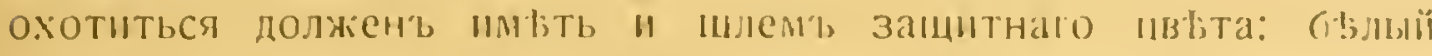

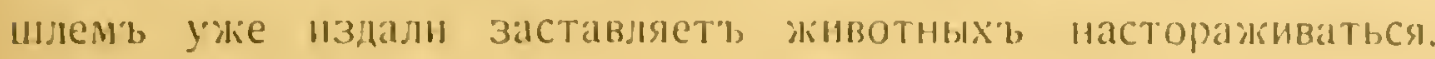
Обыкновеннос европеїское бвлье вполны притодн " для

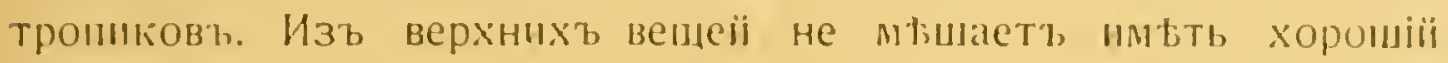
дождевикт.

Къ лагерному снаряженію относятся палатка и постельныя принадлежности. Палатку сльдуетъ покунать непремььнно тропическую, двоіную. ибо черезъ простую слишкомю легко проникаетъ солнце. Кромь⿱⺊口 того, подъ верхнюю покрынку. по бокамъ палатки. ставятся различ!ыя вещи для защиты ихъ отъ дождя. На двошхъ цостаточно взять палатку въ 4 кв. метра при основаніи (150 р. у Дингельцея). Постельный наборъ состоитъ изъ складной кровати, матраца и москитной сыти къ ней, табуретки. складного стола и складного умывальника; стонмость всего набора равна 60 рублямъ (у Дингельдея). Бълье и другія личныя вещи лучше всего запаковывать частью въ непромокаемые брезентовые мвшки, частью въ металлическіе чемоданы (15 р.) не пропускающіе сырости.

Если приходнтся работать въ мьстностяхъ, лежащихъ высоко надъ уровнемъ моря, гды по ночамъ бываеть весьма прохладно, то хорошую услугу можетъ оказать спальный мъшокъ изъ верблюжьиі шерсти (надо изготовить самому). Что касается разныхъ мелкихъ вешеіі, фонарей, лампъ, свъчей, мыла и пр. и пр. подробный перечень которыхъ можно найти у того же Dugm ol eто ихъ можно купить на мвсть.

Изъ оружія у насъ было, кромғ револьверовา. одно дробовое ружье и винтовка Маузера (9,3 mm). Винтовку сльдуеть имьть всякому, намьревающемуся жить караванной жизнью, въ глуши. Можно порекомендовать крупный калибръ, который одинаково пригоденъ "для антилопъ "для болъе крупной дичи и хищни- 
ковъ, а также для толстокожихъ (носорогъ, слонъ, бегемотъ).

Из'ь научнаго снаряженія у насъ быль дорожный микроскопъ Цейсса, шштативная лупа, мелкіе инструменты, довольно большой наборъ стекла и главнъйшія фиксирующія жидкости (въ томъ числьв сулема, пикриново-азотная, смбсь Флемминга, смъсь Германна, жидкость Джильсона и др.). Спиртовой матеріалъ укладывался въ шведскія банки, а болъе крупныя вещи въ объемистый оцинкованный жбанъ изъ подъ молока. Взято было и нбсколько ящиковъ съ ватой для насъвкомыхъ, банки съ ціанистымъ кали. хлороформъ, сачки (водяной, для кошенія и обыкновенный), мьшокъ съ ситомъ для просъиванія листьевъ и т. д. и Т. Д.

Наконецъ, отправляясь въ тропики, необходимо имьть при себъ небольшую аптечку. Она понадобится не голько для себя, но и для туземцевъ. Не только носильщики вашего каравана, но и жители сосъднихъ деревень будутъ обращагься къ всемогущему бълому за медицинской помощью. При составленіи годобной аптеки можно руководствоваться указаніями хотя бы книжки д-ра Пленъ (Plehn. Tropenhygiene) или Кольштока (Kohlstock's Ratgeber für dje Tropen).

Повторяемъ, что большинство перечисленныхъ приготовленій удобнье всего (въ избъжаніе лишнихъ расходовъ) дълать въ томъ портовомъ городъ, гдъ вы садитесь на пароходъ.

А садиться можно или уже въ Гамбургъ, но тогда приходится тратить циллыхъ 12 дней на огибаніе Франціи и Испаніи, или же, лучше всего, въ Марсели, какъ мы и сдьлали.

Въ виду того, что провздъ на пароходъ стоитъ, за такой большой путь, очень дорого, предпочтительнье брать обратные билеты Марсель-Момбаса-Марсель, которые годны въ теченіе года и обходятся на 25\% дешевле билетовъ, взятыхъ в’ь одинъ конецъ. Пароходы французскихъ, англійскихъ и нъмецкихъ линій устроены столь комфортабельно, что можно свободно ьхать и во Il классь (билетъ отъ Марсели до Момбасы и обратно стоитъ около 500 р.).

Тридцать перваго марта 1914 г. мы покинули Марсель и посль 


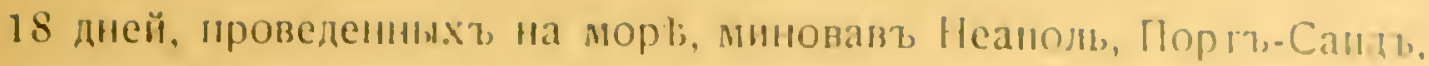

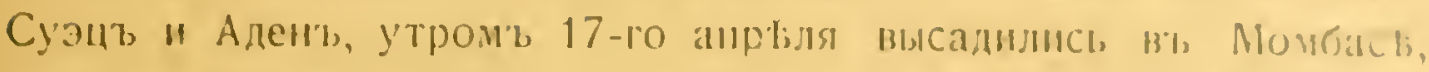
главном' приморскомъ городь, Бритаиской Восточной Африки. Момбаса расположена на неболинои островт, тысно прижавиемся к's материку, так' что между ишмь " континетомь имвется только узкіі проливь. Пароходъ остананлизается въ порту r. Момбасы, которыї называется Килиндини. Тогчасъ же по ирибытіи, путешественнику приходится долго возиться с"b пропускомъ его багажа черезъ таможню. Таможенныі осмотръ ввозимыхъ въ Брит. Вост. Африку вещей довольно строгъ. Все, за исключеніемъ платья и небольшого количества багажа (включая бывшіе въ употребленіи бинокли и фотографическіс аппараты), подлежнтъ тяжелой пошлинъ-въ 10\% стоимости иредмета. Особенное вниманіе обрацается на оружіе. Такъ. напримъръ, намъ за два ружья и два револьвера пришлось заплатить болґе 30 рупії (рупія $=100$ центамь $=6.5$ кон.), т. е. около 20 рублей.

Іроцедура съ осмотромъ вещей заняла у насъ по пріъздт столько времени, что мы остались переночевать въ Момбасъ с’ь твиъ, чтобы на сльдующій день отправиться по Угандской ж. д. вглубь страны, въ столицу края, городъ Найроби, гдъ намиревались выработать весь, дальнбйшій планъ путешествія.

Самый городъ Момбаса лежитъ верстахъ въ двухъ от'ь порта, на противоположной сторонъ острова. Средствомъ передвнженія служатъ или рикши, т. е. маленькія двуколки, или же ,gharr.", маленькія крытыя тентомъ вагонетки, ґздящія по рельсамъ, проложеннымъ по главнымь улицамъ города; "ты и другія, вмтісто лошадей, тащатъ два-три дюжихъ негра.

Городь дблится на очень чистую, усаженную цвьтущими деревьями европейскую часть "нбсколько туземныхъ кварталовъ Въ центрғ города, у морского берега возвышается сьрая громада стариннаго заика, принадлежавиаго нбюогда португальцамъ, ирежнимъ владћльцамъ острова. Португальцы завладғли сстровомь въ XVI в., а въь концв XVIII в. онъ быль завоевань арабами, отъ которыхъ въ свою очередь перешелъ къ англичанамъ (въ $80-х ъ$ годахъ XIX в.). 
Туземные кварталы Момбасы, арабско-индійскій "негритянскій, пестрятъ краскапи и открывають передь глазами путешественника цъдлый калейдоскопъ различныхъ народностей. Прежде всего здъсь можно встрбтить многочисленныхъ индусовъ, впервые перевезенныхъ въ Вост. Африку англичанами въ качествъ рабочихъ для постройки Угандской ж. д. ГІришельцы быстро акклиматизировались въ чуждой обстановк' $и$ теперь въ Брит. Вост. Африкъ насчитывается нбсколько десятковъ тысячъ индусовъ, захвативщихъ въ свои руки всю мелкую торговлю, а также занимающихъ должности мелкихь чиновников'ь, телеграфистовъ, клерковъ и т. д.

Что касается другого элемента туземнаго города-арабовъ, то число ихъ сравнительно невелико и постоянно убываетъь. Вскорғ посль того, какъ англичане завладъли Восточной Африкой и положили конецъ торгу невольниками, который быль главнымъ источникомъ благосостоянія арабовъ, посльдніе начали покидать страну. Въ сравнительно значительномъ количествє арабы сохранились только въ прибрежной полосъ⿱ и на нб̆которыхъ островахъ.

Большой участокь туземнаго города занятъ черными, обмазанные глиной домики которыхъ разбросаны красивыми группами среди рощъ манговыхъ деревьевъ и кокосовыхъ пальмъ. Только что указанныя растенія, вмъстъ съ исполинскими, узловатыми, сърыми баобабами составляютъ наиболъе характерную черту прибрежной флоры.

Большинство обитателей чернаго квартала принадлежитъ къ племени Ва-Суагели. Суагели--жители береговой полосы. Это одно изъ наиболье предпріимчивыхъ и интеллигентныхъ негритянскихъ племенъ, быть можетъ оттого, что въ жилахъ Суагели течетъ и немного арабской крови. Отъ арабовъ они заимствовали магометанскую религію, рядъ различныхъ обычаевъ, да и языкъ суагели пестрить довольно многочисленными арабскими словами. Подобно египетскимъ арабамъ и феллахамъ, въ качествъ главной одежды мужчины Суагели носятъ длинную, почти до пятъ, бълую или рыжую рубаху, а бритую по магометанскому обычаю голову прикрывають феской. Женщины, въ противоположность большин- 


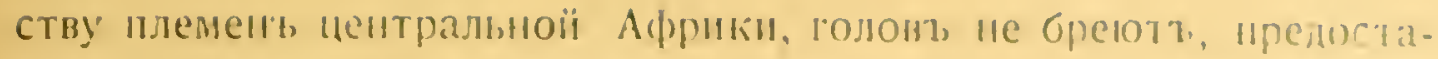

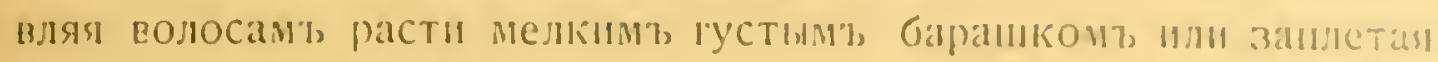

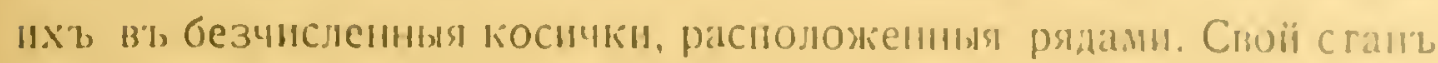

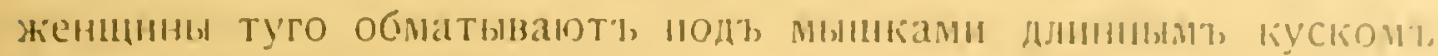
матеріи, ниспадаюшимъ до ном. Плечи и иея остиются открытыми, или же задранировываются цругнмъ кускомь матерін, вю роды платка.

Главная жизнь туземиаго города сосредоточивается вокругы базара, гдњ путешественникъ можеть наблюдать, много любопытныхъ сценъ и ирисмотржться Къ важн ъишимъ иродуктамъ страны.

Nомбаса насчитываеть около 20.000 жителей, изъ которыхъ всего насколько сотъ европейцевъ.

Осмотрбвъ городъ и проспавъ ночь впервые подъ кисейнымь пологомъ, защищающимь спящаго отъ москитовъ, мы на сльдующій день утромъ должны были вығхать изъ Момбасы по Угандской жельзной дорогь.

\section{!I. Угандская жепьзная дорога.}

Эта дорога соединяетъ берегъ моря съ восточної оконечностью озера Викторія-Ніанца и, такимъ образомъ, позволяетъ европейскимъ товарамъ сравнительно легко проникать въ самое сердче Африки. О примьрной интенсивности работы данної линіи могутъ дать представленіе сльлующія цифры, взятыя изъ sThe Leader Annual of British East Africa». Вэ, 1911 г. дорогою было перевезено 400.000 пассажировъ и 41.2 милліона пудовъ груза: въ 1912 году зарегистрировано уже 440.000 пассажировъ " 7 милліоновъ пудовъ цруза. Такиял образомъ, дъятельность дороги, особенно въ смыслғ провоза грузовъ, Значительно усиливается съ каждымъ годомъ. До посльдняго времени Угандская жел. дорога служила и для импорта товаровъ въ сыверную часть Нъмешкой Восточної Аџрнки, пока нұлцы не выстроили другой, параллельноиі еіи лини, отъ царессалама къ озеру Танганаикв (открытіе этой лніи дижно было состоятыся лытомь 1914 года). 
Длина Угандской жельзной дороги равна приблизительно

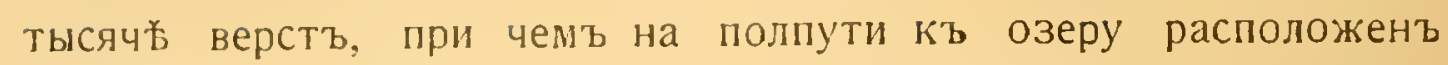
главный городъ Брит. Вост. Африки-Найроби. Въ немъ мы предполагали остановиться на нбсколько дней и установить свой окончательный маршрутъ.

За часъ до отхода поғзда мы были на вокзаль, скромномъ одноэтажномъ зданіи, построенномъ, какъ и многіе дома в'ь, Момбасђ, изъ коралловаго известняка. Поъздъ въ Найроби, идущій разъ въ сутки, былъ уже поданъ. Онъ состоялъ всего изъ 8-9 небольшихъ вагоновъ 1-го, II-го, промежуточнаго и III-го классовъ. Въ первый классъ допускаются только европейцы, во второмъ къ нимъ примбшиваются и зажиточные индусы, хотя всегда есть отдбленіе, предназначенное « for Europeans only». Промежуточный классъ служитъ, главнымъ образомъ, для мелкихъ чиновниковъ- «бабу», т. е. индусовъ, тогда какъ вагоны третьяго класса вплотную набиваются чернокожими. Бхать въ третьемъ и промежуточномъ классь⿱㇒㠯 для европейца считается неприличнымъ и, прямо таки, невозможнымъ. Это-прочно установленная традиція, которая строго поддерживается англичанами, повсюду стремящимися подчеркнуть господствующій характеръ бълой расы. Подобныя мъры сльдуетъ признать въ данномъ случағ весьма разумными, ибо онъ, пріучая туземцевъ изъ покольнія въ покольніе смотръть на бълыхъ, какъ на существа высшаго порядка, позволяютъ ничтожной горсти европейцевъ чувствовать себя среди окружающаго ихъ моря черныхъ въ полной безопасности.

Каждый вагонъ I-го и II-го класса подйленъ перегородкой на два купэ. Купэ перваго класса очень просторны, съ двумя длинными диванами по сторонамъ и большимъ столом'ъ посрединь; дв秀 другихъ постели пристегнуты къ потолку и могутъ спускаться на ночь. По сторонамъ вагона-широкія окна съ маленькими простьнками. Верхняя треть оконъ затьнена особымъ деревяннымъ нав зсомъ, находящимся снаружи вагона,--очень удобное для тропиковъ приспособленіе, не позволяющее солнцу въ самые жаркіе часы дня проникать внутрь вагона. 


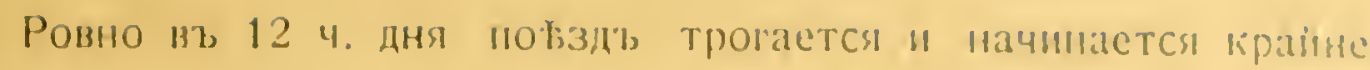

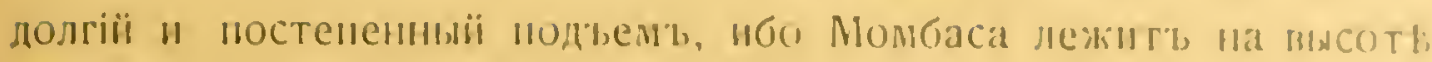

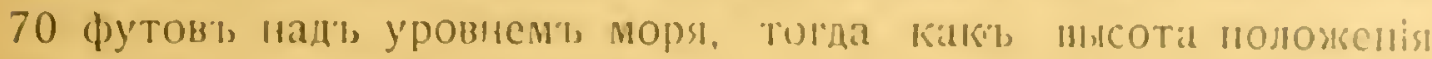
Найроси опредвльется уже шестьо тысячами футовъ. Сначала дорога пцет', черезъ банановыя "кокосовыя илантацін, или

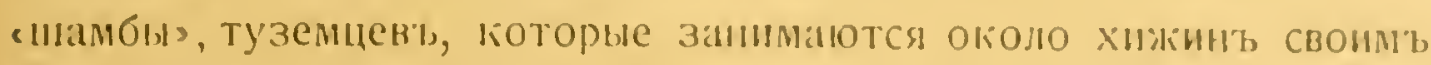
несложным хозяінстомь. Въ тронической, богатой растительностью береговой польь населеніе довольно густо и пондъ останавливается черезъ каждые полчаса.

По мырб удаленія отъ берега, мъстность приниметъ болье пустынный характеръ. Пышная растительность влажной прибрежной зоны уступаеть мбсто акаціямъ и зарослямь колючихъ кустарниковъ сухого плоскогорья, на которое мы постепенно поднимаемся. Главная часть подъема совершается ночью, такъ что раннимъ утромъ, часовъ въ пять, поъздъ мчится уже среди обширныхъ равнинъ вершнны илоскогорья. Равнины эти сначала сще довольно густо покрыты разсеянными по нимъ акаціями, а въ промежуткахъ между посльдними-кустарникомъ. Потомъ кустарникъ исчезаетъ, деревья рьдъють и, наконецъ, при приближеніи къ Найроби мъстность принимаетъ вид'ь совершенно гладкой травяной степи-это знаменитыя обиліемъ дичи равнины Aти (Athi Plains). Именно въ надеждғ повидать крупную дичь " рекомендуется пассажирамъ подняться на разсвєтє. Дєло въ томъ, что, начиная со станціи Цаво (на 133-ей миль отъ Момбасы) дорога проходитъ черезъ огромный заповъдный участокъ, въ которомъ абсолютно восирещается охота за какими бы то ни было животными. Этотъ заповъдникъ, обнимая собою 25.000 кв. верстъ, является превосходнымъ питомникомъ различной дичи, предохраняющимъ многіе ръдкіе виды животныхъ отъ окончательнаго истребленія. Кромє того, избытокъ дичи, накоппяющіїся въ заповъдникъ, можетъ переселяться въ сосъдніе округа, гды охота разрєшастся, и обновлять составъ тамошнеї фауны. Можно было бы думать, что англичане, оставляя такое количество земли лежать втуне, сильно поступаются своими выгодами; на самомъ дєль этого, однако, нътъ. Во-первыхъ, населеніе Брит. Вост. 
Африки пока еще черезчуръ мало для того, чтобы испытывать нужду въ землъ, да и земля, занятая заповъдникомъ, непригодна для обработки изъ за отсутствія орошенія. Во-вторыхъ, искусно рекламируемое богатство дичи является одной изъ главныхъ приманокъ для многочисленных'ь туристовъ и спортсмэновъ, которые приносятъ странғ очень большой доходъ своимъ пребываніемъ въ ней (свыше одного милліона рублей въ годъ).

Вирочемъ, вышеупомянутое рекламированіе является вполнь обоснованнымъ, такъ какъ изобиліе крупныхъ животныхъ, на которое путешественникъ наталкивается въ Брит. Вост. Африкъ, поразительно. Около шести часовъ сряду повздъ идетъ какъ бы черезъ непрерывный зоологическій паркъ. По сторонамъ отъ дороги, иногда въ 100-200 шагахъ отъ рельсъ, ласутся стада изящныхъ газелей, несуразныхъ, длинномордыхъ антилопъ конгони (Bubalis), пестрыхъь зебръ. Порой животныя продолжають спокойно щипать траву, порою же пугливо озираются въ сторону повзда и бросаются прочь большими прыжками. Этой обыкновенной дичи такъ много, что каждый холмъ, каждая ложбина пестритъ точками мирно пасущихся животныхъ, которыхъ можно принять за оставленный на выгонъ домашній скотъ. Конгони и зебры подходят' даже к'ь самымъ станціямъ жельзной дороги. Однако, расположившись поудобнье у зеркальнаго окна вагона, вы можете познакопиться во время пути и съ болье рбдкими представителями африканской фауны. Тамъ и сямъ, въ видъ темныхъ, почти черныхъ пятенъ виднъются группами гну (Connochaetes)—странныя антилопы, очень напоминающія собою по виду буйволовъ; изрғдка попадается и пряморогій ориксъ (Oryx), съ рогами острыми, какъ шпага. За время пробзда мы насчитали до пятидесяти страусовъ, черные съ бвлымъ самцы которыхъ очень эффектны и ничъмъ не походятъ на несчастные, обльзлые экземпляры, влачащіе жалкое существованіе въ зоологическихъ садахъ Европы. Наконецъ, раннимъ утромъ мы видъли у самой дороги трехъ громадныхъ жираффъ, быстро удалившихся своимъ неуклюжимъ галопомъ. Изъ хищников'ъ мы видъли на этотъ разъ только шиакаловъ, но бывали случаи, когда новичку, 


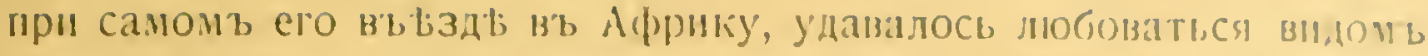

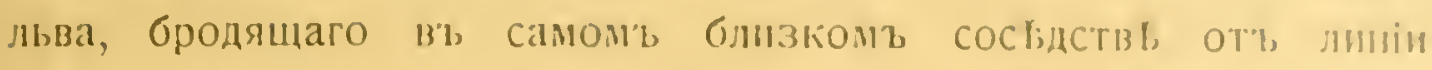
жельзиой дороги. Однимт, слономт, огисываемая но зздка пронзиодить удивитениое висчатльніе.

Можно безъ преувеличенія сказать, что восточная Adpрнка вา, настоящее время является сдинственної страной, гль, крупный звьрь водится еще въ такомь количествы " разнообразіи и гы онъ, при томь, Такъ лекко доступенъ для иаблоденія и охоты. Къ счастью можно быть увтреннымь, что живые занасы Брит. Вост. Африки еще въ теченіе довольно долгаго времени не изсякнутъ, благодаря предусмотрительности англійскаго правительства, во́-время озаботившагося охраной ириродныхъ богатствъ протектората. Безъ этихъ мъръ охраны полное истребленіе дичи стало бы въь самомъ непродолжительномъ времени неминуемымъ. Мы видимъ это на примғр Южной Африки и Трансвааля: за какіе-нибудь 40 льтьь тамь совершенно исчезли съ лица земли милліонныя стада антилопъ, истребленъ особый видъ дикой лошади-квагга, вымеръ южно-африканскій носорогъ и т. д. и т. д. Мғры, принимаемыя восточно-африканскими властями въ защиту животныхъ, - разнообразны. Наиболъе дыйствительная мъра-это учрежденіе резерватовъ, или заповъдныхъ участковъ. Резерваты могутъ быть полными, каковъ вышеупомянутый большой, „южныи“ резерватъ и другой, тоже значительныхъ размъровъ, резерватъ „съверный •, къ съверу отъ горы Кенія. Другіе резерваты частичны, т. е. въ нихъ запрещается охота не на всъхъ, а только на болъе ръдкихъ животныхъ. Такъ, напримъръ, в'ь области озера Баринго нельзя стрғлять сохранившуюся только тамъ въ значительномъ количеств о винторогую антилопу или куду (Strepsiceros). Наконецъ, есть животныя, которыхъ запрещено бить на всемъ протяженіи Брит. Вост. Африки. Таковы страусы и крупныя антилопы - эланды (Oreas), очень напоминающіе общимт видомъ и свисающей кожей на шеъ воловъ. Эланды взяты подъ особую защиту потому, что въ настоящее время идутъ опыты по прирученію ихъ; въ случаъ удачи этихъ опытовъ человькъ пріобрвлъ бы совершенно новую породу крупнаго 
домашняго скота. Почти подъ такой же строгой охраной находятся и слоны. Охота разрғшена только на самцов'ъ и, притомъ, такихъ, у которыхъ въсъ каждаго бивня не менъе 30 фунтовъ.

Другія охранительныя мғры состоятъ въ установленіи высокой пошлины на ввозимое оружіе и не менъе высокой платы за право охоты. Даже мбстный землевладұдлецъ за право охоты на собственной земль долженъ уплачивать 30 р. въ годъ; мыстные жители, не ильюще земельной собственности, платятъ за разрғшеніе охотиться (residents licence) уже 100 р. Что же касается до пріғзжихъ туристовъ, то разрєшеніе бить крупную дичь (sportsmans licence) обходится имъ уже по 500 р. съ человъка. Кромғ того, за свои 500 р. спортсмэнъ имъетъ право убить только строго опредъғленное число животныхъ: напр., 1 носорога, 2 буйволовъ, 2 бегемотовъ, 4 львовъ, 3 гну, 20 зебрь и т. д., въ общемъ немногимъ болъе 100 животныхъ. За слона самца лриплачивается 100 р. лишнихъ.

На первый взглядъ можетъ показаться, что при громадности пространства и скудности населенія провърка дъйствій охотниковъ становится невозможной. Однако, во-первыхъ, каждый чернокожій спутникъ, взятый съ собою спортсмэномъ (а путешествуютъ охотники всегда съ цълымъ караваномъ носильщиковъ), является вмбсть съ тъмъ и шпіономъ, доносящимъ правительству, за награду, разумьется, о проступкахъ своего господина. Кромъ того, всъ трофеи, вывозимые изъ предвловъ Брит. Вост. Африки, подвергаются строгому осмотру и подсчету, и если окажется, что охотникъ преступиль границы своего разрұшенія, то его постигаетъ кара. Въ случағ нарушенія правилъ, провинившійся наказывается лишеніемъ права охоты и облагается тяжелымъ штрафомъ (до 2.000 р. и болье). И, несмотря на столь дорогучо стоимость охоты, ежегодно сотни богатыхъ англичанъ и американцевь нағзжают'ь на охотничій сезонъ въ Брит. Вост. Африку.

Можно уже теперь сказать, что введенныя правила приносятъ очень хорошіе результаты. Такъ, одно время буйволамъ и красивой винторогой антилопғ грозило въ Брит. Впст. Африкъ 


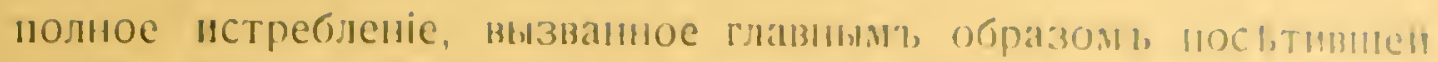

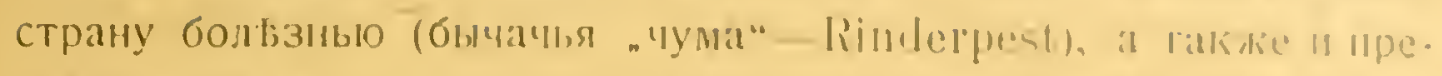

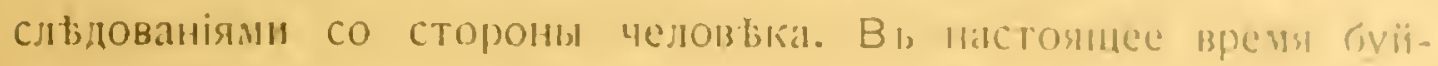

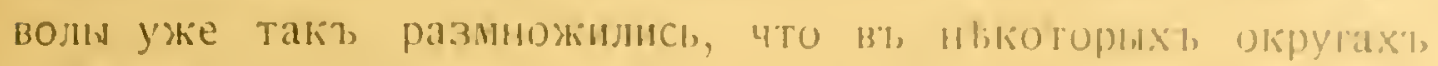

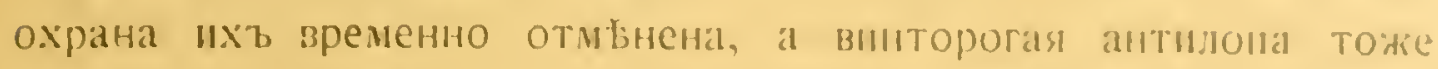

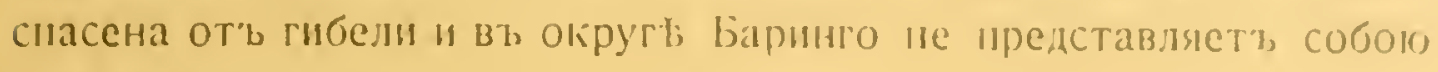
особої ндкости.

\section{III. Найробн. Путь въ Энтеббе.}

На 327-ой милъ поъздь останавливается въ Наирољи (Naіrobi). Найроби былъ основанъ 15 льтъ толу назаль, одновременно съ проведеніемъ Угандской жельзной дороги "за это время успвлъ вырости въ болышой городъ съ общимь количествомъ населенія въ 20.000. Въ немъ можно найти всъ удобства, къ которымъ привыкли у насъ въ Европь: электрическое освъщеніе, водопроводъ, телефонъ, роскошные магазины, первоклассныя гостиницы, банки, церкви, кинематографы, отличныя шоссированныя дороги, движеніе по которымъ совершается на автомобиляхъ, велосиледахъь и рикшахъ и проч.; ежедневно выходятъ двъ газеты. Европейцы, которых’ы въ Найроби насчитывается въ настоящее время не менъе 1.500 , жинутъ на окраннахъ го. рода в’ь болье здоровыхъ возвышенныхъ мыстахъ. Осталыное населеніе представлено инлусами, гоанезами и туземцаии племени Ва-Кикуйю (Wa-líkuуu).

Город'ь производит'ь ндсколько неуютное впечатлғніс благодаря тому, что большинство построек'ь сдылано из' гофрированнаго желғза и, кромь того, расположено какь-то вразброску. Нъсколько непріятно дъйствуютъ на вновь прибывиаго и эњклиптовыя деревья, которыии засажено больиннствоу'ииц, такъ какъ хочется видьть что-нибудь истное, африканское.

$\mathrm{Bz}$ Найроби намъ предстояло выработать марирут", и планъ нашихь работъ. Въь этомъ дыль намъ не мало помогь помощникъ Game Warden'a (заввдующаго животными богатстваши 
края), г-нъ Вудгаузъ, который категорически отсовътоваль идти

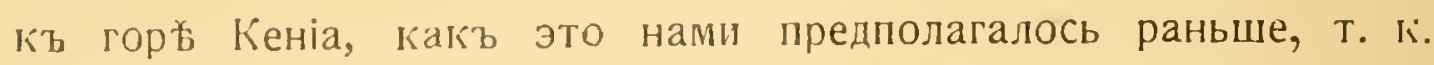
предстоялъ еще посльдній мьсяцъ „Masika“, или дождливаго се- . зона, когда дороги становятся трудно проходимыми, а трава выростаетъ настолько, что двлаетъ почти невозможнымъ наблюденіе крупныхъ животныхъ.

Кромь того, мы познакомились с’ь однимъ крупнымъ землевладыльцемъ, Г-номъ Гроганомъ, къ которому у насъ была рекомендація изъ Европы. Онъ далъ намъ любезное разрбшеніе охотиться и производить сборы въ его владъніяхъ на берегу озера Найваша и въ льсахъ близъ станціи Моло и, кромь того, направилъ насъ въ Угандъ къ г-ну Мартину, завьдующему плантаціями каучуковых’ь деревьевъ въ лъсу Мабира.

Сообра:зуясь съ добытыми данными, мы окончательно установили такой планъ: на два-мъсяца повхать въ Уганду (Энтеббе-Мабира), затъмъ, при возвращеніи назадъ, дълать остановки различной продолжительности вдоль Угандской желъзной дороги (Кисуму, Моло, Найваша), а подъ конецъ, въ самый разгаръ сухого времени года, предпринять пъшеходное „сафари“ въ Тавету и къ озерамъ Чала и Джипе, завершивъ его восхожденіемъ на Килиманджаро, по возможности до пояса альпійскихъ луговъ.

Въ Найроби наше пребываніе длилось ровно недълю, но изъза визитовъ и разныхъ другихъ хлопоть у насъ было весьма мало времени для болъе подробнаго ознакомленія съ его окрест. ностями. То, что пришлось увидъть, насъ нъсколько разочаровало, такъ какъ общій характеръ мъстности, растительность на лугахь (льсовъ подъ Найроби почти нътъ), температура (приблизительно какъ у насъ въ мағ или в’b августь) -все напоминало скорғе среднюю Европу, но отнюдь не Африку, какой мы ее себъ представляли, и менъе всего часть ея, расположенную подъ экваторомъ. Отчасти это надо объяснить тьмъ, что время нашего пребыванія въ Найроби совпадало съ, Nasika“, т. е. съ наиболье холоднымь временемь года, съ другой же стороны, не 


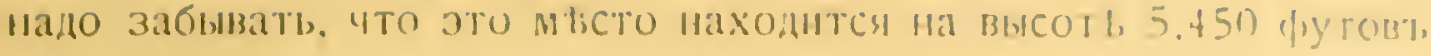
нальь уровнен's моря.

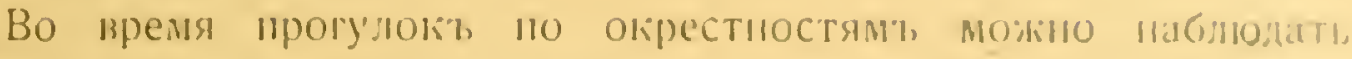

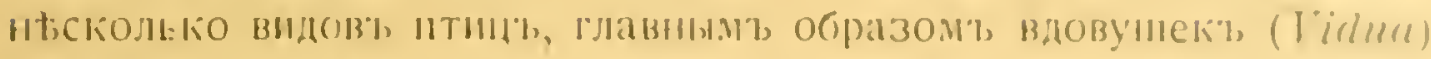

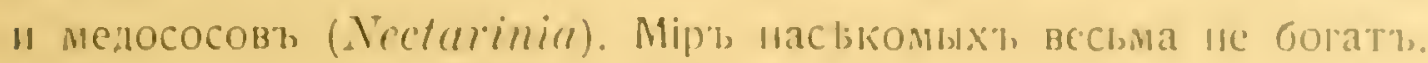

На луговыху растеніяхь иреобладають, разнообразныя Соссіmellidare Curculionidate $и \mathrm{Ly-}$ сіпие Изъ других отрлиов двукрылыя, перепончатокрылыя и клопы; между прочим'ь, изъ посльднихь весьиа распространени красивыві нестрыи Sphuerocoris sp. Очень интереснымь оказался одинь, довольно обыкновенный здъ̆сь, видъ саранчеваго, Phymateus hildebrandti, обладающій способностью выпускать позади задней пары ногъ въ изобиліи жидкость, которая пвнится крупными пузырями.

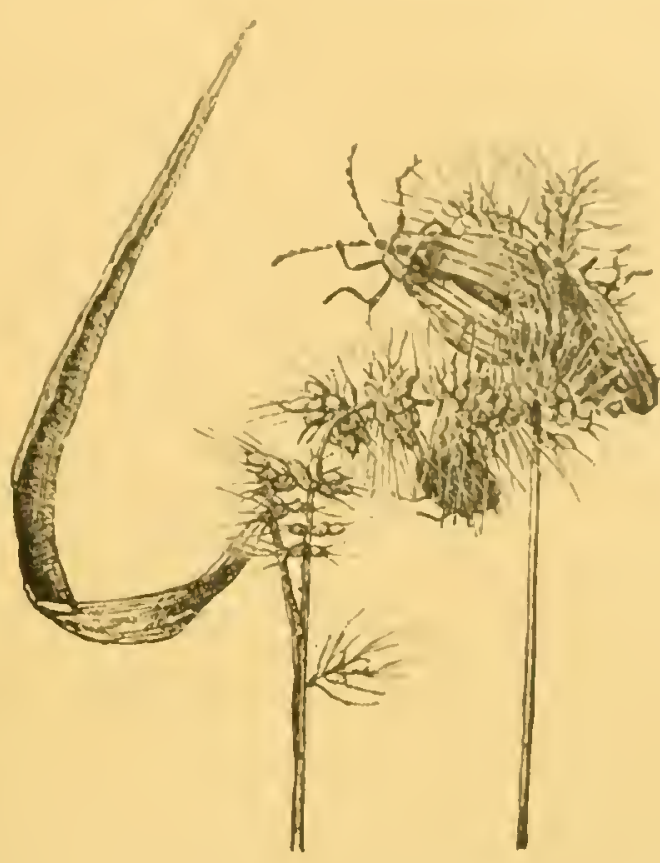

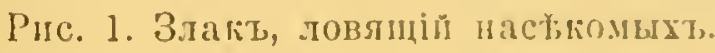

Необходимо еще отмбтить одинъ злакъ, который имъетъ особыя лриспособленія для ловли насъкомыхъ. Отдъльные цвътки ero, составляющіе колосъ, снабжены длинными остями, на которыхъ развиты мелкіе шипики, направленные остріемъ назадъ. Насъкомое или иной посторонній предметъ, попадающій на колосъ снаружи, легко проходитъ между остяди, но его обратное движеніе затруднено благодаря дъйствію шипиковъ. Сверхъ того, ось колоса очень податлива, такъ что при движеніи жертвы, когда она задъваетъ за новыя ости и эти посльднія тоже прињпляются къ ней, колосъ соотвйтственнымъ образомъ загибается. Если по сосъдству имћется другой и третій колосъ, и насъкомое случайно ихъ коснется, то и они иринимаютъ участіе в’ь егонлъненіи. На колосьяхъ находились главнымъ образомъ жуки (I уссіпле, Coccinellidae и др.); въ одномъ случағ попалась довольно круп- 
ная стрекоза, а въ другомъ-большой тараканъь (въ родь Styloруяа). Нћкоторые жуки продолжали еще долгое время двигаться, у другихъ содержимое было какъ бы высосано и сами они высохши. Къ сожал务ію, за недостаткомъ болғе точныхъ наблюденій, трудно сказать, имъемъ ли мы туть дыло съ особымъ типомъ насбиомояднаго растенія, или доведенное до крайности приспособленіе саимянъ въ сторону ципкости, какъ у нашего чертополоха.

Пожалуй наиболье сильное впечатльніе производять на вновь прибывшаго въ Найроби туземцы, относящіеся къ племени Ва-Кикуйю (Та-Кіkuуи). Свое твло они смазываютъ изъ гигіеническихъ соображеній смъсью красной глины и жира. Мужчины носятъ перекинутый черезъ одно плечо большой красный плащъ, а женщины одъввють кожаный передникь и плащъ. Женщины исполняютъ всь⿱㇒㠯 тяжелыя работы, работають на поляхъ и, подобно вьючнымъ животнымъ, носятъ тяжелыя ноши. Ноша кладется за спину въ оольшой кожаный мъшокъ, ремни отъ котораго перекидываются на голову. Наиболье распространеннымъ украшеніемъ у Ва.Кикуйю, такъ же какъ и у всћхъ видънныхъ нами племенъ, служать широкіе браслеты изъ толстой мбдной проволоки, завитой спиралью, которые носятся на рукахъ-выше и ниже локтя, и на ногахъ-ниже кольнъ. На шею туземцы одъваютъ ожерелье изъ бусъ или разноцвьтнаго бисера.

Большое вниманіе удъляется прическамъ. Мелко-курчавые волосы очень часто густо смазываются красной глиной, производя впечатльніе парика. Въ другихъ случаяхъ въ волосы вплетаются веревки, концы ихъ спбираются въ пучки и обматываются тряпкой, такъ что получается впечатльніе прямых'ь палок'ь, торчащихъ спереди и сзади, или по бокамъ.

Mногіе частично бреютъ голову, оставляя отдъльные островки волосъ въ опредьленныхъ мүстахъ и этимъ выказываютъ въ каждомъ отдыльномъ случаъ свой индивидуальный вкусъ. Женщины, какъ правило, начисто бреютъ голову. Другимъ весьма характернымъ способонь украшенія является обычай уродовать уши. Въ мочкъ продълывается отверстіе, въ которое вставляется 


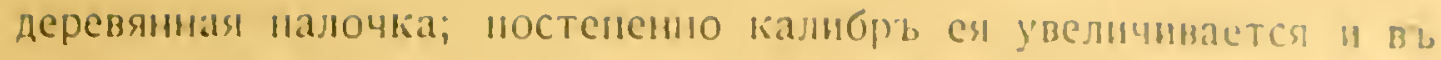

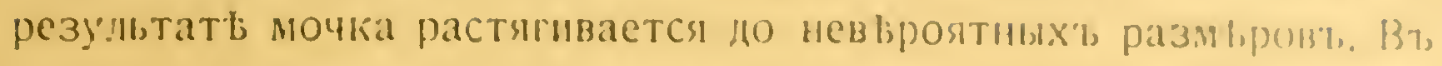

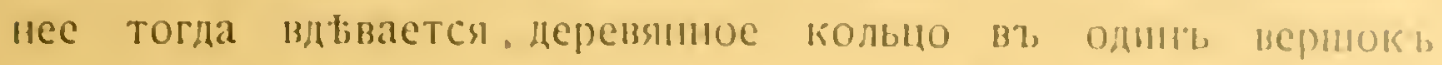
діаметромъ, нли толстый обрубокъ дерева, или даме фарфоромия

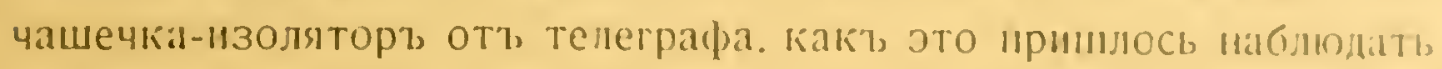

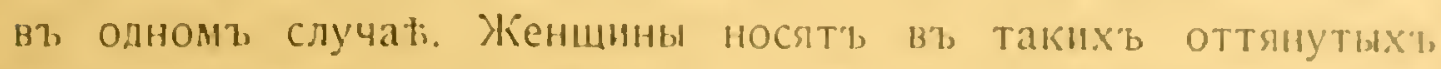
мочкахъ тонкія кольца изь проволокн, съ нанизанинм'т на нес биссромь; одинь разь можно было насчитать цо 40 колеит в\% пдномъ ухь. Въ верхней части ушноі раковины дылаются ещце часто маленькія дырочки, отъ $3-x ъ$ до 4-хъ, 1 иъ нихъ вставляются коротенькія палочки, торчащія кверху.

Къ спжальнію намъ не удалось посътить туземныхь дереву шекъ, находящихся къ западу отъ Найроби.

Посль недьльной остановки въ Найроби, мы двннулись дальне, въ городъ Энтеббе, лежацій на съверо-западномъ берегу Викторія-Ніаниы. Путь въ Энтеббе лежитъ по Угандской ж. д. до восточнаго берега Ніанцы, а нменно до г. Кисуму; оттуда же ндеть иароходъ, прямо до мъста назначенія. Отъ Найроби до озера ъзды 20 часовъ. Дорога сначаламедленно поднимается по холмамъ Кикуіію, вьется среди ложбинъ и ущелій и, въ конщћ концовъ, взбирается на вершину хребта Абердаръ (около 7.500 ф.), спулавъ, такимъ образомъ, подъемъ въ 2.000 футовъ. Какъ склоны, такъ и вершины хребта покрыты мрачными, дъвственными льсами, имъюшими совершенно особенный характеръ высокогорнаго лъса (смотри далье описаніе льса въ Моло). Поднявиись на вершину хребта Абердаръ, поъздъ вскоръ достигаетъ станціи Эскарпментъ " здъсь картина, какъ по мановенію жезла, рбзко измьняетсл. Горный кряжъ, на которомъ лежитъ станція, круто обрывается на западъ и передъ взоромъ путешественника открывается обиирный видъ надолину Рифтъ (Rift-Valley), раскинувшу.ося на 1500 ф. ниже станціи. Долина эта около 100 верстъ шириною. Посредин ея поднимается въ видь правильнаго конуса красавецъ вулканъ Лонгонотъ (10.000 ф. высоты). По другую сторону долина ограни чена съь запада опять таки горнымъ хребромъ в’ь 8.500 (). выни. ною-горами May. Rift.valley orносится к’ числу тьхъ весьма 
своеобразныхъ восточно-африканскихъ долин'ъ, которыя, в’ь видъ длинныхъ, но узкихъ промоинъ, проръзываютъ материкъ по направленіюсъ съвера на югъ. Именно въ системъ подобныхъ долинъ залегаютъ нғкоторыя изъ самыхъ крупныхъ африканскихъ озеръ: Ньясса, Танганайка. К' той же системъ относится, повидимому, и долина Краснаго моря.

Пересбкши вышеуломянутую долину, поъздъ снова медленно тащится въ горы May, представляющія собою точную копію хребта Абердарьь. Здъсь Һдущаго застигаетъ ночь, а утром'ь онъ просыпается уже на берегу Викторія-Ніанцы, въ г. Кисуму, гдъ поъздъ подается къ самой пароходной пристани.

Отъ Кисуму (Port Florence) совершаются правильные пароходные рейсы по озеру Викторія-Ньянца. Три раза въ недылю пароходы идуть на Энтеббе и затбльь обратно через'ь КампалаПортъ и Джинжа (Jinja) въ Кисуму. А разъ въъ недблюд各лается круговой рейсъ по всему озеру съ заходомъ въ германскіе порты Букоба (Bucoba), Мванца (Mranza) и Ширати (Schirati), расположенные въ южной половинъ озера. Плаваніе совершается днемъ; сь наступленіемъ же темноты становятся на якорь и жлутъ разсвъта, такъ какъ маяюовъ тутъ нътъ, а фарватеръ еще недостаточно изучен'ъ, особенно вблизи многочисленныхъ в’ь съверной части озера острововъ. Пароходы, крейсирующіе по озеру, хотя и не велики, но довольно комфортабельны; столъ весьма недуренъ.

Гlервые четыре часа пароходъ идетъ по Кавирондскому заливу, представляющему собой почти совершенно замкнутый бассейнъ, так` какъ онъ соединяется съ открытымъ озеромъ при помощи очень узкаго пролива. Воды залива отличаются своимъ мутнымъ, буровато-коричневымъ цвътомъ. Поего поверхности плаваЮтъ ярко-зеленыя, напоминающія салат’ь, розетки листьевъ Pistia strutiotes (Araceae), корни которой свъшиваются в’ь воду, и цАлые островки изъ папируса, тростника, ситника и другихъ травъ, оторванные бурей отъ береговыхъ зарослей. На нихъ часто можно видъть отдыхающихъ баклановъ (Phulacrocorax) которые летаютъ во всбхъ направленіяхъ, недалеко отъь парохода. 


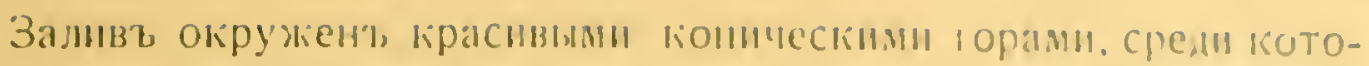

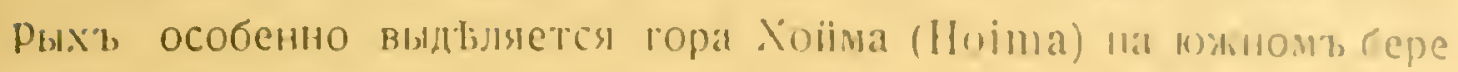
гу. На съверғ мыстность носит', болье плоскіiі :зараклерь.

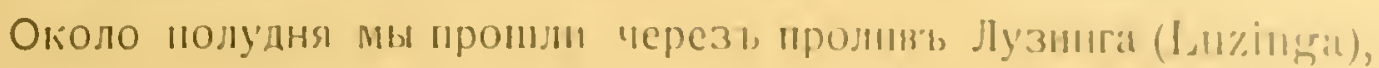

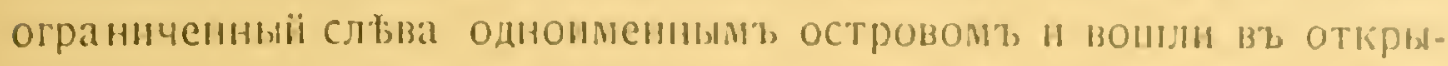
тое озеро. Съ юга открывается безконсчная водная гіац, а на

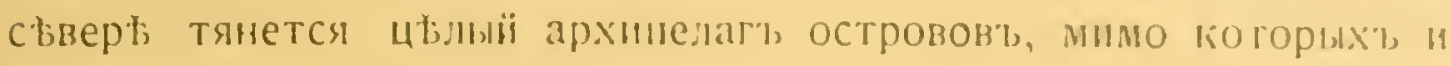
пробирается пароходъ. Острова эти по вньшности очеш, разнообразны. Нвкоторые изъ ниху состоятъ изъ голыхъ, иричудливыхъ. гладко окатанныхъ скаль; другіе покрыты травой " иебогатой-растительностью; третьи наобороть заросли густымъ дтвственнымъ льсом'ь, гдь водится въ изобиліи пуха це-це (Glosina palpalis). Еще сравнительно не так'ь давно эти острова были густо населены чернокожими, теперь же изъ живыхъ существъ можно разсмотрбть на нихъ только птицъ, мъстами образу 1ощихъ большія скопища,-все населеніе унесено въ могилу безпощадной сонной бользнью.

Простоявъ всю ночь на якорђ, мы раннимъ утромъ повхали дальше и около полудня, при сильномъ дождє съ грозої,-явленіе весьма обычное въ прибрежныхъ мбстностяхъ Уганды,-прибыли въ одинъ изъ главныхъ городовъ Уганды-Энтеббе.

\section{IV. Энтеббе.}

Подъ Угандой въ настоящее время понимаютъ область, лежащую къ съверу-западу отъ озєра Викторіи, въ Которую входятъ кромь территоріи Буганда (Buganda) еще " сосьднія территоріи Бузога (Вusoga), Буніоро (Вunуoro), Анколе (Ankole) " Торо (Toro). Вся эта область занимаеть около 200.000 кв. миль и имъетъ отъ 3 до 4 милліоновъ населенія. Въ 1894 г. она была объявлена протекторатомъ Англіи. Въ 1897 г. король Уганды, Мванга, подняль мятежъ. Мятежъ былъ подавлснา, Мванга бъжалъ въь германскія владънія, а королемъ Уганды былъ объявленъ его сынъ. Дауди Чва. Молодой король получилъ университетское образованіе въ Англіи "въ настоящее время на- 
ходится самъ у власти. Разумћется, онъ никакой политической роли не играетъ и страной фактически правятъ англичане, выдавая ему 1.500 фунт. стерл., что составляетъ его годовой бюджетъ.

Столицей Уганды является Кампала, или Менго-быстро растущій городъ, расположенный на семи холмах`ъ, наподобіе древняго Рнма, какъ въ шутку говорятъ мғстные англичане. Въ городъ имъется три гостиницы, и цйлый рядъ коммерческихъ предпріятій; еженедыльно издается газета. Сообщеніе города с'ь берегомъ озера Викторіи (Kampala-Port), отъ котораго онъ отстоитъ на 7 миль, поддерживается моторами и рикшами. Ќромв того почти уже закончена постройка жельзной дороги, которая современемъ должна пройти въ Конго. Въ Кампаль мы были только проъздомъ, такъ что судить о томъ, насколько эта мъстность является интересной для зоолога, является очень труднымъ; но общее впечатльнніе получилось далеко не такое благопріятное, какъ отъ Энтеббе.

Энтеббе (Entebbe) было, собственно говоря, первымъ мыстомъ, съ котораго мы начали болье подробно знакомиться съ жизнью тропической природы. Это небольшой городокъ, чрезвычайно живописно раскинувшійся на юго-восточной сторонъ̆ длиннаго полуострова, далеко вдающагося съ съвера на югъ въ озеро Викторія. На самонъ высокомъ мвсть города расположенъ домъ губернатора. Отъ него по направленію къ берегу тянутся жилища европейцевъ, которыхъ въ Энтеббе не болће ста. Зданія каменныя, съ верандой, всегда обнесенной мелко-ячеистой проволочной рб̆шеткой въ зациту отъ москитовъ, и окруженныя садами съ разнообразными цвътущими деревьями и растеніями (Bougainvillea, Spathodea, древовидный Solanum, Hibiscus, Ficus, различныя акаціи " проч.)

Къ съверу отъ европейской части выстроены съ одной стороны, казармы аскари (чернокожихъ солдатъ, обученныхъ европейскому строю), съ другой-многочисленныя хижины чернокожихъ изъ племенъ Ваганда, Нубійцевъ, Ва-Суагели. Эти хижины, окруженныя рощами банановъ, дыннаго дерева (Carica papaya) и др., тянутся версты на двъ по объ стороны дороги, ведущей на Кампалу.

Почти на самомъ берегу озера, недалеко отъ пароходной 
иристани находится единстненная иъ Эитсббе гостиница, „Oгеи, Викторія," бывная преждс губернаторскимь домоми. Вь ней-очсл, просторныя, удобныя комнаты и весьма недурной столь (иолиый пансіонъ 10 рупіӥ въ сутки). Все зданіе окружено широкой веран. дой, съ которой открывается великольнный видъ на озеро.

Непосредственно къ саду гостиници примыкаетъ ботаническіиі садъ. Онъ занимаетъ большую площадь, десятины иъ 4-5, которая постепенно спускается къ самому озеру. Въ саду собраны преимущественно представители мъстноиі флоры, хотя имбются растенія и изъ другихъ странъ свъта. Одинъ участокъ отведенъ между прочимъ подъ насажденія бразильскаго каучуковаго дерева (Hevea brasiliensis), которое теперь съ успьхомъ культивируется во многихъ мъстахъ колонін.

Ботаническіӥ садъ представляетъ особенный интересъ для орнитолога, такъ какъ онъ чрезвычайно богато населенъ птицами. Губернаторъ Уганды, Ф. И. Джексонъ, самъ хорошій знатокъ птицъ, считаетъ Энтеббе однимъ изъ богатьйшихъ въ орнитологическомъ отношеніи уголковъ міра, и увирялъ насъ, что онъ раздобылъ въ одномъ только ботаническомъ саду до 160-ти видовъ птицъ. Онъ выдаль намъ разрьшеніе на охоту въ черты города и при томъ на всъхъ птицъ (по 2 экз. каждаго вида), за исключеніемъ вънценоснаго журавля (Balearica gibbericeps). Balaeniceps rex и орловъ Haliaetus vocifer: свившихъ свое гнъздо на деревъ, какъ разъ у самой пристани. Мы широко пользовались этимъ разръшеніемъ и почти ежедневно добывали въ ботаническомъ саду разныхъ птицъ для изсльдованія ихъ паразитовъ.

Прежде всего бросаются въ глаза большія птиць-носороги, особенно Bucanistes subquadratus, постоянно оглашающія воздухъ своим' громкимъ карканьемъ и съ шумомъ гоняющіяся другъ за другомъ съ одного дерева на другое. Нћсколько видовъ голубей (Turtur semitorquatus, Chalcopelia aira " др.) очень красиво воркуютъ, при чемъ одинъ изъ нихъ издаетъ звуки, напоминающіе бульканье воды въ быстро налолняемомъ сосудъ. Минатюрные медососы Nectarinil (ныск. ви. 
довъ) переливаютъ на солнцъ всевозможными красками и особенно охотно садятся на оранжевые цвьты одного губоцвьтнаго. Въ густыхъ вьтвяхъ кустовъ прячутся Laniarius erythrogaster съ замьчательно красивой ярко-красной грудью. Туть же можно увидњть кукушку Centropus superciliosus или длиннохвостую

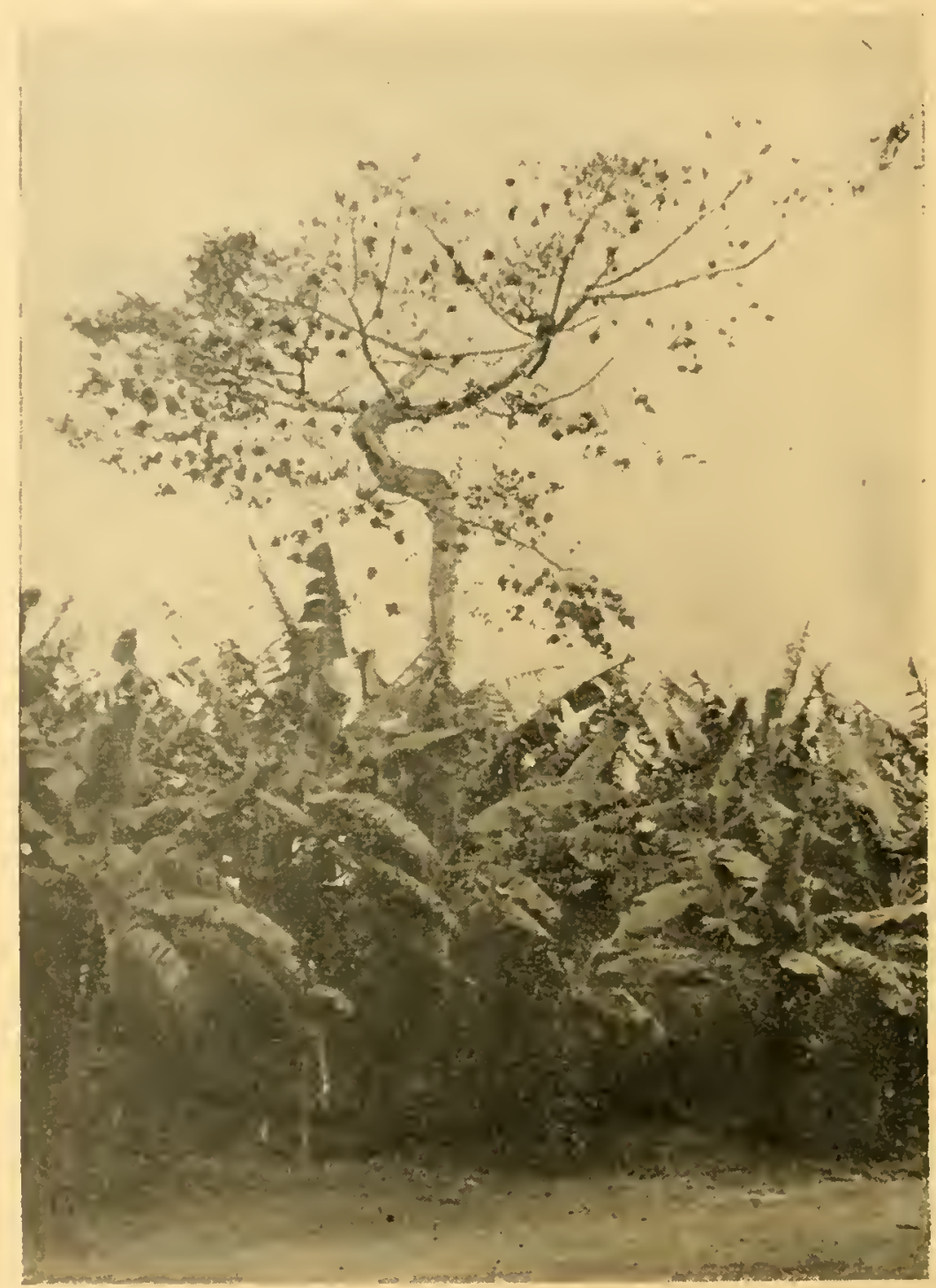

Рнс. 2. Дерево съ гньздами ткачнковь.

Colins lencotis; на высокихъ деревьяхъ отдыхаютъ громадныя совы, а въ воздухъ носятся Eurystomus afer, издающіе короткіе скрипящіе звуки. На открытыхъ мистахъ и у мелкаго кустарника летають большими стаями разные ткачики (Ploceus, monachus, Melanopteryx nigerrimus, Urobrachya phoenicea, Lagonosticta senegala, Vidua sp., Spermestinae и др.) швейки 


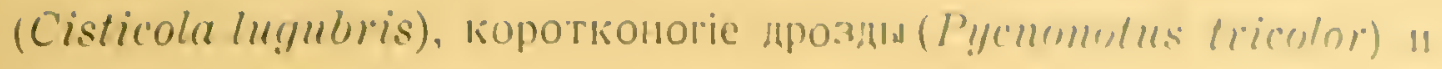
многочисленныя другія воробыниыя *).

у берега озера держатся ибисы и разыны цанли; иестрые и ярко-голубые съ краснымъ клювомъ зимородки (Ceryle rmlis

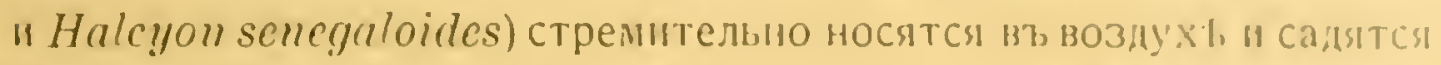
потомъ отдыхать на приорежныя деревья. У самой воцы бінають

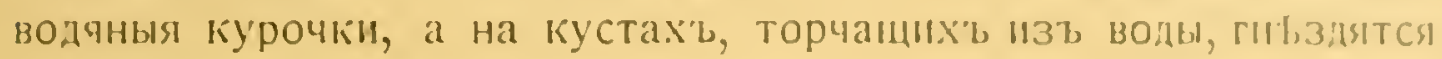

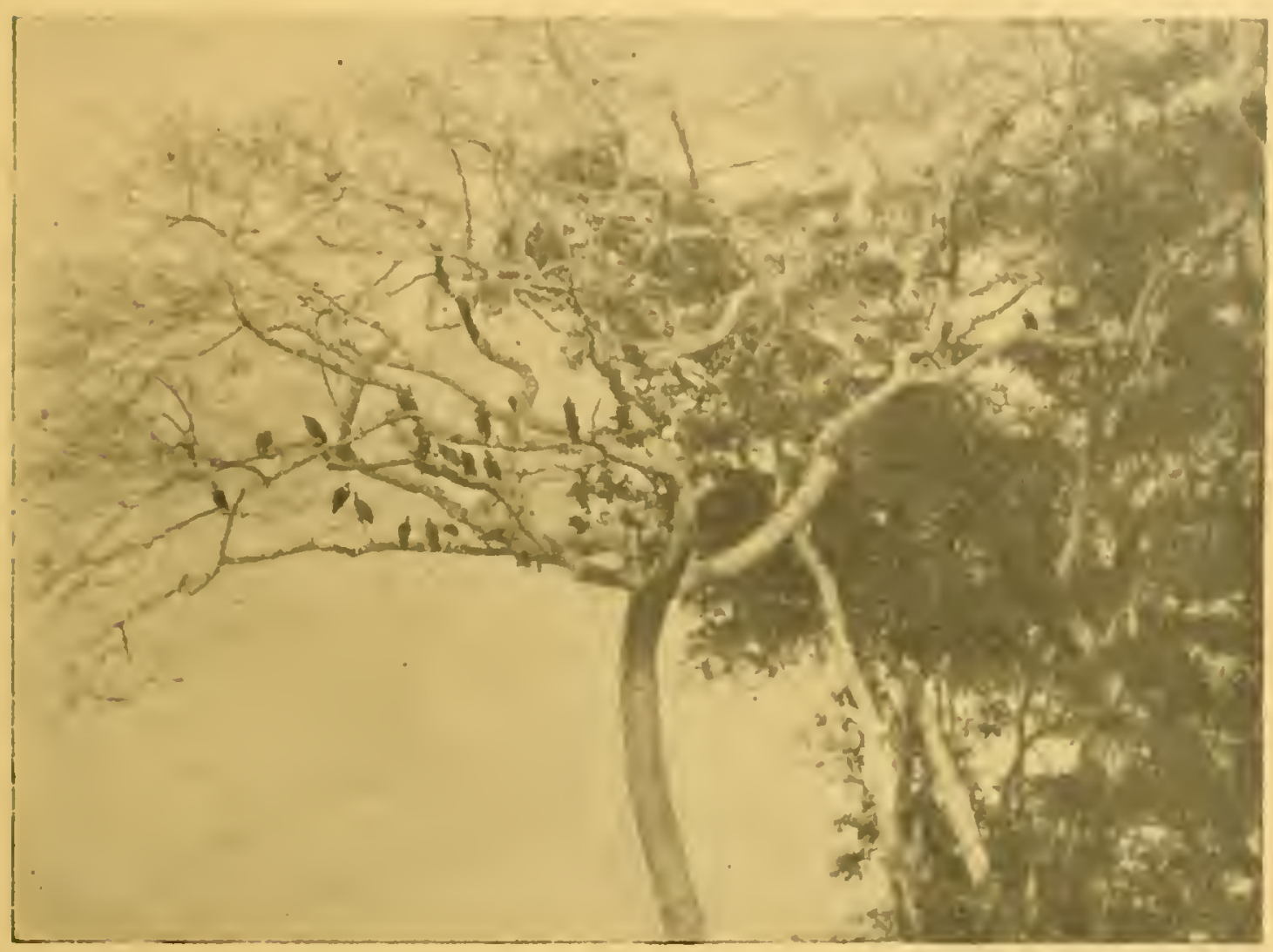

PІіс. 3. Грифы.

бакланы (Phalacrocorax) и ткачики. Эти посльдніе вообще выбираютъ для свонхъ ретортообразныхъ гнћздъ нашменъе достулныя врагу вътви или обнаженные корни деревьевъ, свћшивающіеся съ какого-нибудь обрыва далеко внизъ. Нъкоторыя деревья бываютъ иногда сплошь увбшаны ихъ гнъздами, словно плодами. Тамъ, гдъ пасется скотъ, ему всегда сопутствуютъ красивыя бълыя цапли Bubulcus. Наконецъ, около городской бойни мы

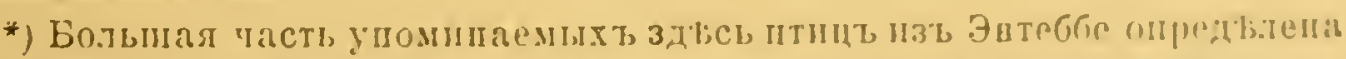

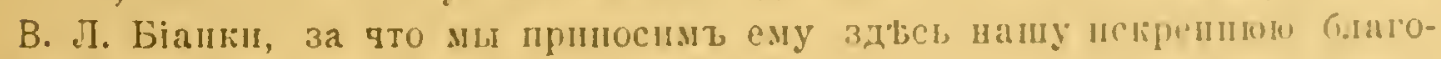
-арность. 
постоянно встрђчали скопище грифовъ, которые, насытившись зловонными остатками убойнаго скота, неизмънно садились на одно сосьднее засохшее дерево, въ ожиданіи новой поживы.

Благодаря разрєшенію завъдующаго ботаническимъ садомъ, мы могли тамъ собирать все, что находили. Собранный матеріалъ прнносился домой и разсматривался на верандъ, гдъ нами была устроена импровизированная лабораторія.

Изъ позвоночныхъ, кромь птицъ, можно было раздобыть въ большомъ количествъ агамъ съ синей головой и гекконовъ. Насъкомыя въ ботаническомъ саду представлены гл. обр. клопами и перепончатокрылыми; жуки попадаются больше подъ камнями, и корой и сухими стволами деревьевъ. Интересно отмътить одну небольшую стрекозу, съ чернымъ туловищемъ и такими же перевязями на концахъ прозрачныхъ крыльевъ. При полетъ этой стрекозы кажется, будто летятъ одновременно три существа. Возможно, что здъсь передъ нами имћется защитное прислособленіе, вводящее въ заблужденіе птицъ, которыя хватаютъ стрекозу за одно изъ крыльевъ, принимая его за туловище.

Огромные пауки Nephila встрбчаются не часто; мы могли раздобыть только два экземпляра, и то черезъ туземцевъ. Зато мелкихъ пауковъ было множество. Въ яйцахъ одного вида были найдены паразитныя перепончатокрылыя. Для систематическихъ же цвлей было собрано большое количество формъ съ деревьевъ, подъ каинями и кошеніемъ. Подъ камнями былъ найденъ одинъ крупный видъ сънокосца, которыї внъ ботаническаго сада не попадался.

Одной изъ наиболъе цбнныхъ находокъ были яйца Polyxenus. Они были найдены совмъстно съ самими многоножками подъ влагалищами листьевъ срубленнаго ствола финиковой пальмы. Здъсь находилось до двадцати слишкомъ кучекъ. Въ каждой кучкъ отложено отъ 15 до 30 (иногда 40) яицъ; яйца расположены правильными рядами въ одной плоскости. Вся кучка окружена рыхлымъ слоемъ волосковъ съ тьла самого Polyxenus.

Подъ камнями и корой, а также при просъиваніи трухи и сухихъ листьевъ добыты мелкіе Pseudoscorpionidae, Ageleni- 
dae, Acarina, Myriapoda, Collembolas. Blattidate сверчки.

Если направиться вา, сторону Камналы и миноват, поселии Ваганда с'ь ихь банановыми насажденіями, то дорога иринедеть къ небольшому, но все же густоліу льсу. Здъсь, по высокии и вфтвямъ ирыгаютъ стаи болышихъ турако (Corythaenla cristatu). а иногда можно видыть " обезьянъ (Cercopithecus). Вдон, льсныхъ тронинокъ летаютъ крунныя Rhopalocera (разыс Pro. pilio. Callima, Charaxes, Acracidar, Danaidae u ир.) На вътияхь

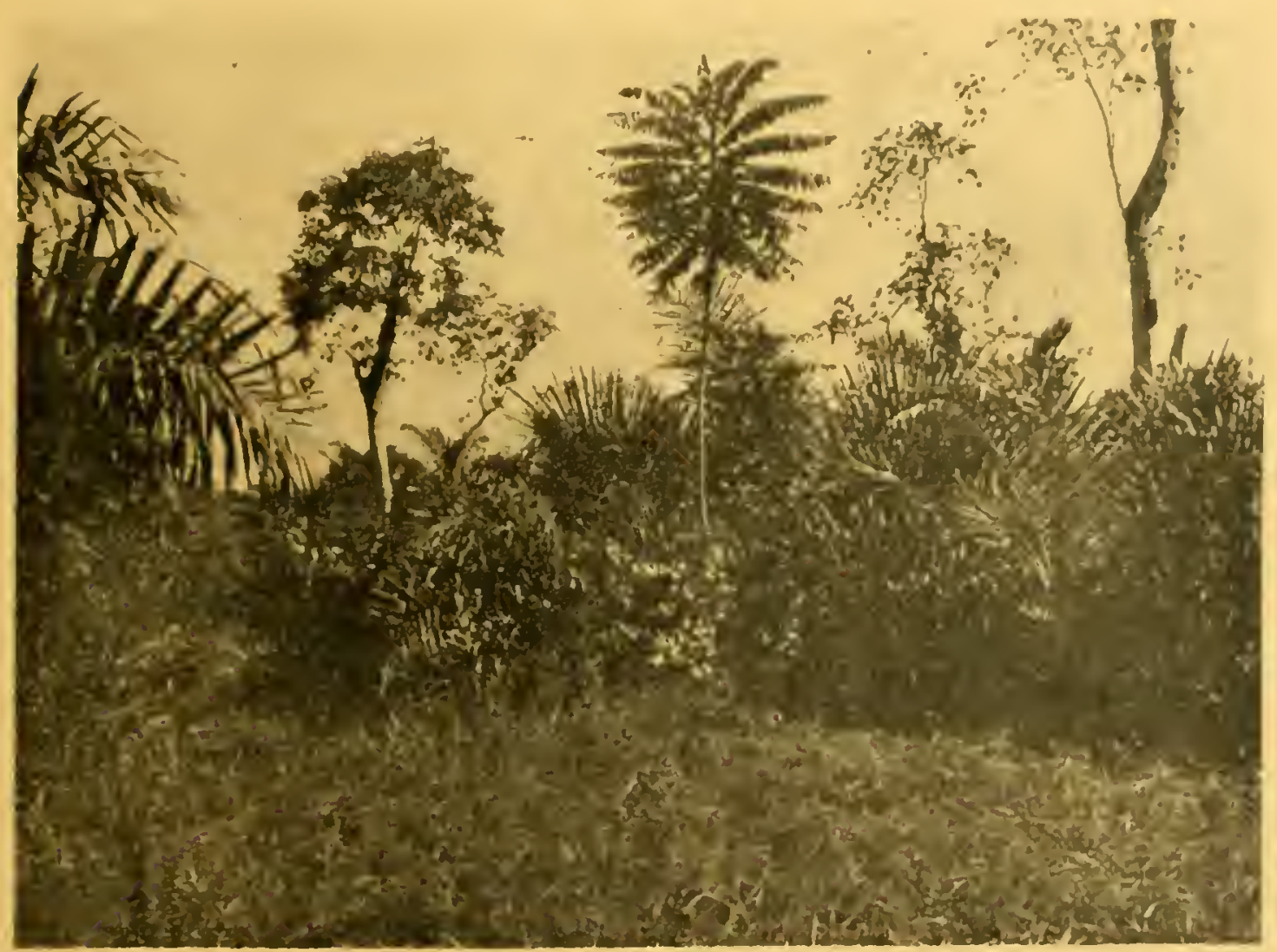

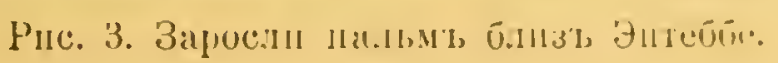

дълаютъ свои постройки разнообразные пауки. Подт угавшими листьями и гнилыми сучьями водятся наземныя планаріи, Araneilla. Phalangida и Myriapoda (Strongylosoma, Julidae " м. пр. гигантскій Julus, достигающій до 4 вершковъ въ длину). Всюду' на земль и на стволахъ деревьевъ находятся галлереи термитовъ Любопытенъ одинъ клопъ изъ Reduviidae, живущіiі у основанія териитниковъ, который носить на спинє высохшія шкурки своикь жертвт-муравьевъ. 
На лугахъ и полянахъ, образовавшихся послъ вырубки лъса, в’ъ большомъ количеств в возвышаются гигантскія конусовидныя постройки одного вида Termes, близкаго къ T. bellicosus, а на ряду съ ними низкія гнбзда другого вида, Cubitermes sp.

На цвђтущихъ растеніяхъ, кромђ многочисленныхъ бабочекъ (Papilionidae, Acraeidae и Danaidae), сидятъ разные жуки (Cöccinellidae, мелкіе Buprestidae, Nalacodermata, особенно много разныхъ видовъ Lycinae), клопы и перепончатокрылыя. На травъ очень обыкновенны два вида бронзовокъ. Одинъ небольшой ярко голубой видъ Cicindela держится исключительно на постройкахъ Termes.

Между прочимъ одинъ видъ Cerambycidae и одна бабочка своей окраской сильно напоминаютъ жуковъ рода Lycus. Въ литературь извйстны весьма частые случаи подражанія разныхъ насъкомыхъ именно представителямъ Lycinae, которые выдъляютъ изъ заднихъ бедеръ бъ́лый вонючій сокъ.

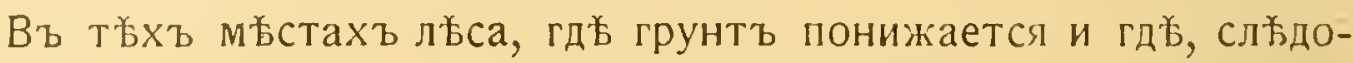
вательно, скопляется вода, роскошно развиваются папоротники, а финиковыя пальмы образують густыя заросли. К'ь водъ слетаются нбкоторыя бабочки и стрекозы, а въ самой водъ водятся жуки, одинъ крупный видь Nepa и Rhabdocoela.

Крайне полезнымъ оказалось для насъ знакомство съ мъстнымъ энтомологомъ, г-номъ Гоуди, который далъ намъ много цънныхъ свъдъъній и много помогъ за все время нашего пребыванія въ Энтеббе, за что считаемъ своимъ пріятнымъ долгомъ поблагодарить его на этихъ страницахъ. Онъ уже четыре года живетъ въ Энтеббе и собралъ за это время очень большую коллекцію мъстныхъ насбкомыхъ (до 6.000 видовъ), которая у него хранится въ образцовымъ порядкъ въ небольшомъ музейчикъ. Для ловли насғкомыхъ онъ приспособилъ двухъ молодыхъ Ваганда, которые почти ежедневно ходятъ на экскурсіи и весьма искусно разыскиваютъ то, что требуется. Кромғ того, одного изъ нихъ онъ обучилъ снимать шкурки съ птицъ и предоставиль пользоваться его услугами и нам'ь.

Подъ конецъ нашего трехнедъльнаго пџебыванія въ Энтеббе мы 
могли наблюдать массовое появленіе т. наз. озерной монии, qline.

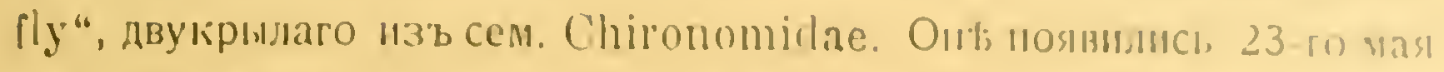
н. ст., причем' поди вечер\% летали надь деревьями огроминми

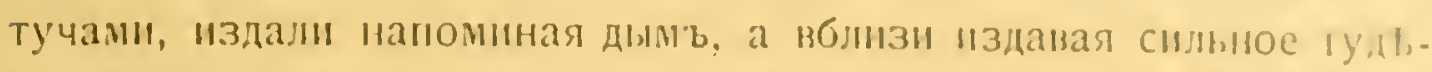

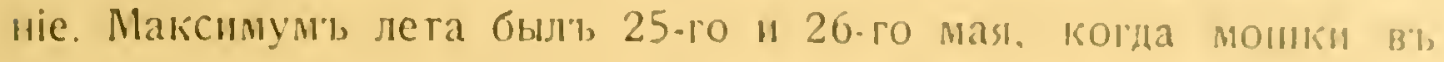
несмыгномь количествы налетали на металинческун сытку веранды, влекомыя сйтомь ламит, "и пронзвоили такой шумт, что казалось, будто идетъ дождь. Онь прользали сквозь щели сътки, обльпляли сплошь бълую стъну веранды, а на лампу налетали такоӥ массой, что, падая вт, стекло, тушили се. Подъ утро слуга выметалъ погибшихъ насъкомыхъ цълыми кучами. 27-юи мая ихъ было несравненно меньше, а 28-го мошки совстмъ исчезли. Мъстные жители говорили намъ, что такія нашествіs „lake-fly совершаются во время каждаго новолунія. Дєиіствительно, когда мы, мъсяцъ спустя, ьхали на пароходь изъ Джинжа въ Кисуму, то надъ островками, мимо которыхъ мы провзжали, виднғлись знакомые намъ рон "lake-fly".

Въ раіон всего озера Викторіи водится муха це-це, Glossina palpalis, распространительница сонной бользни. За посльднее время съь этой болћзнью ведется энергичная борьба, заклю. чающаяся главнымъ образомъ въ профилактическихъ мврахъ. Съ одной стороны, въ населенныхъ мъстностяхъ вырубается береговой льсъ, гдъ любитъ селиться Glossina, какъ это имъетъ, напр. мъьсто въ Энтеббе и ближайшихъ его окрестностяхъ; съ другой стороны, запрещается кому бы то ни было входить въ тұ льса, rдъ водится Glossina; или же, наконецъ, изъ зараженнои области выселяется на нъсколько льтъ все населеніе. Эти мъры внts сомньнія привели къ весьма положительнымъ резульгатамъ Изъ статистическихъ данныхъ, приведенныхъ въ The Leadel Annual 1914-го года, видно, что за 1912 г. было 1.546 смертныхъ случаевъ, за 1913-1.487, тогда какъ раньше они насчитывались десятками тысячъ.

Окончательнаго обеззараживанія мұстности путемъ выселенія туземцевъ на нбсколько лғтъ не удается достичь, так'ь какъ небольшоиі процентъ мухъ остается все же зараженнымъ. Новыи- 
шія изсльдованія показали, что въ такихъ случаяхъ очагомъ заразы являются нбкоторыя прибрежныя антилопы.

\section{V. Мабирскій $n$ бсъ.}

Посль подготовительныхъ работъ въ Энтеббе, мы имъли въ виду познакомиться съ настоящимъ дъвственнымъ тропическимъ льсомъ. Въ качествъ такового нами былъ избранъ Мабирскій льсъ, находящійся верстахъ въ 40 отъ селенія Джинжа (Jinja), которое лежитъ на съверномъ берегу Викторія-Ніанцы, на востокъ отъ Энтеббе. Въ центръ Мабирскаго льса имъется плантація каучуковыхъ деревьевъ, управляющій которой, г. Мартинъ, любезно объщался дать намъ пріютъ. Перебздъ въ Джинжу совершается на пароходъ и занимаетъ около двухъ сутокъ. Само по себъ разстояніе между обоими пунктами невелико, но много времени теряется всльдствіе того, что ночью пароходъ отстаивается на якорғ, опасаясь идти по плохо извъстному фарватеру. Единственная остановка по пути-Кампала-Портъ, небольшое мъстечко, служащее портомъ для г. Кампалы, отъ котораго оно отстоитъ на 7 верстъ.

Прогулки въ окрестностяхъ мбстечка дали намъ богатый сборъ бабочекъ, среди которыхъ особенно много было небольшихъ красныхъ Acraeidae и крупныхъ Danaida mercedonia. Пахучія железы брюшка Danaida и пахучія чешуйки на ихъ крыльяхъ были нами зафиксированы для гистологическаго изсльдованія.

Джинжа, откуда идетъ дорога въ Мабирскій лъсъ, представляетъ собою большое поселеніе, лежащее на берегу узкаго залива, въ глубинъ котораго Нилъ, прорывъ себъ ложе между крутыми глинистыми откосами, устремляется на съверъ, образуя Рипонскіе водопады (Ripon Falls). Это и есть знаменитые истоки Нила изъ озера Викторія-Ніанца. Напболье величественъ первый водопадъ, низвергающійся, благодаря скалистымъ островамъ на его пути, тремя каскадами. Эти островки сплошь заросли зеленью, причемъ на свъшивающихся къ водъ вьтвяхъ висятъ десятками 
гнђзда ткачиковт, обдаваемыя брызами водопада. Ниже

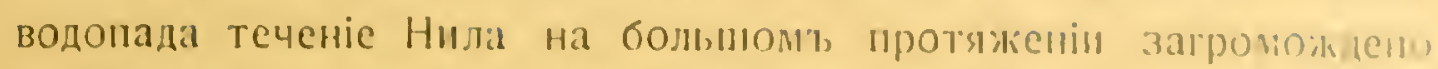

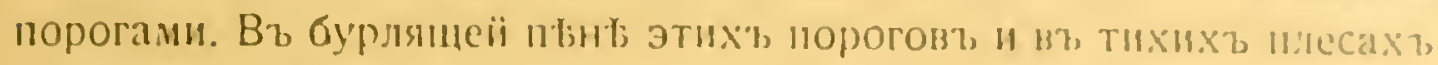
между ними то и дыло выскакивають из\% води крунныс

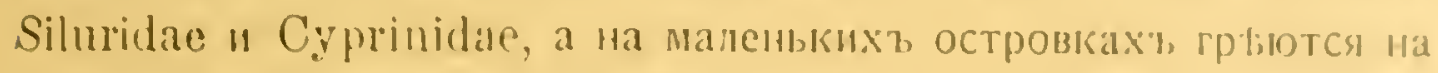
солнць громадные крокодилы. Берега рыки поросли частью вылокой травой, частью мелкимъ, но густымъ кустарникомь и довольно богаты насъкомыми. Преобладаютъ бабочки, особенно picridac.

Сообщеніе между Джинжеї и Мабирской каучуковові илантаціеиі (Mabira Rubber Company) очень удобное. Переґхавт, черезъ вышеупомянутый заливъ на паровокъ паромы, вы садитесь на грузовой автомобиль Мабирскої льсной комианіи, который и доставляетъ васъ черезъ два-три часа на плантацію.

Сначала дорога идетъ по травліктой степи, усьянной рощами акаціiі " эуфорбій, мьстами, на вершинахъ холмовъ, пролегая среди непроходимыхъ зарослей высокой слоновой травы (Ралnisctum). На второй половинъ пути цорога углубляется въ лғсъ, направляясь къ высокому холму, на которомъ бюльютъ домики каучукової плантацін.

Описываемая нами плантація, самая старая въ Угандъ, возникла всего 8 лғтъ тому назадъ, когда одинъ мъстныї англійскій чиновникь впервые открыль, что въ Мабирскомъ лғсу имғются въ большомъ количествь каучуковыя деревья, главнымъ образомъ Funtımia elastica. Для разработки лвсныхъ богатствъ Мабиры немедленно образовалась солиднаэ компанія Съ милліоннымъ капиталомъ, которая и взяла отъ правительства въ аренду весь Мабирскій льсъ, т. е. около 150 кв. верстъ. Сначала компанія довольствовалась эксплоатаціей дикаго каучука, но въ посльдніе годы, когда этотъ запасъ грозилъ изсякнуть, была устроена обширная плантація лучшихъ сортовъ каучуковыхъ деревьевъ, именно бразильской Hevea brasiliensis. Устроена плантація слбдующимъ образомъ: на вершинъ довольно большого холма разбросаны различныя хозяйственныя зданія: контора, сараи, большой и комфортабельный домъ управляющаго, а также нбсколько домиковъ поменьше для его бълыхъ помощниковъ. 
Вся свободная земля на вершинь и всб склоны холма заняты каучуковыми деревьями (Hevea). Это невысокія, подрбзанныя деревья, толщиною въ человъчческое бедро, съ крупными трехюопастными листьями. Деревья рекомендуется сажать на извбстномъ разстояніи, не менъе 10 аршинъ, одно отъ другого. Остающіеся промежутки засаживаются кукурузой или, чапце всего, кустами кофе. Кофе, въ посльддніе годы, становится довольно важнымъ предметомъ вывоза изъ Уганды.

Эксплоатація каучуковыхъ деревьевъ начинается на четвертомъ

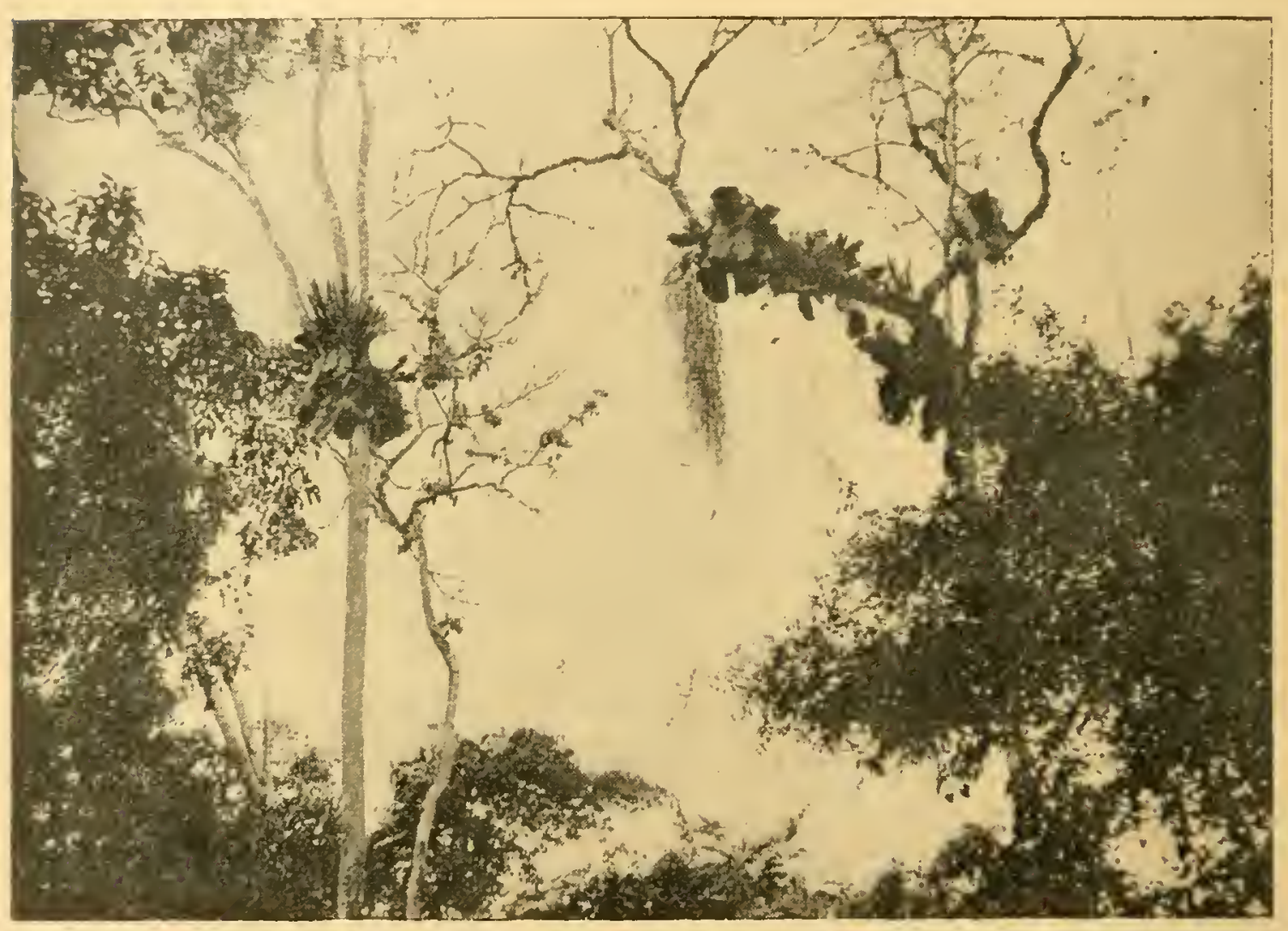

Pис. 5. Эпифитные падоротники.

году посль посадки. Особымъ инструментомъ, въ родъ миніатюрнаго топорика, сдирается съ дерева узкая, но длинная полоска коры. Получается вертикальный желобокъ, длиною въ сажень, заканчивающійся у основанія дерева, на футъ отъ земли. Подъ острымъ угломъ къ главному желобку, по бокамъ его проводятся двъ серіи побочныхъ желобковъ, съ наклономъ книзу и вгадающихъ въ главный. По всей этой системғ желобковъ выдьляемый деревомъ 


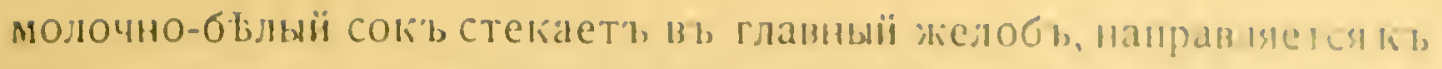

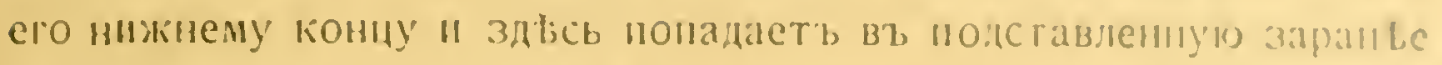

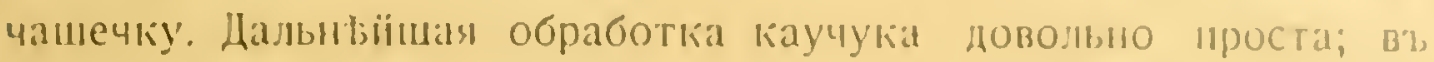

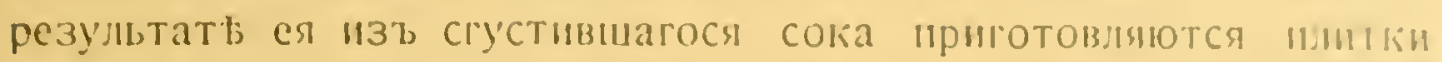
сухої гуттаперчи, которыя " идуть въ иродажу. Въ первыиі годт,

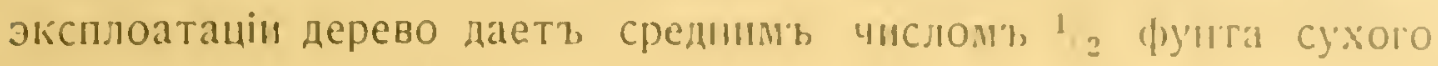

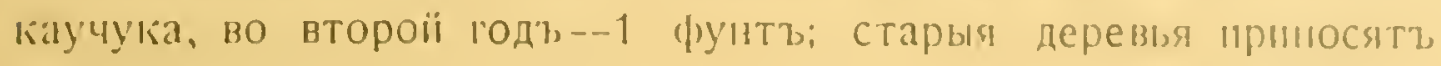
значительно больне. Добываніем' каучука " расииреніслю илантаціи было занято въ Мабирт, болье пятисоть тузелщевъ, находивинхся подт ирисмотромьь восьии англичанъ.

С в холма, занятаго плантаціей, звъздою расходятся во всж стороны дорожки, которыя у его основанія ныряютъ въ гусстоі дъвственный льсъ. Однъ изъ дорожекь ндуть къ негритянскимъ деревнямъ, другія-Къ небольшимъ сосблним'ь птантаціямъ, принадлежащиль тої же компаніи. Вотъ эти дорожки, тянущіяся въ льсу на много верстъ, и служили главнымъ мбстомъ нашихъ экскурсіи и научныхъ сборовъ. По сторонамъ отъ тролинки поднимается густая стйна льсныхъ гигантовъ съ покрывающими ихъ ліанами, эпифитными папоротниками (Pat!леrimm sp.) и т. д. Самые края тропинокъ, гды льсъ расчищенъ, заняты густымъ кустарникомъ. Сплошною зеленою волной выбиваются здъсь растенія изъ почвы кверху, кь свйту, перепутываются, оплетаютъ "душатъ другъ друга, образуя совершенно непроходимыя джунгли.

Любопытно, что жизнь животныхъ въ льсу сосредоточивается главнымъ образомъ на дорогахъ и тропинкахъ, т. е. мћстахъ лучше освъцаемыхъ солнцемъ, въ самой же гущъ лъса жизни почти H占T?.

На самыхъ тропинкахъ нами производились сборы главнымъ образомъ различныхъ насъкомыхъ. Прежде всего поражаютъ наб.юдателя миріады бабочекъ. Въ легкихъ ложбинах`ь. тамъ, гає красная глина дороги сохранила еще въ себь сырость посльдняго дождя. уже издали, за 300-400 шаговъ можно замћтить на земль какія-то яркія цвьтныя пятна, желтыя, былыя. Приближаясь, вы видите, что эти пятна вызваны скопленіемъ тысячт, бабочекъ. Иногда два-три квадратныхъ аршина покрыты силошь сидящили бабочкали. Котория жадно сосуть изъ зенли влагу, засунувъ въ почву свон хсботюи. При 
этомъ, на всемъ указанномъ пространств б бабочки сидятъ такъ т各сно, тәломъ къ твлу, что между ними нельзя просунуть пальца, не задъвъ хотя бы одной изъ нихъ. Многія бабочки, и притомъ нербдко наиболье интересныя и красивыя, садятся особенно охотно на падаль и на пометъ различныхъ животныхъ, Таковы, напримъръ, типичныя лћсныя бабочки рода Charaxes: красивыя, хвостатыя дневницы съ мощными крыльями и быстрымъ, порывистымъ полетомъ, при первой тревогь исчезающія въ чащъ лвса. Подоб.

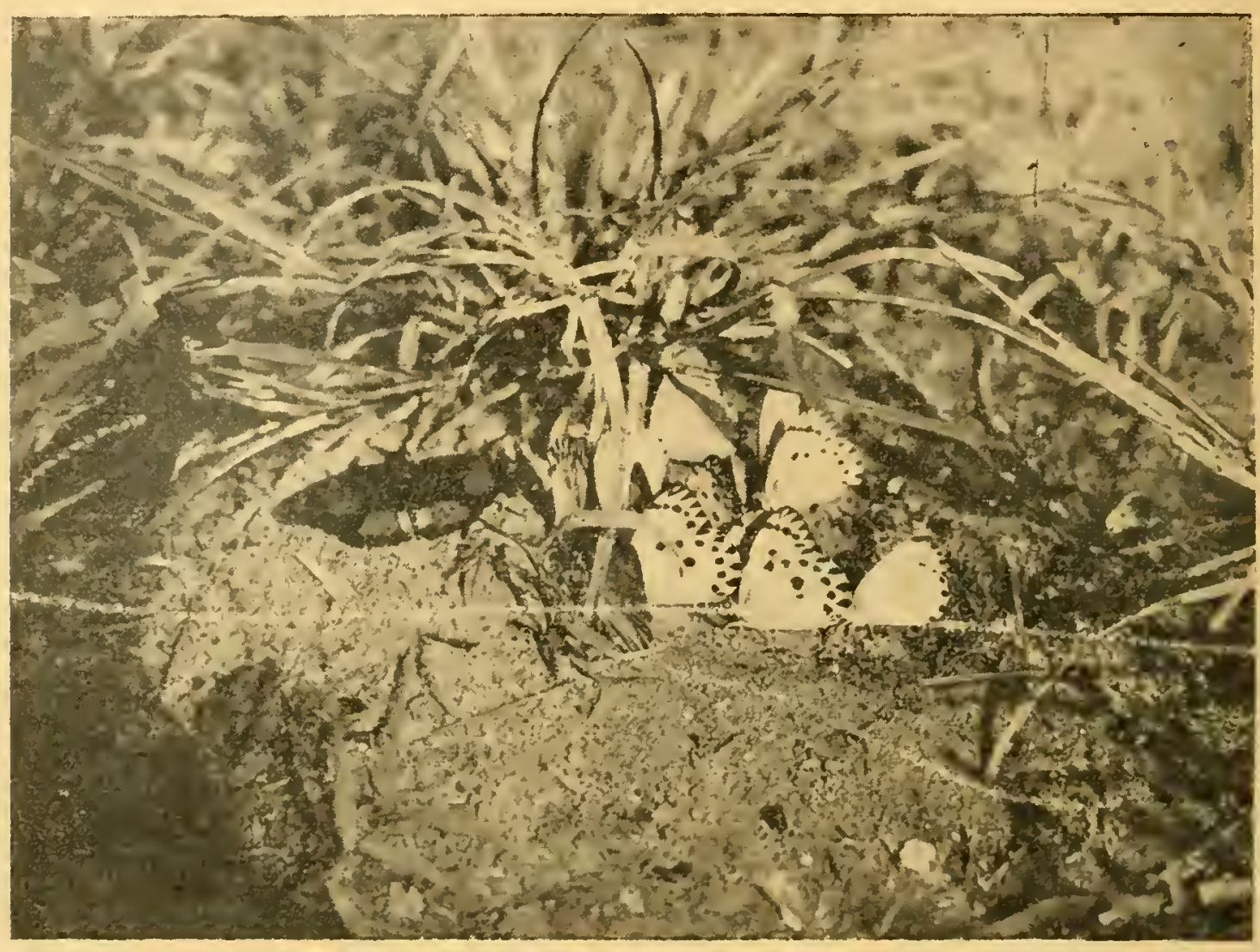

Рис. 4. Бабочни иа дорог"ь.

нымъ вкусомъ бабочекъ и др. насғкомыхъ пользуются нъкоторые причудливые грибы (Dictyophor a). для которыхъ насъкомыяслужатъ, повидимому, распространителями споръ. Такіе грибы испускаютъ ръзкії запахъ падали, привлекая къ себъ десятки видовъ различныхъ мухъ и бабочекъ.

Разнообразіе мабирскихъ бабочекъ очень велико, такъ что мы можемъ здъсь указать лишь на отдъльные виды, особенно бросающіеся въ глаза наблюдателю. Прежде всего становятся 


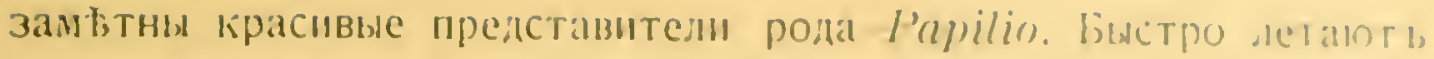

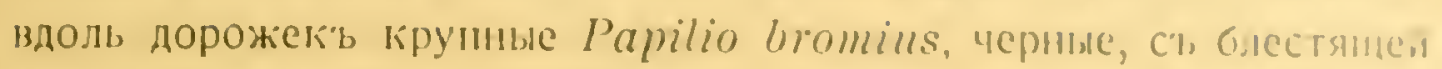

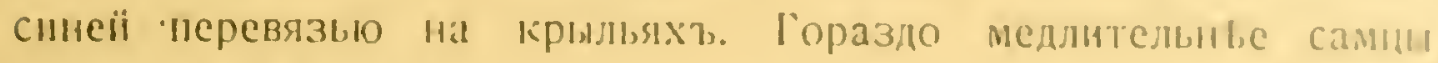
P. dardanks, самки котораго обнаружизатъ иитересинй поли. морфизмъ. Вмћстћ, Съ, этими двумя вндами попалается пироко расиространенный вา, Уганды $P$. demodocus, похожій по вилу na нашего P. machaon. Изрғдка иромелькнетъ траурный громадныі Papilio, повидимому, I' whitnelli. Вьь біологическомъ отношсиіи любопытенъ пестрыіi $P$. mimeticus, въ совериенстнт; полражающіиі защищенной пахучими железами бабочкы Danaida mercelonia. Изъ другихъ Rhopalocera особенно характерны для лtса разиыс виды Charaxes: крупные темно-синіе Ch. castor, красные Ch. lucretius и ярко-рыжіе Ch. monitor, а также нғсколько другихъ. Спеціально льсными бабочками являются и различныя Euphaedra. встрбчающіяся только на самыхъ твнистыхъ тропинкахъ。У береговъ льсныхъ рйчекь во множествь сидять маленькія перламутровыя Cyretis camillus. Pieridae мало разнообразны; однако, только здъсь, въ Мабирскомъ льсу, намъ удалось достать краснвую синевато-зеленую Teracolus thalassina. Изъ другихъ мабирскихъ бабочекъ упомянемъ еще о громадныхъ Hypolymnas и нбсколькихъ видахъ Kallima.

Гусеницы попадались въ меньшемъ количествъ; чю̊м можно было ожидать. Среди нихъ оказалась, однако, одна интересная форма, покрытая массивными и зазубренными ядовитыми волосками, которыми она, при окукливаніи, покрываетъ свиї пергаментный коконъ.

Особенно интересныхъ находокъ по перепончатокрылымъ не было. Фауна прямокрылыхъ, какъ и сльдовало ожидать въ лћсу, довольно бъдна. Вирочемъ, подъ сухими листьями удавалось иногда дйать хорошіе сборы таракановъ.

Изъ Rhynchota насъ заинтересовали любопытныя личинки одного клопа. Эти небольшія, покрытыя бьлымъ налетомъ личинки встрбчались на берегу одного ручья, гды онъ сторожили садящихся на землю бабочекъ. Жертвами ихъ, обыкновенно. становились красивыя Cyretis. 
Изъ двукрылыхъ сльдуетъ упомянуть объ интересныхъ рогатыхъ мухахъ-Diopsis, съ глазами сидящими на длинныхъ стебелькахъ. Кромұ того, въ лъсу во множествй встрбчаются какія-то, ближе не опредъленныя, Simuliidae, вызывающія своимъ укусомъ появленіе на кожь небольшихъ кровоподтековъ. Москиты тревожили насъ въ Мабирғ очень мало.

Жуки, кромъ встрбчавшихся въ Энтеббе формъ, были представлены мнсгочисленными Cerambycidae, которые попадались, главнымъ образомъ, въ окрестностяхъ лъсопильни, на стволахъ огромныхъ срубленныхъ деревьевъ. Тутъ же съ громкимъ жужжаньемъ леталъ и одинъ крупный видъ Buprestidae. Наконецъ, гигантомъ колеоптерологической фауны Мабиры является Goliathus giganteus, подобно нашему майскому жуку летающій вокругь вершинъ высокихъ деревьевъ. Помимо сборовъ на тропинкахъ, мы усердно искали насъкомыхъ подъ корой и въ сухихъ листьяхъ, набирая послъдніе въ холщевые мъшки и затбъм просматривая ихъ дома. Кромъ насъкомыхъ намъ попадались при этомъ мокрицы, клеши, Phalangidae, Pseudoscorpionidae (не менъе 7-ми разн. видовъ.), пауки и многоножки. Pseudoscorpionidae дали довольно большой матеріалъпо эмбріологіи нъсколькихъвидовъихъ. Изъ пауковъ любопытны небольшіе колоніальные Orb itelaria с съ

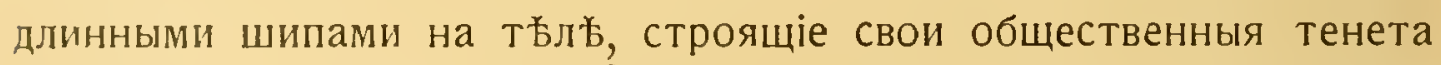
на вътвяхъ, у краевъ тропинокъ. Среди многоножекъ наиболье часто встрбчались Julidae, а также нербдко мы находили и один'ь крупный видъ Polydesmus, въ кишечникъ котораго окаЗались новыя грегарины.

Водныхъ безпозвоночныхъ можно было собирать либо въ небольшихъ льсныхъ ручьяхъ, либо вь ямахъ со стоячей водой, имъввшися кое-гдъ по близости отъ дорожекъ. Фауна этихъ водоемовъ оказалась очень бъдной. Кромъ нбкоторыхъ жуковъ и Ostracoda, можно указать только на креветокъ, водившихся во множествъ въ льсныхъ рбчкахъ.

Позвоночныя представлены въ Мабирскомъ льсу богаче всего птицами, а особенно пресмыкающимися. Посльднихъ намъ доставляли главнымъ образомъ туземцы. Кромъ сцинковъ, агамъ, 


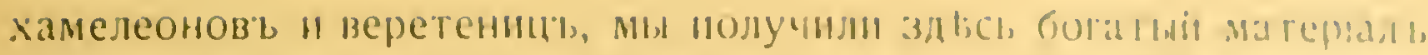

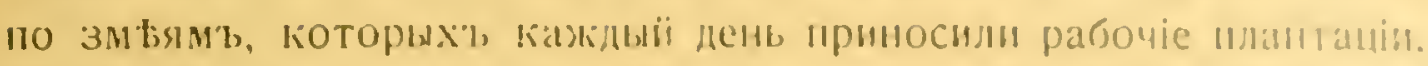

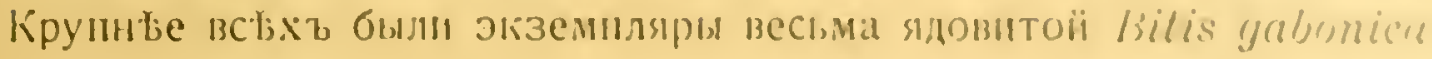
(болье 4-хъ футовъ въ длину). Другіе добытые виды пока еше не опредвлены. Птицы были большею частью ты же, что "вэ, Энтеббе: ткачиіни, турако (Corythcesla), итицын-носороги " т. д. Кромғ того, намъ удалось застрџлить иьсколько красивыхъ
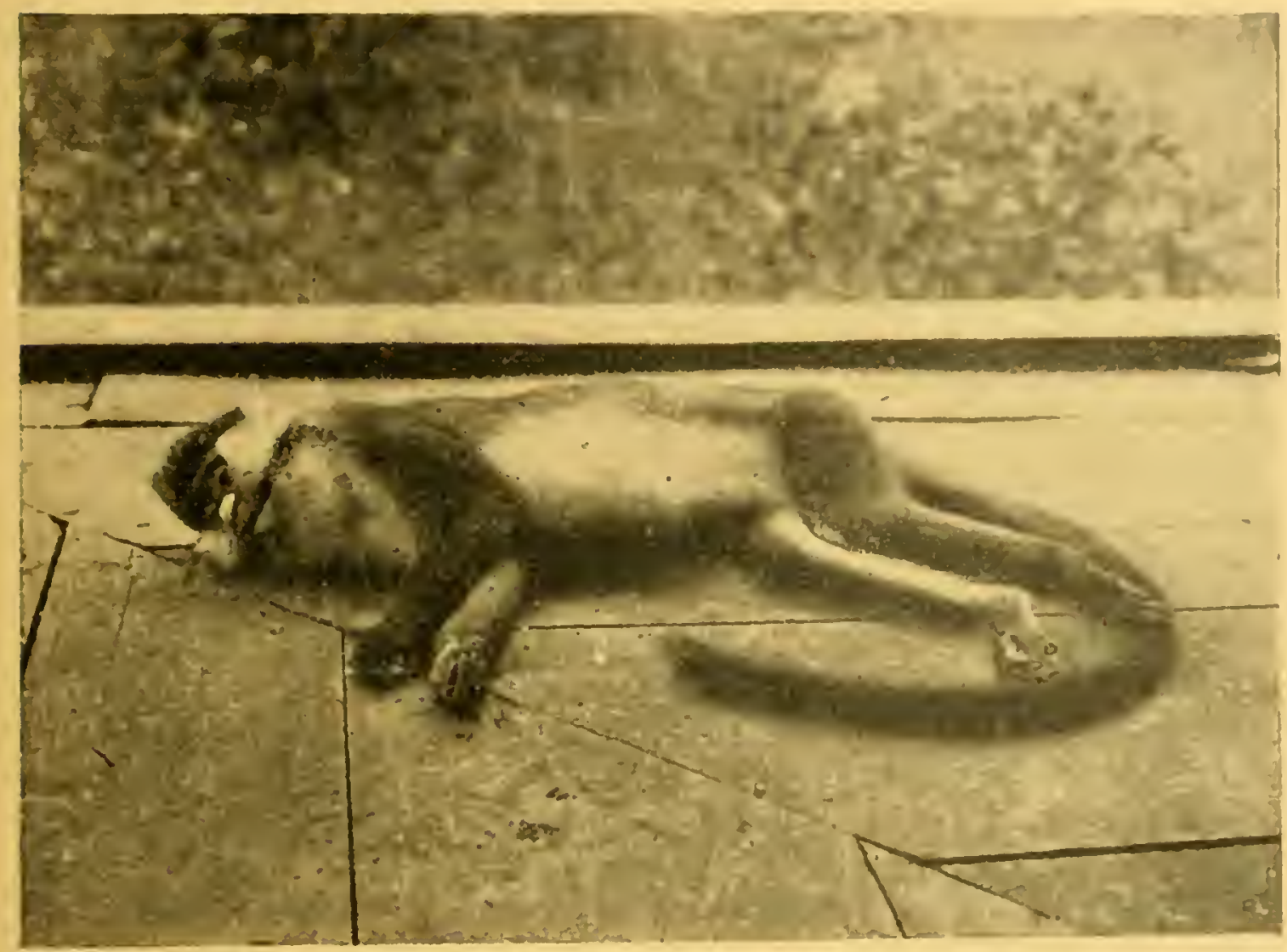

Pirc. 7. Maptünka (Cercopithechs' ruficollis).

Cuculidae и др. Наиболье часто встрғчающіяся Mammalia--это пестро раскрашенныя мартышки Cercopithecus ruficollis " G̈лки. Кромь того, въ льсу имьются, повидимому въ изобилін, древесные даманы (Dendrollyrax), крики которыхъ раздаются каждую ночь, но видъть ихъ намъ не приходилось.

Наконецъ, земноводныя Мабирскаго лыса представлены главнымъ образомъ однимъ видомъ жабъ (Buf(nillк), которыя во множествб встрєчаются на самої плантацін, въ канавахъ, кододцахъ $\|$ Т. ก. 
Всъ́ леречисленныя позвоночныя были изсльдованы въ цйляхъ нахожденія паразитовъ, а у нъкоторыхъ изъ нихъ часть внутреннихъ органовъ была зафиксирована различными способами для гистологическаго изсльдованія.

Пробывъ въ Мабирь около трехъ недбль, мы съ сожальніемъ покинули это мұсто, вернулись въ Джинжу, а оттуда отправились пароходомъ къ конечной станціи Угандской ж. д.--городу Кисуму (который уже проъзжали раньше, на пути въ Энтеббе).

\section{VI. $K$ н $⿻$ у $\boldsymbol{M}$ y.}

Прибывъ въ Кисуму, мы задержались тамъ дня на четыре главнымъ образомъ для того, чтобы ознакомиться съ населяющимъ его окрестности племенемъ Ва-Кавирондо, а также, чтобы постараться добыть различныхъ рыбъ изъ Викторія-Ніанцы. Небольшой городокъ Кисуму выросъ на конечномъ пункть Угандской ж. д.. гдъ товары, идущіе вглубь центральной АФрики, перегружаются на пароходы. Самъ городъ съ его невысокими домиками, спрятанными въ небольшихъ садахъ, раскинулся на склонь пологаго холма. Но вокзалъ съ его пристройками стоитъ у самой воды, недалеко отъ пристани. При вокзаль имъется отдъльный домъ для прівзжихъ (dak-bungalow), нъчто въ родъ гостиницы, содержимой на средства правительства. Здъсь можно за скромную плату (5 рублей въ день) получить комнату и полный пансіонъ. При каждой комнать́ полагается еще маленькая каморка съ ванной. Подобные dak-bungalow им ются на ндсколькихъ важнъйшихъ станціяхъ. Угандской дороги и представляють очень большое удобство, особенно тамъ, гд⿱⺊口 нътъ ни одного отеля.

Мћстность вокругъ Кисуму имъетъ, правда, унылый, но довольно своеобразный характеръ. Эго-плоская, выжженная солнцемъ равнина, покрытая короткой, ощипанной травкой и лишь кое гд⿱ заросшая кустарникомъ. Изъ высокихъ деревьевъ бросаются въ глаза только канделябровыя эуфорбіи съ ихъ темной, мрачной зеленью, да любопытныя кигеліи (Kigelia) съ аршинными, по- 


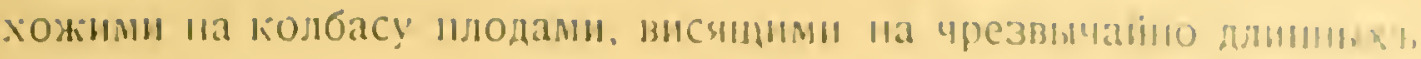

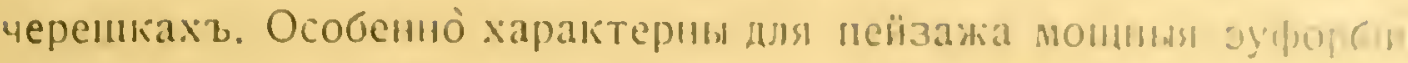

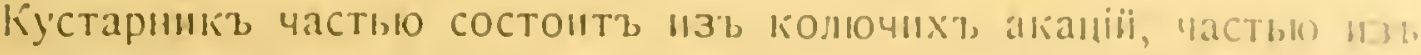

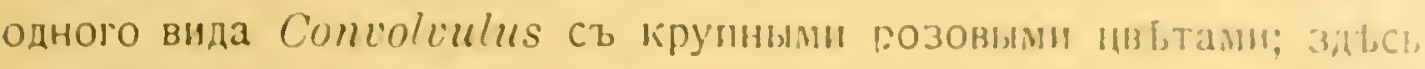

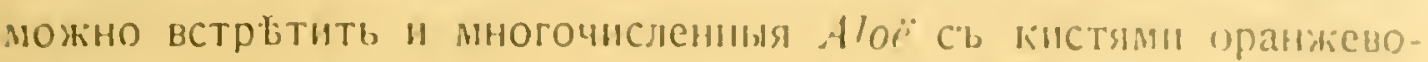

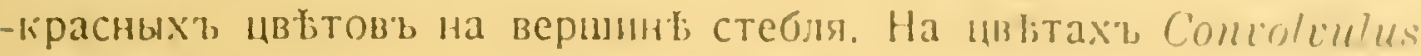
десятками сидять пестрые Mylabridae, въ акаміяхъ и Alö рас. кинуты тенета многочисленныхь пауковъ (Lpeiridar), а вокругъ

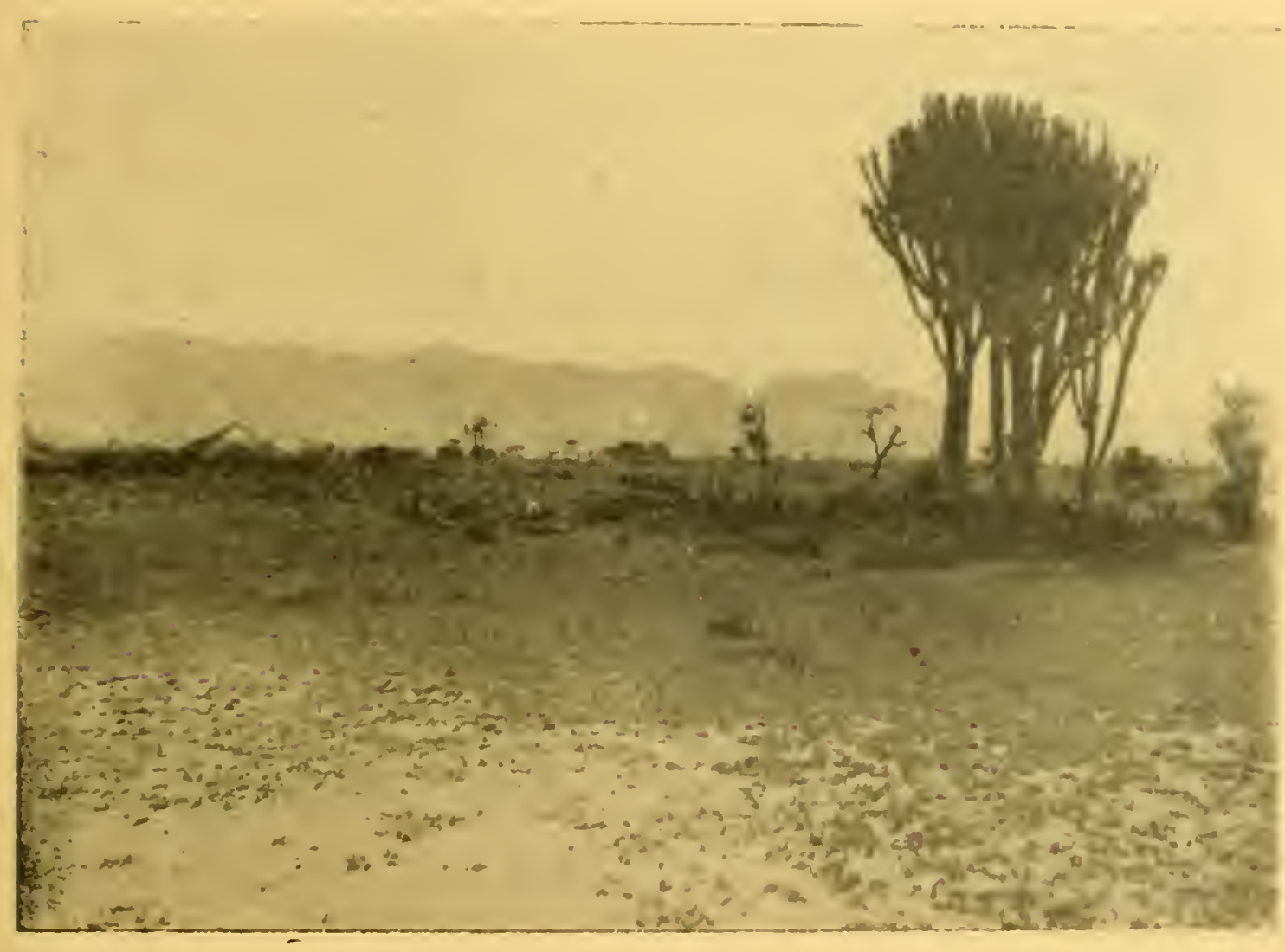

Рнс. 6. Јандшафть близт Кисуму.

душистыхъ цвътовъ одного нензвъстнаго намъ кустарника носятся весьма многочисленныя и разнообразныя перепончатокрылыя. Вотъ главное, что было нами отмбчено изъ мұстныхъ насғконыхъ.

Тамъ и сямъ на равнинб разбросаны деревушки племени Ва-Кавирондо. Несмотря на о́лизость желъзной дороги и другихъ признаковъ цивилизаціи, это племя во многихъ отношеніяхъ больше другихъ сохранило черты первобытнаго состоянія. такъ что вся- 
кій пробзжій европеецъ считаетъ своимъ долгомъ остановиться въ Кисуму и повидать Ва-Кавирондо. При мимолетномъ посћщеніи. каково было наше, въ глаза бросается, главнымъ образомъ, примитивность въ одеждъ или, правильнье, отсутствіе одежды. Мужчины Ва-Кавирондо сплошь и рядомъ ходятъ совершенно голые, или же набрасываютъ на плечи телячью шкуру (немногіе счастливцы щеголяютъ въ леопардовой). Руки и ноги украшаются браслетами

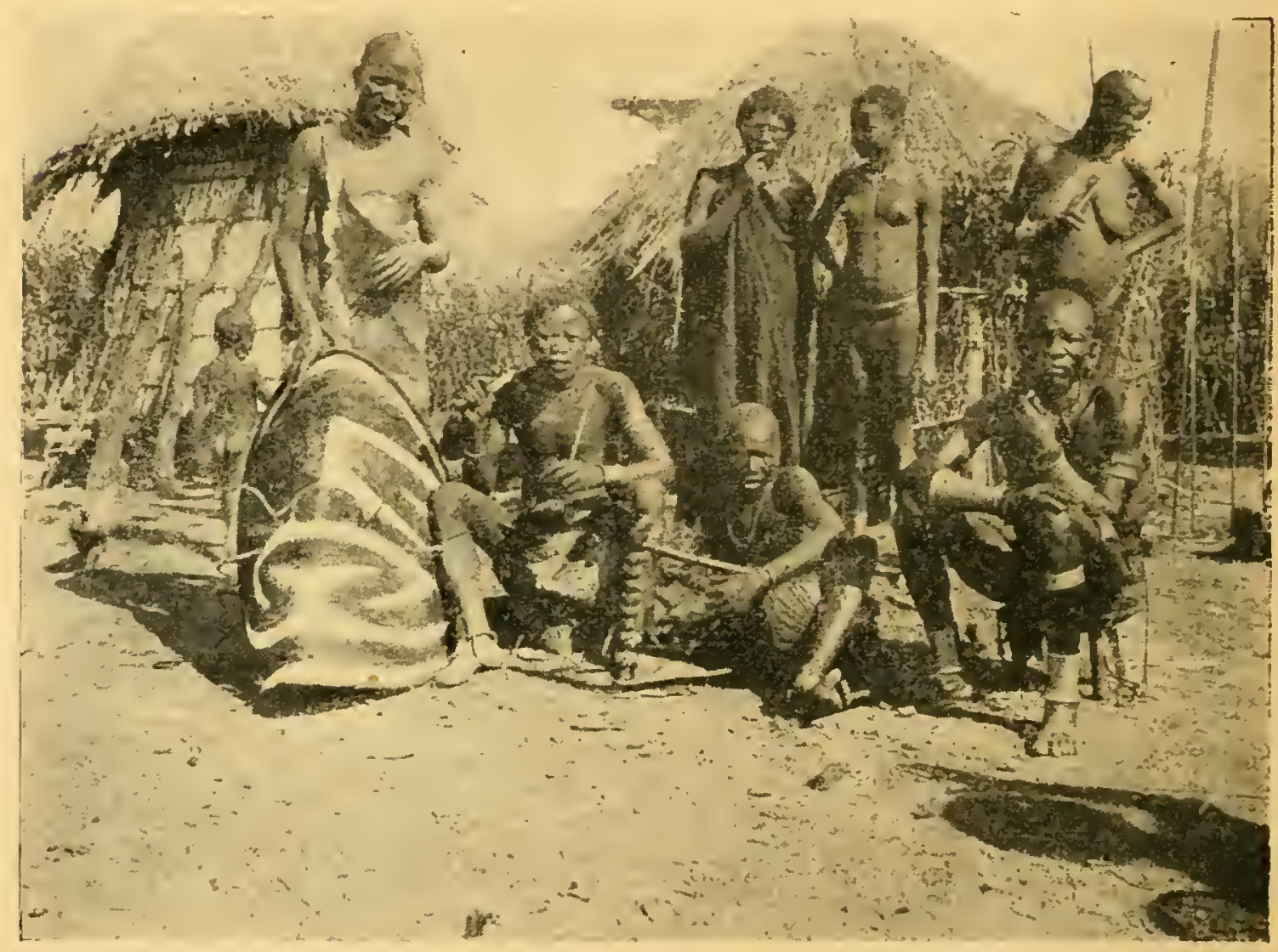

Рис. 9. Группа Ва-Кавирондо.

либо изъ колецъ мъдной проволоки, либо изъ изящно вырбзанныхъ кожаныхъ колецъ. Прическа,-весьма важный отличительный признакъ негритянскихъ племенъ,-у Ва-Кавирондо очень простая: голова бреется, и только на темени, а иногда и по бокамъ головы оставляется по небольшому клочку волосъ. Зато нербдко голову обхватываетъ діадема с’ь торчащими кверху страусовыми перьями. Подобно многимъ другимъ племенамъ восточной Африки туземцы охотно раскрашиваютъ себъ лицо и твло красной " желтой краской. 


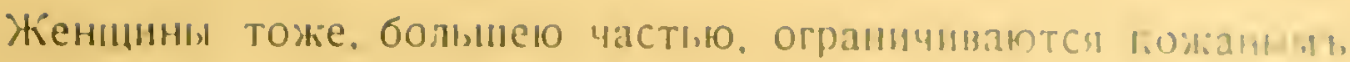
nояскомт, оть которато спереди свиниваетея узиін передини,

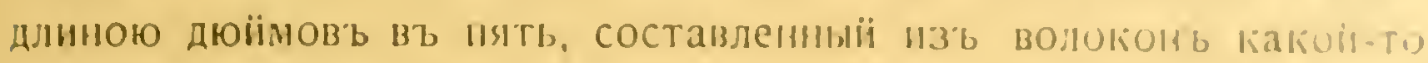
травы, или же изь стальныхъ гонкиху ивиочекь, у за. мужнихъ къ тому же пояску, но сзади, подвынивается пунистыи хвсстъ изъ сухой травы. Женщины не раскранизають, себя, но)

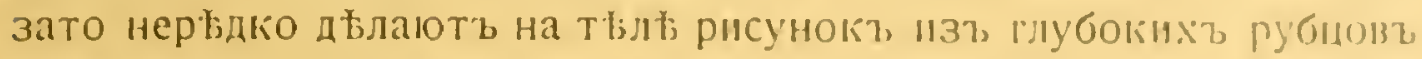
Повидимому, туземцы уже привыкли кь иосытителямь и охотно позваляютъ себя фотографировать за небольшой бакиишъ.

Деревни Ва-Кавирондо всъ построены на одинъ ладъ. Деревня всегда окружена живоі колючеі изгородью или наваленным' вкругъ колючимт, хворостомъ (такъ называемая сбомал). Внутри. вдоль изгороди кольцомъ стоятъ круглыя хижины съ высокими, коническими соломенными крышами. Хижины обмазаны глиной. на ко́торой по сторонамъ двери выведенъ иногда крупныи, но простой орнаментъ въ вида зигзаговъ.

Внутри круга хижинъ помъщается кольцо или кучка небольшихъ амбаровъ для зерна и т. п. Они имъютъ видъ крупныхъ ульевъ, поставленныхъ на кривыя деревянныя ножки. Наконецъ, самый центръ деревни занятъ площадкой утоптаннаго навоза: сюда сгоняется на ночь скотъ. Навозъ идетъ для топлива; его собираютъ, льпятъ изъ него руками шарики "раскладываютъ на солнць сушиться. Тутъ же рядомъ сушится на рогожкъ и просо. Сначала женщины приносятъ съ полей кисти просо, краснаго или лиловаго цвъта; затвмъ ихъ сушатъ, женщины сбиваютъ съ кистей зерна и собираютъ въ плотныя плетеныя корзины. Кромь проса видна на поляхъ кукуруза; бананы же, столь распространенные какъ на морскомъ берегу, такъ "въ Угандъ, здъсь отсутствуютъ. Мєстами около хижинъ видны растянутыя на земль бычачьи шикуры, прнбитыя по краямъ къ земль колышками и сохнущія въ ожнданіи дальнъйшей выдълк. Дальше онь идутъ и для плащей и для обтяжки огромныхъ, выпуклыхъ двускатныхъ щитовъ, которые у Ва.Кавирондо въ большой модъ. Часть волосъ на шкурахъ при этомъ низко выстригается "получаются разные незатъйливые узоры. О близости кавирондской 
деревни можно легко догадаться по воткнутымъ около нея въ землю высокимъ шестамъ, на которыхъ болтаются какіе-то стран ные привъски. Эти шесты столь же характерны для мбстныхъ поселковъ, какъ колодезные журавли для нашихъ деревень. При ближайшемъ разсмотръніи оказывается, что на шест各, одна надъ другой, висятъ нъсколько маленькихъ, плетеныхъ изъ прутьевъ кльтокъ, а въ каждую посажена перепелка, которыхъ туземцы ловятъ и откармливаютъ на убой.

Туземцы, вообще говоря, большіе лакомки и готовы подчасъ щедро заплатить за вкусное блюдо. Такъ, напримбръ, они охотно покупаютъ у бълыхъ. рыбаковъ рыбу, платя за нее довольно дорого. Ва-Кавирондо и сами ловятъ рыбу огромными вершами, но главные рыбные поставщики-европейцы.

Нъсколько ль⿱宀ъ тому назадъ правильную рыбную ловлю въ Кисуму организовалъ одинъ датчанинъ-Аропъ и теперь 'у него уже есть два или три конкуррента. Наиболье нбжная рыба продается на мбсть⿱㇒㠯, тогда какъ бо́льшая часть улова отправляется въ столичу края-Найроби. Чтобы получить матеріалъ по рыбамъ, мы, прежде всего, посьтили мъстный рынокъ, а зать́ьъ совершили поғздку по озеру въ лодк占 Аропа и сами ловили рыбу большою сбтью. На рынк各, кишащемъ голыми продавцами и покупателями, выборъ рыбъ очень невеликъ; мы видъли только четыре разныхъ формы: сомы, крупные карпы, интересные, длиннорылые Mormyridae и такъ называемая «масляная рыба (butter-fish). Повздка съ Аропомъ пополнила нашъ сборъ нєсколькими мелкими видами Acanthopteri, а главное, дала намъ возможность пріобрбсти большого Protopterus, в`ъ аршинъ длиною. Вообще, Кисуму можеть шовидимому, служить базой для ихтіологическихъ изсльдованій на Викторіи-Ніанцъ.

- Изъ Кисуму мы отправились по жельзной дорогь на станцію Моло.

\section{VII. Мопо. Накуру.}

Для изслбдованія горной фауны нами была выбрана станція Моло, въ горахъ Мау. Станція эга лежитъ приблизительно на полпути между Кисуму и Найроби, на самомъ гребнь́ хребта 


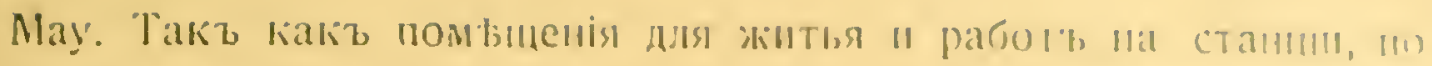

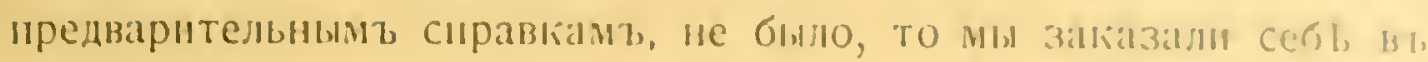

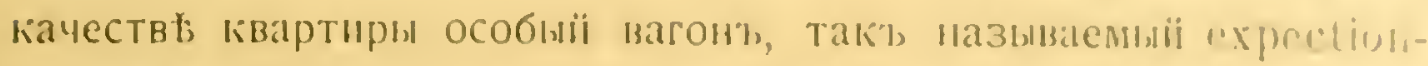
- carriage. Дьло въ томт, что У'андская ж. д. сдаетт, за изиястнук плату внаймы вагоны І-го или И-го класса, которые ирицынляютея кь любому пођзду, и, ири желаніи, оставляются на любої изь станціиі на запасноми пути иа неоредыленно долге времи. Всякії, бдущій въ В. Афрнку Съ научной цъљю, навтрнос, может? разсчитывать получнть подобный вагонъ. Въ пути за такой вагонт, взимается стоимость восьми билетов’ь І-го класса, каждый же ден, остановки оплачивается 8 рублями. Вагонъ подъленъ перегород-

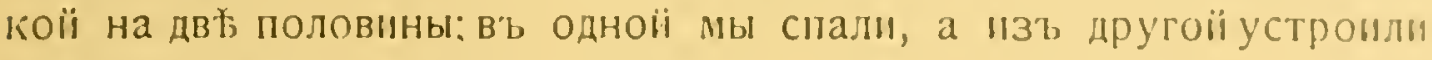
кладовую и лабораторію.

По мғрб подъема отъ Кисуму на вершину горнаго хребта становится все холоднғе. Моло находится на высот́ 8000 футовъ, что даетъ по сравненію съ берегами Викторіи-Ніанцы раз. ницу въ 5000 футовъ. Соотв тственно съ этимъ и климатъ совершенно иної. Большую часть нашего пребыванія въ Моло (а пробыли мы тамъ \& дней) небо было пасмурное, ежедневно шелъ дождь, а по утрамъ температура падала до 90 С. Такая температура чувствуется в’ь тропикахъ, как'ь у насъ 2-30 С. Ночью приходилось спать въ вагонъ, на половину не раздъваясь.

Общій характеръ мбстности въ Моло сльдующій. Вершина хребта Мау состоитъ изъ нбсколькихт рядовъ холмовъ съ пологими склонами и закругленными верхушками; только мъстами ложбины между холмами становятся узкими и глубокими, превращаясь въ ущелья.

Холмы покрыты густымъ, высокимъ лћсомъ, съ которымъ красиво чередуются большія поляны и луга. Растительность на лугахъ поражаетъ своимъ сходствомъ со средне-европейской: такіе же злаки, незабудки, сложноцвб̆тныя, коровяки. цикоріи, что-то въь родъ клевера и т. д. и т. д. Лъса состоятъ главнымъ образомъ изъ хвойныхъ деревьевъ, а именно изъ гигантскаго можжевельника съ листьями какъ у туйи (Juniperus procera), ко- 
торый мъстные англичане называют’ кедромъ. Кромъ того много древовидныхъ Ericaceae.

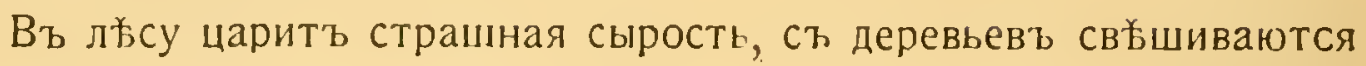
сбдыя космы лишаевъ Usnea, стволы же и лерекидывающіяся

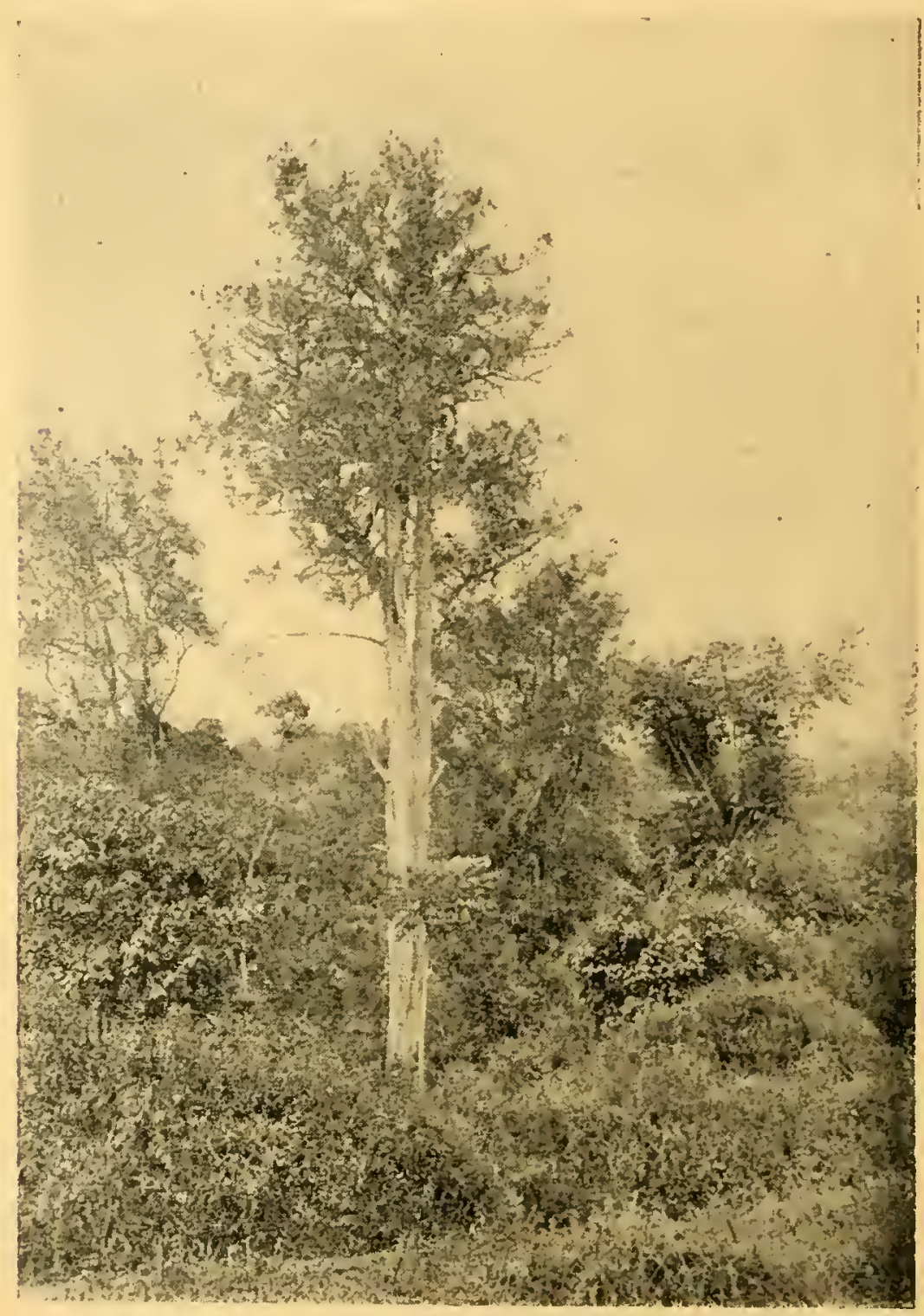

Рис. 10. Можжевельниъ (Juniperus procera).

съ дерева на дерево ліаны покрыты толстымъ слоемъ ярко-зеленаго мха, пропитаннаго водой, какъ губка.

Въ ущельяхъ, на небольшихъ полянахъ высятся гигантскія (до 4-хъ саженъ) лобеліи (Lobelia), придающія ландшафту совершенно своеобразный характеръ; эти растенія являются типичными для высокогорной флоры, встръчаясь, кромғ горъ Мау, на 


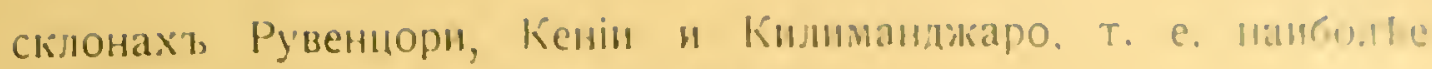
крупныхъ горныхь массизови, Африки.

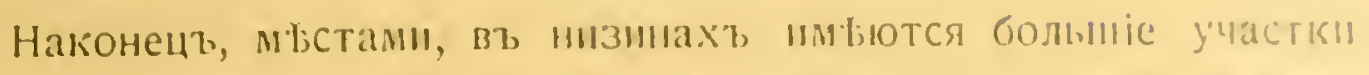

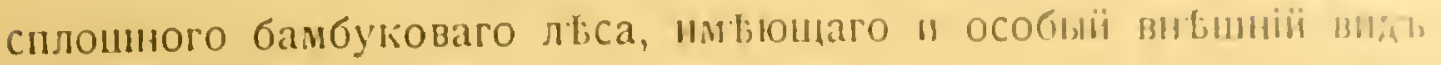
1 характерную фауну.

Животныі міръ Моло, особенно 110 сравненію с', Угандой, поражаетъ своею бъдностью. Изъ млекопитающихъ мы видли

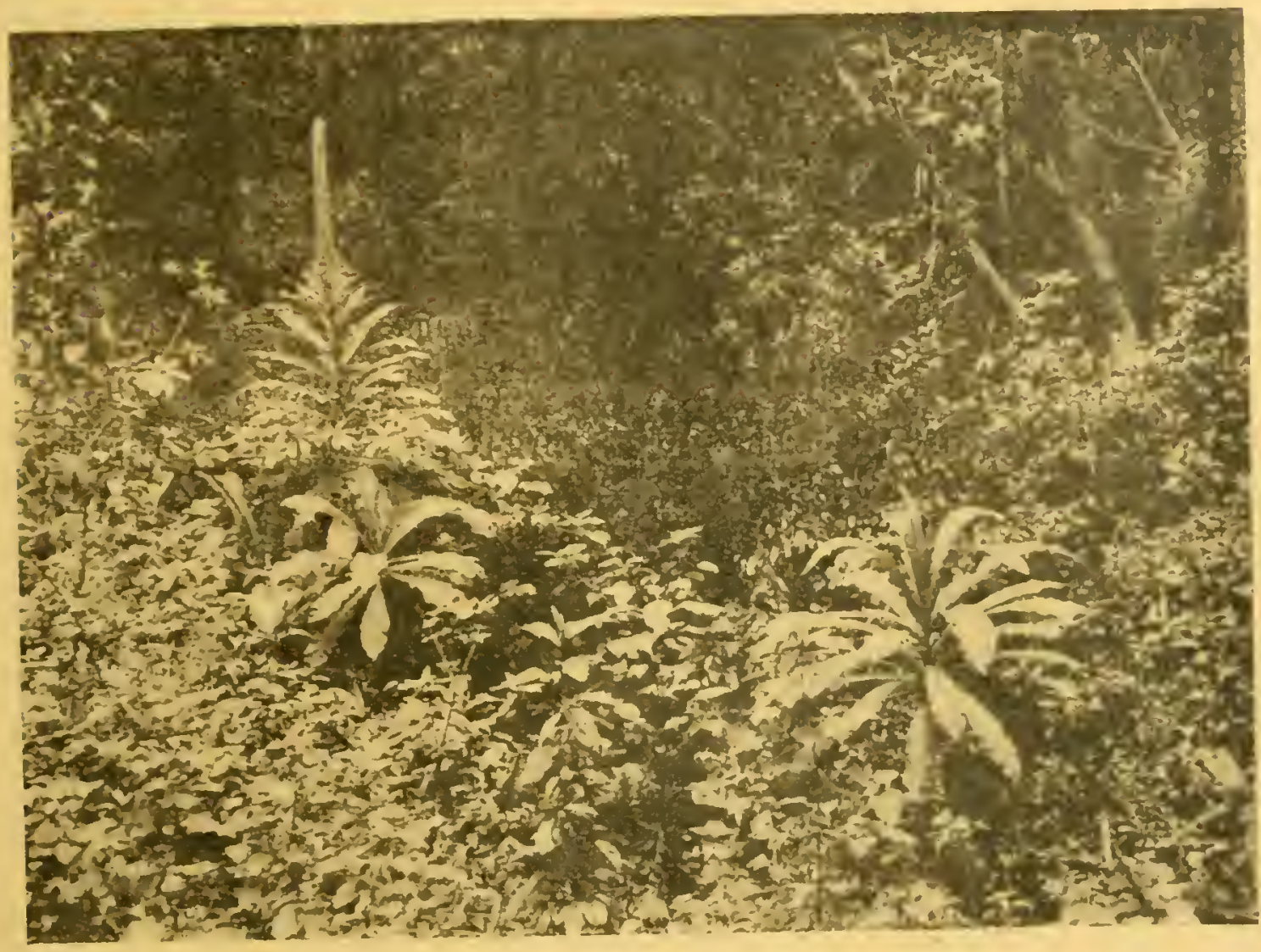

Рис. 11. Тобеліи въ пђсу близт, Моло.

бълокъ и только что убитаго леопарда, давшаго матеріаль по паразитамъ и по гистологіи разныхъ внутреннихъ органовъ. Правда, здъсь водятся красивыя черно-бълыя обезьяны (Colobus), но подобраться к’ъ нимъ очень трудно, такъ какъ онъ живутъ въ самой чащъ льса. Птицы представлены богаче, но мало отличаются отъ птицъ Уганды: бросаются въ глаза ты же турако, птицы-носороги, вдовушки и медососы. Изъ пресмыкающихся больше всего хамелеоновъ (нбсколько видовъ). которые здысь 
лазаютъ по стеблямъ злаковъ и по кустамъ на полянахъ. Амфибій довольно много, есть и лягушки, и жабы и древесницы (Hyla). Особенно замътна бъдность фауны летающими насъкомыми, любящими солнечный свътъ: немного бабочекъ (Pieridae, два или три вида Papilio, нъсколько видовъ Nymphalidae и Lyсаеnidae и много 7ygaenidae), еще меньше клоповъ, поражавшихъ своимъ обиліемъ въ Угандъ, и мелкіе, невзрачные жуки. Изъ перепончатокрылыхъ довольно многочисленны и разнообразны только пчелы Хylocopa. Весьма обыкновененъ одинъ видъ муравьевъ, устраивающихъ свои бумажныя гнизда, величиной съ человъчческую голову, на верхушкахъ невысокихъ деревьевъ.

Болъе интересные сборы можно сдълать только подъ гніющими листьями, подъ поваленными деревьями и въ дуплахъ деревьевъ. Кромъ муравьевъ и термитовъ, намъ попадались здъсь различныя многоножки (Julidae, Strongylosoma, Chilopoda), жуки, нъсколько наземныхъ планарій, Phalangidae, Pse ud os corpi on idae. пауки и дождевые черви. Одинъ крупный паукъ изъ Epeir id aе живетъ большими сообществами. Свои тенета онъ протягиваетъ на большія пространства и подвъшиваетъ к’ нимъ свои коконы. Единственная богатая представителями группа животныхъ въ Моло-это моллюски, какъ наземные, такъ и водяные. Среди наземныхъ особенно много слизней, то темныхъ, то желтоватыхъ, то очень пестро и ярко раскрашенныхъ. Влажность льса, повидимому, является особенно благопріятнымъ условіемъ для ихъ существованія.

Бъдность фауны заставила насъ бросить Моло скор‡е, чъмъ мы думали, и отправиться дальше по жельзной дорогъ къ озеру Найваша, куда насъ любезно приглашаль погостить въ свое помъстье майоръ Гроганъ, одинъ изъ мъстныхъ богачей. Посль двух. дневной остановки въ городкъ Накуру, гдъ, на солоноватомъ озеръ того же имени, мы наблюдали бегемотовъ и огромное количество разной водяной птицы, мы прибыли въ Найвашу.

Вообще, слғдуетъ замғтить, что для орнитолога озеро Накуру представляетъ хорошее мъсто сборовъ. Такъ, на степи, окружающей озеро и поросшей Andropogon мы видъли велико- 


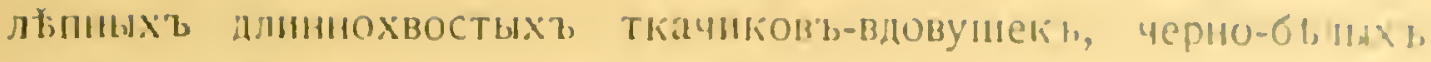

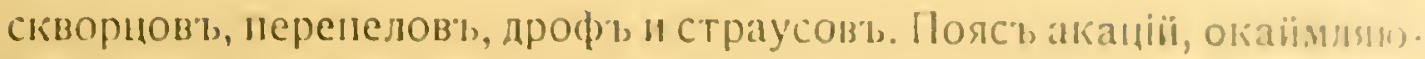
щіиі берега озера, кишитъ различиыми ткачиками, мелососыми,

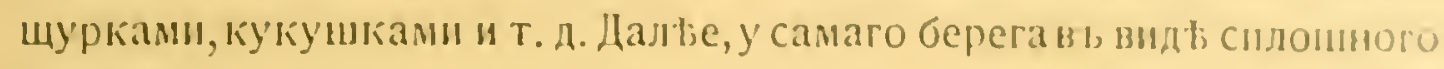

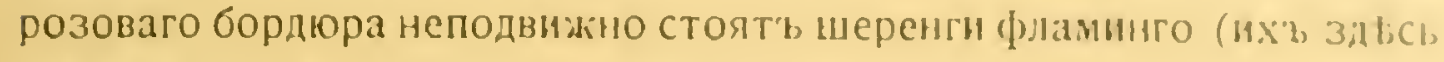
два вида), стан которыхъ насчитываютьы шо ныскольку сотю итукъ. Тутъ же шмыгают’ь юркіе чнбисы, крнчат’ь чаікин и крачки и роются въ илу свонми длинными клювами священныя птицы древнихъ, Егигтянъ-ибисы (черный и бтлый съ черной каймой на крыльяхъ). Наконецъ, спокойныя воды озера испещрены безчисленными точ. ками плавающихъ и ныряющихъ утокъ.

\section{VIII. Озеро Найваша.}

Станція Найваша, подобно Накуру, лежитъ въ большой долинь (the great Rift Valley), пересъкающеї съ съвера на югъ восточно-африканское плоскогорье. На западъ долина ограничена вышеописаннымъ хребтомъ Мау, на востокъ же изъ нея круто поднимаются горы Абердаръ. Дольна эта, какъ уже говорилось, имŁетъ около ста верстъ въ ширину и нъсколько сотъ верстъ въ длину.

Станція находится почти у самаго озера Найваша, а верстахъ въ двънадцати отъ станціи, на берегу озера, расположилось имъніе Лонгонотъ, въ которомъ мы провели двъ недъли. Это одно изъ многочисленныхъ помьстій майора Грогана, имьющаго земли въ самыхъ различныхъ уголкахъ Брит. Вост. Африки. Эти земли Гроганъ получилъ за свои важныя заслуги по открытію Протектората для англіїскаго вліянія. Какъ у насъ встарину огромные участки земли давались первынъ піонерамъ въ Сибири, Строгановымъ, такъ и здъсь Гроганъ, благодаря щедрости англійскаго правительства, сталъ магнатомъ, во власти котораго находится нұсколько сотъ квадратных"ъ верстъ земли. Такъ, одно только Лонгонотское имєніе равняется, приблизительно, ста квадратнымъ верстамъ. Подобныя же обширныя владънія имьются и еще у нъсколькихъ лиць (между которыми сльдуетъ указать на 
любителя-натуралиста лорда Деламира), принимавшихъ участіе въ захвать и организаціи колоніи.

Имъніе, о которомъ идетъ рбъч, раскинулось отъ береговъ Найваши на восток'ъ вплоть до подножія высокаго вулкана Лонгонотъ (10.000 футовъ). Единственный небольшой обработанный участокъ имънія лежитъ у озера. Здъсь имъется два небольшихъ дома для бълыхъ управляющихъ и „шамба“, или плантація, а

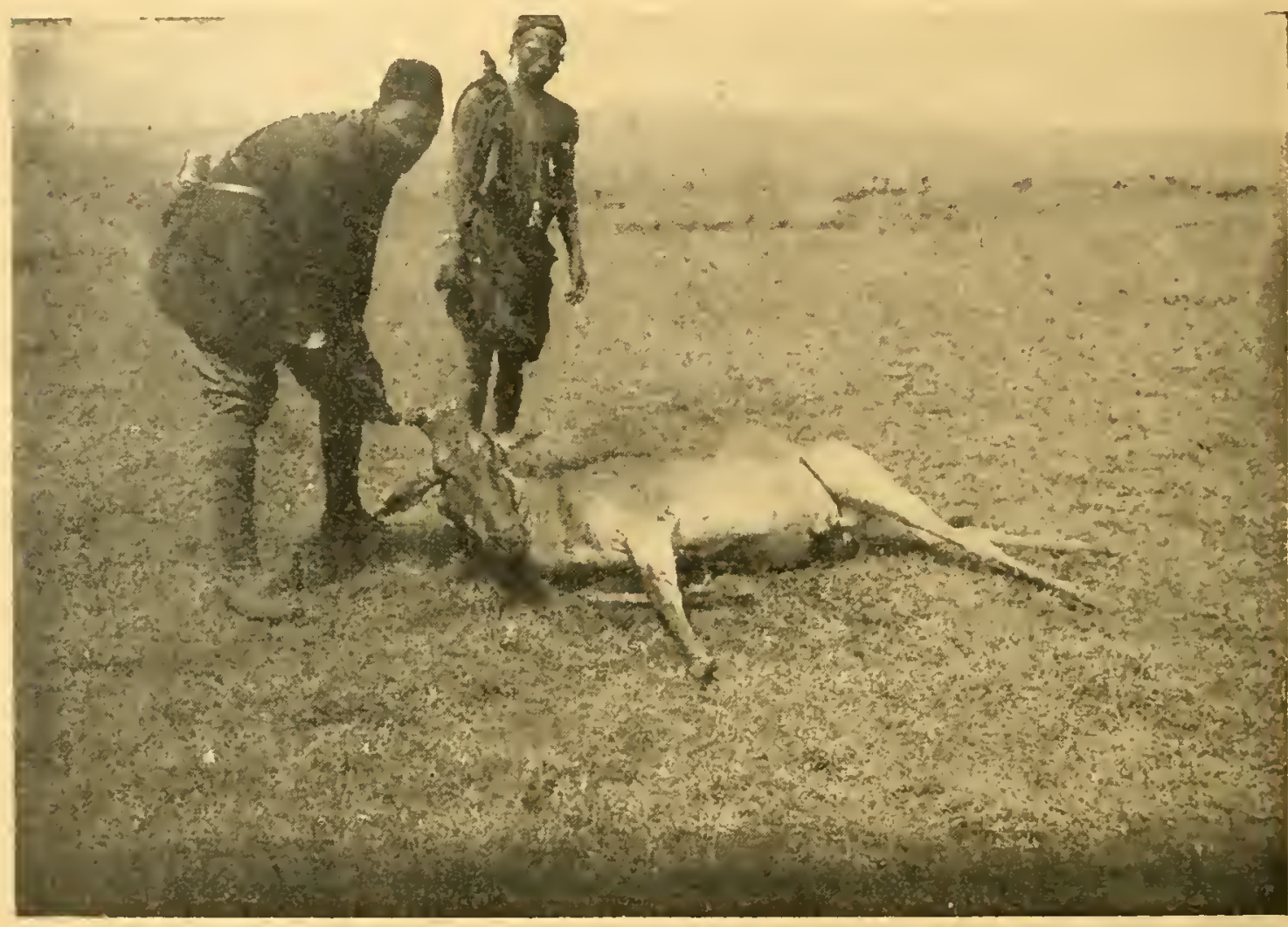

Pне. 12. Конгони (Bubalis cookei).

рядомъ съ ней-страусовая ферма съ нбсколькими десятками страусовъ. Страусы настолько приручены, что днемъ ихъ пасутъ на воль два-три негра, а ночью птицъ, въ защиту отъ леопардовъ, загоняютъ въ загородку. Леопарды постоянно совершаютъ набъги на шамбу, такъ что противъ нихъ поставлено по сосъдству съъ ней нъсколько ловушекъ. Ловушки устроены по принципу мышеловокъ, причемъ приманка (овца или просто большой кусокъ мяса) помъщается въ глубинъ ловушки, сдъланной изъ прочныхъ досок'ь и кольевъ. 
Берега озера Найваши окаімлены, несмотря на зауителиную

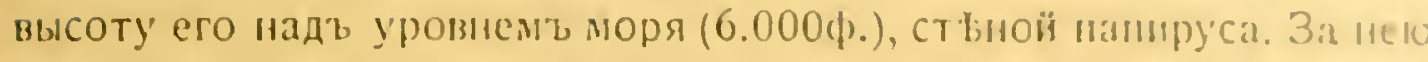
идетъ полоса гестыхъ зарослей желтостволнныхь акацій и др. деревьевъ, а далье разстилется стеиь. мыстами чистая, мьстами покрытая, напоминаюцими серебристую иву кустиками „элелсио“ (Tarchonantus eamphoratus). Въ ньсколькихъ верстахь отъ берега выступаютъ гребни крутых’ы холмовъ, слокенихъ

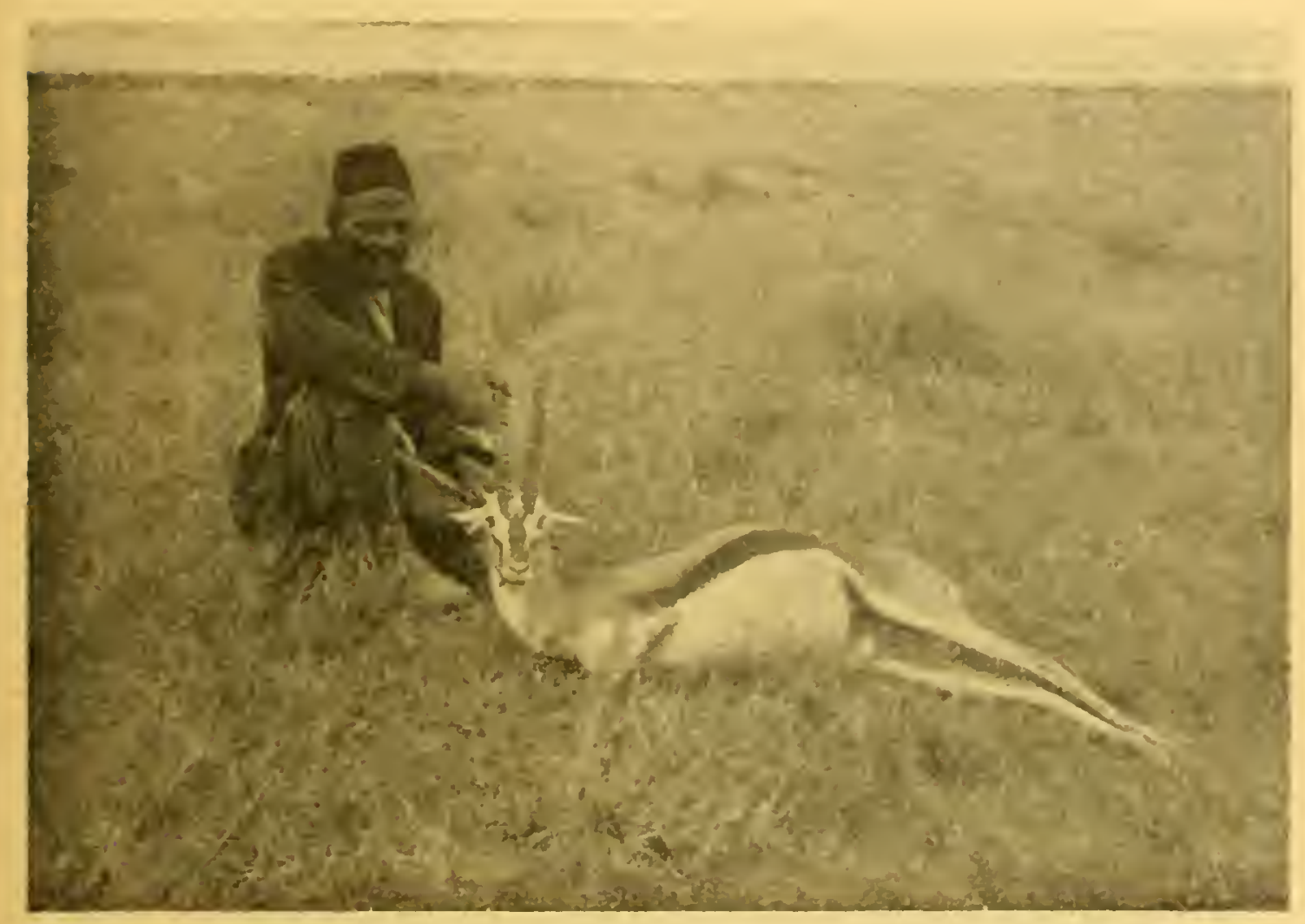

Pис. 13. Газель Томсона (Gazellaithomsoni).

- изъ вулканическихъ породъ, нер‡дко изъ прекрасныхъ базальтовыхъ колюннъ. Гребни эти постепенно переходятъ въ основаніе вулкана Лонгонотъ. Между посльднимъ и озеромъ мғстами тянутся лавовые кряжи, на которыхъ пышно развиваются разныя эуфорбіи и алоэ и цилый рядъ разнообразныхъ кустарниковъ. Въ этихъ заросляхъ любятъ держаться львы и леопарды.

Главною цълью нашего пребыванія въ Лонгонотъ было добываніе матеріала по паразитамъ и по гистологіи крупныхъ млекопитающихъ, и, надо замњтить, что это мьсто для данной 
работы оказалось весьма удачнымъ. Во-первыхъ, окрестности необычайно богаты дичью, во-вторыхъ же у насъ была возможность съ удобствомъ обрабатывать матеріалъ, пользуясь прекраснымъ помьщеніемъ въ домъ управляющаго.

Прежде всего, намъ удалось здъсь собрать, частью самимъ,

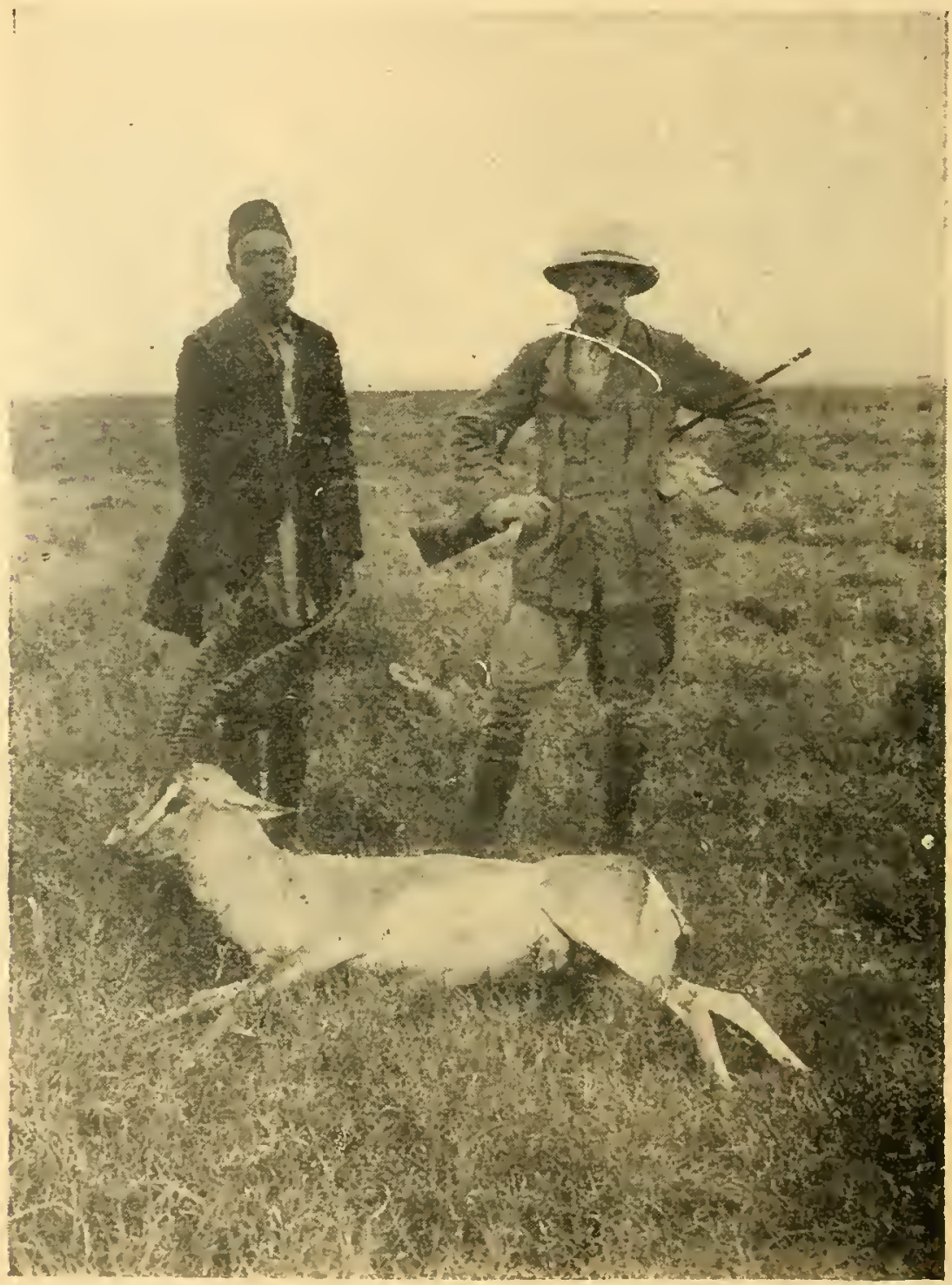

Рис. 14. Газель Гранта (Gazella granti).

частью при помощи управляющаго, г-на Хигнелля, матеріапъ по внутрикишечнымъ инфузоріямъ различныхъ копытныхъ. Въ стеги кругомъ нашего дома бродило безчисленное множество антилопъ конгони (Bubalis cookei), газелей Томсона (Gazella thomsoni) и Гранта $(G$. granti) и зебръ. На заросшихъ кустами „элелешо“ 


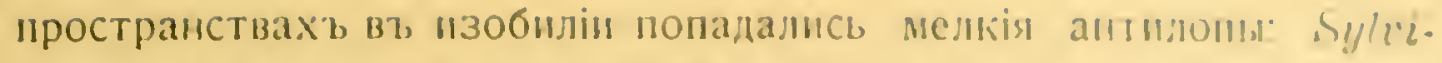

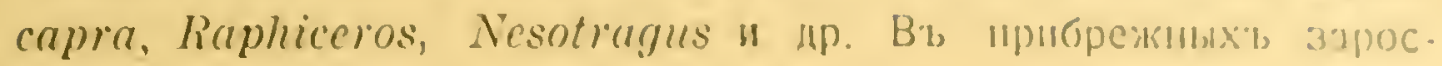

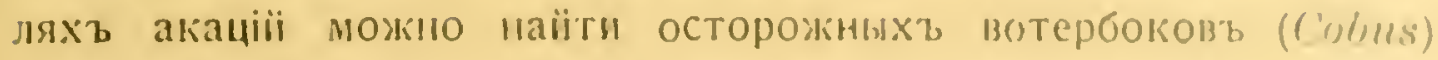
" рыжихъ бушбоковъ ('Tragelaphиs). Наконсцъ, на покрытыхь

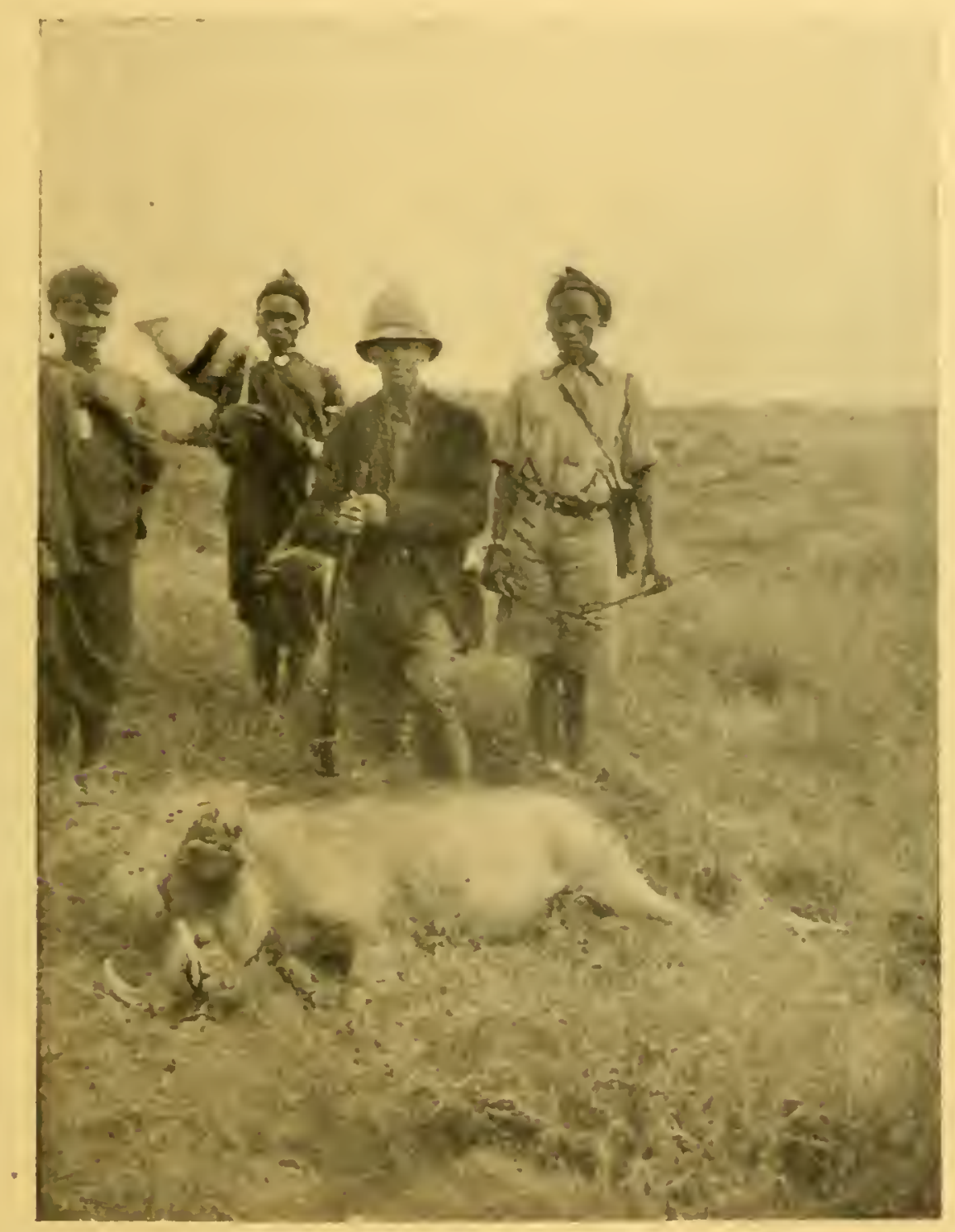

Puc. 15 Бородавочник (Phacochocms).

кустарниками склонахъ холмовъ возль станціи Найваши скрывалось большое стадо антилопъ импала (Аерусегоs). Намь удалось добыть матеріалъ по всъмъ этимъ животнымъ, кромғ вотербока. Иногда достаточно было на полчаса пойти прогуляться, чтобы убить какую-нибудь антилопу.

Списокъ мвстныхъ млекопитающихъ далеко еще, однако, 
не законченъ. Каждый вечеръ можно видъть десятки эфіопскихъ бородавочниковъ (Phacochoerus), тянущихся къ берегамъ озера на водопой; черезъ дорогу, идущую вдоль озера, часто перебьгаютъ ихневмоны; на прибрежныхъ акаціяхъ находятъ себъ пріютъ мартышки двухъ видовъ, а на холмахъ около станціи держатся стаи павіановъ. Наконецъ, въ степи попадается множество норъ интереснаго трубкозуба (Orycteropus), но ни видћть, ни

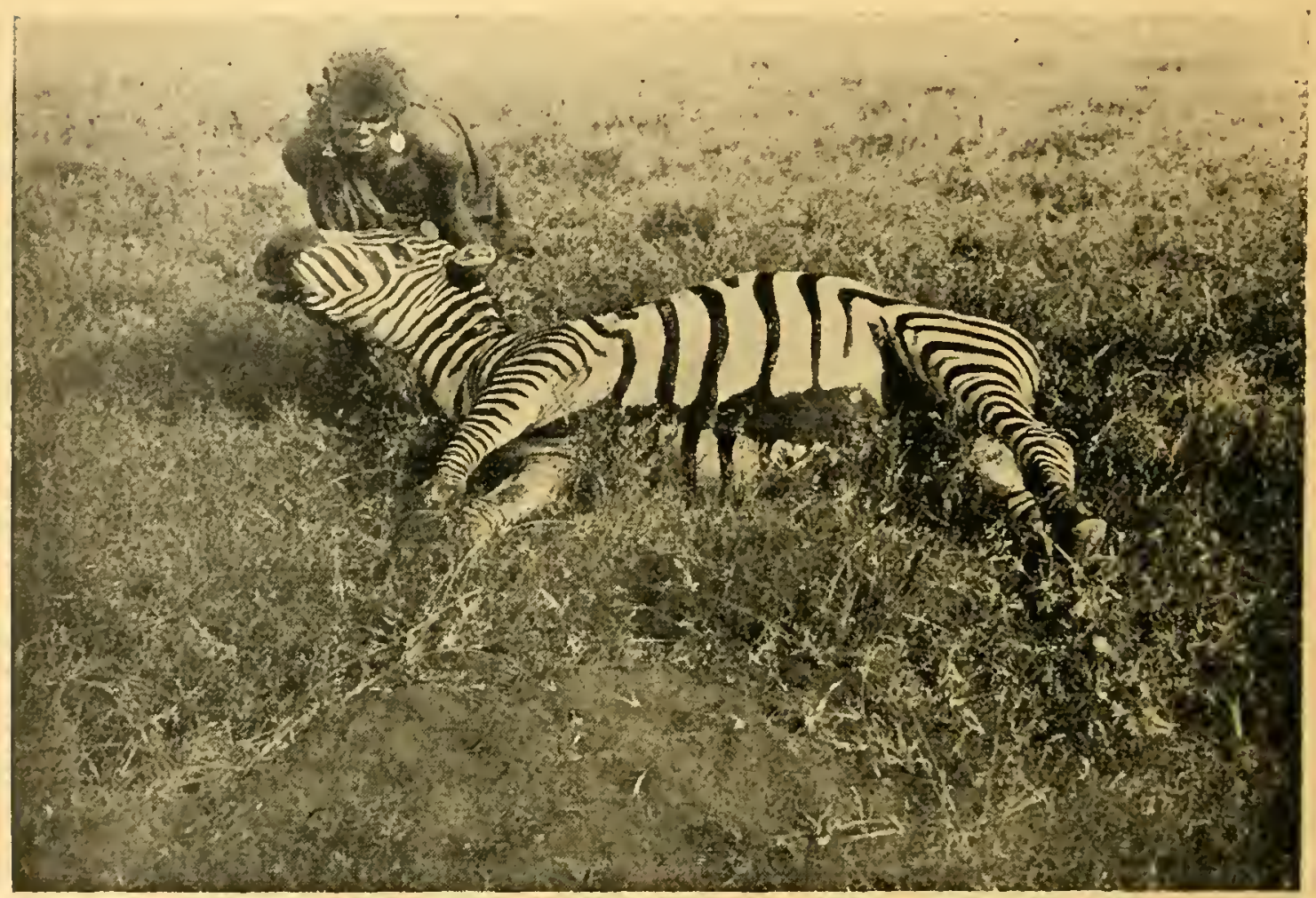

Рис. 16. Зебра.

добыть это животное намъ не удалось изъ за его чисто ночного образа жизни. Изъ другихъ, рбже попадающихся здъсь животныхъ, мы, благодаря любезности г-на Хигнелля, получили матеріалъ по гистологіи и паразитамъ серваля (Felis serval) и дикообраза.

Птицъ на Найвашъ значительно меньше, чъъмъ на озеръ Накуру, а жизнь насъкомыхъ, по крайней мърғ когда мы тамъ были (конецъ нашего іюня), тоже не отличалась богатствомъ. Изъ интересныхъ въ біологическомъ отношеніи формъ здъсь часто попадаются 
муравьи, живущіе внутри вздутыхт, при основаніи ииповъ низкорослыхъ акаціӥ (Acacia fistulosa).

Пробывъ въ Лонгоноть около двухъ недыль, мы оставили его для того, чтобы вернуться въ Найроби и тамъ начать ириготовленія къ походу на югъ, Къ Килиманджаро.

\section{IX. Сафарн оть Станцін Вон до Таветы.}

"Safari * на языкъ Ва-суагели обозначаетъ „путешествіе." Этимъ словомъ называютъ, собственно говоря, всякое путешествіе, но оно имъетъ и свор специфическое значеніе, а именно: путешествіе караваномъ вглубь страны,-и въ этомъ смысль обычно и употребляется. Караванъ составляется изъ чернокожихъ носильщиковъ, которые на своихъ головахъ несутьь всъ вещи путешественника. Способъ, разумбется, довопьно примитивный, но онъ практикуется съ давнихъ временъ и, въроятно, будетъ еще долгое время практиковаться. Зависитъ это, конечно, оть мъстныхъ условіі: съ одной стороны, въ большинствъ случаевъ отсутствуютъ широкія дороги, по которымъ можно было бы вздить,съ другой стороны, даже тамъ, гдћ таковыя имбются, вьючнымъ животнымъ всегда угрожаетъ опасность заразиться трипанозомами и погибнуть отъ наганы или другой бользни *). Наконецъ, если даже возможность зараженія исключена, то разница в`ь цънち за наемъ носильщика и за покупку мула или осла настолько велика, что никому и въ голову не придетъ измънить старому способу передвиженія.

$\mathrm{C}_{ъ}$ проведеніемъ Угандской жельзной дороги наплывъ туристовъ и охотниковъ въ Восточную Африку съ каждымъ годомъ все возрастаетъ. Это вызвало въ Найроби открытіе нъсколькихъ

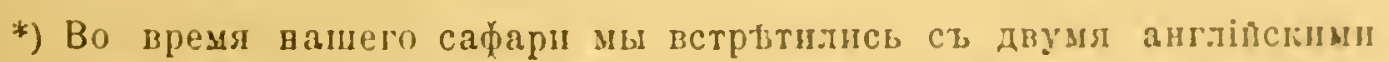
сиортсмэнами, которые находились въ сафари болте мьсяда. у нитъ имьлось дия мула, по одинъ изъ нихъ еще въ самоми патать сафари,

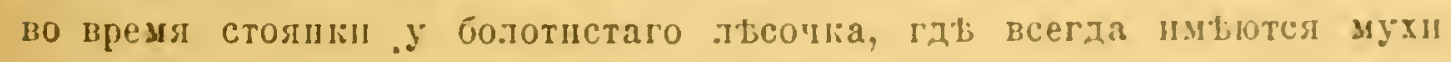
це-це, заразится тринанозомами и, вмвсто шимоци, быль шугепественникамъ только вт тягость. 
учрежденій, цбль которыхъ-организація и оборудованіе какъ охотничьихъ, такъ и научныхъ сафари. Филіальныя-отд‡ленія этихъ агентствъ имъются во многихъ пунктахъ какъ Британской, такъ и Германской Восточной Африки. Вотъ главнъйшіе изъ этихъ, „safari outfitters":

Newland, Tarlton \& Co., London, Nairobj and Nakuru.

Chas. A. Heyer \& Co., Nairobi (австрійское аг-во).

Mc Kinnon Bros., Nairobi and Mombasa.

The British East Africa Corporation, Jtd., London, Mombasa and Manchester.

Boma Trading Co., London and Nairobi.

Вс占 эти агентства имЄютъ то достоинство, что поставляютъ въ буквальномъ смыслб все необходимое для сафари, т. ч. путешественнику нбтъ надобности везти что-либо съ собою изъ Европы. Кромғ того, всъ хлопоты по устройству сафари они берутъ цйликомъ на себя. Путешественнику надо только заблаговременно съ ними списаться, указавъ время и продолжительность сафари, маршрутъ, количество личныхъ вещей, свои гастрономическія наклонности и т. п. Онъ можетъ быть спокоенъ, что къ указанному времени все будетъ готово, и что по пріъздъ въ Африку онъ сразу сможетъ приступить къ сафари. Къ сожал卆ію, однако, всъ эти удобства приходится непомърно дорого оплачивать. Когда мы, еще въ началь⿱⺊口灬 нашей поъздки, обсуждали вопросъ о сафари к’ь горъ Кенія и зашли переговорить относительно этого къ Гейеру, то онъ потребовалъ съ одного лица и за одинъ мъсяцъ 90 фунт. стерл. Newland, Tarlton \& Co. берутъ, повидимому, еще дороже. Слғдуетъ елце замътить, что цъъны нъсколько колеблются въ зависимости отъ сезона.

Всъхъ этихъ лишнихъ расходовъ можно избъжать, если часть необходимыхъ вещей закупить въ Европ各 (везти ихъ надо съ собой, иначе приходится довольно много платить за пересылку),

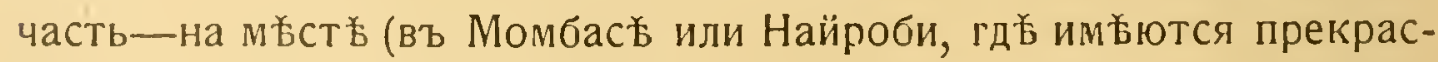
ные и сравнительно недорогіе магазины); провіантъ и продовольствіе (posho) для носильщиковъ тоже лучше закупить самому на мъстъ, посовътовавиись лишь предварительно съ какимъ-нибудь 


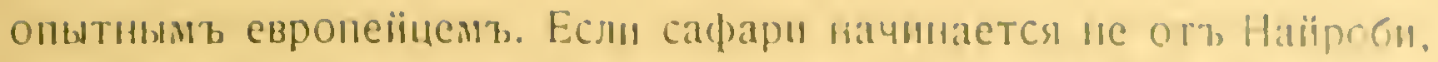

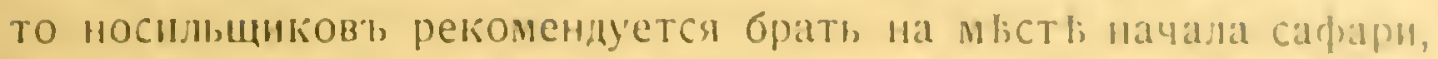
разумнется. ссли есть возможность ихт, тамъ получить, - пначе

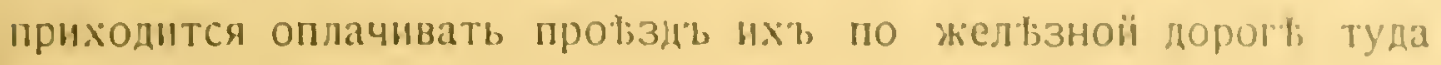
и обратюо. Единственный случай, въ котором'ь, пожалуй, все ніс лучие обращаться за помощью къ агентствамь-это ири наймы слугъ. Благодаря ли рекомендаціи помощника gatmewardenia (т. е. завъдующаго животными богатствами колоніи), г-на Вудгауза, который насъ направилъ къ Newland "Tarlton'y, или благодаря добросовъстности этого агентства вооще, у насъ, за ръдкими исключеніями, были очень удачные слуги. Во время

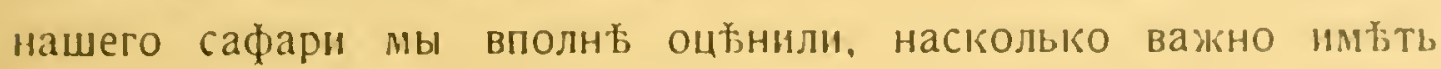
хорошихъ слугъ. Впрочемъ, въ крайнемъ случағ; и здъсь можно обойтись безъ помощи агентствъ, такъ какъ всякіӥ чернокожій иредлагающій свою работу, долженъ имбть при себъ „рабочую книжку“, куда заносятся отзывы господъ, у которыхъ онъ служилъ. Руководствуясь этими отзывами и наведши справки, можно себъ выбрать подходящаго слугу. Такимъ способомъ нами, напр., былъ нанятъ въ Энтеббе поваръ, которымъ мы въ общемъ остались довольны. (Интересно отмбтить разницу въ цбнъ: этому повару мы платили по 16 рупій въ мбсяцъ, - правда, цъны въ Угандъ значительно ниже, чъмъ въ Брит. Вост. Африкъ, -тогда какъ Newland " Tarlton предлагали намъ повара за 45 рупій въ мћсяцъ).

Въ составъ каравана, отправляющагося въ сафари входитъ цбллый рядъ членовъ, изъ которыхъ каждый несетъ опредъленную функцію.

Во главъ каравана стоитъ надсмотрщикъ (wallyampara). Онъ обязанъ присматривать за носильщиками, чтобы они шли вмъстъ и не отставали, такъ же отвъчаетъ за то, чтобы вещи были въ опредъленное время на опредъленномъ мбсть. Кромь того, онъ распредъляетъ между носильщиками и остальными ч.ленами каравана „роsho“ (провіантъ). Во время пути надсмотрщикъ сльдуетъ позади всего каравана.

Аскари-это вооруженные ружьями стражники, на обязанности которыхъ лежитъ, такъ сказать, защита каравана. Поночамъ они 
стерегутъ лагерь и поддерживаютъ передъ палаткой огонь; помогаютъ устанавливать палатку и слғдятъ за тъмъ, чтобы носильщики не льнились; кромъ того, аскари отвъчаютъ за цълость багажа и собранныхъ трофеевъ. У насъ ихъ было двое.

Gunbearer (shikari)-оруженосецъ. Онъ долженъ нести оружіе своего господина и быть неотлучно съ нимъ во время похода и на охотъ. Эти люди хорошо знаютъ повадки разныхъ животныхъ, узнаютъ присутствіе ихъ по слбдамъ, выслбживаютъ ихъ. Если животное ранено, преслбдуютъ его и наносятъ смертельный ударъ ножомъ. Обычно они умъютъ сдирать шкуры какъ съ млекопитающихъ, такъ и с’ъ крупныхъ птицъ и очищать черепа. У насъ у каждаго было по оруженосцу. Одинъ изъ нихъ, который поступилъ къ намъ на службу уже въ Найвашъ, прежде участвовалъ въ научныхъ экспедиціяхъ и былъ намъ весьма полезенъ.

Бой, или слуга. Онъ прислуживаетъ за столомъ, дЄлаетъ кровать, чиститъ сапоги и одежду, готовитъ ванну, стираетъ бълье, укладываетъ личныя вещи и вообе заботится объ удобствахъ своего господина. Собственно, почти каждый европеецъ, пріъзжающій въ Африку, даже если и не намъревается дълать сафари, нанимаетъ себъ боя.

Поваръ (mpishi). Въ качествъ кухоннаго мальчика ему обычно, по взаимному соглашенію, прислуживаетъ одинъ изъ носильщиковъ, носитъ воду и пр.

Всъхъ этихъ слугъ, за исключеніемъ повара, мы наняли у Newland и Tarlton. Плата имъ полагалась сльдующая: надсмотрщику 35 рупій, аскари по 15 руп., оруженосцамъ по 30 руп., боямъ, одному 25, другому 30 руп. въ мұсяцъ. Помимо жалованья всъмъ членамъ каравана выдается ежедневно „posho“ (продовольствіе), в’ь населенныхъ мъстахъ деньгами, отъ 10 до 30 центовъ, смотря по рангу,-во время сафари натурой (обыкновенно это мука изъ кукурузы-mealy-meal, количество которой тоже варіируетъ въ зависимости отъ ранга; такъ, напр., простой носильщикъ получаетъ въ день одну $\mathrm{kibaba-около} 1 \frac{1}{2}$ фунт., надсмотриику же и оруженосцамъ полагается по 2 и по 3 kibaba). 


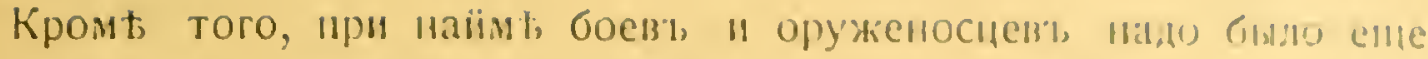
заплатить особо за их", обмундиронку 11010 руліві.

Wараяані-ногильцики составляють, такь сказать, ялро каравана. Они переносят'ь вещи путешественняка на голові; обмагыная ее шерстянымъ плащемъ. Олна ноша не должна иревышать б0-тн англ. фунтовъ. Жалованье имъ полагается различное, смотия по тому, въ kакой мъстности и въ какое время года они вербуются. Мы платили очень дешево, по 8 рупій в॰ь мәсяцъ. Разумбется, сверхъ этого они получають свое ежедневное „posho“. Для носильщиковъ полагается брать особыя простыя палатки и котлы для варки пищи.

Предлринимая наше сафари, мы имъли въ виду слъдующій планъ. Добхать изъ Найроби до станиіи Вои, собрать тамъ караванъ и идти на западъ мимо горъ Бура въ Тавету. Здъсь предположено было обсльдовать небольшой, но типичный тропическій льсъ, расположенный по берегамъ р. Луяи (Lumi) и познакомиться съ фауной двухъ сосълнихъ озеръ: кратернаго озера Чала (Chala) и оз. Джипе (Јіре); посль всего этого мы должны были проити в г Германскую Вост. Африку, на станцію Моши (Moschi), чтобы оттуда предиринять восхожденіе на Килиманджаро и затбмъ вернуться по жельзной дорогъ отъ Моши въ Танга, къ океану. Здъсь, передъ отъъздомъ въ Европу мы нам ьревались поработать нбкоторое время въ сельско-хозяйственномъ институть въ Амани. Къ сожалєнію, міровая война, начавшаяся какъ разъ во время нашего сафари, помбшала намъ выполнить намьъченный планъ до конца. Но и то, что мы успвли пережить за это время, является пожалуй наиболье яркой страницей изъ всей нашей Африканской поћздки.

Г-нъ Вуснамъ-gamewarden, қоторому мы сдълали въ Найроби передъ сафари визитъ, очень заинтересовался нашей пођздкой. Узнавъ, что мы изучаемъ паразитовъ крупныхъ млекопитающихъ, онъ далъ нам'ь разрбшеніе убить цълый рядъ не входяцихъ обычно въ travellers licence (малое охотничье свидьтельство) антилопъ и одинъ экземпляръ Colobus. Кримь того, онъ послалъ въ 
Вои къ областному комиссару (District commissioner) телеграмму съ просьбой найти для насъ носильщиковъ.

Окончивъ разсчеты съ Newland, Tarlton \& Co., которые помогли намъ устроить сафари (кстати сказать, ими мы остались не особенно довольны), мы 22-го іюля вығхали изъ Найроби. Снова нашъ поъздъ бхалъ черезъ заповъдныя мъста и снова мы наслаждались единственнымъ въ міръ зрълищемъ-лрироднымъ звъринцемъ. Въ часъ ночи мы прибыли въ Вои и расположились на ночлегъ въ имъющемся на самой станціи dack-bungalow.

Станція Вои расположена въ 103 миляхъ отъ Момбасы. Селеніе находится по объ стороны жельзной дороги у небольшой ръчки Вои. Съ съверной стороны дороги живутъ немногочисленные евролейцы (въ томъ числъ комиссаръ области Теита (Тeita), къ которой принадлежитъ Вои) и индусы-торговцы и жельзнодорожные служащіе. Съ южной стороны раскинулось поселеніе чернокожихъ. Въ западномъ налравленіи довольно большую площадь занимаетъ плантація сисаль-агавъ.

Въ ближайшихъ окрестностяхъ Вои расположены небольшія деревеньки туземцевъ, принадлежащихъ къ племени Ва-Теита. Онғ въ общемъ напоминаютъ селенія Ва-Кавирондо. Хижины расположены кругомъ, въ центръ котораго сдъланъ загонъ для скота. Снаружи все селеніе обнесено изгородью (boma) изъ колючихъ вътвей и бревенъ. Однажды, передъ самымъ входомъ въ селеніе мы видъли родъ воротецъ, вышиною въ человъческій ростъ и сдъланныхъ изъ длиннаго согнутаго и воткнутаго концами въ землю прута; другой короткій прутъ лежалъ на дорогъ между концами перваго; на самыхъ воротцахъ былъ повбшенъ мертвый цыпленокъ. На нашъ вопросъ о значеніи этихъ воротецъ, два старика, вышедшіе изъ-за изгороди, объяснили что это „даша“, т. е. средство противъ забольванія скота, который, насколько мы поняли, долженъ прогоняться черезъ эти воротца.

Характерной особенностью Ва-Геита является обычай клинообразно обтачивать ръзцы верхней челюсти. Они представляютъ собою въ настоящее время мирное племя, занимаюшееся ското- 
водствомъ (козы, овцы, зебу) и земледыліемь (бананы, кукуруза,

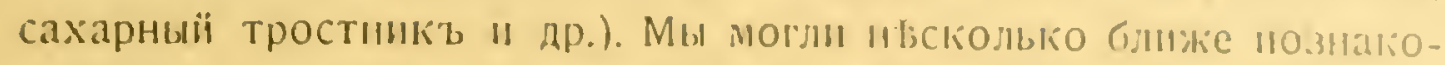
миться съ ними, такт как'b всы нани носилщики принадлежани къ этому племени. Они оказались весьма добродушинии и общим ь складомъ характера " своеиі безпечностью и веселостью совершенно напомннали дытей. Намь они вполны, довыряли, такь, как", видъли, что мы относимся Кь нимъ сираведливо; обращались силон,

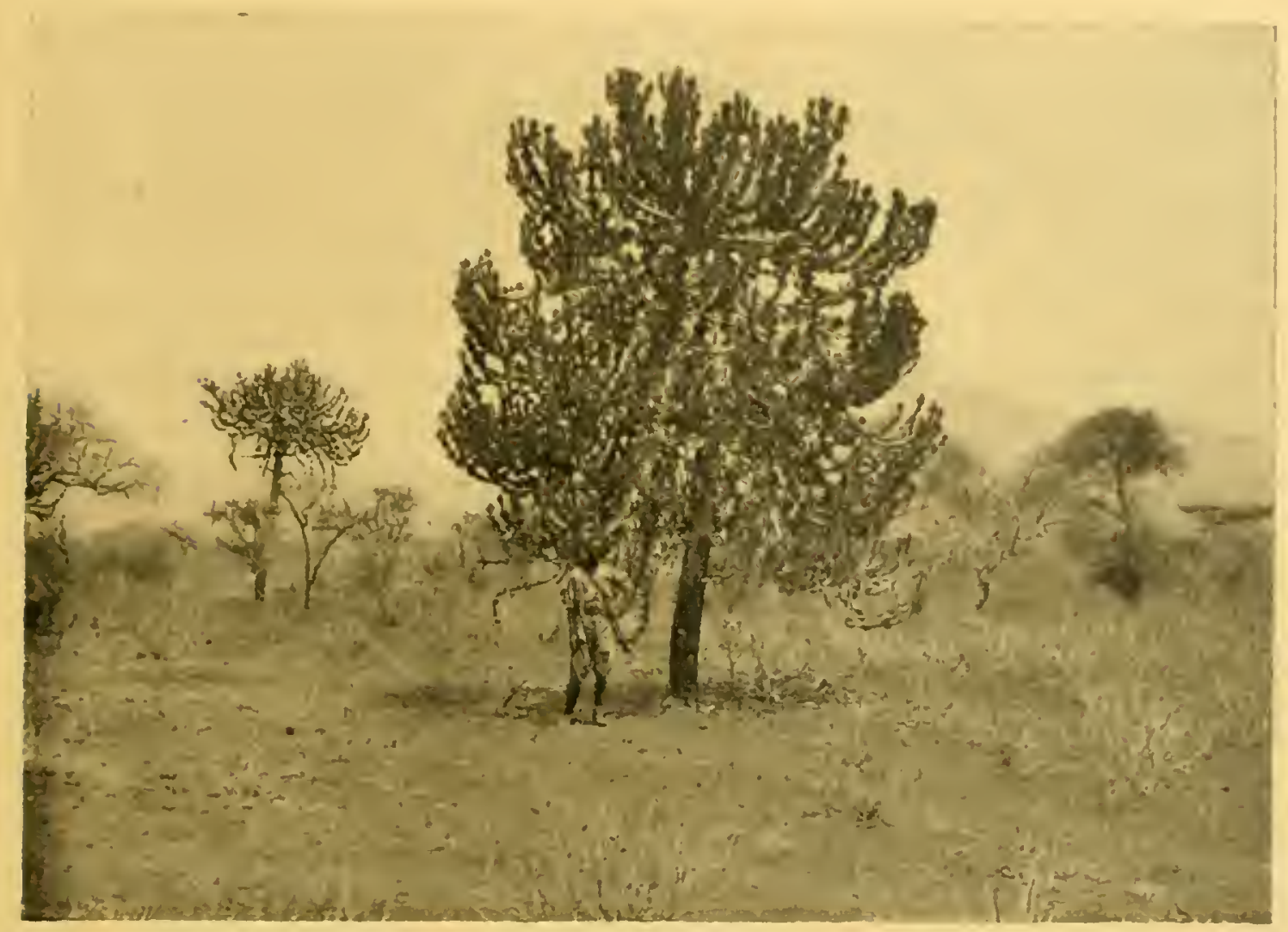

Рис. 17. Эуфорбји близъ Вои.

" рядомъ за медицинской помощью и т. Л. Они не уродуютъ своихъ ушей и не дълаютъ сложной прически. Въ виды украшеній Ва-Теита носятъ лишь небольшіе браслеты изъ проволоки и ожерелья изъ бисера. Вся одежда состоитъ изъ платка, которыи обматывается вокругъ бедеръ; иногда имбется еще короткая рубашка. Большой шерстяной плащъ во время переноски поклажи обматывается вокругъ головы, ночью же служитъ одъяломъ. У женщинъ наряды тоже сравнительно простые. Обычно вокругъ тъла обвертывается подъ мышками большой кусокъ матерін. У 
другихъ можно часто встрбтить особыя коротенькія юбочки, иногда двойныя, въ родъ юбскъ балеринъ. Юбочки эти густо разукрашены разноцвътнымъ :бисеромъ, подчас'ъ замъчательно искусно. Изъ такого же бисера сдъланы и ожерелья. На рукахъ и иногда на ногахъ имъются небольшіе браслеты изъ витой мъдной провопоки. Въ мъстечкъ Мвататэ мы видъли нбсколькихъ женщинъ, у которыхъ ожерелья имъли видъ широкихъ (до двухъ вершковъ) хомутовъ и были составлены из’ нысколькихъ десятковъ бисерныхъ колецъ.

Мы пріғхали въ Вои въ такое время, когда „masika“дождливый сезонъ-уже давно прошелъи наступило сухое время года. Въ виду этого вся мбстность имъла довольно безотрадный видъ. Невысокія деревья (гл. обр. разныя акаціи и Commiphora) и различные кустарники были совершенно лишены листьевъ и вмъсто нихъ всюду торчали голые сучья, колючки, крючья, шипы... Трава высохла и пожелтьла и только разнообразныя эуфорбіи и другія незнакомыя намъ мясистыя с'ъ бълымъ сокомъ растенія оживляли своей зеленью картину. Вообще мъстность была совсъ̆мъ не похожа на видұнные нами до сихъ поръ ландшафты.

Соотвътственно съ этимъ и фауна оказалась весьма своеобразной, при чемъ особенно много любопытнаго представила фауна мғстныхъ насъкомыхъ. Такъ, напримъръ, насъкомыя окрестностей Вои, обнаруживаютъ очень много примъровъ покровительственной окраски. Въ мбстной природъ, въ описываемое нами время года (іюль), преобладаютъ надъ всъми прочими два цвъта: красный цвътъ глинистой почвы и съровато-черный цвбтъ засохшей травы и кустарниковъ. И вотъ, соотвътственно съ этимъ, мъстныя насъкомыя самыхъ различныхъ отрядовъ распадаются на двъ біологическихъ группы: одни изъ нихъ подражаютъ общему фону почвы, другія-цвьту выжженной солнцемъ растительности. Изъ первыхъ можно легко набрать длинную серію: таковы различные рыжіе тараканы, красные кузнечики и личинки саранчевыхъ, пчелыс'ь рыжеватымь пушкомъ на спинъ, бабочки (Pieridae) съ рыжеватой нижней стороной крыльевъ, наконецъ, многочисленные жуки изъ разныхъ семействъ. Так'ъ, напримъръ, можно найти 
нолзающими рядомъ рыжихъ и красно-бурыхъ иредставытелеи Tenebrionjdae, Curculionidae "Llateridac, Heptako и по формъ похожихъ друг"ь на друга (рис. 18).

Туть ясно бросается въ глазаявленіе конвергениін въ окраскии формъ тюла, вызванное вліяніемъ окружающей среды. Рядомъ съ такими вполнъ ириспособленными по окраскъ къ субстрату формами, можно среди жуковъ выдълить еще одну кате горію - это виды, обладающіе инымъ (чаще всего чернымъ) цвьтомъ, который они маскируютъ, покрывая спинную сторону своего твла мелкой красноӥ глинистой пылью. У такихъ формъ приспособленіе къ окружающимъ усло-
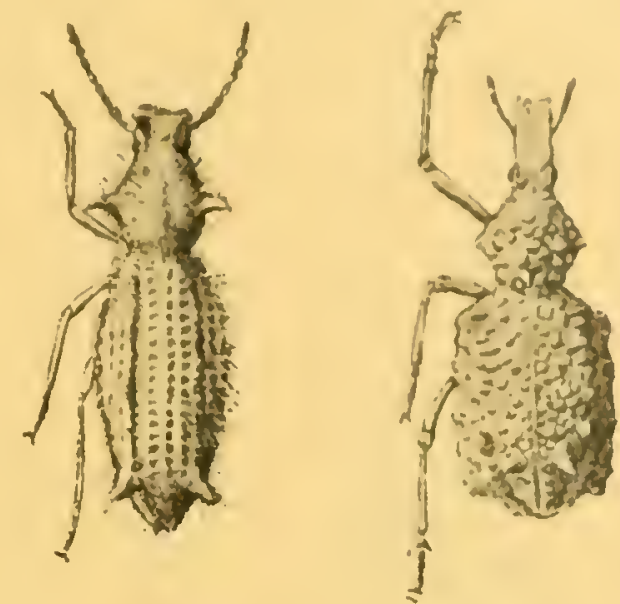

Рис. 18. Примурт сходства представителей цвухт разиых самействъ жуковъ ('Tenebrionidae II Curculionidae). $3 / 2$

віямъ сказывается въ пріобрбтеніи ихъ надкрыльями неровной, шероховатой поверхности, облегчающей приставаніе пыли къ тълу животнаго: у однихъ спинная сторона покрыта бугорками
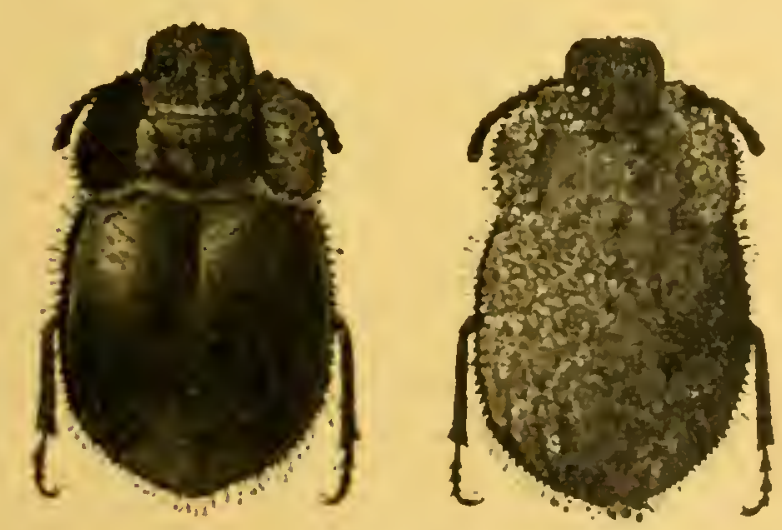

Рис. 19. А-жукъ безъ пыли. В-жуукъ, покрытый пыль10. $5 / 1$.

и шишечками, между которыми застревають частицы глины, у другихъ спина испещрена многочисленными продольными желобками, наконецъ, у третьихъ, плоскіе края надкрыльевь нъсколько загнуты кверху, такъ что элитры образуютъ собою какъ бы подносъ, на которомъ скопляется пыль, не скатываясь съ него въ стороны (рис. 19).

Вторая біологическая группа насткомыхъ окрестностей Вои полражаетъ окружающей средъ, т. е. сухої травъ, не только по цвъту, но и по формь тьла. Всь относящіяся сюда насъкомыя обла- 


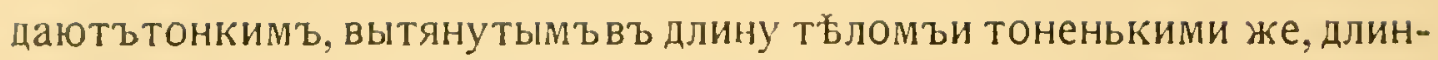
ными ножками, напоминая обломки стеблей, или засохшіе листья злаковъ. Подражаніе травъ мы находимъ, главнымъ образомъ, среди прямокрылыхъ, какъ, напримъръ, у сърыхъ, длинныхъ богомоловъ (рис. 20 А), у различныхъ палочниковъ (В) и отчасти у труксаловъ (Truxalis, C); однако, аналогичную структуру тъла и окраску

$\mathrm{B}$
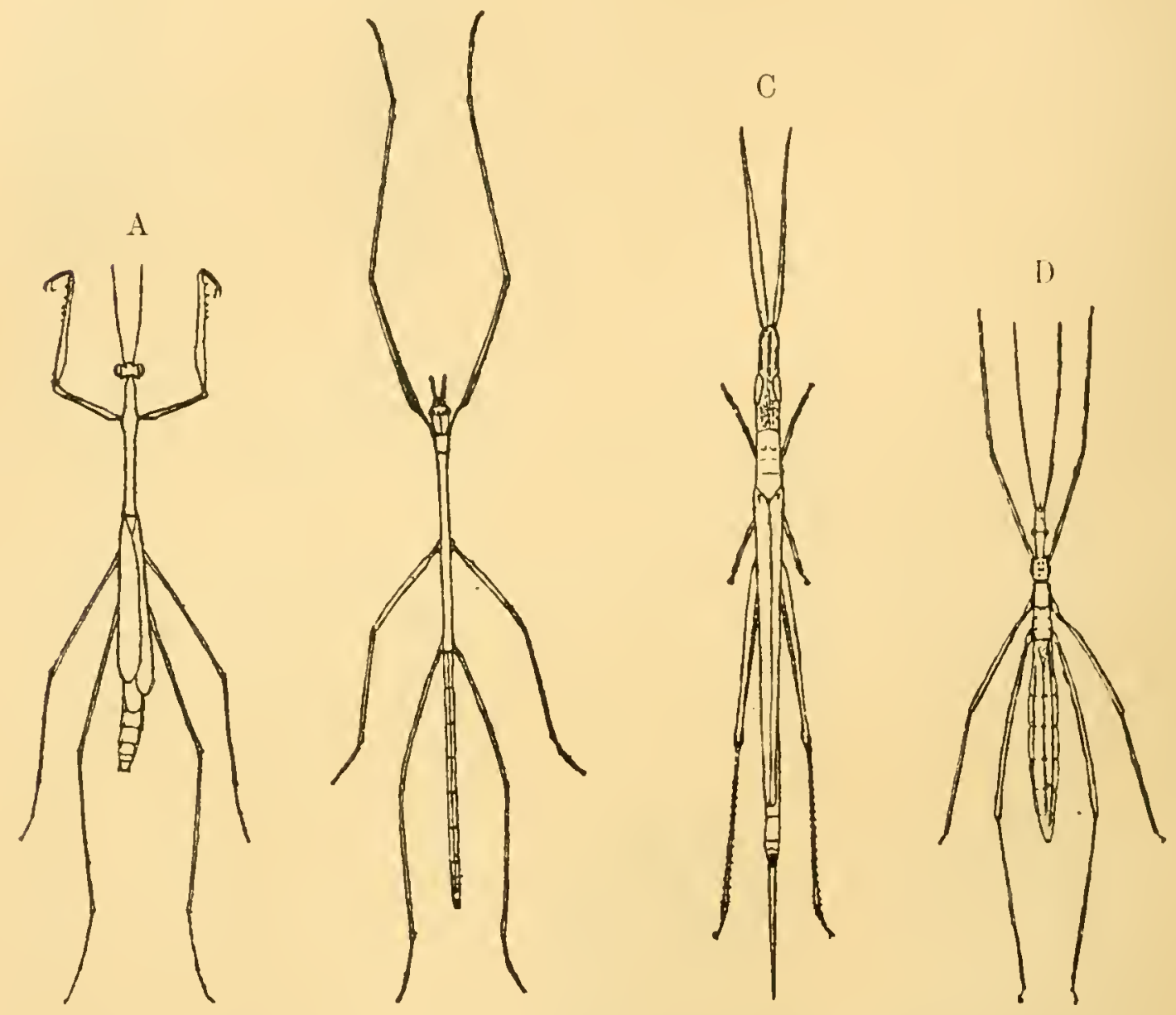

Рис. 20. Формы наськомыхъ изъ Вон, подражающихъ травъ.

обнаруживают’ь и нбкоторые хищные клопы (Raphidosoma, D).

Ръзкую противуположность со всћми перечисленными, хорошо укрытыми отъ враговъ, формами насъкомыхъ представляютъ нбкоторые жуки и бабочки, которые ясно выд‡ляются на окружающемъ фонъ совершенно неподходящей подъ него окраской. Таковы-блестящіе, черные 'T e n eb rion ida e изъ жуковъ (рис. 21) и нъжно-розовыя Acraeidae изъ бабочекъ. 
A priori можно было бы цумать, что подопныя незащищениыл насъкомыя ведутъ, по крайней мырб, скрытый образъ жызни, или обладаютъ большей быстротой двикеніи. Но, нLть: черные жуки медленно ползають по красной глин дорог'ь, а розовыя акрен едва колышатся въ воздухъ, порхая надъ кустами.

Объясняется такое пренебреженіс всякими иредосторожностями по всей въроятности тъмъ, что многія Acraeidac ut Tellebrionidae снабжены особыми пахучими железами, защищающими ихъ отъ нападеній насъкомоядныхъ животныхъ.

На станціи Вои мы иробыли три дня, а затьмъ 25-го іюля н. Ст., когда караванъ былъ вполнъ готов'ъ, тронулись въ путь на Тавету.

Отъ Вон вплоть до Таветы ведетъ прекрасная широкая дорога, годная даже для автомобилей (что уже практиковалось нъкоторыми спортсмэнами). Дорога настолько широка, что носильщики, вопреки обычаю, шли не «гуськомъ», а «вразсыпнуюљ. Сначала она идетъ вдоль рельсъ, по направленію къ Найроби, а затбмъ сворачиваетъ

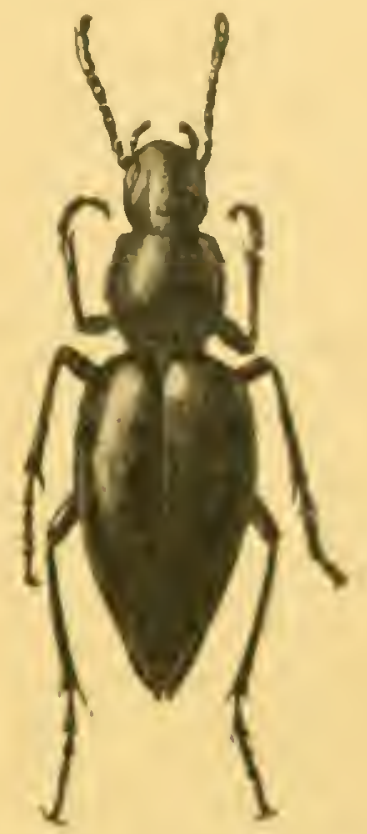

Pис. 21. Кіуки из cem. Tenebrionidae изъ огрестносей Вои. вльво, имъя общее направленіе на западъ, минуетъ упомянутую выше плантацію сисаль-агавъ,' за которої видньются неуклюжіе баобабы, ", наконецъ, вступаетъ въ безлюдную, пустынную область, тянущуюся вплоть до мъстечка Мвататэ. Эта область представляеть собою сплошную заросль различныхъ 6. ч. колючихъ кустарниковъ, Commiphora и разнообразныхъ низкорослыхъ акацій. Большинство ихъ въ іюль было лишено листьевъ. На ряду съ ними много разныхъ эуфорбіiі. У однихъ-толстыя мясистыя вбтви съ четковидными иеретяжками, правильно расположенныя въ видъ канделябровъ; другія облалаютъ тонкими вєтвями, которыя развътвляются на концахъ наподобіе пальцевъ руки; третьн пмьютъ видъ свъшивающихся внизъ веревокъ и растутъ эпифитно на другихъ деревьяхъ. Слидуетъ 
отмбттиь одно интересное растеніе Adenia globosa (Passiflor.), у котораго им вется стволь, напоминающій большой обросшій мохомъ камень, изъ котораго въ видъ густого букета во всъ стороны расходятся длинныя и тонкія вътти съ многочисленными супротивно расположенными, короткими и толстыми колючками. Весьма обыкновенна Senseviera, извъстная въ литературъ подъ названіемъ «Bajonettpflanze», т. к. ея въерообразно расположенные листья имъютъ видъ прямой толстой шпаги и оканчиваются чрезвычайно острымъ и твердымъ шипомъ. Тамъ и сямъ попадаются разныя Aloё, подчасъ превышающія двойной человъческій ростъ.

Большихъ животныхъ здъсь не видно. Иногда пробъжить черезъ дорогу ихневмонъ или выпрыгнетъ заяцъ. Птицъ-больше. Особенно обыкновененъ небольшой видъ носорога съ краснымъ клювомъ и сърый турако с`ъ большимъ хохломъ. Насъкомыя тъ же, что и въ Вои.

Черезъ 7 миль мы достигли небольшой рбчки Вои. Берега ея слегка обрывисты и, какъ всегда, поросли галлерейнымъ лбсомъ, яркая зелень котораго ръзко выдъляется на общемъ съромъ, ‘зимнемъ> колорить пейзажа. На 14-ой миль находится мъстечко Мвататэ (Mwatate), откуда посль трехъ-часового привала мы тронулись дальше. Около 5-ти час., перешедши по двумъ мостикамъ ръчку Бура, мы разбили свой лагерь недалеко отъ нея. Въ виду большой продолжительности перваго перехода ръшено было весь слбдующій день остаться въ Бура.

Горы Бура, передъ которыми мы расположились, круто поднимаются из'ь окружающей равнины, причемъ весь горный массивъ имъетъ какъ бы форму большой подковы. Онъ достигаетъ почти $2 \frac{1}{2}$ клм. высоты надъ ур. моря и обладаетъ весьма крутыми склонами с'ь ясно выраженной, м ъстами, слоистостью. На склонахъ зеленъютъ, въ видъ отдъльныхъ пятенъ, высоко расположенныя насажденія банановъ и повсюду разсъяны деревушки и отдъпьныя хижины туземцевъ. На самой вершинъ растетъ густой лъсъ. У подножія горъ выстроена католическая миссія, основанная болье двадцати льтъ тому назадъ. 


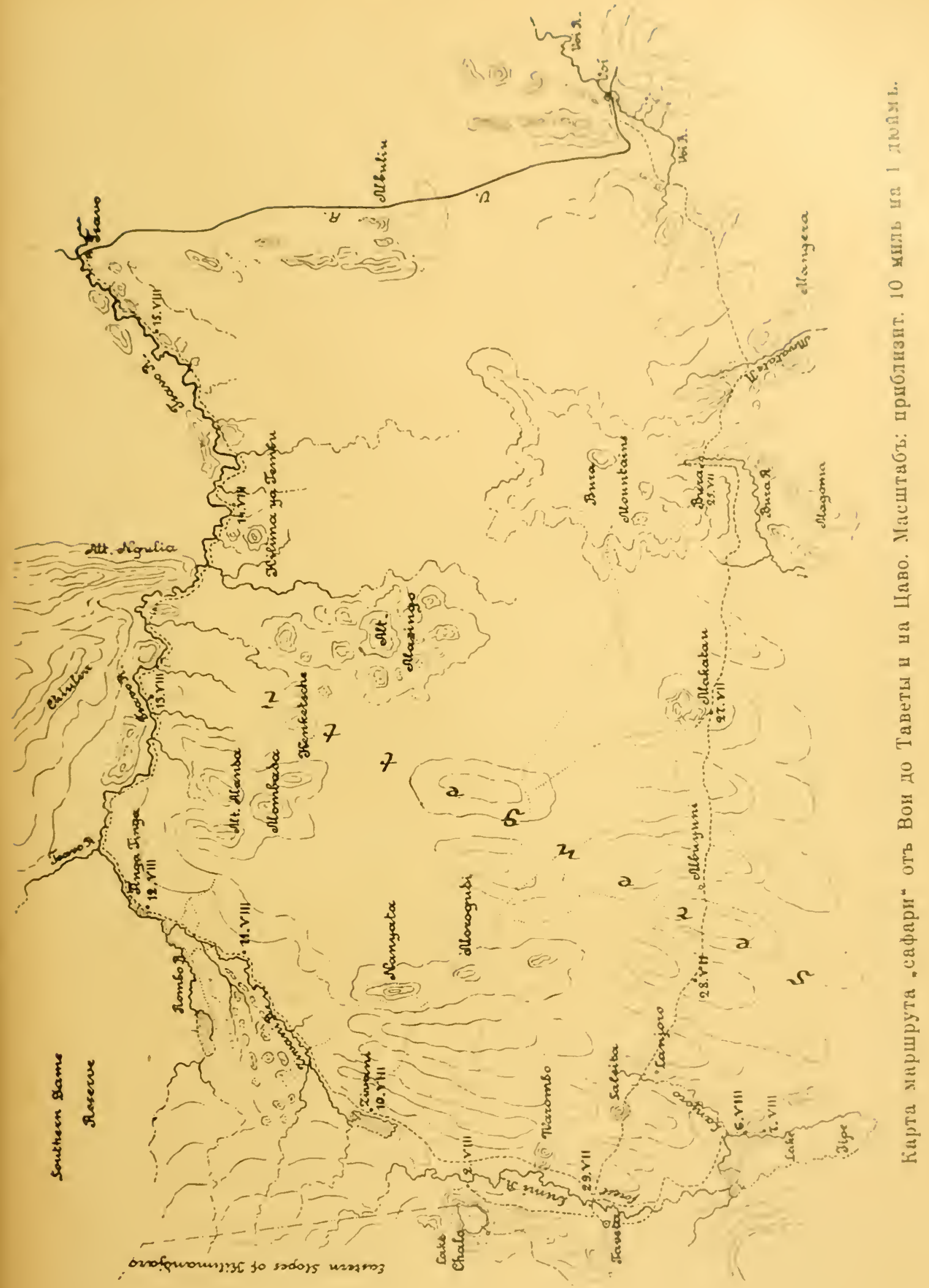


Воспользовавшись стоянкой, мы рбшили посьитить миссію. Дорога к'ь миссіи идетъ въ видъे прямой линіи параллельно ръчкъ Бура. Самой ръчки не видно, но ея русло обозначено яркой зеленью обширныхъ банановыхъ плантацій, которыя нъсколько выше смъняются сахарнымъ тростником’ь. Миссіонеры приняли насъ очень любезно, показали свои владънія, хозяйство, огородъ, гдъ у нихъ растутъ картофель, капуста, салатъ, горохъ и земляника; провели въ каменную церковку съ простой обстановкой и съ изреченіями изъ Евангелія, написанными на стьнахъ на языкъ ки-суагели. На нашъ вопросъ относи. тельно того, какъ прививается христіанство въ странғ, они замътили, что много мьшаетъ антагонизмъ между протестантами и католиками; кромъ того, туземцамъ весьма трудно внушить отвлеченныя идеи религіи, Т. ч. въ большинств б случаевъ они перенимаютъ лишь внышнюю сторону христіанства.

На обратномъ пути къ лагерю намъ посчастливилось найти подъ корой одного дерева громаднаго четырехлегочнаго паука-перваго за все время нашей экспедиціи. Потомъ, обыскивая другія деревья, мы нашли еше два вида Tetrapneumones, болье мелкихъ, и вмъстъ съ ними Dipneumones, близкихъ къ р. Nephila. Вечеромъ на свътъ была поймана сольпуга.

27-го іюля утромъ караванъ отправился въ дальнъӥшій путь. Девять носильщиковъ несли жестянки изъ подъ керосина, наполненныя водой, т. к. теперь предстоялъ трехдневный путь по мъстности лишенной въ это сухое время года воды. Рбчка Бура съ ея зеленымъ галлерейнымъ льсомъ остается съ львой стороны и м бстность сразу принимаетъ характеръ кустарниковой степи: это начало обширнаго степного пространства, извъстнаго подъ названіемъ равнинъ Serengetti. Изрбдка попадаются сльды слоновъ и носороговъ и постепенно начинаютъ показываться различныя млекопитающія, правда, пока еще въ небольших'ь количествахъ: суслики, водяные козлы (Cobus), конгони (Bubalis cookei), импала (Aepyceros suara), Tragelıphus masaicus и др. Здъсь же намъ впервые удалось наблюдать на сравнительно 


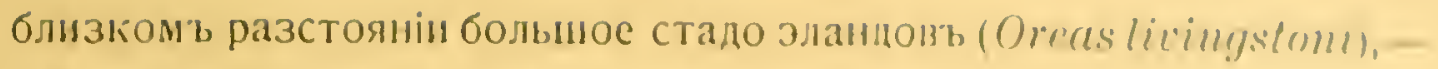
самнхъ крупныхъ изъ африканских", антнлоия.

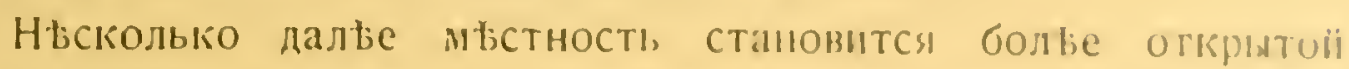
Здъсь, среди раскидистыхъ акацій, сохранившихт свою мелкую листву, было замъчено стадо жираффь, состолинее изъ семи головъ; онъ не очень пугливы, такъ что возможно было сдылать нЊсколько снимковъ, правда, на довольно далекомъ разстояніи.

Въ часъ дня мы пришли на урочище Мактау (Maktan) и расположились здъсь пагеремъ. Всь, идущіе на Тавету, обычно останавливаются на этомъ мъстъ. Поэтому тутъ устроено изт, соломы два навъса, поддерживаемые бревнами. Вокругъ расчищена небольшая площадка и все это обнесено стьной изъ колючаго хвороста. Это сооруженіе должно представлять собою защиту отъ львовъ, которыхъ, по словамъ миссіонеровъ, водится немало въъ этихъ мьстахъ.

Минутахъ въ тридцати ходьбы отъ лагеря возвышаются холмы Мактау, около которыхъ имғются ямы, наполненныя в'ъ дождливое время водой. Скалистые холмы Мактау живописно поросли эуфорбіями, и съ нихъ открывается широкій видъ на окрестности. Далеко во всъ стороны простирается равнина Серенгетти, сплошь покрытая цилымъ моремъ деревьевъ, кажущихся сърыми въ это сухое время года; на западъ высится неясная громада Килиманджаро, съ покрытої облаками вершиной, а на съверғ видна очень красивая панорама горъ Кіуліу и Нгуліа, тянущихся вдоль долины ръки Цаво (Tsavo), и цвлый рядъ небольшихъ вулканическихъ холмовъ.

28-го іюля мы выступили въ путь еще въ полной темнотђ, такъ какъ наканунь нашъ старшина заявилъ, что носильщикамъ жарко идти, если выходить позже. На разсвытв удачно охотились на цесарокъ, которыя еще сиали, сидя на деревьяхъ, и на франколиновъ (ихъ здъсь нтсколько вндовъ). Посль восхода солнца показались стада конгони и одинъ экземиляръ былъ убитъ къ великой радости нашихъ людей. Далье животныя стали встрбчаться чаще. Среди зеленыхъ зонтиковидныхъ акаціиі видъли снива жираффъ, затьмъ газелей (Cazella granti "I G. thomsoni), 
разныхъ мелкихъ антилопъ, птицу-секретаря (Serpentarius serpentarius) и др. Сльдуеть еще отмғтить, что во время всего пути во множествъ встрьчаются какъ отпечатки ногъ, такъ и пометъ различныхъ хищниковъ изъ кошачьихъ (серваля, гепарда и др.), но ихъ самихъ мы ни разу не видали. Насбкомыхъ почти совсъмъ не видно; только Mutillidae бъгають по дорогъ. да личинки муравьиныхъ львовъ всюду понарыли множество воронокъ.

За урочищемъ Мбуюни (Mbujuni), гдъ растетъ ньсколько баобабовъ, мы снова видъли жираффъ, затьмъ страусовъ, газелей, эландовъ. Продолжая путь, встрбтили цйлое стадо Oryx beisa, которое скрылось быстрымъ галопомъ. Около 4-хъ час., на югъ, передъ высокой цынью горъ, показалась полоска воды-это было озеро Джиле. Въ 5 час. разбили у дороги лагерь. За отсутствіемъ камней для нашего очага поваръ пустиль въ ходъ нъсколько кусковъ термитника Termes bellicosus, оказавшагося по сосъдству. На закатъ солнца любовались грандіознымъ массивомъ Килиманджаро съ его двумя вершинами: Kibos (6.010 м.), покрытой кольцомъ ледниковъ и вйчнаго снбага, и Mawenzi $(5.360$ м.) съ причудливо-за зубреннымъ контуромъ. За основаніемъ льваго склона, очень далеко, неясно виднълась другая конусовидная вершина съ паразитнымъ кратеромъ съ л各ой стороны; мы ръшили, что это должен'ъ быть вулканъ Меру (Meru).

На слғдующій день утромъмы наблюдалибольшоестадожираффъ, головъ въ пятнадцать, а за м. Ланьоро (Lanjoro) впервые встрьтили любопытныхъ жираффовыхъ антилопъ, или геренукъ (Gazella walleri), названныхъ такъ изъ за чрезвычайно длинной шеır.

Часа черезъ три-четыре ходьбы равнина нъсколько понижается; пейзажъ становится болье привътливымъ, такъ как'ь встръчается все больше и больше зелени, но за то дорога покрывается сьрой пылью. Вскоръ она приводит’ь к’ь рәкъ Луми (Lumi), опоясанной густой полосой деревьевъ. Вдали, за рйкой, виднъется мбостечко Тавета. Перешедши деревянный мостъ, мы тутъ же устроили лагерь, такъ какъ не хотъли далеко отходить отъ воды. 


\section{Х. Тавета. Озёра Иапа н Джипе. Возвращенlе.}

Минутахъ въь сорока ходьы отъ мғста лагеря расноложен само селеніе Тавета ('T'areta). Оно-неболыное, хотя и синтается административнымь центромъ однонменнаго округа. Кромт хижинъ мвстнаго племени Ва-Тавета имююся сше жилища Ва-Суагели, затьмь католическая миссія, гды в’ь настоящее время нют», ни одного бълаго, двъ индусскія лавочки и, наконецъ, каменный домъ самого окружного комиссара, единственнаго европейца въ этоиі мъстности. Вокругъ выстроены казармы чернокожихъ aскари, а на дворъ возвышается мачта съ англіїскимъ флагомъ.

Г-нъ Лафонтенъ, мвстный комиссаръ, принялъ насъ съ твмъ гостепрінмствомъ, какое мы всюду привыкли встрбчать со стороны англичанъ, быль виднмо заинтересованъ нашей экспеднціей и сообщилъ намъ много цънныхъ свъдъній. По его словамъ, озеро Джипе еще никъмъ не было изсльдовано.

Вверхъ по теченію р. Луми, начиная отьь моста, тянется типичныї узкій галлерейный лєсъ. Ниже моста льсъь этотъ расширяется и достигаетъ мьстами до $1 \frac{1}{2}$ мили въ ширину. Ръка Луми быстро несетъ черезъ него свои воды въ озеро Джипе. Льсъ очень красивъ и носитъ типичный тропическій характеръ. Есть въ немъ высокія деревья съь пластинчатыми корнями. напоминающія фикусы, есть и ліаны " другія вьющіяся растенія, наконецъ, разнообразныя акаціи; на его опушк' встрбчаются Kigelia съ ихъ колбасовидными плодами, а вдоль рбки растутъ въ дикомъ состояніи финиковыя пальмы, бананы и ароидныя съ крупными листьями. Въ одномъ мьстю́, гдв ръка образуетъ нбсколько излучинъ " рукавовъ, шмъются заросли гигантской пальмы Raphic, вайи которой достигають порою двьнадцати и даже восемнадцати метровъ длины. Къ сожалұию, льсъ сильно нассленъ туземцами Ва-Тавета и изрґзанъ во всғхъ направленіяхъ многочнсленными тронинками. Эти тронинки вь сухос время года очень пыльны и пыль покрываетъ близь растущія растенія. Въроятно сухое время года было также причиної " того, что наши 
энтомологическіе и арахнологическіе сборы далеко не оправдали ожиданій.

Подъ корою деревьевъ найдены немногочисленные Pseudoscorpionidae и шкурки скорпіоновъ. Въ сухихъ листьяхъ, валя-

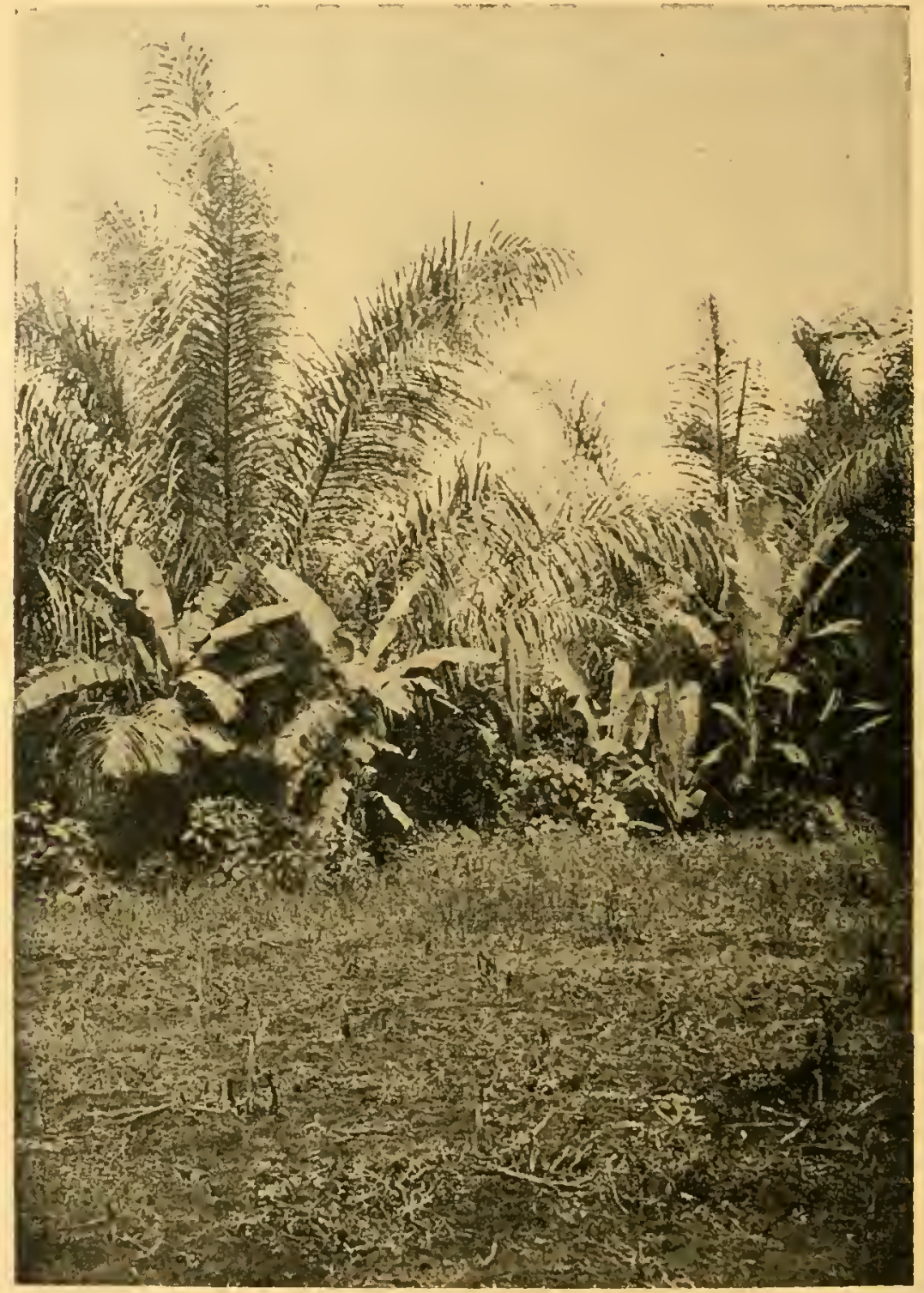

Pне. 22. Пальмы Raphia вы лбосу близъ Таветы.

ющихся на земль, попадается много таракановъ. На льсной полянкъ, на одномъ видъ Convolvulus, который въ изобиліи росъ среди кукурузы, поймано насколько видовъ мелкихъ и очень крупныхъ жуковъ, близкихъ къ Mylabris, сидъвшихъ въ большомъ количествъ на цвьтахъ.

у ръки водятся мухи изъ сем. Diopsidae. Вообще же насъ- 
комыхъ. за исключеніемт, пожалуї переночатокрылыхь, очен,

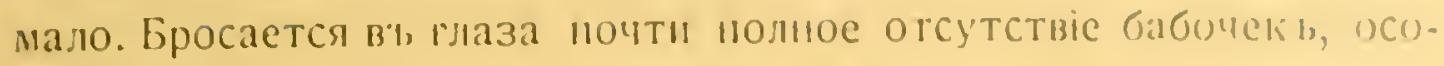
бенно, если сравнить богатство ими мабирскаго лыса. Зато термиты

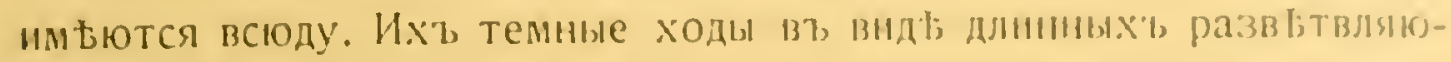
щихся лентъ, заходятъ высоко вверх"ь вдол, стволопъ деревьевт. При прикосновеніи къ этнмъ ходамъ, изнутри всенда раздастся размъренное постукнваніе солдать.

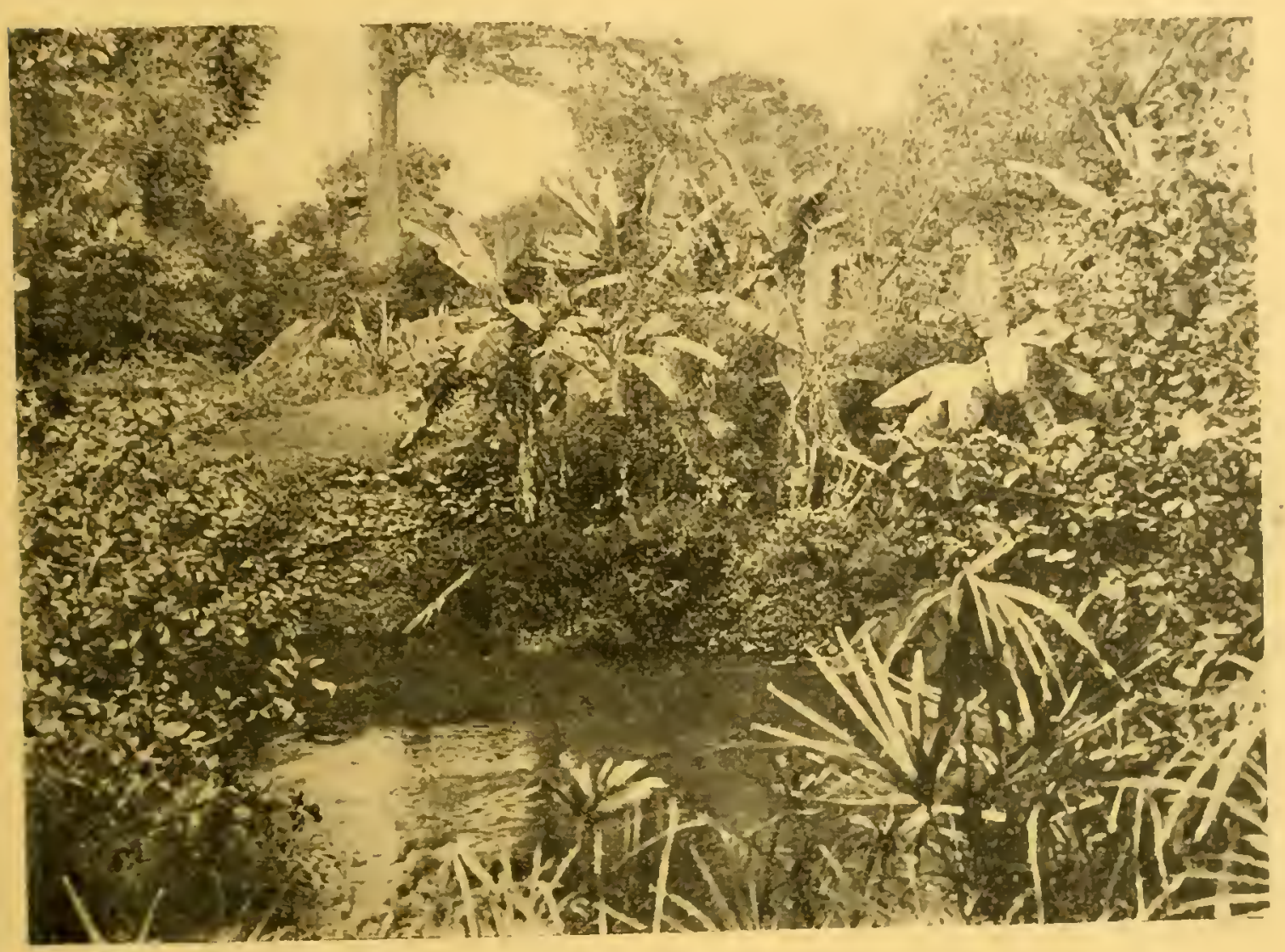

Рнс. 23:_Видъ льса близь Таветы.

Изъ позвоночныхъ сльдуетъ отмътить лягушекъ, ящерицъ, змъй, затьмъ баклановъ на рбчкъ и носороговъ (Bucanistes sp.), весьма сходныхъ съ таковыми же изъ Энтеббе, но съ болъе чернымъ опереніемъ, и, наконецъ, обезьянъ-мартышекъ и бабуиновъ. И тов и другіе держатся стаями, часто до тридцатн штукъ. Большой интересъ представляло для насъ раздобыть Colo. bus, для которыхъ Тавета считается наиболье низко расположеннымъ мбстомъ, гдъ они водятся,-но мы ихъ не видали вовсе. Какъ уже было сказано, въ льсу расположены селенія 
Ва-Тавета. На кругломъ, обнесенномъ легкой изгородью из'ь сучьевъ, дворикъ строятся три-четыре хижины. Матерьяломъ для постройки служатъ сучья и главнымъ образомъ длинные черешки пальмъ Raphia, крыша же дълается изъ сухихъ влагалищъ банановыхъ листьевъ. На дворикъ часто можно видєть дынное дерево (Carica papaya), а рядомъ всегда-насажденія бананов'ь и кукурузы. Передъ входомъ во дворикъ устраивается „dаєа“ для предохраненія скота отъ бользиней.

Населеніе питается главнымъ образомъ бананами, большія плантаціи которыхъ находятся въ южной части льса, и кукурузой; держитъ коровъ, козъ, овецъ и куръ. Наконецъ, оно занимается пчеловодствомъ. На многихъ окрестныхъ деревьяхъ можно видйть длинные ульи, сдъғланные изъ выдолбленныхъ обрубковъ деревьевъ и высоко подвъпенные къ во̆твямъ при помощи ліанъ.

Женщины носятъ интересныя украшенія въ видъ двухъ большихъ дисковъ, сдъланныхъ изъ толстой, завитой спиралью, мъдной проволоки. Диски эти помъщаются надъ грудями и подвъшены посредствомъ ремешка къ непомирно растянутымъ мочкамъ ушей. На шеъ одћты ожерелья изъ разноцвътныхъ бусъ, на рукахъ и на ногахъ-браслеты; ноги, сверхъ того, обуты въ сандаліи. Изръдка женщины одъваютъ черезъ плечи, крестъ-на-крестъ, украшенія изъ многочисленныхъ цйпочекъ, и еще рбже раскрашиваютъ себъ лицо-мода, которую до сихъ поръ мы встрбъчали только у мужчинъ.

Мужчины, такъ же, какъ и женщины, прикрываютъ твло кожей или тканью и носятъ въ изуродованныхъ ушахъ оригинальныя серьги въ видъ большихъ оваловъ, скатанныхъ изъ сала и изукрашенныхъ тонкими мъдными цъпочками. Другіе вставляютъ въ верхнюю часть ушной раковины по длинной черной палочк节, которыя торчатъ кверху, наподобіе рожковъ. Прическа дъзлается сложная, изъ закрученныхъ и связанныхъ въ пучки волосъ, совсъимъ какъ у Массаевъ. Вообще говоря, Массаи, населявшіе еще въ недавнее время эти мъста, а теперь выселенные на съверозападъ (въ Massai-reserve) во избъжаніе въчныхъ ссоръ со своими сосъдями Ва-Чагга (Wa-Chagga), на восточномъ склонъ Ки- 


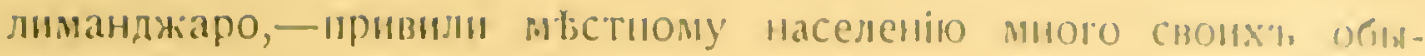
чаевъ.

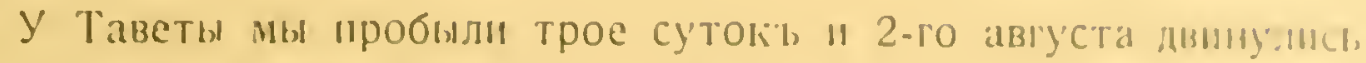

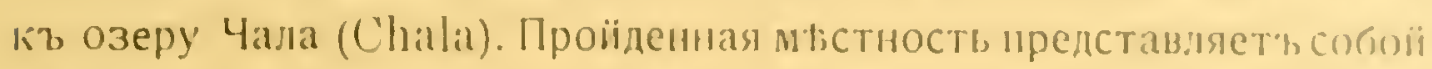
тиничную кустарикковую степь. По направленію кі, озеру она все время понемногу повышается, причемт, почва носитт, явно вулканическіиі характеръ; мғстами обнаженъ, вулканическії туфъ

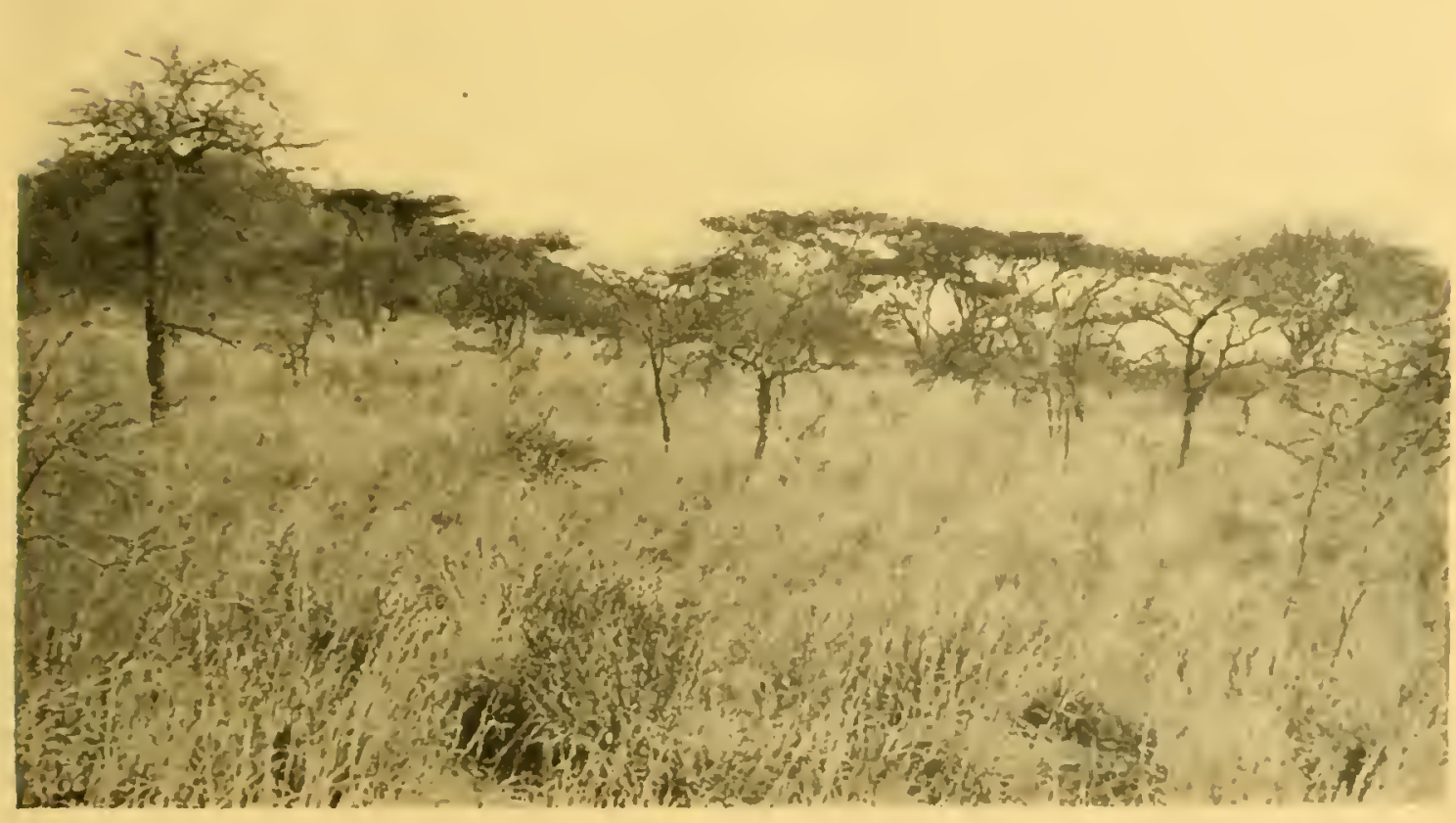

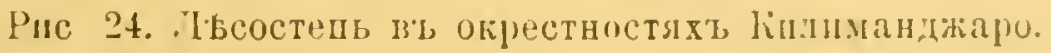

и всюду валяются камни изъ пористой лавы. Поверхность, кромъ того, вся-неровная, въ легкихъ складкахъ иморщинахъ. Кое-гдъ приходилось переходить черезъ сухія русла небольшихъ ручьевъ.

Озеро Чала представляетъ типичное кратерное озеро и принадлежитъ уже къ системь кратеровъ восточнаго склона Килиманджаро, являясь самымь крайнимъ изъ нихъ. Кратеръ Чала имъетъ почти круглое очертаніе. Его края сравнительно высоко поднимаются надъ уровнемъ окружающей степи, такъ что для подъема требуется не менъе получаса (на обходъ же вдоль края 
надо считать по крайней мъръ три часа). Наружные скпоны кратера радіально складчаты и по характеру растительности ничъмъ не отличаются отъ прилегающей степи. Внутренніе же склоны

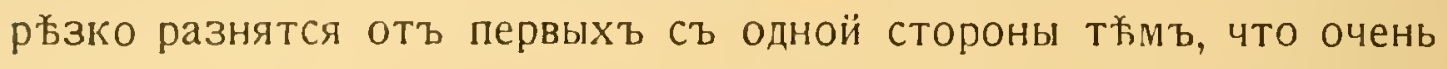
круто, почти отв Һсно, спускаются внизъ къ водъ, съ другой стороны твиъ, что носять иного характера растительный покровъ. Благодаря непрерывному испаренію, внутри кратера бываетъ всегда

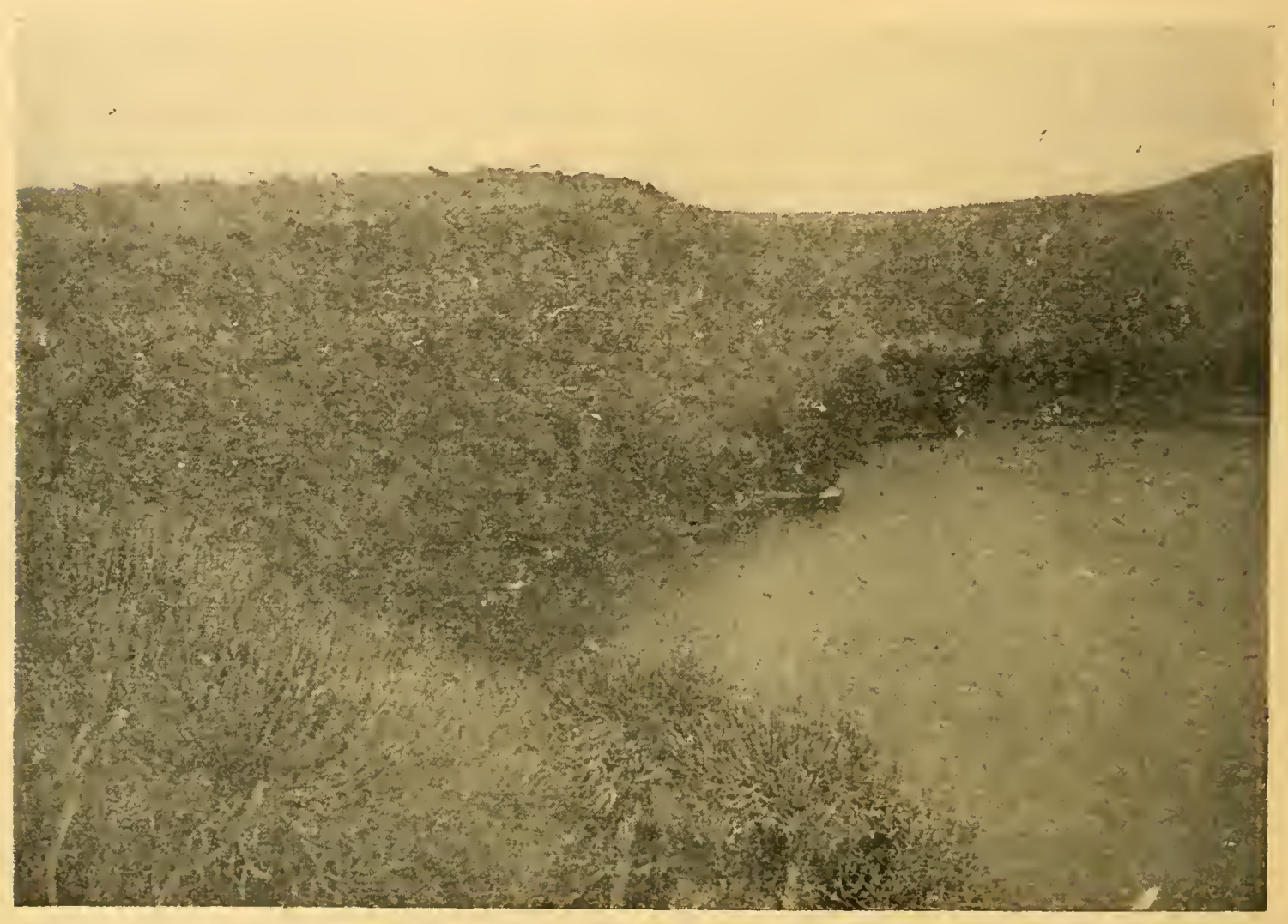

Pнс. 25. 0зеро Чала (Chala).

достаточно влаги, и она способствуетъ пышному развитію одного вида эуфорбій, густо покрывающаго обрывистые склоны. У самой же воды зеленъетъ сплошная заросль разнообразныхъ лиственныхъ деревьевъ, ліанъ, кустарниковъ и пр.

Черезъ озеро проходитъ англо-германская граница. На германской сторонь, у самаго края обрыва, выстроено нбсколько домиковъ, гдъ живутъ аскари (бълыхъ во время нашего посъщенія не было). Отсюда выбита въ каменистомъ склонғъ широкая тропинка, которая, извиваясь зигзагами, приводитъ къ небольшой площадкъ, покрытой валунами,--единственному мъсту доступа къ водъ. 
По всей же остальной окружности озера берега совериенио отвысно снускаются въ воду, на основанин чего можно закличит. что озеро должно имтть значительную глубнну.

У мұста спуска оказалась лодка-однодеревка, ст, привязаниымн 110 бокамъ. для устойчивости, бревнами. Мы ею восиользонались, чтобы взять пробу планктона. Вопреки ожиданіямъ осадокъ вл цилиндрђ получнлся крайне ничтожиыі. Ца и вообще, озеро оказалось весьма бъдно заселеннымь. На удочку было поймано нъсколько рыбокъ одного вида изъ группы Асанthopteri, подъ қамнями, вынутыми изь воды, найдены мелкіе рачки, а съ поверхности воды взяты небольшіе клопы; "только рачницей, на мясную прнманку, намъ удалось вытянуть за короткіiі срокъ порядочное количество крабовъ, по всей вғроятности Telphusu Крокодиловъ, о присутствіи которыхъ здъсь говорилъ комиссаръ, мы не видали.

Къ востоку отъ озера Чала находятся верховья рбки ЛумиЗдъсь она имъетъ, въ сухое время года, видь узкаго, мелководнаго ручья, въ дождливый же сезонъ высоко подымается, о чемъ свидътельствуютъ обнаженные и обмытые корни на ея крутыхъ берегахъ, вывороченныя съ корнями и нагроможденныя другъ на друга деревья, образующія мъстами природные мосты, и комки ила и травы, застрявшіе высоко въ прибрежныхъ кустахъ. У самой воды зеленғютъ густыя заросли травянистыхъ растеній. На нихъ въ большомъ количествъ сидятъ мухи изъ сем. Diopsidae и мелкіе кузнечики. Вокругъ летаетъ нбсколько видовъ стрекозъ и бабочки преимущественно изъ Pieridae. У самой воды бъгають небольшіе блестящіе Carabidae и зарываются въ сырой песокъ. По поверхности воды снуютъ разныя Hydrometridae и вертятся Csrinidae. ПІодъ камнями прячутся крабы и тутъ же скачутъ молодыя лягушки и жабы, а ихъ головастики скопляются въ мьстахъ съ тихимъ теченіемъ. Вообще присутствіе здъсь воды сразу сказывается на богатств в животными.

Возль самой нашей палатки былъ найденъ одинъ крупный видъ термитовъ Hodotermes mossambicus, живущій полъ землей и производящій свои работы на поверхности почвы при дневномъ 
освъщеніи. Въ кишечникъ этого вида оказались 'Trichonymphidae.

Въ окрестностяхъ озера и вдоль ръки водится много млекопитающихъ: зебры, носороги, бородавочники, кабаны, конгони, бушбокъ, выдающій свое присутствіе характернымъ лаемъ, эландъ (Oreas), затьомь мартышки (Cercopithecus) и т. наз. „blue-monkеу“, бълки, зайцы, дикообразы, иглы которыхъ валяются чуть ли не повсюду; по ночамъ завываютъ гіены; наконецъ, иногда попадались и сльды львовъ. Изъ птицъ особенно много франколиновъ и цесарокъ.

6-го августа, рано утромъ, мы двинулись обратно на Тавету и, не заходя въ нее, пошли прямо по направленію къ озеру Джипе. Дорога идетъ все время вдоль лъваго берега р. Луми черезъ упомянутый выше таветскій льсъ. Часа черезъ полтора ходьбы льсъ начинаетъ р‡дъть и дблается типичнымъ галлерейнымъ. Вскоръ дорога выходитъ на открытое мъсто, поросшее невысокой зеленой травой. То тамъ, то сямъ на немъ растутъ красивыми группами финиковыя пальмы и неболышіе экземпляры пальмы Hyphaеле. Нъсколько далье, за небольшимъ льсомъ желтоствольныхъ акацій безъ подльска, гдъ мъстами из’ земли торчали пунцовокрасныя соцвьтія Sarcophyta sanguinea (изъ Balanophoraceae), потянулись вновь банановыя плантаціи. Наконецъ, за пересохшимъ русломъ одной рбчки съ густыми зарослями финиковой пальмы, мъстность принимаетъ совсъмъ новый характеръ. Почва получаетъ бъловатый оттънокъ и покрыта низкой, высохшей травой. Въ нъкоторыхъ мзстахъ растетъ низкорослая, не выше полу-аршина, эуфорбія и одинъ видъ Aloё съ чрезвычайно толстыми мясистыми листьями и кистями красныхъ цвътовъ. Однако, наиболъе характерной особенностью являются многочисленныя высокія пальмы Hyphaene coriacea, растущія вперемежку съ акаціями. Ихъ стволъ нбсколько разъ (часто въ одной шлоскости) дихотомически вътвится, а на концахъ вътвей собраны густыми пучками красивые въерообразные листья. Старые сухіе листья остаются подъ ними, такъ что наиболье длинныя вътви обычно густо одъты черешками, располагающимися правильными, слегка закрученными рядами. 
7-го августа, рано утромь, спеціально взятый проводиякь (kiongozi) повелъ насъ еце по сильно росистой, жесткой праны, къ озеру. Озеро Джипе (Јіре) имтет’ь силью уллинениую

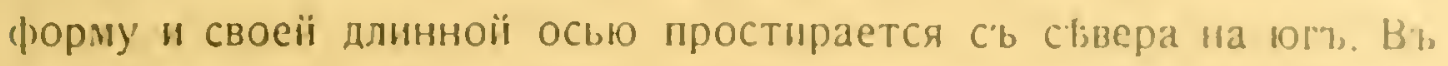
его сьверную оконечность, окруженную общирным болотомъ, впадает’ь рька Луми; западный берег”ь ограничен', кряжем'ь высокихъ горъ, а восточный-незамттно нереходить въ стешныя пространства Серенгетти. Вдоль его берега, на большом' иротяженіи

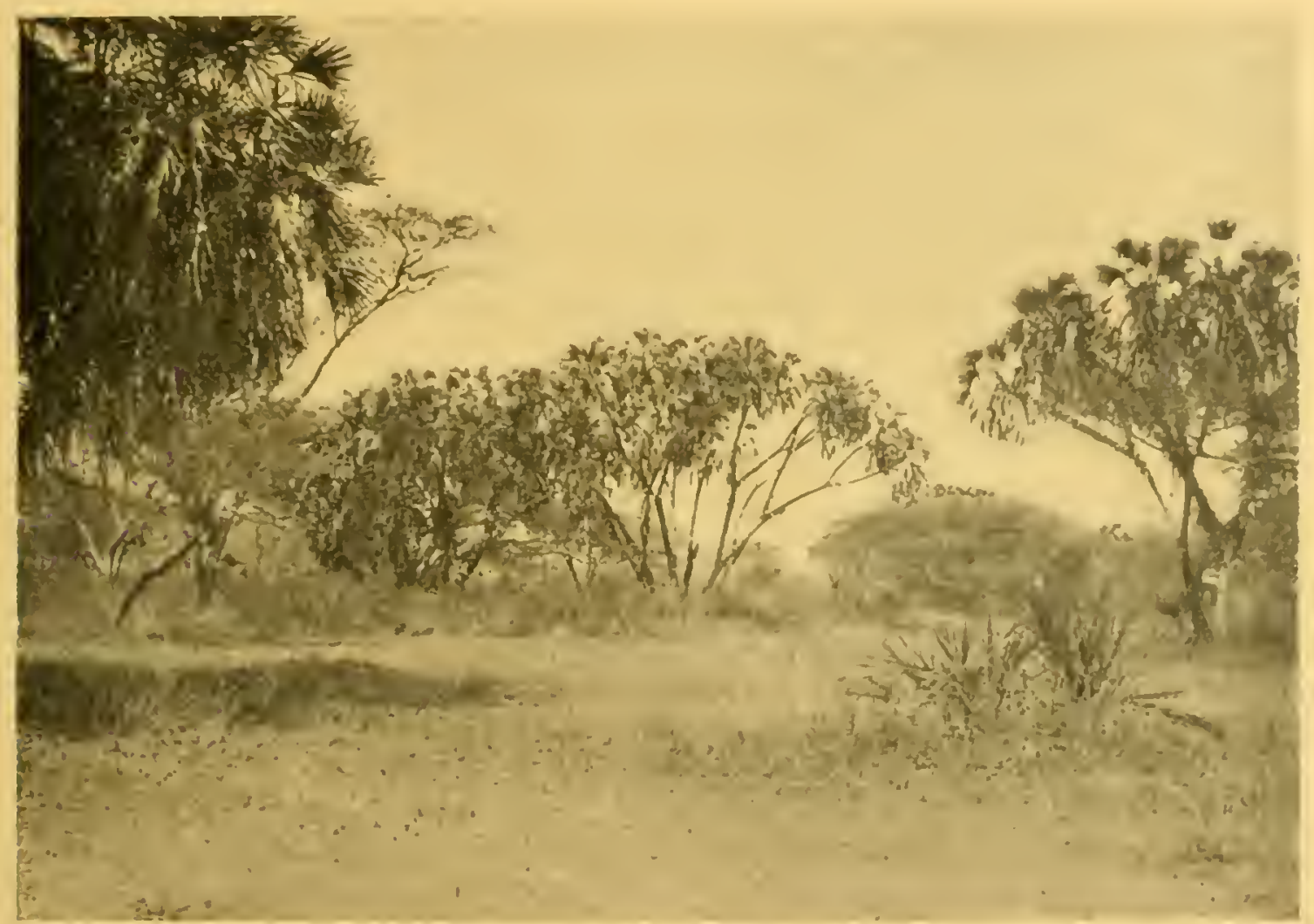

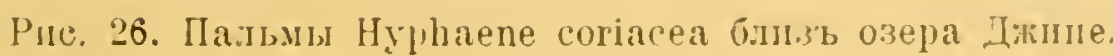

растутъ узкимъ поясомъ желтоствольныя акаціи (какъ это было и у озера Накуру), а от’ь нихъ вплоть до самой воды сльдуетъ широкая зона высокаго тростника, осоки и разнообразныхъ прибрежныхъ травянистыхъ растеній.

Эти заросли настолько густы, что пробраться сквозь нихъ не представляется никакой возможности. Лишь въ одномъ узкомъ молсть есть непосредственный доступъ къ воды. Въ этихъ заросляхъ водится громадное количество москитовъ и среди нихъ множество Anopheles, успғвшихъ заразить одного изъ насъ за 
одинъ день пребыванія на оз. Джипе малярійными паразитами.

Когда мы подошли къ водъ, то увидъли совсъмъ близко отъ берега болће десятка торчащихъ изъ воды головъ крокодиловъ. Слова комиссара, который увърялъ, что озеро Джипе буквально кишит'ь крокодилами, оправдывались. Одного изъ нихъ намъ удалось убить; онъ былъ болье 3-хъ аршинъ длиною и содержалъ паразитовъ изъ Nematodes.

Мћстность вокругъ нашего лагеря, съ красной латеритовой почвой, несмотря на знакомый характеръ растительности, неожиданно оказалась интересной въ фаунистическомъ отношеніи. Такъ, за время краткой экскурсіи въ окрестности были цобыты изъ-подъ коры и поваленныхъ деревьевъ: Scorpionidae, Pseudoscorpionidae (3 вида), Tetrapneumones (3 вида, одинъ очень крупный) и другія Araneina; впервые найдено нбсколько видовъ Carabidae изъ группы Anthiina, жуки изъ Troginj (Scarab.), въъ большомъ количествъ скоплявшіеся около изверженій разныхъ хищниковъ, и нбк. др. Особенно любопытной должна являться фауна галлъ одного вида акаціи, близкаго къ Acacia fistulosa, такъ какъ въ нихъ, помимо муравьевъ, были найдены небольшія гусеницы, жучки, перепончатокрылыя и мн. друг. Однако, дальнъйшее изсльдованіе, объщавшей много интереснаго, мыстности и, главное, озера пришлось оставить, такъ какъ въ тотъ же день въ нашъ лагерь прибылъ нарочный отъ комиссара съъ запиской, въ которой мы извъщались о начавшихся въ Европъ военныхъ событіяхъ.

На сльдующій день утромъ въ лагерь явился патруль, состоявшій изъ двухъ правительственныхъ аскари въ полной военной формъ и трехъ туземцевъ Ва-Камба, вооруженныхъ луками и стрболами. Они принесли другое письмо отъ комиссара с'b совътомъ идти скоръе въ Тавету, что мы и сдблали.

По прибытіи въ Тавету мы узнали, кромъ разныхъ.политическихъ новостей, и о томъ, что намъ невозможно идти старой дорогой на Вои. Дьло въ томъ, что для этого путешествія необходимы были водоносы, а у насъ теперь имълся всего двадцать одинъ носильщикъ, такъ какъ остальные двадцать были от- 
пущены сразу послғ; перваго прихода иъ Тавету; о новыхт, же носильщикахъ, благодаря паникь среди Ва-Тавета, вызваниой военными служамн, нечего было и лумать. Оставаляя только одини исходъ: идти съ имъвшимися налицо носнльщнками кружными, но обильнымъ водою, путемъ на рбку Цаво ('l'saro) и на одио. именную станцію Угандской жельзной дороги. На этотъ путь предстояло затратить семь-восемъ дней.

Отдохнувши сутки въ Таветь и оставивъ тамъ нъкоторыя лишнія вещи, мы выступили 10-го августа вь путь.

Дорога, или върнъе узкая тропинка, мъстами каменистая и неровная, идетъ сначала на съверъ, вдоль льваго берега р. Луми и потомъ постепенно заворачиваетъ на съверо-востокъ. Мћстность представляетъ кустарниковую степь съ преобладаніемъ кустарниковъ и богата крупными животными.

Въ первый день лагерь былъ разбитъ у большого болота Зивани (Ziwani), гдъ были произведены нъкоторые сборы. 11-го августа нашъ путь лежалъ уже вдоль праваго берега порожистой ръки Зивани, вытекающей изъ болота. Берега ея окаймлены въ верховьяхъ желтоствольными акаціями, а затьмъ деревьями съ ярко-зеленой листвой. Сама тропинка ведетъ черезъ колючій безлистный кустарникъ. И здъсь мъстность отличается обиліемъ крупныхъ животныхъ. Мы видъли много импалъ (Aepyceros), малыхъ куду (Strepsiceros), конгони, разныхъ мелкихъ антилопъ. кабановъ, бородавочниковъ и пр. Изъ птицъ-секретаря, грифовъ, кружившихся вокругъ отбросовъ покинутаго недавно лагеря, голубеіі, франколиновъ и прямо невъроятное количество цесарокъ: съ одного только небольшого участка мы спугнули ихъ болъе сотни.

12-го августа мы продолжали ицти въ томъ же направленіи, пока часа черезъ четыре не пришли къ болье открытому мъсту. напоминающему окрестности озера Джипе. Здъсь также въ изобиліи растетъ жесткая трава, а ближе къ рбкъ снова множество пальмъ Hyphaene coriacea, которыя отсюда продолжаютъ намъ сопутствовать, сльдия течснію рбкъ Ромбо (Rhombu) и Цаво. вплоть до жельзной дороги. Вперемежку с'ь ними растутъ и финиковыя пальмы. Въ зтихъ местахъ, какъ всюду по всеї 
равнинъ Серенгетти, разбросаны въ большомъ количествъ гигантскія постройки Termes bellicosus, съ характерными трубами на ихъ поверхности. Одинъ изъ термитниковъ осебенно поразилъ насъ своей высотой, такъ какъ превышалъь двойной человъческій ростъ.

На сльдующій день мы слъдовали уже вдоль теченія рбки Ромбо, въ которую впадаетъ Зивани. Въ мъстахъ, лишенныхъ травы, на красной песчаной почвъ,, повсюду видны сльды носо-

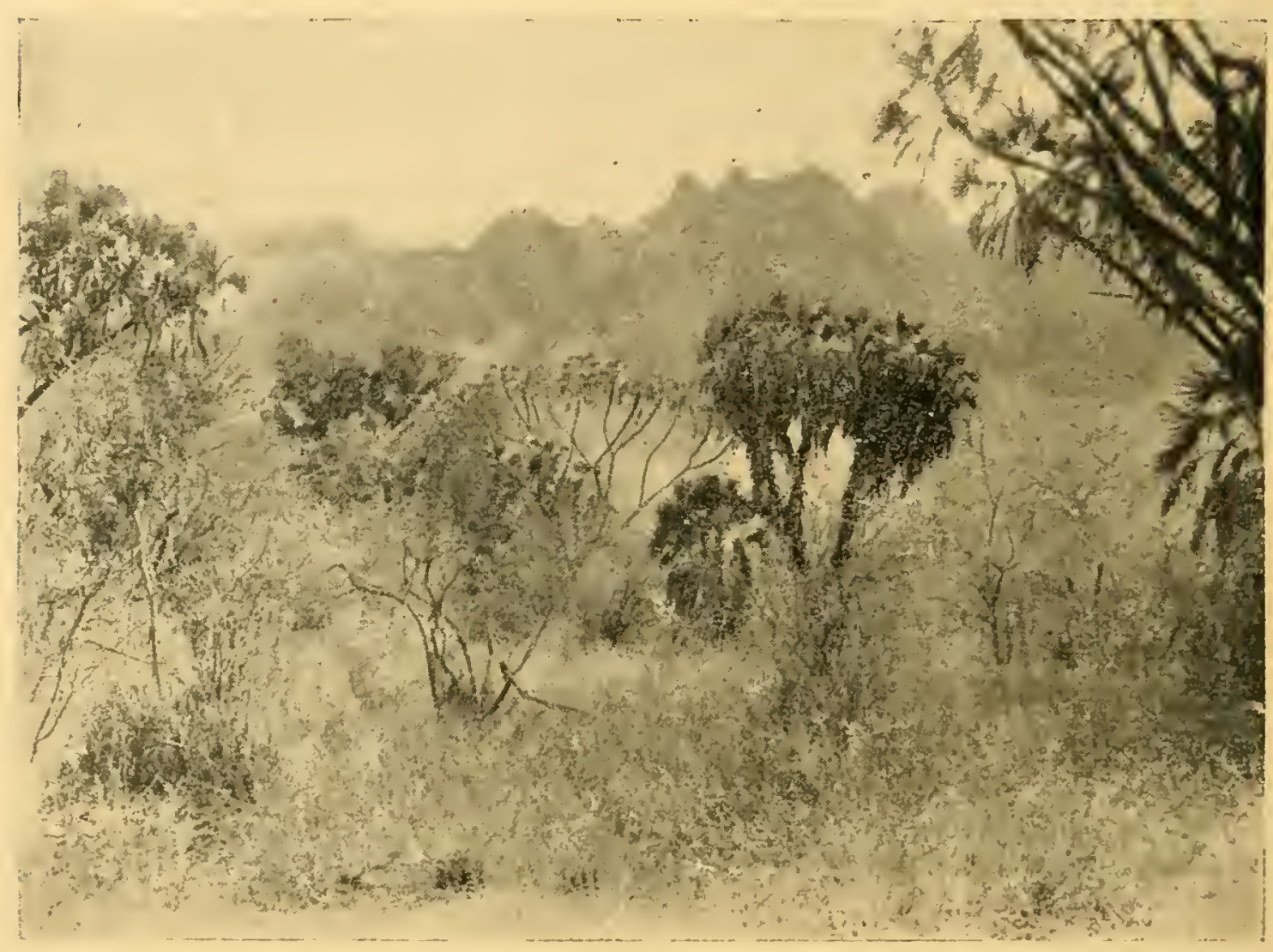

Рнс. 27. Ландиаф̆ть у рьки Цаво.

роговъ: отпечатки ногъ, вырытыя ими ямы и объемистыя кучи навоза. Вообще, они изобилуютъ въ этой мъстности, но, какъ это ни странно, мы видъли ихъ всего разъ. На лъвомъ берегу Ромбо мы разсмотръли дощечку съ надписью „game reserve*: это южная граница большого заповљднаго участка (Southern game leserve).

Далъе по дорогъ стали попадаться довольно часто слғды слоновъ, гл. обр. въ видъ старыхъ изверженій, но въ одномъ мбстъ 


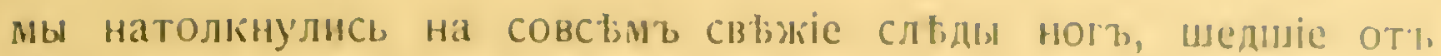

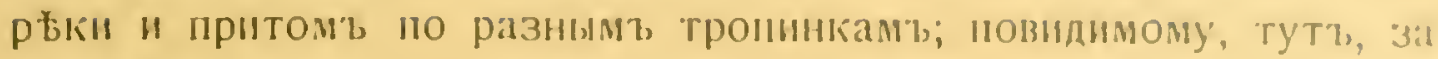

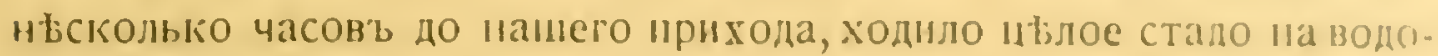
пой. Видұли также слұды буйвола и бегемотовъ, которые в иеболышомь количестны водятся в’ р. Цаво. Plкa изобилуеть рыбой " наши носильщики не разъ ловили ес на удочку.

Одинъ разъ пришлось переходить черезъ невысокіі, но очени, тяжелый для ходьбы, вулканическіиі кряжъ. Лагерь былъ устроенъ, противъ длинної цъпи горъ Kiуліу (Chiuliu), расположенныхъ къ съверу отъ р. Цаво. На востокъ цвпь эта замыкается кряжемъ горъ Нгуліа (Ngulia), оріентированныхъ къ первой под' острымъ угломъ.

Два сльдыующихъ дня мы шли черезъ густыя, сплошныя заросли кустарника, которыя характерны для всей мбстности вдоль р. Цаво. Благодаря кустамъ, крупныхъ жнвотныхъ почти совсъмъ не видно. То и дъ́ло приходилось переходить, совершенно пересохшія въ это время года, русла многочисленныхъ притоковъ р. Цаво.

Наконецъ, 16-го августа, перешедши черезъ скалистый кряжъ, поросшій эуфорбіями, и изрбдка баобабами и красиво цвљтущими Adenium coaetaneum, достигли жельзнодорожной станціи Цаво. Зльсь мы разсчитались со всћми свонми слугами, раздарили нмъ кіоі-какія веши и въ тотъ же день отправились съ проходившимъ случайно воинскимъ поъздом'l, на который любезно были приняты англійскими офицерами, въ Момбасу. Посль недъльнаго пребыванія въ Момбась⿱㇒⿻二丿亅, намъ удалось попасть на итальянскій пароходъ, отправлявшійся въ Геную, которыі и доставилъ насъ в' Европу.

Въ заключеніе обзора нашей поъздки мы считаемъ не лишнимъ, дать краткій, не претендующіи на полноту, спнсокъ книгъ ") статеіі, которыя могутъ оказаться полезными для натуралиста, cooирающагося посьтить Восточную Африку. 
L. A. Herzog von A bruzzen. Der Ruwenzori. Leipzig. 1906.

Allua ud et J eannel. Faune de l'Afrique Orientale. Выходить вышускамиз.

С. В. А в е р и н д е в ъ. Предварительный отчетъ о поъздкв па стипендію, учрежденную при Бейтензоргскомъ Ботаническомъ садъ. Зап. Имп. Акад. Наукъ. V'll sér. Т. 31, № 6. 1913.

A. B erger. In Afrikas Wildkammern als Forscher and Jäger. Berlin. 1910.

I. Bland-Sutton. Man and Beast in Eastern Ethiopia. London. 1911. D u g m or $\theta$. Wild, Wald und Steppe. 1913.

Engler. Die Vegetation del Erde. Die Pflanzenwelt Afrikas. 3 Bde. 1910. H. Johnston. The Úganda Protectorate. 190\%.

Koh Is tock's Ratgeber für die Tropen.

H. M e y e r. Der Kilimandljaro. Reisen und Studien. Berlin 1900.

A d o lf v. M e c k l e $\mathrm{nburg}$. Ins innerste Afrika. Bericht über den Verlauf der deutschen wissenschaftlichen Zentral-Afrika-Expedition 1907-1908.

В. Н. Н и ки т и в. На берегахъ Викторіи Ніанды. Природа. Май 1914. Ple h n. Tropenhygiene.

Purvis. Through Uganda to Mount Elgon. Londan 1909.

Th. Roos e velt. Afrik anische Wanderungen.

C. G. Schilling s. Mit Blitzlicht und Büchse. 4. Abdr.

C. C. Schillings. Im Zauber des Elelescho. Neue Beobachtungen und Erlebnisse in der Wildnis inmitten der Tierwelt von ÄquatorialOstafrika.

I. S jöstedt. Wissenschaftliche Ergebnisse der schwedischen zoologischen Expedition nach dem Kilima-Ndjaro, dem Meru und den umgebenden Massaisteppen Deutsch-0st-Afrikas 1905-06. 3 Bde.

3. Ф. С в ато ш ъ. Краткій маршрутъ экспедидін кн. А. К. Горчакова по Восточной Африкъ. Ежег. Зоол. Муз. И. Ак. Н. т. ХVII. 1912.

Вл. Троицкій. Поъздка въ центральную Африку съ 21 февр. 1912 до 27 марта 1914 годовъ. Тамъ же т. ХХ. 1915.

V e I t e n. Suaheli-Grammatik. 1913.

Velten. Taschenwörterbuch der Suaheli-Sprache. 1911. 


\section{The route and brief description of the travel.}

The expedition, the results of which form the subject of this hook, was perforned by us in the summer of 1914 and necmpied about 6 months (from the 5 -th April till the 30-th September). The chief purpose of this travel was collecting material on the anatomy and embryology of the lower, invertebrate animals. Collecting of the rertebrates and fannistic investigations were placed by us in the second plane, as we could not expect to attain good results in this rirection owing to the comparatively modest means that were at our disposal. Besides this, systematic collections seemed less important to us, as they formed the only object of most expeditions that risited British East Africa.Notwithstanding such a tendency, our collections gave material for a series of fallnistic works as well, as may be seen from the contents of this volume.

Our route was as follows: having hoarded the steamer at Marseilles we reached Mombasa, the chief port of the British East Africa Protectorate, having passed via Naples, Port Said, Suez and Aden. Mombasa is the starting point of the Uganda Railway joining the shores of the Indian ocean with the Eastern shore of lake Victoria Nyanza. From here we set forward to the capital of the country, Nairobi, situated along the railway line between Nombasa and lake Victoria Nyanza. At Nairobi we worked out our ronte of travel further with the most hearty assistance of M-r Woodhouse, performing the duties of Game Warden. IJuring onr weekly stay at Nai. 
rohi ve also made some entomological collections, but most of the time weut in preparing for the journey further. Our plan consisted in first getting further into the interior of the continent and then gradually returning to the sea-shore. The town Eutebbe on the northern shore of Victoria-Nyanza was chosen as the extreme west point of the expedition. At this place we remained about three weeks, having arranged a laboratory on the wide verandah of the hotel "Victoria". Collections were gathered partly in the Botanical garden, partly in the roods of the neighbourhood, and on the way from Entebbe to Kampala. We first of all succeeded in taking a considerable number of parasites of birds and lizards here, as well as some material on the embryology of chameleons and agamas (Chamaeleonidae and Aganidae). Besides, different invertebrates were examined for parasites, and some interesting gregarines were found in Myriapods (Juljdae) and in the bodycarity of a large Nepa. The Pseudoscorpionidae and Polyxenus which were found mostly on the trunks of date-palms provided us with embryological material. In the Botanical garden land Planarians were found under falien tree trunks. At the same time we were occupied in collecting insects and spiders for systematic, purposes; the insect world at Entebbe is very varied, as it may be seen from the rich collections of the local entomologist, M-r Gowdey. The orders Rhyuchota and Hymenoptera are especially abundantly represented. Collections on Jake Victoria Nyanza gave us several samples of the plancton, crabs and fresh-water shrimps. From Entebbe we left for Jinja with its celebrated Ripon Falls, from which the Nile starts its course from Victoria Nyanza. Without stopping at this place we proceeded further north to the rubber plautation of the Mabira Rubber Company, the manager of which, M-r Martin, kindly offered us his hospitality. The plantation is situated amidst a splendid tropical forest the fanna of which we intended to make the object of our acquaintance. Begiuning from the plantation, which is situated on the summit of a 


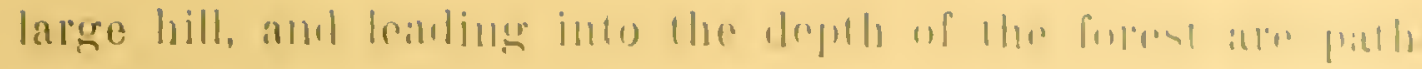

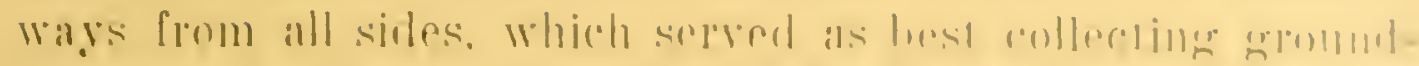

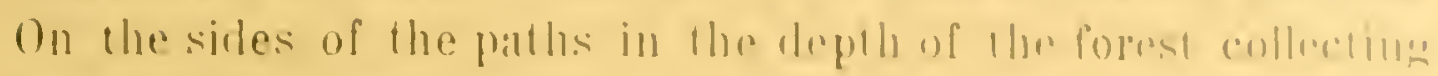
gare much worse results (only hose animals lhat sholloperl under rotting leaves were to he fomml here).

Concerning the anatomical-emblyological matebial, 11 . have collected the following in the Mabira forest: intestinal and hlood-parasites of different hipds, reputes (of sllatios as well, as they are to he foumd in abmulanco in Mahilia), amb amphibians. Parasites of the intestine of a larege Polydesmus. Abundant material on the embryology of some species of l'spmloscorpionidae. An interesting form of calcupillars provillel with poisonous hairs which they use for covering the coconm before pupification. Material ou the anatomy of odoriferous rrandic of Danaida mercedonia. The stalked eyes of lities of the family Diopsidae were fixed for histological inrestigation, etc.

To the systematic collections were added abundant collecfions of Lepidoptera which fly along the wood-paths in enormous quantities. Amongst the butterflies that were caunht the following may be mentioned: numerous representatives of the genus Charaxes, different Lallima, large Hupolimnas and brightly coloured Papilio, of which P. mimeticus is especially interesting as it imitates the aforesaid Incmaidu mercedoniu. The Coleoptera give us rarious Cerambycidae and some forms living under the bark, and also mighty coliathbeetles which are characteristic for West Alrica chicfly. In all. the Mabira forest gave us the most abundant material in insects during all the travel. Collections of spiders and myriapods were also plentiful. The water fama was examined from a small rirulet and in separate holes wilh water, that were to be met in some places along the roal. Simmerons shrimps were caught in the rivulet, and the holes yielded several forms of Ostracoda and Cladocera.

Haring stayed is days at Mabira we marle nur next halt in the town lisumu, the ultimate station of the Lgandir Rly. 
We stopped in Kisumu, because here it was possible to get material in fishes of the Victoria Nyanza lake, as in this town regular fisheries have been established for several years already by a Dane, M-r Arap, and two or three other undertakers. And indeed, during the 4 days that we stayed at Kisumu we succeeded in getting some large carps, Silurus, Mormyrus, Protopterus (those can easily be got here), and different Acanthopteri; we also gathered plenty of endoparasites from them.

In order to get acquainted with the fauma of great heights. we returned from Kisumu in the direction of Nairobi to the station Molo (8000 ft. above the sea-level) which is situated on the summit of the mountain ridge Mau. The difference in height compared with the places we risited before (Kisumu $2400 \mathrm{ft}$, Mabira $2800 \mathrm{ft}$ ) is at once noticeable in a colder climate (only $9-11^{0} \mathrm{C}$. at 8 a. m.) and a different character of vegetation. The slopes of the ridge are covered with dense gloomy forests mingled with open lawns and meadows the composition of the grass vegetation lesembles the European flora rery much; in the forests abietic trees are predominant, viz. junipers (Juniperus procera), but in some parts the forests consist of bamboo exclusively. The fauna of Molo proved to be very poor, so we shortened our stay here to 8 days. Especially flying insects that Iike the sunshine are scarce at this place. There were few butterflies (Pieridae, 2 or 3 species of Papilio, several forms of Nymphalidae. Lycaenidae and 7ygaenidae), still fewer bugs which were surprisingly numerous in Uganda, and small unseemly Coleoptera. Nore interesting collections could have been made only under rotting leaves, under fallen trees and in the hollows of trees. Besides auts and termites there are to be found here myriapods (Julidae, Strongylosoma, Lhilopoda), beetles, land planarians, Phalangidae, Psendoscorpionidae, spiders and earthworms.

The dampness of the climate in the mountains favours 


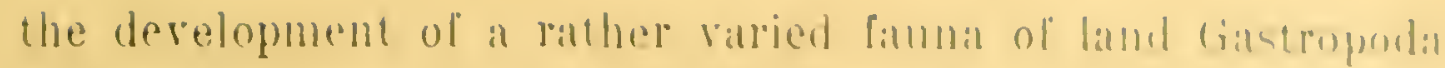

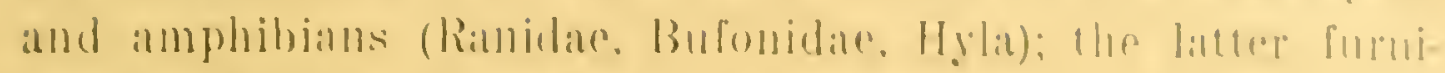
shed us with some material on emdopatrates.

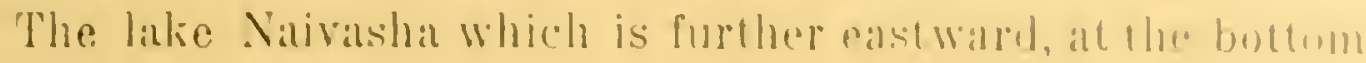
of the grealt Rift lalley, wats malled as the next hattimg-

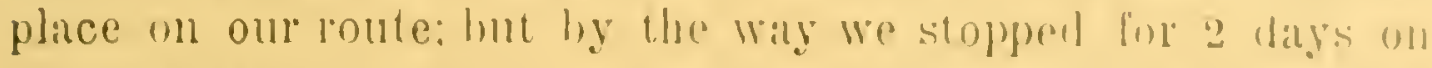
the lake Nakuru where we were surprised at the abmulance of different kinds of water-birds.

The lake Nairasha is on a height, of about 6000 lt. and the place surromeling it has the character of a plain chiefly. Here we stopped in the estate of Major Groginn, Longonnt bistite, who kindly put the manager's house, which is situaterl on the very bank of the lake, at onr disposal. 'The chiel object of omr investigations at Longonot was collecting of material on histology and on parasitic Infirsoria from the intestine of dillerent hoofed animals. The abundance of big game in the ricinity of the estate greatly facilitated our objrct. Partly ourselves, and partly with the kind assistance of the manager, M-r Hignell. we collected material on liongoni (Bubalis cooliei), Thompson's gazelle (Gazella thomsoni), Grant's gazelle (G. granti), zebras, dik-dik and bushbock. Besides, we succeded in getting material on intestinal worms and rn the histologs of the wart hog (Phacochoerus) serval cat and porcupine.

The famna of invertebrates, except small entomological collections and plancton taken from the lake, and samples of ground with Ostracoda, was very little dealt with at Longonot.

After a fortnight's work at longonot we found ourselres in Nairobi lor the second time, in order to make the necessing preparations for the last part of colr royage. The latter was to consist of a "safari“ on loot from the station Voi fon the way hetween Nairobi and Mombasa) to the sonth toward the frontier ol British East Africa, and to Kilima-Njaro. We intended to make a halt at an English settlement Tareta to exanine two neighbouring lakes (l. Chala and l. Jipe), then to 
pass into the Cerman possessions at Moshi and ascend the Kilima-Njaro up to the snow-line, after that to return by the German rly to port Tanga on the sea-shore. This port was to be the point of our departure for Europe.

Owing to the breakont of the great war, only the first hall of our plans could be fulfilled.

As we have already mentioned, we had so start our "safarj", i. e., a cararan march with $40-50$ carrier's, from the station Ioi. Part of the personnel of the cararan was, engaged at Nairobi, but the greater part of carriers we got in Voi with the assistance of the local District Commissioner. The two days that were occupied in finding carriers we spent making excursions in the nejghbourhood of Voi which is scorched by the sum. Here we paid attention to the remarkable coloration of the local Insecta. The majority of them are either of a rulons, or dark-gray colour. This circumstance may serve as an example of protective coloration, for in the nature of Voi (at any rate, during July) the predominant colours are those two mentioned: red is the colour of the clayey or laterite ground, and gray is the colour of faded grass. Adaptation is also often transferred to the shape of the body: the red insects imitating the colour of the earth are rery often corered with tubercles, and their surface is uneven, thus resembling sand-grains (e. g'., Tenebrionidae, Curculionidae), as concerus the gray Insecta, imitating the grass, they usually have their bodies elongated, bacilliform, with thin thread-like feet. Nany black beetles of Tenebrionidae not being provided with a protective coloration, throw sume red clay-dust on their backs and, thus, become unnoticeable.

On the 25-th July we started on our journey. From Voi right to Taveta there is a beautiful wide road, so that travelling on foot is very comfortable here. The road first leads in the direction of the Bura monntains, where we made our first halt for the night not far l'rom the building of the Catholic mission. Owing to sufficient irrigation, the regetation here is 
much richer than in Voi. this is also to he seen from the collections we male during ome one day's halt alt linral. Amonerst the collections must he mentioned the capture of there sperefes of 'Tetrapnemmones (the lirst that we saw in Alrical) all the same place, and even at loj, we hegan to meet with Solpungdate.

Further, during three days, our way lay through the arid Serengetti Plains (water had to be carried along wh us) covered in some places only with grass, in others also with acacias, Commiphora, and near 'Taveta with baobabs as wefl. We were going amidst numerous herds of Kongoni, Cirint's gazelles and Oryx beisa. Not so often we met with giriffes, Willer's gazelles, elands, impalas, zebras and ostriches. The iuroluntary speediness ol our march (owing to absence of water) compelled us to limit oul collecting to halting-places. Mostly we found beetles, cockroaches and scorpions (under fallen trees).

On the fifth day of our departure from Voi we reached Tareta. This is a very small settlement situated at a distance of 40 minutes walk from the river Lumi. Formerly it stood near the very river, but from feal of malaria the station was afterwards transferred to a more safe place. We encamped near the river on a lawn, lrom which before sunset and in the morning there opened a beautilul view on the snowy summit of Kilima-Njaro (in the day-time all the upper half is enveloped in clonds). Our halting-place was chosen near the Taveta forest where we intended to collect for a few days. The Taveta forest in fact represents the gallery forest of the river Lumi widely expanded and differs from the ordinary gallery forest in richness and width-it is like an oasis of a virgin, tropical forest amidst surrounding plains. With a length of 10 miles the forest attains the width of $1 \frac{1 / 2}{2}$ miles in some places. Unfortunately the forest is too much traversed by numerous foot-paths of the matives Wa-Tareta, whose villages and banana-plantations are distributed in the forest. From 
the paths there rises fine gray dust which settles itself on the roal-side plants, therelore in July, when we risited Taveta, the forest has not a very attractive aspect. The forest famna presents not much variety. There were very few butterflies, amongst beetles only Mylabridae (on clearings) were abundant; along the banks of the river Immi winding in the forest curious horned flies (Diopsidae) conld be sanght, and on the outskirts around blooming mango trees swarms of Hymenopteri and different Cetonia filled the air. Under lallen leaves we took the usual harvest of cockroaches, spiders and crickets, and under fallen trees in some places numerous passages of termites were to be found. In one of such nests of Rhino. termes mutorius we were fortmate in finding an interesting termitophilous catterpillar of the family Tineidae. The Rhinotermes termites themselves contained in their intestine nume. rous parasitic Trichonymphidae which we sought for in vain amongst the termites of Uganda.

In two hours distance from Tareta there is a small lakeChala, across which the Anglo-German frontier passes. This is a typical crater-lake situated on the top of a rather high vulcano and possessing exceedingly steep and, in places, eren vertical shores. As the acquaintance with the fauna of one of the numerous crater-lakes was of great interest for us, we made an excursion to lake Chala. We stopped at the foot of the vulcano Chala on the banks of river Lumi which is very narrow in this place, and here we stayed for 3 days. The descent to the lake is possible only from the German side by a path leading to the water from a frontier post of askari, i. e. black soldiers. From all other parts descent to the water is possible only by means of a rope from the edge of the crater. 'The lake did not gratify om expectations. Plancton is very poor, nearly absent. Under stones that line the shore only several Isopoda were to be found. Angling gave us only several small fishes of Acanthopteri; and by means of lobster-traps brought from Russia and baited with meat it was lound that the lake pos- 


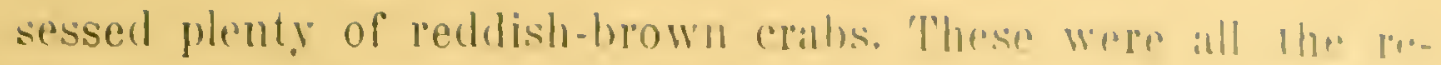
sults of our investigattions ol lake l'balil.

In the vicinty of the lake, chiefly alonge the hatuks of lo ver lumi, a good dral of Inseeta were calleglit 'Thus, on 1 he very shore there were mally dragentilies and oll the whas

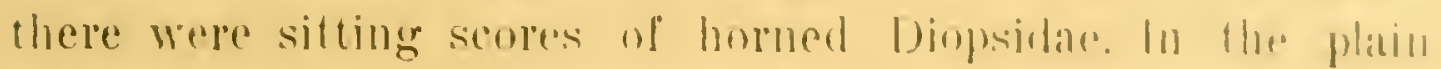
there were to be found from timn to time, besides the aboli. nary grass-hoppers and Phasmidace enormons Mylumeleontilato with ornamented Wings. Neal onr camp scores of Hodotermes mossambicus were rumning to and fro near their burrowand in their intestine severil species of trichonymphidit. swarmed. 'The vertebrate fama was vory varied. Besides the antelopes named above (see description of the Way lrom lof to 'Tareta), we saw 2 species of pigs, heard the screaning. of hyenas, saw traces of lions, and once came across a large rhynoceros. The birds were most abundantly represented by francolins and goninea-fowls which sometimes congregate into coveys of about 30 - 40 birrls, and about 2, 3 and more coreys can be seen together.

From lake Chala we started to the Fist, to the large lake Jipe situated 10-15 miles on the other side of 'Taveta. This lake is a full contrast to the lake Chala described above. It is a lake of the plain, probably not deep, with sloping shores densely grown with reed. Only in two places there are apertures in the wall of reeds, where it is possible to approach the water immediately. The lake is simply swaming with crocodiles (we sncceeded in killing one and gotting from him material on histology); besides, hyppopotanus are to be lound in it, their grunting was distinctly heard. We wished to study the lauma more minntely here, but, mfortunately we had to stay only one day on its shores. In the evening of this singlr day we were informed from the Tareta District Commissioner, M-r Lafontaine. Hhat the great European conflict has begun, and we had to think of geetting further from the dangerous neighbourhood of the German lrontier and return to 
the line of the Uganda Rly. During our stay on lake Jipe we succeeled in collecting some water insects, different large Calabidae and a good many scorpions which provided us with embryological material. To any zoologist wishing to work on the shores of lake Jipe advice may be giveu to encanp at a considerable distance from the water, the best near the foot and even on the top of the Wilima-rawili hills. Although this may offer some discomfort it will to a certain degree guarantee him against malaria. Wé stayed only one night near the shore of the lake in a locality full of mosquitos, and that was sufficient for one of our party to catch the severest malaria.

The journey back from Taveta is of no scientific interest, as we travelled fast, without stopping on the way and hardly making any collections. We had to return to the road by at long, circuitous way, as we had not the extra 10 carriers necessary for carrying water across the arid Serengetti Plains. Not wishing to leave behind any of our collections we tonk a much longer route where water was abundant and, in this way all our carriers could be ntilized in carrying the luggage. Our way lay first up the river Lumi to the West, then along the tributaries of river Tsavo and along this river itself to the North, and up to the rly station Tsavo. On the eighth day of our march we reached this point, on the same day we left for Mombasa, and a week later we took an Italian steamer which was destined ria Suez to Europe.

At the conclusion of this brief description of our travel I must mark with the warmest gratitude the attention and kindness with which we met everywhere during our royage from the part of local Englishmen. Both govermment officers and private persons were always most obliging to us and showed an unalterable readiness to help us in our task.

We shall always retain in our memories a number of persons who will for ever stand in our minds not as passing acqaintances, but as our good friends. 
We consider it mo pleasint duty to express in thesp pages our gratitude and wamest appreciation at loast to llose persons whose help in the lulfilment of our plans was especially essential. We beg the following persons to receive onr thanks: M-r . Voreton Frewen, lisfo. (Brede Place, Sussex), who gave us raluable letters of introdnction to his friends in British Last Afriea: Major Grogan, who kindly offered us his hospitality at his estates in .Iolo and Longonot; .1-r Woosnam, Game Warden and M-r Woodhonse of the Game Department, who greatly assisted us in making up the general ronte of the travel and in its fulfilment; M-r (iowdey from the lintomological Laboratory in Eutebbe, who facilitated our first acquaintance with the tropical famma; M-r James Martin, to whose kindness we are indebted for our stay in the Mabira forest which galve us most of our material: Mrr Hignell, with whom we spent so many pleasant hours at the Longonot Fstate and who helped us in collecting the material on parasites of Mammalia. 



\section{№ 2}

B. A. $A O\ulcorner E \cap$ b.

\section{Изсльдованія надь паразитическими Рrotozoa изь кишечника термитовъ,}

I. Tetramitidae.

$$
\text { V DOG IE L. }
$$

Researches on the parasitic Protozoa from the intestine of termites.

I. Tetramitidae. 



\section{Изсльдованія надъ паразитиче- скими Protozoa изь кишечника термитов'ь.}

I. Tetramitidae.

B. А. Догель.

(Проф. Петроград(каго университетв).

Меня уже съ давнихъ поръ интересовала богатая фауна своеобразныхъ P'rotozoa, населяющихъ кишечникъ различныхъ термитовъ. Эти простьйшія не только привлекают'ь къ себћ вниманіе свией сложной морфологіей, но любопытны " съ біологическоіі стороны, являясь, повидимому, не обыкновенными паразитами, а необходимыми для благосостоянія хозянна симбіонтами, облегчающими термитам'ь перевариваніе пищи.

По этимъ причинам'ъ, какъ только представилась возможность, я и постарался собрать для соотвътственной работы подходящій матеріалъ. Лбтомъ 1914 г., во время своей повздки въ Британскую Восточную Африку, я тщательно изсльдовалъ содержимое пищеварительнаго канала всъхъ поладавшихся термитовъ. Сначала, въ Угандъ, поиски за паразитами были мало успъшны, но, позже, въ окрестностяхъ Таветы (Тавета-маленькос поселеніе на границ между англійскими и германскими владъніями въ В. Африкъ, лежащее у подножія,Килиманджаро) мнь удалось найти два вида термитовъ, содержащихъ въ себъ цвлый рядъ разныхъ Trich on y m ph ida Указанные два вида термитовъ были любезно опредєлены для меня О. И. Іономъ, которому я приношу здьсь за это мою 
глубокую благодарность. Одинъ изъ нихъ быль Hodotermes mossambicus Hag. (изъ сем. Protermitidae Holmgr.), другойRhinoternesputorius Sjöst. (изъ сем. Ne soterm i ti da e Hol m gr.). Добытый матеріаль быль настолько разнообразенъ, что я рбшиль разрабатывать его по частямъ. Публикуемая здъсь часть изсль. дованій обнимаеть собою представителей семейства T e tra m it i d a e. Tetram it i d a e, какъ изввстно, входятъ въ составъ установленнаго Блохманом в порядка Polymastigina, куда принадлежатъ жгутиконосцы съ 4-8 жгутиками, одинъ изъ которыхъ можетъ образовать волнообразную перепонку ${ }^{1}$ ). Наиболье извъстный представитель семейства, родъ Trichomonas сдълался въ посльднее время предметомъ многихъ работъ, такъ что морфологія его хорошо изучена. Другіе роды разработаны гораздо слабъе.

Матеріальи методы изсльдованія. Матеріаломъ для работы послужили прежде всего изготовленные на мъсть мазки, фиксированные жидкостью Шаудина. Кромъ того, я фиксироваль высыпанное въ пробирки содержимое кишечника термитовъ различными способами: смбсью Жильсона, жидкостью Шаудина, смъсью Флемминга. На днь пробирокъ освдалъ порошокъ, состоявшій частью изъ пищи термитовъ (древесные огрызки), частью изъ паразитовъ. Этотъ порошокъ изсльдовался по порціямъ, окрашивался и служиль какъ для изготовленія тотальныхъ препаратовъ, такъ и для разрғзовъ. Фиксированіе кишечниковъ термитовъ цйликомъ, со всъмь содержимымъ, не дало хорошихъ результатовъ: все содерержимое спекается при этомъ въ плотную массу, в’ь которой даже на серіяхъ разрғзовъ трудно разыскать паразитовъ.

Лучшіе результаты въ качествъ фиксирующей жидкости давала смъсь Флемминга. Однако, посль нея необходимо обезцвъчивать матеріаль при помощи 1\% марганцово-кислаго кали (минуть $10-15$ ) и затьмъ $1 \%$ щавелевой кислоты (минутъ 10-20).

1) Іравильные было бы называть перепонку волиообразно пзгибающейся ("membrane ondulante", "undulierende Membran»), но этоть терминъ нөудобень своей длнной. 


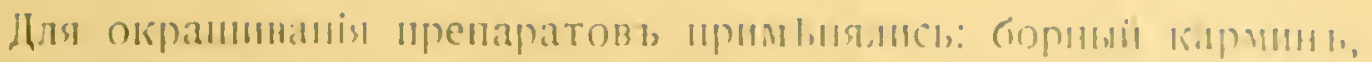

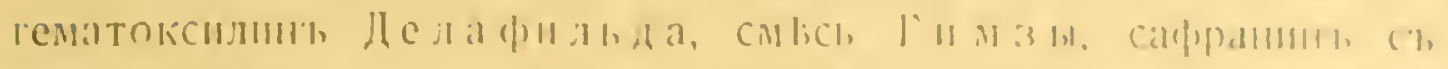

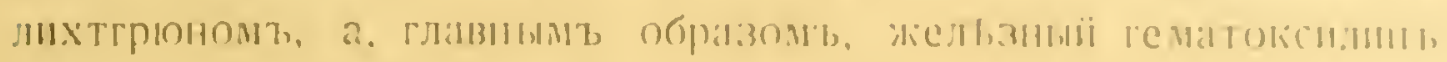

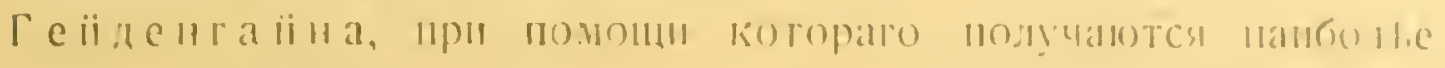

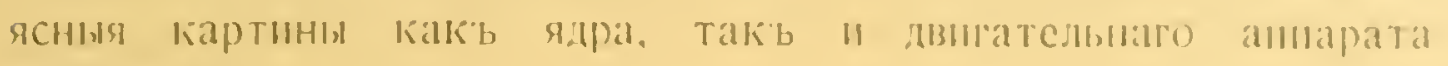
паразитовъ.

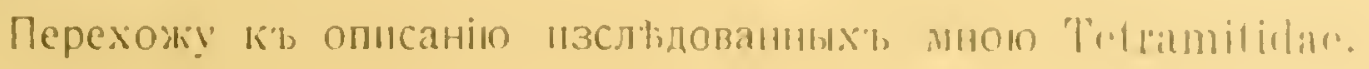

I. Trichomonas (Tetratrichomonas) termitidis " sp.

Это сдинственныї видъ простьйшихъ, найденныі мноп въ, термитахъ Уганды, блнзъ г. Энтеббе (повидимому, въ одиоми изъ видовъ Thinotermes). По присутствію 4 свободныхъ жтутнковъ (кромт волнообразной перепонкн) данная форма должна быть отнесена къ подроду Tetratrichomonas. Как', нзвыстно,

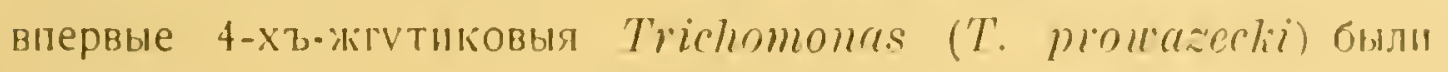
описаны Алексвевымъ (2) изъ кишечника саламандры илр. амфибііі. а затвмь возведены въ степень особаго подрода итальянцемъ Паризи (Parisi 21), который наблюдаль тоть же видъ T. prnияazecli въ кишечникъ Crocodilus palustris.

Описываемый мною видъ, не представляя въ своей морфологіи какихъ-нибудь интересныхъ особенностей, имъетъ немаловажное значеніе въ другомъ отношеніи. Въ посльднее время не разъ возбуждался вопросъ о происхожденіи " родственныхъ отношеніяхъ 'Trichonymphida e, причемъ нервдко (Грасси11, Яницкіiі 16, Бючли) они ставились вь связь, съ типичныли Mastigophora изъ рода Trichomonas. Однако, до сихъ поръ виды этого рода были находимы почти исключительно въ различныхъ позвоночныхъ; только Гр асси нашелъ въ 1882 г. одну трихомонаду, которая впосльдствіи подъ названіемъ Tirlinmastix orthopterorum была описана Паризи (21), въ кишеч. нuќ Blatta. Нахожденіе типичныхъ Trichomonas въ термитахъ не только подтверждаетъ высказанное упомянутыми учеными предположеніе, но "I дьлаетъ возможнымъ, (какъ нокажутъ нє- 
которыя другія формы) непосредственно производить нбкоторые внды, относимые къ Tr i chon y m p i d a e, отъ трихомонадъ.

Какъ уже было указано, T. tormitidis (табл. І, фиг. 1, 2 и 4) устроена по общему для всъххъ трихомонадъ типу. Тә́̆ло продолговатое, цилиндрическое, длиною въ 14-18 микроновъ. Впрочемъ, нербдко наблюдается, что размћры животнаго варіируютъ въ довольно широкихъ предвлахъ (то же наплюдается и у другихъ трихомонадъ), даже у особей, встрбчающихся въ одномъ и томъ же кишечникъ́ и обладающихъ вполнб̆ одинаковымъ строеніемъ.

Отъ передняго конца тйла отходятъ 4 не вполнь одинаковой длины жгутика, которые, какъ это наблюдается у многихъ Trichomonas, нербдко у основанія какъ бы склеены вмбсть (табл. І, фиг. 2). Отъ передняго же полюса тйла беретъ начало довольно высокая, ясно выраженная волнообразная перепонка -приставшій къ тйлу пятый жгутикъ. Перепонка направляется кзади, описываетъ при этомъ вокругъ тв́ла полукругъ и затбмъ заканчивается короткимъ свободнымъ жгутикомъ (табл. I, фиг. 4). Тамъ, гдъ начало волнообразной перепонки подходитъ къ основанію свободныхъ жгутиковъ, располагается сильно красящееся жельзнымъ гематоксилиномъ зернышко. Это-базальное тъльце. Вћроятно, имъется, какъ у многихъ другихъ трихомонадъ, на самомъ дағль два такихъ-т务льца (одно для свободныхъ жгутиковъ, другое для перепонки), и только недостаточно хорошая фиксировка или окраска заставляютъ ихъ казаться слитыми въ одно цълое. Цитостома у T. termitidis мнғ обнаружить не удалось.

Позади базальнаго твльца лежитъ овальное ядро съ ясной оболочкой и мелкими зернами хроматина, разсъянными внутри него. Наконецъ, животное снабжено длиннымъ, довольно толстымъ аксостилемъ (терминъ этотъ, введенный Добелле мъ, является наиболье удобнымъ). Задній конецъ аксостиля часто выдается изъ тьлла наружу, передній же, судя по моимъ наблюденіямъ, окружаетъ собою ядро. Вопросъ, какъ заканчивается аксостиль на переднемъ полюсъ тьла, еие лалеко не выясненъ. Большинство наблюдателей (Л аверан`ь 20, Добелль 6, Паризи 21, 


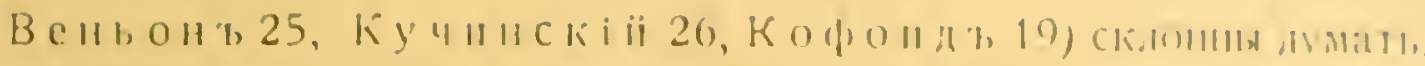

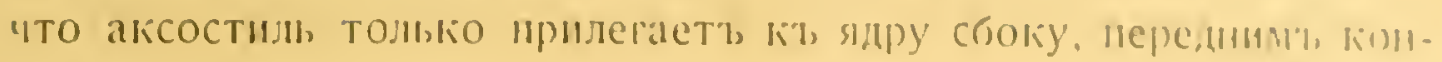

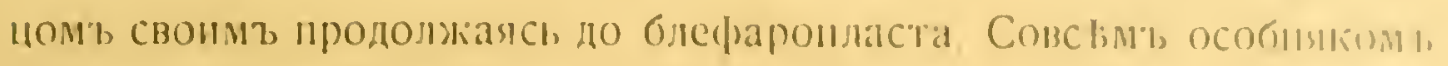

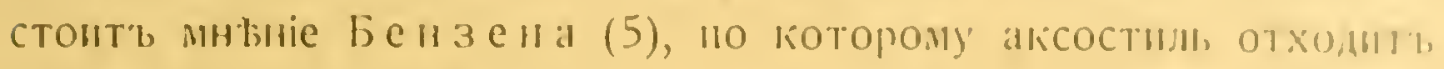
назац'ь от’ь каріозома ядра. т. е. прободаеть ядернун) облочку.

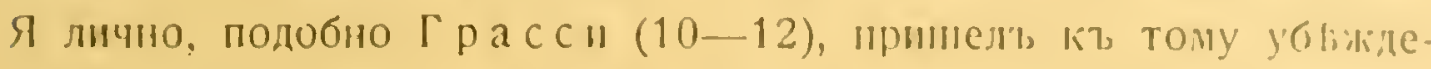
июю, что аксостиль Trichomonas такъ же, какъ аналогиное образованіе у Lophomonas (сравни изсльдованія Яиищкаґи 16), охватываетъ своимъ верхнимъ концолъ ядро на подобіе бокала. Къ этому выводу я пришелъ, какъ на основаніи наблоденій надт, T. termitidis, такъ, особенно, надъ другими родственными паразитами (см. далыше), у которыхъ устройство описынаемаго апиарата гораздо легче выясннть вслғдствіс болье крупныхъ размғровъ животнаго.

Протоплазма T. termitidis содержить в’ь себъ нерьдко вакуоли. а также интенсивно красяцціеся пищевые комочки, составт, которыхъ я точно опредълить не могъ.

Стадіи размноженія въ имъющемся у меня небольшомт матеріаль отсутствуютъ.

Относительно экологіи паразита можно замттыть, что въ пораженномъ видь термитовъ трихомонады встрғчаются въ каждомъ безъ исключенія экземплярв и, притомъ, въ огромномъ количествғ. Паразиты оживленно снуютъ среди кииечнаго содержимаго, причемъ волнообразная перепонка изгибается крайне быстро. Въ каплғ воды подъ покровнымъ стекломъ T. termitidis живутъ въ теченіе нъсколькихъ часовъ. Иногда, однако, при этомъ задній конецъ аксостиля далеко обнажается, причемъ на концћ его остается какъ бы капелька протоплазмы. Данныї видъ былъ найденъ въ Энтеббе (Уганда), въ кишечникґ небольшихъ темныхъ термитовъ, взятыхъ изъ невысокихъ, черныхъ, грибовидныхъ термитниковъ.

II. Trichomonas (Tetratrichomollas) macrostoma n. sp.

Этотъ видъ найденъ около озера Чала, у береговъ р. Луми въ кишечникь Hodotermes mossambicus Hag. Въ общемъ форма тьла такая же, какъ и у предыдущаго вида, но размыры нбсколь- 
ко меньше, а именно длина тьла равна 12-15 пикронамь. Аксостиль, жгутики и базальныя ть́ьльца имьютъ тоть же характеръ. Волнообразная перепонка идеть по тьлу кзади въ болюе прямомъ направленіи н свободный конецъ ея очень коротокъ едва выдается надъ поверхностью тьла.

Въ ядрь иногда замбтны $1-2$ крупныхъ хроматиновыхъ глыбки. Нанболье рбзкій отличнтельный признак'ь вида заключается въ очень большомъ и глубокомъ цитостомь, который расположенъ на брюшной сторонь тћла, у лередняго его конца. Задній край цитостома сильно выдается на брюшную сторону въ видъ губы (табл. I, фиг. 3 и 5). Часто въ этой губъ находятся 2 -3 небольшихъ включенія-пищевые комочки. Кромь того, и вообще въ протоплазмъ задней половины тбла часто встрғчаются пишеварительныя вакуоли. Въ однихъ случаяхъ можетъ быть ньсколько небольших'ь вакуолей, въ других'ь-одна крупная вакуоль, содержимое которой явственно состоитъ изъ округлыхъ KOKКОВ'ъ.

Нербдко прииходится наблюдать приготовленія къ инцистированію, причемъ животное складывается вдвое на свою брюшную сторону (табл. I, Фиг. 6 и 7); жгутики сбрасываются. Грасси описаль подобныя стадіи подъ названіемъ цист’, хотя самъ говоритъ, что настоящей оболочки у нихъ часто не наблюдается. Въроятно, онъ, подобно мнъ, имълъ дъло съ экземплярами только подготовлявшимися къ инцистированію. Судяпо работь Д об елля о трихомонадахъ амфибій (6), позднвйшія стадіи окружаются довольно толстой, ясно зам бтной оболочкой.

Одинъ или два раза я видблъ картины, напоминавшія начало дъленія, но такъ какъ указанные экзеипляры были окружены остатками пищи хозяина и плохо различимы, то я оставляю эти случаи безъ описанія.

Trichomonas macrostoma встрьчалась во всьхъ безъ исключенія изсльдованныхъ мною экземплярахъ Hodotermes. 
III. Gigantomonas herculea 11 , yen. II. sp.

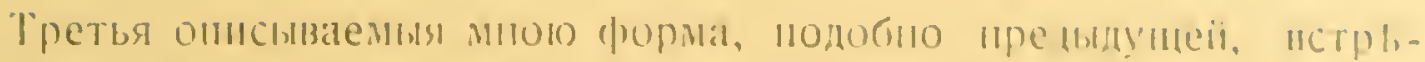

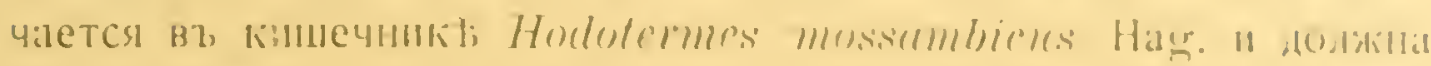

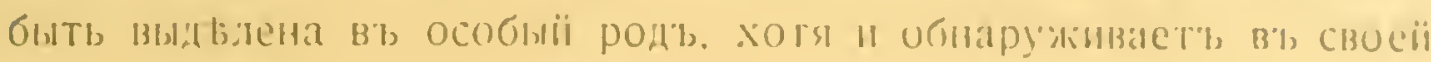

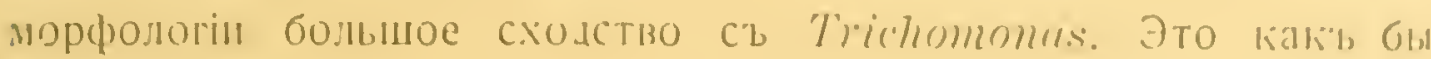
Trichomonas, разросшаяся до гигангекихъ разияровт. Дьїствительно, Cigyntomunus. какт, я иредлагаю иазваты, это животиое, достигаеть (сиптая отъ перетняго конца түла до конца аксостияя) 60-75 микроновъ въ длипу, при 30-35 микронах`ь толщины. Между твмь, нанболье крупная изъ извьстныхъ до сихь порь

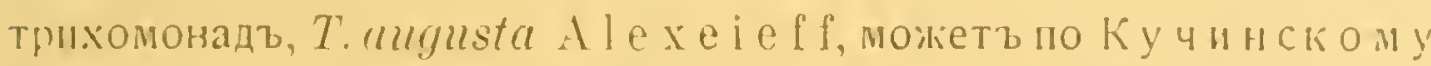
(26) достигать какъ максимальной величины 28 микронов’ длины II 18 микроновъ толцины.

Общая форма твла и его главныя составныя части такія же, какъ \| у многихь тршхомонадъ. Тъло (табл. І, Фит, 9 и 10) ииєетъ яіицевидную фориу, нъсколько заостряясь по направленію къ заднеиу концу, на которомъ оно продолжается въ довольно длинную, прямую нглу-выдающійся изъ твла задній конецъ аксостиля. Поперечныі разръзъ черезъ твло имъетъ форму круга. Передній, расширенный полюсъ твла закругленъ. Немного отступя оть передняго конца тьла, на его брющной ${ }^{1}$ ) сторонt берутъ начало органы движенія животнаго. Таковы, прежде всего, 4 свободныхъ жгутика; впрочемъ, видћть вст четыре жгутика одновременно удается лишь въ рыдких случаяхъ, чаще же нъкоторые изъ нихъ при фиксированіи животныхъ и приготовленіи препаратовъ отрываются. Мжсто отхожденія жуутиконъ отъ тъла нерьдко замьтно въ видє маленькаго бугорка, или носика (табл. І, фиг. 10). Жгутики не только различнойі длины, какъ это наблюдается у трихононадъ, но " различной толцины,

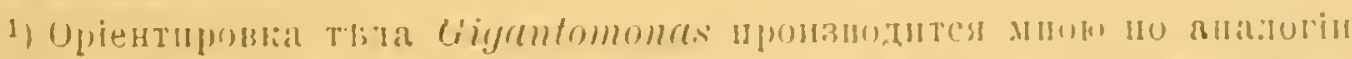

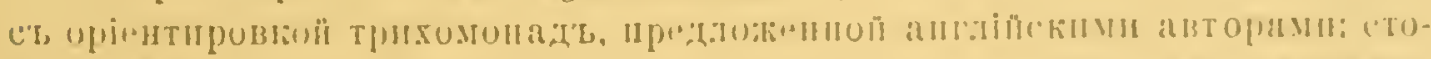

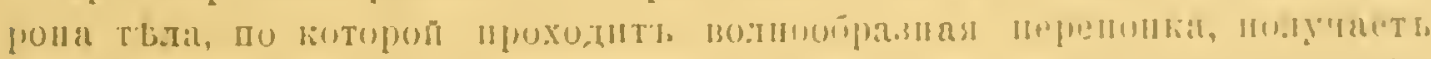

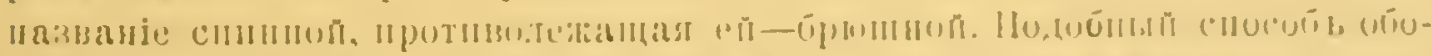

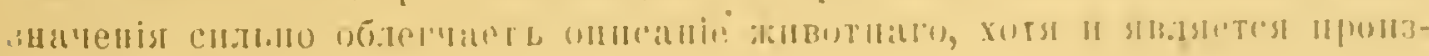

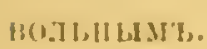


причемъ можно различить один'ь главный и три побочныхъ жгутика. Главный жгутикъ значительно длиннъе всего тъла Gigantomonas, побочные довольно коротки. Впрочемъ, точных'ь размъровъ жгутиковъ я привести не могу, ибо наблюдалъ ихъ лишь у фиксированныхъ животныхъ, гдћ жгутики сильно скручены и извиты. Толщина жгутиковъ настолько велика, что (при разсматриваніи ихъ подъ иммерзіей въ $2 \mathrm{~mm}$.) они представляются въ видъ двуконтурной нити, а не простой черточки. Интересная гистологическая особенность жгутиковъ Gigantomonas заключается въ томъ, что они совершенно не окрашиваются гематоксилиномъ Гейденгайна, который очень интенсивно краситъ жгутики мелкихъ Trichomonas termitidis и другихъ трихомонадъ. По той же причинъ, въроятно, мнғ не удалось обнаружить базальныхъ тилецъ у основанія жгутиковъ, между твмъ у объихъ ранте описанныхъ формь эти т青ьца были легко различимы.

Рядомъ съ основаніемъ жгутиковъ беретъ начало и волнообразная перепонка. Она вскорғ переходитъ на спинную сторону тьла, направляется кзади, заворачиваясь спирально вправо, и у основанія хвостовой иглы выхпдитъ снова на брюшную сторону т务ла. Здъсь волнообразная перепонка заканчивается, постепенно понижаясь, причемъ самый конец’ь ея неръдко бываетъ загнутъ кпереди. Характерно, что перепонка не выдается надъ поверхностью тьла, но на всемъ своемъ протяженіи лежитъ въ глубинъ особаго желобка, връзающагося въ тыло. Этоть желобокъ, недостаточно умъло мною изображенный, лучше всего виден'ь на рис. 9 таблицы І-ой. Перепонка наиболъе высока у своей средины, тогда какъ по направленію къ обоимъ концамъ, особенно же къ заднему, постепенно понижается. Волнообразная перепонка Gigantomonas является очень мощной и, судя по различной интенсивности окраски, утолщается отъ свободнаго края к'b основанію. Въ большинствъ случаевъ такое усиленіе окраски перепонки идетъ очень постепенно, причемъ свободный край ея является слегка съроватымъ (по нему пробъгаеть темный краевой жгутикъ); далъе, по направленію к’b основанію перепонка становится синеватто-черної (при окраскъ гематоксилиномъ Г’ ейден- 


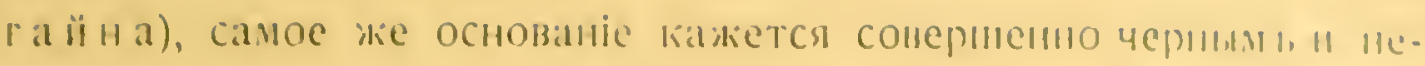

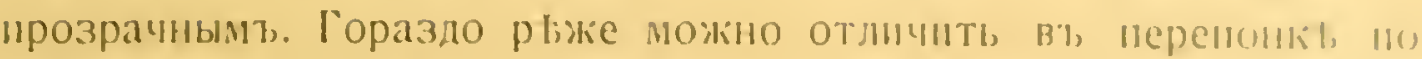

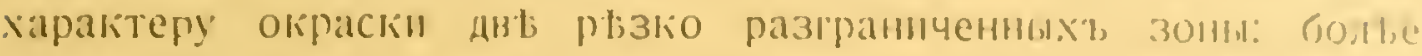
темную основную зону " свьтыую днстальную. Как', on то ни

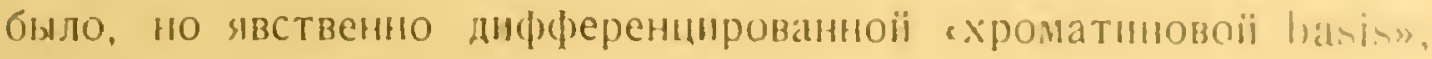
по терминологіи Добелля (6), мнњ обиаружить не удалось, хотл темное основаніе перенонки " можно было бы, на нериыи взглялю, иринять зал таковую.

Bообще, вопросъ о «хроматиновой basis» требуетъ еще цальньйшаго разьясненія. «Хроматиновая bisis», схроматиновая линія» (Мартинъ и Робертсонъ 24), или ребро (Алексъевъ 1 и 2 " ир.) иредставляеть собою дугообразное, сильно красящееся гематоксилиномъ образованіе, залегающее у основанія волнообразноі перепонки трихомонадъ. Большинство авторовъ ограничивается описаніенъ этого органа, и только Кучинскій (26), въ своеі подробной работь о различныхъ видахъ Tiichomonas высказывается относительно физіологическаго " морфологическаго значенія хроматинової базы. Кучинскій полагаетъ, что basis, в.ъсть съ аксостилемъ, представляютъ собою систему волоко. нецъ, соединяющихся въ блефаропласть и служащихъ въ качествъ опоры отходящимъ отъ блефаропласта жгутикамъ. Тєсную связь хроматиновой базы съ волнообразной перепонкой Ку чннскіи, насколько я могу понять его нъсколько запутанное изложеніе, отрицаетъ и не считаетъ возможнымъ установить, оказываетъ ли basis извъстное вліяніе на дъятельность волнообразной перепонки. Въ независимости обоихъ поименованныхъ образованій другъ отъ друга Кучинскаго убъждаютъ главным' образомъ такія формы, какъ Trichomastix gallinarm и Protrichomonas legeri, у которыхъ, при полномъ отсутствін перепонки, хроматиновая basis инъется. Точка зрғнія Кучинскаго кажется mнt недостаточно обоснованной. Во-первыхъ. при тщательноми изученіи литературы невольно бросается въ глаза твсная морфо. лопическая связь между basis и волнообразной перепонкой. Хроматиновая база имъетъ такую же изогнутую цугообразно (юому. какъ " перепонка, "лежитъ всегда въ основаніи носльдней 
Если бы эти два образованія не имвли между собой ничего общаго. то между ними не сльдовало бы ожидать и подобной зависимости въ ихъ расположеніи. Далъе, хропатиновая база Protrichomonas Tegeri произвольно принимается Кучинскимъ за таковую, ибо Алексъевъ (3), описавшій даннаго жгутиконосца, приравниваетъ найденную им' у Protrichomonas хроматиновую нить аксостилю трихомонадь, а отнюдь не хроматиновой basis. Только присутствіе хроматиновой basis у Trichomastix gallinamm не находитъ себъ покуда объясненія.

Наконец’ь, мнғъ, на основаніи наблюденій надъ такими крупными объектами, какъ Gigantomonas, кажется, что хроматиновой базы, какъ отдъльнаго, самостоятельнаго образованія вообще не существуетъ. Хроматиновая basis представляетъ собою основную, болъе толстую и сильнъе красящуюся часть волнообразной перепонки, и ничего больше. Такое впечатльніе получается не только у Gigantomonas, но и у Trichomonas augusta, судя по новъйшей работь Кофоида и Свизи (19), которые находятъ, что волнообразная перепонка состоитъ изъ «а waving protoplasmic film in whose margin lies a deeply staining chromatic thread, and at whose base is a heavier basal chromatic rod. Posterioply the two chromatic structures mnite... in the lightly staining posterior flagellum». Ошиока Кучинскаго можеть быть объяснена тълъ, что у относительно очень мелкихъ трихомонадъ переходъ basis въ перепонку плохо замвтенъ, и потому ръзко красящаяся «хроматиновая basis» можеть быть иринята за самостоятельный органоидъ кльтки.

Базальнаго твльца, отвъчающаго волнообразной перепонкъ, у Gigantomonas мнғ обнаружить не удалось. На переднемъ конц тъла, направо отұ начала иерепонки имвется слабо развитой цитостомъ (табл. І, фиг. 9 и 10); а именно, здъсь имъется слегка выступающій надъ поверхностью тъла валикъ, который я считаю за закранну, или губу цитостома. Самъ цитостомъ въ видж, едва выраженнаго вдавленія помьщается между губой и волнообразной перепонкой. Относительно точнамо поноженія и строенія губы я р`шаюсь говорить лишь съ большой осторожностью, 1160 y' пе- 


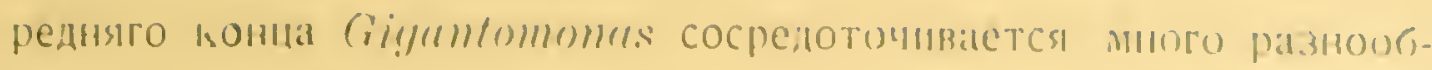

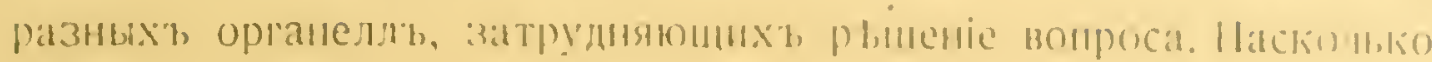

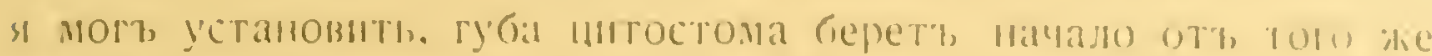

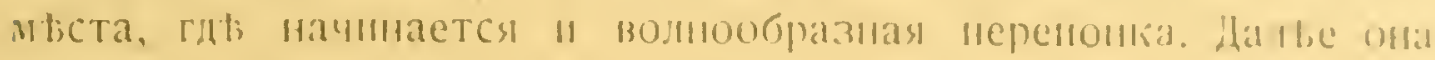

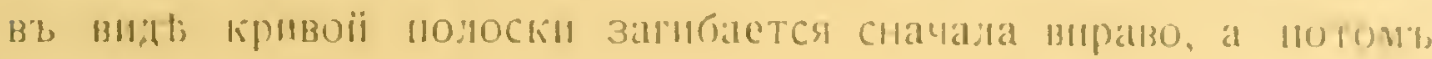

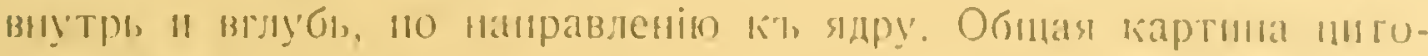

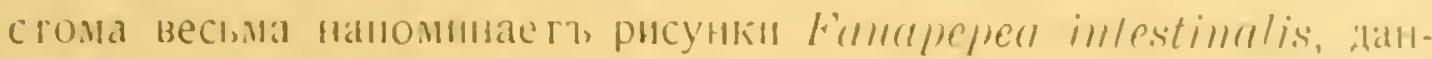

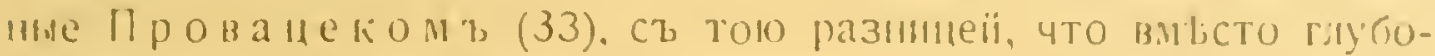

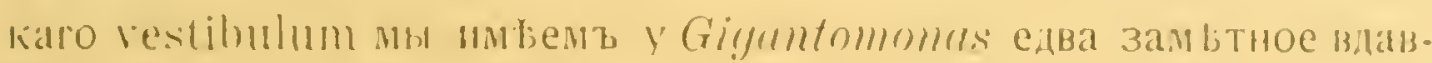
лепіе. а волнообразиая перепонка у моеиі формы разита несранненно ситьнене.

Ядро Gigantomonas помьщается, как" " у' трихомонадъ, иа переднемъ конць тьла, тотчасъ же подъ началомъ волнообразної перепонки, къ основанію которой оно тьсыо ирилегаетъ. Ядро довольно велико " состоитъ изъ внутренней массы " ядерной оболочки; посльдняя очень часто немного отстаетъ отъ вну. тренней массы (артефактъ?). Ядро обыкновенно очень быдно хроматиномъ и окрашивается гематоксинномъ Гейденгайна въ сьроватый цвотъ. То же отмұчаеть Кучинскій (26) для ядеръ трихомонадъ. Лишь въ ревкихъ случаяхъ внутри ядра имются многочисленныя зерна хроматина, чаще всего бывають замғтны только два или три крупныхъ хроматиновыхъ зерна. Каріозощъ " центріоли отсутствуютъ.

Выхожденіе изъ ядра въ окружаюшую плазиу хроматина представляетъ собою процессъ иногократно описанный какъ у иростьишши'ь, такъ и въ кльткахъ многокльточныхъ жнвотныхъ. Tакое образованіе уромидіевъ, въ видъ зеренъ. насчетъ ядра было констатировано иу трихомонадь Кучишскимь (стр. 173). у Gigantomonas тоже наблодается постолнное выхожденіе $113 \mathrm{t}$ ядра въ плазму красящагося гематоксилиюон Гейденгайна иъ темный цвъть вещества, путемъ любопытнаго нысачиваніз его новерхностью ядра. Высачнваніе пронсхидить, на спнниі стороны "на боковыхъ сторинахь ядра (табл. І, (ич. 10, 11 " 12), ко-

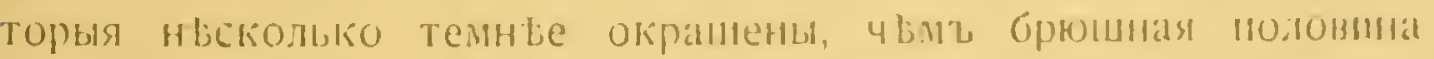

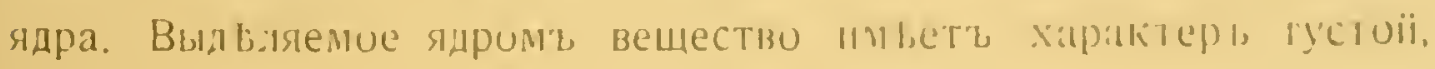


вязкой жидкости; посльдияя сначала образуетъ на соотвъ́тственномъ участкъ ядерной. оболочки тонкую пленку, прерывающуюся тамъ и сямъ (какъ видно при разсматриваніи самой поверхности ядра) широкими отверстіями. Затъъъ эта пленка утолшается и сливается въ сплошную шапочку, сицящую на ядрғ или сбоку, или со спины; изрғдка въ шапочкъ видны небольшія вакуоли. Далъе, шапочка (табл. І, фиг. 11), увеличиваясь, становится все болье и болъе выпуклой и, какъ капля густой жидкости, дилящаяся надвое, отдћляетъ отъ себя довольно большое, совершенно гомогенное овальное тьльце. Тбльце это сначала лежитъ возль самого ядра, потомъ же мигрируетъ къ заднему концу тъла, гдъ и располагается у самой его поверхности, подъ перипластомъ. Между тблъ, вышеупомянутая шапочка вязкаго вещества становится, посль отдъленія овальнаго тъльца, болъе плоской, а позднъе снова увеличивается и можетъ отдълить второе тъльце. Иногда ядро бываетъ снабжено одновременно дву мя шапочками (табл. І, фиг. 12). Овальныя тйльца всегда обладаютъ весьма рбзкими контурами и, обыкновенно, окружены узкой свҰтлой зоной. Въ образованіи этихъ тьлецъ наблюдается извьстная правильность и періодичность. Въ общемъ, можно сказать, что по мърғ формированія ихъ насчетъ ядра они передвигаются къ заднему концу твла; тамъ происходитъ резорбированіе ихъ, а тъиъ временемъ на переднемъ концъ твла формируется новое овальное тьилье, на смњну исчезающему. На исчезновеніе тьйецъ указываютъ нъкоторые экземпляры, у которыхъ заднее тйльце очень мало; кромъ того, и свътлая зона, имъющаяся вокругъ тъльца. указываетъ, быть можетъ, на постепенное таяніе этого посльдняго.

Вотъ нъкоторыя статистическія данныя относительно количества и распредъленія овальныхъ твлецъ. 1) Экземпляры, у которыхъ единственное овальное тъ́льце еще не вполнь отдълилось отъ ядра,-4.2) Одно отдълившееся тйльце у передняго конца тもла-2 экз. 3) Одно отдълившееся тъльце на переднемъ концъ, и одно готовое к’b отдъленію--2 экз. 4) Одно тъльце на заднемъ 


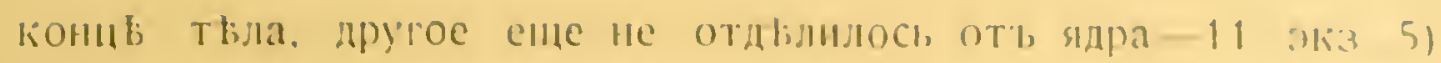
Одио заднес и одио передиес овалыне тыные-3 экіз.

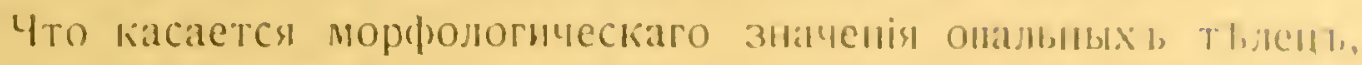

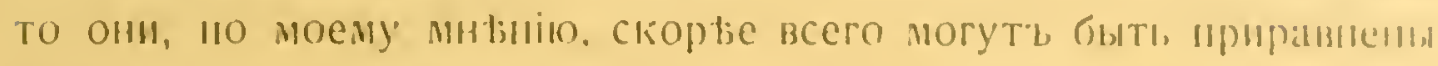

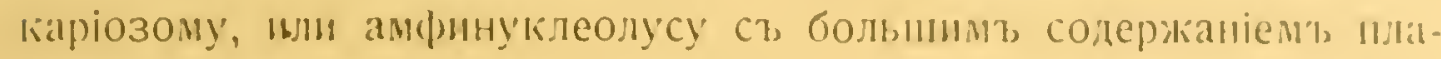

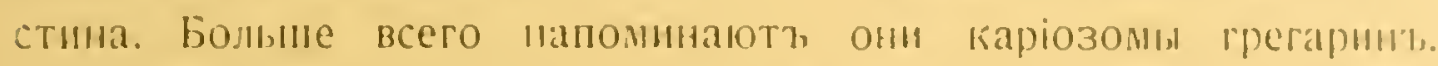

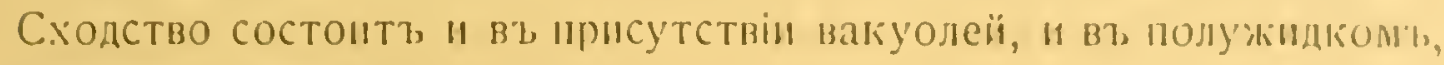
щизкомъ характерь овальнаго тьльца "въ томъ, что оно в" значительної мьры состонт'b изь пластин, как' то показынает', ero okраска. У ныкоторыхъ грегаринъ, как'ь, напр., Cystoli, chividotue Dog., я виджль, какъ каріозомъ приблшжается к», поверхности ядра " растекается по внутренней сторонъ его оболочки, причемъ получается картина, весьма паноминающая Giyantomonas, только, какъ я уже отмғтиль, внутри, а не вны; ядра. Разлившіісся по ядерной оболочкъ каріозомъ Cystobia выдыляетъ часть своего вещества изъ ядра въ плазму. въ виды мельчайшихъ зеренъ. Такое же выдъленіе наружу вещества liрiозома мы имъемъ и у' Gigantomonas, съ тою разницеї. что здес оно внутри ядра находится въ видъ зернышек'ь, которыя при выведенін наружу сльваются в'ь шапочку и затьмъ дають овальное тъльце. За сходство съ каріозомомъ говоритъ и періодическая измєняемость овальныхъ тълецъ. Такія же періодическія колебанія въ величинь и формб, иногда даже полное исчезаніе каріозома, наблюдаются и у другихъ Plotozoa, напр, у грегаринъ (Porospora gigantea) и др.

Такимъ образомъ, на основаніи всего сказаннаго я склонень считать овальныя твльца Gigrntomonas за внғядерные каріозомы.

Дальныйшее постоянное включеніе Gigantomomas-брюпшои хромидій. Приблизительно посрединћ твла, ближе къ его брюшной сторонъ располагается губча́тая или же зернистая мácса неправильныхъ очертаній, большею частью с'b не особенно pl;зкими контурами. Зерна, или комочки, составляющія эту массу красятся, как'ь хроматинъ. Положеніе хромидія можеть нысколи-

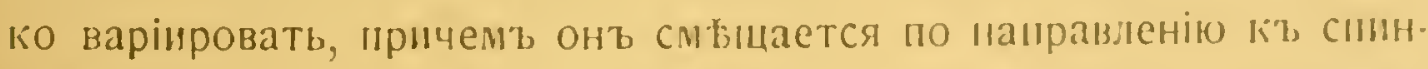

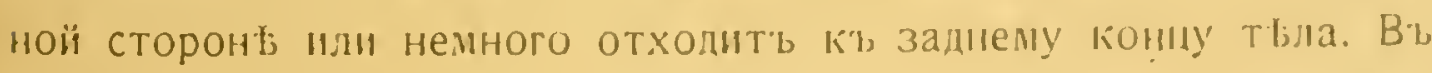


очень рьдкихъ случаяхъ вивсто обьчнаго одного хромидія имьются 2 или 3 хромидіи меньшихъ размғровъ. Хромидіи въ видъ правильно расположенныхъ, небольшихъ сидерофильныхъ зеренъ были описаны уже у многихъ трихомонадъ. Хромидій Gigantomonas интересенъ твмъ, что онъ по своему строенію напоминаетъ скорће хромидіальныя съти корненожекъ, губчатую центрозому Actinnsphaеrimm или же хромидіи, ооразующіеся при овогенезъ Paludina (М. Поповъ).

Кромғ постояннаго хромидія, у некоторыхъ экземпляровъ я видвль разсъянныпи в’ плазмғ сильно красящіеся гематоксилиномъ Гейденгайна тяжи и зерна неизвъстнаго происхожденія; это тоже, повидимому, образованія имйющія хромидіальный характеръ.

Наконецъ, весьма важнымъ органоидомъ, обусловливающимъ въ значительной мюрғ форму кльтки Gigantomonas, является аксостиль. Аксостиль имєетъ форму довольно толсгаго веретена, проходящаго вдоль черезъ все тьло. Передній конецъ веретена, достигая ядра, здъсь теряется (судя по аналогіи со сльдующимъ видомъ этотъ конецьь обхватываетъ собою ядро). Задняя треть аксостиля заостряется въ хвостовую иглу и микроновъ на 20-30 высовывается изъ задняго конца тьлла. Въ оптическомъ поперечномъ разрвзъ твла аксостиль занимаетъ центральное положеніе-это главная ось твла. При внимательномъ наблюденіи оказывается, что хвостовая игла не выдается свободно изъ твла, но что она на всенъ своемъ протяженін одыта плазматической пленкой, постепенно утончающейся къ концу иглы. Как’ при жизни, такъ и послъ окраски гематоксилиномъ Гейденгайна аксостнль остается совершенно безцвьтнымъ, прозрачнымъ, что n затрудняетъ выясненіе отношеній его къ ядру и другимъ органондамъ передняго конца тёла.

Что касается до тонкаго строенія аксостиля, то посльднії состонт'ь изъ множества твсно прилегающих'ь другъ къ другу тончайиихъ волоконецъ. Такое строеніе его устаповлено мною вн, всякаго сомндніл, что я виду утверждепіиі Кучинскаго (26), будто аксостиль всъхъ 


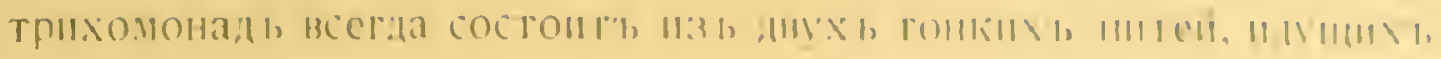

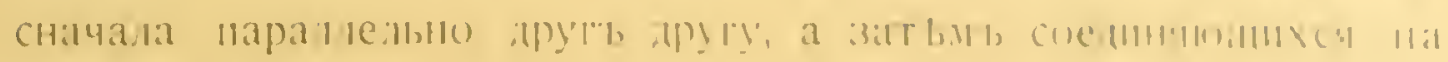

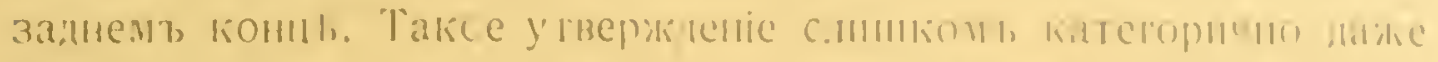

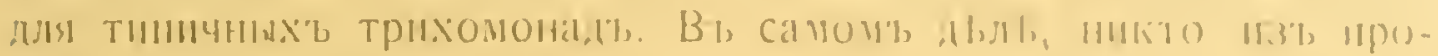

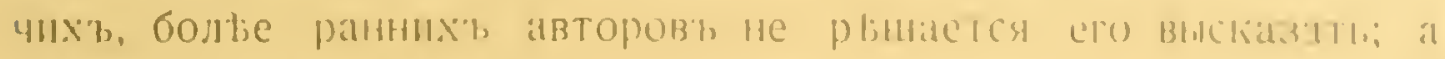

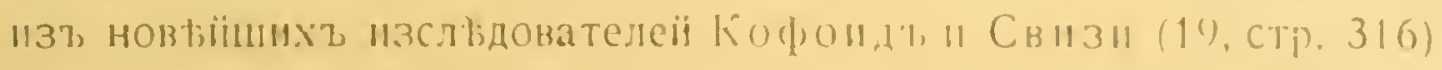

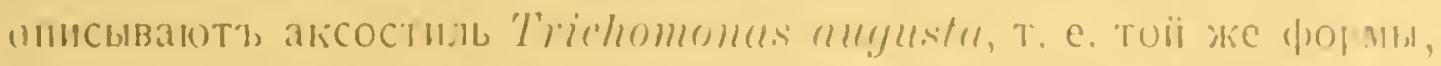
надъ которої было произведено большинство наблоденіiі К!у чи-

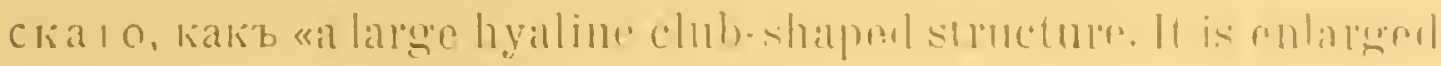

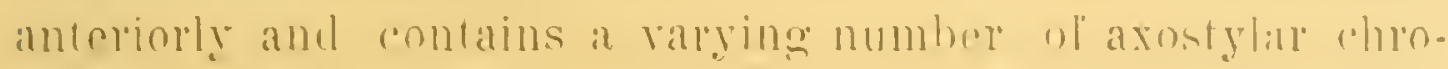
midia». Здысь, во-шервыкъ, алериканскіе шзсльдова гелы называютл аксостиль булавовидныль образованіель, во-вторыхь же указы. ваютъ на присутствіе внутри него хромидіевъ. Госльдніi факт’ь, шзвистның уже " раныне (Алексқевь 1-4, Кучинскіi 26). Кучинскії толкуеть такъ, что хромидалыныя зерна лекать будто бы между обънии нитяпи аксостиля, а не внутри него. Nнt; кажется по отношенію къ Gigantomonas несомиғниымь. а по отношенію къ тршхомонадамъ в бровытнымь, что аксостиль представляеть собою скор ве всего нли пучек'ь тонкихь волоконъ или же. въ другихъ случаяхъ, трубку. сть̈ни которой слагаются изь множества волоконъ. Такая трубка, расширяясь на переднеиъ Концf, можетъ обхватывать собою и ядро, какъ, напр.. у Tiкhomastix motellue по Алексьеву (3), у Gigantomonas и у нъкотоpыхъ Tuichongmphidae.

Тъло Gigantomonas имветъ весьма постоянную форму', что указываеть на присутствіе довольно плотної пелликулы. Дифюеренцировки на эктоплазиу " энтоплазму нътъ; вся протоплазиа. носить очень однородныі, мелкозернистыї характеръ. Вакуолеї въь плазмь не замћчается, пишевыя включенія тоже совершенно отсутствуют'b. Въ фиксированномъ состояніи консистенція тьла очень плотная, а поверяность сно весьиа гладкая. всльдствіе чего Gigrntomsnas при ириготовленіи пренаратови изъ содержимаго кишечника териитовъ сохраняется лиши, среди густыхъ хлопьевъ грязи; иногіе же экзелпляры, по исъиъ въроя- 
тіямъ, ускользаютъ во время окрашиванія и другихъ подготовительныхь операцій.

По отношенію къ различнымъ трихомонадамъ не разъ наблюдался временный переходъ ихъ къ амебоидному состоянію, выпусканіе псевдоподій и т. д. Одно подобное наблюденіе имъется и въ моемъ распоряженіи. А именно, одинъ экземпляръ Gigantomonas, найденный мною среди очень хорошо сохранившагося матеріала, фиксированнаго смғсью Флемминга, явственно имбльь амебоидный характерь (табл. І, фиг. 8). Тъло, сплющенное въ видъ пластинки имъло ромбическую форму, плазма его была дифференцирована на болъе свьтлую и гомогенпую эктоплазму ॥ болье темную эндоплазму. Жгутики и хромидій отсутствовали. Ядро нормальное, волнообразная перепонка, изогнутая въ видъ буквы $\mathrm{S}$, находилась на одной изъ плоскихъ сторонъ тьла. Типичный прозрачный аксостиль отличался своей короткостью и лежалъ цьликомъ внутри тьла, утративъ связь съ ядромъ. Наиболъе любопытно было присутствје внутри тьла большихъ пищевыхъ включеній въ видъ обломковъ дерева и какихъ-то споръ.

Насколько нормально подобное измънненіе формы тъла, по единичному факту очень трудно судить. Весьма заманчиво предположеніе, по которому Gigantomonas для принятія пищи должна всегда переходить въ амебоидное состояніе. Въ такомъ случағ мы имьлли бы въ данномъ жгутиконосць извьстный переходъ (относительно способа пріема пищи) отъ заглатывающихъ пищу цитостомомъ трихомонадъ къ Trichonymphidae, питающимся до извъстной степени на подобіе амебъ (сравни наблюденія Портера 22, Яницкаго и др.).

Стадіи размноженія Gigantomonas мнъ, къ сожальнію, не попадались.

Данная форма встръчалась не во всъхъ экземплярахъ Hodotermes mossambicus, нзсльдованныхъ мною: были паргіи термитовъ, совершенно свободныя отъ Gigantomonas.

Однимъ изъ препятствій, затруднявшихъ произведеніе Trichonymphidae от’ болье просто устроенныхъ Mastigophora,

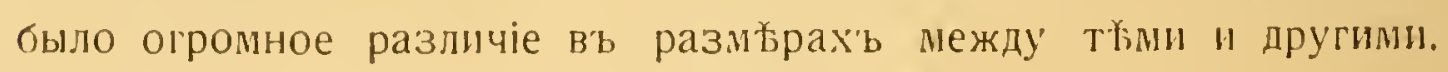




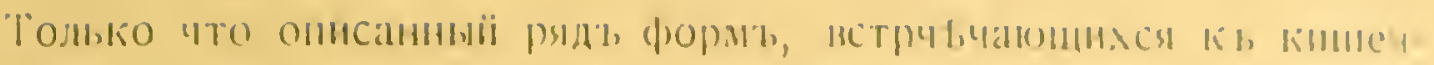

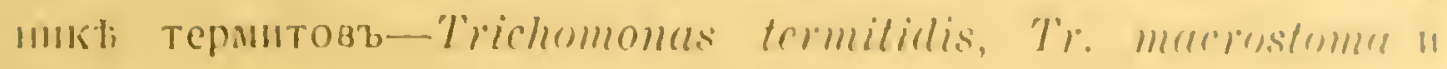

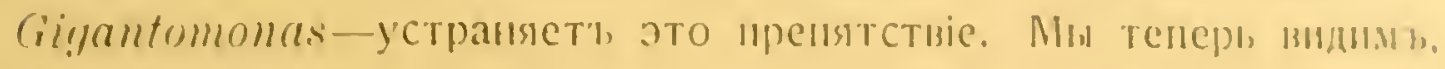

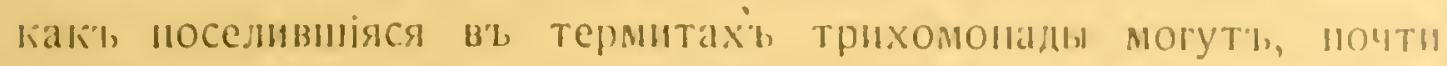

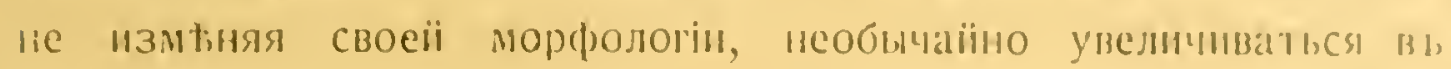
размырахъ, всльдствіе почему-то особенио благопріятныхь усло-

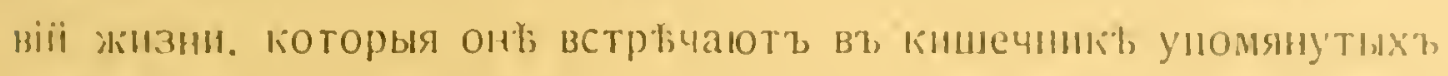
насқкомыхь. Такое рызкое увеличеніе размұровъ клітокт, не представляетъ собою рбдкости у внутренностныхъ паразитовъ; достаточно вспомнить крупныхъ паразитических's Nematurfes, которые отличаютя отъ свонхъ мелкнхъ сородичеї не столько Количествомъ, сколько большою величиною кльтокъ ихъ тила.

Въ заключеніе можно сказать ньсколько словъ о генетическихъ отношеніяхъ между только-что описанными формами. Одновременное присутствіе въ кинечникъ термитовъ Gigantomonas herculea и типичныхъ Trichomonas, правильнъе всего можетъ быть, по моему мнғнію, истолковано такъ, что Gigantomonas uмtетъ гораздо болье длинный періодъ паразитической жизни внутри термитовъ, а потому и является гораздо болье измьненной, чъмъ Trichomonas; посльдняя должна въ такомъ случат, представлять собою сравнительно недавняго паразита термитовъ.

IV. Myxomonas polymorpha n. gell. n. sp.

Aмебоидное состояніе, въ которомъ Gigantomonas встрғчастся лишь очень рбдко, у даннаго рода двлается постояннымъ. М!/коmonas иредставляетъ собою трихомонаду, которая приняла амебовидную форму и утратила цитостомъ "п передніе, свободные жгутики. Мyxоmonиs попадаются совмбстно съ предыдущимา родомъ въ кишечник' Hodotermes mossambicus llin.

Описываемыї видъ встрбчается внутри кишечника одного " того же термита въ нъсколькихъ болъе или менте сильно отличающихся другъ отьь друга формах’ь, представляющих”ь различныя стадіи цикла развитія жинотнаго. Въ дальныишемь изложеніи мы сначала цадимъ описанія всъхъ этихъ формъ, лалье же 
укажемъ на наблюдавшіяся очень часто стадін безполаго размноженія и на вьроятныя взашмоотношенія описанныхъ формь Мухоmonas.

Начинаемъ описаніе со стадіи, наиболғе напоминающей Tri(homonas, и которую мы назовемъ формой $A$.

Форма А. Форла твла (табл. II, фиг. 17 и 18) измбнчивая, неправильная, амебоидная, большею частью вытянутая въ длину, хотя встрбчаются и почти совершенно округлые экземпляры. Одинъ изъ концовъ тєла, задній, нербдко суживается, но не рвзко, какъ у Trichomonas, а постепенно; оба конца твла закруглены. Размьры Myхоmоnаs довольно сильно варіируютъ, какъ можно вид务ь изъ нғсколькихъ ниже помбщенныхъ измъреній.

Длина " нашбольшая ширина Myxomonts въ микронахъ: $28: 25,50: 40,55: 25,65: 40,70: 25,80: 25$.

Твло Myxоmonas обыкновенно ясно дифференцировано на толстый ободокъ эктоплазмы и внутреннюю эндоплазматическую массу. Эктоплазма, окрашивающаяся гематоксилиномъ Ге йденг айн а въ сьро-желтый цвътъ, болье или менъе гомогенна; только иногда кажется, будто она состоитъ изъ мельчайшихъ ячеекъ. Эктоплазма, повидимому, цовольно плотной консистенціи, ибо задній конецъ аксостиля, достигая эктоплазмы, не пронизываетъь ее, но, упираясь въ нее, загибается кпереди и, такимь образомь, не высовывается изъ тьла наружу. Иногда у фиксированныхъ на покровномъ стеклғ въ мазкахъ особеї эктоплазма уплотняется еще больше и даже нъскколько отстаеть от’ь эндоплазмы, такъ что между обоими слоями мистами появляется щель. Это или артефактъ или же, возможно, начало инцистированія.

По краямъ сплющеннаго тћла эктоплазма образуетъ псевдоподіе-образные выступы, въ видъ тупыхъ, закругленныхъ натековъ. Насколько быстро мғняется форма и положеніе этихъ псевдоподій я сказать не могу, нбо Myхомюmas въ живомъ состояніи ऽ не наблюдаль.

На заднемъ концъ тъла эктоплазма иногда образуетъ нъ. сколько короткихъ, складчатыхъ сосочковъ, довольно интенсивно 


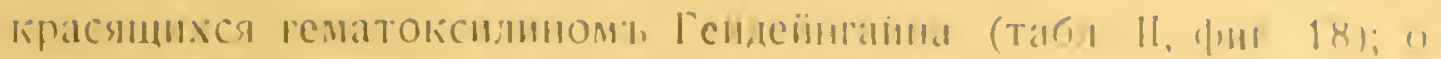

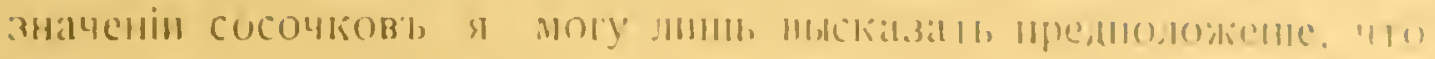

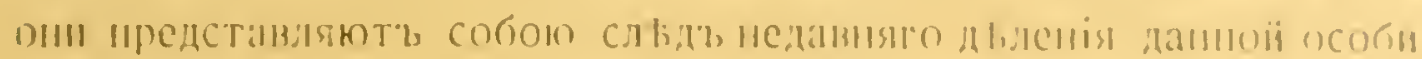

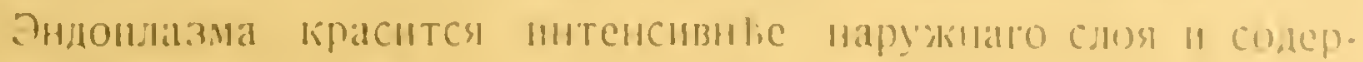

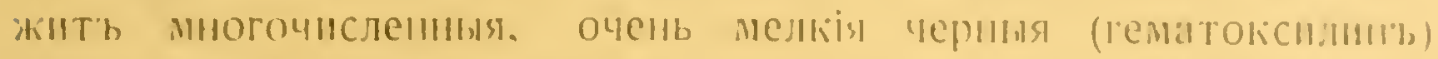
зернынки. Изрьдка внутри тыла замытны дия-три очсыь круш-

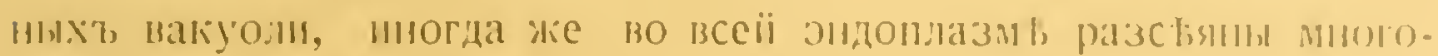

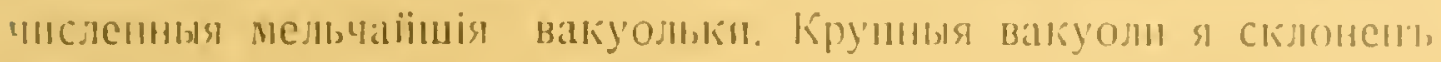
считать за артефакты, получакщіеся ири изготовленіи мазковт.

Какія (ия то ни было пищевыя вклоченія, какт иранили, отсутствують. Только одннъ разъ я видыль въ тыль формы безусловный кусокъ растительной клғтки; въ диухь другихм, случаяхъ мною было констатировано присутствіс въ знцонлазмт нвсколькихา, мелкихъ, очень, темнооканенныхт, включеній, которыя. быть можетъ, представляли собою остатки пищи.

Изъ ностоянныхъ органондовъ кльтки - мы встръчаемт, у Мyлетопяе типа А вслнообразную перепонку, аксостиль и ядро.

Ядро помњщается, большею частью, у расширеннаго конца тъла, которыї я, 1 аналогіи съ трихомонадами. " считаю поэтому, за передніиі. Однако, въ связи съ апебопдної формой твла M!y romonas, ядро пожеть сильно перемъщаться, находясь иног, а посрединь тбла. Ядро крупное и ићеть иравильную шаровиднуп форму. Внутренность ядра можеть имғть весьма различныї видъ Такъ, очень часто ядро содержить н нжнуо лининовую съть, весь же хроматин ядра сосредоточенъ въ крупномъ каріозомl, которыї может’ь находиться то ириблизительно въ центры ядра, то

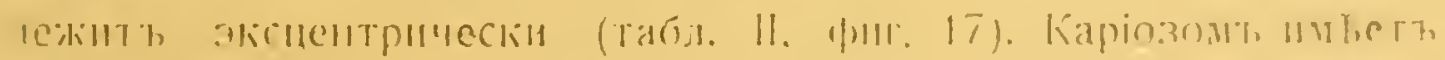

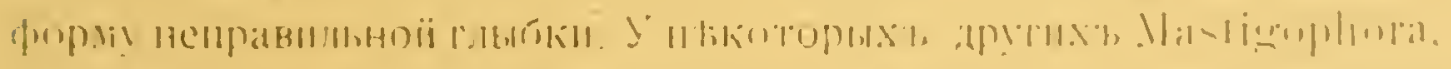

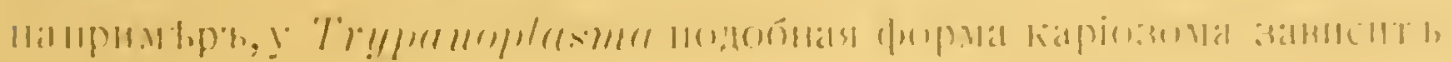

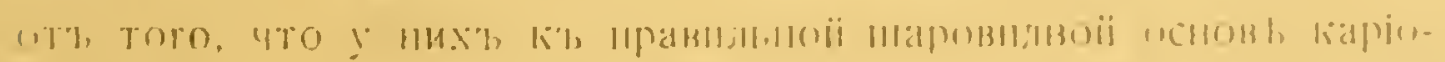

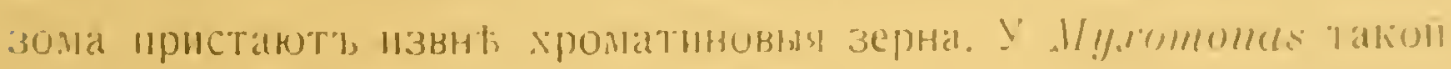
шаровидної основы въ каріозомб нбть, и весь онъ иредстанляетт:

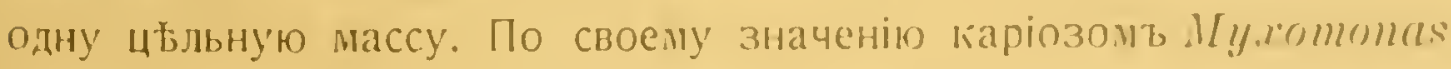
блнже всего стоить къ таковому грегарниъ. 'Такь же, какъ и у' грегаринъ, въ ядрџ могуть имвться, виюсто одного, два ,три, 
иногда даже до пяти каріозомсвъ меньшихъ размғровъ (табл. II, фиг. 16). Наконецъ, попадаются экземпляры, у которыхъ, кромъ одного крупнаго каріозома, въ съти линина видны 1 или 2 маленькихъ хроматиновыхъ глыбки; это, въроятно, осколки, отдълившіеся отъ каріозома (сравни аналогичные процессы у грегаринъ).

Въ другихъ случахъ съть линина, окружающая ядро, очень густа и въ узловыхъ точкахъ съти находятся многочиспенныя, довольно крупныя хроматиновыя зерна. Два или три раза я наблюдаль и такую картину: все ядро состоитъ изъ крупныхъ ячеекъ, а внутри каждой ячеи находится правильное, округлое зерно хроматина. Наконецъ, у случайно вывалившихся изъ тьла $M y$ xomonas при приготовленіи мазковъ ядеръ внутриядерная съть часто отсутствуетъ. Въ такомъ случағ вся внутренность ядра занята скопленіемъ очень мелкихъ хроматиновыхъ зеренъ (табл. I, фиг. 14), или же хроматинъ собранъ въ неясныя, переплетающіяся между собой нити, напоминая фигуру спирема (табл. I. фиг. 15). Описанное разнообразіе картинъ строенія ядра особенно характеризуетъ особи, взятыя изъ мазковъ, а не фиксированныя путемъ высыпанія содержимаго кишечника Hodotermes въ фиксирующую жидкость (такихъ особей формы $A$ у меня оказалось больше всего). Всльдствіе этого, я считаю возможнымъ, что упомянутое разнообразіе зависитъ отчасти отъ быстрыхъ измъненіӥ, происходящихъ въ ядрахъ при приготовленіи мазковъ; интересна въ такомъ случағ замғчательно быстрая метаболія ядра, ибо на приготовленіе каждаго мазка уходило не болъе 2-3 минутъ.

Съ ядромъ тъсно связанъ передній конецъ волнообразної перепонки. Посльдняя весьма походитъ по своей мощности и по отношенію къ краскамъ на перепонку Gigantomonas. Ходъ волнообразной перепонки можегъ очень сильно варіировать но, въ обцемъ, она имъетъ тенденцію закручиваться въ одной плоскости въ крутую спираль, окружающую ядро. Изрбдка перепонка проходитъ, изгибаясь, по одной изъ плоскихъ сторонъ тъла, или образуетъ родъ винтовой спирали, или же, чаще всего, какъ сказано, скручивается в’ь одної плоскости. Детали строенія 


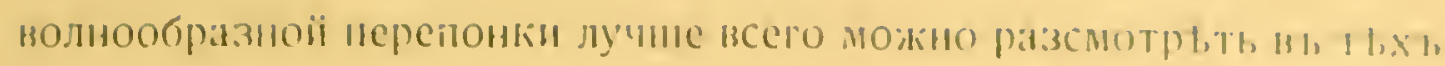

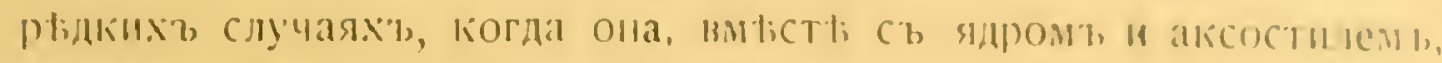

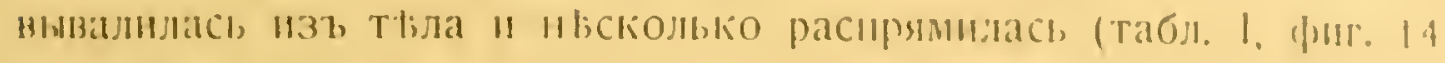
11 15).

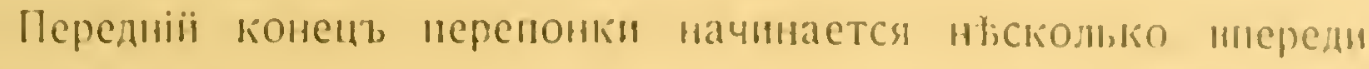
ядра " основною свосю частью обхватынаеть ядро сверху. На подобіс подковы; очсы, часто эта подковонидная част, неренонии

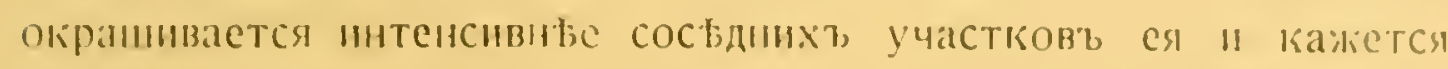
самостоятелыныъ образованіемъ. По направленію кзади высота перенони возрастаеть, достигаетъ своего максимума въ концті перелнсї ея трети и, затьмъ, очень постепенно понжастся. Такь же, какъ и у Gigantomonas, основная часть перепонки окрашивается гематоксилиномъ Г е іи де н га йна гораздо интенсивныс ея свободнаго края; при этомь граница между свътлої и темноіi зонами перенонки можетъ быть очень ръзкой (табл. 1, (ри. 14), или же объ зоны весьма постепенно переходятъ одна въ другую. Перенока Myxomonas легко можетъ быть, отличена отъ такової предыдущаго рода по устройству ея свободнаго наружнаго края. Во-первыхъ, посльднії образуетъ гораздо больше изгибовъ (сильнъе гофрированъ), чъмъ у Gigantomonas, во-вторыхъ же, у М!xomonas подъ краевой нитью (краевымъ жгутикомъ) перспонки проходитъ на очень близкомъ разстояніи вторая, подкрџпляющая первую, нить. Такія дополнительныя нити уже неоднократно описывались въ перепонкахъ трихомонадъ (Лаверанъ и М е ниль 20, Кучинскі ї 26, стр. 139). Гофрированность края перепонки зависитъ, главнымъ образомъ, отъ того, что красвоі жгутикъ, образующій край ея, значительно длиннъе самої перспонки. Поэтому, когда краевой жгутикъ случаїно отстанетъ (табл. I, фиг. 15 ), свободный краї перепонки выпрямляется.

Аксостиль хорошо развитъ. Онъ подходитъ къ ядру сзади и обхватывает’ь ядро свонм расширеннымъ переднимъ концомъ въ видь тонкой пленки, приходя въ связь и съ подковообразнымъ основаніемъ перепонки, которое какъ мы выдылы, прикрђпляется къ ядру спереди. Лучшее доказательство тьсноі связи между ядромъ, перепонкої и аксостилемъ заключается въ томъ, чтс 
ири изготовленіи мазковъ, образованія эти легко могутъ быть выдғлены вонъь изъ твла, не отрываясь другъ отъ друга (табл. 1, фиг. 14, 15 и табл. II, фиг. 16). Совокупность аксостиля и волнообразной перепонки представляетъ собою опорно-двигательный аппарат'ь Myxomonas. Аксостиль состонтъ изъ болье свйтлаго периферическаго слоя, какъ бы оболочки, и черной (прн окраскъ гематоксилиномъ Г ей де н га й на) оси. При о́крашиваніи препаратовъ сафраниномъ аксостиль совершенно не окрашивается и почти незамбтенъ. Волокнистое строеніе аксостиля, отмйченное для Gigantomonas, здъсь различить не удается, хотя, вьроятно, оно имғется и у даннаго рода. Аксостиль Myxomonas иялетъ ту важную особенность, что онъ цйликомъ лежитъ внутри тъла животнаго, не выдаваясь наружу и не образуя хвостовой иглы, какъ это обычно бываетъ у трихомонадъ. Отходя отъ ядра, аксостиль направляется къзаднему концу тъла, натыкается на плотную эктоплазму, загибается снова кпереди и образуетъ болышую или меньшую дугу; очень нерьдко задній конецъ аксостиля загибается кпереди такъ сильно, что почти соприкасается съ ядромъ (особенно часто мы находимъ такія картины у экземпляровъ, гд屯 волнообразная перепонка скручена вокругъ ядра въ одної плоскости въ крутую спираль). Какимъ образомъ заканчивается аксостиль на своемъ переднемъ концъ, сказать очень трудно. Только на одномъ выдъленномъ изъ твла Myxomonas опорнодвигательномъ аппарать я ясно видблъ, какъ наружная оболочка аксостиля, окружив'ъ ядро, образовала на передней его поверхно-

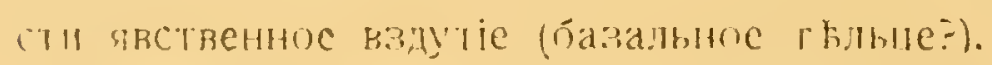

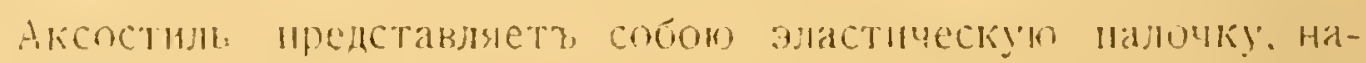

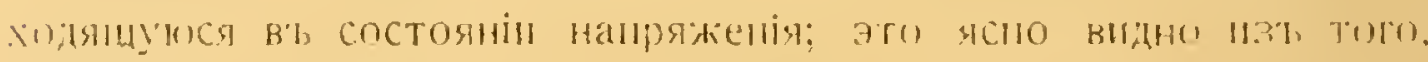

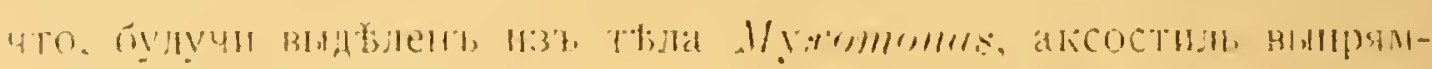

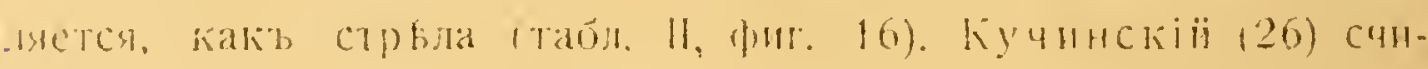
тает” н аксостиль и “хроматнновую ьаsis» перенонкн образованіяли, служащими лишь въ качествь точекъ опоры для жүутиковаго аппарата. Такое толкованіе этихъ органоидовъ черезчуръ односторонне: $и$ аксостиль и волнообразная перепонка, безу- 


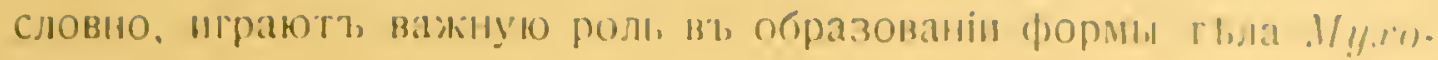
111011\%s.

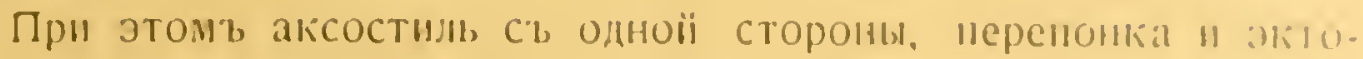

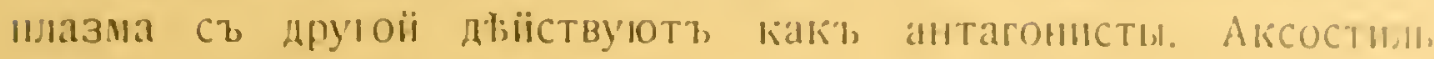
имLеть тенденцію выняянться и, такимя ояразоми, спосия-

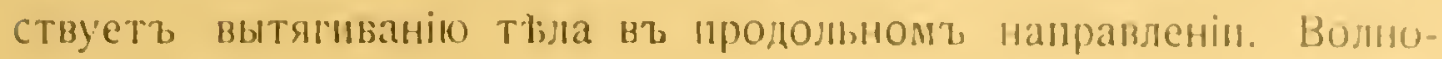
образная перенонка стремится к̌ скруинванію 13\% спираль на переднемъ концы тьла въ одної плоскости (прнолнзителин нерпендиулярной къ осн аксостиля); а, такь как"ь перенони лежитъ въ эктоплазм в и тடсно связана Съ нею, то при скручиваніи она стягиваетъ эктоплазматическій мњшокъ къ шерелнему концу ॥ этимъ заставляетъ задній конецъ аксостиля загнуться кілеред, а само тьло животнаго укоротиться. Нормальное (если можно такъ выразиться) положеніе аксостиля и перепонки становится яснымъ въ тҰхъ случаяхъ, когда опорно-двигателыны аппаратъ выдъленъ случайно изъ тєла и, такимъ образомь, освобожденъ отъ вліянія на него эктоплазпатическаго чехла. Тогда аксостиль выпрямляется, перепонка же сильно скручивается въ спираль въ одной илоскости (табл. ІІ, Фиг. 16); гораздо ръже перепонка такого аппарата находится въ выпрямленном' состояніи,вもроятно, будучи близка къ отмиранію (табл.1, фиг. 14 แ 15$)$.

Итакь, форма тєла Myxomonas можеть быть выражена как', равнодұйствующая двухъ силъ: силы воздъйствія аксостиля и силы воздъиіствія волнообразной перепонки.

Три или четыре переднихъ жгутика, характерныхъ для всъ.хъ трихомонадъ, у Мyхомопая, повидимому, отсутствуютъ. Впрочемъ, это обстоятельство отнюдь не должно препятствовать включенію даннаго рода въ число Tetramitidac. Во-первыхъ, мнв удалось

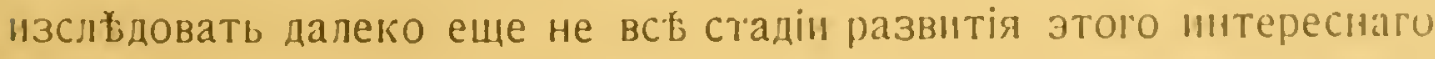
иаразита; во-вторыхъ, у двухъ экземпляровъ Мухотолая я видьль образованія, напоминающія собою жгутики. А нменио. въ обонхъ укказанныхъ случаяхъ, я нашель у самаго передияг, заостреннаго конца волнообразної перепонки два черныхт, зер.

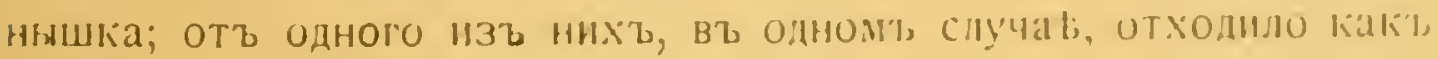


будто двъ тонкихъ нити (табл. І, фиг. 13). Такія зернышки легко можно толковать какъ базальныя тьильца жгутиковъ, а упомянутыя нити, какъ самые жгутики. Однако, я предпочитаю относиться къ сдъланному наблюденію весьма осторожно оттого, что гематоксилинъ Гейденгайна краситъ, кромъ базальныхъ тьлецъ, и всевозможныя иныя включенія плазмы; съ другой стороны, Myxomonas окружены обыкновенно безчисленнымъ множествомъ тонкихъ, волосовидныхъ бактерій, которыя очень похожи на жгутики, вслъдствіе чего судить о присутствіи жгутиковъ и Myxomonas толыко по одному, изображенному на рис. 13 , препарату слишкомъ рискованно.

Форма В въ общемъ тождественна съ предыдущей, но лишена аксостиля. Этотъ факгъ не препятствуетъ относить объ формы къ одному виду и только лишній разъдоказываетъ, насколько подверженъ измъненіямъ организмъ трихомонадъ и родственныхъ имъпростъйшихъ. Уже Робертсонъ и Мартиньъ (24, стр. 67) отмьчаютъ по отношенію къ Trichomonas gallinarum, что аксостиль у этого вида встръчается лишь иногда. Кромъ того, у многих飞 трихомонадъ аксостиль временно исчезаетъ, передъ началомъ дєленія животнаго. Что касается Myxomonas, то въ однъхъ пробахъ мнб попадались только особи тина $A$, въ другихъ-особи типа $B$, тогда какъ въ третьихъ и тв и другія встрбчались вмъсть. Нахожденіе подобныхъ варіацій у Myxomonas снова вызываетъ къ жизни вопросъ о систематическомъ значеніи Формъ Trichomonas и Trichomastix, которыя Дофлейномъ считаются за варіанты одного вида, тогда какъ прочими новъйшими изсльдователями признаются за самостоятельные виды. Повидимому, въ Irichomonas и Trichomastix мы имъемъ такіе же варіанты одной и той же формы (только варіація здъсь касается другого морфологическаго признака), какъ и типь $A$ и $B$, найденные мною у Myxomonas.

Форма $B$ (табл. II, фиг. 19) настолько походитъ на форму $A$, что относительно нея можно јограничиться лишь нъсколькими дополнительными замъчаніями.

Величина формы $B$ колеблется в’ь тъхъ же предълахъ, как'ь 


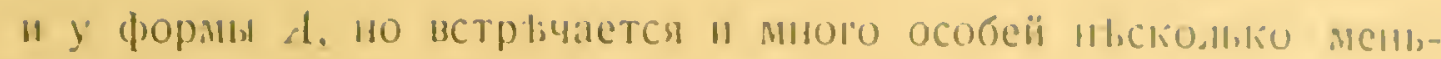

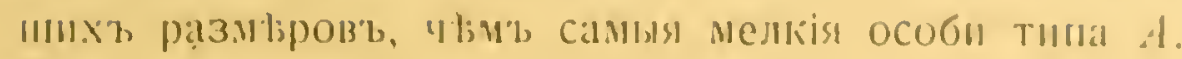

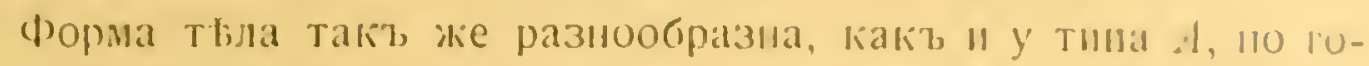

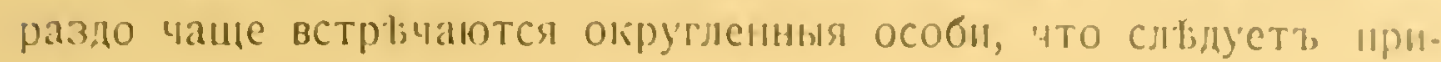
нисать отсутствію аксостиля.

Эндоплазма формы $B$ нерқдко очень силино вакуолизирована, причем'ь иногда все твло пронизано мельчай:шимн вакуолями, вь цругхх же случаякъ имыются 2-3 очень крупныху вакуоли:

Строеніе волнообразной перепонки такое же, какъ у тина $A$, но здьсь она значительно чаще скручивается вокругъ ядра въ спираль, лежащую въ одной плоскости,-опять-таки результатьь отсутствія антагонистической дъятельности аксостиля. Ядро формы $B$ отличается тымъ, что весь хроматинь его обыкновенно разсълиъ въ видъ мелкихъ зеренъ въ летляхъ лининовой сьти, каріозома же нътъ. Формы $B$, подобно предыдущимъ, совершенно не содержатъ пищи; только въ одной особи я видъль нбсколько пищевыхъ включеній.

Форма С. Сюда я отношу особей съ еще болье редуцированнымъ опорно-двигательнымъ аппаратомъ, чьмъ у типа В. Такія особи шмъютъ видъ крупныхъ, иногда даже очень крупныхъ амебъ съ одним'ь ядромъ, къ которому прилегаетъ маленькая (въ нћсколько разъ меньше, чъмъ у формъ $A$ и $B$ ) волнообразная перепока (табл. II, фиг. 20, фиг. въ тексть 1). Аксостиль и жгутики отсутствуютћ.

Описываемая форна очень легко отличима отъ предыдущихъ не только по величинъ перепонки, но и по строенію протоплазмы " нъкоторымъ другимъ признакамъ.

Форма тъла " величина особей типа $C$ варінруетъ въ широкихъ предълахъ. Наиболье часто встръчаются нЊсколько сплющенные въ видъ лепешки экземпляры округлаго или неправильно четырехугольнаго очертанія; нъсколько болье ръдки особи вытянутыя въ длину, овальныя или даже лентовидныя. Наконецъ, очени своеобразныиі видъ имњютъ грушевидныя амебы съ сильо суженнымъ однимъ концомъ тєла " вздутымь колбовидно лругнж. 
Длина " ширина твла формы С могуть быть выражены вь сльдующихъ цифрахъ: $70: 45,75: 50,90: 65,130: 60,130: 80$. - Эктоплазма " эндоплазма ръзко разграничены и лишь въ очень рбдкихъ случаяхъ постепенно переходять одна въ другую, какъ это имьетъ мғсто у формъ А и В. Эктоплазма окружаеть төло животнаго вь виде широкой свнтлой каймы. Толщина эктоплазматическаго слоя въ различныхъ точкахъ поверхности тұла можетъ быть весьла различной. Так’b, на однопь концғы тыла эктоплазма можетъ образовать нъчто въ роды мощной. ииро_

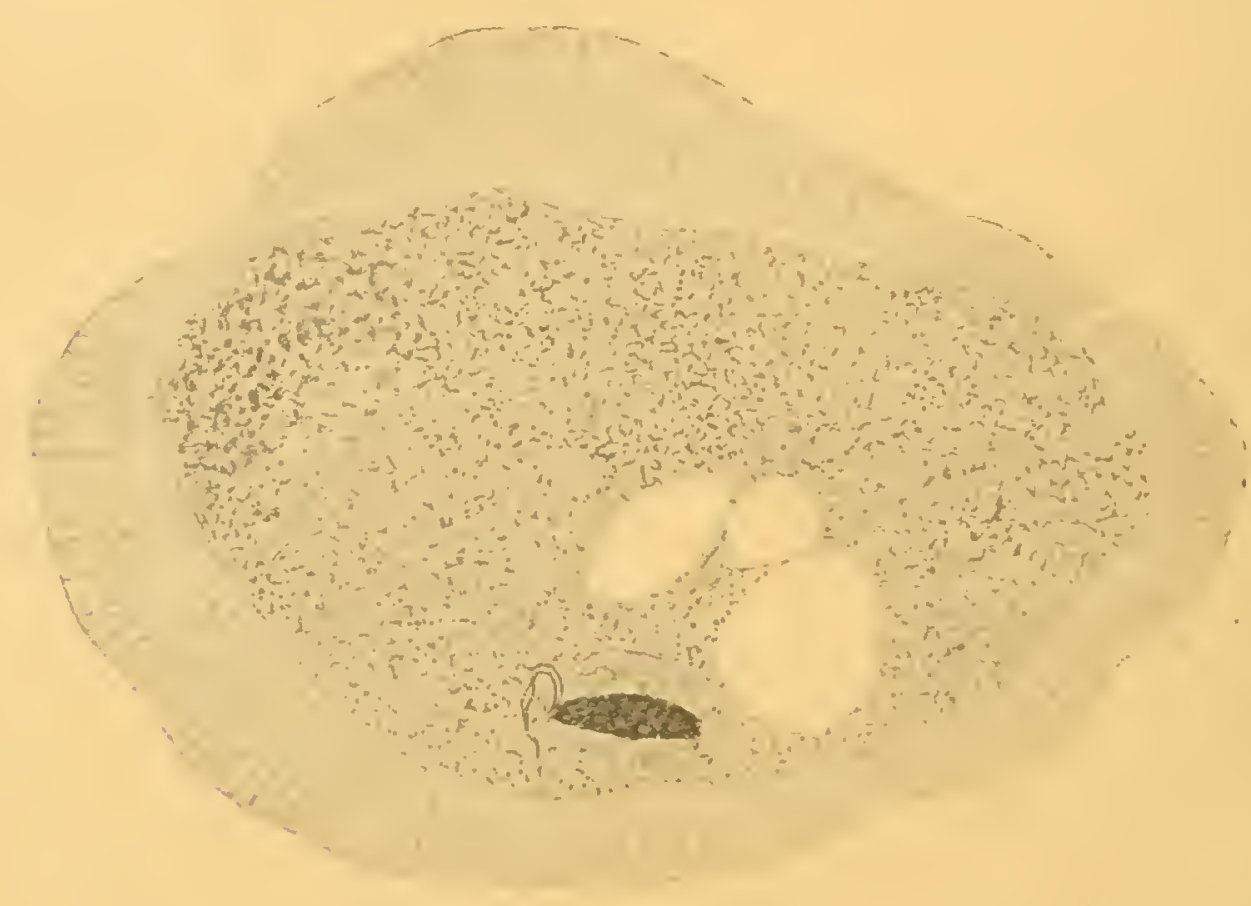

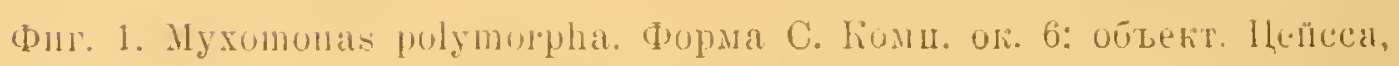
пммерія 2 мм.

кой псевдоподін, тогда какъ въ других пвстахъ сходитъ иногда почти на нътъ: шли, на одной половинғы четырехугольнаго тюла эктоплазма очень толста, а на другой образуетъ тонкую пленку'. Наконецъ, имюются и такіе экземпляры, у которыхъ толщина эктоплазматическаго слоя повсюду приблизительно одинакова. Вся эктоплазма полна очень мелкихъ вакуолей, которыя сильно вытянуты въ радіально'ь направленіи и расположены, хотя и не вполн'ь правильно, в’1, одинъ рядъ, параллельно одна другой. Эктоплазма пріобртаетъ вслџлтвіе этого исчерченный въ радіаль- 


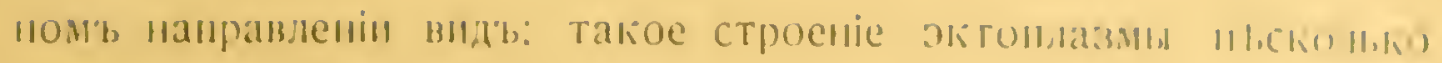

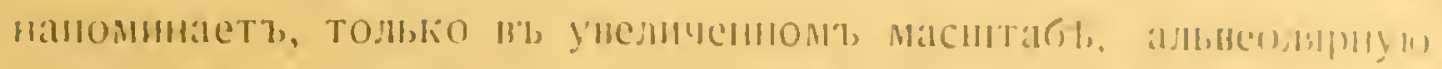

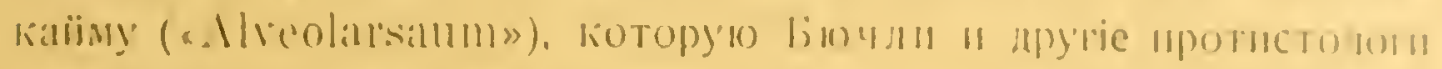

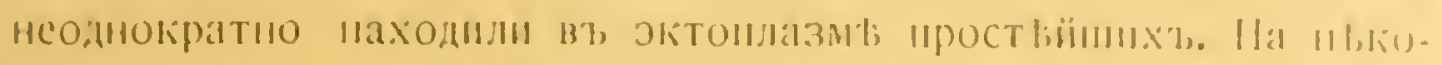

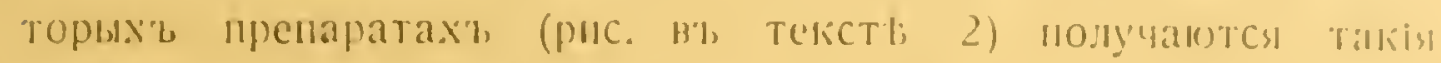

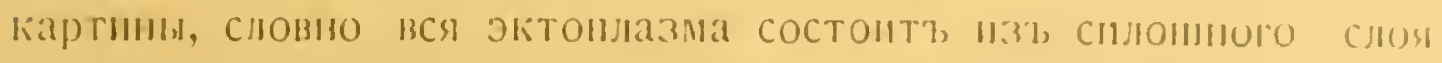

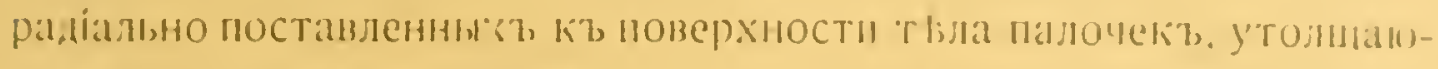

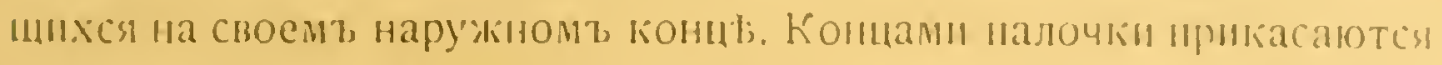

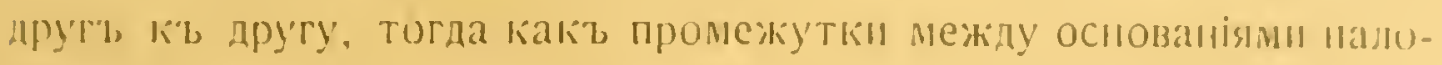

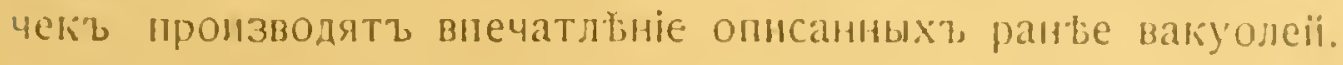

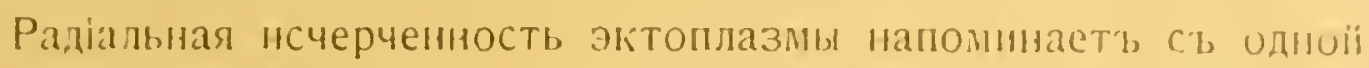

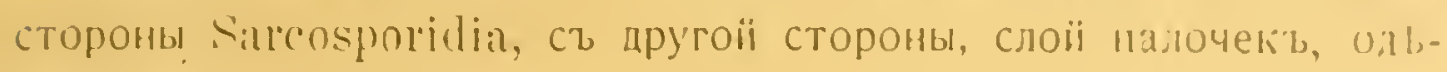

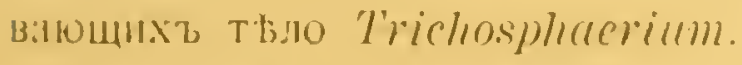

Эндоплазма окрашивается значителын теннде эктонлазиы Это занисить какъ отьь общаго болъе темнаго тона эндоплазиы.

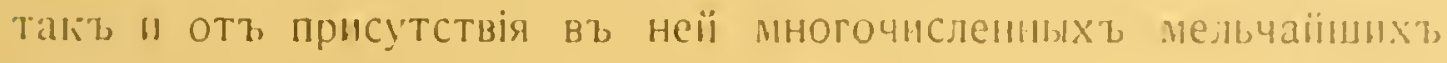
черныхт (прн окраскт, гематоксилипонь Гейденгаіна) зернышекъ того же характера, какъ и вт эндоплази форм' 4 .

Мъстами въ эндоплазмь разбросаны очень крупныя, свътлыя вакуоли. у значительнаго большинства псобей

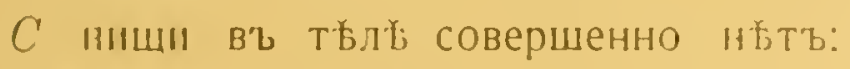
такь, 11зъ 32 отмьченныхъ мною на

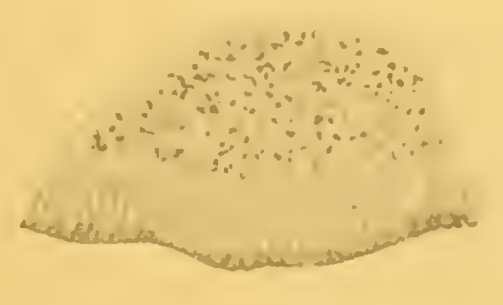

(1) 2. Myxomumas [mlymorpha, Crpoente alitollat-

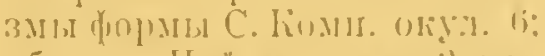

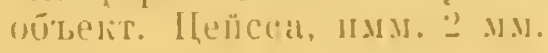
одной части монхъ препаратовъ особей. пнща пмғлась лншь $y$ 5, ла " то въ небольшонт количествв. Пиша состонтъ изъ мелкінх кусочковъ дерева, которыпи наблваютъ свой кишечищкь термиты.

Ядро (табл. ІІ, фиг. 22: табл. ІІ, фиг. 44), каки обикновенио у амебъ, не занимаетъ въ тыль строго опредыленнаго мыста, находясь то въ центры тұла, то блнже къ его периферіи. ни

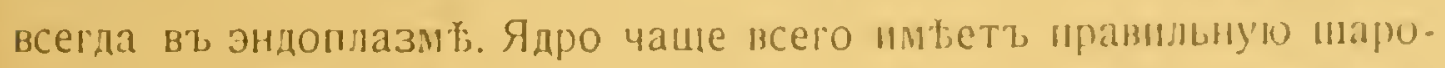

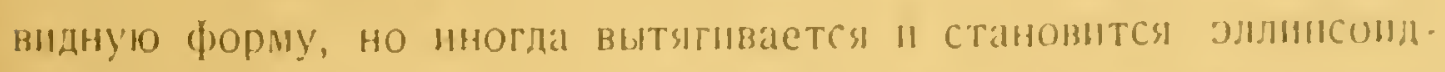

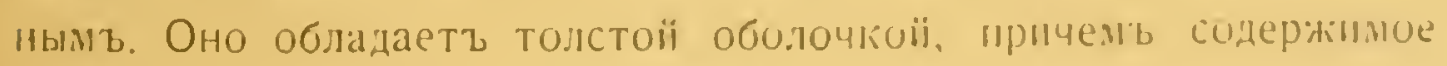


ядра отстаеть оть оболочки или по всей периферіи ядра, или лишь на сторон向 противоположной той, къ которой прилегаетъ волнообразная перепонка (табл. II, фиг. 22). Подобное отставаніе содержимаго ядра отъ оболочки описывается и изображается у многихъ Polymastigina и Hypermastigina (Joenia, Trichomympha, Devecsovina, Stephanonympha). Строеніе ядра въ деталяхъ варіируетъ, но чаще всего наблюдается сльдующеє. Ядро содержитъ крупный каріозомъ; посльдній въ наиболће простыхъ случаяхъ шаровиденъ (табл. II, фиг. 20), но гораздо чаще вытягивается въ одномъ направленіи и принимает', овальную или яйцевидную форму (табл. II, фиг. 22). Вытягиваясь еще больше, каріозомъ нербдко однимъ своимъ концомъ достигаетьь периферіи ядра (табл. II, фиг. 25), а иногда и второй конецъ его продълываетъ то же самое, и тогда каріозомъ принимаетъ характеръ темной ленты, или тяжа, пересъкающаго ядро (табл. IV, фиг. 44). Иногда конецъ каріозома, прилегающій къ периферіи ядра, какъ бы расплывается, и каріозомъ становится похожимъ на широкій клинъ, вдающійся отъ периферіи ядра къ его центру (тасл. II, фиг. 25). Шаровидные и овальные каріозомы кажутся гомогенными и окрашиваются гематоксилиномъ Гейденгайна въ густой черный цвъ̆ть. Сильно вытянутые въ длину и расплывающіеся каріозомы позволяють установить составъ каріозома изъ двухъ различныхъ веществъ, хроматина и пластина. Особенно хорошо это видно въ тъхъ случаяхъ, когда хроматинъ отходитъ къ периферіи или къ концамъ каріозома (либо въ видғ сплошныхъ натековъ, либо въ видъ отдағльныхъ зеренъ), оставляя въ центрь слабо красящуюся, гомогенную массу пластина (табл. II, фиг. 22 и 25). Довольно часто весь каріозомь (когда онъ вытянутьь въ длину) состоит’ь изъ крупныхъ, округлыхъ зеренъ хроматина, напоминающихъ собою хромозомы (табл. IV, фиг. 44). Такое сходство, однако, лишь кажущееся. Дъло въ томъ, что въ нъкоторыхъ случаяхъ массивный шаровидный каріозомъ бываетъ окруженъ хроматиновой нитью, закрученной въ клубокъ (спирем'ъ). Насчеть этого сиирела, повидимому, и происходятъ хромозомы при дъленіи ядра. У большинства особей каріозомъ окруженъ 


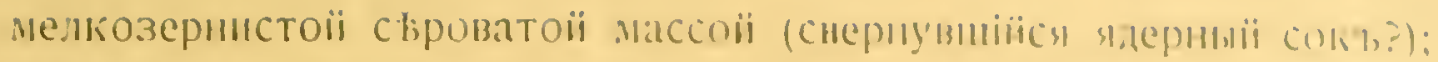

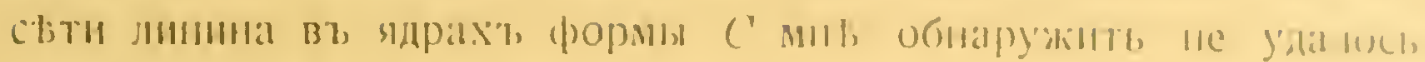

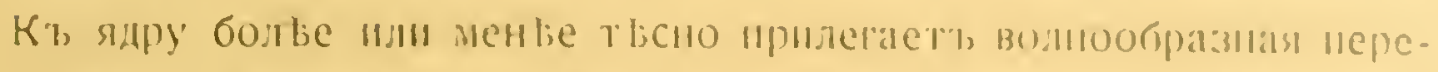

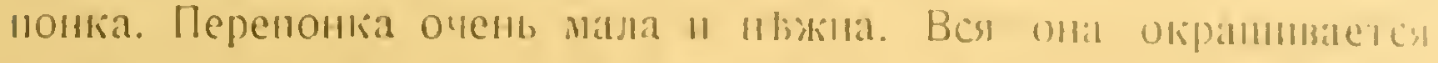

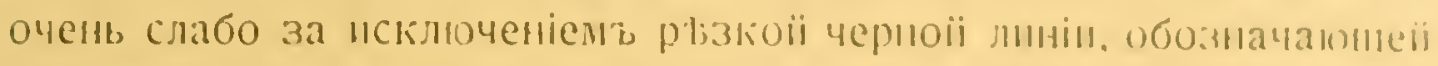
основаніе мембраны, и такої же, но болье тонкой линіи, ири-

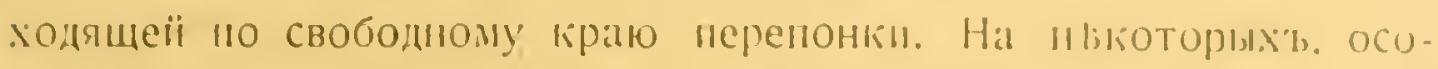
бенно удачныхь пренаратахь я видылт, что параллельно красызиі синьно красяшейся лини, или нити, проходить црутая оплtе нliжная нить. Этанить, безъ сомнтнія, отвъчаетъ второї олорної нити перепонокъ форит А " $B$. Однимъ своимъ концом' (переднимъ, по аналогіи ст, Gigantomonas и Trichomonas) перепонка тьсно прилегаетъ къ оболочкь ядра, другої же конецьь мембраны можетъ далеко отставать отъ ядра. На одноми экземпляр‡ я видълъ у передняго конца перепонии двойное черное (окраска гематоксилинон'ь Гейденгайна) зерно-базальное тйлье. Волнообразная перепонка формы С въ огромномъ большинствъ случасвъ, лежитъ вићсть съ ядромъ внутри эндоплазмы, не выдаваясь надъ поверхностью тғла. Это обстоятельство особенно интересно, ибо оно указываетъ какъ бы на рудиментарный характеръ перепонки у особеиі типа С. И, дъйствительно, при малой величинъ перепонки и сравнительно огромныхъ размұрахъ самой амебы, перепонка едва ли можетъ играть здъсь важную роль какъ двигательный аппаратъ, или какъ приспособленіе для захвата пищи.

Среди особей типа $C$ довольно часто попадаются экземпляры, подготовляюціеся къ инцистированію (табл. IV, фиг. 40). Подобныя особи округляются или принимают'ь правильную овальную форму, слой эктоплазмы становится по всеиі периферіи твла одинаково толстымъ, а эндоплазма переполняется иногочисленными хромидіями. Хромндіи имъютъ весьма разнообразыую форму: частью это мелкозернистыя черныя скопленія, частью отыльныя, болье крупныя глыбки; иногда хромидіи располақатся ит

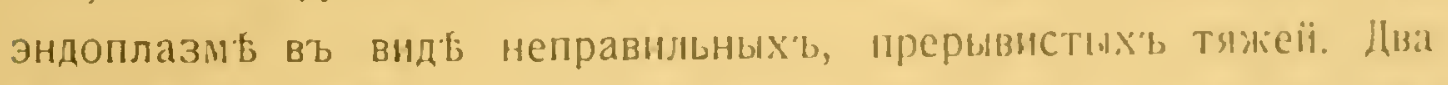
или три раза мнє удалось наблюдать, что гакіе тяжи берутт 
начало изъ ядра. Ядро инцистирующихся особей сильно обогащается хроматиномъ, который скопляется вокругъ каріозома въ видъ довольно крупныхъ зеренъ; эти зерна, выходя изъ ядра въ окружающую плазму, и даютъ начало хромидіальнымъ тяжамъ.

Позднихъ стадій инцистированія и образованія оболочки цисты я у Myxomonas не наблюдаль; тьмъ не менъе, я считаю вышеописанныя особи за инцистирующіяся по аналогіи съ нькоторыми Trjchony mphidaе изъ того же Hodotermes, у которыхъ неоспоримое инцистированіе начинается такими же стадіями.

Кромб одноядерныхъ особей вышеуказанныхъ трехъ типовъ, въ кишечникъ Hodotermes столь же часто попадаются двуядерныя стадіи безполаго размноженія Myxomonas. Среди такихъ двуядерныхъ особей однъдаютъ начало формамъ $A$ и $B$, другія по строе. нію ядра и волнообразной перепонки должны быть поставлены въ связь съ типомъ $C$.

Форма D. Разсмотримъ сначала первыхъ. Дълящіяся особи (табл. III, фиг. 27-29), дающія начало формамъ $A$ и $B$, имьють амебоидный характеръ, причемъ тотчасъ же могуть быть узнаны по присутствію въ эндоплазмъ большого количества пищи. Это иризнакъ чрезвычайно характерный для дълящихся Myxomonas; просмотрђвъ болье сотни особей, обладавшихъ дълящимся ядромъ, s) только въ одномъ экземплярб не нашелъ пищевыхъ включеній. Пища Myxomonas довольно разнсобразна. Главнымъ образомъ онъ питаются обломками дерева и частями растительныхъ кл‡токъ, заглоченныхъ термитомъ-хозяиномъ. Иногда поглощаемые вмебой кусочки дерева такъ велики, что однимъ изъ своихъ концовъ торчатъ изъ тъла наружу, прободая эктоплазму. Кромъ дерева, въ эндоплазм В Myxomonas часто можно найти множество какихъто спорьь, принадлежащихъ, новидимому, грибамъ. Споры очень интенсивно окрашиваются гематоксилиномъ Гейденгайна и, набивая собой тю́вло животнаго, маскируютъ ядра посльдняго.

Наконецъ, попадаются и какія-то зернистыя пищевыя включенія, характеръкоторыхъ не поддается болъе точному опредъленію. Пища большею частью прямо покоится въ эндоплазмь, не будучи окружена пищеварительными вакуолями. То же мы находимъ и у 


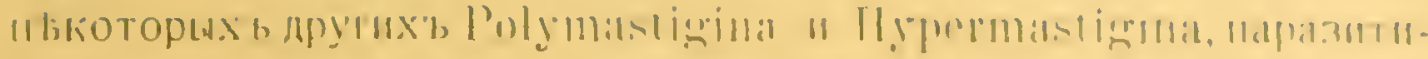

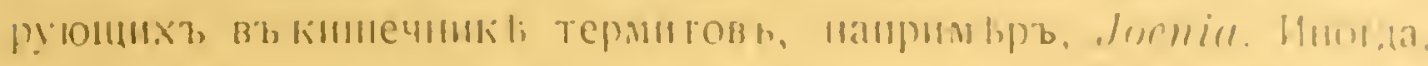

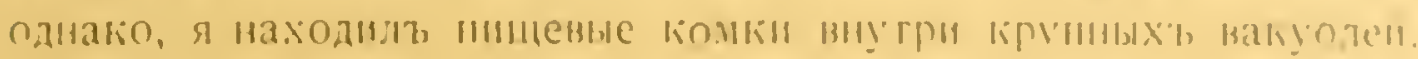

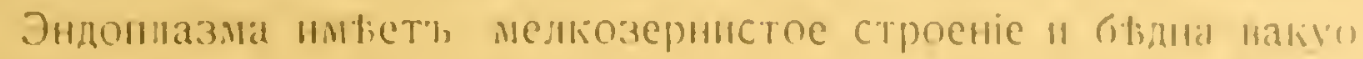

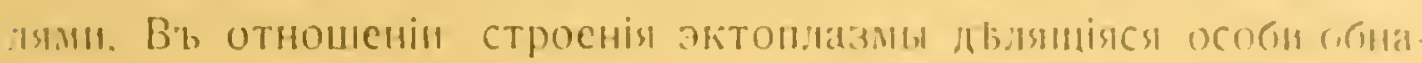

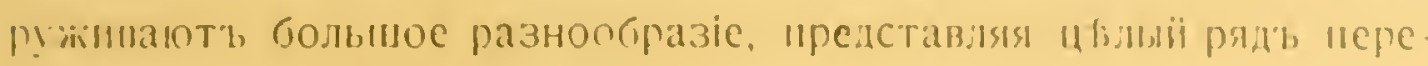

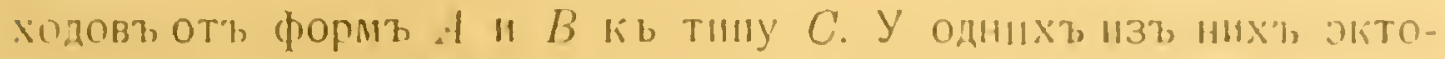
илазма имыеть болье или ненье гомогенный характеръ и пере-

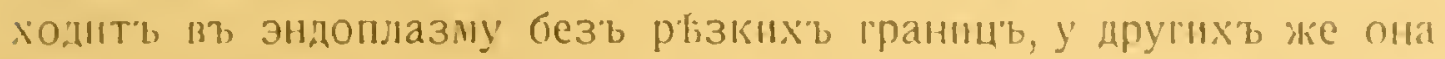

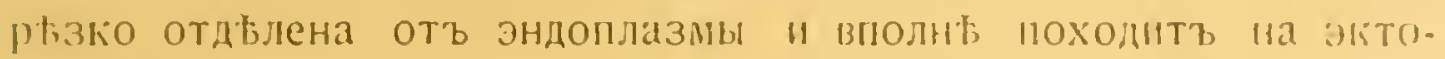
плазму фориь C. Величина формь $D$ варінруеть очень сильно,

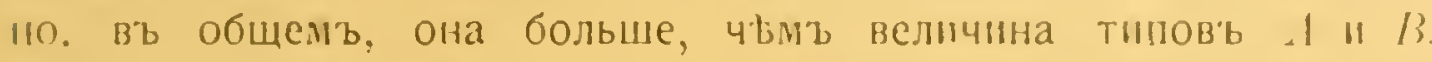
Вотъ ићкоторыя измбренія нашбольшей длины и ширшны: 50:50. (1): $: 511,70: 50,90: 40,95: 55,120: 55$.

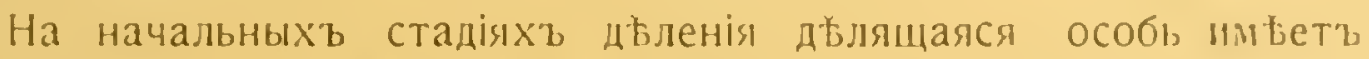
одно ядро округлої формы, лежашее вь глубинь энлоплазмы. При ядрћ нћтъни волнообразної перепонки, ни аксостиля, а само яяро оснаруживаеть нбкоторые признаки начала діленія. Что дћлается передъ диленіешъ съ перепонкої материнской особи. а. въ случағ присутствія у нея аксостиля, " сь аксостилемъ, я, къ сожальнію, сказать не могу. Вғроятно, эти органопды резорбируются, " такое апріорное предположеніе поддерживается двуня или тремя препаратани, на которыхъ вокругъ дълящагося ядра замғтны какіе черные (при окраскћ гематоксилиномь Гсйденга інна) обломки-остатки перенони материнскаго индивида.

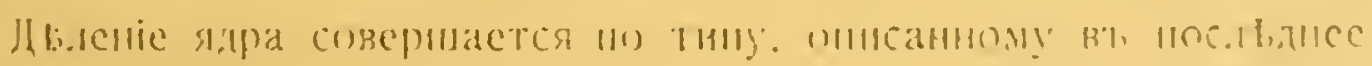

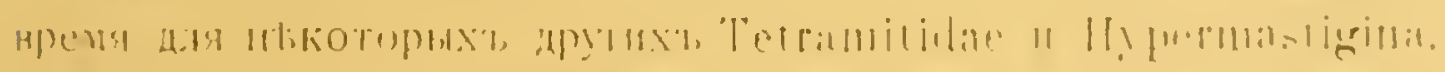
11 koтoprong 9

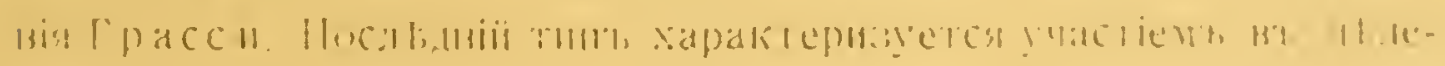

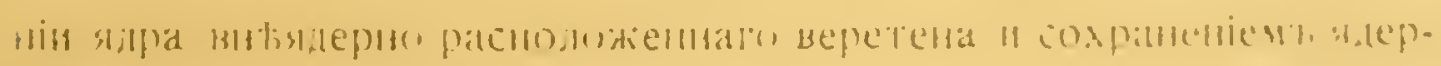

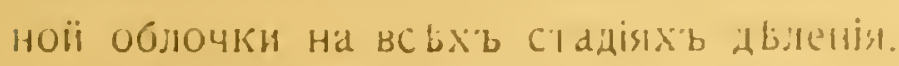

Самая ранняя наблюдавшаяся мною стадія дыленія ядра имыст" сльдующіiі видъ (табл. ІІ, фиг. 23). Ядро имыет" обнчиую 中орму " содержить среди многочисленныхъ мелкихъ зериынекъ, занолняющихъ внутренность ядра, распавшіиіся ча двьь части каріозомъ. 
Ядро охвачено дуговиднымъ веретеномъ, тъсно прилегающимъ къ его облочкъ. Веретено интенсивно красится гематоксилиномъ Гейденгайна и имбетъ волокнистое строеніе, какъ можно видъть из̧ь рисунка. Заканчивается веретено небольшими утолщеніями, какъ бы пуговками, выдающимися надъ поверхностью ядра; лучше дифференцированные препараты показываютъ, что на концахъ веретена имғются дв центріоли; центріоли продолговаты, какъ у Lophomonas (Яницкій 16) инбкоторыхъ Tetramitidae. Откуда происходитъ веретено, я съ точностью установить не могъ. Сначалая предполагалъ, не есть ли оно неспосредственный дериватъ подковообразнаго основанія волнообразной перепонки, которое охватываетъ ядро формъ $A$ и $B$. Однако, впосльдствіи, послғ находки двухь базальныхъ тьлецъ, расположенныхъ у передняго конца перепонки, я получилъ убъжденіе, что веретено (такъ же какъ у Trichomonas, Lophomonas и мн. др.) возникаетъ въ вид центродесмозы при дйленіи одного изъ базальныхъ тйлецъ.

Дальньйшій ходъ дъ̆енія ядра просльженъ мною довольно детально. Каріозомъ бльднъетъ и резорбируется, а ядро нъсколько удлиняется (табл. III, фиг. 27). Два раза я видълъ (табл. III, фиг 30), какъ отъ концовъ веретена отходили на этой стадіи тонкія изгибающіяся нити, которыя, еще болъе утончаясь, заканчивались въ эндоллазмъ. Значеніе этихъ нитей остается невыясненнымъ (остатки волнообразной перепонки материнской особи?). Далъе вся внутренность ядра заполняется большимъ количествомъ (больше сотни) довольно крупныхъ, округлыхъ хроматиновыхъ зеренъ-хромозомъ (табл. II, фиг. 26). Ядро становится овальнымъ, а хромозомы, вытягиваясь, принимаютъ форму нитей (табл. ІІІ, фиг. 30).

Расщепляются ли эти нити продольно или нътъ, сказать трудно, но только вскорб онғы располагаются въ двъ̆ группы, причемъ всъ хромозомы однимъ своимъ концом’ оріентированы къ срединъ ядра, а другимъ къ одной изъ центріолей. Соединительныхъ нитей, связующихъ у Trichomonas (по Кучинскому, 26) концы хромозомъ съ центріолью, я, быть можетъ, изъ-за многочисленности и скученности хромозомъ, замитить не могъ.

Ядро и прилегающее къ нему веретено вытягиваются еще 


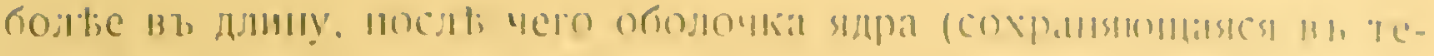

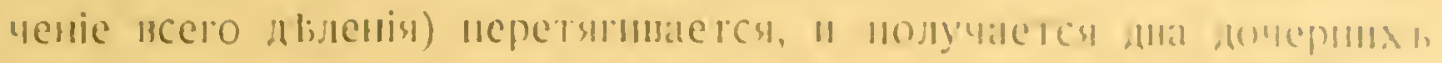

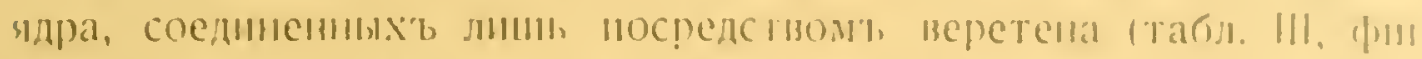

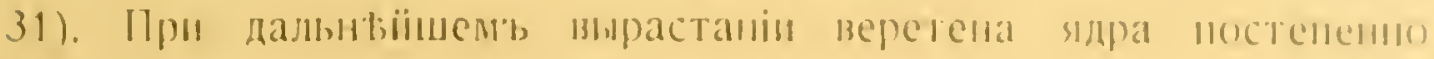

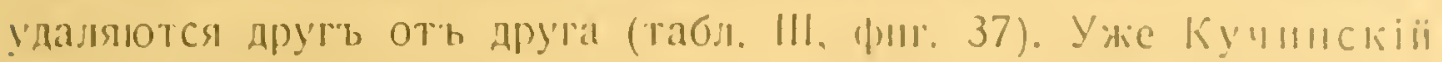
(26) высказаль предиоложеніе, что рость веретена имғеть :иаченіе въ раздвнганін дочернихт ядеръ. У Муят) ніс дочерних ядер’ среди протонлазмы, пабитої пнщені. встричаеть большія затрудненія. " веретено играеть ири этомь очени, важную роль. Веретено, въ выдњ разрастающсйся эластической палочки, пробиваеть себъ путь среди включеніі плазмы и у'влекаеть свопми концами дочернія ядра в’ь противоположныя стороны. Иногда при этомл, плазма оказываетъ такое сонротивлсиіс, что веретено выгибается въ крутую дугу; посльдняя в’ь паллежащіиі моментъ, вьроятно, быстро распрямляется, что ведетъ къ расхожденію дочернихъ ядерь. Помимо своего расхожденія другъ, отъ аруга, дочернія ядра очень часто дълаютъ одно по отношенію къ другому поворотъ вокругъ осн, которую представляет? собою веретено (табл. ІІІ, Фиг. 37). Этотъ поворотъ вызывается характеромъ строенія веретена. Веретено составлено изъ довольно значительнаго числа волоконъ, которыя илутъ отъ одного конца его къ другому не прямо, а будучн нъсколько скручены (какъ волокна веревки, см. рис. 36, табл. III). Пока ядро еще не раздълилось, волокна веретена сохраняють свое положеніе, но, какъ только образовалось два ядра, эластичныя волокна веретена стремятся выйти изъ скрученнаго положенія, выпрямиться, и разворачиваются своими концами въ иротивоположныя стороиы, заставляя дочернія ядра сдвлать вышеописанный поворотъ. Аналогичное строеніе веретена было отмъчено Грасси (12) у Јосліа, но вліяніе его на положеніе ядеръ ускользнуло от"ь вниманія наблюдателя.

Дочернія ядра постепенно принимають строеніе покоюшагося ядра. Процессь этотъ можеть идти болюе или менђе быстро. Так'ь, въ однихъ случаяхъ (габл, III, 中иг, 32) дочернія ядра. лежащія совсьмъ рядомъ и соединенныя очснь короткимъ вере- 
теномъ, т.-е. недавно раздълившіяся, имъютъ видъ покоющихся ядеръ съ каріозомоль и сътью линина. Въ другихъ случаяхъ (табл. III, фиг. 37), далеко отодвинувшіяся другъ отъ друга дочернія ядра сохраняють весь свої хроматинъ въь виды пучка хромозомъ. Каріозомы дочернихъ ядеръ въ большинств Б случаевъ окрашиваются очень слабо.

Посль образованія дочернихъ ядеръ начинается формированіе при каждомъ изъ нихъ нової волнообразной перепонки. Перепоки образуются отъ концовъ веретена, т.-е. вьрнъе, отъ центріолеї, лежащихъ на обоихъ концахъ веретена. Сначала замлтны отходяція отъ концовъь веретена тонкія нити, твсно прилегающя къ ядру и описывающія вокругъ него приблизительно половину окружности (табл, III, фиг. 34, m); это зачатки основанія перепонки, а именно той передней части основанія, которая у фоормъ $A$ и $B$ охватываетъ ядро на подобіе подковы. Далъе перепонка одновременно растетъ и въ вышину и въ длину (табл. III, фиг. 35 и 39), причемъ конецъ основноіі нити отщепляется отъ ядра и погружается свободно въ эндоплазму. Длинный рядъ послєдовательныхъ стадій роста нити приводит'ь нас'ь, наконецъ, къ амебє, обладающей двумя ядрами, при которыхъ имћется по большой, характерної для формъ А и $B$ перепонкв (табл. III, фиг. 29); ядра все еще соединены посредствомъ веретена. Положеніе перепонокъ въ подобныхъ особяхь не обнаруживаетъ особой правильности. Иногда онъ лежатъ болье или менъе параллельно другъ другу, или перекрещиваются свонми свободными концами, или же занимаютъ

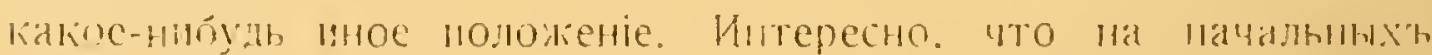

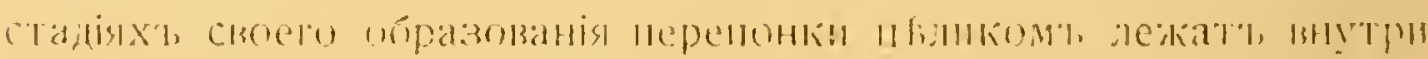

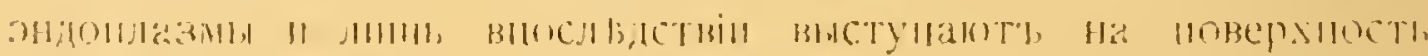
Tfind.

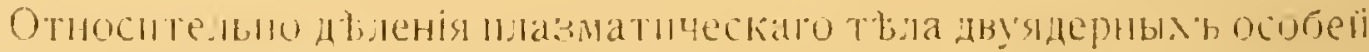
у меня имғется мало данныхъ, однако, по всей вғроятности, оно пропсходитъ путенъ простой перепнуровки. Три или четыре раза я находиль одноядерныхъ амебъь типа В, у которыхъ кромб волнообразной перепонки отъ ядра отходилъ постепенно утон- 


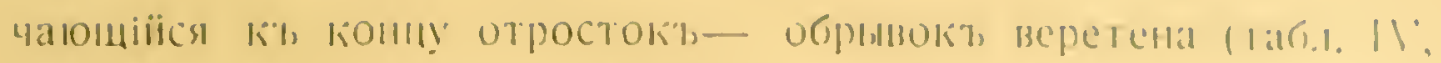

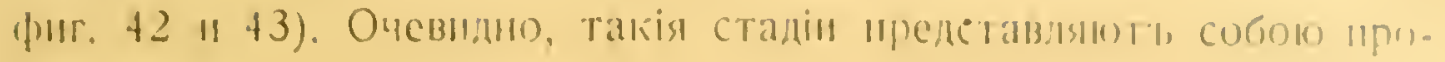

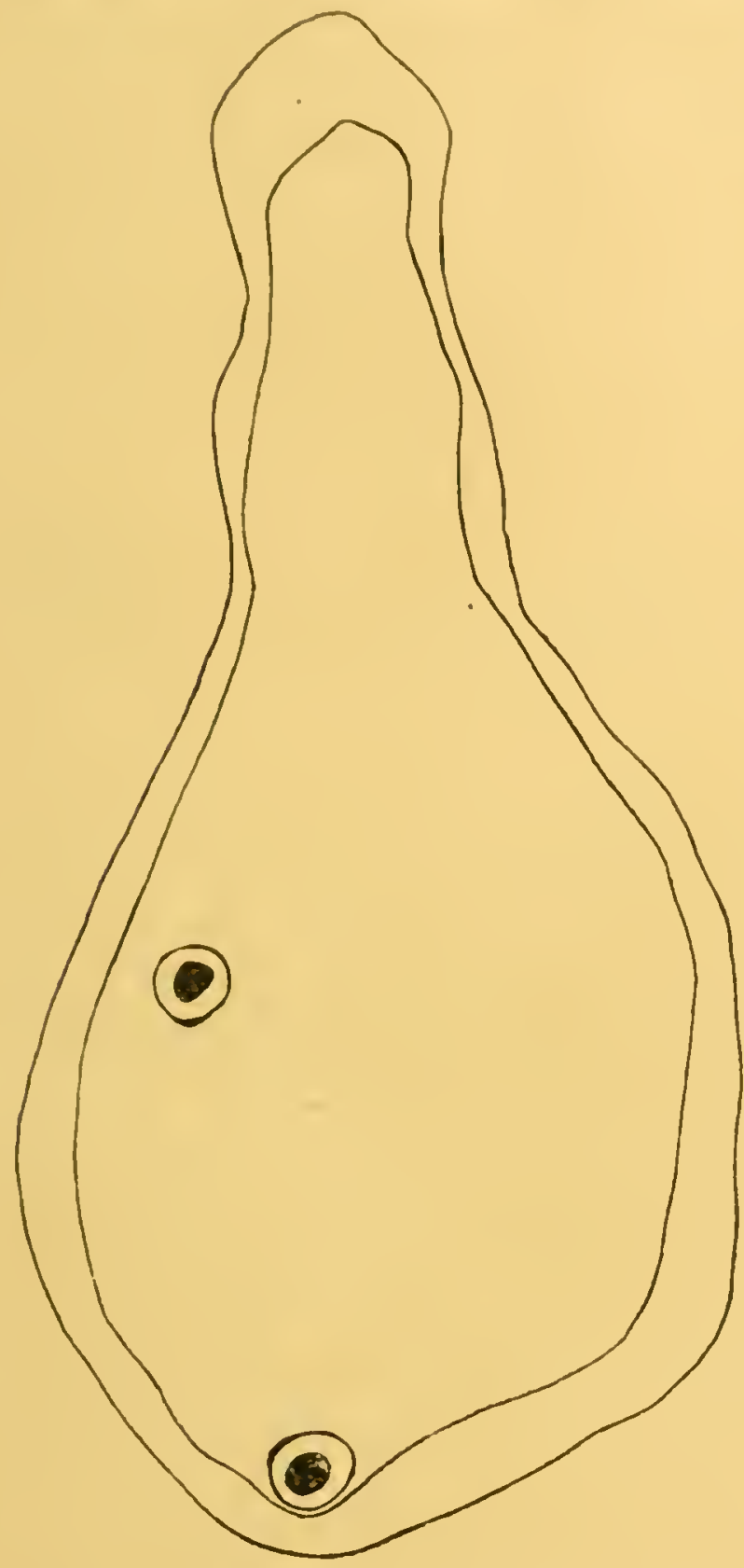

Tur. 3. Ifyxomonas polymorphat. Wopsan B.

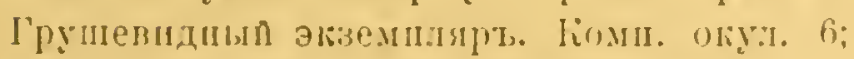
оби-ект. ILй̈сса, имм. 2 мм.

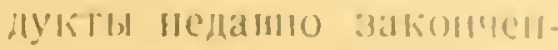
иато дыленія, ири кото. ром'веретено разривартся lla лвв части. Цали. mbiimas cymbla meperena

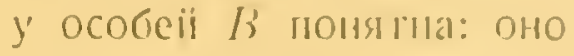
постенении резорбирует. cя. Что касается особеiі тина А, то я полагаю, что ихъ аксостиль есть ирямой дериват'ь веретена дылеиія, которое въ данном'ь случав не только сохраняется, но " разростается въ каждой дочернсіі особн. Въ пользу такого мньния свидътельствуетъиформа, и одинаковая окраска обо"ххъ сравниваемых`ь образованій и отношенія ихъ къ ядру. Далье, таково же пропсхокденіе аксостиляу Lophomonas (kakz показали безупречныя наблюденія Янищкаго 16) "y Juenia (Гpacc 1 12). Hakонецъ, по данныль нкоторыхъ хотя далеко не всъхъ. авторовъ. нанримьрь, Добелля (6), аксостиль трихомонадь тоже пропсходть изъ центродесмозы.

Какъ бы то ин было, но только что описаншыя дыляндяся формы, которыя можно назвать, тноиъ /), дають начало особямв $A \backsim B$. 
Форма Е. Одновременно съь ними встрбчаются, однако, крупныя двуядерныя амебы (табл. II, фиг. 21), которыя должны быть поставлены въ связь Съ одноядерными формами C, и которыя я назову особями типа $E$. Форма, величина и строеніе эктоплазмы особей $E$ вполнъ напомннаетъ индивидовъ, принадлежащихъ къ типу $C$ (рис. въ текств 3). Эндоплазма переполнена пищей и имъеть тоть же характерь, какъ и у дъляцихся особей $D$; !аконецъ, въ т并л особей $E$ имғются всегда два ядра совершенно такого же, вплоть до подробностей, строенія, какъ у особей С, причемъ ядра снабжены и такими же маленыкими, ньжными волнообразными перепонами. Одно изъ ядеръ лежитъ у самой поверхности тьла, и соотвътственная перепонка выдается наружу (табл. ІІ, (иг. 25 ); другое ядро съ его перепонкой въ большин. ствъ̆ случаевъ покоится въ глубинь эндоплазмы. Въ ядр‡ имъется каріозомъ, строеніе которого варіируеть въ той же мьрғ, какъ 11 у особей С. Изрғдка я наблюдалъ, что вокругъ каріозола имғется закрученная въ клубок'ъ ллинная хролатиновая нить. Въроятно, такія ядра подготовляются к’ дұленію. Всльдствіе Своихъ большихъ размъровъ, особи типа Е неръдко раздавливаются при приготовленіи мазков'b " ядра выпадают’ь изт, них'ь наружу. Въ такихъ выдыленныхъ ядрахъ хроматинъ очень часто располагается въ вид с спирема: каріозомъ бльднъетъ и исчезаетъ, а большая часть внутренности ядра занята закрученною въ клубокъ хропатиновой нитью. Состонть ли весь клубокъ изъ одной нити, или же онъ образованъ нбсколькими длинными нитевидныпи хромозомами, я с’ь точностью сказать не могу. Въ данномь случав мы, в вроятно, имьемь дыло сьь ненормальнымь

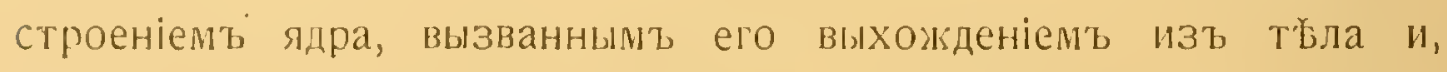
вообще, измъненіемь окружающих'ь условій. К'ь типу Е относятся нанболье крунныя особи Муяотопаs, какъ показывають нижесльвдющія измъренія наибольшей длины и ширины ндкоторыхъ особеіі: 90: 60, 140:40, 140: 90, 170:50.

Откуда берутся особи $E$, рбшить довольно трудно. Однако, судя 110 нъкоторымъ препаратам'ь, онь происходять изъ одноядерныхъ особей путемъ дњленія ядра, которое сопровождается 


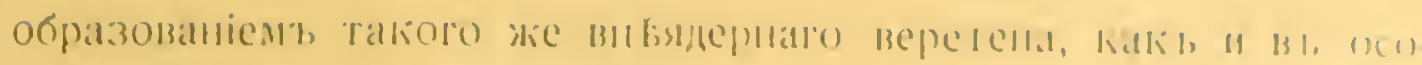

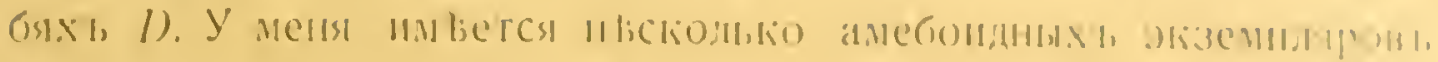

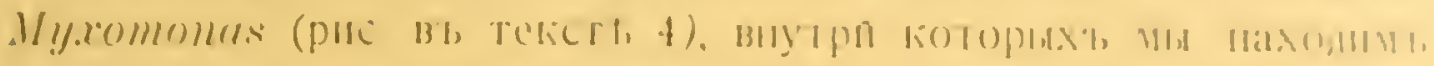

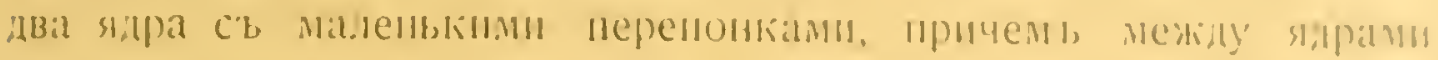

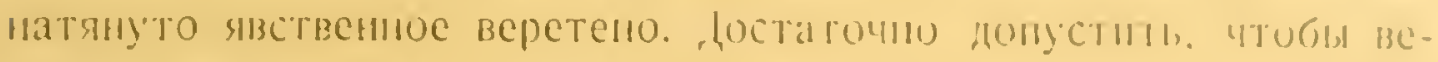

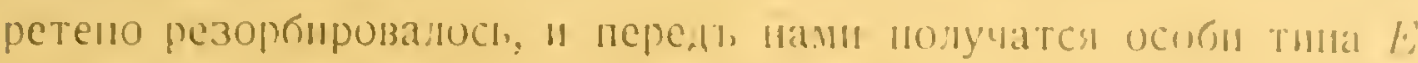

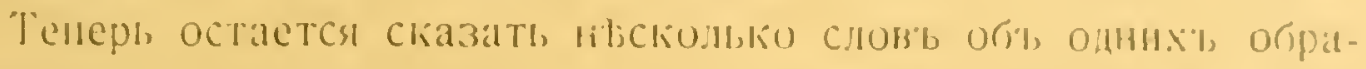

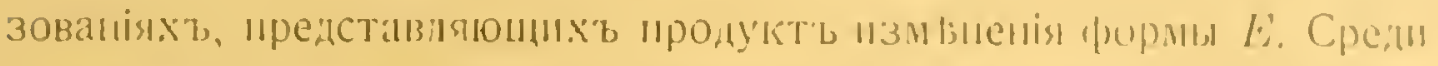

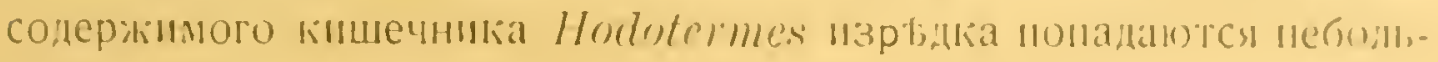

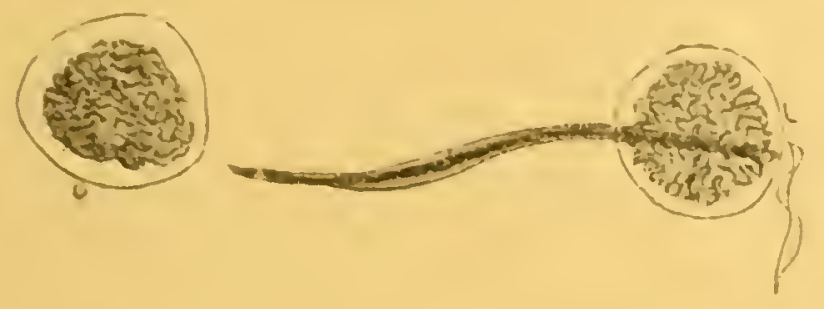

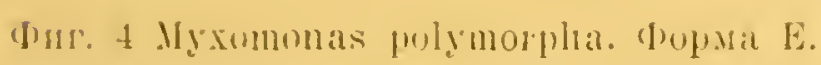

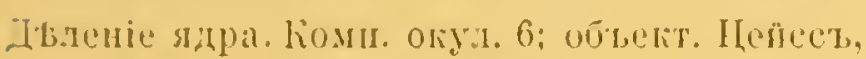
IIM.M. 2 M.M.

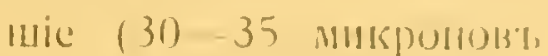
B'b dianetplif \|I a pル॥ (тасіл III, p)e. 38) cocto. sulic $113 \mathrm{~L} \quad 0,1110$ pod110 мелкозернистоі глазмы

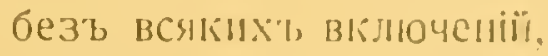
lipont; kipymaro я,y)a. расположеннагоу поверхности шара. Ядро ићсколько вытянуто въ длину " устроено ядсръ особеї $E$; ґъ нему тєсно прилегаетъ выдающаяся надъ поверхностью шара паленькая волнообразная перепонка. Сначала происхожденіе подобныхъ формъ Myxomonas оставалось для меня загадочиымъ, пока я не натолкнулся на стадіп, изображенныя на рис. 41 таблицы IV-ой. Зднсь мы видимь Myromonas типа $E$, плазма котороӥ дєлается болье жидкої, чвмь обыкновенно; участки протоплазмы отдұляются оть тұла ш, округляясь, иревращаются въ шарики. Нвкоторые изъ такихъ щнариков's малы " состоятъ "зъ одной плазмы. другіе крупне и содержать въ себж ядро съ соотвьтственной перенонкоі-такіе пролукты распаденія формы E и отвъчають только-что описанным' мнон образованіямъ (назовемт ихъ фұорлоӥ F\%. Въ рсзультать вся крупная амеба тиша $E$ распадается па розетку плазматическихъ шариковъ, въ целтрб которой остается кучка находнвщихся внутри амебы цимевыхъ включенії. Шарики, состоящіс изъ одної протоплазиы, разумбется, погисають, что же касастея 
до особеіі типа $F$, то дальнийшая судьба ихъ остается невыясненной. Для меня наиболье вђроятнымъ кажется, что и эти послвднія тоже обречены на гибель. Образованіе особей типа $F$ отнюдь не является результатомъ раздавливанія крупныхъ амебоидныхъ Myxomonas, ибо онғ встрұчались мнъ. не въ мазкахъ, а въ очень осторожно фиксированномъ въ пробиркахъ содержимомь кишечника Hortotermes.

Генетическая связь между различными формами Myхоmollas. Какъ легко можно видъть изъ моего описанія, въ моемъ распоряженіи находились далеко не всб́⿱ стадіи цикла развитія Myxomonas; такъ, напримъръ, остаются неизвъстными половыя стадіи размноженія. Что касается до стадій, описанныхъ мною, то ихъ отношенія между собою вырисовываются для меня въ сльдующенъ видъ. Основною формою являются одноядерныя особи типа $C$ съ маленькой волнообразной перепонкой. Округляясь и обогащаясь хромидіями, эти особи могуть инцистироваться. Съ другої стороны, оны могутъ, начавъ питаться (сп, ръцкіе случаи нахожденія пищи въь особяхъ $C$ ), дать начало двуядернымъ амебам'ь типа $E$; такимъ образомъ, я думаю, что формы $C$, начавъ заглатывать пищу, испытьваютъ диленіе ядра. Особи типа $E$ въ ненормальныхъ условіяхъ распадаются на розетку шариковъ и даютъ формы $F$. Обыкновенно же онб уснленно питаются, дблятся, уменьшаются нбсколько въ разм врах'ь и дають начало формамъ $D$; посльднія, подобно предыдущимъ, набиты пицей и находятся.въ состояніи дыленія, но при дыленіи образуютъ уже не маленькія, а большія волиообразныя перепонки типа $A$ и $B$. Посль окончанія дияленія, особи D, сдълавшись одноядерными, освобождаются оть пищи и превращаются такимъ способомъ въ формы $A$ или $B$, смотря по тому, сохраняется.ли у нихъ веретено (въ видъ аксостиля), или же оно резорбирустся. Дальивйшая судьба особей $A$ и $B$ остается нензв ғстної, но, быть может”, это форлы подготовляющіяся къ половому размноженію (вь, пользу этого отчасти говорить полное отсутствіе въ иихъ инщи).

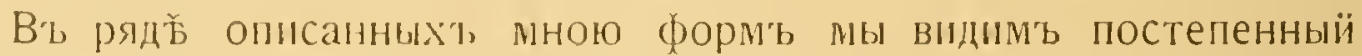
шереходъ отъ типичныхъ $\|$ по величинь и по строенію Tricho- 


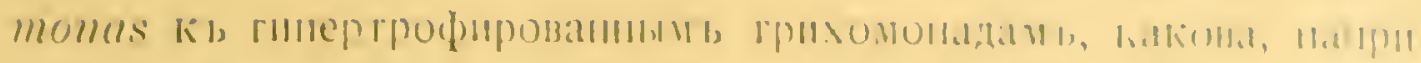

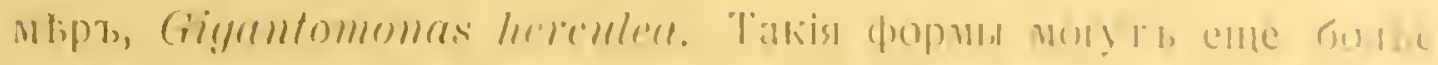

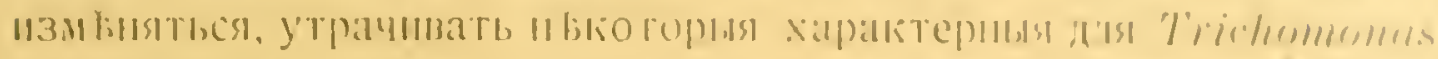

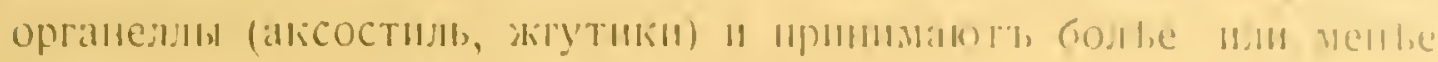

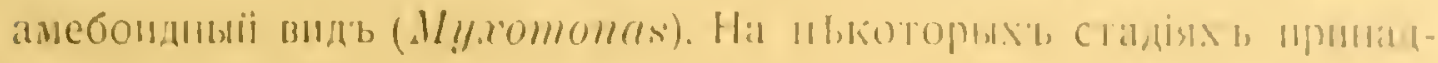

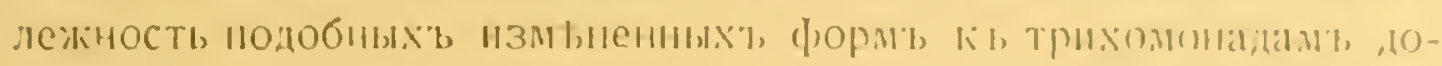

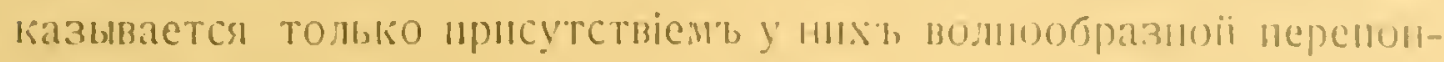

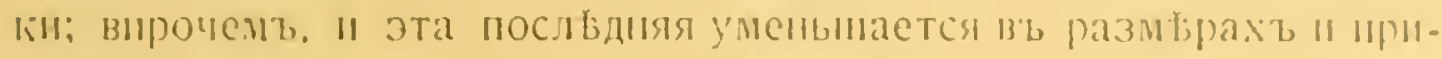

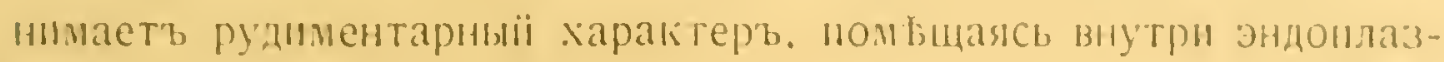

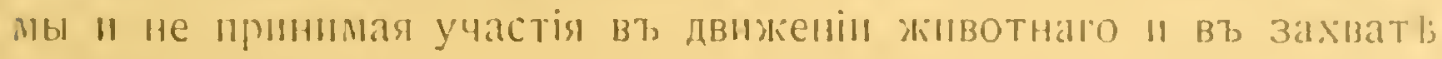

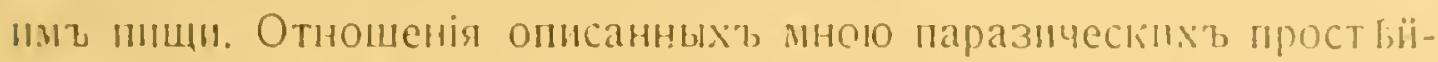

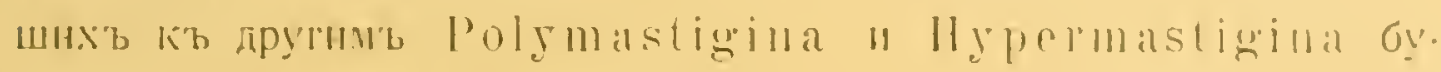
дутъ разсмотрғны мною в'ь, другой статьє, носвященної описанію

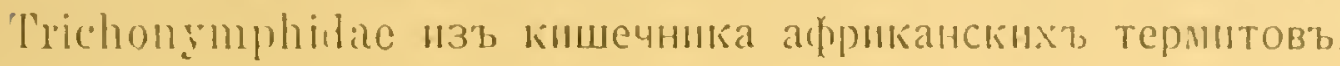

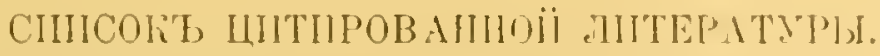

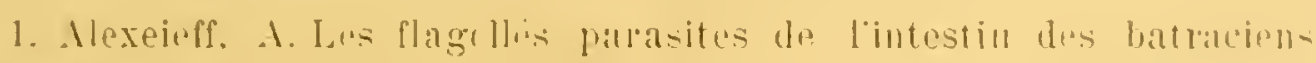

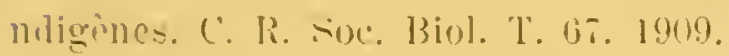

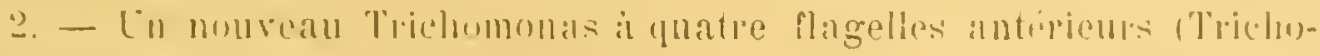
monas mowazeli n. Sp.). Hid.

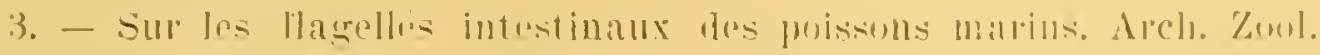

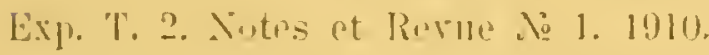

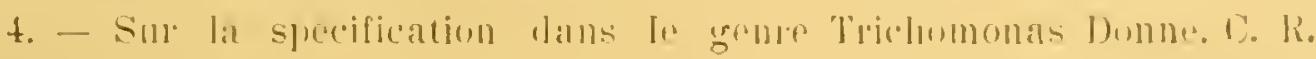
soc. Biol. T. 11.1911.

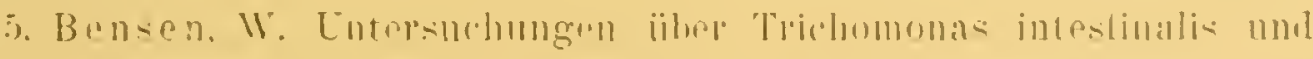

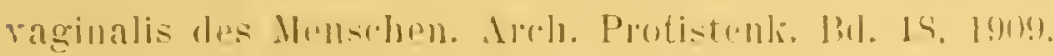

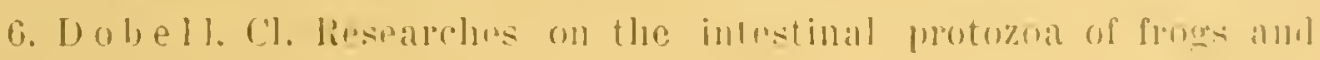

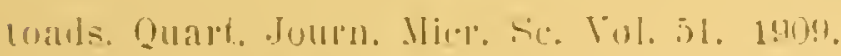

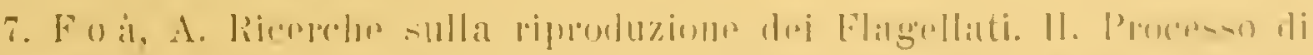

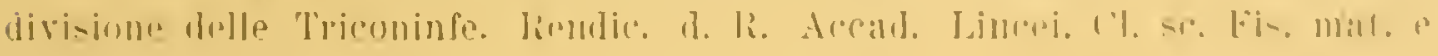
uat. Vol. 13. 19114.

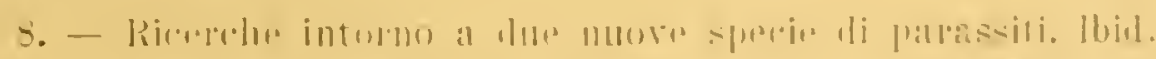

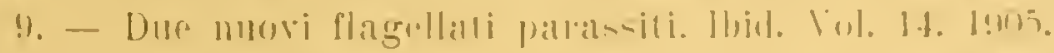

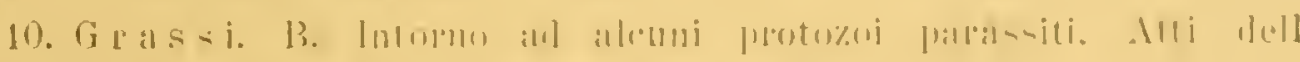

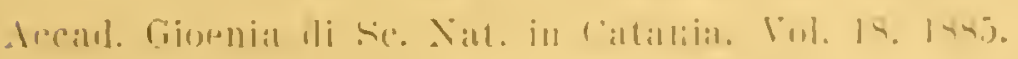

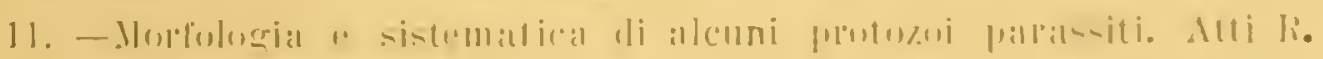
Areal. Jinued. Vul. 4. 1545. 
12. - e Fo i, A. Ricerhe sulla riprotuzione dei flagellati I. Processo di divisione delle Joenie. R. Accad. Lineei. Tol. 13. 1904.

13. - e Sa nd i as. A. Costituzione e sviluppo della Societa dei Termiti. Con un appendire sui Protozoi parassiti. Catania. 1893.

14. H a r.m a n n,. M. Untersuchungen über Bau und Entricklung dor Trichonympididen. Festschr. Hertwigg. Bd. 1. 1910.

15. - und Prow a rek. S. Blepharoplast. Caryosom und Centrosom. Arch. Protistenk. Bd. 10. 1907.

16. Ja n i cki. C. Untersuchungen an parasitlschen. Flagellaten I. Lophomonas blattarum, Lophomonas sthiata. Zcitschr. wiss. Zool. Bd. 95. 1910.

17. - Zur Kentnis les Palabasalapparites bej parasitischen Flagollaten, Biol. Centralbl. Bd. 31. 1911.

18. - Bemerkungen zum Kernteilungsvorgang bei Flagellaten. namentlich bej parasitishen Formen. Terb. Naturf. Ges. Basel Bd. XX111. 191?.

19. Kofoid. Ch. A. and Swe e zy, O. Mitosis in Trichomonas. Proc. Nat. Acad. Sciences. Baltimore. Vol. 1. 1915.

20. L a ver a 11 , A. et. N esn il, F. Sur la morphologie et la systimatique des Flagellıs à membrane ondulante, C. R. Acad. Sc. Paris. T. 133. 1901.

21. Parisi, B. Sn alcuni flagellati endoparassiti. Arch. Protistenk. Bd. 19. 1910.

2.2. Porter, J. F. Trichonympha and other parasites of Termes flavi. pes Bull. Mus. Comp. Koology Harwari Coll. V. 31. 1897-95.

23. Prow a ze k. S. Zur Kenutnis der Flagellaten des Darmtraktes. Arch. Protistenk. Br. '23. 1911.

24. Robertson and II a r in. Further observations on the coecal parasites of fowls with some reference to the rectal fama of other vertebrates. Quart. Tourn. Micr. Se. Tol. 57. 1910.

25. Wenyon, C. M. Observations on the protrizoa in the intestine of Nice. Arch. Ptotistenk. supplen. Bil. X. 1906.

26. Kucinsky. Untersuchungen an Trichomonalon. Arch. f. Protistenli. Bd. 33. 1912.

\section{Описаніе рисунковъ.}

\section{ТА БЛ Л II А I.}

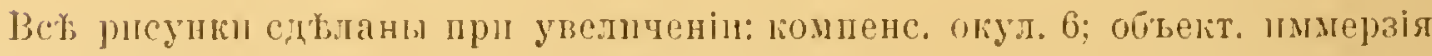
IIellecal 2 min.

(b)r. 1. 'Prichomonas termitidis.

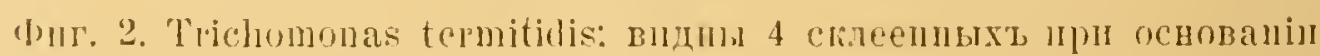

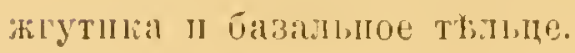




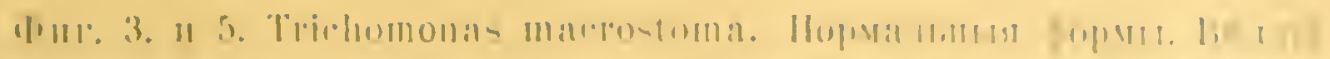

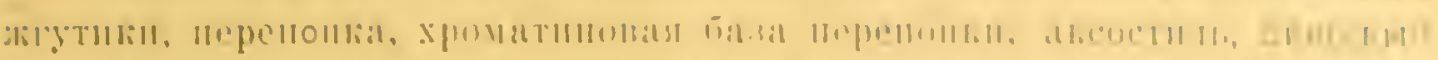

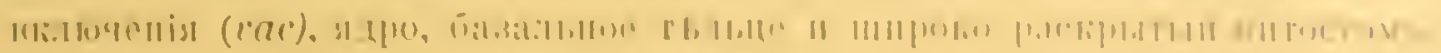

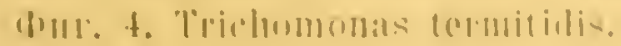

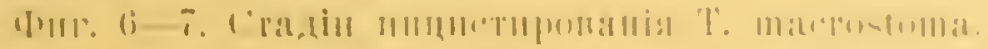

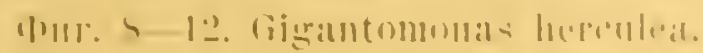

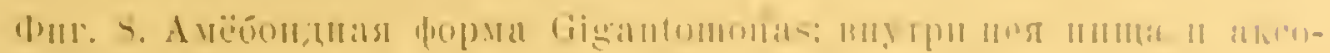
('T11.T1, $(11.1 \%)$

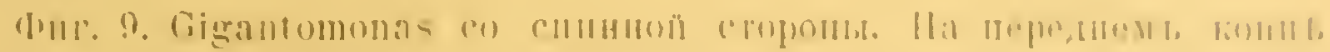

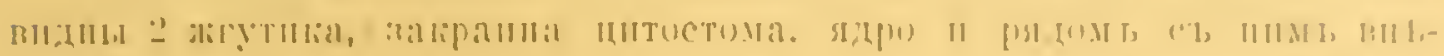

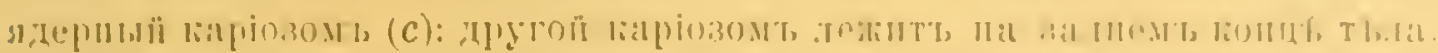

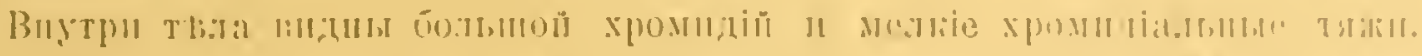

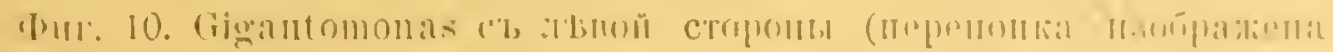

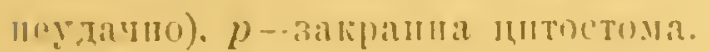

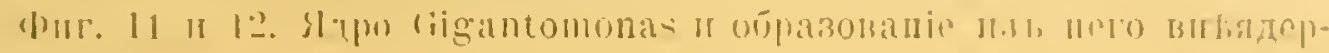
liaro liapiozoma.

ओur. 1:- 15. Myxomomas.

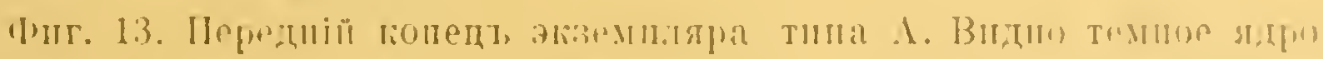

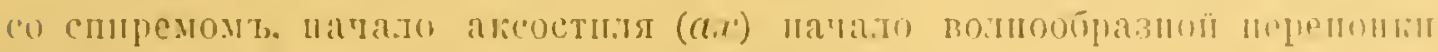

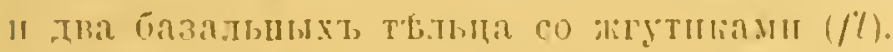

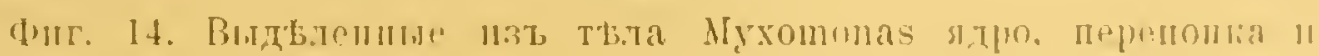
alicuethith,

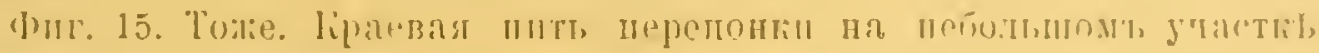
отсрна.тась оть пос.ть, тй.

\section{T $\triangle \mathrm{B} .7 \| \amalg I 1$.}

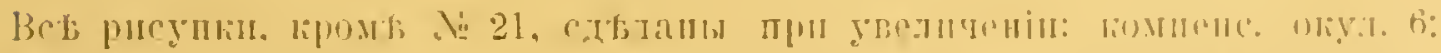

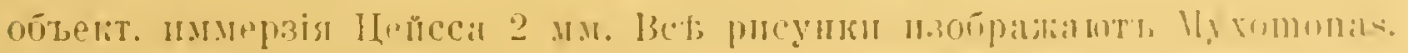

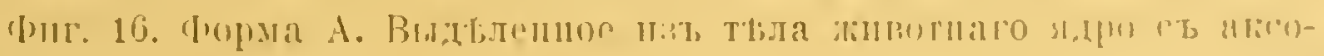

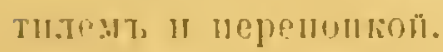

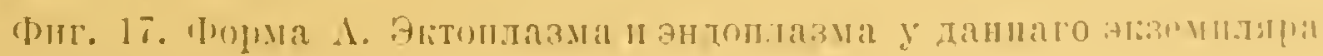
แ.тохо) :

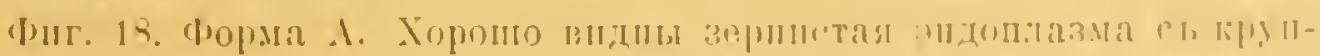

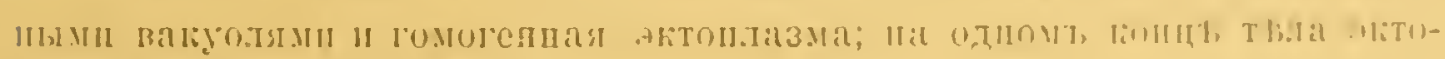

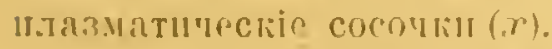

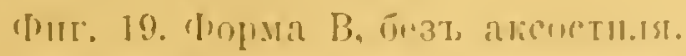

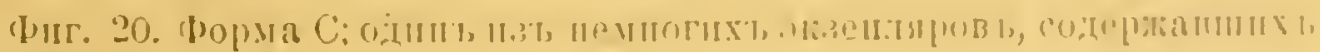

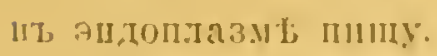

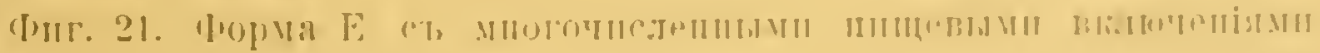

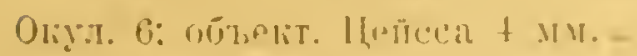

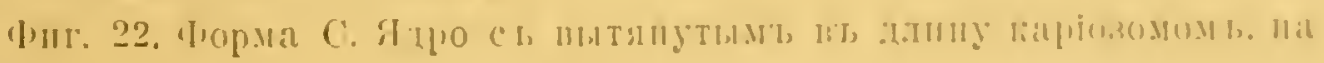


ионцахт, котораго скоплетея хроматинь; содеріныое лдра чаетьн отетало отъ оболотин; прп ядрк маленькая перепонка.

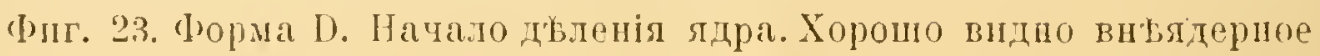
неретено. ст центріолями иа попцахт.

Фиг. 24. То же. Веретено состопт пзъ перекрутенныхт па подобіе веревки волоконт; внутри лдра крупныя скопленія хроматина (нродукть распаденія каріозима).

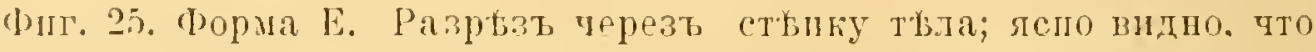
волнообазнал перепола (п) выдаетсл надт поверхиостьо тьла.

Фиг. 26. Форма D. Напало дыленія лдра; лдро иаполено множествомь кругыхь хромозомт.

\section{Т А Б Л II А III.}

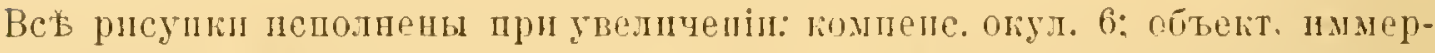

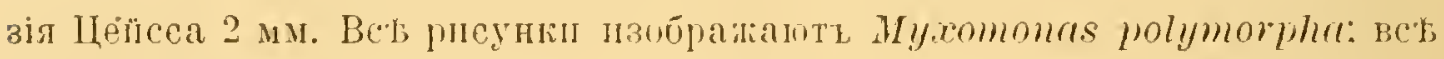

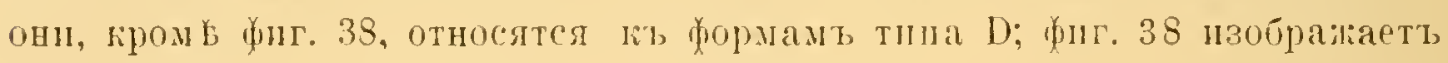
особі тина F.

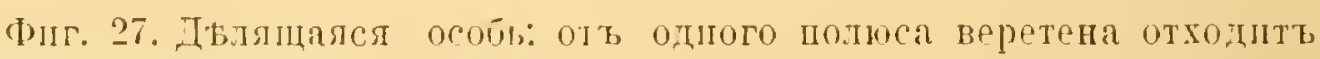

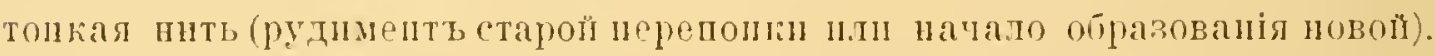

Фиг. 25. То же. Дочериіл лдра посльь двленіл прнияли впдъ пололщихел ядеръ; меж:ду ядрами-пвпгптое веретено.

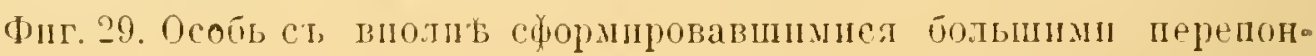
ками.

Фиг. 30-37. Различин стадін дьленіл тдра у формъ тиша D; mойразугпцасл перепона.

Фиг. 39. Осойь типа F.

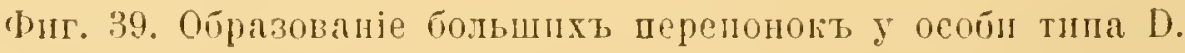

TA БIII II A IT.

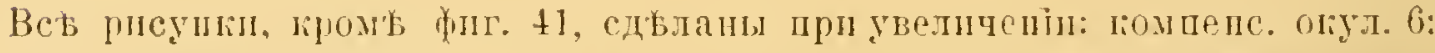

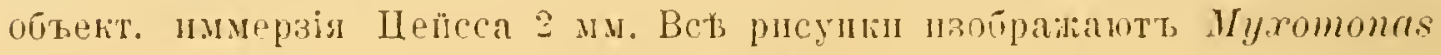
potymoryhre.

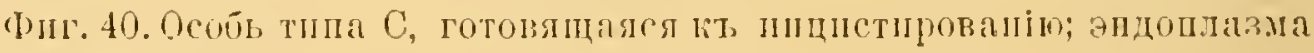
набита хромидiямн.

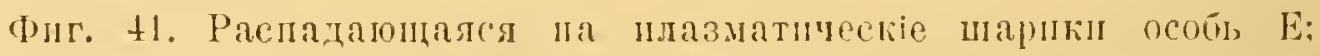

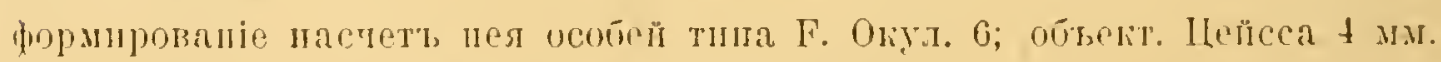

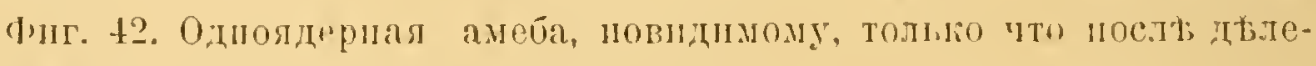
нія; видна ноловныа раздылывшатося веретена $(a x)$.

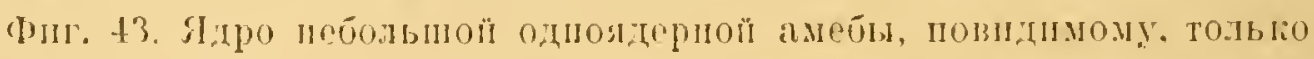

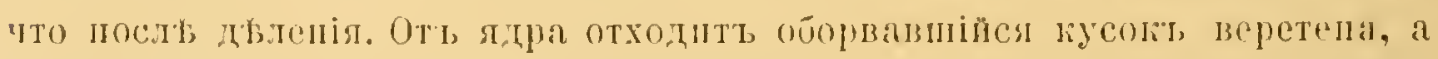

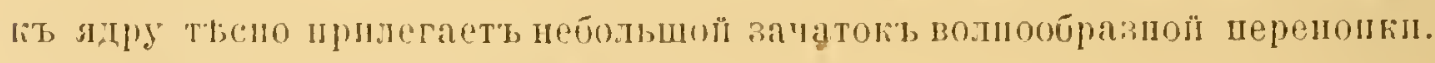

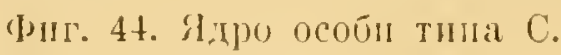




\title{
Researches on the parasitic Protozoa from the intestine of termites.
}

\section{Tetramitidae.}

\author{
V. A. Dogiel.
}

Professol in the Imprepal Lnirersity of Patroglat.

The miterial for this paper was obtained by me from the intestines of some Afrian termites during my royage in british East Africa in the summer of 191 t. The parasites were taken in the Incality of Tavetal on the banks of river l.mmi lrum the intestine of Hodotermes mosstmbicus Hag. and hlinotermes mutorius Sjöst., and one species from termi. tes found in lezinda.

In this paper I am describing some new forms of Petramitidate partly belonging to the genus Trichomonas, which is already known, and partly to altogether new genera.

\section{Trichomonas (Tetratrichomonas) termitis n. sp.}

This form is fomm in the intestine of termites (probahly Rhinotermes) taken noal the town Entehhe in Eganda. ()wing to the presence of 4 linee lagella (besides an molubating

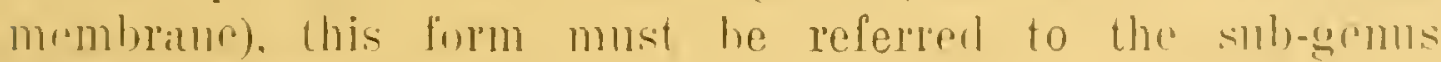
Tetrutrichomomas established by Parisi (21).

The ehief point of interest in the species described hy mo is its rely presence in the intestine of termites. The ruestion of the origin and alfinities of "Trichongmphidar has heen flepuently discussed rerently, and they were often connected with the trpical Mastigophola liom the menus Trichomonas. Howrerer, entil the present the seredes of this genus were lombl nearly without recerption in different vertebrates; only in 1ss:2 Girissi fommd one Trirhomonas in 
the intestine of Blatta; they were afterwards described by Parisi under the nane of Trichomastix orthopterorum. Thus, the occurence of typical Trichomonas in termites not only confirms the suppositions of filassi and others. but also justifies (as will be shown in some other forms) the immediate derivation of some species referred to Trjehony $\mathrm{m}$ phidae from Trichomonads.

The structure of $T$. termitis follows the general type for all the Trichomonads. The body is elongated, its length is about 14-18 microns. From the anterior extremity of the borly there proceed 4 flagella not guite equal in length. At the same point with them is the beginning of a rather high membrane; it is directed backwards. forming a semi-circle around the body and terminating in a short free flagellum. At the starting point of the membrane and the 4 anterior flagella there is a distinct basal corpuscle (possibly double). Posteriorly to it is the oval nucleus. The cytostome is absent. The long and rather thick axostyle protrudes out of the body with its posterior extremity. The anterior extremity of the axostyle, according to $11 y$ obselvations (especially on anothel representative of $\mathrm{T}$ e tra $\mathrm{m}$ it i d a e, viz. Myxomonas). surrounds the nucleus (contrary to most investigators of the Trichomonads: Laveran, Jobell, Parisi, Kucinsky, Kofoid).

\section{Trichomonas (Tetratrichomonas) macrostoma n. sp.}

Is found in the intestine of Hodotermes mossambicus Hag. The shape of the body is as in the preceding species, but the size is somewhat smaller. The axostyle, fligella, basal body and nuclens are the same. The membrane runs poste. riorly along the body in a straighter direction and its free end is rery short, being hardly at all elerated above the body surface. The most sharply distinguishable charicter ol the species is the large and deep cytostome sitnated on the ventral side of the body, at its anferior end. The posterior margin of the cytostome is much extended ventrally in the form of a lip.

Preparations for encystment are frequently to be observed, in the process of which the animal bends into two on its ventral side, the flagella being ast off (t. I, lig. 6 and 7 ). According to Dobell's work (6) on the Trichomonads of 


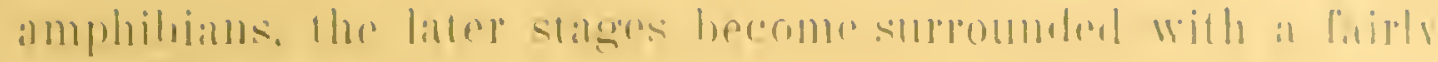
llick infersument.

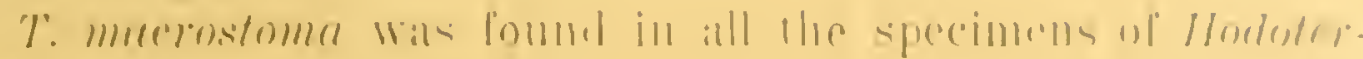
mes eximined by mo.

III. Gigantomonas herculea 11. gen. 11. sp.

This form, als the prereetimg is fouml in the intutime of

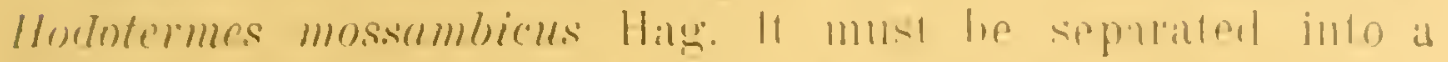

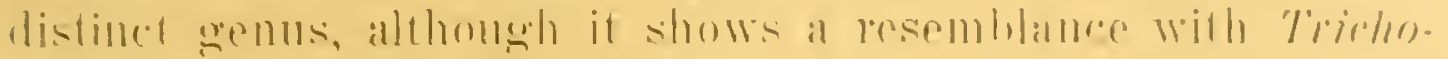

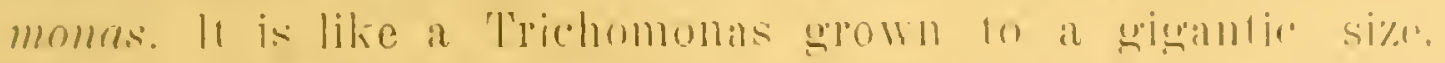

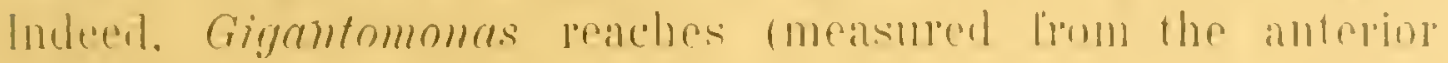
culd ol the body w the end of the axostyles $60-7.5$ a. in

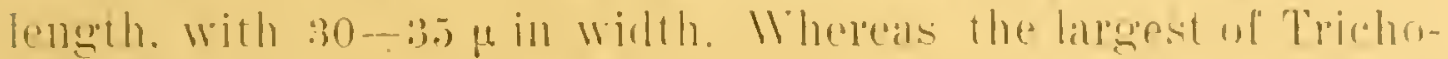
momads known, Trichomonas mugnsta A lexejefl may attain the maximm of 25 a in lemgth and 15 p.in wilth, aroording to ki uc i nsky (20).

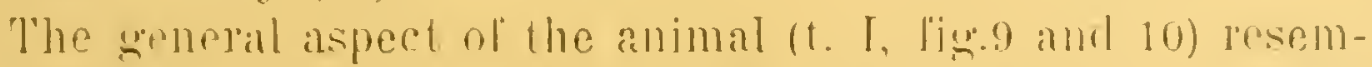
bles Trichomnuas. Thr shape of the body is oroid, becomims sharper towards the posterior end where it is continmed into a long. strainht neerle (the free end of the axostyle).

slightly hehind the anterior end of the body, on its rentral side 1), the olumas of locomotion of the animal arise. It possesses + free flagellia, one of which is considerably longer and thicker than the rest. The point from which the flawella arise is often liscemable as a small tubercle.

At the base of the flagella is the commencement of the mondulating membrane as well. It rery soun basses to the

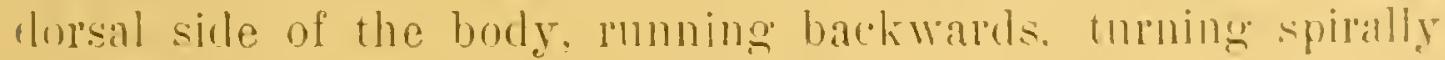
to the right. and anain returning to the rentral sills of the broty at the base of the calldal needle. It is remarkihle that the membrane does not project above the surfice ul the body, but in all its extent lies at the lonttom of it suecoial furrow set into the bolly-will. This furrow, my lritwing al which is not quite satislactory. is best seen mll lige a, tablo 1. The highest part ol the membrame is its mildle. Whoreas

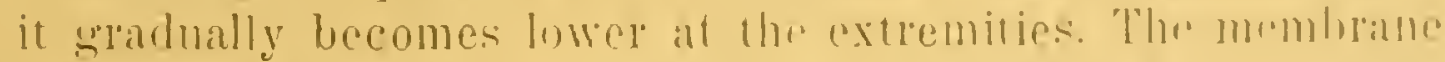

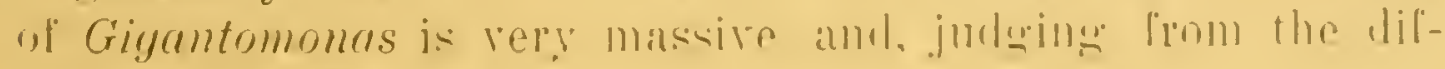

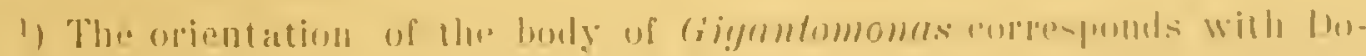

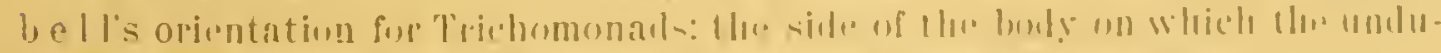
latiog membrane passes is termed dorsal, il uppuxilu ventral. 
ferent intensity of the stain, it becomes thickened from its free border to the hase. In most cases this intensification of the dye of the membrane is rery gradual, its free border being slightly grayish (along it rums the dark border fligellum); further, towards the base. the membrane becomes bluish-black (after being stained with Heidenhain's haematoxylin), and the base itself seems absolutely black and not transparent. It is more seldom to distinguish in the membrane 2 shirply limited zones: a darker basal zone, and a lighter, distal. At any rate, I did not succeed in observing a distinctly differentiaterl «chomatic hasis», according to Dobell's terminology. Altogether, the rnestion of a "chromatic hasis" requires to be cleared l'urther. The uchromatic basis» presents an arcuate formation. srongly stainable with haematoxylin, sitnated at the base of the membrane in Trichomonas. Nost of the anthors restrict themselves to the description of this organ and only Kucinsky (26) stops to examine the question of the physiological and morphological significance of the chromatic basis in his large work on Trichomonals. Kucinsky supposes that the basis together with the axostyle prescnts a system of fibrils joined in the blepharoplast and serving as a support for the free flagella of the animal. As far as I can judge from his rather confused account, Kncinsky denies the close comnection between the chromatic basis and the membranc. Kucinsky's conviction of the independence of both named formations is chiefly upheld hy such forms as Trichomonas gallinarmm and Protrichomonas legeri in which together with a total absence of a membrane the chromatic basis is present. I consider Kucinsky's views to be founded on insufficient prools. Firstly, the study of the literature points to a rery close morphological connection between the basis and the membrane. The chromatic basis has the same curved, alcuate shape as the membrane, and always lies at the base of the latter. Further, the chromatic basis of Protrichomonas is arbitrarily taken for such by Kucinsky, as Allxeieff (3) who has described the given Mastigophora, compares the rhromatic filament found by him in Protrichomonas with the axostyle of frichomonads. and not with the chromatic basis.

And lastly, observations on such large objects, as Gigantomonas have brought me to the couchsion that the chromatic basis, as a distinct, independent formation, does not exist at 


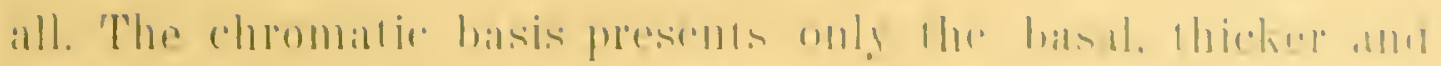
more infellsely stalinthe portion of the momblane.

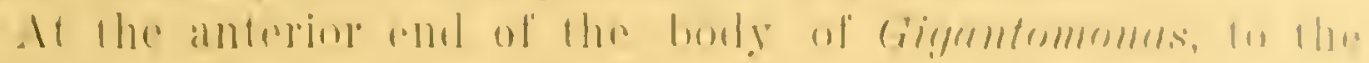

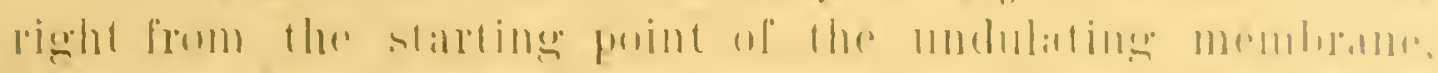

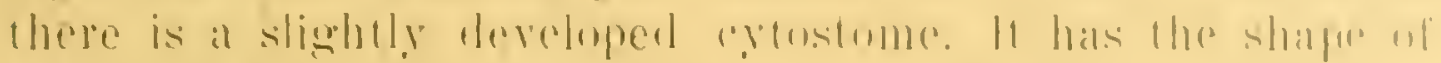

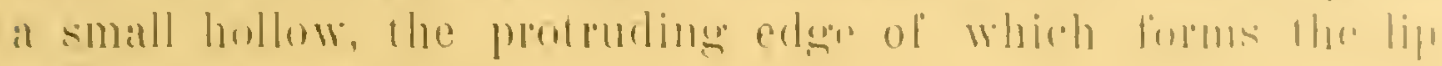
(lah. I, lige. a and 10).

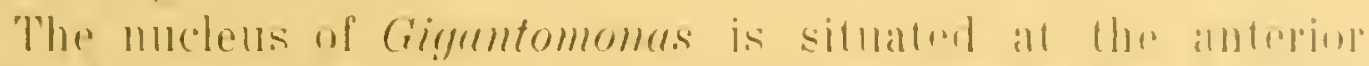

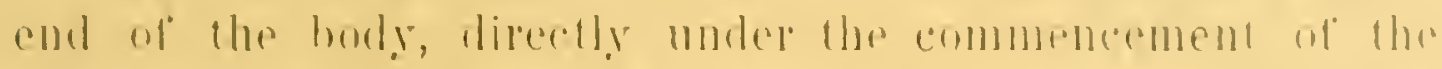
membratle, to the base ol which it is closely allarehed. The

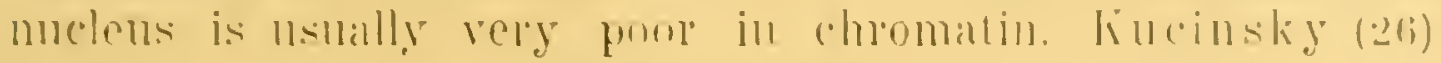
matis the same in the muclens of the Triehomonals.

It is remarkable that notwithstamding sureh a scarcity ol chromatio the muclens contimually casts out into the smropmoling protoplasm a considerable quantity of material starining like chromatin. This material is producen fom the surlace of the nucleus in the lollowing mannel: the stufl cast out appears to hive the consistence of a dense, riscons fluid; the latter first forms a thin libm with laree apertures at a certain portion of the nuclens membrane; then this film thickens (tah. I, fig. 12), and flows together to form a hoor placed on the muclens. Further; the houd becomes more and more prominent, and a part of it hecomes serered from it in the form of a homogneous oval hode (tib. I. lig. 11). The latter first lies near the rere uncless. lut later it migrates to the posterior end of the body. "J'here the oval body is absorberl, as it seems. The appealrance of a light zone aromed it speaks in lavour of that riew (the horly seems to melt). In the meantime the hood of riscous stuff, remaining on the nucleus, grows laryer, and casts ofl a new oral hody to take the place of the first.

As concerms the morphological significance of the oval bodies, they may he best of all compared to the liaprosome. in my opinion: apecially to the karyosome of Gresarines, for instance. The resemblance to the karyosome is also supporter hy the fact of small vacuoles (as in the kayposomes of cime warrines) having heen sometimes ohserved inside thr hood which grives origin to the bodies, as well as by the semiliquid, viscous charactere of the oval bodios. I have often obsere-

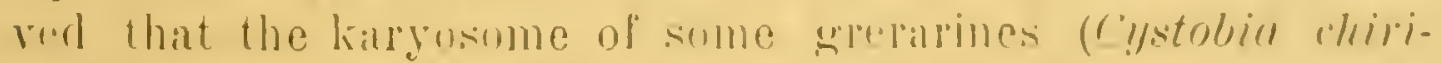
dotue Dog.) flows on the intrior side of the muclous-ment- 
brane in the same manner, as the hoor, which produces the oval bodies, flows on the exterior surface of the membrane. Anothel fact, speaking in farour of the resemblance to the karyosome is the periorlical change in size of the oral bodies (compare analogons processes in P'orospora gigantea).

Thus, on account of all that has been said, I am lead to consider the oral bodies of Gigantomonas as extranuclear karyosomes. Another permanent inchusion in Gigantomonas is the ventral chromidium. Nearly in the middle of the hody, nearer to its rentral side, is situated a spongy ol grmulater mass of irregular outlines, usually with the contonrs not sharply marked. The grannles, or lumps composing this mass stain like chromatin. Chromidia in the shape of regularly arranged small siderofilons grains have already been described in many Trichomonids. The chromidium of Gigantomonas is remarkable for its structure, which resembles the chromidial reticula in Rhizopoda, or the spongy centrosome in Actinosphaerium.

Besides the constant rentral chromidimm, in some specimens (tab. I, fig. 9) I saw dispersed in the plasm rods and grains of mknown origin, staining very intensely with $\mathrm{Hei}$ denhain's haematoxylin. Those formations also seem to bear the chromidial character.

And lastly, the axostyle presconts a rery important organoid, which is greatly responsible for the shape of the cell in Gigantomonas. The axostyle (tah. I, fig. 9 and 10) has the form of a rather thick spindle which passes along the whole body. 'The anterior end of the spindle becomes lost after reaching the uncleus. The posterior third of the axostyle sharpens into the caudal spine, and projects out of the hinder part of the body on 20-30 microns. When attentively examined, it may be seen that the candal spine does not project freely out of the borly, kut is corered by a plasmatic film on all its course. The axostyle is ynite colourless and transparent, both in life, and after treatment with Heidenhain's haematoxylin.

Concerning the more detailed structure of the axostyle, the latter is composed of numerous linest fibres lying closely one to another; I liave established this structure of it withont any doubt, which point I consider it my duty to state, owing to Kucjusky's (26) statement that the axostyle of all 


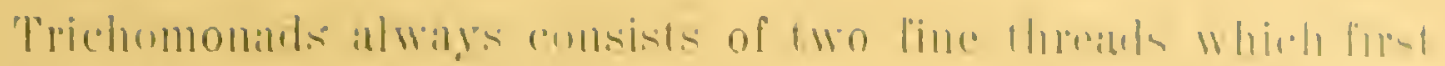

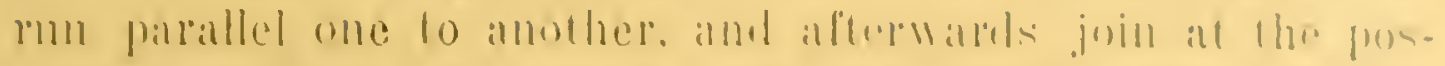

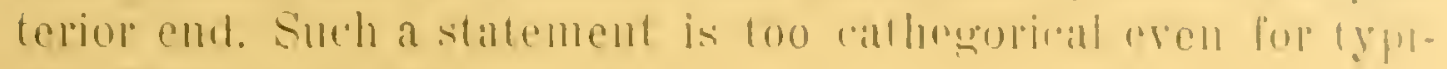
(a) Trichomonals.

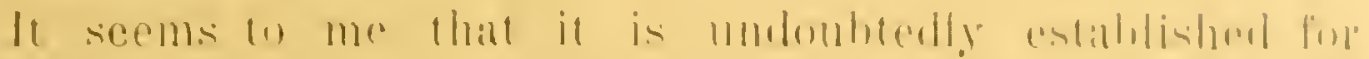
Gigumtomonas. and possihy for the Trichomomads, Hall the

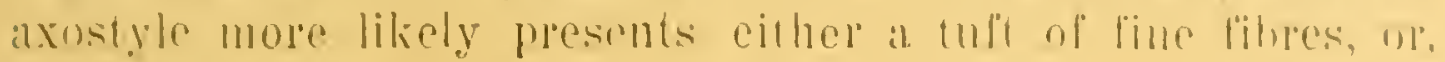
in other cases, a thbe, the walls of which alle romposed of mumeloms fibles. Such al fube may widen amelionly, so as lo envelope thr muclens, as, e. g... in Trichomasti.l motellar accorling (n Alexeicll (3); and, as it seems, in Crigumtomonos, amel in some Trichomymphidate.

The body of Ciguntomomas has a rery constant shape, which points to the presence of a rither complact pellicule. There is no dillerentiation into an ectoplasm and endoplasm; all the protoplasm is of a homogeneous, finely crannlated character. There are no vacuoles to be found in the plasm, and food inclusions are also altogether absent.

It has been frequently observed, with respect to different Trichomonals. That there is at temporiry transition to the amoeboid condition: psendopodia are let out etc. I have also mate one observation of this character. Namcly, one-specimen of Gigantomonas was of a purely amoeboid character (tab. I, fig. S). The body heing compressed flatly had a rhombic shape, its plasm was lifferentiated into a lighter and homogeneous ectoplasm, and a darker endoplasm. The flagella and the chromidium were absent. The nucleus was molmal, and the undulating membrane bent in the shape of letter $S$ was situated on one of the flat sides of the body. The Iypical transpalent axostyle was remalkable for its short sime and lay wholly insidr the boly being separated from the nucleus. 'The most interesting latet was the presenrer of laren foorl-inclusions in the form of particles of llower and some kinds of spores insirte the houly.

It is very diflicult to judge from onre late how fill such a change in the form of the body is normat. It might he at very attraction supposition that in orler to talie in foud Giguntomonas must always pass into an anoeboid statr. In this case the given Flagellate would affort us a transitury form. (with respect to the manner of ingesting looul) lrom lhe Tri- 
chomonads, which ingest food throngh the cytostome, to the Trichonymphidae, which feed to a certain degree like amoebae.

One of the obstacles, which make it difficult to derive the Trichonymphirla from the more simply built Nastigophora, is the great difference in size between the two groups. The series of forms just described, found in the intestine of termites-Trichomonas temitis. Tr. macrostoma and Gigantomonas - remove this obstacle. We see now, that the Trichomonarls living in the termites may attain enormous sizes, without hardly at all undergoing any morhological chinges, owing to some especially favonrable life conditions with which they meet in the intestine of the insects named.

At the conclusion, a few words may be said about the genetic relations between the forms just described. The presence of two species in the intestine of Hodotermes, which are so alike in morphology, and so unlike in size. as Trichomonas macrostoma and Gigantomonas herculea. may, in my opinion, be explained in the manner, that Gigantomonas has passed a much longer period of parasitic lite in termites, and is therefore changed much more than Trichomonas.

\section{Myxomonas polymorpha n. gen. n. sp.}

The amoeboid state, in which Gigantomonas is found but rarely, becomes constant in this genus. Myxomonus presents a Trichomonad which has assumed the amoeboid form, and lost the cytostome and the anterior, free flagella. Myxomonas is found together with the preceding genus in the intestine of Hodotermes mossambicus $\mathrm{Hag}$.

The species described is found in the intestine of the same termite in several forms, which differ one from another to a greater or smaller degree, and which present different stages in the cycle of development of the animal.

We shall begin the description from a stage which resembles Trichomonas more closely, and which we shall name type A.

Type A. The body-shape is changeable, amocboid (tab. II, fig. 17 \& 18). The sizes of Myxomonas rary considerably, as is seen lrom the following ratios of length to the maximum width expressed in microns: $28: 25,50-40,55: 25,65: 40$, $70: 25,80: 25$.

The body of Myxomonas is usually clearly differentiated into a thick lajer of ectoplasm, and an interior endoplasmatic 


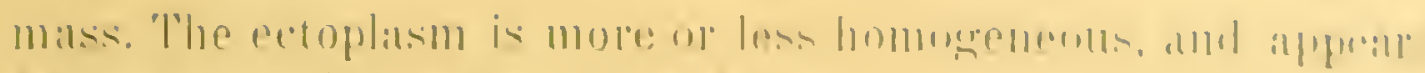

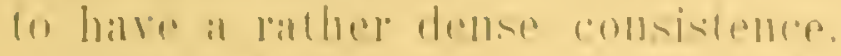

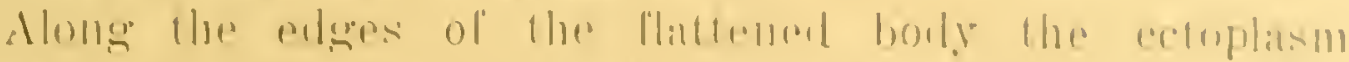

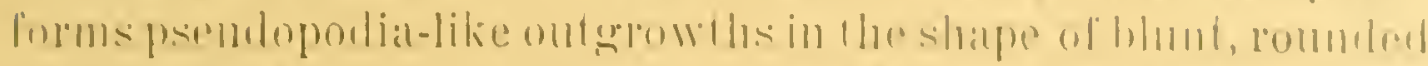

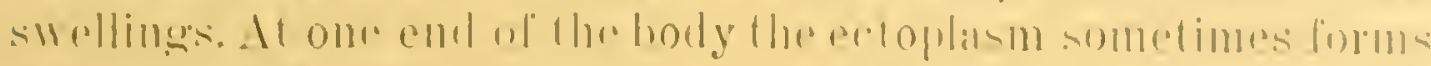

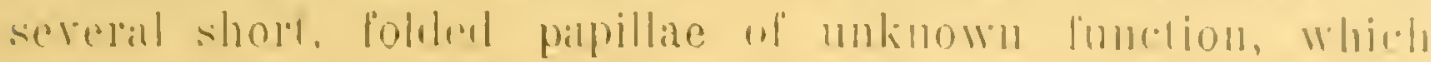

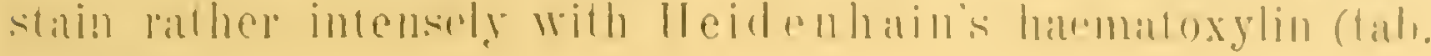
11. fig. 1s).

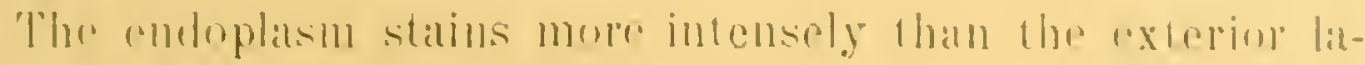
rele and contaims mmeroms, rely small hack (hamematoxylim) spranules. There atre sometimes visible inside thre horly two ne three very liarere racuoles, and sometimes there alle numerous minntest riacuoles dispersed in all the endoplasm.

All kinds of tood inclusions are, as a rule, absent (I saw them only inside three indiriduals).

Out of the constant cell-olganoids in Myromonas of lype A are found the modulating membrane, axostyle amel nuclens.

The mucleus is mostly situated at the widened end of the body, which l, therefore, in analogy to the Trichomonarls, consiner to he the anterior end. Althongh, in connection with the amoeboid form of the body of Myxomonas, the nuclems may he cousiderably displaced, sometimes heing placed in the midelle of the body. The muclens is large and has a regular spherical shapr. The contents of the nucleus may have a very varierl aspect. Thus rely oftor the nucleus contains a tender linin network, all the chromatin being concentrated in the linge kiryosome (tah. T, fig. 18). The karyosome has the shape of an irlegular lump. The karyosome ol Myromonas stands the nearest to that of the Gregarines. Just as in Gregurines, there may be present in the mochens instead of one, two, three and sometimes even to fire karyosomes of smaller size (tab. II, fig. 17). Ant lastly, there are specimens in which besides one laree karyosome in the linin network there are to be seen 1 or 2 small chromatin lumps: these may be framents fallen ofl from the killyosome (com. pare analogous processes in (ireganimę).

In other cases the linin network surmunding the melems is rery dense, and in the nodes of the network there are numerous large chromatio granules. (Inre, or twice I hare observed that the whole nucleus comsisted ol harge alrooles. 
each alveole containing a regular, rounded chromatin granule. Lastly, in nuclei that have accidently fallen out of the body of Myxomonas in the process of preparation, the intranuclear network is often absent. In that case all the interior of the nucleus is occupied by an accumulation of very minute chromatin gramules, or the chromatin may be gathered into indistinct threads interlaced together, and resembling the spirem figure. The varieties in the structures of the nncleus described are especially characteristic for individuals taken from smears, and not fixed by means of dropping the contents of the intestine of Hodotermes into the fixing liquid. On account of this, I think it is possible, that this varjety partly depends on the rapid changes which take place in the nuclei, when the smears are prepared.

With the nucleus is closely connected the anterior end of the undulating membrane. The coulse of the undulating membrane may vary greatly, but generally it has a tendency to coil in one plane into a very closely winding spiral surromnding the nucletis. The details in the structure of the undulating membrane are best to be seen in those rare cases, when it falls out of the body together with the nucleus and axostyle, and straightens out a little (tab. I, fjg. $1 \pm$ \& 15 ).

The anterior end of the membrane begins somewhat in front of the nucleus and clasps the nucleus from abore with its basal portion, like a horse shoe; very often the horse-shne-shaped part of the membrane stains more intensely than the neighbouring parts of it, and has the appearance of an independent formation. Similarly to Gigantomonas the basal portion of the membrane stains with Heidenhain's haematoxylin much stronger than its free edge, the border between the light and dark zones being either very. sharpiy outlined (tab. I, fig. 14), or both zones gradually passing one into another (tab. II, fig. 17 \& 18). The membrane of Myxomonas is easily distinguishable from that of the preceding genus by the structure of its free exterior edge. It is peculiar to Myxomonas that under the border filament (border flagellum) of the membrane there passes at a close distance a second filament which supports the first. Such additional filaments have been often described in the membranes of Trichomonads.

The axostyle is well developed. It approaches the nucleus from behind and envelopes it with its widened anterior 
end in the shape of a thin film, amd beeomes commonem will the holse-shoe-shaped hase of the membrante which is allat

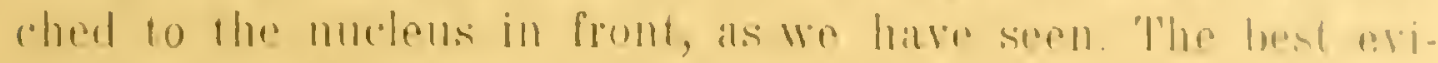

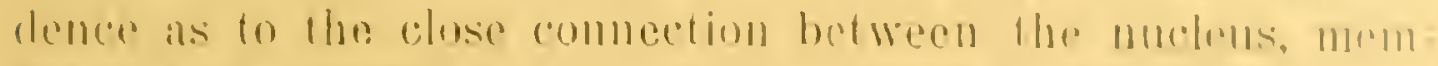
brane alld axostyle is borme by the linet that in the prores

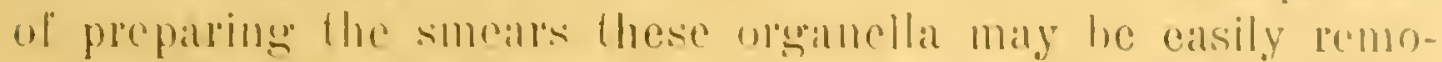
ved ont of the hody, without. however, becoming disconmeted (see lig $1+d$ is. tah. T.) The axostyle consists of a lighter peripheral layer, like an integument, and a black axis. (afler stainimg with Heidenhain's hamemtoxylin). The axostyto of Myromonus has an important peculiarity in that it lies entirely insile the body of the animal, without projecting mutside, and without forming the candal spine, as it is usual in the Trichomonads Leaving the muclens, the axostyle rums to the posteriol and of the body, but here it meets with the compact ectoplasm, bends again forwards and forms a greater or smalker arih: rery often the posterior end of the axostyle bends forwards so much, that it nearly touches the muclens fsuch cases are especially mumerous in specimens, in which the undulating membrane is coiled around the nuclens in one plane into a rery winding spiral). It is rery difficult to decide how the axostyle terminates at its anterior end. Only in one specimen of M!rxomonas, in which the apparatus was separated, I saw distincty that the external covering (integument) of the axostyle after surrounding the nucleus has formed on its surface a clearly risible knoh (basal body.).

The axostyle presents an elastic rod which is in the state of tension; this is clearly seen from the fact that, when remored out of the body of Myxomonas, the axostyle straightoms like an arrow (tab. I, fig. 14, 15). It is clear that both the axostyle, and the muluating membrane play an important rôle in giving the shape of body to Myxomonas.

The axostyle on one hand, and the membrane and ectoplasm on the other, act as antagonists. The axostyle has a tendency to straighten and, thus, helps to stretch the body longitudinally. The undulating membrane tends to coil into a spiral lying in one plane (nearly perpendicular to the axis of the axostyle) at the anterior end of the body; and as the membrane lies in the ectoplasm and is closely comnected with it, it draws the ectoplasmatic sac to the anterior end when it contracts, and in this way it makes the posterior end 
of the axostyle bend forwards, and the body of the animal shorten. The normal (if we may use that expression) position of the axostyle and the membrane is revealed in those cases, when they accidently become separated out of the body, and are thus freed of the influence of the ectoplasmatic corer on them. Then the axostyle straightens, and the nembra:le be. comes contracted into a spiral in one plane (tab. II, fig. 16). It is a much rarer occurence that the membrane of such an apparatus is in a stretched state, possibly already degenerating (tab. I, fig. 14 \& 15 ).

Thus, the shape of the body in Myxomonas may be expressed as the resultant of two forces: the force of action of the axostyle, and the force of action of the undulating membrane.

The three or four anterior llagella peculiar to all 'richomonads, are absent in Myxomonas. Only in two specimens of Myxomonas I saw formations resmbling flagella. In both of these cases I have found at the most anterior, sharpened end of the undulating membrane two black granules; from one of them, in one of the cases, there seemed to project two fine threads (tab. I, fig. 13). Such granules may easily be interpreted as basal bodies of the flagella, and the threads mentioned-as the flagella themselves. Nevertheless it is too risky to make any conclusions on the presence of flagella in My.xomonas from one preparation, shown in fig. 13.

Type B is in general identical to the preceding, but devoid of an axostyle. This fact does not prevent us from referring both forms to one species, and only serves to prove again, how changeable the the organism of the Trichomonads and Protozon related to them is. Already Martin and Robertson (24 p. 67) have stated that in Trichomonas gallinarum the axostyle in only in rery few cases present. Besides, in many Trichomonads the axostyle disappears temporarily before division of the aninal begins. Concerning Myxomomas, in some samples I found only individuals of type $A$, in others individuals of type $B$, whereas in some both were to be found together.

Type $B$ resembles type $A$ so closely, that with regard to it only a few additional remarks may be marle.

The size of type $B$ raries in the same limits as in type $A$, but there occur many individuals of smaller size, than the minutest individuals of type $A$. 
'The shape of the hody is as varionl, as in 1,ye . I, lum

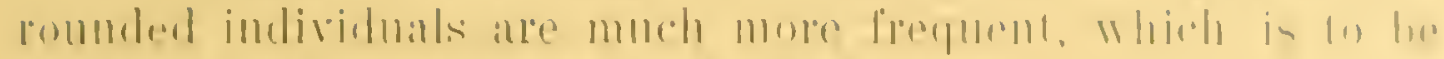
explaimed by the alsenere of the axostiple.

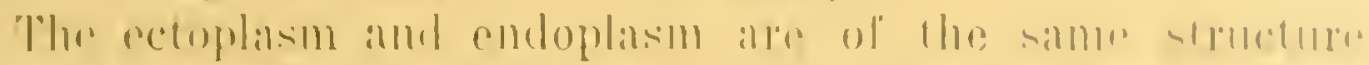
as in type A. The structure of llar molulatime momblam is

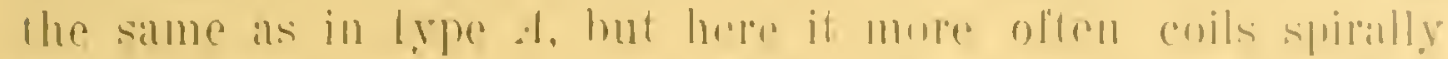

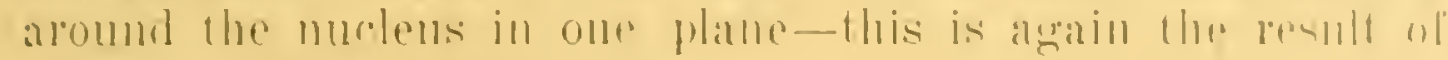

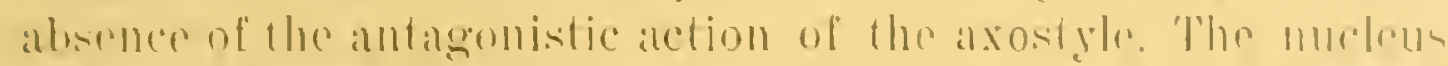

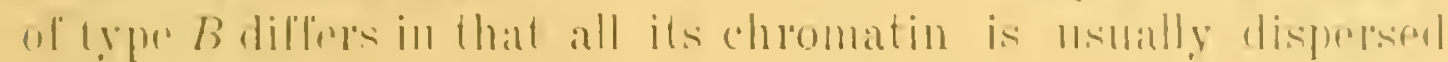
in the shape ol' small ermmoles in the nodes of the linin net-

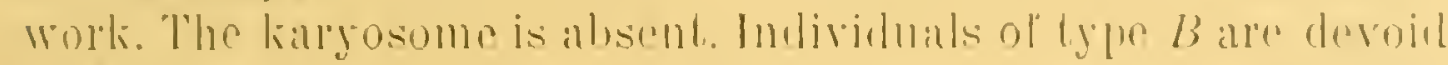
of lood-parlicles as the precediug; only in oue individual dir I spe sereral pood inclusions.

Type C. "l'o this I refere the individuals with the locomolory appalatus still more resluced than in lype B. Surh imbiriduals hatre the appearance of larege, and sometimes rely large amoebae with one nucleus to which is aljacent a small (sevelial times smaller than in types $A$ d $B$ ) undulating membrane (t. 1I, 1. 20). The axostyle and flagella are absent.

T'he shape of the body and size of individuals of the type C vary greatly.

The length and wilth of the borly in type $C$ may be expressed in the following way: $70: 45 ; 75: 50 ; 90: 65: 180: 50$; $130: 50$.

The ectoplasm and endoplasm are sharply delimited. and only in ritre cases do they gradually pass one into another, as is the case in types A and $B$. The cotoplasm surrounds the borly of the animal in the form of a wide light horder. All the ectoplasm is filled with very mimte viluoles very mureh elongated radially, and arranger although not quitr resularly, in parallel rows. The ectoplasm therelore acyulues the appearance ol being raulially striated. Such a structure of the ectoplasm in a langer stale resembles the alveolar bou'der (alreolatsaum») which Biitschli and other protistolomists repeaterly found in the ectoplasm of Protn\%lat.

The endoplasm stains considrably darke than the ectophlism. This repends both on the genelally ritrker shate of the nmloplasm, and on the presencer of nmmeroms minntust black gramules (after staining with Heidenhain's hamatnxylin) in

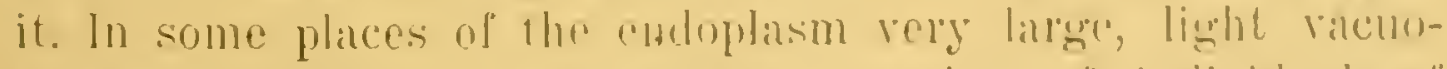
les are dispersed. In the gereater nmmber of individuals of 
type $C$ there are no food particles in the body: thus out of 35 individuals singled ont by me in a part of my preparations, only in 5 food was found.

The nucleus is mostly ol a regular spherical shape, but sometimes becomes elongated into an ellipsoid. It possesses a thick membrane, the contents of the nucleus being detached from the membrane. A similar detachment of the contents of the nucleus from the membrane. A similar detachment of the conten!s of the nucleus from the membrane is described and figured in many Polymastigina and Hypermastigina. The structure of the nucleus is mostly as follows: the nucleus contains a large karyosome, the latter is in more simple cases spherical (tab. II, fig. 20), but more often elongated in one direction, becoming oral or oroid (tab. II, fig. 22). The karyosome may become still more elongated and reach the periphery of the nucleus with one of its ends (tab. Il, fig. 25); sometimes its second end may do the same, and then the karyosome assumes the shape of a dark band cross-secting the nucleus (tab. IV, fig. 44). In some cases the end of the karyosome approaching the periphery of the mucleus becomes expanded and the karyosome bears the likeness of a wide wedge driven to the centre of the nuclens from its periphery (tab. II, fig. 25). The spherical and oral 'karyosomes appear to be homogeneous and are stained with Heidenhain's haematoxylin into dark black. The karyosomes that are elongated and expanded allow to establish the presence of two different constituents in the karyosome, the chromatin and the plastin. Very often the whole karyosome (when elongated) consists of large, round grains of chromatin resembling the chromosomes (tab. IV, fig. 44). In most indiriduals the karyosome is surrounded by a finely grimulated grayish mass (coagulated nuclear sap?). I did not succeed in finding a linin network in the nuclei of type $C$.

An undulating membrane is more or less adjacent to the nucleus. The membrane is very small and tender. The whole stains very weakly except a sharp black line forming the base of the membrane and a similar, but thinner line runnings along the margin of the membrane. In some especially successful pre. parations I remarked that parallel to the margin-line, or filament, which stains intensely, there rums ancther finer filament. This filament, without any doubt, corresponds to the 
seend supporting filament in the memblanter of tymes at

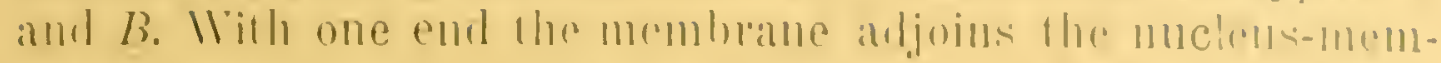
hrane rely closely, whilst thr other and ol the memblame

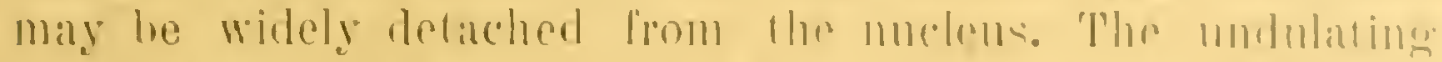
membrame of type $C$ in most cases lise together wilh dh. muclems inside the endoplasm not projectime above the bodysurface. 'This circumstance is especially muteworthy as it fostsibly points at the molmentary chatretor of the memblame in individuals of trpe $C$. Inderd, taking into accomb the imsignificant size of the memlarane and the comparatively emopmoms size of the amoeba itself, the membrane maly hallyg he supposed to play any important rôle as a locomotopy appraliatus here, or as an adaptation for urasping foon.

Amongst the individuals of type $C$ there are often louml specimens preparing for encystment (lab. IV. lig. 40). Sinch individuals begin to round themselves off and assmme a regular oral shape, the cetoplasm layer becomes miformly thick on all the periphery of the bods, and the cndoplism fills up with numerous chomidia.

Besides the minuclear iudividuals of the named three types, there are to be found in the intestine of Hodotermes just as often binucleate stages in the asexual reproduction of Wyromonas. Amongst such binucleate individuals some give origin to types $A$ and $B$, and others must be connecter with upe $C$. on accomnt of the structure of their nucleus and undulating membrane.

Type D. Let us first examine the former. Individuals undergoing division (tab. III, lig. $2 \overline{7}-29$ ) which give the origin to types $A$ and $B$ are of amoeboid character, and are easily distinguishable by the presence of great quantities of food in the endoplasm. This character is remarkable for the dividing Myxomonas. The food of Myxomonas is rather varied. It fecds chiefly on pieces of wood and parts of regetative cells swallowed by the termite-host. Besides woor, in the endoplasm of Myxomonas may often be found mmerous spores probilly belonging to fungi. The food lies right in the endophasm $n$ ot being surrounded by fool-vacmoles. The cudoplasm has a finely grambiar structure and is pool in racuoles. Is concorns the structure of the octoplasm, dividing imdividuals present a great variety, there being a whole serius of transitury forms from types $A$ and $B$ to type $C$. 
In the first stages of division the dividing individual has one nuclens of a round shape lying deep in the endoplasm. 'There is neither an nndulating membranc, nor axostyle with the nucleus, and the latter 'xhilsits some characters of the begimning division. I am sorry that I was not able to clear the question as to what becomes with the membrane of the maternal individual before dirision, and with the axostyle, if present. These organoids possibly become absorbed.

The division of the nucleus follows on the lines recently described in Tetramitidae and Hypermastigina, and which Janicki (18) proposed to name Grassi's type of division. The latter is characterized by the spindle situated externally to the nucleus doring the nuclear dirision, and by the preservation of the nuclear membran in all the stages of division.

The earliest stage of nuclear division observed by me has the following aspect (tab. II, fig. 23). The nucleus has the usual spherical shape ard contains the karyosome split in two parts amongst numerous granules, which lill up the mucleus. The mucleus is clasped by an arcuate spindle closely adjoining its membrane. The spindle stains intensely with Heidenhain's haematoxylin and has a fibrillar structure. The spindle terminates in small knobs, which prove to be two centrioles. I did not succeed in stating exactly from where the spindle originates.

The further progress of the nuclear division was investigated by me in detail. The karyosome becomes lighter and is absorbed, whilst the nucleus grows in length. (tab. III, fig. 27). Twice I saw thin curved threads extending from the ends of the spindle in this stage, these threads become thinner and terminate in the endoplasm. The significance of these threads remains unsolved (remnants of the mndulating membrane of the maternal individuals?). Then the interior of the nucleus becomes filled "up with a great number (over al hundred) of rather large, round chromatin grains-the chromosomes (tab. II, fig. 26). The nuclens hecomes oral, and the chromosomes elongate and assume the shape of threads (tab. IH, lig. 30). It is dilficult to state whether they split longitudinally or not, but they soon become arranged into two groups, all the chromosomes being directed with one of the ends towards the middle of the nuclens, and with the other to one ol the 


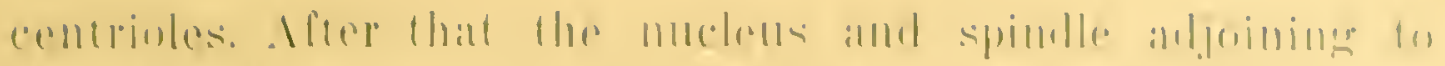

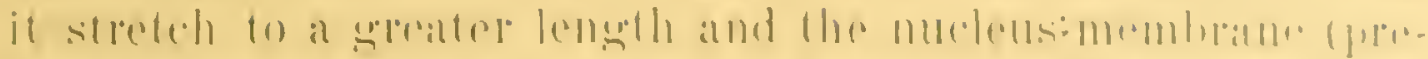

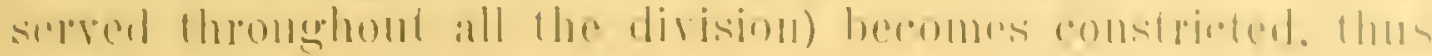
lorming two dimghter maclei commected only hy means or

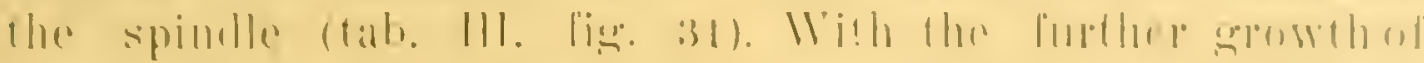

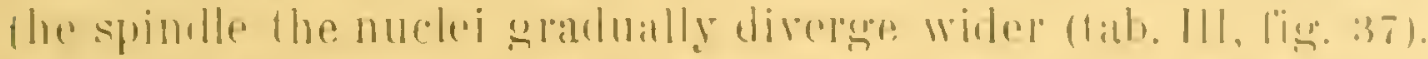

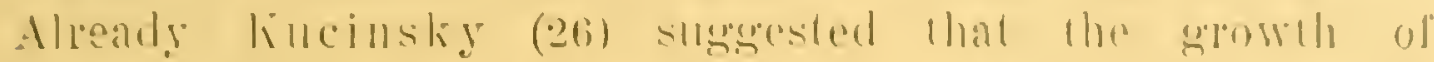

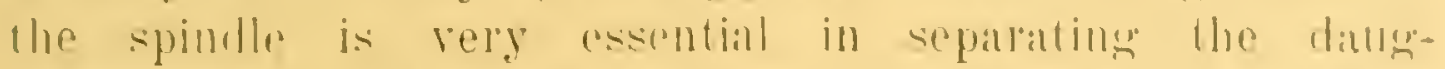
her-mmelei. In .Myromomas the divergence ol the dameher-mlectei in the midst of a protoplasm libled with loor mrets with what difliculties, and the spimble in this come plaps a vere important rôle. The spindle in the manner of a growing elastic rod forees its way throngh the inclusions of theplasm, alld with its ends draws the damghter-muclei to opposite silles. In such cases the plasm is sometimes so resistant, that the spindle bends into an acute areh, and the latter, probably. fuickly straightens, which leads to the diverence of the daushter-muclei. The daughter-muclei, besides direrging one from another, rely olten turn one to the other aromit the axis lormerl hy the spindle (tab. III, lig. 37). 'This turning is eroked "wing to the particular stucture of the spindle. The spindle is composed of a rather great number of fihrils, which run from one of its ends to tho other not directly, but hecoming slightly twisted (as the lihres in a rope. see fig. 36, tah. IlI). Before the mucleus has dividud the spindie-librils maintain this arrangement, hut as soon as 1 wo nuclei are formed: the elastic fibrils of the spindle strive to get out of the twisted condition, to straighten, and their

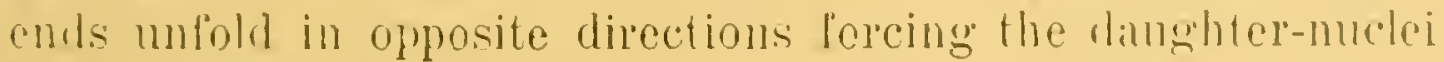
to turn as described above.

The laughter-nucle gramally assume the structure of the resting state. This process may he more or less speedy.

Aler the formation of the daughter-muclei. neal eareh of them a new undulating membrane begins to form. The membranes are formed from the ends of the spinclle, more correctly-liom the centrioles Jying at both ends ol the spindle. First fine threads are seen to be leaving the combs of the spindle. They are closely apposent to the nucleus and form aloumd it nearly a semi-circle (tah. III, fig. 34). They ale the rudiments of the membrane base, - namely. ol' the anterior part of the hase which in lyes $A$ and $B$ chasp 
the mucleus in the form of a horse-shoe. Further the membrane grows in height and length simultaneously (tab. III, fig. 35 and 39 ), the end of the basal thread severing from the nucleus and freely sinking into the endoplasm. A long series of succeeding stages in growth lead to the formation of an amoeba possessing two nuclei, each of which is supplied with a large membrane characteristical for types $A$ and $B$ (tab. III, fig. 29), the nuclei being all the while connected by the spindle. It is interesting to note that in the primary stages of their formation the membranes lie wholly inside the endoplasm and only afterwards project abore the body-surface.

Concerning the division of the plasmatic body of binucleate individuals, I have only few data, but, probably, this takes place by means of simple constriction. Three or four times I found minucleate amoebae of type $B$, in which, besides the andulating membrane, there was an ontgrowth of the nucleus, becoming gradually thinner towards the end. This was a part of the spindle constricted (tab.IV, fig. 42). Evidently, such stages present the results of a recently concluded division, in the course of which the spindle is torn in two parts. The fate of the spindle in individuals $B$ is clear: it gradually becomes absorbed. As concerns individuals of type $A$, I presume that their axostyle is a direct derivative of the divided spindle, which is not only preserved in this case, but grows further in each daughter-individual.

Howerer the case may be, it can be stated that the dividing forms just described, which may be termed type $D$, give origin to individuals $A$ and $B$.

Together with those there are, howerel, to be found large binucleate amoebae (tab. II, fig. 21), which should be connected with the mninucleate forms $C$, and. which I shall name as individuals of type $E$ (tab. II, fig. 21). The shape, size and structure of the ectoplasm of individuals $E$ closely resemble that of the individuals belonging to type $C$. The endoplasm is filled with food. Lastly, in the body of the $E$ individuals there are always two nuclei of exactly the same structure as in the $C$ individuals, provided with the same small, delicate undulating membranes. One of the nuclej lies near the very surface of the body and the corresponding membrane projects to the exterior (tab. II, fig. 25); the o:her nucleus with its membrane lies in the endoplasm in most cases. In the mucleus there is a karyosome, 


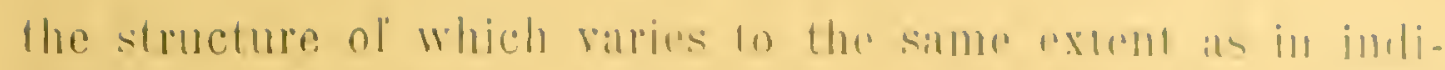

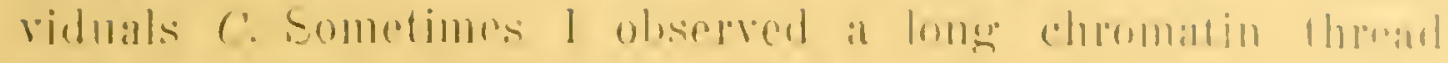

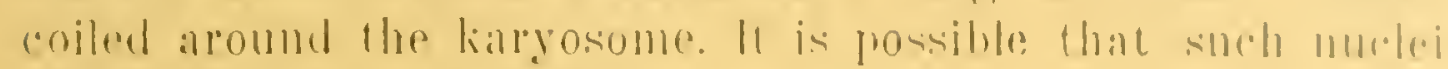
are preparing for division.

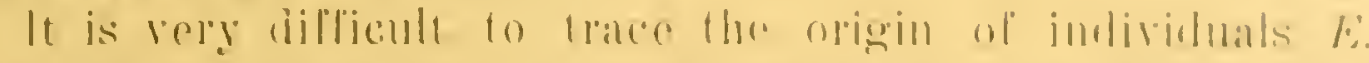

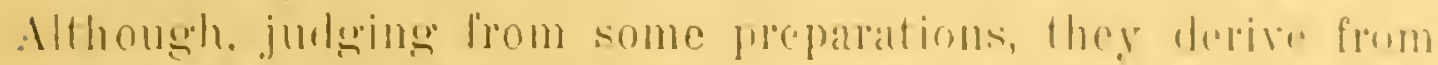
monucleate individuals by means of division of thr muetens alecompanied by the formation of a spindle omtside the murlems similar to that in individuals $D$ ).

'Phere remain to be said a lew words about ceptain foremations which are produced ly a change in the type ti. Amoninst the rontents of the intestine of Hodotermes there are sometimes to be found small (30-35 microns in diameter) balls (tal). HI, fig. 3s), ronsisting of homogeneous finely

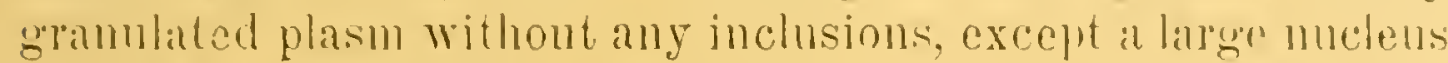
sitnated mear the surface of the ball. 'The mucleus is somewhat plongated and built according to the melens tyon of the $F$ irdividuals: to if is clnsely adjacent a small modulating membrane projecting above the surlace of the body. At first the origin of such forms of Myxomonas was inconcervable for me, until I met with the stages draw in fig. H, tab. IV. Here we see a Myxomonas of type E, the plasm of which becomes more fluid than is usual; portions of the protoplasm separate from the body and, romding ont, they form balls. Some of these balls are small and consist of plasm alone, while others are larger and contain a mucleus with the corresponting membrane. Such products of breaking up of the type $E$ individuals correspond to the formations just described by me (let us name them type $F$ ).

The genetic relations between the different types of Myxomonas. As may he seen casily from my description, I was far lrom having at my disposal all the stages of the cycle of devolop)ment of Myxomonas: for instance, the sexual stages of repronduction remain muknown. As concerns the stanes described by me, the relations existing between them seem fo mo to bear the following aspect. The limdimbental form is presented by the uninncleate indiriduals of type $C^{C}$ with a small modulacing memblane. These individuals male corest, after lombling

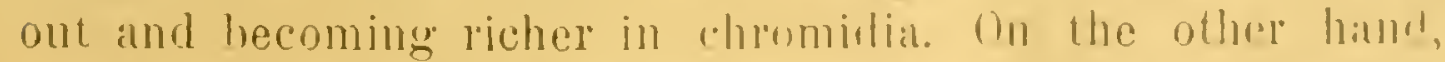
after feeding (see the rare cases, when fool was foumd in indiriduals $C$ ) they may grive orignin to binucleate amombite of 
type $E$. Thus, I think that type $C$ after ingesting fond undergoes nucleus division. Individuals of type $E$ in mnormal conditions break up into a rosette of balls, and produce type $F$. But usmally they feed intensely, divide, become smaller and give origin to the type $D$; the latter are filled with food like the freceding, and are in the state of division. However, in dividing they do not produce small undulating membranes, but large ones of the type $A$ and $B$. After division is finished, the indiriduals $D$, having become uninucleate, are freed from food, and are thus transformed either into type $A$ or $B$, which depends on the maintenance of the spindle in them (in the shape of an axostyle), or on its absorption. The further fate of individuals $A$ and $B$ remains mnknown, but is it possible that these forms are preparatory to sexual reproduction (the total absence of food in them speaks in farour of that view). 


\section{Description of the figures.}

I’.」BI, に I.

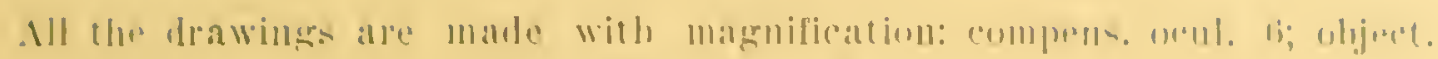

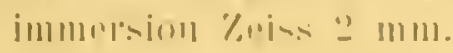

lFig. 1. Trichomonas: termilis.

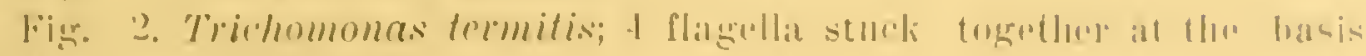
and the batsal body an sinest.

Fir.. 3. Trishomonas marrostoma.

lï. 4. Trichemonns termitis.

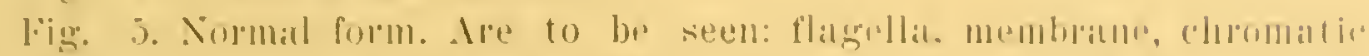
hatse of the membrame, axustyle, food-indusions (ror'), nucleus, latsal bouly, and the widely open eytostome.

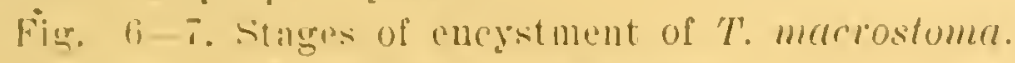

Fig. s-12. Gigantomonas herculeu.

lig. S. Amoeboid form of Cigantomonas: inside it is food and the axistyle $(a, x)$

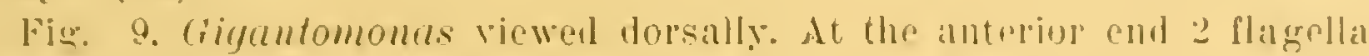
are seen, the cytostome-matrin, nucleus and externally to it the kargosome (c): the other liaryosome lies at the posteriur and of the borly. Inside the body a large chromidium and fine chromidial rods are seen.

Fig. 10. Gigantomonas from the left side (the drawing of the membrane has failed), p-cytostome-margin.

Fig. 11 and 12. Nucleus of Giguntomonas and the formation of the karyosome externally to it.

Fig. 13-15. Wy.romonas potymorphe.

Fig. 13. The anterior end of a specimen of trpe A. A latk nuclus with the spirem is seen, the commencement of the axostyle (ax), the commencement of the undulating membrane and two basal bodies with flagella (fit).

Fig. 1t. The nucleus, membrane and axostyle remored from the body of My.xomonts.

ligg. 15. Idem. The border.filanent of the membrane has torn off frum the latter in a small portion.

\section{T \ B L E: 11.}

All the drawings except fig. 21 were made with the magnifieation: compens. ocul. 6; obj. immersion of Zeiss 2 mm.

All the drawings represent My.romonas.

Figr. 16. Type A. The nucleus with axostyle and mombane remorest from the body of the animal.

lFig. 17. Type A. The ectoplasm and endoplasm in the given sperimen are hadly differentiated.

Fig. 18. Type A. The granulated endoplasm with latrege vacuoles and the homogeneous ectoplasm alle well reen; at one emb of the bods there are cetoplasmatic papillae $(x)$.

Fig. 19. Type $B$, without axustyle. loplasm.

Fig. 20. Type $C$; one of the few sperimens containing food in the ch- 
Fig. 21. Type E, with numerous food inclusions. Comp. ocul. 6; obj. Zeiss $4 \mathrm{~mm}$.

Fig. 22. Type $C$; the nucleus with elongated karyosnme, at the ends of which chromatin is collected; the contents of the mucleus are often detached from the membrane; close to the nucleus is a small undulating membrane.

Fig. 23. Type D. The beginuing of nuclear dirision. The spindle outside the nucleus with centrioles at the ends is well seen.

Fig. 24. Idem. The spindle consists of fibles twisted in the manner of a lope: inside the nucleus there are collected masses of chromatin (products of metabolism of the karyosome).

lig. 25. Type C. A section through the body-wall; it is clearly seen that the undulating membrane $(m)$ projects above the surface of the body.

Fig. 26. Type $D$. The beginning of nuclear division; the nucleus is filled with numerous round chromosomes.

\section{T A B I, E III,}

All the drawings ale made with the magnification: compens. ocul. 6, object. immersion Zeiss $2 \mathrm{~mm}$.

All the drawings represent Myxomonrs polymorpha; all of them, except fig. 35, refer to forms of type $D$; fig. 39 represents an indivislual of type $F$.

Fig. 27. Dividing individual; from one pole of the spindle a thread runs (a rudiment of the old membrane or the beginning of the formation of a new one).

Fig. 28. ldem. The daughter-muclei after division have assumed the state of resting nuclei; between the nuclei is the bent spindle.

Fig. 29. In individual with fully formed large membranes.

Fig. 30-37. Different stages in the division of the nucleus in the forms of type $D ; m$-formation of undulating membrane.

Fig. 38. An individual of type $F$.

Fig. 39. The formation of large mrmbranes in an individual of type $D$.

\section{T A B L E IV.}

All the drawings, except fig. 41 , are marle with the magnification: compens. ocul. 6; objelit. immersion of Zeiss $2 \mathrm{~mm}$. All the drawings represent iiyxomomas polymorpha.

Fig. 40. An individual of type $C$ preparing for encystment; the endoplasm is filled with chromidia.

Fig. 41. An individul of type E breaking up into plasmatic balls; the formation of individuals of type $F$ from it. Ocul. 6 , object. of Zeiss $t \mathrm{~mm}$.

Fig. 42. An uninueleate amoeba: as it seens, having just finished the division; a half of the divided spindle is visible $\left(a \cdot x^{\prime}\right)$.

Fig. 43. The nucleus of a small uninucleate amoeba, just after division, as it seems. From the nuclens there passes a piece of the spindle torn off, and a sinall rudiment of the mudulating memlnane is closely apposed to the nueleus.

Fig. 44. Nueleus of an individual of type $C$. 
Description of the text-figures.

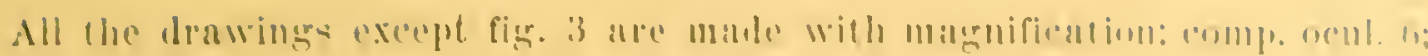

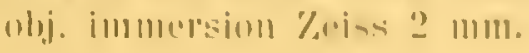

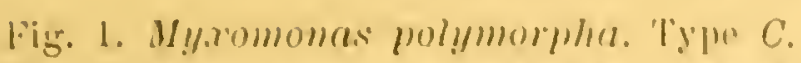

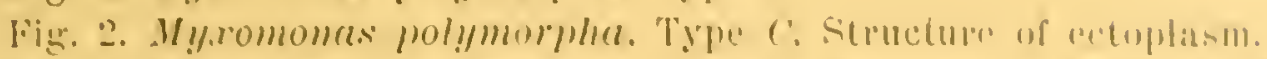

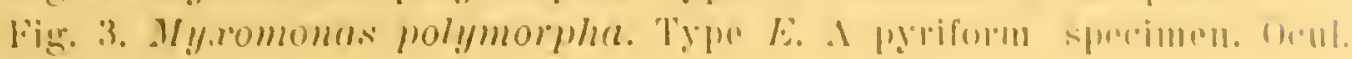
6: obj \%eiss \& $1111 \mathrm{~m}$.

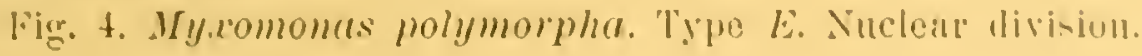






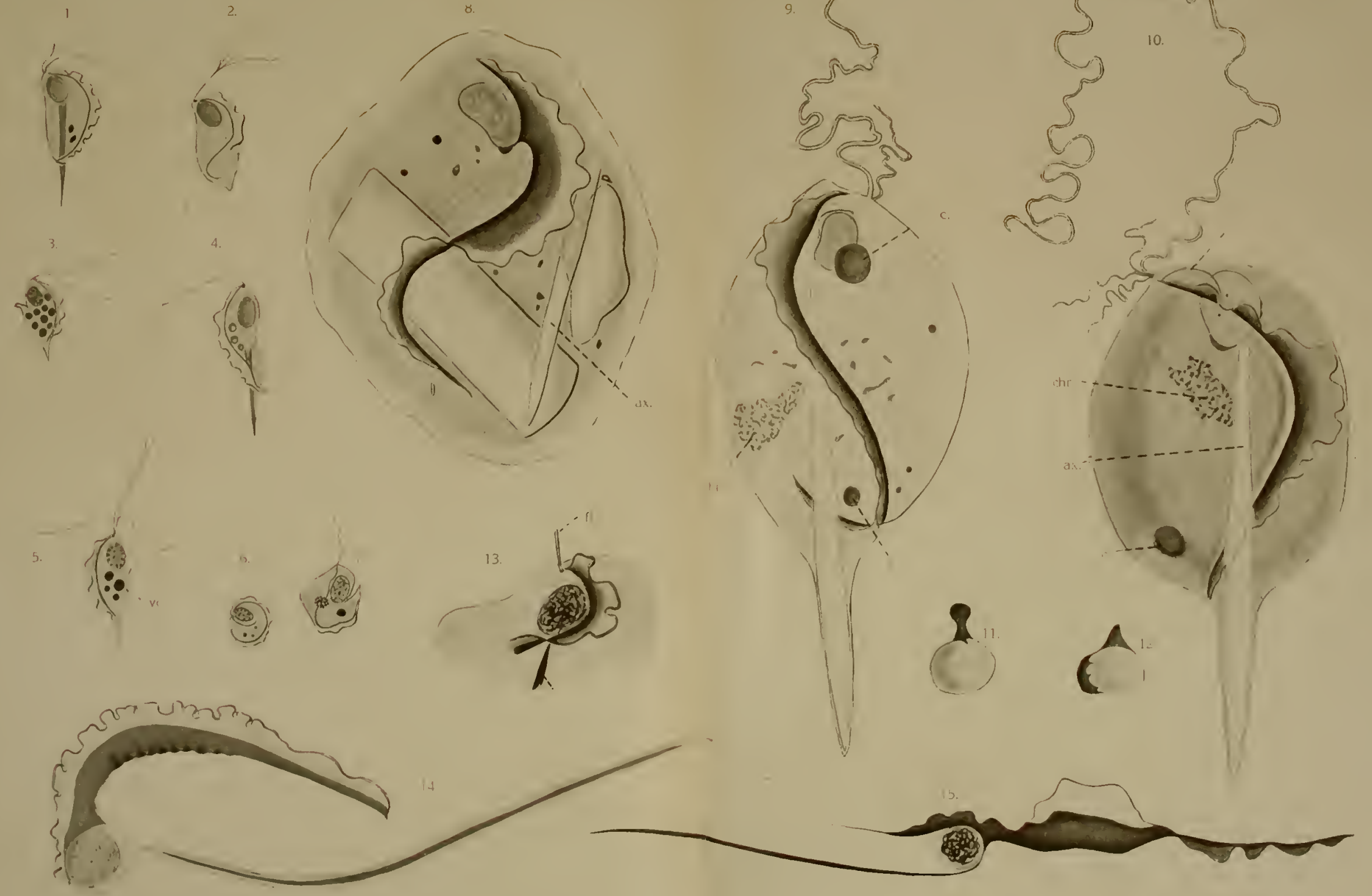






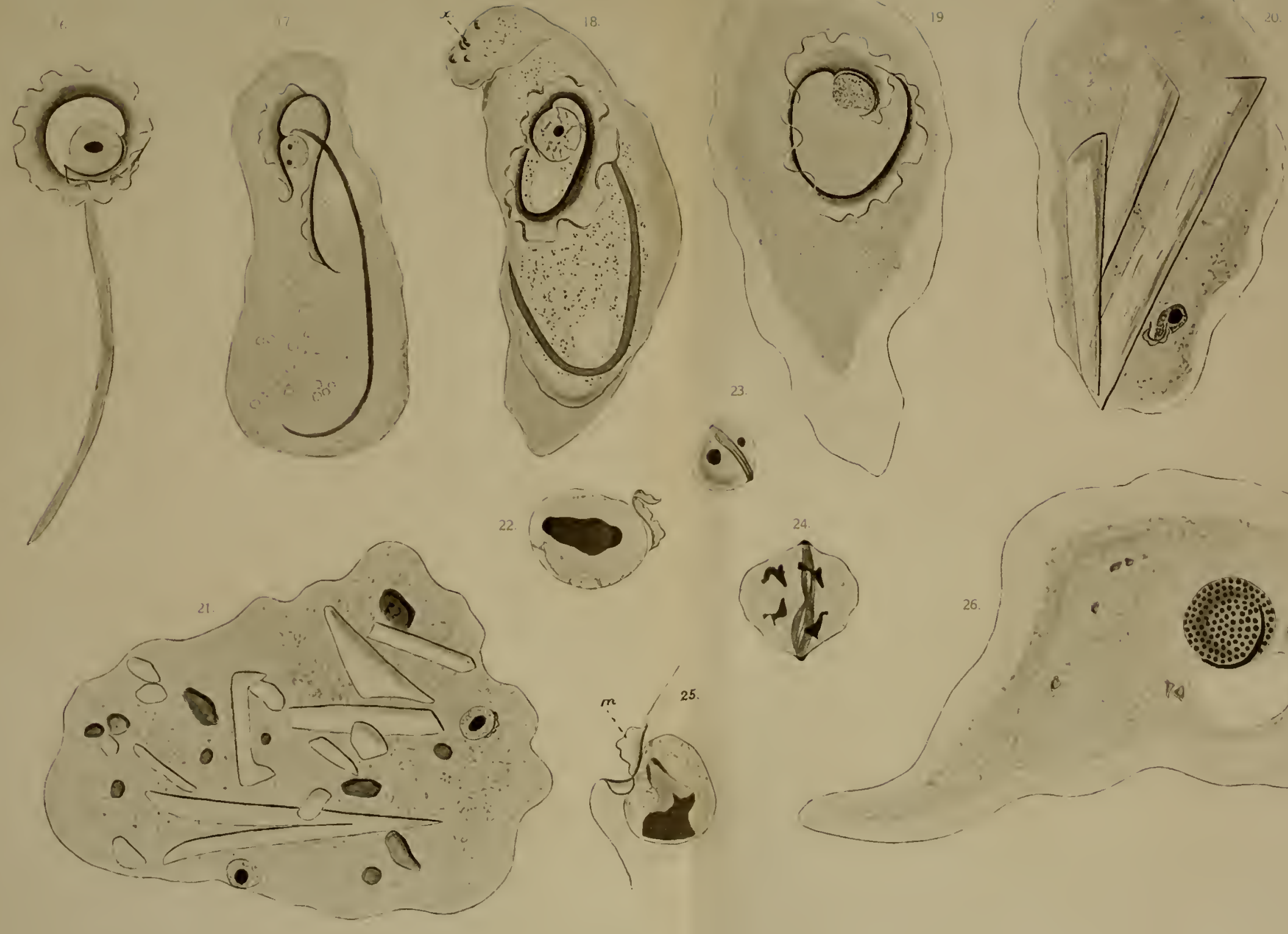




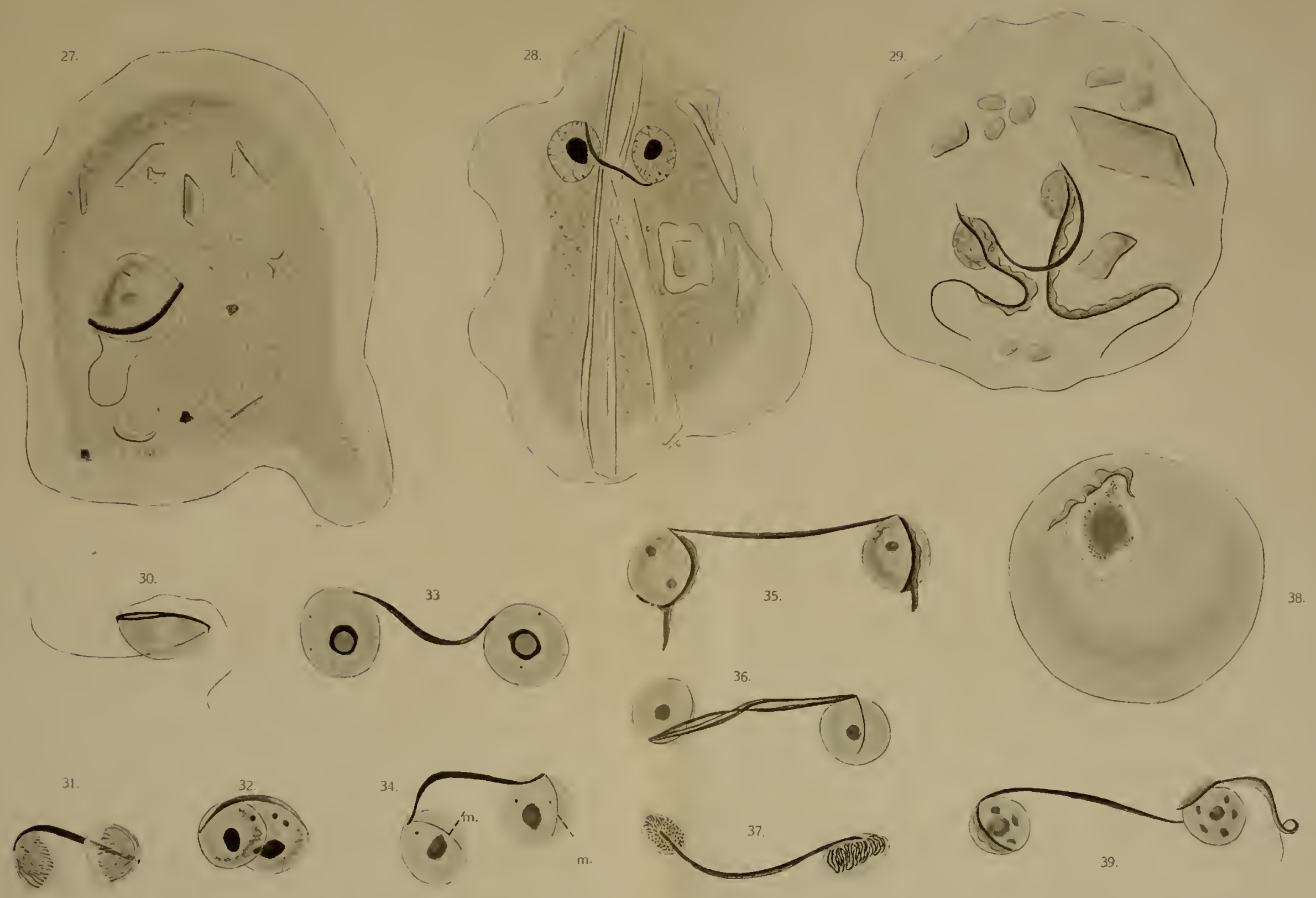




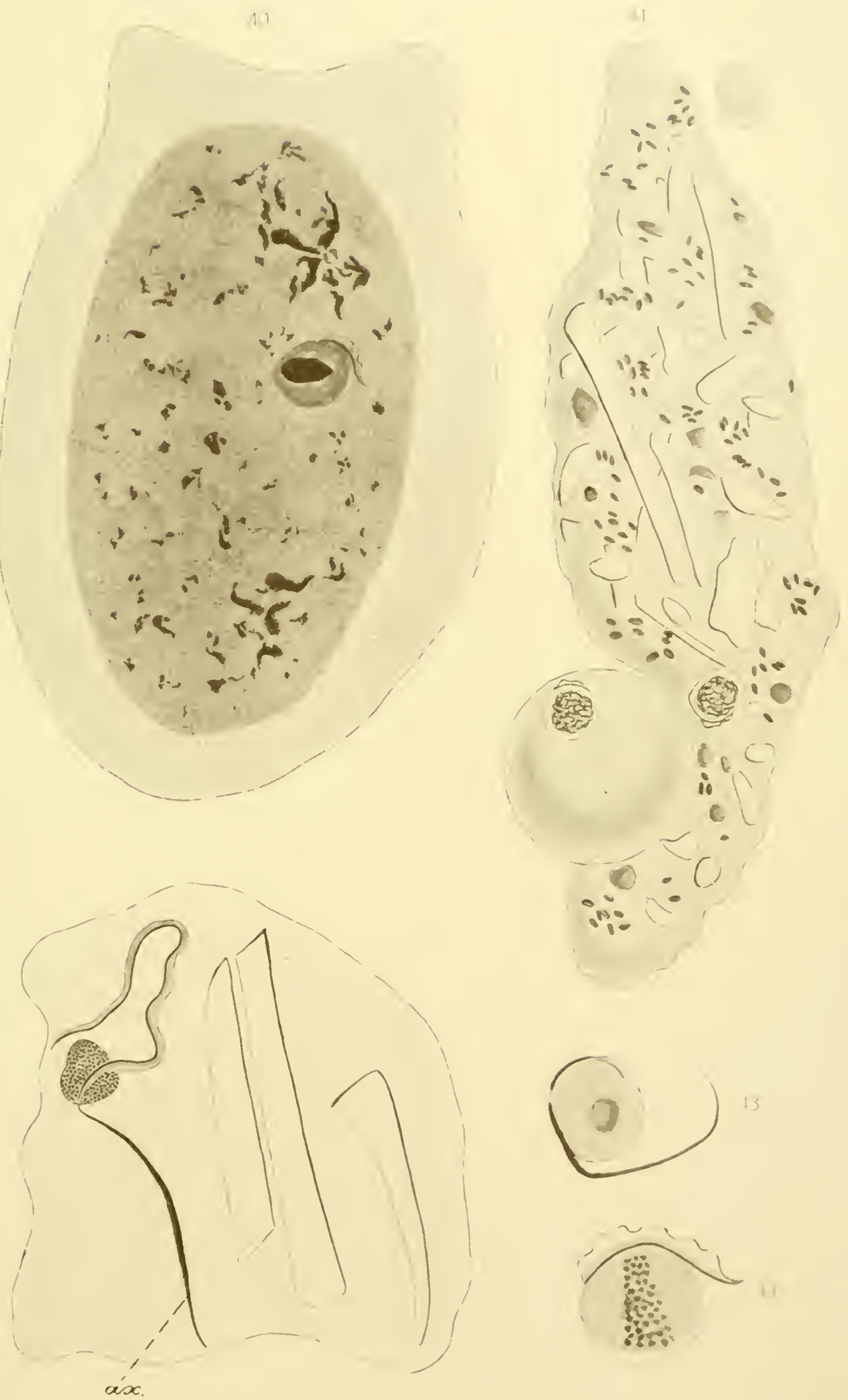

№ 5 .

E. Н. ПАВ ПОВСКIЙ.

Кь анатомin Phymateus hildebrandti $B$ ol. (Orthoptera, Phymateidae) вь связи сь особенностями его кожной секрещіи,

On the anatomy of Phymateus hildebrandti (Orthoptera, Phymateidae) in connection with the peculiarities of its dermal sekretion. 



\title{
K'b a натомin Plymateus hildebrandti Bol. (Orthoptera, Phymateidae) B'T связи с'ь особенностями его кож- ной секреціи.
}

\author{
Е. Н. Павловскій.
}

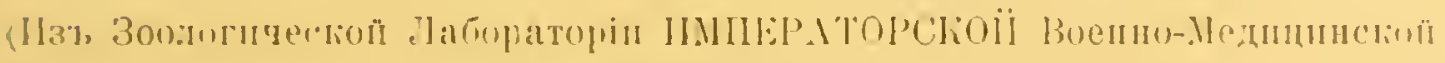

Alialeminl).

В. А. Д огель передаль мны для изсльдованіз матеріаль по строенію Ph!mmatens hildebrandti Bul. Вт, связи со cnocoбностыо названнаго прямокрылаго выдтлять на иоверхности своего тъла пънообразную жидкость. Любезно предоставленныї в’ь мое распоряженіе матеріалъ былъ собранъ В. А. Догелемю и И. И. Соколовымъ въ окрестностяхъ Найроби и Мабиры и представляль собою части груди съ прилежащими двумя члениками брюшка и основаніями заднихъ ногъ насъкомаго. Кусочки были фиксированы пикриново-азотной смьсью, сулелпю, жидкостью filson’a и просто спиртомь. Экземпляръ, сохраненныі для образца, былъ опредъленъ Н. Н. Аделунгомъ.

И. И. Соколов' сообциль мнб сльдующія выдержки изт своего цневника, касающіяся Ph!mmatens.

«7/ н. ст. Если насъкомое взять въ руку, то оно выпијскает’ь позади заднеї пары ногъ довольно обильну'о жндкость, Которац сильно пинится крупными пузыряпи. Можеть быть железы. выдъляющія эту жидкость, стоять в'ь какой либо связи с'ь трахеямй (\%).

8. V. На растенін, напоминающемъ во всеиъ нашъ картофелн, нашелъ саранчезыхъ, выпускающихъ пүну. Главнымь образомъ 
она идетъ изъ складки между I и /[ сегментами брюшка. ${ }^{1}$ ) При близительно черезъ минуту пъна перестаетъ течь (насъкомое все это время держится въ рукахь за крылья). Одновременно изо рта капаеть обычная темная жидкость. Интересно отмбтить, что среди этихъ насъкомыхъ часто наблюдаются поврежденные или уродливые экземпляры. У одного не было надкрыльевъ, у другого--объихъ заднихъ ногъ, у третьяго крылья одной стороны были слабо развиты, у четвертаго - задніе концы крыльевъ были совершенно высохшими, желтаго цвьта и т. д. Этотъ видъ зд屯сь обыченъ: на одномъ кустикъ сидъло сразу двънадцать штукъ. Прыгать не любятъ и даютъ схватить себя безъ труда руками, ири этомъ растопыриваютъ заднія ноги, выпускаютъ пвну и слюну и не дълають попытокъ освободиться. Полетъ ихъ не быстрый и очень красивыі, такъ какъ заднія.ихъ крылья окрашены у основанія въ синії, на концахъ же въ красный цвътъ. Вмғсть съ ними сидели, вьроятно, ихъ же личннки (окрестности Найроби)».

Матеріаль быль залить мною въ парафинъ и разложенъ на серіи сръзовъ. Лучше всего ръзались кусочки, фиксированные пикриново-азотною смғсью. Такъ какъ хитиновыя части сръзовъ не всегда можно было надежно наклеить бълкомъ, то я пользовался дополнительнымъ укрбпленіемъ ихъ коллодіемь (24) на время окраски и обезвоживанія. Краски примћняль обычныя-гематоксилинъ, эозинъ и желғзный гематоксилинъ. Кромъ того, хоро-

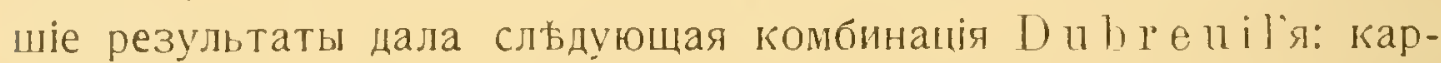
минъ (М а уег'а) и метилблау съ пикриновой кислотой. ${ }^{2}$ ) Этотъ способъ особенно пригоденъ для окраски срьзовъ черезъ части насъкомаго, состоящія изъ различныхъ тканеиі. Очень рбзковъ синій цвовтъ-окрашиваются хитиновыя части препарата. Эноциты принимаютъ ярко-желтую окраску и т. д.

Производимое изсльдованіе было-бы въ значительной стелени облегчено разсмотръніемъ подъ микроскопомъ свъжей пћны, выдљленной Phymateиs. Относительно природы пвнистой жидкости возможны два иредположенія: она является или секретомъ какихълибо железъ, или же-кровью, выпускаемой изъ тьла. Изсльдованіемъ секрета вопросъ этоть быль бы разрғшень сразу, а безъ

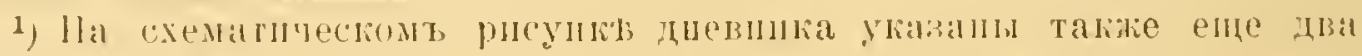

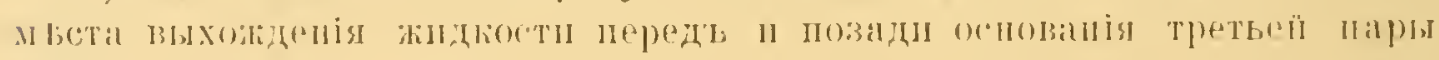
HOTh.

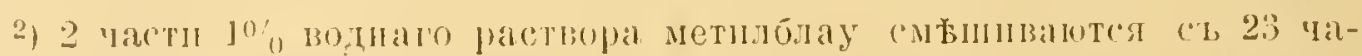

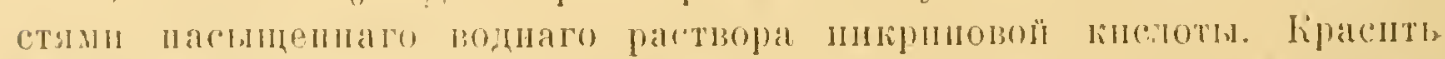

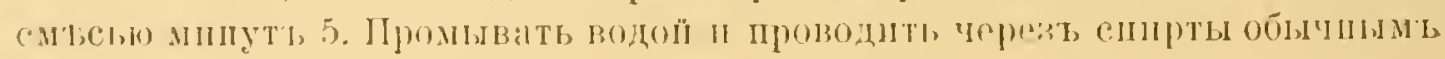

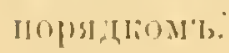




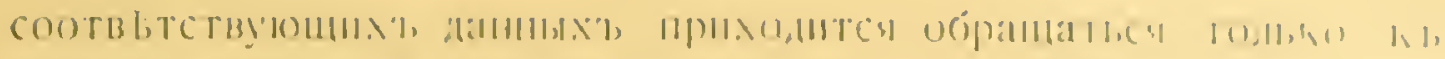

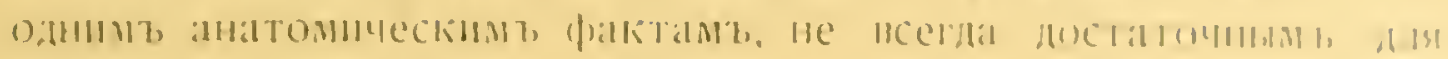

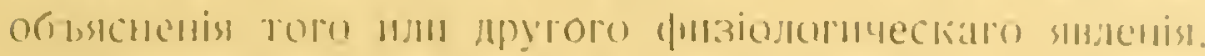

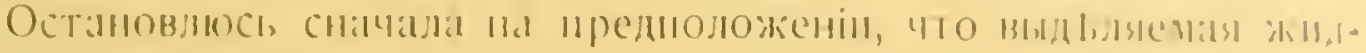

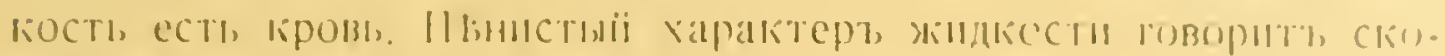

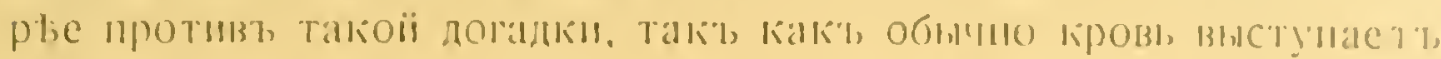

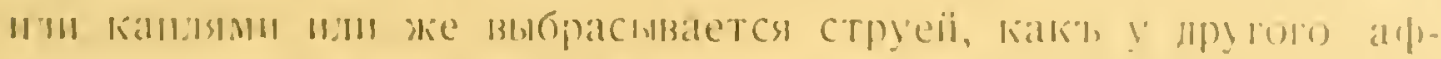

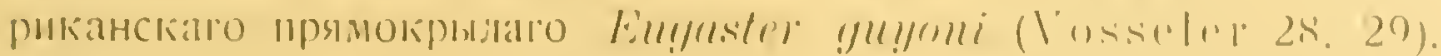

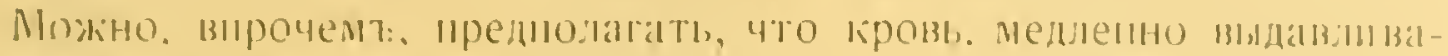

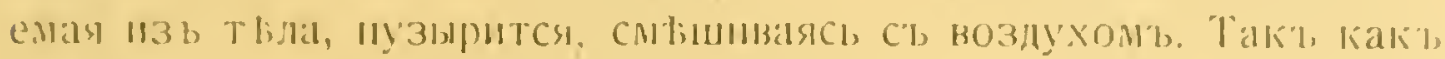

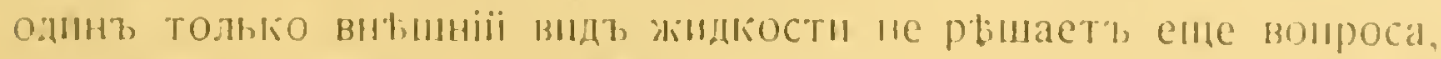

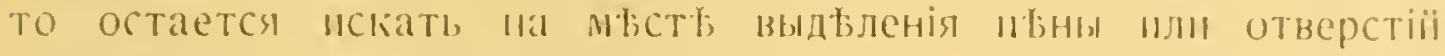

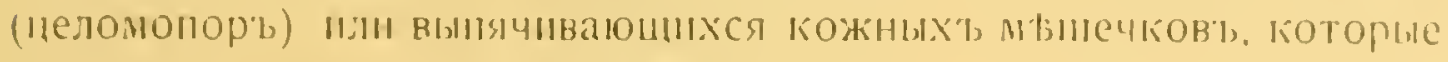
лопаются при перенолненіи ихъ кровью.

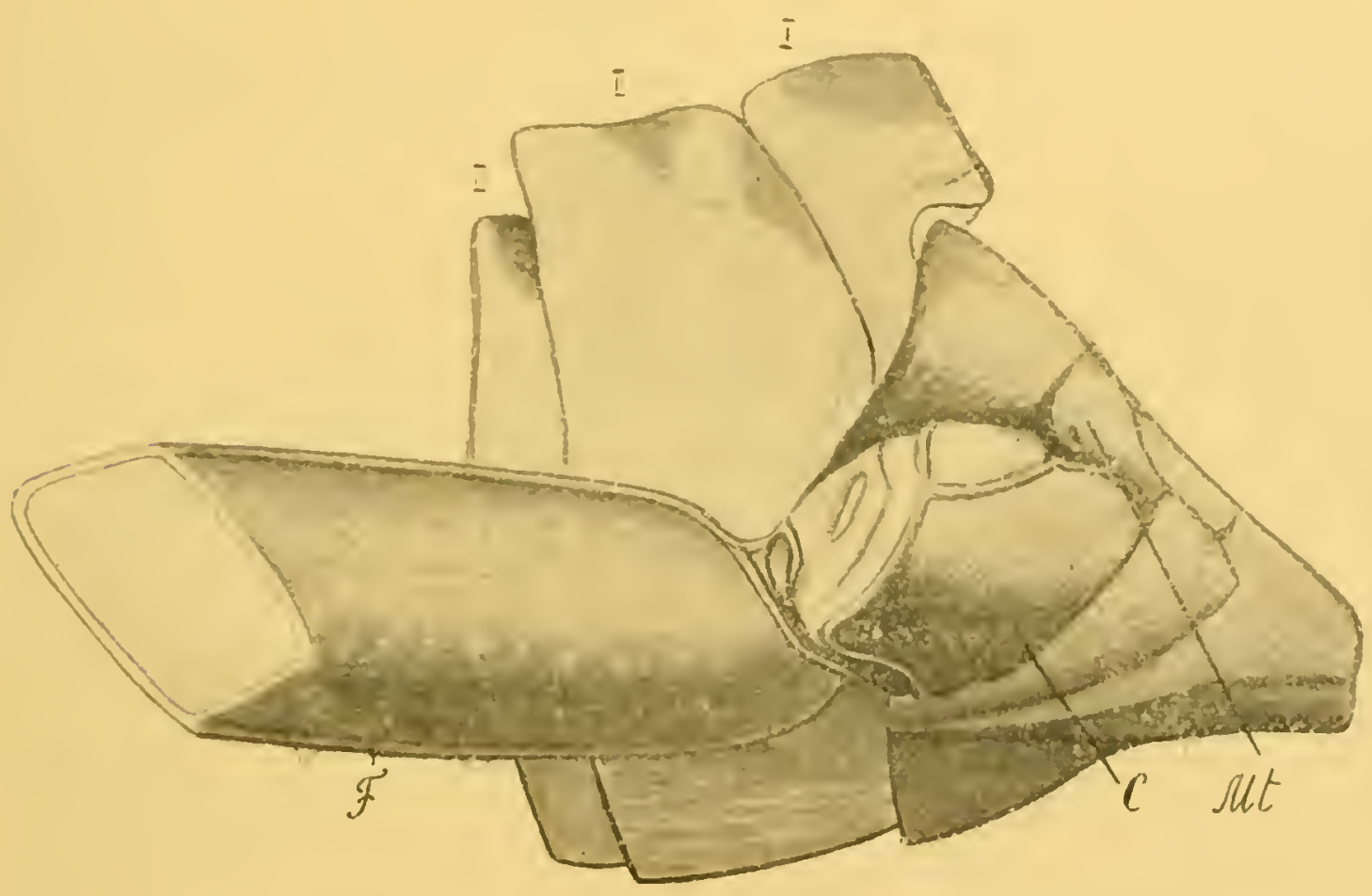

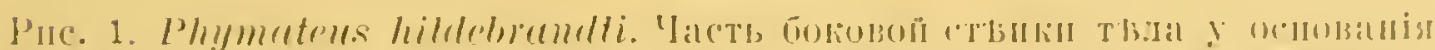

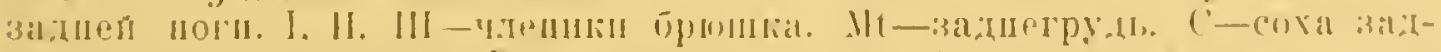

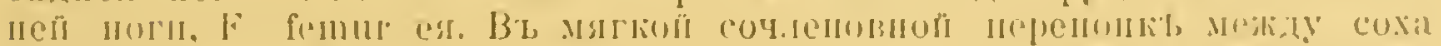

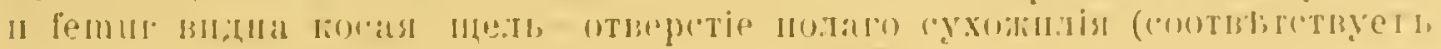

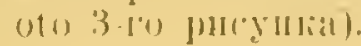

При наружном осмотры I'l!!matrils 13', сочленовнов перепонкв между твлоиь и соха, а такжс межщу соха и (елромь')

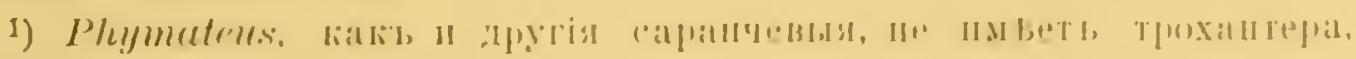

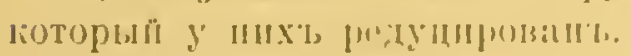


вндны отверстія-въ первом’ь мвсты круглое (рис. 2, ot), во второмъ щелевидное (рис. 1). Невольно напрашивается сравненіе этихъ отверстій съ порой, имьющейся по V'osselery у Eugaster. между trochanter и соха и служащей мъстомь выхожденія крови нзъ твла.

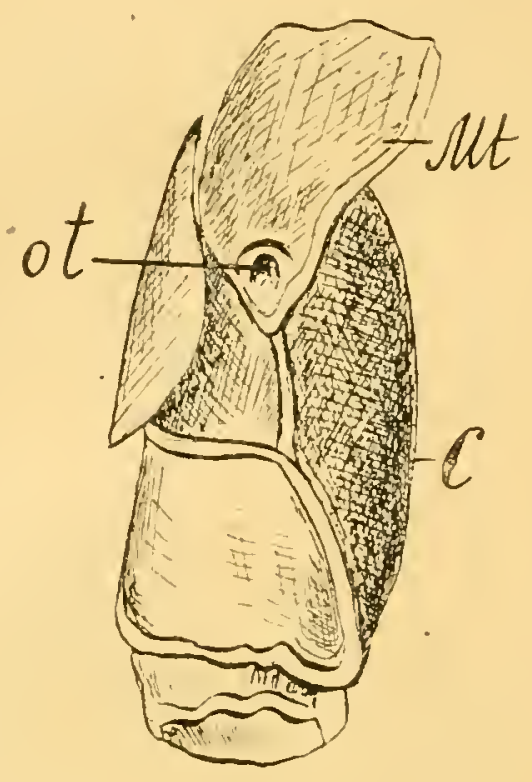

Pinc. 2. Coxa (C) правой задней ноги Phymateus hildebrandti сверху. Mt-часть, заднструди; otотверстіе, ведуцев вт полое сухониль (ср. ot phic. 3 II 4$)$.

Разсматривая продольные србзы черезъ часть бедра, соха задней ноги и прилежащій отдъль заднегруди, можно видъть, что мягкая сочленовная перепонка въ мъсть наружныхъ отверстій впячивается внутрь, образуя полыя сухожилія, направленныя своими вершинами въ сторону заднегруди насъкомаго. Сухожиліе перепонки между соха и заднегрудью (рис. 3, ot) болће развито и длинне, ч九мъ таковое же между соха и бедромъ (рис. 3, oto). Къ нимъ обоимь прикрғпляются мускуль. Въ полости сухожилій имълись слғды какого-то зернистаго вещества (рнс. 4, ot). Описываемое строеніе представляетъ извъстное сходство съ приспособленіемь для выпрыскиванія крови у Eugaster, открытая пора котораго имъетъ по I’ o s s el e l’ у (28) форму воронки. Когда пора закрыта (шодъ вліяніемъ брюнного давленія), воронка замыкается по всей своей оси, что видно изъ рис. 9 таб. 1 работы Vosselс r’a (28). Для раскрыванія отверстія служит'ь особый короткій мускулъ, прикрљиляющійся кь воронкъ. У Ph!mmateиs полое су- 


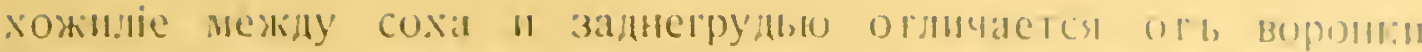

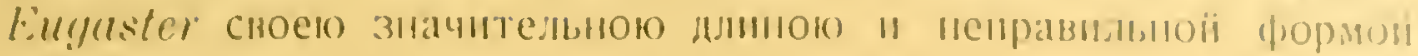

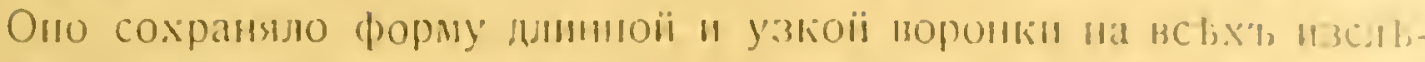

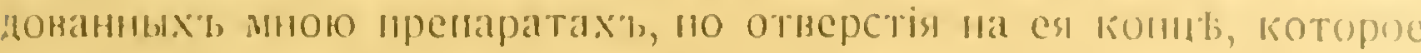

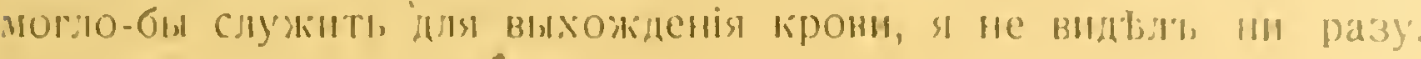

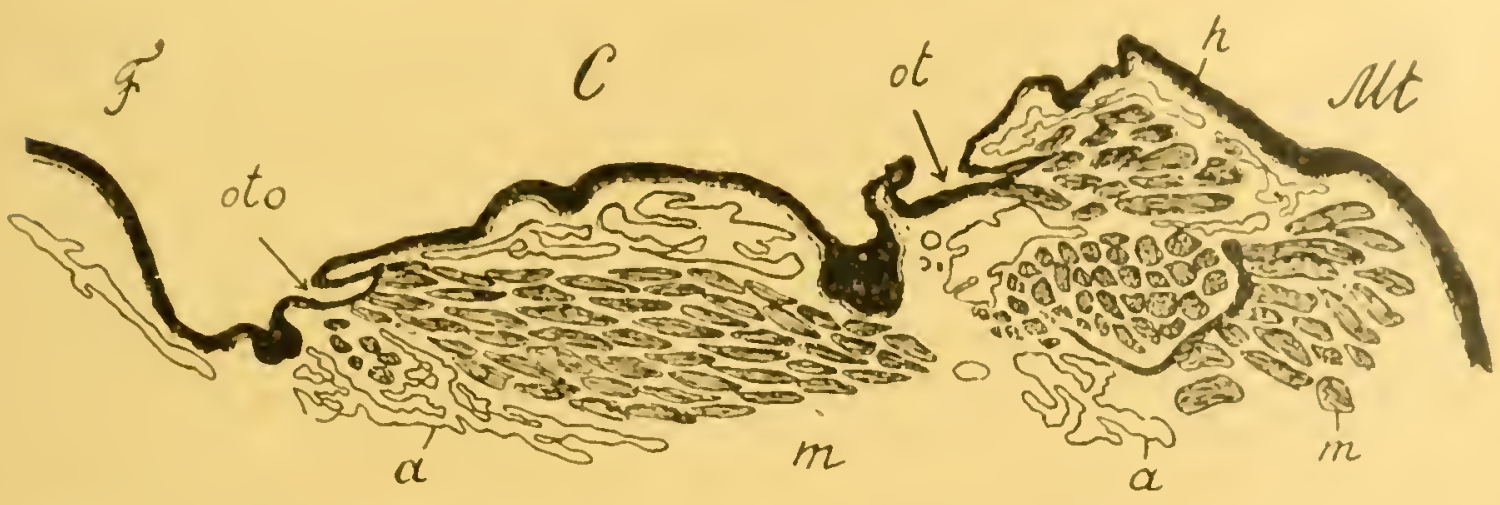

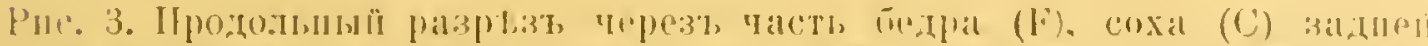
nurl

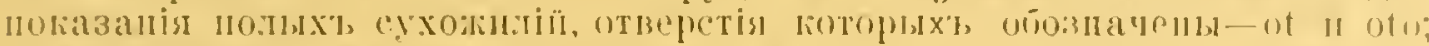

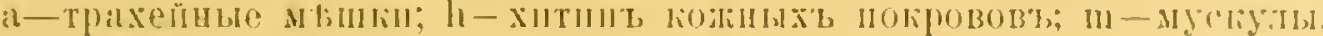

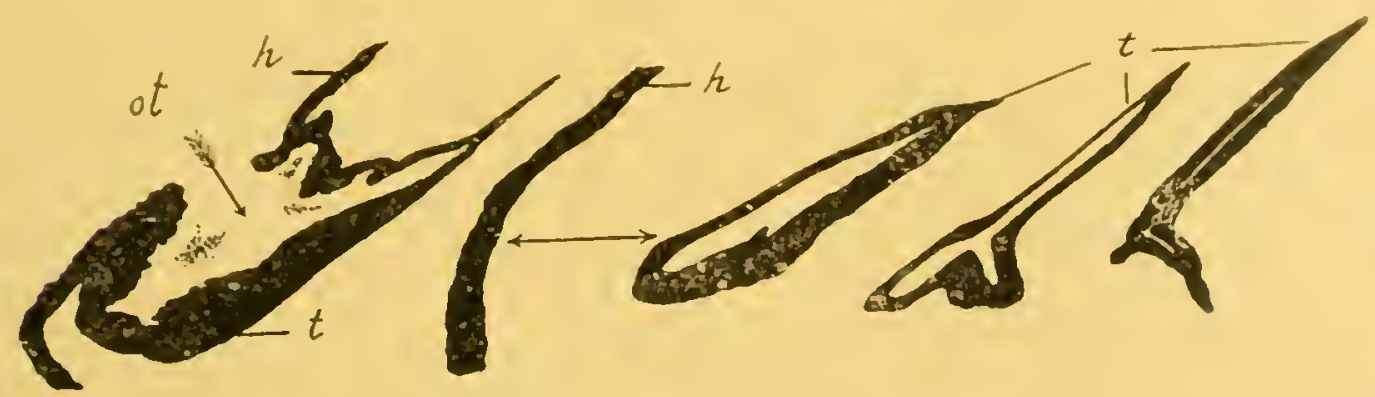

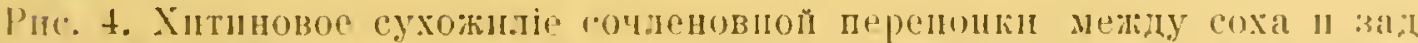

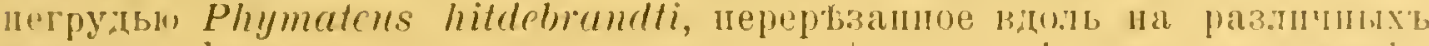

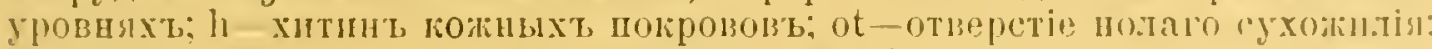
t-хитнит, сухонилія.

Болье короткое сухожилје перенонки между соха " бедромь также было замкнуто на своей вериинж. По иросмотрбнныльь ıрепаратамъ я не могу категорически рбшить вошроса-служать ли эти полыя сухожилія для выведенія крови изъ твла или

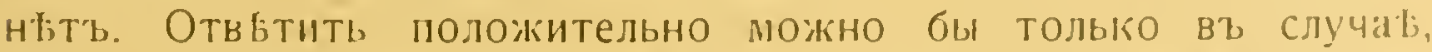
hогди наськомое убито въ моленть выведенія крови и воронка сухожилія при этомъ не спалась. Лишь при такихт условіяк" Н. А. Хоподковскому (4) удалось установить правильное мвстоположеніе " наличность поръ, служацихъ у личинки 
Cimbex (Trichiosomn ritellince) для выбрасыванія крови изъ тбла. Въ закрытомъ же состояніи эти поры не видны даже и на срғзахъ. Так' и по отношенію къ моимъ препаратам'ь можно было бы иримвнить толкованіе, что воронки полыхъ сухожилій имъютъ на концахъ своихь отверстія въ полость твла, но отверстія эти закрыты. Наконецъ, еслі принять во вниманіе литературныя данныя, то оказывается, что для выведенія крови даже не требуется въ нбкоторыхъ случаяхъ наличности предсу-

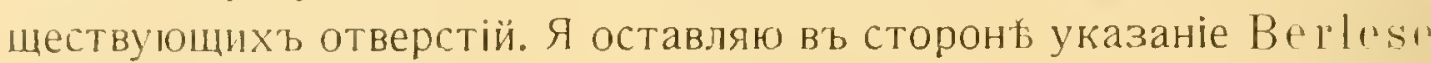
(1), что у Meloe кровь можеть просачиваться сквозь мягкую соч-

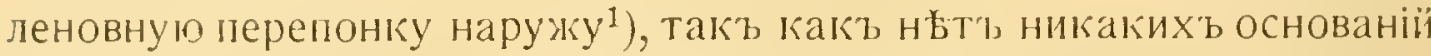
допускать возможность проникновенія плазмы крови и форменныхъ элементовъ ея сквозь неповрежденные гиподерму и хитинъ. Holland (11). наблюдавшій явленіе автогеморрагіи у 111 видовъ насыкомыхъ²), различаетъ четыре способа ея:

1) Разрывъ кожныхъ покрововъ въ тонкихъ мћстахъ подъ вліяніемъ увеличенія внутриполостного давленія (напримьрь, по краю элитръ Teleرlloлиs. въ сочленовной перепонке́ брюшныхъ члениковъ Lygaens, личинокь Coccinellidas и пр.).

2) Выворачивающіеся кожные мбшки наполняются кровью и лопаются (Ephimnigera brumeri Bol., Gryllus campestris L.).

3) Кровь выходить путемь отклейки (décollement) сочленовной перепонки въ мъстћ прикрғпленія сухожилія мускула (феморотибіальное сочлененіе жуковъ-Meløe, Н(аlyzи).

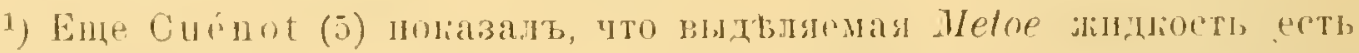

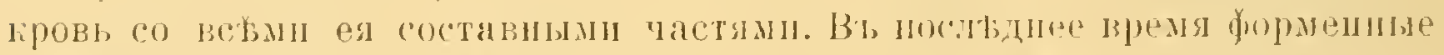

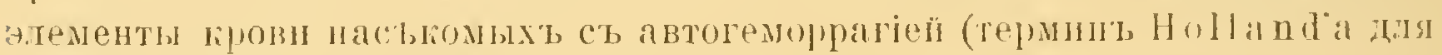

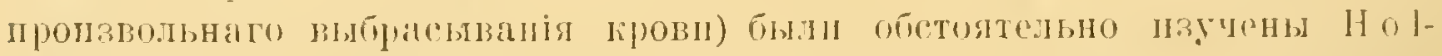

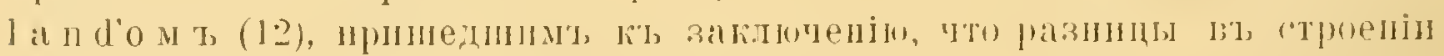

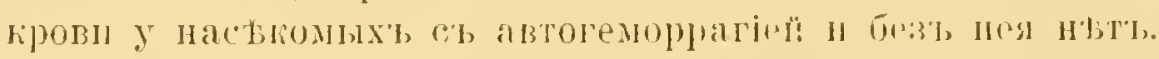

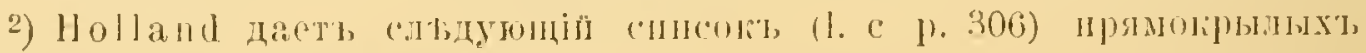

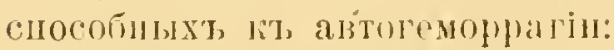

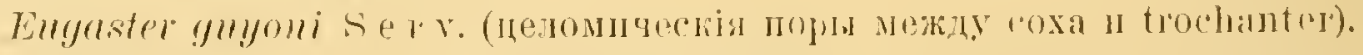

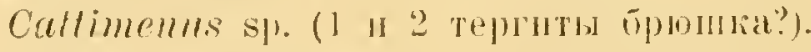

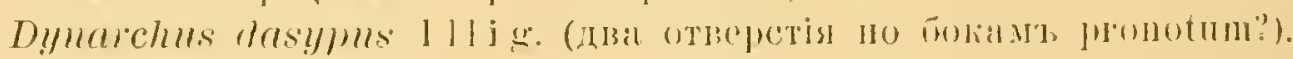

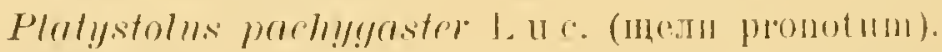

Ephiphigera mammeri Bul. (résicules sanguints).

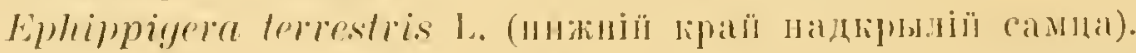

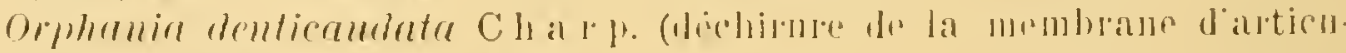
lation enture hanches et trochanters).

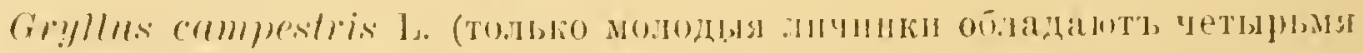

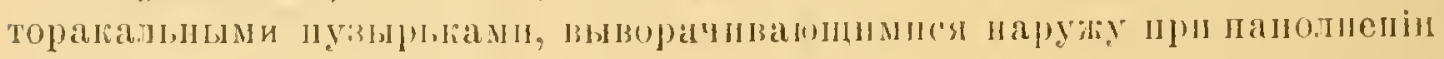

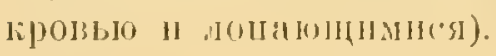




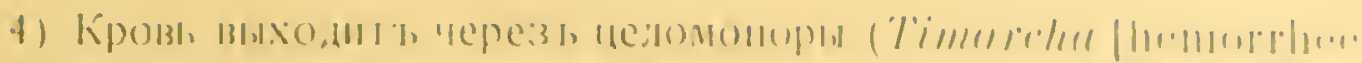

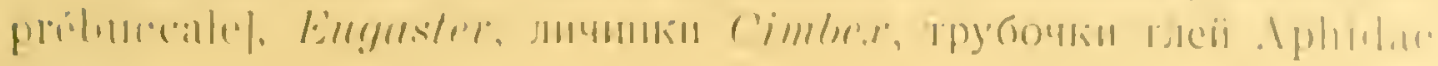
11 др.)

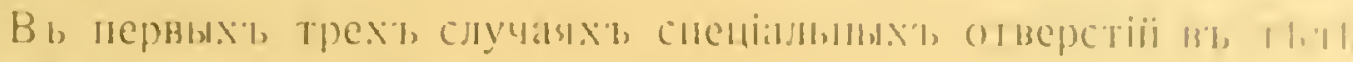

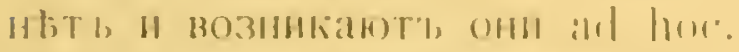

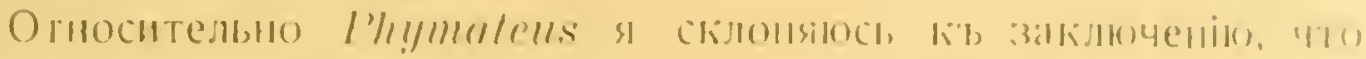

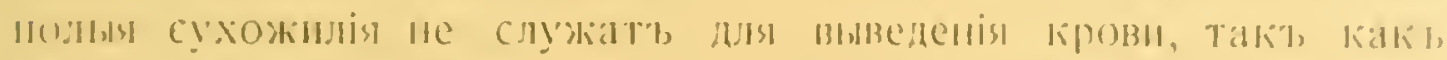

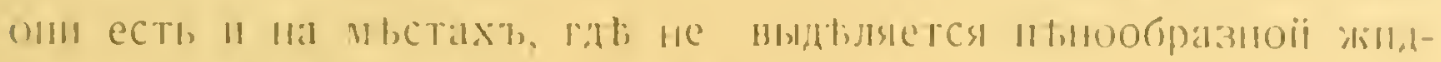
hости. напринырт, между соха и бедром'

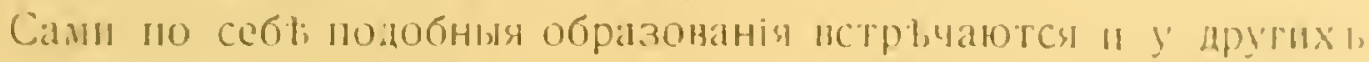

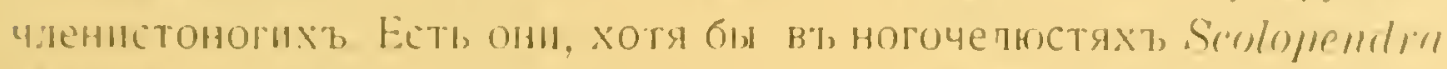

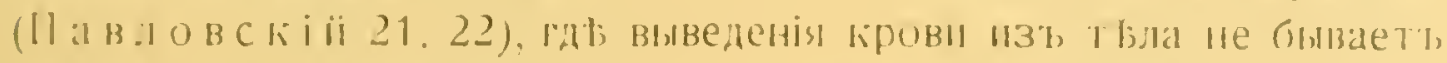
никогла. Изъ ириведенных"ь сообраненіі иытекаетт, что иля

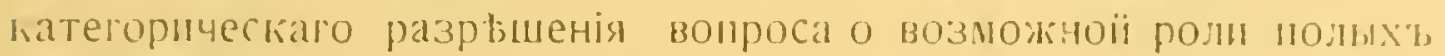
сухожилії при процессь автогеморраніи необхонио изсль;довать свжжую нли фиксированную жшдкость. выдћляемую пасткомымъ; суднть же пин, по сохраненному вь, спирты или друтихт реактиважь матеріалу о характерь выдтляемої жидкости и снособности насњкомаго къ самопронзвольному вынусканію крови

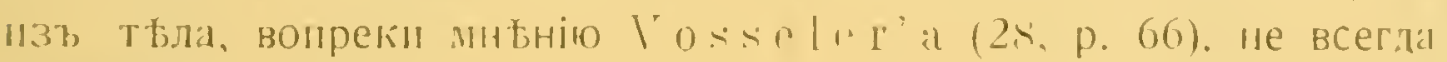
возможно "легко.

Придя кт такому заключенію, сльдуеть направит, пзсльдованіе по арыгому путы " обратить вншманіе на строеніе первыхт. двухъ члениковт брюшка, изъ склалки между которыли и ироис-

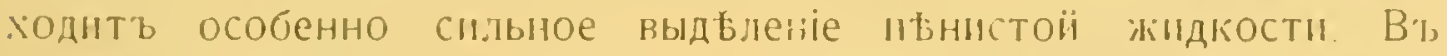
верхне-боковыхъ частяхь тергита перваго членика брюшка I'/!!ииtell: номыщается съ каждой стороны твла надь тимпанальнымь органомь но сильно развитої мышетчатой железь (рис, 5, 6, 7, 8, 1)) лежащеї нодъ гиплермой. Каждая железа открывается въ глубны складки кожных’ь покрововъ между первымьь и вторныъ члениками брюшка, rдt mылется особая расширенная камера или полость, (рис. 5, Ао, 0). На переднеіі стғнк'; этой камеры. насколько ниже мьста открыванія железы есть глубокое виячиваніе гиподермы въ полость тьла. Виячнваніе имъетъ форму иилиндической трубки

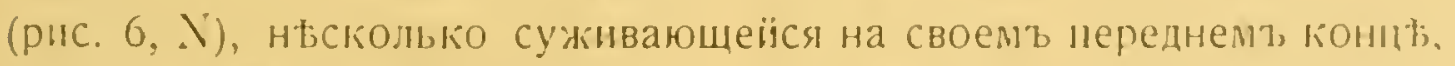
кீь которому прикрыпляются небольие пускульные пучки. Напрашивается предположеніе, что указанная трубка можеть служиты для выхода крови изъ тьла наружу, но доказать этого нельзя,

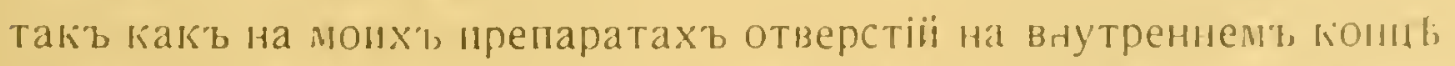
этоиі трубки не видно. Косвенным свндытельствомъ вт, полизу высказаннаяо сооблаженія пожетъ служить характеръ мынит, ири- 


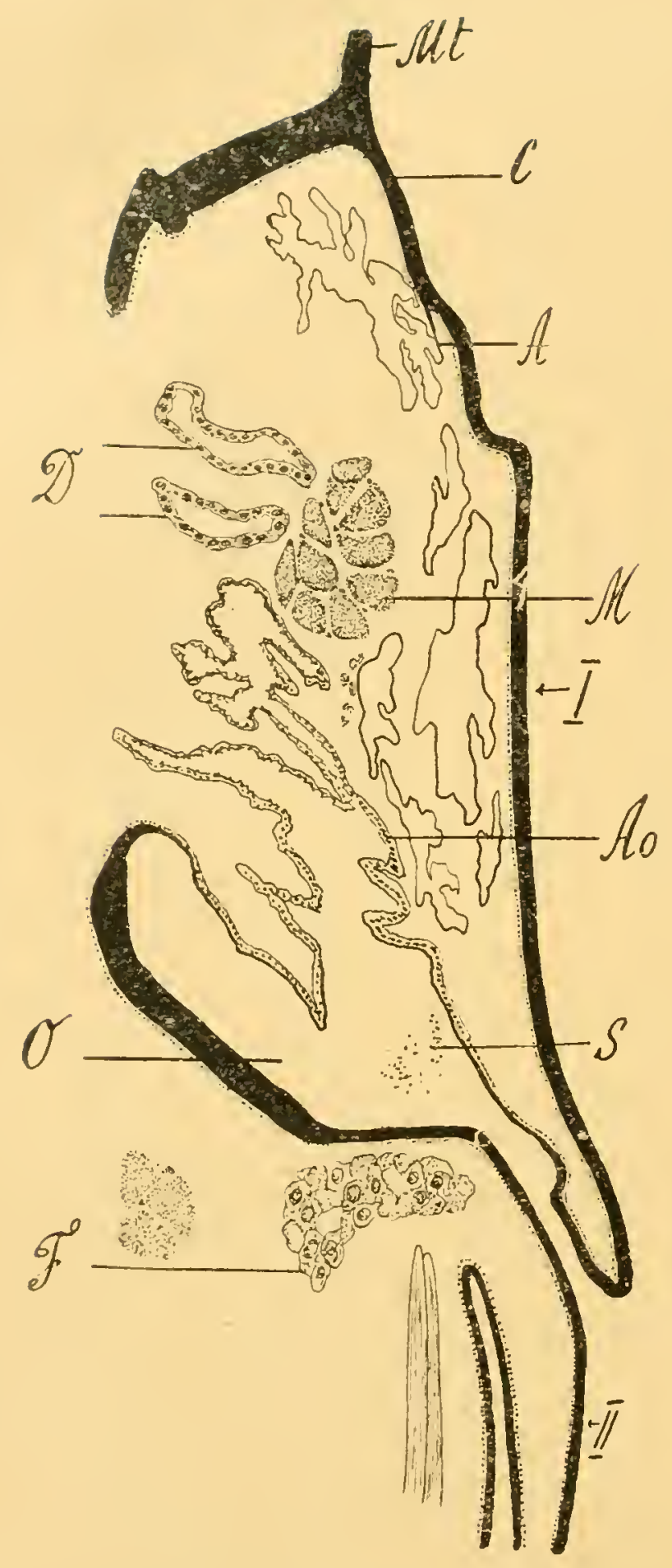

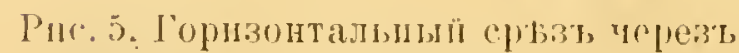
нервы й и част, второго тлениновт,

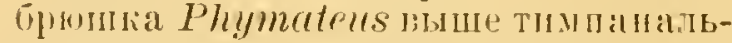
nalo annapata. Buдno внаденir (Ao)

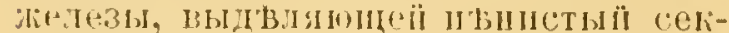

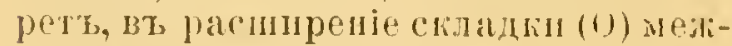

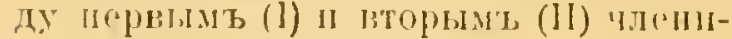
камп бйонка.

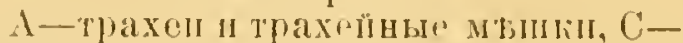

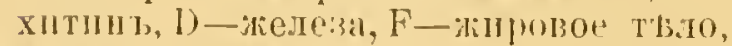

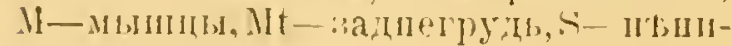
стьй секретт.

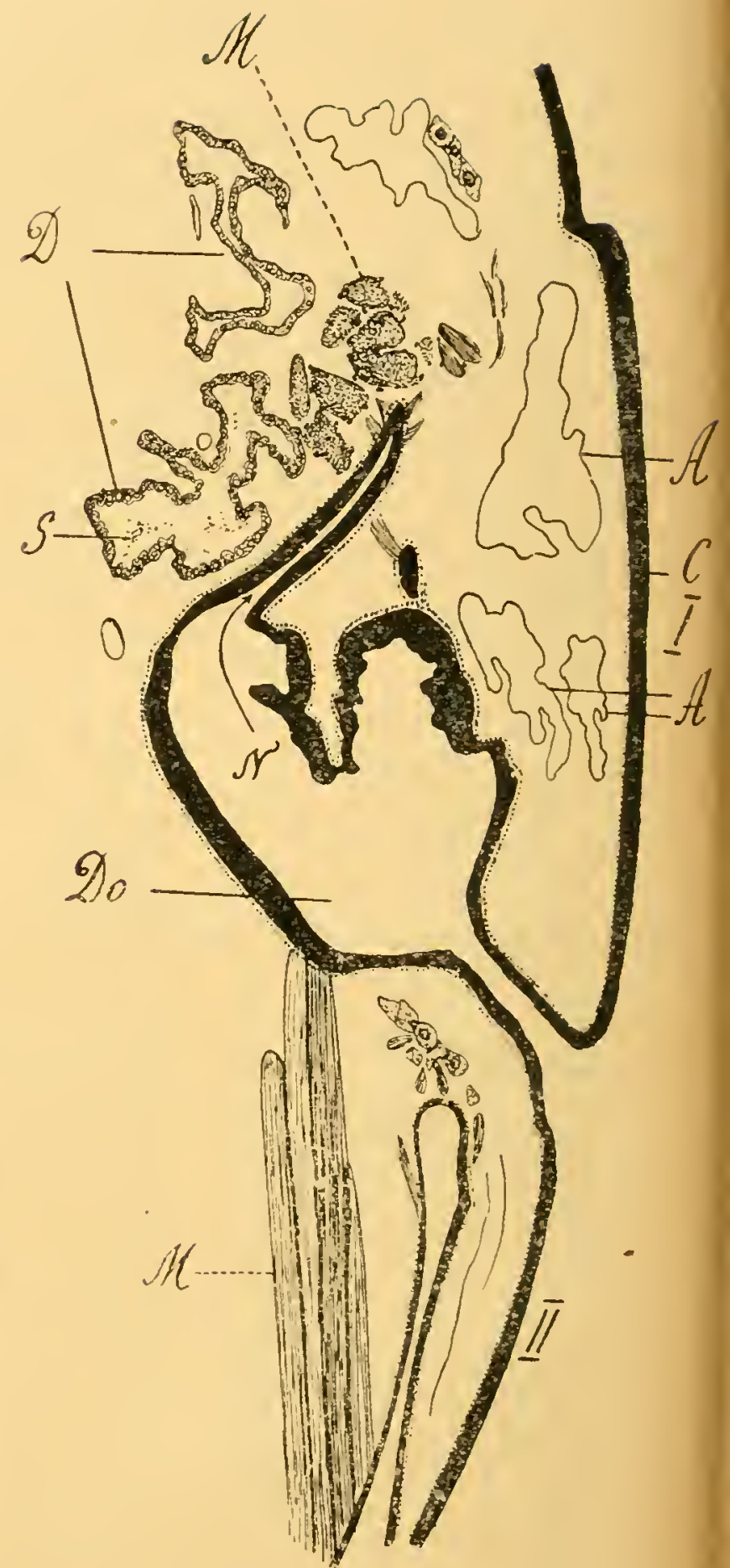

Рис. 6. Срцаз пзт той же серіи, уто II pле. 5, поо на немного болье низ-

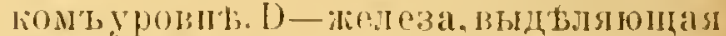

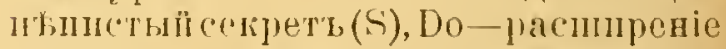

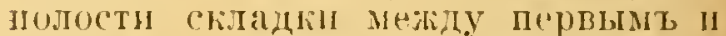
вторым' тлениками бришна, отт,

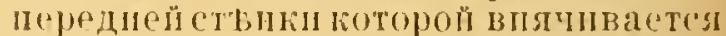

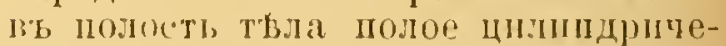

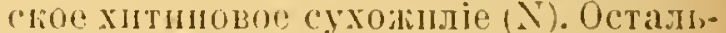

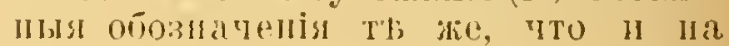
fill : 5. 


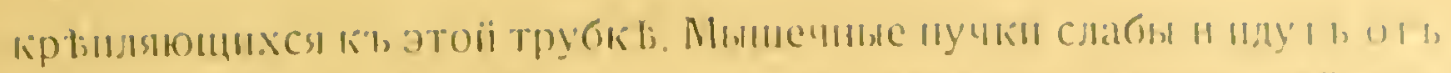

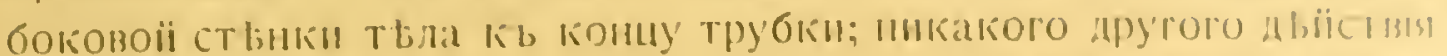

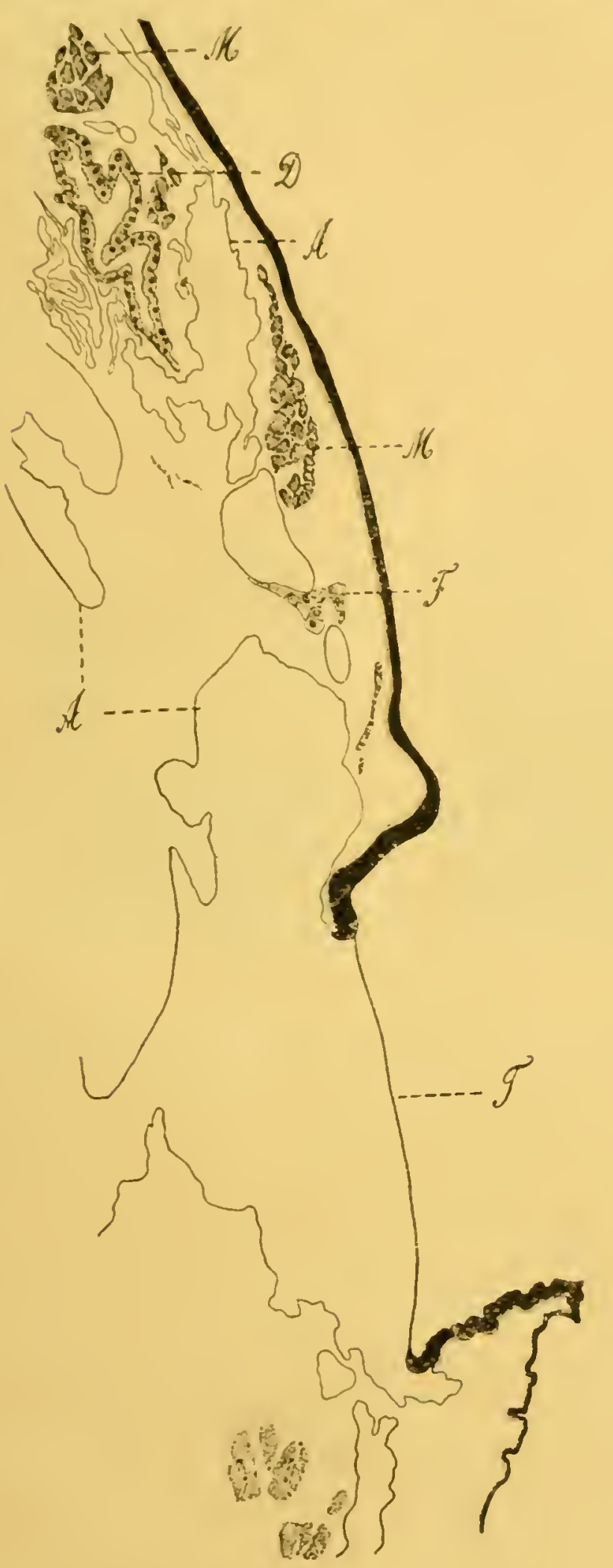

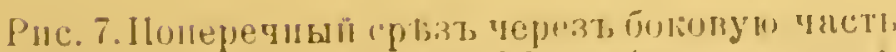

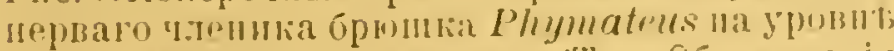

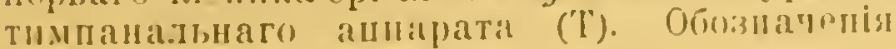

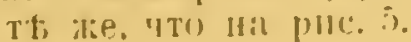

кроиl; Hallp)siaclls es,

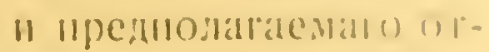

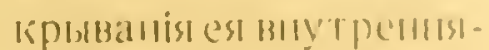
ro komla oll, nuckush. куу nожіlо судыты на основаніи исп():11,30ваннаго матеріала, производить не могуть.

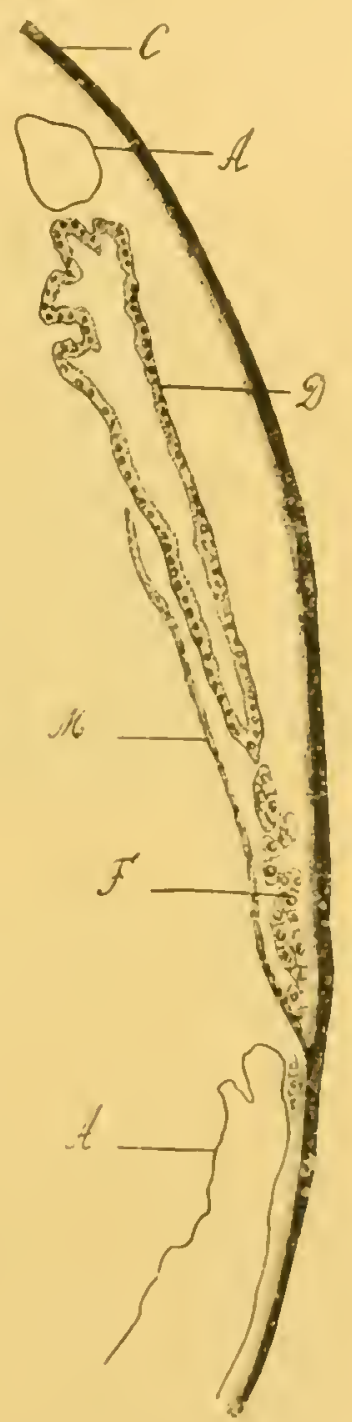

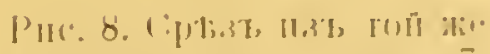

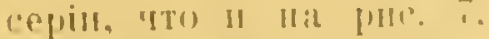

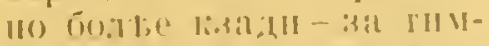
Hat

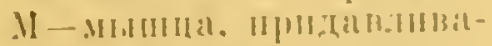

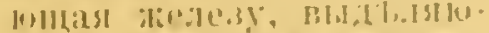

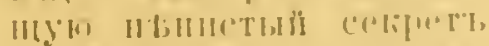

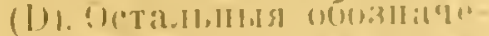

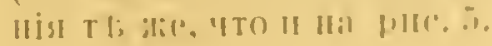


Возвращаясь снова къ бокової железъ, имюющей складчатыя стьнки, нужно отмбтить присутствіе въ ея задней части узкой вертикальной мышечной ленты (рис. 8, М), натянутой между точками кожныхъ покрововъ, лежащихъ выше и ниже железы. При своемъ сокрашеніи эта мышца оказываетъ давленіе на стЕнку железы и на ея содержимое. Мышечное снабженіе железы въ общемт очень слабо и выведеніе секрета происходитъ главным'ь образомъ на счетъ увеличенія внутри-бр.иного давленія, дъйствуюıцаго равномбрно по всей поверхности органа.

Железа находится въ тұсномъ сосддств б съ трахеями " трахейными мбшками, нмғющими на препаратах'ь сильно складчатую форму (рис. 5, 7, 8, А).

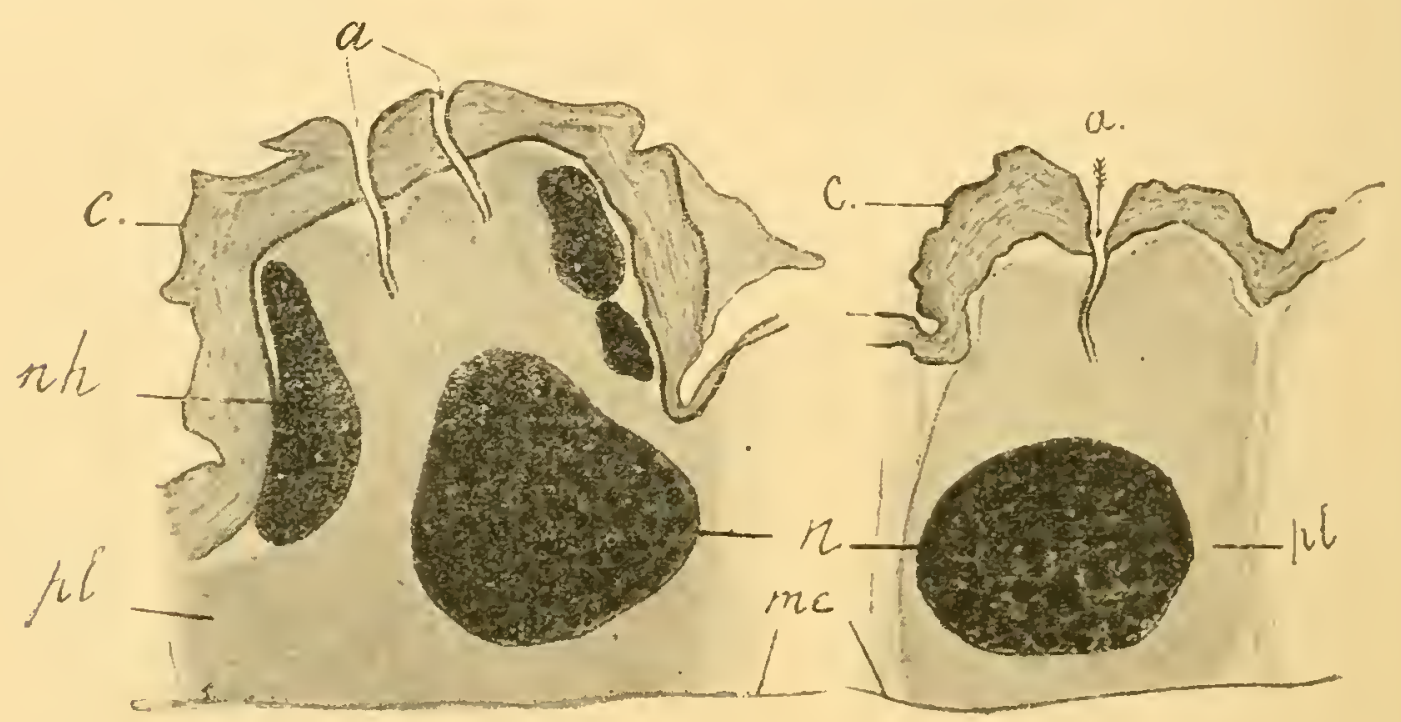

Pиг. 9. Часть стынғи железы. выдыляицей пвнообразный секреть.

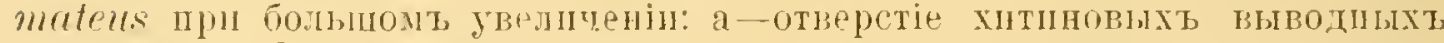

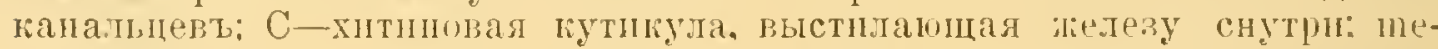

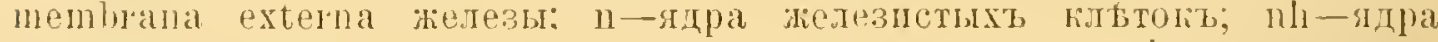

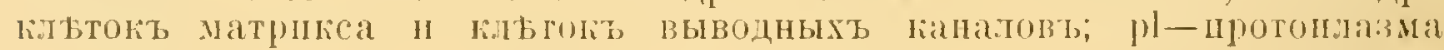

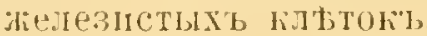

О микроскопическомъ строеніи железы можно сдълать слғдующія замъчанія. Снаружи она одъта тонкой membrana exterlla c’b ядрами (рис. 9, те); подъ ней лежить слой кубическихъ или цилиндрическихъ железистыхъ клғтокъ съ крупными ядрами въ нихъ (рис. 9, pl, н). Со стороны полости железы эпителіі покрытъ хитинової кутикулой (рис, 9, 10, с), отъ которой отходятъ в’ь железистыя клютки тончайпіе, хитиновые же канальцы, (рис. 9, а. рис. 10, d), служащіе для выведенія секрета. ПІодъ хитиновой кутику лой лежатъ ядра кльтокъ матрикса (рис. 9, иh) (непосредственнаго продолженія гиподермы) "кльтокъ выводныхъ каналовъ, хитиновыя части которых’ы только что были упомянуты. 


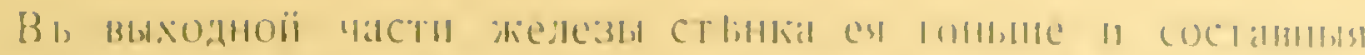

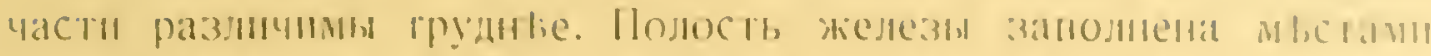

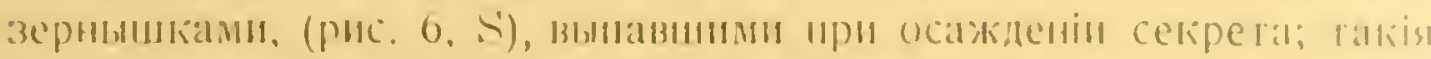

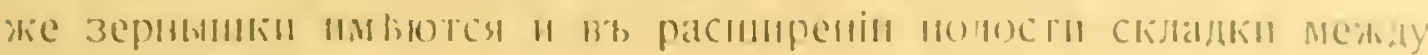

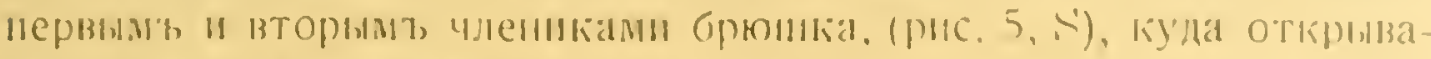

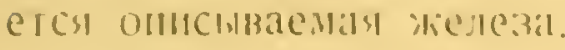

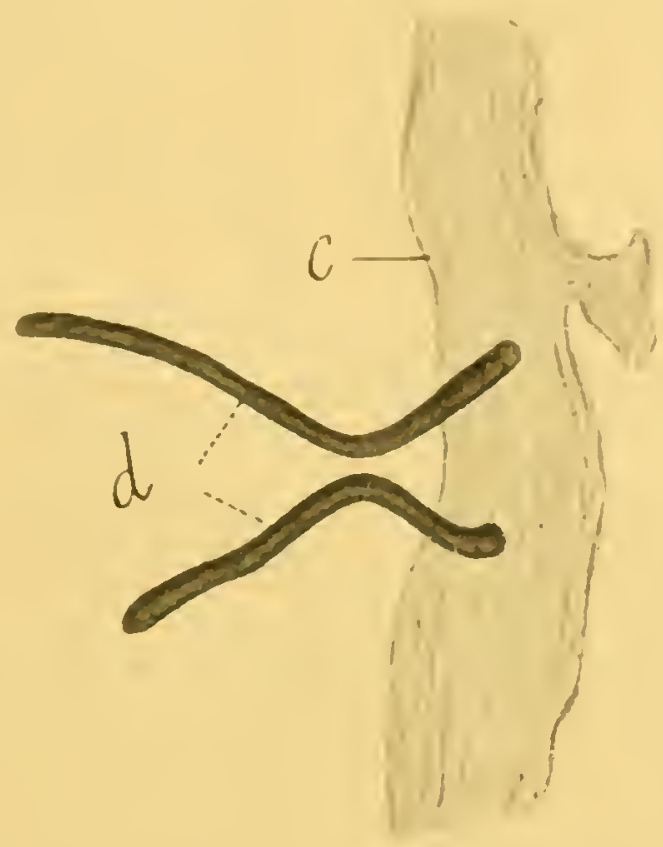

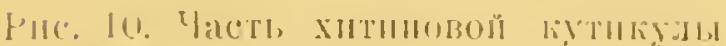

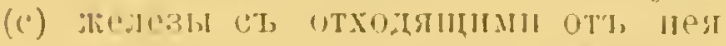

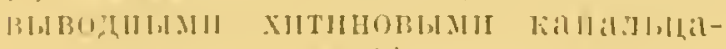
IIII (1).

Въ морфологическомъ отношеніи этоть органъ долженъ быть отнесенъ къ групп иғшетчатыхъ штеиновсихъ железъ. Типъ штеїновских' железъ характеризуется твм', что основнои структурної единицеї органа явля отся двђ кльтки-железистая " выводная, иронизанная хитиновымъ канальемъ; эти клғтки всегда лежатъ подъ гиподермой, дающей въ мғшетчатых" " вообще въ сложныхъ железахъ слої так', называемаго матрика.

Чрезвычайно сходныї по микроскопнческому строенію органт, описаль также у саранчевыхъ lossole l (2S) поды названіеми пахучеиі железы (Stiukdriisen). У Oednlens smo!nulensis his.

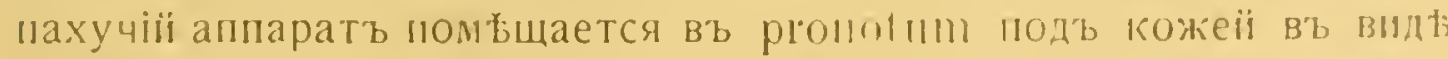
трехугольнаго, способнаго выворачиваться наружу, мtика: dist обратнаго впячнванія его служатъ особые мускулы. По микроскопическому строенію своему железа ()erlulnus тождествснна

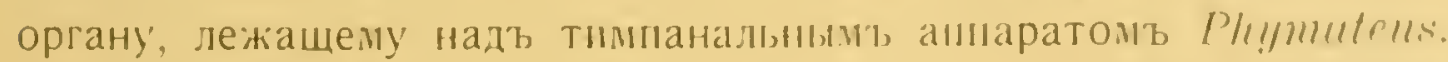
только железистыя кльтки первої болье уплощены. Интерссно 
что Vosseler видъль и нарисоваль всь характерныя черты строенія пахучей железы Oedaleus, но не вполнб оцънилъ истинное значеніе ихъ, Такъ, онъ описываетъ въ стьнкъ железы три сортаи ядеръ-въжелезистыхъ клъткахъ, вънаружной tunica propria и слой ядеръ подъ хитиновой кутикулой. Онъ отмъчаетъ, что секретъ выводится очень тонкими и длинными хитиновыми трубками, иногда пронизывающими ядра (рис. 6, таб.2), и добавляетъ: „)b diese Befunde zufällig odier der Wirklichkeit entsprechende sind. war nicht zu entscheiden. Aus homologen Organen liisst sich kein Gegenstiick zu diesem Verhalten beibringen" (S. 86, 1. с.). Изъ данныхъ строенія железы Oedaleils несомнънно вытекаетъ принадлежность ея также к'ь типу мышетчатыхъ штейновскихъ железъ, который, какъ это отмъчено въ одной изъ моихъ посльднихъ работъ (23), не получиль надлежащей оцъннки въ иностранной литературъ. Между тћмъ, данныя, имъвшіяся въ рукахъ Tosseler'a, были совершенно достаточны для правильнаго толкованія типа строенія пахучихъ железъ Dedaleus. Достаточно видъть такую характерную картину строенія, которую онъ привелъ на рис. 6 таб. 2., гдъ ізображена выводная кльтка „штейновскаго комплекса“ железы съ ядромъ и хитиновымъ канальцемъ (протоплазма кльткки сильно редуцирована), чтобы отнести этотъ органъ Oedcleus къ типу штейновскихъ железъ, впервые достаточно обоснованному въ литературб Насоновымъ $(17,18)$.

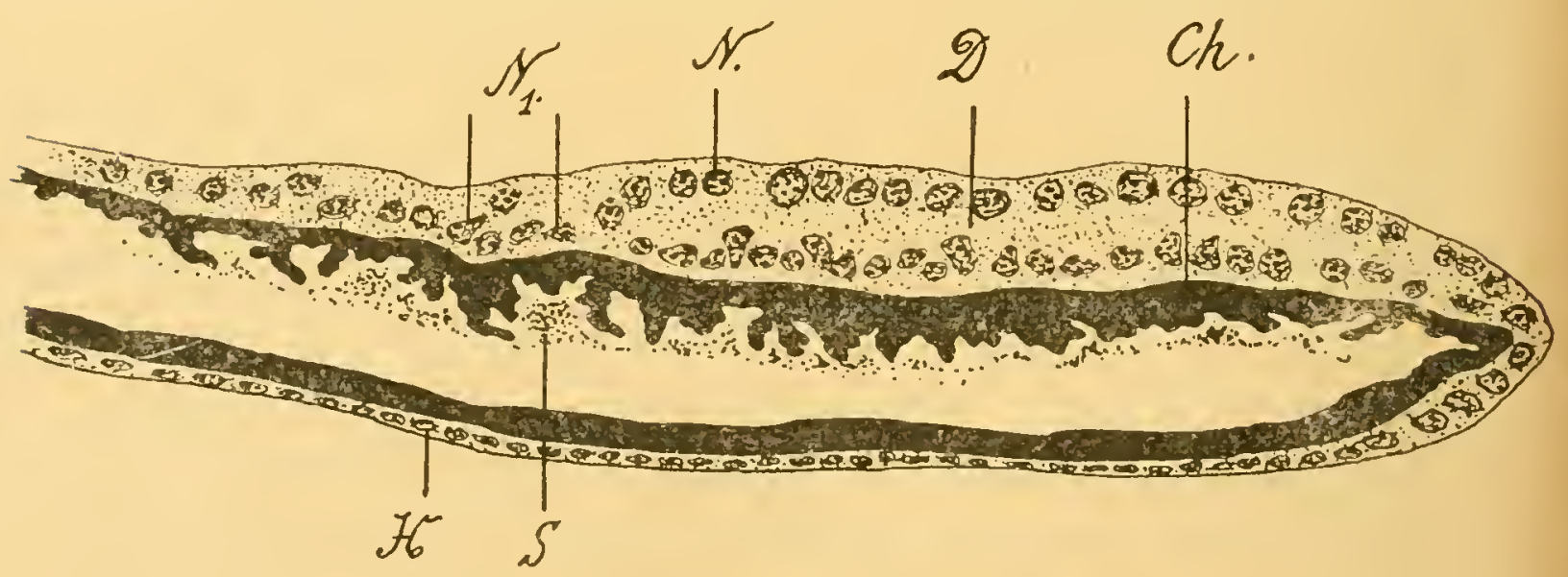

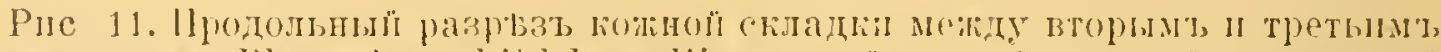

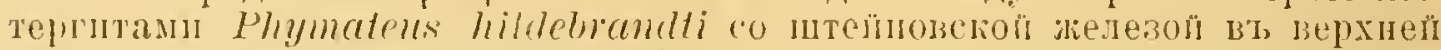

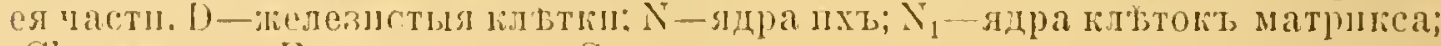
Ch-хитив: H-гиподема; S-зерпынил секрета вт полости складки.

Vosseler совершенно правильно указываетъ далғе, что пахучая железа Oedalous напоминаетъ таковые же органы уховертокь (27), состоящіе изъ одноклғточныхъ железъ, похо- 


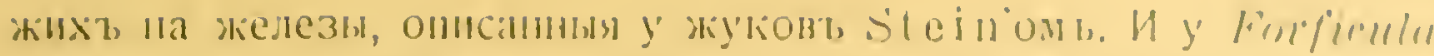

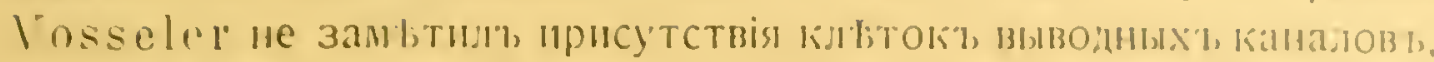

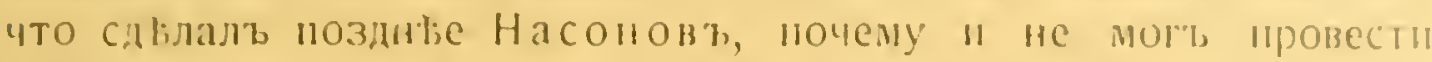

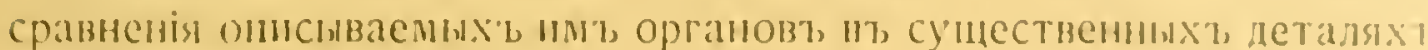

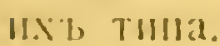

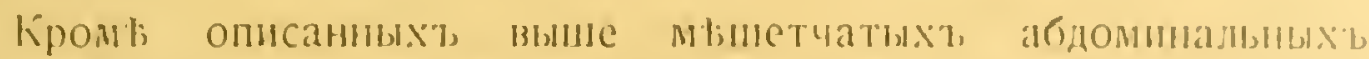
железъ, я напель еше железы на дорзалыоі поверлности складын

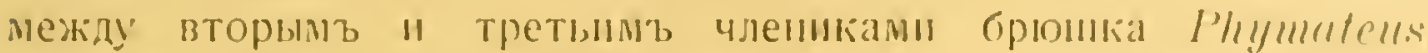

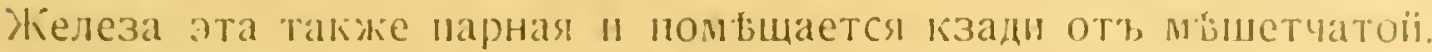
Она представляеть собою слоӥ железистыхь кльток. леканихь подт гиподермой со складчатымъ хитиновымъ покровомьь (рис. 11 ,

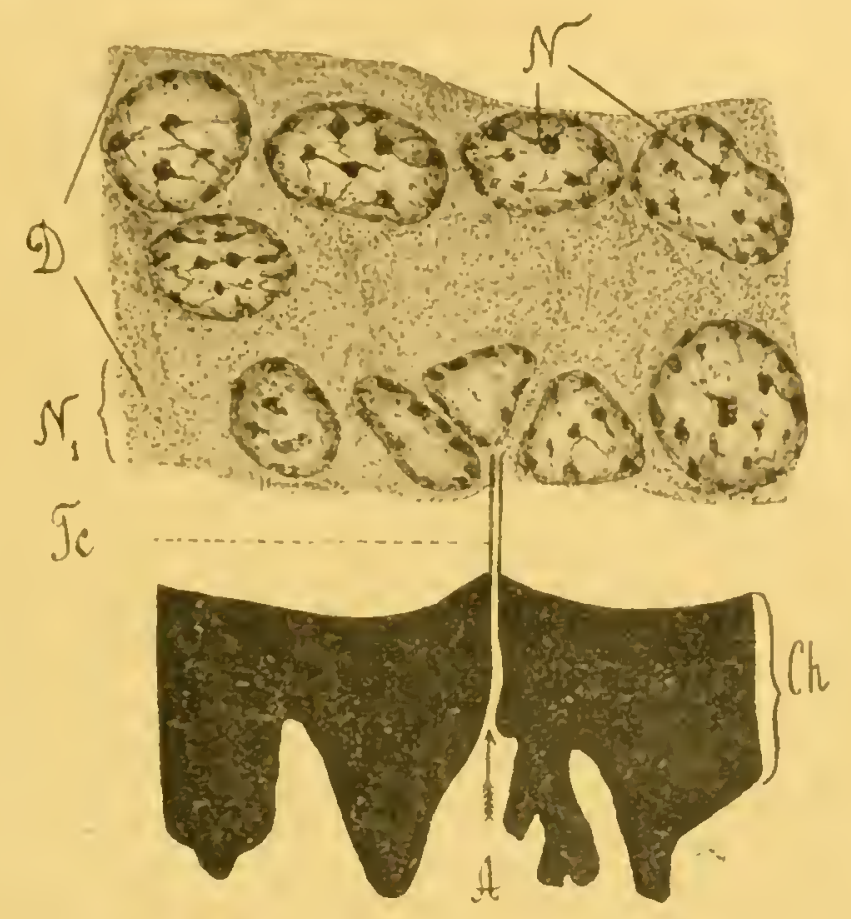

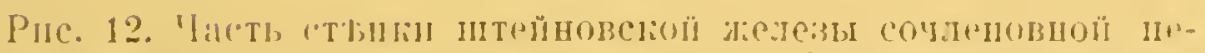

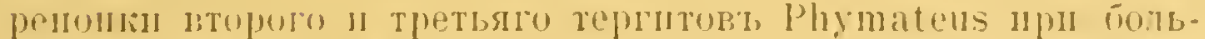

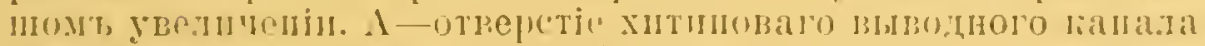

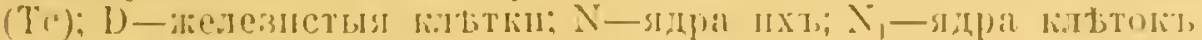

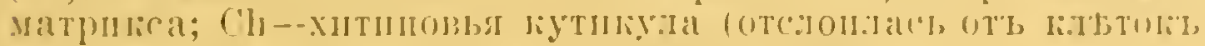

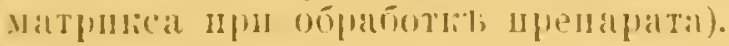

1). N. $\mathrm{N}_{1}$; Рнс, 12, [)). Посльднії пронизан хитиновыми же канальцами (ясно видными на препаратахъ съ отставшей при фиксированін кутикулой), опускающинися въ железистыя кльтки (рис. 12, Тс). Между складкаши хитиновыхъ покрововт, видны зернынки выпавшаго секрета (рис. 11, S).

Эта железа также должна быть безснорно отнесена къ штеїновскимъ, но она примитивнде вышсописаниой млшетчатої 
железы, такъ какь представляетъ собою лишь железистое поле образованное тбсно прилежащими другъ къ аругу штейновскими комплексами.

Образованія, близко сходныя с', этой железої, имъются у прочихъ прямокрылыхъ. Естественно вспомнить пахучія железы тараканов"ь, къь каковой групів относятся авторапи различные органы. У $\zeta^{\prime}$ q Periplanetr orientralis no Minchin' y $(15,16)$ " К Кульвецу (14) пахучія железы помғщаются въ перепонк между тергитами $V$ и VI члениковъ брюшка. Кульвец у указываеть, что эти органы имғютъ видъ подушкообразныхъ выпячиваній сочленовной перепонки. Хитиновая кутикула железы несетъ вЕтвящіяся полыя щетинки, служащія для выведенія секрета. Насоновь (17) даль полробное описаніе ихъ микроскопическаго строенія и причислилъ къ групп в мышетчатыхь штейновскихъ железъ. R. М. Н allison (10) нашла въ 1906 г. также у обоихъ полов` Periplaneta orientuli: непарную мғшетчатую пахучую железу 1), открывающуюся по средней линіи твла между стергитами шестого и седьмого члениковъ брюшка. В o l d a s (2) за пахучую железу ठ ㄹ Periplaneta orientalis ir $P$. americana счель органъ в’ виды реторты, открывающійся наружу подъ половымъ отверстіемъ. Въ отношеніи Periplancta неясно, всъ ли три железы дъйствительно пахучія или

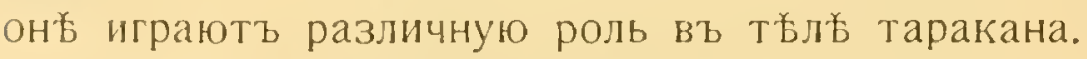

Самцы Phyllodromia germanica также имьють пахучія мћшетчатыя железы на шестомъ и седьмомъ тергитахъ брюшка. На тергить седьмого же членика Ectobia lapponica открывается двураздальная пахучая железа. Аналогичное образованіе находится

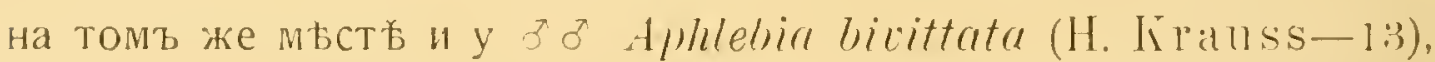
железа котораго, впрочемъ, отличается присутствіемь большого количества хитиновыхъ волосковъ на своей внутренней поверхности. Функиія этихъ органовъ объясняется также предположительно.

железистые мвшки Plyllodromia yermanica, описанные впервые Наase (9), были изсльдованы въ 1906 году Oettinger омъ (19). Этотъ авторъ разспотрғл'ь детали строенія железъ, но далъ имь неточное толковлніе. Клутки выводныхъ каналовъ (рис. 5, (I, таб. IV: Курсъ энтомологіи Насонова) онъ считаеть за опорныя клғтки железы (Stiitzzellen), к' каковымъ относить

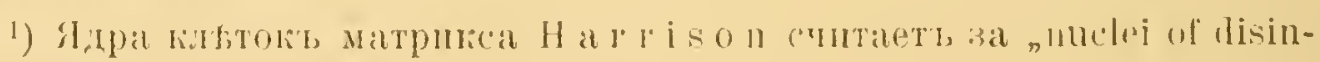
tegrating colls" (n, fig. $6,7,12$, T.XII). 


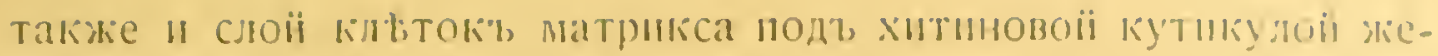

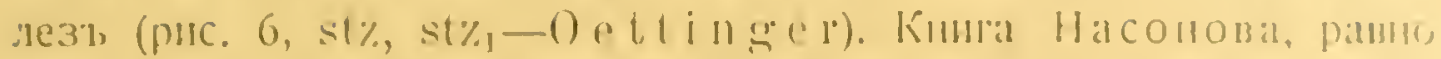
какт, и работа Кульнеца, Oе

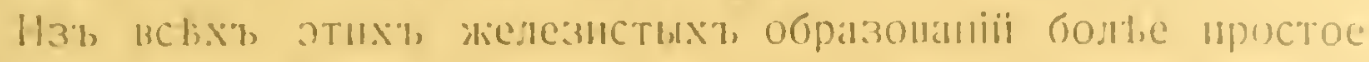

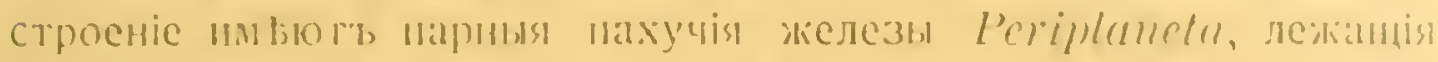

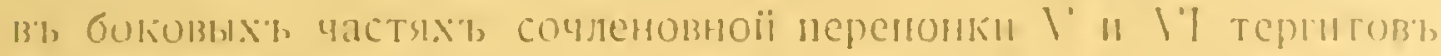

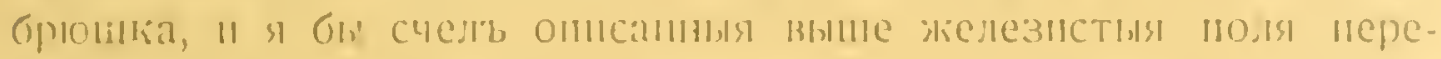

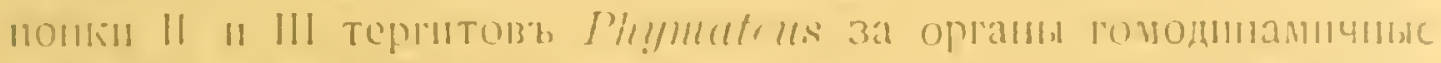

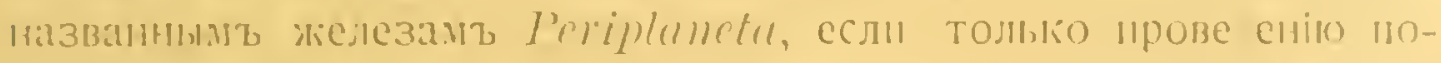

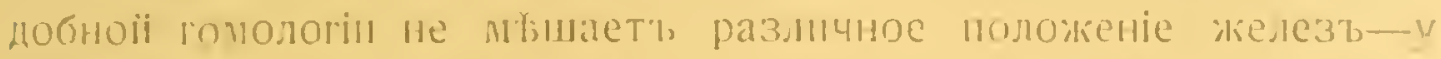

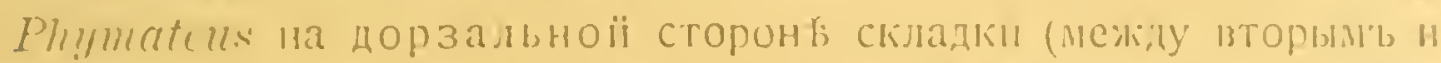

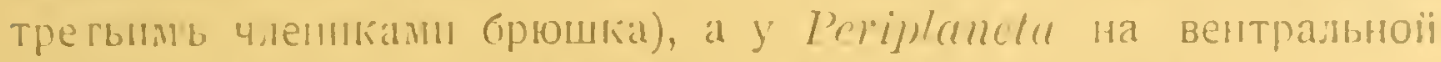

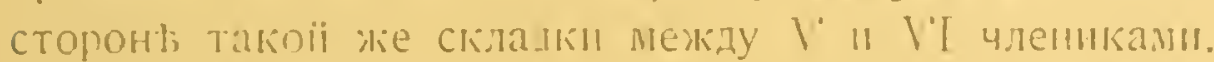

Визвранаюсь теперь къ установлсніо связи между кожной секреціей l'hymatens и его железами. Наибольс сильное выдъленіе птнообразной жндкости происходить изь складки между первыль и вторымъ члениками брюшка насъкомаго. Какъ показало пропзведеннсе анатомическое изслъдованіе, въ эту складку открывается съ каждоӥ стороны твла по объемистой мбшетчатой железъ штейновскаго типа. Въ полости железы имєиись зерна секрета такого же вида, что "вь складкғ между члениками брюшка, въ полыхъ сухожиліяхъ " другихъ углубленіяхъ на поверхности тбла. Отсюда можно сдълать только одинъ выводъ, что описанная мвшетчатая железа даетъ, пьнообразную жидкость, покрывающую насъкомое, если его взять въ руки. ${ }^{2}$ )

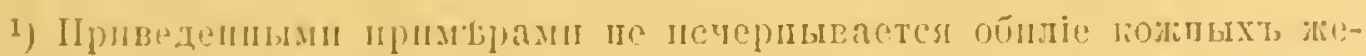

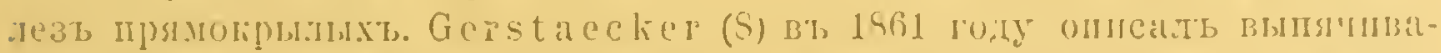

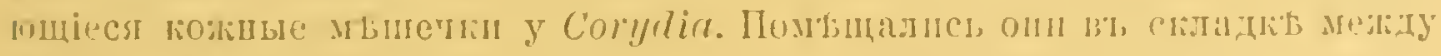

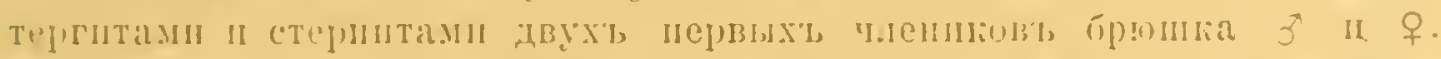

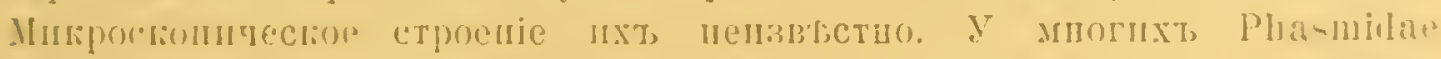

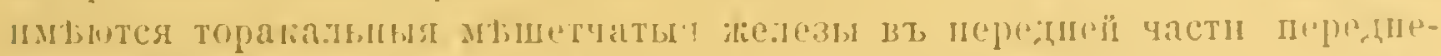

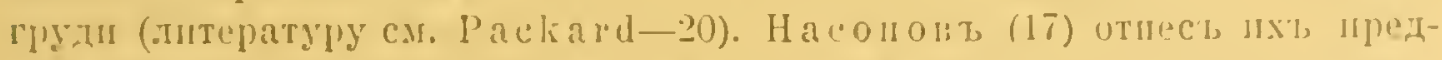

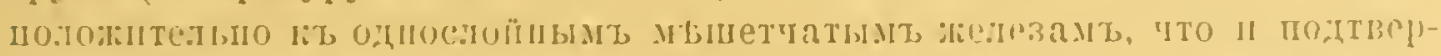

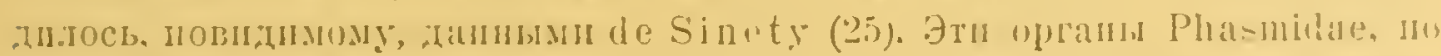

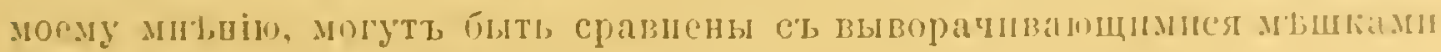

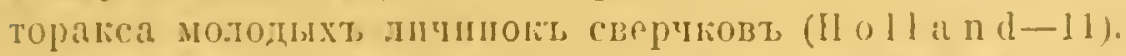

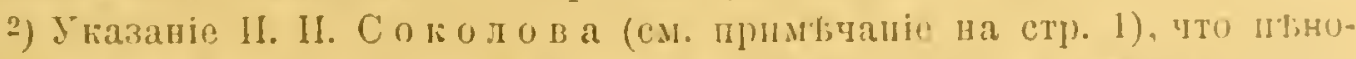

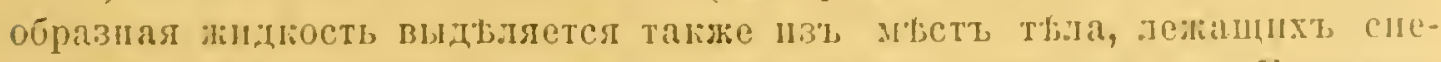

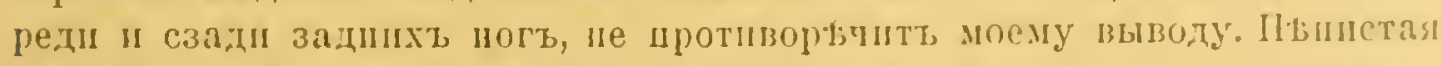

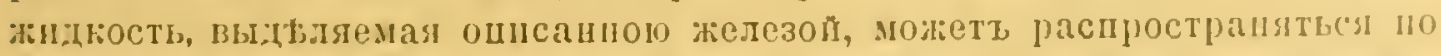
складкы менду первымъ и вторымь члениками брюнка и выстушать

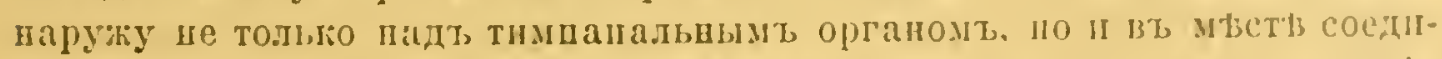

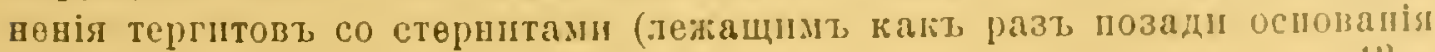


Установить причастность крови къ образованію пъны нельзя, потому что ни на одномъ поломъ сухожиліи не видно отверстій, которыя могли бы служить для выведенія крови наружу. Если и

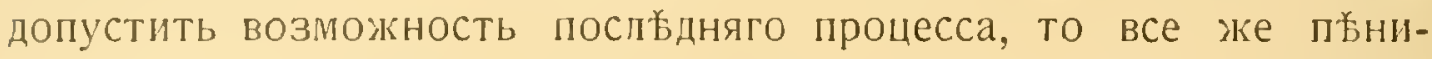
стый секретъ сльдовало бы въ такомъ случағ считать по крайней мъръ за смъсь крови и секрета боковой мъшетчатой железы, совсъмъ не принимать которую въ соображеніе основаній нътъ.

Кожныя железы, гомодинамныя, по моему мнйнію, парнымъ пахучим в железамь Periplaneta orientalis, едва ли играють какую нибудь роль въ образованіи пънообразной жидкости вслғдствіе своей незначительной величины и топографическаго

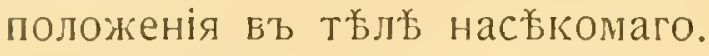

Соображеніе, что пахучая железа Oeclaleus, тождественная по своему строенію боковымъ железамъ Phymateиs, выдъляетъ не пънистый секретъ и выворачивается наружу, особеннаго значенія не имъетъ, такъ цакъ железы весьма близкія и по строенію, "по функціи нербдко вырабатывають вещества довольно ръзко разнящіяся по своимъ физическимъ свойствамъ. Можно вспомнить общеизвбстный примғръ-жука боло́ардира (Brachymus crepitans), секретъ анальныхъ железъ котораго кипить при температурғ ншже-150. Благодаря этому жукь выбрасываетъ изъ своихь железъ облачки газа, тогда какъ другія жужелицы выдъляют'ъ жидкость, правда легко испаряющуюся. Dytiscus же пользуется маслянистым секретомь анальныхъ железъ для смазыванія краевъ надкрылій и брюшка, благодаря чему вода не можетъ проникать въ пространство между элитрали и брюшколь, гдғағ помғщается воздухъ, необходимый для дыханія жука (объ анальныхъ железахъ жуковъ см. D і сlсkх 6, 7).

По отношенію къ Phymatens можно предположить, что секретъ его боковыхь мұшетчатыхъ железъ обладаеть значительною вязкостью. Если такая жидкость будеть медленно выдавливаться черезъ узкія шели, то естественно при смъшиваніи съ воздухомъ возникнетъ пъна, которая и покроетъ твло насъкомаго.

Интересно было бы изсльдовать цругое прямокрылое-Callimemus, у котораго происходитъ выдъленіе какой то жидкости изъ

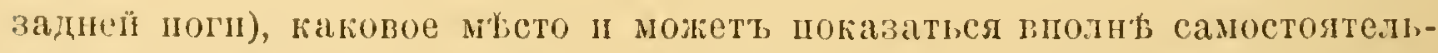

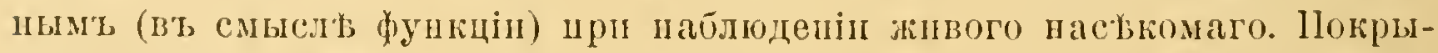
вающій тьло пънистй секреты, поладаеть естественно во всякіл складки н виадны кожвыхь покрововъ. Этим и объясняется шрнсутствіе зерпистаго секрета въ нолости сухожнліи соченовныхъ перөпонок между соха и прилежацими уастями тыла и задней ноги (рис. 3). 
склақи между ||

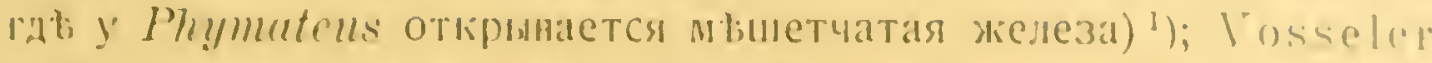

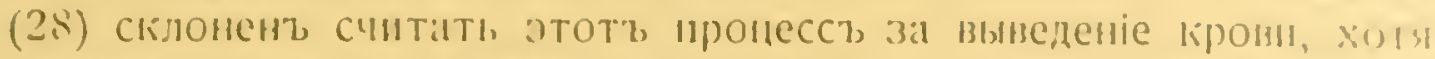

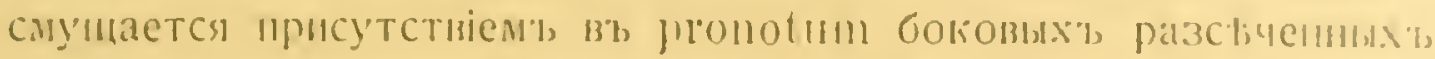

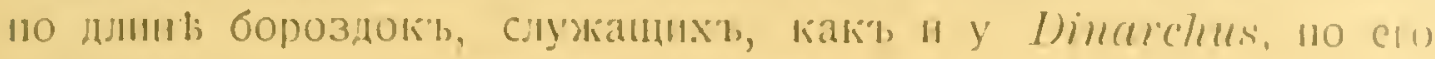
предиоложеніо, лия иниеденія крови.

Выбрасываніе крони через' склани между теритами толык не брюшка. а груди наблюдаль Holla l] (1 (11) у молодыхъ личинокт сверчка. Mягкая сочленовная перепока образовывала чстыре выпячиваюшихся мынечка (1о два съ каждоӥ стороны), которые под7, давленіемъ крови выворачнвались наружу " лопались.

Выдыленіе пинобразнаго секрета кожными железами у насћомыхъ явленіе рыдкое. Я могу иривести только один'ь до нћкоторої степени подходящіі примбрь-личинокъ пьнницы (Aphrophor" spumaria), отличающихся тb»ъ, что пвна, которої онъ окружены, nостоянна, а Ply!matels выдтляеть итнистый секреть лишь по м. руз надобности. Поскольку трудно бываеть иногда правильно объяснить то или другое біологнческое явленіе явствуетъ изъ

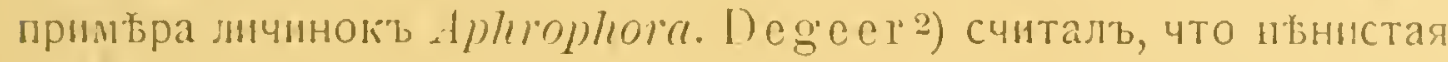
жидкость выталкивается изъ заднепроходнаго отверстія личинки. Polt а видълъ в'ъ жндкости секретъ кожныхъ однокльточныхъ железъ, въ которыиі пузырьки воздуха вносились валиками

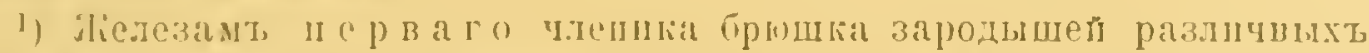
nactions

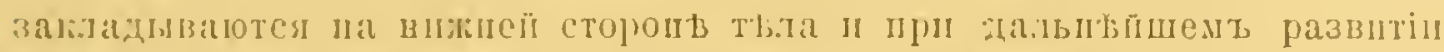
yoryto nepent,

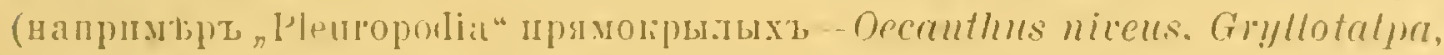
Struobothrus mo $1 V^{\circ}$ loelery [On the appendages of the first abdominal Sugment of Embryo Insects. Transact. of the Wiscousin Acalemy of sciencer.

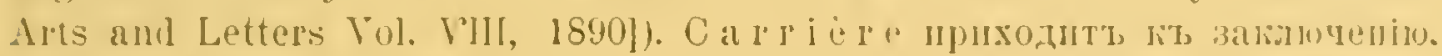
"To dirse Drüse. Welelie ilre Hauptentwickolung im hotzten Drittel des Embryonallebens gewinnt, muss nach allem als oin wohl ausubiletetos cmbryonalis Oron betrachtet werden, nicht als rullimentäres, etwa len Beiuanlagen der Bienenembryone vergleichbares“ (1. c. 1. 126). Эти жеслезы.

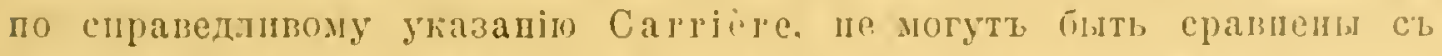

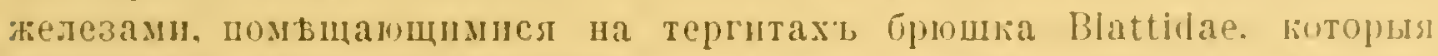

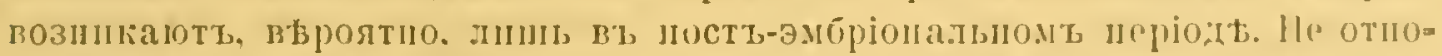

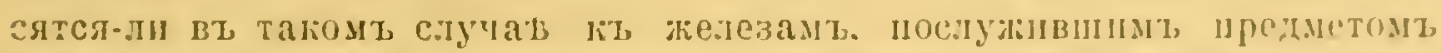
работь Wh e le r’a

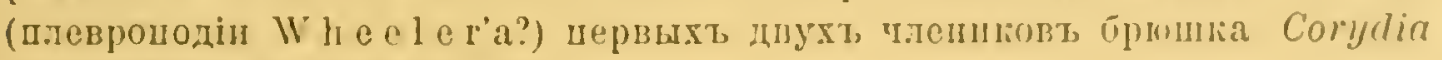
(см. прнмтгане иа стр. 17).

2) Jитература обт, Aphrophora spumaria uриведена y sulc'a (26) и

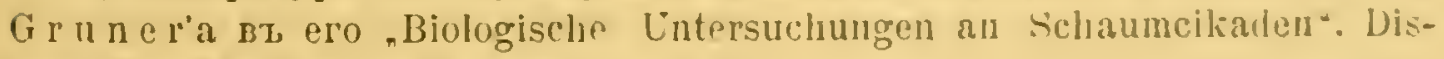
sertation der Berliner Lniversitit. 1901. 
тергитовъ. Gruner допускалъ выталкиваніе воздуха изъ задней пары дыхалецъ въ жидкость, выходлщую изъ анальнаго отверстія. Sulc (26) даетъ иное объясненіе. Жидкость выходитъ изъ кишечника, въ ней есть энзимы, расшепляющіе воскъ, выдъляемый кожными железами 7 и 8 члениковъ брюшка. Благодаря присутствію щелочей образуется своего рода мыльный растворъ, в’ь который воздухъ вдуваетсл воздухоноснымъ каналомъ брюшной стороны тюлла, благодаря чему и образуется пжнистая жидкость.

Выдъленіе п务нобразнаго секрета Phymatels можно считать защитной реакціей и поставить въ причинную зависимость отъ нея отсутствіе способности к'b автотоми заднихъ ногъ, а также и наличность вь природъ множества дефектныхъ особей, о которыхъ пожно дулать, что онж подвергались нападенію насъкомоядныхъ животныхъ, но вышли изъ опасности лишь съ нбкоторымъ физическимъ ущеро́омъ для сео́я.

I. XI. 1915.

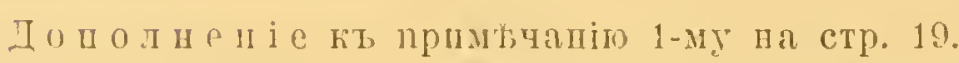

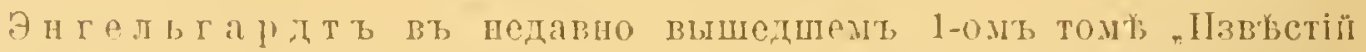

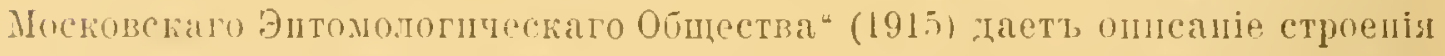

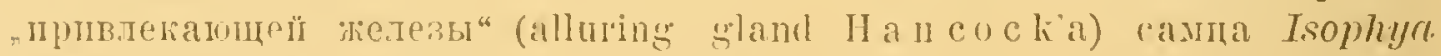

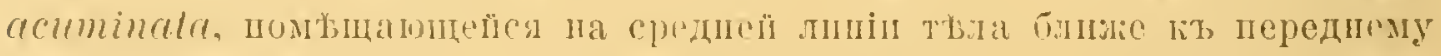

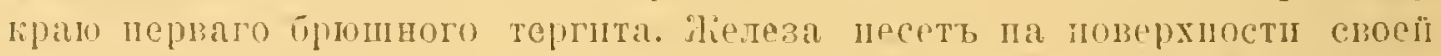

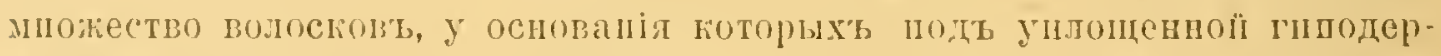
мой лежатт, железистыя и текогенныл клитит. Вт, ойем'т, железа устpoena гораздо проце, нежели гомодогичй оргапь самцов Oecanthus fasciatus (Hancock, Amer. Nat. 39: 1905), относлиійсл по Энгсль г рдту (1914, Zool. An\%. К. ХL/') къ штейниским, желсзамъ. Болдырев' (1913)

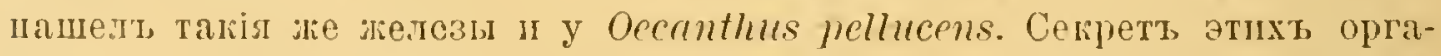
повт пождастел самкой при копуляцін. Вопрось этоть съ біологптеской сторопы подробно освнщатея Болдыревы м в в его работахт о сперматофорахь и кошулядіи различнхт прлмокрылыхт (посльднля работа-Матеріалы иъ познанію строеніл сперматофору и особенностей спариваніл у Locistodea и Gryllodea. Тр. Русск. Эит. О-ва вт Петрогр. T. XLI, 1915). 


\section{Цитированная литература.}

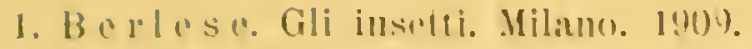

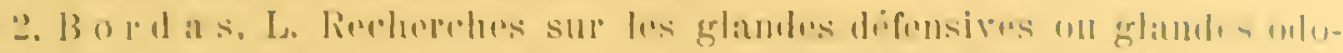

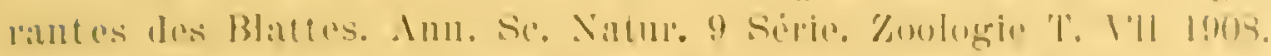

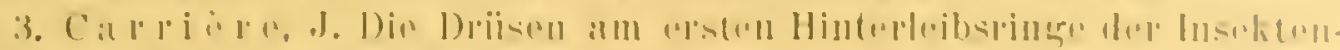

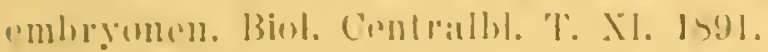

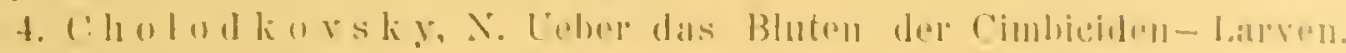
How. Sim. lintom. lioss. T. 30. I \9k.

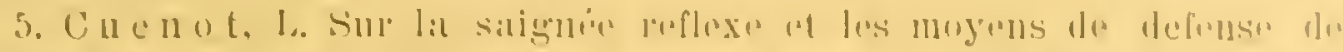

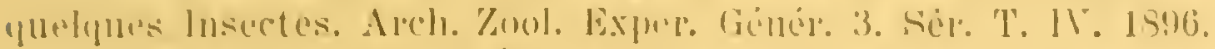

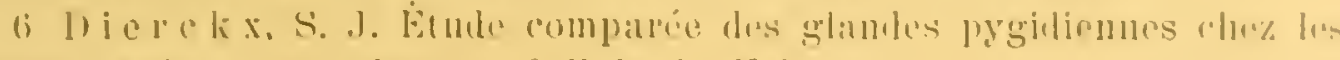
Carabiles at les Iytiscides. lai Cellute. 'I'. XYI. 1899.

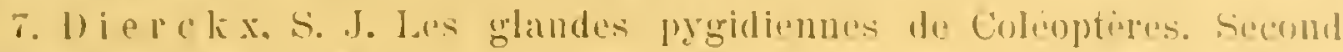
Mimoire. Ibillem. T'. Xlill.

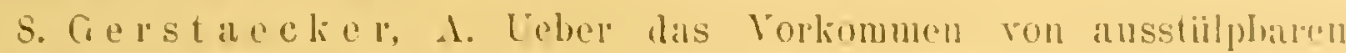
Hantanhängen am Hinterleibe der Schaben. Arch. l'. Naturor. 'l'. 27. 156il.

9. II a a se, E. Zur Anatomie der Blattiden. Zool. Anz. 1889. 'T. XII.

10. H a r is o ll, R. M. Preliminary Acconnt of a New Organ in Periplaneta orientalis. Quart. Journ. Microsc. Sc. N. S. V. 50. 1906.

11. Holl a nd, A. Ch. Liantohémorrhée ou le rejot du sang chez les Insectes. (Toxicologie du sang). Aleh. Anat. Mier. T. 13. 1911.

12. H o 1 l a nd, A. Etude histologique comparéc du sang les Insectes it liémorluée et des Iusectess sans hẻmorrhée. Alch. Zool. Expérin. Génér. 5 Silie. T. VI. 1911.

13. Kra uss, II. Die Duftdrïse der Aphlebia bivittala Brullé (Blattidae) rou Teneriffa. Zool. Anz. T. XIII. 1890.

14. Кульведъ, К. В. О колиыхт железахт Orthoptera II Hemiptera Heteroptera. Bapmaв. Уиив. IІзв. 1898 г.

15. If inchin. Note on a New Organ and on the Structure of the Hypodermis in Periplaneta orientalis. Quart. Journ. Microsc. Sc. N. S. T. XXIX. 1859.

16. If i $1 \mathrm{c}$ h in. Further Observations on the Dorsal Gland in the Abdomen of Periplaneta and its allies. Zool. Anz. T. XllI. 1890.

17. Н а с о н о т. Куреь энтомологін. В. 1. Козиые полровы. Варшава. 1901.

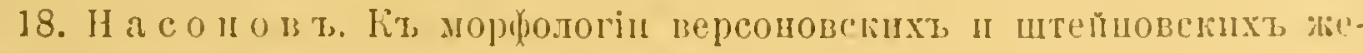

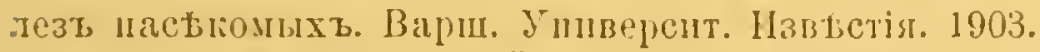

19. Oetting er, R. Über die Driisentaschen am Abdomen ron Periplaneta orientalis und Plyllodromia germanica. Znol. An\%. 1900. T. ХХХ.

20. P a ck a l d, A. S. Literature on delensire and repunguatorial grands of insects. Journ. New Jork Entomolog. Socicty. Vol. IV. 1590.

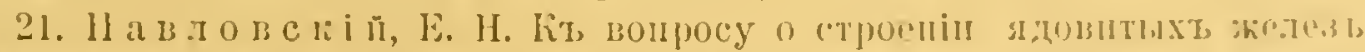

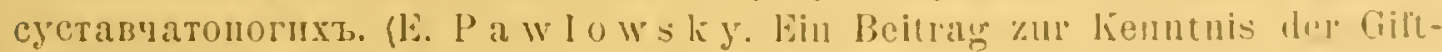

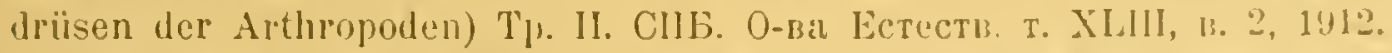

22. P a w l 0 s k y, E. Ein Beitrag zur lienntuss des Baues der Liftdrüsen von Scolopendra molsitans. Zool. Jalntl. Abtl. Anat. T. 36, 1913.

23. Paw low s ky. Celper den Bau der Stunlidriisen von Gnaptor splinimamus Pall. (Coleoptera. Teuebrionidae) im Hinblick auf die Morploblo- 
gie der Stein s clı e n Drüsen. Pycck. Энтом. 0бosp. Rev. Rus. d'Entomol. T. XV. 1915.

24. П а в ло в с к і й, Е. Н. Кь методикь обработиі сръзовъ съ хитиноиыми частями. Тр. II. Петр. О-ва Естеств. Отд. Зоол. Т. XLVI, выш. 1. 1915.

25. d e S i n íty, R. Recherches sur la biologie et l'anatomie des Phasmes. Lierre. 1901.

26. Sulc, Karel. Uber Respiration, Tracheensystem und Schaumproduktion der Schaumciliadenlarven (Aphrophorinae-Homoptera). Z. Wiss. Zool. T. XCIX. 1911.

27. Vosseler. Die Stinkdrüisen der Forficuliden. Arch. Mikr. Anat. T. 36.1590.

28. Vosseler, J. Beiträge zur Faunistik und Biologie der Orthopteren Algeriens und Tunesiens. Zool. Jahrb. Abth. Syst. T. 16, Heft. 2, B. 17. Heft. I. 1902.

29. V o s s e l e r, J. Ueber Anpassung und chemische Vertheidigungsmittel bei nordafrikanischen Orthopteren. Verhand. Deutsch. Zool. Gesellsch. 1902. 


\title{
On the anatomy of Phymateus hilde- brandti (Orthoptera. Phymateidae) in connection with the peculiarities of its dermal secretion.
}

\author{
E. Pawlowsky.
}

(From the Zoulogrical Labolatory of the Imperial Military Mealical Acarlemy)

'The material that served for this work was taken by Y. A. Inogial and T. I. Sokolor in the neighhomrhood of Najrobi and Mabilat. Phymateus hildebrandti (the specimen presejered als a sample was determined by N. N. Adehng) drew attention owing to its capability of discharging on the surface of the hody al foamy fluid, which is discharged thicfly from a lold between the 1 and 2 abdominal segments, when the insect is taken in the hands.

'Tw" suppositions maly be made concerning the nature of this fluid. It is either secreted by glands, or it is the blood llowing out of the body. Owing to the lack of any data as to the aspect of the fresh fluid under a microscope, the question has to be solved by anatomical investigation. At an extermal examination of the bases of the hind legs of Phymateus, in the articulation membrane between the coxa and metithorax, and coxa and femur, there are to be scen pores (fig. 1,2 ot) leading-as it is demonstrated in the sections-into special hollow hypodermal tendons which are directed with their apices towards the metathorax of the insect. The tendon of the membrane between the coxa and metathorax (fig. 3 ot) is longer than the same between the coxa and femur (fig. 3 oto). 'To both of them muscles are attached, and in their catvity there were traces of some kind ol gramular stufl (fig. 4 ot). The structure described has some resemblance to the pore which in Eugaster guyoni serves for discharging the blood (Tosseler, 28, 29), and has in the open state the form of a short funnel. The hollow tendon of Phymatens 
tiffers from the coelomopore (Hollande, 11) of Eugaster in its greater length and irregular shape. In all the preparations he tendons had no opening at their apex, therefore it is difficult to state positively whether the opening is really absent, ol it is closed, and in this case, of conlse, invisible. Nerertheless, I am of the opinion that it is hardly probable that the hollow tendons serve for the discharge of the blood. for they are present in such places as well, in which no foamy fluid is secreted e. $g$. between the coxa and femur.

In investigating the structure of the wall of the first and second abdominal segments above the tympanal apparatus, there are to be seen on both sides of the body under the hypoderm a sac-shaped gland with rery lolded walls. Each gland opens in the depth of the fold of the dermal integuments between the first and second abdominal segments, where there is a special widened cavity or chamber (fig. 5, Ao, 0$)$. On the anterior wall of this chamber the dermal integmments form an invagination into the body-cavity in the shape of a cylindrical tube, also blind at the end (a sort of hollow tendon fig. 6, N). The sac-shaped gland lies chiefly in the first abdominal segment, and from the interior it borders by its posterior part with a narrow muscle-band (fig. 8, M), which presses upon it in contraction. From the exterior the gland is covered by an external membrane (fig. 9. me) containing nuclei; internally to this membrane there is a layer of cubic or cylindrical gland-cells with large nuclei (fig. 9, n). From inside the gland is covered with a chitin cuticula (fig. 9, c) with a layer of cells of the matrix (derivative of hypoderm) under it (fig 9, nh). From the cuticula there lums a very fine canal (fig. 9 a, 10 d) rnto ech gland-cell serving as an outlet of the secretion out of the cell into the cavity of the gland which is partly filled with the gramules of the secretion in the preparations.

From the morphological point of view this organ must be referred to the group of sac-shaped Stein's glands. The type of Stein's glands, as it is established by Nassollor, is characterised by the fmomdamental structural unit of the organ being a complex of two cells, glandular and deferent, pierced by a chitin canal. 'These two cells lie under the hypoderm which forms in the sac-shaped and in complex glands generally a layer of the so called matrix. 
The sac-shaped gand of Phymateus loes $n 0$ prosent a typical example of Stoin's colls, as in sections the murlei nle the eolls of the deferent camils are discermed only with difficulty in the matrix layer farcording to Nassund $\mathrm{N}$ (17) the muclei and protoplatsm of hose cells may in some calsen

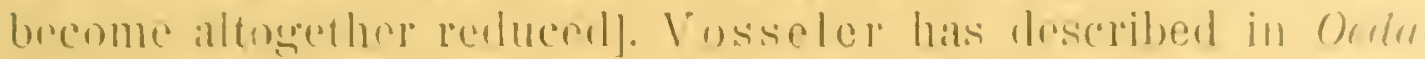

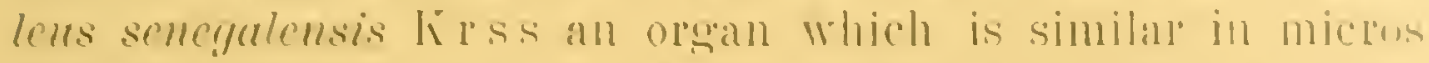
copical structure, and to molich he gave the mame of mblot ferens gland. It is situated in the pronotum muder the skin in the lorm of a triangular sac capable of eversion outside. This gland Vosseler compares with the odoriferous stand ol Forficula.

Brsides the sac-shaped abdominal gland described ahore, I have found in Phymateus two more glands on the lorsial surface of the fold between the second and third abdominal segments. Each organ presents a layer of glamdular cells lying under the hypoderm, which is covered by folded chitin (lig. 11, D, N, N; fig. 12, D). The latter is pierced by chitin canals, which is clearly visible in preparations with the cuticle exfoliated. The canals lead into the gland-cells (fig. $12 \mathrm{~A}$ ) the secretion of which falls ont in the form of grains (fig. 11, S),

This is also a Stein's gland, but more primitive than the sac-shaped abdominal gland, as it presents only a glaudular area formed by Stein's complexes of cells closely adjoining one another. Similar lormations to those dorsal glands are to be found in other Orthoptera, namely, in cockroaches. Minchin $(15,16)$ and Kinlretz (14) have described in $\sigma^{*}$ and $q$ of Periplaneta orientalis paired odoriferous glands in the membrane between the tergites of the $V^{r}$ and VI abdominal segments. Nassonor (17) has given a more detailed description of their microscopical structure and referred them to the group of sac-shaped Stein's glands.

I should consider the dor'sal glands of Plummaters as homodinamous to the dorsal odoriferous glands ${ }^{1}$ ) of Periplaneta

1) Ruth M. II ariosn (10) has found in both sexes of Periplancta an unpared sac-shaped odoriferous gland, opening on the median linu of th." body betwoen the sternitus of the VI and VIl segments of the abdomin. and Bordis (2) considers the organ in the shape of a retort opening muler the genital aperture of Periplaneta orientalis and $P$. americana as it orloriferous gland. 
orientalis, if only the establishment of such a homology were not prevented, owing to the different orientation of the glands in Plummateus on the dorsal side of the fold (between the I and II abdominal segments), and in Periplaneta on the ventral side (of an analogons fold between the $\mathrm{V}$ and VI segments).

In solving the cause of the discharge of the foamy fluid in Phymateus it is necessary to base the statements on the fact that the greatest discharge takes place out of the fold between the first and second segments of the abdomen, into which the aforesaid sac-shaped gland opens. I presume that this is the gland that emits the foamy fluid covering the body of the insect, when taken into the hands. It is impossible to decide as to the participation of the blood in forming the foam, as in none of the hollow tendons (which open into the same dilatation of the fold between the first two segments, as the sac-shaped gland) ase any openings which could have senver for discharging the blood to the exterior to be seen. Eren if the latter process be allowed for, the foamy secretion would have to be considered, at any rate, as a mixture of blood and the secretion of the sac-shaped gland.

The dermal glands which are in my opinion homodinamous to the paired odoriferous glands of Periplaneta orientatis may hardly be supposed to play any rôle in the formation of the foamy flujd, owing to their too insignificant size and topographical position in the body of the insect.

The presence of a granulous secretion in the hollow tendons of the hind legs and in other recesses and slits of the body I explain by the foamy secretion of the sac-shaped glands getting into them when it flows over the body. This secretion is probably very viscous; on account of that, when slowly pressed out, the liquid forms bubbles in mixing with air and prodnces a foam covering the body of the insect.

The discharge of the foamy secretion in Phymateus is to be considered as a protective reaction, and in causal dependence with it is to be put the rery slight tendency and possibly the complete absence of a capability for autotomy of the hind legs, the slow movements of Phymateus, and the presence of many defective individuals in nature which are supposed to have been attacked by insectirorous animals and to have escaped dauger with only slight injury for themselves. Explanation of figures. 
Explanation of finglues.

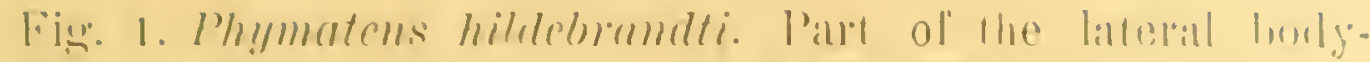
- Wall at the batse of the hind lege. I, II. III-abdominal sergments. Itt-metathotiax. C-coxa of the hind leng, li-ils lemmo In the solt articulation membrane hetween the coxal and the femtur is seen all oblipue slit-llee opening of the hollow len. ton (collesponding to oto in lis. 3).

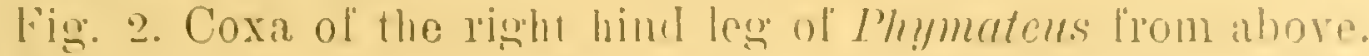
It the point of junction of the coxa (c) and metatholax (.Mi) is seen the opening of the hollow tendon (ot), corresponding to o to in lig. 3.

Fig. 3. Longitudinal section of the upper surface of the coxa (c) and the adjoining parts of the metathorax (MIt) and femur (F) of the hind leg ol Phymateus. A-tracheal sacs. h-chitin, m-muscles, ot-opening of the hollow tendon of the solt articulation membrine between the coxa and metathorax, oto-opening of a similar tendon (but shorter) between the coxa and lemur. Lens, magnified $\times 16$.

Fig. 4. From a series of sections of the hollow tendon of the solt articulation-membrane between the coxa and metatholax of Phymateus (ot in fig. 3). Oto-cxternal aperture of the tendon with grains of some kind of stulf (foamy secretion? in its carity: in-chitin of the skin, t-chitin of the tendon) Zeiss AA oc. (1) The figure is diminished on $1 / 4$.

Fig. 5. Longitudinal section of the upper lateral portion (abore the tympanal organ) of the metathorax (Mt), I and II abdominal segments. The slit between the first and second abdominal segments leads into a widened cavity (0), into which the dermal gland (I)) secreting the foamy fluid opens (Ao). A--tracheal sacs; C-chitin; F-fat-body; M--muscles; Ssecretion of the gland. Zeiss AA. oc. O. The figme is diminished.

Fig. 6. From the same series of longitudinal sections as in fig. 5. Into the cavity (Do) between the I and II segment of the abdomen opens the hollow tendon-N. The remaining denotations are as in fig. 5 .

Fig. 7 . Transverse section of the first abdominal segment of Plymateus through the tympanal organ (T). Abore the y"mpanal organ is situated part of the glind (D) discharuing the 
foamy secretion. The gland is surrounded by tracheal sacs (A). N-muscles; F-fat-body. Zeiss ob. AA, oc. O.

Fig. 8. Transverse section of the anterior part of the second abdominal segment of Phymateus. The posterior part of the gland (D) discharging the foamy secretion is seen. The gland is limited from inside by a narrow muscle-band (Mi). A-tracheal sac, C-chitin, F-fat-body. Zeiss AA oc. O.

Fig. 9. Part of the rall of the gland discharging the foamy secretion in Phymateus. C-chitin cuticle from which chitinous deferent canals (a) lead into the gland-cells; n-nucleus of gland-celi; pl-its plasm; nh-nuclei of matrix-cells producing the chitinous cuticle of the gland (c); me-external membrane of the gland. Zeiss hom. imm. 1/12, oc. 4.

Fig. 10. Part of the chitinous cuticle (c) of the same gland exfoliated from the cellular layer of the latter. 'T'wo chitinous. deferent canals are seen (d). Zeiss $1 / 12$ hom. imm., oc. 4.

Fig. 11. The deeper part of the fold between the II and III abdominal segment of Phymateus cut longitudinally in the upper lateral portion of the body. The hypoderm $(\mathrm{H})$ in the dorsal part of the fold is replaced by a layer of Stein's glands forming a simple glandular area. D-gland-cells, $\mathrm{N}$ their nuclei, $\mathrm{N}_{1}$-nuclei of the matrix-cells and of the cells of the deferent canals. Ch-chitinous cuticle very folded and pierced by the apertures of the deferent canals (not shown in the figure). S-secretion of Stein's glands. Zeiss ob. DD, oc. 0 .

Fig. 12. Part of the glandular area of the preceding figure, strongly magnified (Zeiss $1 / 12$ hom. imm., oc. 4). The place is drawn, where the chitinous cuticle (ch) has exfoliated from the cellular layers of the gland whereby the chitinous deferent canal Te (at $\mathrm{A}$ is its aperture) is clearly seen. D-gland-cells, N-their nuclei, $\mathrm{N}_{1}$-nuclear layer of the matrix-cells and of the cells of the deferent canals. 


\section{№ 4 .}

\section{Паразитическіе Trematodes и Nematodes, соб-}

ранные экспедиціей Профю. B, А. Дигеля и V. И. Соколова въ Британской Весточной Африкь' и Угандь, К. Н. СКРЯБННЪ.

Parasitic Trematodes and Nematodes collected by the expedition of Prof, V. Dogiel and 1. Sokolov in British East Africa. 



\section{Паразитическіe Trematodes и Nemá- todes, собранные экспедиціей проф. В. А. Догеля и И. И. Соколова път Брнтанской Восточной Африк'і и Уrandils}

К. И. Скрябинъ.

\section{Введеніе.}

Въ нояпрь 1914 года я получилъ отъ грофессора В. А. Цогеля предложеніе принять участіе въ разработкі коллекии трематодъ и паразитическихъ нематодъ, добытыхъ экспедиціей В. А. Догеля и И. И. Соколова льтонь 1914 года въ Британскихъ владћніяхъ Восточної Афрнки.

Разработка этой коллекціи, состоявшей изт 10 видовъ трематодъ и 26 видовь паразитическихъ нематодъ, собранныхъ у 38 различныхъ хозяевъ, объщала дать интересные результаты, такъ какъ сборы ея велись въ мъстности, почти вовсе не изученної въ гельминто-фаунистическомь отношеніи.

Число видовъ паразитическихъ червеіі. привезенныхт участниками экспедиціи (к`ъ вышеупомяну'тому числу паразитовъ необходимо присоединить еще нбсколько десятковъ видов' цестодъ и 3-4 вила Acanthocephali) приходится признать довольно значительныэъ, принимая во вниманіе какъ кратковременность экспедиціи, "и палочисленность ея персонала, такъ, равныпь образомъ, "I то обстоятельство, что сборъ паразитовъ не являлся главної цълью экспедиціи, а велся попутно съ собираніен'ь остального зоологическаго матеріала. Если же приомнить, что большинство такихъ крупныхъ зоологическихъ экспедиціiі, какъ нымецкая арктическая экспедиція 1898 года, англіӥская антарктическая 1901 - 1904 и1910 - 1913 г.г., обставленныхъ съ большимъ научнымъ момфортомъ, привозили всего какихъ-либо 2-3 десятка видовъ паразитическихъ червей, а знаменитая экспедиція Challenger’a доставила всего 9 видовъ нематодъ, 6 видовъ цестодъ и 2 личиночныя формы трематодъ-то сборы проф. В. А. Догеля и И. И. Соколова приходится считать ирямо-таки богатыми. 
Африканскому материку въ смыслғ изученія егогельминтофауны посчастливилось больше, чблъ остальнымъ частямъ свбта за исключеніемъ Европы. Объясняется это не только тъмъ, что черный материк'ь издавна привлекаль своею сказочной природой многочисленные кадры натуралистов’ всъх'ь спеціальностей, но, въ значительной степени, случайнолу стеченію благопріятныхъ обстоятельствъ: дъло въ томъ, что в’ь настоящее время зоологнческія кафедры двухъ африканскихъ университетовъ заняты выдающимися

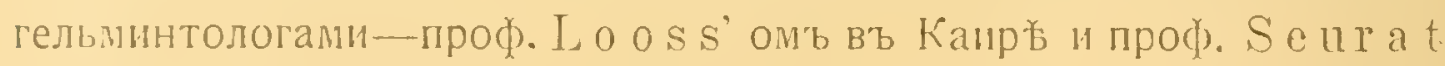
въ Алжиръ. изъ коихъ первый уже свыше 20 льтьъ, а второйсвыше 6 льгть интенсивно работають по изученію фауны паразитическихъ червеї Африки.

Громадную роль въ дълғ познанія африканской гельминтофауны сыграла шведская зоологическая экспедиція въ Егинет’ь и на Бәлый Ниль 1901 года. Глава экспедиціи Iägerskiöld-пзвъстный шведскій гельминтологъ, совм ъстно со своимъ сотрудникомъ $\mathrm{T}$ h. O d hnег'омъ лу лучшиъ изъ современныхъ знатоковъ трематодъ, обратили особенное вниманіе на собираніе паразитическихъ червей, каковые и были или добыты въ такомъ значительномъ количествъ, что полная ихъ разработка не закончена и по на. стоящее время. ${ }^{1}$ )

Остается упомянуть, наконецъ, о многочисленномъ контингент各 представителей прикладного естествознанія-въ частности о ветеринарныхъ и медицинскихъ врачахъ, работавшихъ на африканскопъ материк- по изученію цълаго ряда т. н. тропическихъ заболъваній животныхъ и человъка, въ томъ числғ и такихъ, которыя вызываются паразитическими червями (бильхарціазисъ, всевозложные филяріозы, анкилостолозы и проч.). Ихъ коллективную работу, какъ по собиранію, такъ отчасти и по разработкъ гельминтологическаго матеріала приходится признать поистинғ громадной, о чемъ краснорбинвъе всего свидътельствуютъ всь ть многочисленные прегараты, которые украшаютъ собою главныйшіе зоологическіе музеи Западной Европы.

Для разработки этихъ музейныхъ богатствъ, естественно, потребовался цълый кадръ изслъдователей-спеціалистовъ, труды коихъ мало-по-малу выясняли гельминто-фаунистическую физіономію африканскаго материка. Первое мъсто въ числь ихъ занимаетъ, безспорно, vou Lins to w, которому, за 50-льтній періодъ его

1) До настояцаго времени вышли пзъ печати лишг цестоды птнц

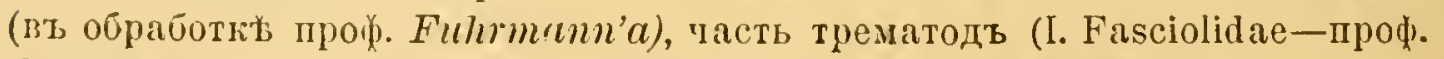
Odhner'a) н 'асть шематодт (вт обработи' проф́. Iïgerstiold'a). 
гельминтологической діятельности, принлось описать, миожество африканскихъ формъ. За нимъ (я не говорю уже объ упопянутьхт выше авторахъ, какт, Looss. Semrat, Odhuer, liigeresioild)

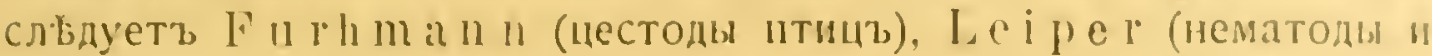
трематоды), Seh i pley (гл. обр. цестоды), G e 11 d l е (нематоды),

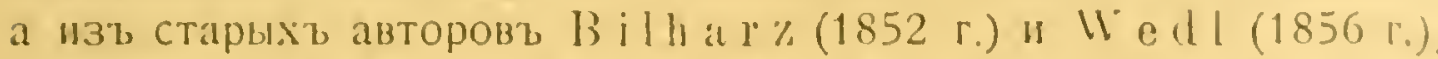
Наконецъ, цилыі рядъ изслтдователеіі занимался случайным изученіемь отджльиыхъ представителей африканской гельминофауны, какъ, напр., проф. Lïhe (цестоды собранн. въ Тунисl), lila ploc\% (цестоды изъ египетскаго Судана и Съв. Уганды), Beddard (цестоды), К. И. Скряббин (цестоды итиць изъ Берлин. Музея и Шведскоиі зоол. экспедиціи 1901 года) н мн. др.

Приглядываясь однако внимательнъе къ работамъ вынеушомянутыхъ изслұдователей, мы замъчаемъ, что фауна пдразитическихъ червеіі разрабатывалась по территоріи африканскаго материка далеко не равномърно. Громадное большинство этихъ работъ падаетъ на изученіе съверной частиі Африки, въ особенности-же на Египетъ, Тунисъ и Алжиръ. Наоборотъ центральная, экваторіальная Африка изсльдована въ гельминтфаунистическомъ отношеніи значительно слабъе. Напболъе крупными работами по изсльдованію паразитическихъ червей центральной Африки приходится считать сльдующія: 1) Linstow. Helminthen von den Lfern des Nyassa-Sees, ein Beitrag zur HelminthenFauna rou Süd-Afrika. Ienaisch. Zeitschr. Naturwissensch. 1901. Tol. 35. p. 426: 2). Linstow. Neue Helminthen aus Westafrika. Ceutralbl. für Bakt. und Parasitenkunde 1904. Vol. 36. p. 379; 3). L e i per. Some new Parasitic Nematodes from Tropical Africa. Proceedings of the Zoological Society of London, 1911. Part. II. p. 549-555.

Что-же касается, наконецъ, работъ по изученію червеї, собранныхъ спеціально въ Британскихъ владьніяхъ Восточной и Центральной Африки, т. е. именно въ тьхъ мъстахъ, гдъ работала экспедиція проф. Догеля " Соколова, то таковыхъ до настоящаго времени въ печати не появлялось. ${ }^{1}$ )

Такимъ образомъ, и съ этой стороны матеріалъ проф. Догеля и Соколова пріобрбтаетъ немаловажный научный интересъ и значеніе.

1) Въ 1904 r. Linstow’ым описапо нъсколько формъ паразитическихт червей изъ англйскихъ владыніи Западной Афрни (см. Centralbl. f. Bakter. Paras. Abt. I. Orig. Bd. 36, 1904, p. 379-383.) 
Переходя къ спеціальной части своего изслбдованія-систематической разработкъ трематодъ, я считаю своимъ долгомъ выразить глубокоуважаемымъ профессору Валентину А лександровичу Догелюи Ивану Ивановичу Соколову свою искреннюю признательность за предоставленіе в’ь мое распоряженіе столь интереснаго гельминтологическаго матеріала.

Ветеринарной Лабораторіи М. В. Д.; въ лицб ея представителя Сергғя Николаевича Павлушкова, пользуюсь случаемъ выразить свою искреннюю благодарность за предоставленіе мнь права пользоваться услугами художника, благодаря чему я имълъ возможность иллюстрировать болъе или менъе полно настоящую работу.

Петроградъ 14 ноября 1915.

\section{A. Trematodes.}

Трематоды коллекціи проф. В. Догеля и И. И. Соколова относились къ 10 видамъ, добытымъ у 8 различныхъ хозяевъ.

Виды эти являлись представителями 9 родовъ и 7 семействъ. Въ числь⿱㇒㠯 хозяевъ трематодъ имблись представители всъхъ классовъ позвоночныхъ, за исключеніемъ млекопитающихъ.

Трехъ представителей этой колпекціи я описываю въ качестьъ̆ новыхъ видовъ, причемъ одинъ изъ нихъ является типомъ новаго рода: Laureriella lateriporus nor. gen. nor. spec., Mesocoetium sokolowi n. sp. и Prosthogonimus dogicli nov. sp.

Наиболье интереснымъ паразитомъ изъ числа трематодъ этой коллекціи является, безъ сомнънія, новый представитель сем. Allocre a di id a e---Laureriella lateriporus n. g. n. sp. (изъ кишечника хамелеона); Јауреровъ каналъ этого паразита чрезвычайно удлиненъ и открывается не на дорзальной поверхности тьла, а на правомъ боковомъ его крағ, -особенность, отличающая его отъ всбхъ извъстныхъ по настоящее время трематодъ. Интересно отмітить также родство этого паразита съ родами семейства Allocreadida e, которые, за однимъ лишь исключеніемъ, паразитируютъ въ кишечникъ рыбъ.

Mesocuelium sokolowi n. sp. (тоже изъ кишечника одного изъ хамелеоновъ) представляетъ интересъ въ томъ отношеніи, что является вторымъ, и притомъ рептильнымь, видом'ь рода Mesocoelium 0 d ln n e r 1911 (изъ сем. Dicrocoeliidae), къ како- 
вому, по настоящее время, относили всего лишь одного паразитаMesocoetium sociale (L ii h e 1901) отъ амфибій.

Prosthogonimus dogieli n. sp.—найденъ въ фабриціевой сумкъ обыкновенной деревенской ласточки (Hirundo rustica), а потому не является специфическимъ паразитомъ африканскаго материка; въроятно видъ этотъ будетъ современемъ обнаруженъ и въ Европ占.

Нахожденіе паразита Ganeo glottoides Klein 1905 var. africana nov. var. (кишечникъ одного изъ представителей Ranidae) въ предълахъ Африки является чрезвычайно интереснымъ фактомъ, такъ какъ видъ этотъ былъ описанъ до настоящаго времени только одинъ разъ у Rana hexadactyla изъ Индіи.

Наконецъ, у вида Nephrostomum ramosum (S o n s in o 1895) (изъ кишечника Ardea sp.) представляетъ интересъ нахожденіе 51 шипика на головномъ воротникъ, тогда какъ предшествующіе изсльдователи констатировали 46-49 шипиковъ (Sonsino, Dietz, Odhner). Фактъ этотъ заслуживаетъ быть подчеркнутымъ потому, что доказываетъ варіированіе числа шипиковъ на воротникъ Echinostomidae въ предилахъ одного вида; между т悉ъ большинство гельминтологовъ считаютъ количество этихъ шипиковъ надежнымъ критеріемъ для отличія однихъ видовъ отъ другихъ.

Къ сожалънію, я не могу привести въ настоящей работь научныхъ наименованій нғкоторыхъ хозяев’ь описываемыхъ паразитовъ-а именно тєхъ, шкурки и консервированные препараты которыхъ, благодаря военнымъ осложненіямъ, остались на африканской территоріи. Современемъ, когда хозяева паразитовъ будутъ точно опредъдены, мною будетъ сдълано соотвбтственное дополненіе къ настоящей работ各.

Прежде чъљъ перейти къ описанію отд厹льныхъ видовъ трематодъ, я считаю полезнымъ привести 1) таблицу распредвленія изсльдованныхъ трематодъ въ зоологической системъ̆ и 2) таблицу распредъленія ихъ по хозяевамъ.

Распредьленіе трематодъ коллекціи проф. Догеля и Соколова въ зоологической системђ.

A. Fam. Paramphistomidae Fischoeder.

1. Gen. Diplodiscus Diesing 1836.

1. Diplodiscus subclavatus Goeze 1782. 
B. Fam. Allocreadidae Odhner.

II. G e n. Lamreriella. gen. nov.

2. Laureriella lateriporus spec, nova.

C. Fam. Lecithodendriidae Odhner.

III. Ge n. Gameo Klein 1905.

3. Ganeo glottoictes Kłein 1905, var. africana nova var.

D. Fam Dicrocoelidae Odhner.

IV. Ge en. Mesocoetinm. Odhner 1911.

4. Mesacoelium soliolowi sp. novi.

E. Fam. Lepodermatidae odhuer.

V. Gen. Prosthogonimus Lïhe 1899.

5. Prosthogonimus dogieli spee. nova.

F. Fam. Echinostomidae Dietz.

VI. Gen. Echinoparyphium Dietz 1909.

6. Echinoparyphium volvulus Odhner 1911.

VII. Ge n. Nephrostomum D i etz 1909.

7. Nephrostomum ramosum (Sonsino 1895.)

VIII. Gen. Mesorchis Dietz. 1909.

8. Mesorchis denticulatus (Kud, 1819).

G. Fam. Holostomidae Brandes.

IX. Gen. Diplostomum v. Nordm.

9. Diplostomum sp.

10. Diplostomum sp.

Распредьленіе трематодъ коллекціи проф. Догеля и Соколова по хозяевамъ.

\section{А. Птицы:}

1. Ciconifiormes

1. Ibis sp.

2. Ardea sp.

Echinoparyphiumvolvulus Odhn.1911. Nephrostomum ramosum (So n sino 1895). 
II. Passeriformes

3. Hirundo rustica L. Prosthogonimus dogieli sp. nova.

III. Lariformes

4. Larus sp.

В. Рептиліи: личиночная форма Diplostomum sp.

Mesorchis denticulatus (Rud. 1819).

IV. Chameleontidae.

5. хамелеонъ № 18. Laureriella lateriporus gen. nov.sp.n.

6. хамелеонъ № 8 Mesocoelium soliolowi sp. nova.

\section{C. Амфибіи:}

V. Ranidae

7. Gen. sp. № 7. Diplodiscus subclavatus Goeze 1782. Ganeo glottoides Klein 1905. var. africana n. v.

\section{д. Рыбы:}

VI. Cyprinidae

8. Рыба № 6 .

Diplostomum sp.

\section{A. Сем. Paramphistomidae Fischoeder.}

Въ своей работь 1910 г. Stiles and Goldberger ${ }^{1}$ ) подраздъляютъ это семейство на сльдующія подсемейства:

1. Paramphistominae Fischoeder 1901.

2. Cladorchinae Fischoeder 1901.

3. Diplodiscinae Cohn 1904.

Въ моемъ матеріаль имғется одинъ паразитъ изъ подсемейства Diplodiscinae Cohn 1904, относящійся къ роду Diplodiscus Diesing 1836.

1) Stiles and Goldberger. A Study of the Anatomy of Watsonius watsoni of man etc. Washington 1910 p. 60 . 


\section{І. Родъ Diplodiscus Diesing 1836.}

Діагнозъ:

Круглая задняя присоска снабжена въ своей средней части небольшимъ вдавленіемъ; ротовая присоска не доходитъ до границы 1 и 2 трети длины тв̆ла; пищеводъ в’ь своей задней части явственно вздутъ; кишечные стволы располагаются симметрично, имғютъ прямое направленіе и оканчиваются на уровн в задняго края яичника. Продольные стволы экскреторной системы, извивающіеся возл ъ̆ кишечныхъ в ́̆тей, наполнены непрозрачными конкреціями. Половое отверстіе располагается приблизительно на границ б первой и второй трети длины твла. Съменники у молодыхъ индиеидовъ въ количествъ 2-хъ, у взрослыхъ же экземпляровъ съменники сливаются вмвсть, образуя единичный круглый органъ, отъ котораго отходятъ, однако, два vasa efferentia. Яичникъ лежитъ позади съменника, въ нъсколько латеральномъ направленіи. 2 ряда латерально расположенныхъ желточниковъ, дошедши до передняго края задней присоски, заворачиваются въ медіанномъ направленіи, образуя уголъ. Типичный видъ: D. subclavatus Go ez e 1782.

\section{Diplodiscus subclavatus Goeze 1782}

Этотъ щироко распространенный и хорошо изученный видъ былъ найденъ въ кишечникъ крупной зеленой лягушки изъ сем. Ranida e $(27 / \mathrm{vl}$, Kistmu).

\section{B. Сем. Allocreadiidae Odhner.}

До настоящаго времени вс‡ представители семейства Allocreadid a e 0 d h n e r были описаны въ качествъ паразитовъ рыбъ. Однако 0 dhner въ своей работъ 1911 года ${ }^{1}$ ) на стр. 72 говоритъ, что въ его распоряженіи имвются экземпляры трематодъ изъ кишечника Lacerta vivipara (изъ Копенгагенскаго Музея), которые являются типичными представителями Allocreadi ina e. Описываемый мною ниже паразитъ-La几reriella lateriporus n. g. n. sp. изъ кишечника хамелесна является тоже характернымъ представителемъ этого семейства. Та-

1) Od h n e r. Nordostafrikanische Trematoden. Results of the Swed. Zool. Expedition to Egypt. Part 1V. 1911. p. 72. Прнмьчанie. 
кимъ образомъ хозяевами трематодъ семейства Allocreadi idae приходится считать не только рыбъ, но и рептилій.

Новая форма трематодъ, оказавшаяся въ моемъ матеріаль, которую я называю Laureriella lateriporus gen. nov. sp. nov., характеризуется чрезвычайно удлиненнымъ Лауреровымъ каналомъ, который открывается наружу не съ дорзальной стороны, какъ это бываетъ обычно, а на правомъ краю тъла.

\section{II. Родъ Laureriella gen. nov.}

Діагнозъ: Средней величины паразиты съ гладкой кутикулой. Пищеводъ удлиненный, кишечные стволы доходятъ до конца твла. Половое отверстіе располагается кпереди отъ брюшной присоски, медіанно. Bursa cirri небольшая, не доходящая до уровня середины брюшной присоски; pars prostatica развита. Круглые съменники располагаются медіанно, одинъ позади другого. Круглый яичникъ лежитъ въ пространств Б между переднимъ сьименникомъ и брюшной присоской, медіанно. Желточники располагаются по объ стороны кишечныхъ стволовъ, причемъ въ задней части твла желточники правой стороны сливаются съ таковыми львой стороны. Лауреровъ каналъ чрезвычайно удлиненъ, открывается отверстіемъ не на дорзальной поверхности тьла, а на правомъ крағы тәла. Немногочисленные извивы матки располагаются въ пространствь между переднимъ сьменникомъ и половымъ отверстіемъ, причемъ петли матки переходятъ слегка за латеральный край стволовъ кишечника. Паразиты кишечника рептилій. Типъ и пока единственный видъ: Laureriella lateriporus Skrjabin 1916 г.

\section{Laureriella lateriporus nov. sp.}

(Табл. I, рнс. 1.).

Хозяинъ: Яцерица № 18 (изъ сем. Cham a ele onti da e; Nulo I/VII).

Локализація: кишечникъ.

Описаніе вида.

Тъло плоское, равномърно закругленное на обоихъ концахъ. Длина тбла достигаетъ $6,12 \mathrm{~mm}$. при максимальной ширинб $1,275 \mathrm{~mm}$. въ средней своей части. Кругловато-овальная ротовая присоска, отверстіе которой обращено на вентральную сторону, 
достигаетъ 0,476 mm. длины при ширинъ $0,51 \mathrm{~mm}$. Прилегающій къ ней pharynx имъетъ $0,30 \mathrm{~mm}$. въ діаметръ. Довольно длинный пищеводъ, достигающій $0,37-0,4 \mathrm{~mm}$., переходитъ въ кишечные стволы, доходящіе до задняго конца тбла.

Два правильно-круглой Формы сбменника, имююющіе 0,510,54 $\mathrm{mm}$. въ діаметрв, располагаются медіанно, одинъ позади другого въ задней части твла паразита. Своими краями съменники неръдко соприкасаются другъ съ другомъ. Половое отверстіе находится передъ брюшной присоской, по средней линіи тьла, тотчасъ позади развилка кишечника. Bursa cirri очень небольщой величины, своей задней частью слегка заходитъ за передній край брюшной присоски (въ дорзальномъ направленіи). Круглый, ц бльно-крайній яичникъ располагается медіанно въ пространствъ между переднимъ съменникомъ и брюшной присоской. Желточники располагаются по сторонамъ задней половины тћла. Начинаются они на уровнъ передняго края передняго съменника и тянутся кзади до самаго конца твла. Располагаются они не только въ латеральномъ отъ кишечныхъ в各вей направленіи, но, равнымъ образомъ, и медіальнъе посльдннихь. Желточные фолликулы сгруппированы такимъ образомъ, что образуютъ какъ бы 4 продольныхъ полосы, тянущіяся параллельно другъ другу (по 2 полосы съ каждой стороны тъла). Въ заднемъ конць тъла желточники правой части т务а смыкаются съ таковыми лъвой, причемъ граница между отдағльными вышеупомянутыми полосами стушевывается. 2 желточныхъ канала отходятъ отъ переднихъ участковъ желточниковъ по направленію къ средней линіи тъла, гдъ сливаются другъ съ другомъ, образуя желточный резервуаръ.

Матка развита очень слабо: немногочисленными своими извивами она занимаетъ пространство между заднимъ краемъ яичника и наружнымъ половымъ отверстіемъ. Часть матки извивается, такимъ образомъ, въ дорзальномъ отъ брюшной присоски направленіи; причемъ въ нъкоторыхъ мостахъ ея петли пересъиаютъ лъвый кишечный стволъ, выступая за наружныіі его край. Ни у одного изъ изслғдованныхъ мною экземпляровъ въ матк не находилось ни одного яйца, всльдствіе чего о формъ.и величинь посльднихъ я, къ сожальнію, не могу привести никакихъ данныхъ. Изъ вспомогательныхъ половыхъ органовъ укажу на наличносгь receptaculum seminis, который имъетъ неправильно овальную форму и располагается своей длинной осью въ поперечномъ къ длинб тєла направленіи въ пространствъ между яичникомъ и переднимъ съменникомъ. 
Самымъ характернымъ органомъ нашего паразита приходится считать Лауреровъ каналъ, который отличается какъ своей чрезвычайной удлиненностью, такъ, равно, и своеобразнымъ расположеніемъ. Начинаясь въ предъ̆лахъ средней линіи ть́ва, позади яичника, каналъ этотъ образуетъ ньсколько извивовъ, направляющихся кпереди и къ правому краю твла паразита; здъсь, на самомъ боковомъ крав тв́ва, на разстояніи $2 \mathrm{~mm}$. отъ головного конца, Лауреровъ каналъ открывается отверстіемъ наружу.

Признакъ этотъ, ръззко отличающій нашего паразита от’ь остальныхъ трематодъ, у которыхъ, какъ извйстно, отверстіе Лаурерова канала открывается на дорзальной поверхности тйла, послужилъ главнымъ поводомъ для обоснованія новаго рода Laureriella. Характеръ же строенія и взаимоотношенія всъхъ остальныхъ органовъ другъ къ другу (въ частности расположеніе половыхъ железъ, характеръ матки, желточниковъ и проч.) вполнъ обезпечиваютъ прочное мъсто роду Laureriella въ семейств并 Allocreadi id a e.

\section{C. Сем. Lecithodendriidae Odhner.}

$\mathrm{Kъ}$ этому семейству $0 \mathrm{dhner}$ относитъ 2 подсемейства:

1) Lecithodendriinae Looss (=Brachycoeli inae Lss. minus Brachycoelium).

2) Pleurogenetinae Looss.

Въ своей работь 1911 года $0 \mathrm{dh} n \mathrm{e} \mathrm{r}^{1}$ ) отнесъ къ подсемейству Ple urogenetina L Loss родъ Ganeo Kle in 1905. который до настоящаго времени имълъ изолированное положеніе въ системв трематодъ.

Въ моемъ матеріапь имбется единственный представитель сем. Lecithodendria ia (подс. Ple urogenetina Looss), относящійся къ роду Ganeo Kle i n 1905.

\section{III Роді Ganeo Klein 1905.}

Lі і геоз ъ:

Мелкія трематоды съ тйломъ удлиненно-овальной формы. Кутикула покрыта въ передней части ть́丿ла мелкияи шипиками. Ротовая и брюшная присоски почти равной величины. Посльддняя

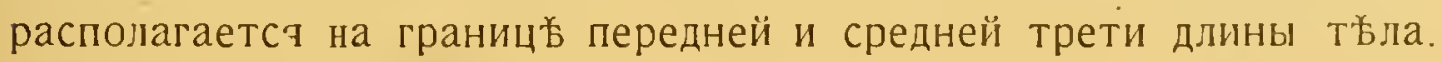

1) Odhner: Nordostafrikanische Trematoden. Results of the Swedish Zoolog. Expedition to Egypt and the White Nile 1901 under the Direction of L. A. Jägerskiöld. Part. IV. 1911 p. 84-85. 
Удлиненный пищеводъ переходитъ въ кишечные стволы, не доходящіе до самаго задняго конца тъла. Половое отверстіе

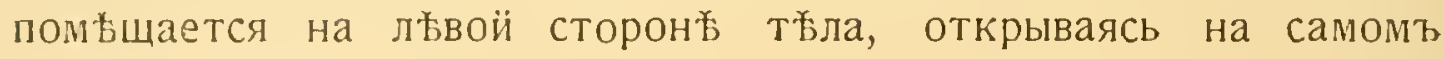
боковомъ его крағ въ глубокую полость, образованную впячиваніемъ кутикулы (половая клоака) и располагающуюся въ передней части тбла, приблизительно на уровны середины пищевода. С悉енники располагаются въ передней трети тълла, причемъ передній сбленникъ находится кпереди отъ брюшной присоски, а задній-своимъ заднимъ краемъ почти на одномъ съ ней уровнъ, или же съменники располагаются какъ кпереди, такъ и кзади отъ брюшной присоски. Яичникъ позади съменниковъ. Pseudobursa cirri удлиненная, искривленная, достигающая своимъ заднимъ краемъ брюшной присоски. Желточники располагаются близъ боковыхъ краевъ тєла въ области средней трети его длины. Матка занимаетъ пространство между брюшной присоской и стволами кишечника, доходя до задней границы послъднихъ или же до самаго задняго конца тъла. Мелкія яйца съ бурой скорлупой овальной формы. Паразиты кишечника амфибій. Типичныї видъ: Ganeo glottoides Kle in $1905^{\text {1) }}$ изъ Rana hexadactyla (Индія)

Въ моемъ матеріалғ имъется одна форма трематодъ, стоящая чрезвычайно близко къ виду Ganeo glottoides K l e i n 1905. Какъ будетъ видно изъ нижеприводимой таблицы, сходство между африканской и индійской формой такъ разительно, простираясь даже на такія мелкія особенности, какъ, напр., длину глотки длину пищевода и проч., не говоря уже о размърб яицъ, что мнъ пришлось и африканскую форму отнести къ виду Ganеo glottoides Klein. Единственно, что отличаетъ моего паразита отъ такового Klein' a,-это нъкоторое различіе в` положеніи половыхъ железъ. Особенность эта даеть мнъ право разсматривать моего паразита, какъ представителя новой разновидности вида Ganeo glottoides K le in 1905, которую я назызаю var. africaina nova var. (найдена въ Kisumu, 27/VI).

\section{Ganeo glottoides Klein 1905 var. africana nov. var.}

(Табл. I, рис. 2).

Литература:

1. Klein. Über Distomen aus Rana hexadactyla. Zoolog.

1) Klein. Neue Distomen aus Rana hexadactyla. Zoolog. Jahrbüch. Syst., Bd. 22, 1905, p. 72-78, Fig. 6-7. 
Jahrbiich., System., Bd. 22. 190う. p. 72-78. Taf V, Fig. 6-7: Ganeo glottoides n. g. n. sp.

2. Odhner. Nordostafrikanische Trematoden. Results of the Swedish Zoological Expedition to Egypt and the White Nile 1901 mder the direction of L. A. Jägerskiöld, Part IV, 1911, p. 84-85. (указаніе на принадлежность Gапео къ сем. Lecithodendriidae, къ подсем. Pleurogenetinae Looss).

Новая разновидность-Ganeo glottoides Kle in 1905-var. africana nov. var., какъ я уже упоминалъ выше, почти во всбхъ деталяхъ своей организаціи вполн各 тождественна виду, описанному изъ Индіи. Я не буду здъсь вдаваться въ подробное описаніе своей разновидности, такъ какъ это значило-бы повторить то, что уже мастерски выполнено Klein'омъ;一я сстановлюсь лишь на твхъ особенностях'ь строенія африканской формы, которыя заставили меня разсматривать ее, какъ представителя новой разновидности.

При сравненіи африканскаго паразита съ индійскимъ, прежде всего бросается въ глаза то обстоятельство, что кишечные стволы у перваго почти доходятъ до задняго конца твла, у второго-же сльпые концы кишечника отстоятъ отъ конца тьлла на довольно значительномъ разстояніи (см. рис. 6 работы Klein'a).

Однако признаку этому нельзя придавать видового характера, т. к. у нъсколькихъ экземпляровъ Ganeo glottoicles K le i n наблюдалъ различную длину кишечныхъ стволовъ. Значительно болъъе серьезнымъ представляется различіе въ расположеніи половыхъ железъ. У индійскаго вида передній съвенникъ располагается непосредственно позади развилка кишечника, а задній съменникъ лежитъ кпереди отъ брюшной присоски; у африканской же разновидности передній съменникъ имъетъ такое положеніе, какое занимаетъ задній съменникъ паразита Klein'a; что-же касается задняго съменника африканскаго паразита, то онъ располагается позади брюшной присоски. Иначе локализируется у этихъ формъ и яичникъ: у индійскаго вида яичникъ располагается справа отъ брюшной присоски, соприкасаясь съ правымъ стволомъ кишечника (какъ разъ такъ, какъ расположенъ задній съъменникъ у var. africana!), у африканской же разновидности яичникъ лежитъ вльво отъ средней линіи тъла, позади брюшной присоски.

Чтобы нагляднъе очертить объ формы вида Ganeo glottoides, мною приводится таблица ихъ сравнительной характеристики. 
Сравнительная характеристика разновидностей вида Ganeo glottoides Kl le in 1905.

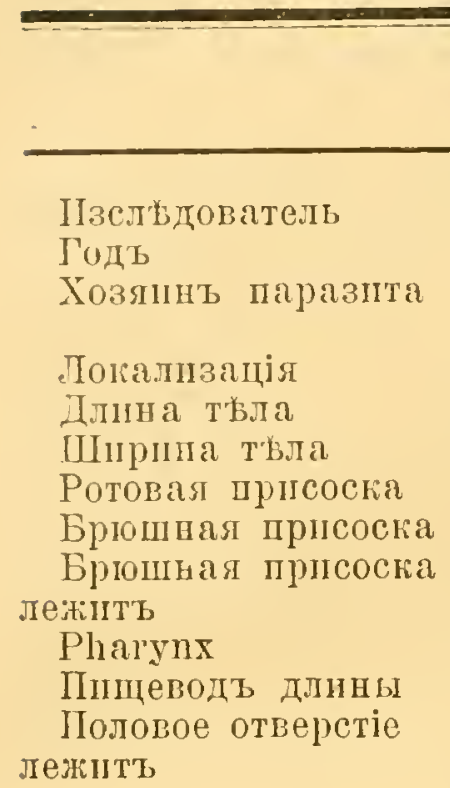

Переднй съменникъ лежить

Задній съменникъ лежить

„Psendocirrusbeutel длины

Располагаетея онъ задіг. ионцомт

\section{Личникь лежінть}

Размььр личника Matia pacioлaraетел

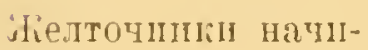
наттел

Shiestromninit konчa10те:

Яйща длџцы

Яйца IIIIpHII

Географ. распроcтpanenic
Ganeo glottoides Klein var. africana

K. II. С к 1915.

Больш. .лгушиа пзъ сем. Ra n i d a e. Кнпечникь. $2,3 \mathrm{~mm}$.

$0.51--0.76 \mathrm{~mm}$.

$0,119: 0,136 \mathrm{~mm}$. $0,187 \mathrm{~mm}$. то-же.

$0,055-, 0102 \mathrm{~mm}$. $0,255 \mathrm{~mm}$. то-жіе.

на львомъ крат тьла между pharynx'омь и развилкомъ кишечника.

по средней линіи ть' ла, непосредственно позади развнлка кншечника.

кшереди 11 справа оть бр10нноп̆ прнсоскіг, прнлегая къ правому стволу кишечника $0,66-0,9 \mathrm{~mm}$.

дорзально оть брюш. прнсоскі, 10 не заходить за ел задній край.

справа оть бр. присоски, соприкасалсь съ

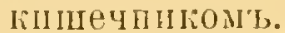

$0.18-0,21 \mathrm{~mm}$.

позади бр. прпеоскі между петлям ІіIпекъ. Лишь позади niाнечнla matka mo-

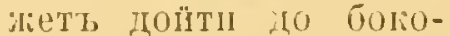
выхь частей тъла.

возль Задняго края

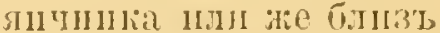

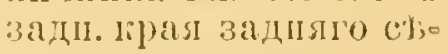
melinilia.

по середин' мсжду бр10 III. ILpHCOchö̈ II задн. концомь тыла.

$0,028-0,034 \mathrm{~mm}$.

$0,014-0,018 \mathrm{~mm}$. ІІндія. кцереди и справа оть брюшной црисоски, далеко кзади оть развилка кишечника. позади и справа оть брюнной прпсоскп.

\section{$0,7 \mathrm{~mm}$.}

сльва ш дорзально оть брюш. ирлес, не заходя ва ел задній край.

цозади прюшной трисоски, н бсколько вльво отъ среднейлиніи тџла. $0,16: 0.1 \mathrm{~mm}$.

позади брлош. шрисоскі между петлямll kil шечншка. IIозадд-эке

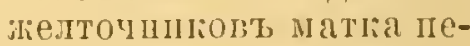

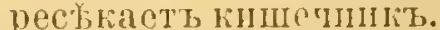
11 доходя, одинан. До боковыхт красеь т"b.а. To-ike.

To sie.

$0.02 \hat{h}-0.032 \mathrm{~m} 11$. $0,0145-0,016 \mathrm{~mm}$. Џептральная Афрнка. 


\section{D. Сем. Dicrocoeliidae Odhner.}

Къ семейству этому $0 \mathrm{~d} h \mathrm{~h}$ е r относитъ слЕдующія подсемейства:

1) Dicrocoeliina e Looss и

2) Brachycoeli inae Odhner nec Looss.

Kъ подсемействy D i clocoli in a e еще въ недавнее время относили лишь паразитовъ, обитающихъ въ желчныхъ ходахъ печени и въ выводныхъ протокахъ панкреатической железы млекопитающих'ь и птицъ (роды:" Dierocoelium, Lyperosomum, Platynosomum, Eurytrema и Athesmia). Въ настояшее-же время

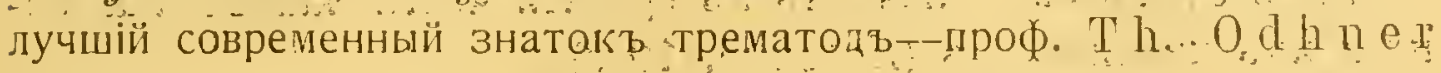
(въ Христіаніи)-присоединиль. къ วтому подсемейству еще два рода: Hoplocterna $\mathrm{C}$ o hn 1903 и Mesocoelium O d h n e 1911 , обитающихъ въ қишечникъ рептилій.и амфибій.

Въ.моемъ матеріаль имется одинъ представитель подсемейства D. i r o eli il a е (изъ кишечнағо канала одного изъ хамелеоновъ), относящійся къ роду Mesocoetium 0 d h n e r 1911. До настоящаго времени къ роду Mesocoelium $0 \mathrm{dh}$. относился всего лишь 1 видъ-Mesocoelium sociale (L ̈̈ he 1901). ${ }^{1}$ ) Нашъ паразитъ-Mesocoelium sokolowi n. sp. является, такимъ образомъ, вторымъ видомъ этого рода.

\section{IV Родъ Mesocoelium Odhner 1911.}

Діагнозъ:

Мелкія трематоды, языковидное тбло которыхъ суживается въ задней своей части больше, ч६мъ въ передней. Кутикула покрыта мелкими чешуйчатыми шипиками. Брюшная присоска меньшей величины, чъмъ субтерминально расположенная ротовая. Пищеводъ или очень небольшой, или же совершенно отсутствуетъ. Кишечные стволы доходятъ до уровня задней четверти длины ть́, или же до конца тьла. Неправильно овальной формы съменники располагаются на одномъ уровнб по бокамъ и кзади отъ брюшной присоски. Яичникъ располагается въ лъвой части паразита, прилегая къ заднему краю съменника. Небольшой receptaculum seminis и Лауреровъ каналъ имъются. Желточники располагаются по объимъ сторонамъ ть́ла паразита, въ латеральномъ и

1) L üh e. Zwei neue Distomen aus indischen Anuren. Centralbl. $f$. Bakt. Parasitenk. 1901. Bd. XXX. Orig. p. 171-173, Fig. 5. 
отчасти дорзальномъ отъ кишечныхъ стволовъ направленіи; въ задній конецъ т各ла желточники не заходятъ. Матка распредълена въ пространств Бे между сбленниками и заднимъ концомъ тъла, причемъ отдъльныя петли ея переходятъ за границу латеральнаго края кишечныхъ стволовъ. Паразиты кишечника амфибій и рептиліiі. Типичный видъ-Mesocoelium sociale (Lïh 1901 ). Второй видъ: Mesocoetium soliolowi Skrja bin 1916.

\section{Mesocoelium sokolowi nov. spec.}

(Табл. I, рис. 3).

Видъ этотъ былъ найденъ въ средней части кишечника одного изъ хамелеоновъ (Entebbe, 19/v).

Тъло плоское, языковидное, суживающееся по направленію къ заднему концу. Длина твла 3,7-4,335 mm. при максимальной ширинъ 1,36-1,70 mm. У нғкоторыхъ экземпляровъ передній отдълъ тбла былъ очень расширенъ, напоминая рисунокъ Distomum sociale въ работь Lühe 1901 года. Поверхность кутикулы вооружена мелкими чешуевидными шипиками. Брюшная присоска располагается на границ первой и второй четверти длины тьла, совершенно такъ, какъ у Mesocoelium sociale. Размьръ брюшной присоски меньше такового ротовой. Ротовая присоска достигаетъ 0,4-0,45 mm. въ поперечникъ, брюшная же присоска имъетъ 0,255-0,29 $\mathrm{mm}$. длины и 0,29-0,32 $\mathrm{mm}$. ширины. Сферическій pharynx достигаетъ $0,17-0,20 \mathrm{~mm}$. въ діаметрь. Пищеводъ совершенно отсутствуетъ. Кишечные стволы достигаютъ задняго конца твла. Съменники располагаются по объ стороны брюшной присоски, нбсколько кзади отъ нея, причемъ своими латеральными краями переходять за таковые кишечныхъ стволовь. Форма съменниковъ неправильно-овальная и слегка лопастная. Спиралевидно свернутая bursa cirri располагается въ пространствђ между глоткой и брюшной присоской, причемъ своимъ заднимъ краемъ помбщается дорзально отъ посльдней. Строеніе этого органа подробно я изучить не могъ, всльдствіе ограниченнаго количества матеріала, имъвшагося въ моемъ распоряженіи.

Яичникъ неправильно круглой формы, значительно меньшаго размъра чъмъ сьменники, располагается въ львой половинъ паразита, прилегая кь задней части внутренняго края льваго съменника. Желточники начинаются на уровн各 задняго края съменниковъ и доходятъ до границы третьей и задней четверти длины твла. Располагаются желточники не только по бокамъ 
кишечныхъ стволовъ, но и въ дорзальномъ отъ нихъ направленіи, причемъ главные желточные каналы соединяются другъ съ другомъ по средней линіи, приблизительно на уровн古 середины длины тъла. Матка локализируется въ предълахъ между съменниками и заднимъ концомъ тъла. Петли матки располагаются не только въ промежуткъ между кишечными стволами, но отдъльные ея участки пересъкаютъ кишечникъ и почти достигаютъ боковыхъ краевъ тьла. Матка наполнена яйцами, длиною $0,032 \mathrm{~mm}$. при ширинь $0,019 \mathrm{~mm}$.

Половое отверстіе располагается медіанно, кпереди отъ брюшной присоски.

Изъ нижеприведенной таблицы явствуетъ совершенно опредъленно видовая самостоятельность нашего паразита, котораго я позволяю себъ назвать Mesocoelium sokolowi n. $\mathrm{sp}$. въ честь члена экспедиціи-Ивана Ивановича Соколова.

\section{Сравнительная характеристика видовъ рода}

Mesocoelium Odh ne r 1911.

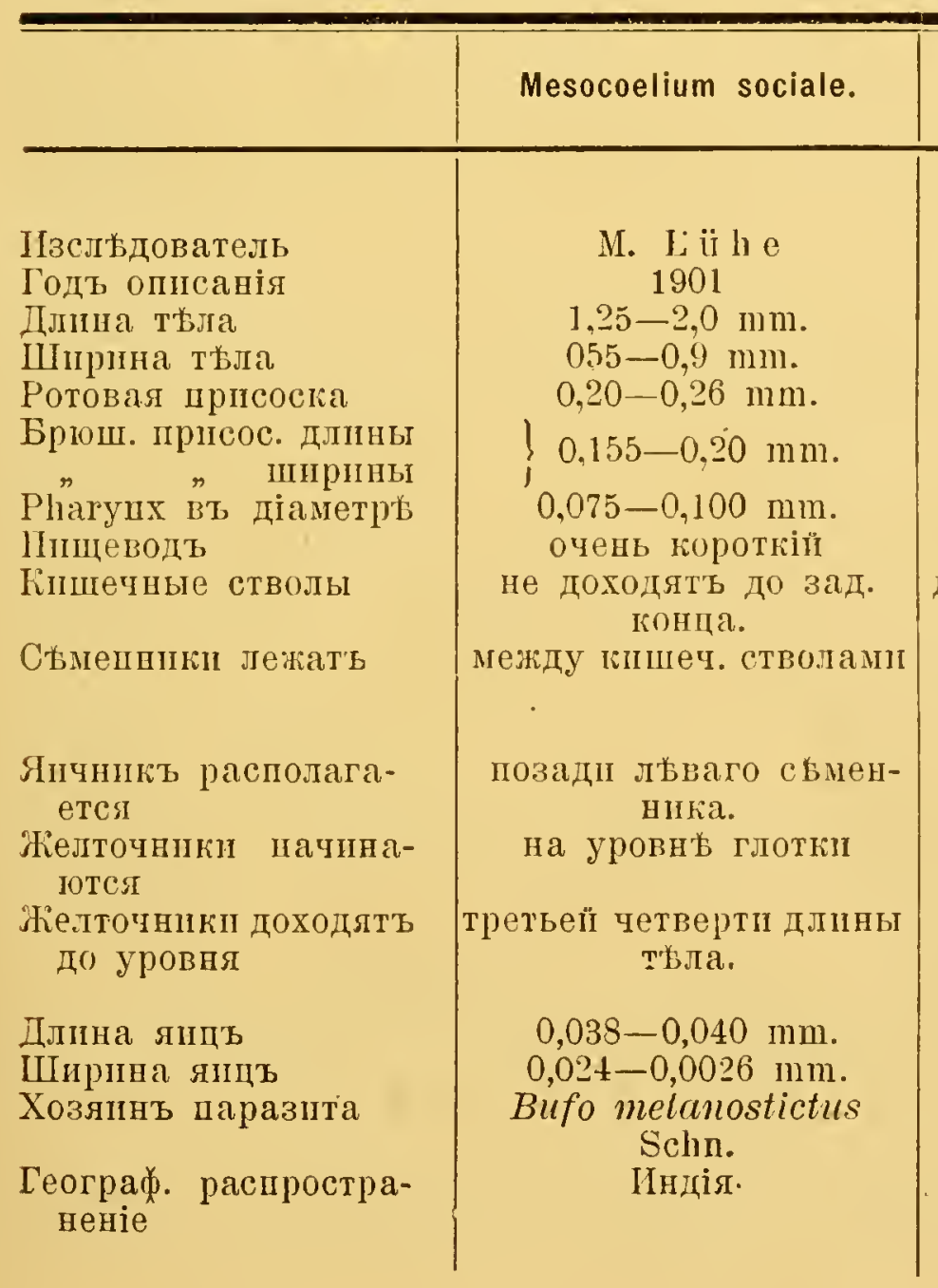

Mesocoelium sokolowi.

К. II. С г р $б$ ин в. 1916.

$3,7-4,335 \mathrm{~mm}$. $1.36-1,70 \mathrm{~mm}$. $0,4-0,45 \mathrm{~mm}$. $0.255-0,29 \mathrm{~mm}$. $0,29-0,32 \mathrm{~mm}$. $0,17-0,20 \mathrm{~mm}$. отсутствуеть. доходять до зад. конца. переходять за латеральные края кпшечныхъ стволовъ.

квнутри оть льваго с'ьменника.

на уровн's задняго края съменніковь. границы третьей ил посльдней четверти длины тьлла. $0,032 \mathrm{~mm}$. $0,019 \mathrm{~mm}$. хамелеонъ.

Центр. Африка. 


\section{E. Сем. Lepodermatidae Odhner.}

Изъ представителей этого семейства въ изслъдованномъ мною матеріаль нашелся лишь одинъ видъ, относящійся къ роду Prosthogonimus L ï he 1899 (Prymnoprion Looss 1899).

\section{Gen. Prosthogonimus Lühe 1899.}

\section{Ді агн $0.3:$}

Средней величины или маленькія дисстомы, съ широкимъ, плоскимъ, закругленнымъ сзади тбломъ, суживающимся нб̆скольк̆о жпереди. Тювл воружено въ большинств случаевъ пипиками. Pharynx, oesophagus присутствуютъ. Кишечникъ не доходитъ до̆ задняго конца тила. Половое отверстіе располагается возль ротовой присоски, сльва отъ нея на самомъ крав твла. Bursa cirrí удлиненной формы, доходитъ или недоходитъ до развилка кишечника. Рядомъ съ burșa cirri проходитъ конечный участокъ влагалища, открывающійся непосредственно возлґ мужского отверстія. Съменники расположены симметрично позади брюшной присоски. Яичникъ болье или менъе сильно лапчатой формы, лежитъ впереди сбменниковъ. Receptaculum seminis и Лауреровъ каналъ при-

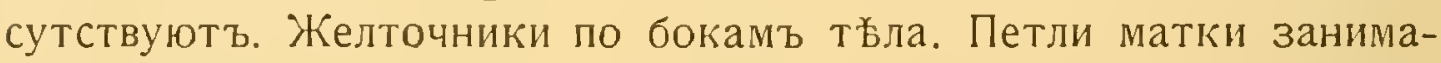
ютъ заднюю половину тьлла, пересбкая кишечникъ и простираясь до самыхъ краевъ тблла; иногда петли матки распространяются и кпереди отъ яичника. Яйца мелкія, многочисленныя. Паразитируютъ въ фабриціевой сумк各 и въ яйцеводъ птицъ. Типъ: Prosthogonimus ovatus ( $\mathrm{R} \mathrm{u} \mathrm{d.} \mathrm{1803.).}$

По настоящее время извбстны 7 видовъ этого рода, изъ числа коихъ одинъ видъ, Prosthogonimus cuneatus ( $\mathrm{Rud}$. 1809), былъ находимъ уже въ Африкъ [проф. Looss' омъ, описавшимъ этого паразита иодъ 2-мя названіями: Prymnoprion ovatus от’ь Passer domesticus и Prymnoprion anceps отъ Machetes pugnax; однако оба эти вида, какъ показалъ въ своей работь 1902 года Brau n ${ }^{1}$ ) должны считаться типичными Prosthogonimus cuneatus (R u d. 1809).].

Въ числь трематодъ, собранныхъ экспедиціей проф. В. Д о г е л я и И. Соколова, оказался одинъ новый представитель рода Prosthogonimus Lüh e 1899, который, въ честь Валентина

1) M. B r à u n. Fascioliden der Vögel Zoolog. Iahrbiich., Abt. Systemat. Bd. XVI. H. I. 1902. 
А лександрови ча Догеля, названъ мною Prosthogonimus dogieli spec. nova. Въ нижесльдующемъ изложеніи мною будетъ дана характеристика этого новаго вида, а затъмъ, чтобы рельефнъе очертить его видовую самостоятельность, мною будетъ приведена сравнительная характеристика всъхъ извъстныхъ по настоящее время видовъ рода Prosthogonimus L ï h e 1899.

5. Prosthogonimus dogieli spec. nova.

('Таб̆л. І, рніс. 4).

Хозяинъ: Hirundo mustica (Энтеббе, 20/V 1914).

Локализація: фабриціева сумка.

Тъло грушевидной формы, плоское, съроватаго оттънка съ темно-исчерченнымъ рисункомъ въ задней своей части. Длина тьвла $-4,75 \mathrm{~mm}$. при ширинъ-3,65 mm; уже этотъ признакъ отводитъ нашему паразиту особое мбсто в’ь ряду другихъ видовъ рода Prosthogonimus, такъ какъ у посльднихъ ширина твла обычно составляетъ около $1 / 2$ его длины (см. таблицу). Поверхность кутикулы покрыта шипиками, направленными свободными концами кзади; длина шипиковъ достигаетъ 0,029-0,030 $\mathrm{mm}$. Шипики покрываютъ всю поверхность т各а, не исключая и задней ея части.

Присоски развиты довольно мощно. Ротовая присоска достигаетъ $0,289 \mathrm{~mm}$. длины при ширинғ $0,314 \mathrm{~mm}$. Опять таки, въ противоположность другимъ видамъ Prosthogonimus, у нашего паразита ширина ротовой присоски больше ея длины. Почти шаровидный pharyux, дпиною 0,22 mm. при ширинъ $0,238 \mathrm{~mm}$., переходитъ въ пищеводъ, достигающій 0,29 mm. длины, который, въ свою очередь, вилообразно развъ́тляется на 2 кишечныя вътви. Сльпые концы кишечника, наполненнаго чернымъ содержимымъ (пища), заходятъ за задніе края съменниковъ, не достигая, однако, задняго конца тьла.

Брюшная присоска располагается на границб передней и средней трети длины төла, достигая $0,85 \mathrm{~mm}$. длины при ширинъ $1,0 \mathrm{~mm}$.

Овальные съвенники располагаются въ средней трети т各ла, на одинаковомъ уровнб, будучи подраздъилены другъ отъ друга извивами матки. Края сь⿱㇒扌енников'ь ровные, безъ какого-либо намека на выемчатость. Своею длинной осью съменники расположены параллельно длинъ тьла. Латеральные края съменниковъ слегка прикрываются кишечными вб̆твями. 
Bursa cirri дозольно своеобразной ретортовидной формы, доходящая своимь дномъ до мғста развътвленія пищевода на кишечные стволы; длина bursa cirri $=0,883 \mathrm{~mm}$. Открывается она наружу мужскимъ поповымъ отверстіемъ, которое располагается въ львой половинғ паразита, возль отверстія ротовой присоски, между послъднимъ и отверстіемъ женскаго полового аппарата.

Яичникъ гроздевидной формы, многолопастной, располагается ночти медіанно, какъ кзади отъ брюшной присоски, такъ и въ дорзальномъ от’ь нея направленіи. Желточники, помъщающіеся возль обоихъ боковыхъ краевъ твла, начинаются на уровнъ середины разстоянія между переднимъ краемъ брюшной присоски и развилкомъ кишечника, оканчиваются-же они нбсколько впереди сльпыхъ концовъ кишечныхъ вътвей. У нъкоторыхь экземпляровъ наблюдалось асимметрическое расположеніе желточниковъ: справа они достигали большаго развитія, чьимъ съь лъвой стороны. Однако, всегда желточники переходили за уровень задняго края с'⿳亠丷厂енников'ъ (отличіе отъ Prostlogonimus ovatus Rud. 1803). Желточники состоятъ изъ чрезвычаііно мелкихъ фолликуль, которые не сгруппированы въ грозди, как'ь это наблюдается у видовъ Prosthogonimus pelluciclus Linst 1873 и $\mathrm{Pr}$. putschkouskii Skrjabin 1912. Длина праваго желточника зарисованнаго мною экземпляра достигала 3,06 mn., а лғваготолько 2,04 $\mathrm{mm}$.

Матка занимаеть своими извивами почти всю заднюю часть т条ла, равно какъ и среднее поле, ограниченное брюшной присоской и обоими кишечныли стволами. Извивы матки располагаются не только позади яичника, но 11 по боканъ посльдняго. При этомъ даже въ области тйла кпереди отъ брюшной присоски имғется довольно запутанный участокь петель патки, располагающіїся, однако, лишь медіанно и не переходящій за боковые края кишечныхз вєтвей, какъ то имғеть м'всто у Prosthogonimus ovatus (Rud. 1803). Открывается патка наружнымь половымъ отверстіемь въ лғвой половинь төла паразита. рядомъ съ мужскимь отверстіемъ, слъва оть посльдняго.

Многочисленныя мелкія яйца, наполняющія матку, достигаютъ 0,029—0,031 mm. длины, при ширинъ $=0,0174 \mathrm{~mm}$.

Характерныли чертали, отличающими нагшего паразита отъ остальныхъ видовъ рода Prosthogonimus, являются признаки, выдвинутые еще въ 1901-1902 г. г. проф. Вrапn'омъ въ качествб́ кардинальныхъ: 1) положеніе яичника не только кзади, но 
" дорзально от’ь брюшной присоски и 2) наличность петель матки кпереди оть брюшной присоски. Эти признаки характерны " для вида Prosthogonimus ovatus (Rud. 1803). Однако. у послъдняго вида весь яичник'ъ располагается дорзально, отъ брюшной присоски, между тұмъ какъ у Pr. dogieli задній отдълъ яичника лежитъ позади брюшной присоски; что-же касается второго признака, наличности петель матки кпереди отъ брюшной присоски, то у нашего вида таковыя располагаются лишь возлғ задней линіи твла, не переходя за края кишечныхъ вътвей, что имъетъ мъсто у Prosthogonimus ovatus. Само собой разумъется, что к’ъ этимъ признакамъ присоединяется цълый рядъ болье мелкихъ отличій, характеризующихъ видовую самостоятельность Prosthogonimus dogieli n. sp., что наглядно видно на прилагаемой таблиц ъे сравнительной характеристики всъхъъ извъстныхъ по настоящее время видовъ рода Prosthogonimus L ï h e 1899.

Размћры въ нижеприводимой таблиць (см. стр. 24-27) приведены въ миллиметрахъ.

\section{F. Сем. Echinostomidae Dietz.}

Въ изслъдованномъ мною матеріаль имғлись 3 представителя этого семейства, относящіеся къ родамъ: Echinoparyphim D i e tz 1909, Nephrostomm. D i tz 1909 и Mesorchis D i etz 1909.

Оба первыхъ паразита были уже описаны изъ Африки, причемъ одинъ изъ нихъ, Echinoparyphium volculus Od h n. 1911, является специфическимъ представителемъ африканской гельминтофауны, такъ какъ въ другихъ частяхъ свъта, до настоящаго времени, обнаруженъ не быль. Видъ Nephrostomum ramosum (Sous in o 1895) быль находимь не тслько вь Aфрик先 (Sollsino. O d huer), но и на о-вв Суматра ( $\mathrm{L}$ a c. C a $1 \mathrm{lum}$ ).

Mesorchis denticulatus (Rud. 1819)-для Африки является новой формой.

\section{VI Родъ Echinoparyphium Dietz 1909.}

Діагнозъ:

«Мелкія формы, узкое тұло которыхъ суживается въ задней своей части еце болъе. Почковидный головной воротникъ съ двойнымъ рядомъ шипиков'ъ. қоторые не прерываются на дорзальной сторонъ. Шипики обоихъ рядовъ не равной величины: въ аборальномъ рядъ они крупнъе, ч九зъ въ оральномъ. Кутикула передняго отдъла

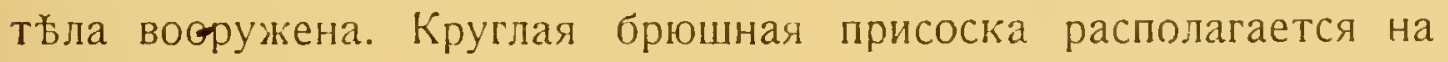
границ 1 и 2 четверти длины тьла. Развилокъ кишечника близ’ь 


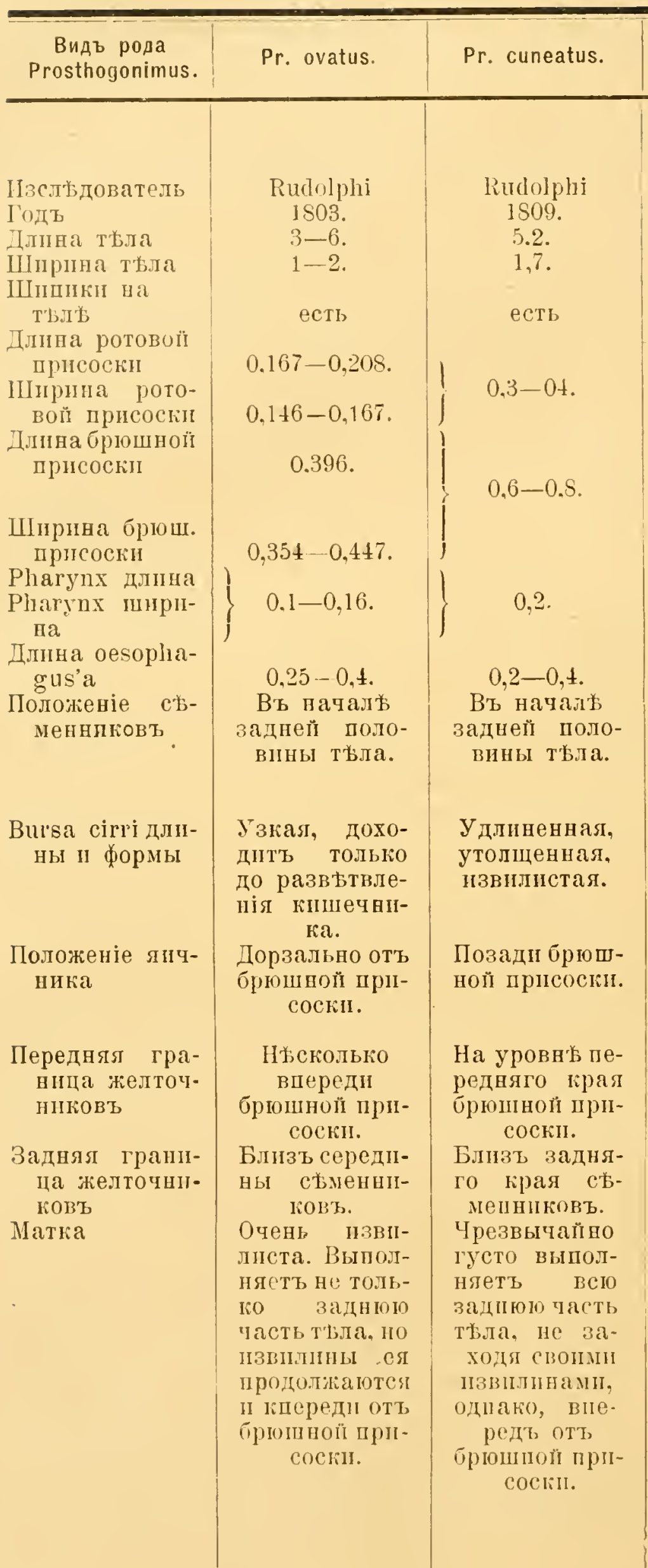

Pr. pellucidus.

Pr. anatinus.

едипшчные ва средин в тйла. $0,766-0,833$.

$0,666-0,733$. $\left\{\begin{array}{c}0,833-1,0-1,3 . \\ 0,20-0,23 . \\ 0,26-0,3 . \\ 0,4-0,5 .\end{array}\right.$ Позади брюшіной присоски.

длинная, переходлщая за разв ътвл. кишечника.

Позади бр10пной ирисоски.

Близъ задняго края бргшнof̂ прнсоски.

Нъсколько иозади свменНI1КОВ'

IIзвиваетея не очень густыми петлями вт, задней часті тьла. Вгереди бргон ной присоскі петель, П'ВТъ.
Markow 1902.

$$
2,4-2 . \mathrm{S} \text {. }
$$$$
\text { 1,1-2. }
$$

есть.

Измьреній

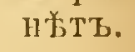

брюниая присоска въ $2^{1 / 2}$ раза болье potoBor̆.

На серединъ между брюшной присоской и заднимъ кондомь ть̈ла. Извилиетая, начинаетел подъ развнлкой кишечніка.

Позади брюшной присоски.

Только до SIIчн Iка.

Позади задняго свменника.

Слабо развита Извивы только въ задней часті твла, ближе къ средпей липіп тьл: 


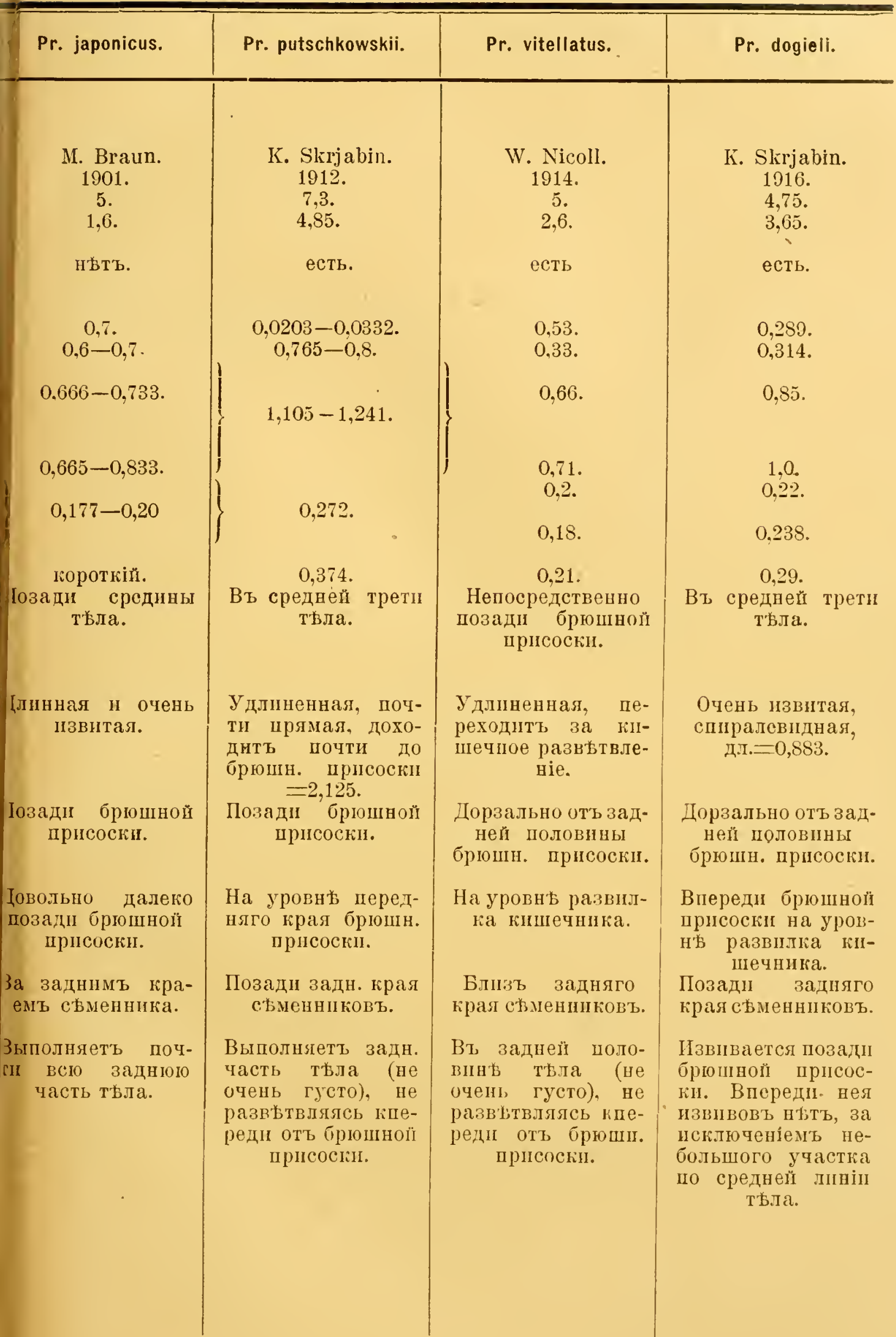




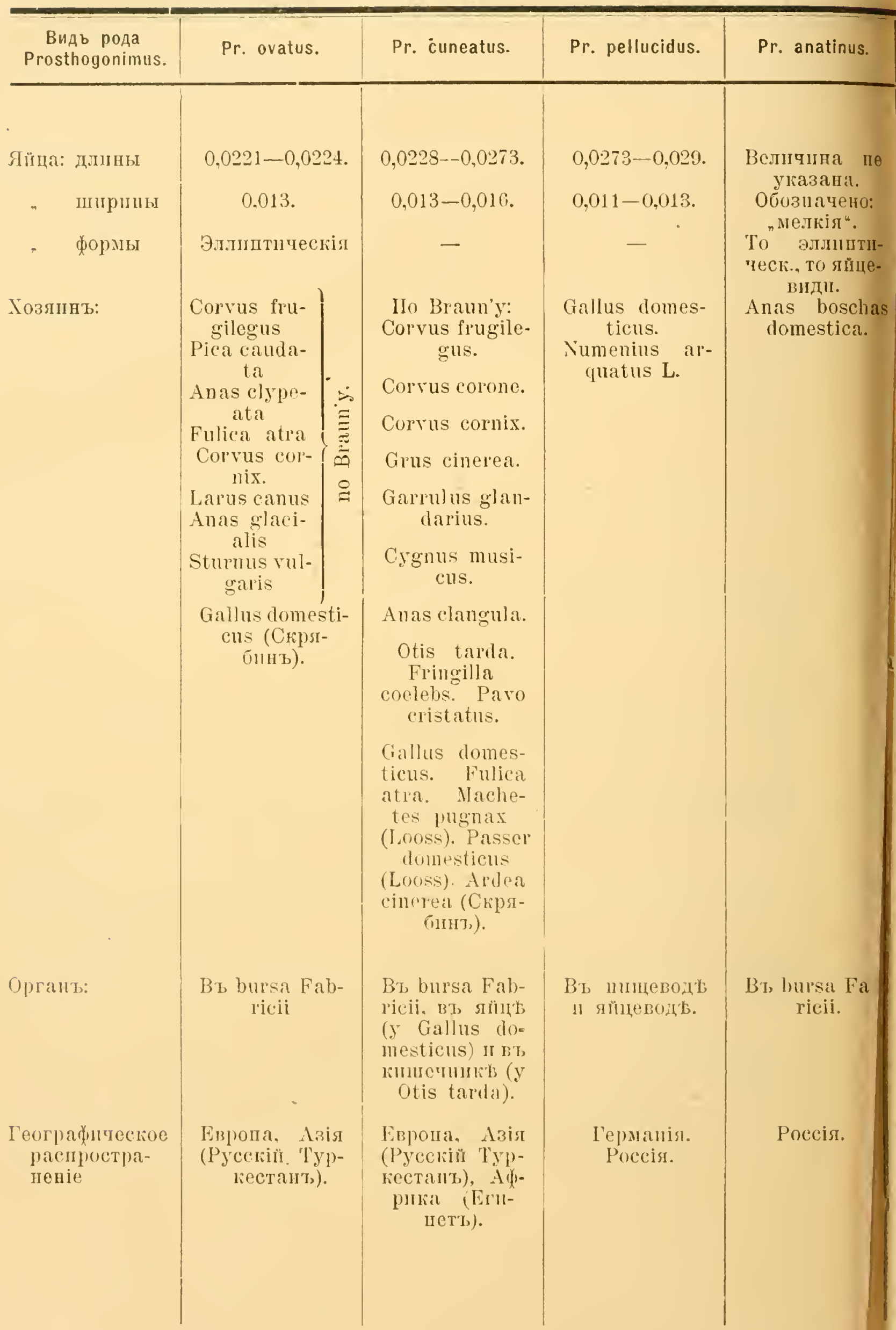


Pr. japonicus.

Pr. putschkowskii.

0,024
0,012
-

Gallus domesticus.

Вร яйц๖.

Японія (Іедо).
Bъ bursa Fabricii.

Bт, bursa Fabricii.

\section{Platalea leucorodia. Dicrura bracteita.}

Hirundo rustica.

\section{thim}

Bъ bursa Fabricit.

Pr. dogieli.

$0,029-0,031$.

0,0174 .

Овальныя.

Британская цен-

Австралія (Квинслэндъ). 
передняго края брюшной присоски. Bursa cirri небольшого размъра, простирается лишь немного за границу передняго края брюшной присоски въ дорзальномъ направленіи. Кругловато-овальные или эллиптической формы съменники располагаются медіанно, одинъ позади цругого въ серединғ задняго отдъла тъла, причемъ неръдко они своими смежными краями прилегаютъ другъ къ другу. Круглый яичникъ располагается медіанно или нбсколько въ латеральномъ направленіи, близъ передняго края передняго съменника. Желточники располагаются по краямъ задняго отдъла тьла, причемъ передняя ихъ граница не достигаетъ задняго края брюшной присоски. Матка короткая. Немногочисленныя яйца достигаютъ довольно крупнаго размъра: 0,084-0,103 $\mathrm{mm}$. длины и 0,0520,068 $\mathrm{mm}$. ширины. Типичный видъ: Echinoparyphium elegans (L O O S S 1899).» ${ }^{1}$ )

Въ изслғдованномъ матеріаль имъется одинъ представитель этого рода-Echinoparyphium volvulus O d h n e r 1911.

\section{Echinoparyphium volvulus Odhner 1911.}

Литература:

(Pirc. A).

Odhner. Nordostafrikanische Trematoden grösstenteils vom Weissen Nil. Results of the Swedish Zoological Expedition to Egypt and the White Nile 1901. under the direction of L. A. Iägerskiöld. Part. IV, 1911. p. 114-116 и 160. Taf. 3, Fig. 4-6, Taf 6, Fig. 6-7.

Видъ этотъ до настоящаго времени былъ найденъ всего лишь одинъ разъ 0 dh n e r'oмъ въ переднемъ отдъль кишечника Theristicus (Ibis) hagédash. Изсльдованные мною экземпляры были собраны въ кишечникъ чернаго ибиса (Kisumu, 27/VI).

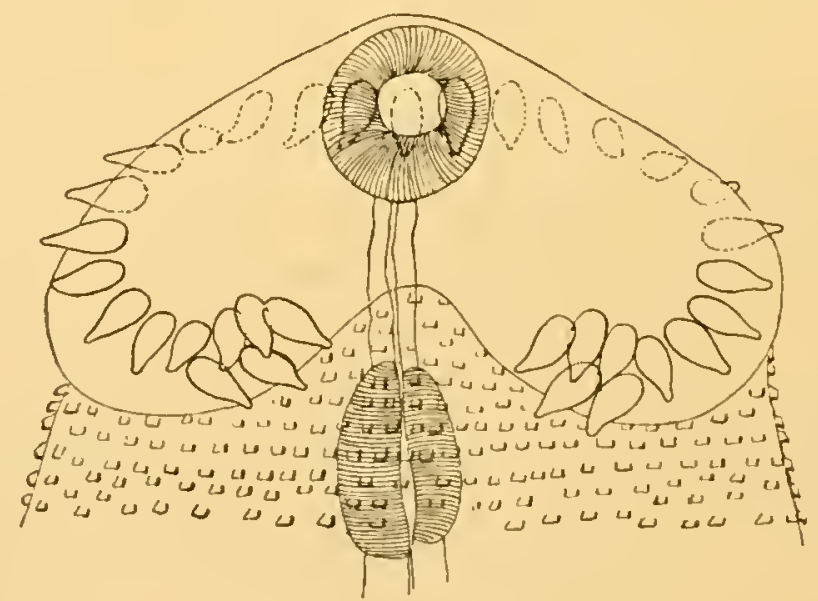

(Puc. A)

1) D i et\%. Die Echinostomiden der Vögel. Zoolog. Jahrb. 1910 Supplem. 12, Heft 3. p. $379-380$. 
Экземпляры эти во всъхъ деталяхъ своей организаціи вполнб совпадали съ паразитами, описанными $0 \mathrm{dhner}$ 'омъ. Единственно, въ чемъ не было полнаго тождества-это въ формъ шипиковъ воротника. Odhner описываетъ и изображаетъ на рис. 5 свосй работы удлиненные, почти цилиндрической формы шипики съ заостренной вершиной, между т各ъъ какъ шипики изсльдованныхъ мною паразитовъ имъли типичную грушевидную форму, изображенную на прилагаемомъ рисункъ. Посльдній воспроизведенъ самымъ точнымъ образомъ при посредствй рисовальнаго аппарата Цейсса.

Число шипиковъ на воротник古 $=33$. У одного экземпляра число ихъ доходило только до 29.

\section{Gen. Nephrostomum Dietz 1909.}

Dietz въ работь⿱ 1910 г. $^{1}$ ) даетъ сльдующій діагнозъ этого рода:

«Средней величины или выше средняго дистомы, съ тбломъ приплюснутымъ въ дорзо-вентральномъ направленіи. Головной воротникъ широкій, почковидной формы, съ слабо выраженной дорзальной и бол‡е сильной вентральной вырұзкой. Головные шипики располагаются въ одинъ рядъ, не прерванный съ дорзальной стороны; дорзально, вблизи средней линіи тю́лла они очень мелкіе, по направленію же къ боковой сторонъ величина ихъ постепенно возрастаетъ. Поверхность тйла безъ шипиковъ. Präpharynx почти отсутствуетъ, пищеводъ короткій, кищечникъ раздваивается непосредственно передъ брюшной присоской. Посльдняя очень удлиняется воронкообразно по направленію кзади, располагаясь, однако-же, въ передней четверти длины тб́ла. Петли кишечника достигаютъ задняго конца тйла. Bursa cirri небольшая, располагается дорзально отъ передняго конца брюшной присоски. Съменники располагаются медіанно, непосредственно одинъ позади другого в’ь задней половинъ тйла. Яичникъ поперечно растянутъ, располагается медіанно, кпереди отъ передняго съменника. Желточники по сторонамъ задней части т各а, достигая кпереди до задняго края брюшной присоски. Матка удлиненная, сильно извитая; Яйца чрезвычайно многочисленныя, 0,102-0,108 mm. длины и 0,0612-0,068 $\mathrm{mm}$. ширины. Типъ и, до настоящаго времени, единсгвенный видъ: Nephrostomum ramosum (Sonsino 1895).

\footnotetext{
1) D i et z. Die Echinostomiden d. Vögel. Zoolog. Iahrbüich. 1910.
} 
7. Nephrostomum ramosum (Sonsino 1895).

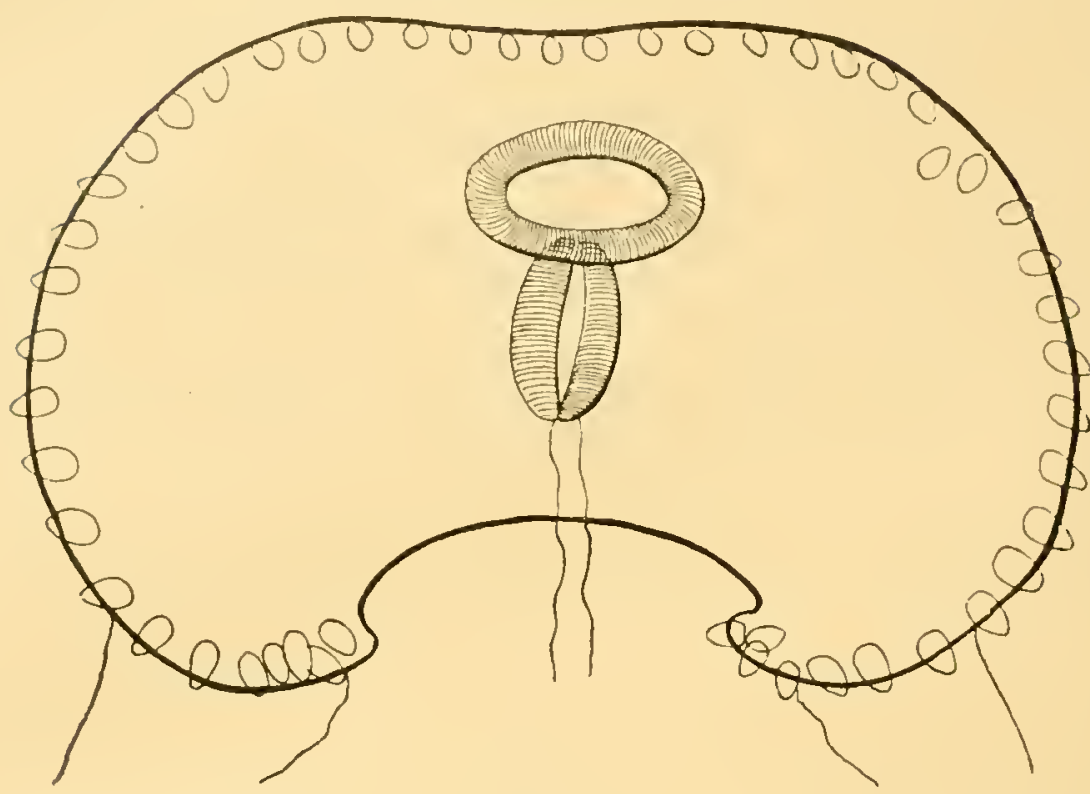

(Puc. B.)

Литература:

1. Sonsino. Di alc. Entozoi raccolti in Egitto finora non descritti. Nonit. Zool. Ital. 1895. p. 123. (оть Ardea bubulcus).

2. Na c C a $11 n$ m. Zoolog. Iahrb. Abt. f. Systemat., Bd. 20. 1904. p. 541-548: Echinostonre garzettce n. sp.

3. Th. Odhner. Nordostafrikanische Trematoden grös. stenteils rom Weisspn Nil. Results of the Swedisch \%oological Expedition to Egypt and the White Nile 1901 under the direction of L. A. Tägerskiöld. Part. IV, 1911. p. 106-109 Tal. 3, Fig. 1; Taf. 6, Fig. 5. (оть Ardea bubulcus [Bubulcus ibis]).

4. E. Dietz. Die Echinostomiden der Vägel, Zonlogisch. Iahrbïcher, 1910, Suppl. 12, Heft 3,

Паразитъ былъ найденъ въ кишечникъ сърой чапли-Ardea sp. (Entebbe, 18/v) (рис. В).

Интересной особенностью изсльдованныхъ мною экземпляровъ явилась наличность 51 шипиковъ на головномъ воротникЕ паразита. Sousino въ своей работь о описываетъ 46 шиликовъ на воротник: описаннаго имъ Erhinostomum ramosum; Od hu er находиль 47 - 49 шиипиковъ у своихъ экземпляровъ; D і е l z, наконец’ь, считает’ь число шипиковъ на воротникъ этого паразита равным’ь 48. Въ виду варіированія числа шипиковъ на воротникъ у Nephrostomum ramosum я не счель возможнымъ выдълить изльдованных`ъ мною паразитов’ $\mathrm{C}^{\prime} \mathrm{b} 51$ шипикомъ в`ъ особый 
вндъ, а должен'ь былъ признать ихъ идентичными Nephrostomum ramnsum, (S o us in o 1895), твмъ болъе, что во всьхъ осталь. ныхъ деталяхъ своего строенія паразиты эти совершенно сходны другъ съ другомъ, о чемъ наглядно свидътельствуетъ нижеприлагаемаяı таблица.

\begin{tabular}{|c|c|c|c|}
\hline & \multicolumn{3}{|c|}{ Nephrostomum ramosum (Sonsino 1895). } \\
\hline & по Odhner'y & по Dietz'y & $\begin{array}{l}\text { Собсгвенп. } \\
\text { пзыьенія }\end{array}$ \\
\hline 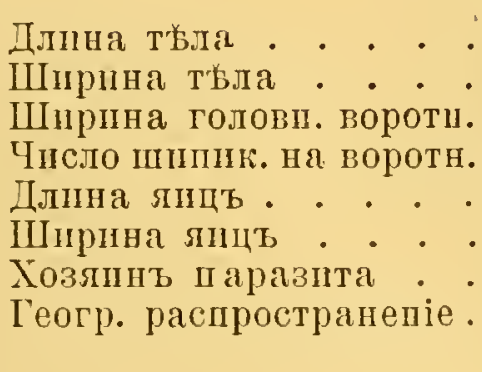 & $\begin{array}{c}8-12 \mathrm{~mm} . \\
2-3 \mathrm{~mm} . \\
1,0-1,5 \mathrm{~mm} . \\
47-49 . \\
0,09-0,105 \mathrm{~mm} \\
0,05-0,055 \mathrm{~mm} \\
\text { Bubulcus ibis } \\
\text { Египеть }\end{array}$ & $\begin{array}{c}12-18 \mathrm{~mm} . \\
3,3-3,4 \mathrm{~mm} . \\
1,56-1,61 \mathrm{~mm} . \\
48 . \\
0,102-0,108 \mathrm{~mm} . \\
0,0612-0,065 \mathrm{~mm} . \\
\text { Bubulcus ibis } \\
\text { Египетт }\end{array}$ & $\begin{array}{l}12 \mathrm{~mm} . \\
3 \mathrm{~mm} . \\
1,7 \mathrm{~mm} . \\
51 . \\
0,119 \mathrm{~mm} . \\
0,06 \mathrm{~mm} . \\
\text { Ardea sp. } \\
\text { Epir. Boct. } \\
\text { Aфplina. }\end{array}$ \\
\hline
\end{tabular}

\section{Gen. Mesorchis Dietz 1909.}

Діагнозъ:

«Мелкія или средней величины Echinostomidae съ удлиненнымъ твломъ. Брюшная присоска на границъ 1 и 2-ой четверти длины т䎹а, или же болъе кпереди. Головной воротникъ съ простымъ рядомъ одинаковой величины шипиковъ, прерванныхъ с`ъ дорзальной стороны по средней линіи тъла. По бокамъ воротника располагаются съ каждой стороны по 2 болће мелкихъ шипика, сдвинутыхъ болье кзади. Тъло вооружено щетинками. Развилокъ кишечника передъ брюшной присоской. Bursa cirri небольшая, располагается почти вся передъ брюшной присоской. Круглые или овальные съменники, медіанно другъ за другомъ расположенные, лежатъ приблизительно на серединъ длины тьла. Яичникъ расположенъ медіанно или нъсколько ближе къ одной сторонъ, кпереди оть́ съменниковъ. Желточники занимаютъ пространство позади съменниковъ; кпереди желточники доходятъ не дальше середины передняго съменника. Матка слабо развитая, съ поперечно расположенными петлями. Овальныя яйца достигаютъ 0,065-0,10: 0,043-0,059 mm. Паразиты кишечника птицъ, главнымъ образомъ морскихъ.

Въ изсльдованномъ матеріалъ нашелся 1 представитель этого рода-Mesorchis denticulatus (R u d. 1819). 


\section{Mesorchis denticulatus (Rud. 1802).}

Литература:

1. Rud ol phi. Entozoor. Synopsis 1819, p. 116 и 419: Distomum denticulatum.

2. D u j a r i n. Hist. natur. Helm. Paris 1845, p. 430.

3. Di esing. System Helminth. I. 1850 p. 391.

4. Cobbold. Synops. of the Distom. 1859 p. 36.

5. Stossich. I distomi degli Ucelli, Bolletino della Societá Adriatica di Scienze naturali in Trieste, 1892. Vol. XIIJ. P. II. p. 28-29, 스 51: Echinostomum denticulatum.

6. E. Di e tz. Inaug. Dissert. Königsberg 1909 p. 14.

7. M. Lüh e. Trematodes. Süsswasserfauma Deutschlands, herausgegeben von Dr. Brauler. Jena 1909. p. 80.

8. E. Dietz. Die Echinostomiden der Vögel. Zoologisch. Jahrb. Supplem. 12. Heft 3. 1910. Mesorchis denticulatus.

9. Odhner. Nordostafrikanische Trematoden. Results of the Swedish Zoological Expedition to Egypt and the White Nile 1901 under the direction of L. A. Jägerskiöld. 1911, Part IV. p. 162: Stephanoprora denticulata (Rud.).

Этотъ давно извьстный видъ, паразитирующій въ кишечникъ чаекъ, оказался въ количествђ 1 экземпляра въ коллекціи проф. Догеля и Соколова (изъ Larus sp. Entebbe, 29/v), совмбстно съ личиночной формой Diplostomum sp.

\section{G. Cem. Holostomidae Brandes.}

Изъ представителей этого семейства въ разработанной мною коллекціи имъется всего лишь одна личиночная форма, относяшаяся къ роду Diplostomum v. Nordm.

IX Gen. Diplostomum v. Nordm.

Плоская личинка Holostomidae, твло которой имъетъ листовидную форму; боковые края телла обращены въ вентральную сторону, причемъ соединены друг'ъ с'ь другомъ посредством'ъ особаго вентрально расположеннаго образованія. Всльдствіе этого, наряду съ переднимъ отдъломъ тъла, вогнутымъ съ вентральной стороны, образуется еще неболышой сосочковидный задній выростъ. По бокамъ ротовой присоски обычно имєются два ушковидныхъ выпячиванія, образованныя наличностью особыхъ железистыхъ скопленій. 
Паразитируютъ въ . инцистированномъ видъ въ различныхъ частяхъ твла пртсноводныхъ рыбъ.

\section{Diplostomum spec.}

Свободная личинка изъ кишечника Larus sp. Повидимому чайка получила этого паразита отъ рыбы, причемъ паразитъ не успблъ еще доразвиться до половозрълой стадіи въ организмб своего окончательнаго хозяина.

Тъло почти круглое, плоское, чрезвычайно нызжное, достигающее $0,9 \mathrm{~mm}$. длины при ширинв $0,73 \mathrm{~mm}$. Ротовая присоска $0,055 \mathrm{~mm}$. длины при ширинъ $0,05 \mathrm{~mm}$; брюшная присоска, расположенная на разстояніи $0,53 \mathrm{~nm}$. отъ передняго конца тв́ла (въ его задней половинъ), достигаетъ $0,068 \mathrm{~mm}$. въ діаметрғ. Овальный pharynx $=0,05 \mathrm{~mm}$. длины при ширинъ $0,034 \mathrm{~mm}$. По сторонамъ ротовой присоски располагаются 2 небольшихъ ушковидныхъ выпячиванія. Къ сожальнію, вида этого паразита точно установить не представляется возможнымъ.

\section{В. Паразитичесніе Nematodes.}

Паразитическія нематоды коллекціи проф. В. А. Догеля и И. И. Соколова относились къ 26 видамъ, добытымъ у 30 различныхъ хозяевъ.

Виды эти являлись представителями 14 родовъ и 7 семействъ. $\mathrm{Bъ}$ числь хозяевъ паразитическихъ нематодъ имблись не только представители всъхъ классовъ позвоночныхъ, но даже два вида многоножекъ (Myriapoda).

Въ настоящей работь⿱一𫝀口 мною описываются 12 новыхъ видовъ, изъ числа коихъ два паразита являются представителями двухъ новыхъ родовъ. Вотъ ихъ перечень: 1) Amphibiophilus acanthocirratus n. g. n. sp. (изъ представителя сем. Ranidae), 2) Ascaris zebrae и. sp. (изъ киш. зебры); 3) Orneoascaris chrysanthemoides и. g. n. sp. (изъ киш. представителя сем. Вufonidae); 4 Oxyuris myriapodicola n. sp. и 5) Oxyuris leidyi n. sp. (изъ кишечника Polydesmus sp.); 6) Oxyuris praeputialis п. sp. (изъ киш. Bufo sp.); 7) Oxynuis megalocerca n. sp. (изъ кишечника геккона); 8) Oxysomatium dogieli n. sp. (изъ В u fo sp.); 9) Isacis multipapillata n. sp. (изъ кишечника Iulus sp.); 
10) Physaloptera britanica n. sp. (nзъ Agama sp.); 11) Diplotriaena sotioloui u. sp. (изъ Halcyon senegaloides) и 12) Angiostomm chamucleonis 11 . sp. (изъ легкихъ хамелеона).

Подробное изученіе паразита Ascaris Teticina (Molin 1860) изъ кишечника крокодила, заставило выдълить его изъ стараго рода Ascaris L. въ новый родъ, названный глною Trispiculascaris, благодаря наличности у самцов'ь gubernaculnm, который, какъ извъстно, у типичныхъ аскаридъ всегда отсутствуетъ.

Однимъ из'ь наиболье интересных'ъ паразитов'ь въ полученной мною коллекціи приходится считать представителя новаго рода Amphibiophilus acanthocivratus и. g. 11. Sp. изэ кишечника амфибіи (из'ь сем. Ranidae). Ротовая капсула этого паразита построена по типу Amidostomm (паразиты птиц'ъ), въ то время какъ совокупительная бурса самца имъет’ь характеръ таковой анкилостомъ (паразитов'ъ млекопитающихъ).

Интересенъ также новый родъ аскаридъ Orneoascaris chrysanthemoides изъ кишечника амфибій (сем. Bufonidae), который характеризуется как'ь наличностью широких'ь крыльев’', так'b, въ особенности, строеніель кутикулы на хвостовом'ъ конц各 самца, которая имьетьь чрезвычайно сложный мозаичный рисунок'ъ; хвостовыя папиллы самца имғютъ причудливую форму, напоминая собою въниикъ махроваго цвътка.

Особенно богато представлены были в'ь коллекціи виды рода Oxyuris, причемъ изъ числа 7-ми ихъ представителей 4 паразита мною выдәлены въ новые виды. При изученіи Oxymis'oвъ я обращаль особенное вниманіе на строеніе ротовыхъ органовъ,признак'ь, которыі долженъ оказать неоцьненную услугу дияу систематической перегруппировки представителей этого рода, отличающихся нербодко другъ отъ друга признаками не видового, а, несомнбнно, родового характера.

Заслуживаетъ быть отмьченнымъ новый видь рода Isacis Lespes: Isacis multipapillata n. sp., изученіе коего позволило установить діагнозъ для этого стараго, почти вовсе не упопинаемаго современными гельминтологами, рода.

Изученіе литературы рода Oxysomutim Raill. et Hemry 1913, заставило перегрупировать нбкоторыхъ его представителей, отнесши ихъ к' другим ролам'ь нематод'ь, и, наоборот'ь, включить в’ь этот’ь родъь одного изъ тьххъ паразитовъ; который фигурироваль в’ь литературғ, как'ь представитель совершенно иного рода.

Большую долю вниманія я удълилъ рисункамъ; которые, 
нербдко, гораздо рельефнбе характеризуютъ опредъленные виды, ч бмъ самое подробное описаніе послюднихъ ${ }^{1}$ ).

Описанію отдйьныхъ представителей нематодъ коллекціи цогеля и Соколова я считаю полезнымъ предпослать 1) таблицу распредъленія ихъ въ зоологической системғ, и 2) таблицу распредъленія ихъ по хозяевамъ.

Распредђленіе паразитическихъ нематодъ ноллекціи проф. Догеля и Соколова въ зоологической системь.

A. сем. Strong yli da e Cobbold 1864. (s. lato).

1. Gen. Amphibiophilus gen. nor.

1. Amphibiophilus acanthocirratus u. sp.

II. Gen. Diaphanocephatus ]) i es.

2. Diaphanocephalus costatus (Rud. 1819).

B. Сem. A s carida e Cobbold 1864.

III. Gen. Ascaris Lin $n$ i 1758 (s. lato).

3. Ascaris enxina Linst. 1903.

4. Ascaris filaria D $1 \mathrm{j}$ a $\mathrm{r} d .1845$.

5. Ascaris zebrae nov. spec.

6, Ascaris sp.

7. Ascaris sp).

IV. Cien. Trispiculascaris gen. nov.

8. Trispiculascaris helicina (Nolin 1860).

V. Gen. Ormeoascaris gen. nor.

9. Orneoascaris chrysanthemoides spec. nor.

C. Cen. Heterakidae Raill. et Henry 1941.

VI. Gen. Subutura Molin 1860.

10. Subulure suctoria Molin 1860.

VII. Gen. Strong!luris A. M ï 1l. 1894.

11. Strongyluris brevicandata Miill. 1894.

12. Strong!luris elegans Gendre 1909.

д. Сем. O х у и r i da e.

VIII. Gen. Oxyuris Rud. 1803 (s. lato).

13. Oxyuris myriapodicola $\mathrm{n}$. sp.

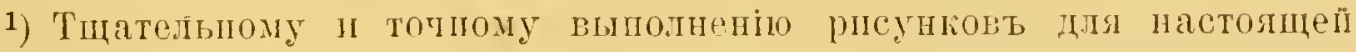

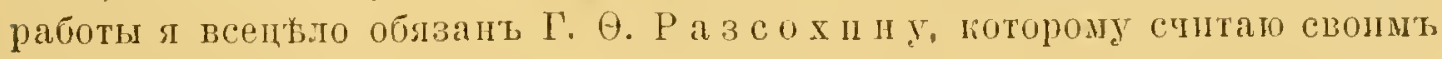
долгомт выразить сердечпую благодарность. 
14. Oxyuris leidyi nov. sp.

15. Oxyuris praeputialis n. sp.

16. Oxyuris megalocerca n. sp.

17. Oxyuris spinicauda Duj. 1845.

18. Oxyuris ammulata Linst. 1899.

19. Oxyuris obvelata Zed. 1803.

IX Gen. Oxysomatium Raill. et Henry 1913.

20. Oxysomatium dogieli nov. spec.

X. Gen. Isacis Lespes 1856.

21. Isacis multipapillata nov. spec.

Е. Сем. Physalopteridae Leiper 1911.

- XI. Gen. Physaloptera R u d. 1819.

22. Physaloptera britanica n. sp.

23. Physaloptera abbreviata R ud.

F. Cem. Filariidae Claus 1885.

XII. Gen. Diplotriaena Raill. et Henry 1909.

24. Diplotriaena sololowi nov. spec.

25. Diplotriaena ozouxi Raill. et H e n r y 1909.

G. Сем. Angiostomidae.

XIII. Gen. Angiostomum Dujard. 1845.

26. Angiostomum chamaeleonis nov. spec.

Особое мбсто въ систем Бо должно быть отведено личиночнымъ формамъ нематодъ, объединеннымъ въ

XIV. Gen. Agamopsirura R a ill. He n r y et Sisoff 1912.

Распредьленіе паразитическихъ нематодъ коллекціи проф. Догеля и Соколова по хозяевамъ.

\section{А. Млекопитающія.}

Perissodact yla

1. Equus zebra Ascaris zebrae n. sp. Rodentia

2. Murida e gen. Oxyuris obvelata Zed. 1803. sp.
В. Птицы.

Steganopodes

3.Phalacrocoraxsp. Ascaris euxina $\mathrm{L}$ ins t. 1903. 
Passeriformes

4. Halcyon senega-Diplotriaena soliolowi n. sp.

loides A. Sm it h.

5. Птица № 7 изъ Diplotricence ozouxi Ra ill. Hen ry cen. Ploceidae 1909.

6. Centropus super-Subulura suctoria М o l. 1860. ciliosus

7. Larus sp. Agamospirura (въ кистахъ). Ga!liformes

8. Птица № 16. Ascaris sp.

\section{С. Рептиліи.}

Lacertilia.

9. Scincidae № 6. Oxyuris ammulata Linst. 1899.

10. Agama № 13. Strongyluris brevicanda Mï II. 1894.

11. Agana № 11. Strongyluris brevicauda Mïll. 1894.

12. Agama № 2. Strongyluris brevicauda M üll 1894.

13. Хамелеонъ № 21. Strongyluris elegans Gendre 1909. Angiostomm chamaeleonis 11. sp.

14. Гекконъ № 4. Oxyuris megalocerca n. sp.

15. Гекконъ № 1. Ox!luris spinicauda D) u j. 1845.

16. Agama № 12. Physaloptera britanica 11. sp. Physaloptera abbreviata $\mathrm{R} u \mathrm{~d}$.

Crocodilia.

17. Crocodilus sp. Trispiculascaris helicina (Mol. 1860). . 0 p hidi a.

18. Bitis gabonica. Ascaris filaria D uj. 1845.

Ascaris sp.

19. Змйя 8/vil Diaphanocephalus costatus R u d. 1819.

20. Зйья А. 20/vi. то-же

21. Змья № 1. 6/ $\mathrm{vi}$, то-же.

22. Змвя № $822 /$ мг. то-же

\section{Д. Амфибіи.}

23. gen. sp. № 8. Amphibiophitus acanthocirratus n. $\mathrm{g}$. 11. sp.

24. Bufo № 10 . Oxyuris praeputialis $11 . \mathrm{sp}$.

25. Bufo $15 /$. Oxyuris praeputialis $\mathrm{n}$. sp. Orneoascaris chrysanthemoides $\mathrm{n}$. g. 11. $\mathrm{sp}$. 
26. Bufn.

Oxysomatium dogieli n. sp.

Oneorserris chrysanthemoides n. 11. sp.

E. Рыбы.

Crprinidae.

27. Рыба изъ карпо- Ayamospirmla.

выхъ.

Siluridie

28. Рыпа № 8 28/n. Agamospinima.

Безпозвоночныя.

F. Myriapoda.

L i plopoda.

29. Julus sp. Isacis multipapillata n. sp.

30. Polydesmus sp. Oxymuis leidyi 11. sp.

Orymris myriapodicola n. sp.

\section{A. Cem. Strongylidae Cobbold 1864.}

Къ этопу семейству, понишая его въ широкомъ значеніи, я отношу двухъ представ!телеї коллекціи Догеля н Соколова, относящихся къ различнымъ родамъ: 1) Amplibiolhitus n. (2. . 2) Diaphanocephalus I) i esing.

\section{I. Родz Amphibiophilus gen. nov.}

В’ь одной изъ пробирокъ коллекціи проф. Догеля 11 Соколова оказались интересные стронгилиды (изъ кишечника амфибіï сем. Ra n i (la e), своеоб́разно совмғщавшіе въ сео́ пр пизнаки. свойственные какъ роду Amidostomum Ra ill. et Henly 1909, такъ равно и роду Ankylostommm I) ub in i 1843. Головной конецъ этнхъ паразитовъ быль снабженъ чашечковидной ротовой капсулой, на днғ которой располагался крупныі треугольный, направленный остріенъ кпереди зубецъ, что вполнћ соот-

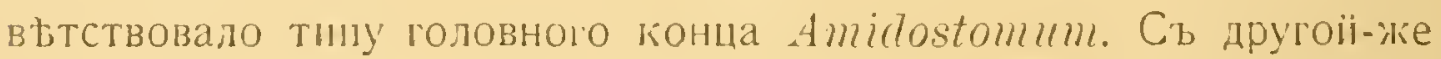
стороны хвостовая бурса самца была снабжена ребрапи, расположенными почти по такопу-же типу, какъ у иредставителеиі рода Ankylostomum. Паразитовъ этихъ я отношу к’ новому роду нематодь сем. Strongylidae Coblinld 1864, которому даю наименованіе Amphibiophilus nov. gen. 
Ді і гно 3 ъ.

Нужные, нитевидной формы нематоды, самецъ и самка которых`ъ пребываютъ въ состояніи длительнаго совокупленія, какъ то имъеть мъсто у рода Syngamus r. sie.b. 1836. Головной конецъ снабженъ ротовой капсулой, построенной по типу рода Amidostomum Raill. et Hen ry 1909, на днь̌ которой располагается коническії, направленный кпереди, заостренный, крупныї зубецъ. 2 латеральныхъ и субледіанныхъ сосочка. Пищеводъ короткій $\left(1 / 1 \sigma^{1} / 23\right.$ часть длины тыла), постепенно утолшающійся по направленію к’ь заднему своему концу. Хвостовой конецъ самца снабженъ бурсой. ребра которої распредвлены сльдующимъ образомъ: costae anteriores состоять изъ 2-хъ реберъ, начинающихся общимъ стволомъ; 3 costae mediae начинаются общимъ стволомъ, отъ котораго отходить отдвльно costa anterior externa, въ то время какъ costa lateralis media и costa lateralis posterior опять таки им'ютъ общій стволь. Costae posteriores externae соединены въ общій, чрезвычайно короткій стволь съь costa posterior, н образуютъ самостоятельныя удлиненныя ребра; costa posterior дихотомически раздвоена в’ задней четверти своей длины. причемг каждое изъ ея раздвсеній образуетъ на своемъ конц各 трезубецъ. 2 спикулы равной велнчины состоять изъ передняго шиирокаго и плоскаго отдила и задняго узкаго, цилиндрическаго, снабженнаго на концй маленькимь загнутымъ крючечкомъ, состоящимъ изъ 2-хъ вътвей. Хвостовой конецъ самки тонкій, заостренныіi. Inka располагается въ задней половинъ тв̈ла, на границ ней четверти его длины. 2 яичника. Яйца содержать сфориированнаго зародыша. Паразиты пищеварительнаго тракта амфџибій. Типъ и пока единственный видъ- Amphibiophilus acanthocimatus nor. spec., изъ кишечника представителя сем. Ranidac.

1. Amphibiophilus acanthocirratus n. sp.

(Таб. Н, рпс. 1 -5).

Хозяинъ: представитель сем. Ranidae. (Molo. 3/ı1).

Локализація: кишечник'ъ.

Описаніе вида.

ГЪ̆ло тонкое, нитевидное, цилн:дрическое, очень нвжное. Самецъ и самка всљхъ изсльдованнь:хъ экземпляровъ находились въь состояніи совокупленія, причемъ самецъ настолько крбпко 
былъ связанъ с’ь самкой, что напоминалъ представителей рода Symgamus r. Siebold.

Самецъ. Длина тъла доходила до 7,14-7,40 mm.; ширина: в’ь области задняго отдъла пищевода $=0,08.5 \mathrm{~mm}$., въ средней части твла $=0,1 \mathrm{~mm}$. и въ области апия' $\mathrm{a}=0,09 \mathrm{~mm}$. Круглое ротовое отверстіе переходитъ въ чашечковидную ротовую капсулу съ закругленнымъ дномъ, въ центрб котонаго возвышается коническій зубецъ. направленный остріемъ кпереди и доходящій своей вершиной до верхняго края капсулы. Ширина ротовой капсулы доходитъ до $0,051 \mathrm{~mm}$. Ротовое отверстіе окружено 6-ю сосочками: 2 латеральными и 4 субмедіанными. Поверхность кутикулы имъетъ сльдъ нъжной исчерченности въ продольномъ направленіи. Пищеводъ короткії, составляющії $\frac{1}{16,4}$ часгь общей длины тьла (длина пищевода $=0,425-0,45 \mathrm{~mm}$.). Вı, своей начальной части онъ имъетъ цилиндрическую форлу, далье же постепенно расширяется, образуя въ заднельь концй булавовидное вздутіе. Хвостовоіі конецъ самца снабженъ совокупительной сумкой, которую поддерживаютъ симметично расположенныя ребра. Costae anteriores двойныя, имвющія общій для обоихъ стволь. 3 costae mediae объединены въ общій стволь, причемъ costa anterior exterua располагается отъ остальныхъ двухъ среднихь реберъ отдъльно, въ то время какъ costa lateralis media " costa lateralis posterior спаяны въ своей базальной части воедино. Costae posteriores externae объединены короткимъ стволом'ь съ costa posterior, отъ котораго однако они вскорь от:зодятъ, образуя самостоятельныя, тонкія удлиненныя ребра; costa posterior въ задней четверти своей длины дихотомически раздвоена, причемъ каждая изъ ея вътвей образуетъ на своемъ конць трезугецъ. Какъ видно изъ приведеннаго описанія, хвостовая бурса сапца этого вида сформирована по типу нғкоторыхъ стронгилидъ, паразитирующихъ у млекопитающихъ, какъ, напр., у Ankiylostoma. Двъв спикулы равной величины, длиною 0,221 mm., имъютъ чрезвычайно характерную форму; передняя ихъ половина широкая, плоская, съ зернистой поверхностью, въ то время какъ задняя иоловина, наоборотъ цилнндрическая, ннтевидная. Задній конецъ спикулы оканчивается дихотопическимъ расщенленіемъ, образуя какъ бы крючечекъ изъ двух'ь вьтвей, загнутыхъ въ одну и ту же сторону. Къ спикулапь прилегаетъ веретенообразпой формы s̆ıренасиlum, достигающіï $0,09 \mathrm{~mm}$. длины.

С амка достигаетъ $11,73 \mathrm{~mm}$. длины при ширинс тъла въ области конца пищевода $=0,136 \mathrm{~mm}$, въ области расположенія 
полового отверстія $=0,136 \mathrm{~mm}$, на уровнғ аmus'a $=0,05 \mathrm{~mm}$. Ротовая капсула шириною до $0,07 \mathrm{~mm}$. Пищеводъ, одинакового характера съ таковымъ самца, составляеть $1 / 23$ часть общей длины т务а, достигая 0,51 mı11.- длины. Хвостовой конецъ суженный, конически-заостренный; auus располагается на разстояніи $0,22 \mathrm{~mm}$. отъ хвостового конца. Vulуa открывается отверстіемъ на границъ третьей и задней четверти длины твла, на разстоянік 2,9 $\mathrm{mm}$. отъ хвостового конца. (У цругого экземпляра самки-на разстояніи 2,3 mm. оть хвостового конца). Отъ короткаго влагалища расходятся в’ь противоположныхъ направленіяхъ 2 матки, заключающія ограниченное количество яицъ, помьйающихся въ одинъ рядъ и располагаюцихся своей длинной осью то параллельно, то перпендикулярно къ длинь̈ тьла. Яйца овальной формы, 0,085 mm., длины гри ширинб 0,05 mm., и заключаютъ сформировавшагося зародыша.

\section{I1. Родъ Diaphanocephalıs Dies.}

Родъ этоть еще не нашель себъ ппред悉леннаго мвста въ подотряды Strongylata, а отнесенъ современнымъ создателем'ь системы стронгилидъ, проф. Railliet къ групп占 „genres, non encore classés"

Діагнозъ для этого рода я предлагаю сльдующій. Среднеї величины нематоды, ротовое отверстіе которыхъ имъетъ характеръ узкой дорзо-вентральной щели, ведущей въ ротову! капсулу, которая состонтъ изъ 2-хъ спмиетричныхъ, латерально-расположенныхъ щитковъ. Каждый щитокъ представляетъ собою цвлый комплексъ хитиновыхъ пластинок’ь, в’ь промежутк' между которыми распоғагаются 3 параллельныхъ, удлиненныхъ, тянущихся къ ротовому отверстію сосочка. Хвость сапца снабженъ бурсой со слғдующимъ распредъленіемъ реберъ: costae anteriores слегка расщеплены въ области своей вершины: costae mediae представльютъ собою 3 равныхъ вьтви, начинающихся общимъ стволомъ; costae posteriores externae начинаются отъ середины удлиненнаго ствола' costae posteriores; посльднія дихотомически раздъғлены въ своей задней части, причемъ кпереди отъ ихъ расщепленія отходитьь латеральная вытвь, всльвдствіе чего каждая изъ costae posteriores имғетъ трехлапчатый характеръ. 2 равныхъ спикулы и gubernaculum. Vulva располагается въ задней половин 占 тйла. 2 матки, расходящіяся въ противоположныхъ направленіяхъ. Паразиты пищеварительныхъ органовъ рептилій. 
Типичный видъ: Dicuphanoceplualus gateatus (Rud. 1819) изъь Podinema teguixin въ Бразиліи.

До настоящаго времени описаны в’ь литературъ 14 видовъ этого рода ${ }^{1}$ ), изъ числа коихъ несомнбнно многіе идентичны другъ другу. Не будучи в'ь состояніи, благодаря отсутствію в’ь моемъ распоряженіи "типовъ", приняться за разборку всбхъ описанныхъ представителей этого рода, я все же свожу насколько видовъ Diaphanocephalus къ одному, считая D. vallei (Stoss. 1895), D. ersilice (S toss. 1896) " D. willeyi (Linst. 1904) идентичными старому рудольфовскому виду D. costatus (R ul (l. 1819).

Въ полученной коллекціи обнаруженъ мною Diaphanoce. phalus costatus (Rıd. 1819) въ 5-ти пробиркахъ, относящихся къ нь̆сколькимъ различнымъ хозяевамъ.

\section{Diaphanocephalus costatus (Rud. 1819.)}

(Тай.т. 11, pre. 6-11).

Литература:

1. Rn l ol phi. Entozonrum Synopsis. Berolini is19. p. 647.: strongylus costatus.

2. एu j a r flin. Hist. natmr. d. Helminthes, 1845. p. 260.: Sclerostoma costatum.

3. Dicsing. Systema Helminthum, Vindobonac 1851. Vul. II. I. 297-295: Diapleanocephalus costatus.

4. Tujesing. Revision der Nematoden. Sitzmngserichte der Kaiserl. Akad. d. Missensch. Mien, 1861, Bd. 4르 p. 715.: Diaphanocerhatus costatus.

๖. Di cesing. Denkschr. d. Kais. Akad. d. Wissensch. Wien, 1850, IX, p. 182.: Tab. II. Fig. 10-16.

6. Moli n. Il sottordine degli Acrofalli. Mrmorie del'mstituto Veneto, 1S60, IX, p. 4st-455. Tab. XXXll, Fig. 6.

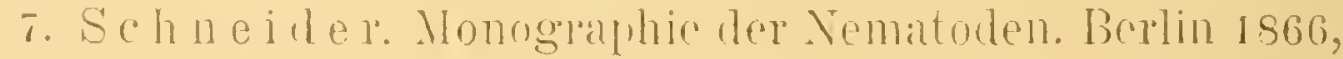
p. 137, 'Tal. IX, Fig. 4; Strongylus costatus li.

1) 1) D. yaleatus (R u d. 1s19); 2) D. costatus (R. 1S19); 3) D. riperae (R u (I. 1819); t) D). rallei (Stoss.); j) D). ersiline (s tos s.); (j) D. inermis (.Iol.); 7) D. strumosus (1I ol.): S) D. subulatus (IIol.); 9) D. appendiculatus (.IOl.); 10) D. murronatus. (.I ol.); II) D. breripenis (\$lol.); 12) D. witteyi (Linst.); 13) D. boce (k. B I an (ch.): 14) ? D. bothropes (.1) 01.$)$. 
s. L i n s to w. Compendium der Helminthologie, Hannovel 1878, p. 182: Strongylus costatus D i es.

9. Stossich. Notizic elmintologiche. Bolletino della Societí Adriatica di Scienze Naturali in Trieste, Vol. XVI, 1895. p. 34. Fig. 32-34: Dochmils vallei (нзъ киш. Vipera (tmmodytes).

10. Stossicb. Ricerche Elmintologiche. Bollettino della Societí Adriatica di Scienze Naturali in Trieste, Tol. XVII. 1896, p. 12t. Fig. 11-13: Strongylus ersitice (о изъ кишечника Python molurus).

11. Stossich. Note parasitologiche. Boll. della Societá Adriatica di Scienze Naturali in Trieste, Vol. XVIII, 1897. p. 6: Sclerostomum. viperae Rud. (Самка изъ Callopeltis aescuIapii). Утверждаетъ. что его Dochmins vallei S toss. 1895 идентична Strongylus viperce $R u d$.

12. Linstow. Helminth. Colombo Nusemm. Spolia Ceylanica, Bd. I, 1904. p. 99-100., fig. 14--18: Kalicephalus willeyi n. sp. изъ Tipera russelli Gray и Coluber helena.

Я считаю относящимися къ этому виду сльвдующихъ паразитовъ полученной мною коллекціи:

1) оть Bitis gabonica (змвя № 415 VI. Mabira).

2) отъ змйи (8:VII. Nakuru).

3) отъ змюи А. (20 VI Mabira).

4) отъ змви № 1. (6. VI. Mabiris).

5) оть змъи № 8. (22/VI. Nabira).

Прилагаемые рисунки дають точное пзображеніе строенія ротовыхъ частей и хвостовой бурсы салца, воспроизведенное при помощи рисовальнаго аппарата Цейсса.

Самцы изслғдованныхъ экземпляровъ достигали $11-13 \mathrm{~mm}$. длины при ширинғ 0,3-0.35 mm. Самки: 16-18 $\mathrm{mm}$. длины и $0,544 \mathrm{~mm}$. ширины. Длина пищевода у салца $=0,5-0,6 \mathrm{~mm}$. при ширину въ заднемъ отдыл $=0,2 \mathrm{~mm} ;$ у самки соотвьтственныя цифры достигают”s 0,544 mm. и 0,255 mm. Хвостовая бурса сапца типичная для рода: costae anteriores слегка расщеплены близъ своей вершины; costae mediae представляютъ собою 3 вйтви общаго ствола; costae posteriores externae и costae posteriores начинаются общимъ стволомъ, причемъ первые отходятъ приблизительно оть середины этого ствола; costale posteriores состоятъ изъ 3-хъ лопастей, образованныхъ изъ дихтомическаго расщепленія задней части ребра и изъ боковой вътви, отходящей кпереди отъ мбста этого расщепленія. 
Длина спикуль $=0,51-0,54 \mathrm{~mm}$ gubernaculum $=0,17-0,2 \mathrm{~mm}$. Vulva располагается въ задней части твла, подраздвляя участки посль̆дняго въ отношеніи $5: 3$.

Анальное отверстіе самки отстоитьь на разстояніи $0,765 \mathrm{~mm}$. отъ хвостового конца.

Строеніе спикуль чрезвычайно своеобразно: он务 состоятъ изъ основного тйла и сопровождающаго его крыла; твло темнокоричневаго оттинка, съ болье или менье крупными бугорками на своеіі поверхности; прозрачныя крылья исчерчены въ лоперечномъ направленіи. Задній конецъ спикулъ штопорообразно скрученъ. По своему. характеру спикулы чрезвычайно напоминаютъ таковыя у внда. описаннаго Linsto wымъ въ 1907 г. подъ именемъ Deletrocephalus stylosıs (изъ кишечника носорога).

Соломенно-желтаго цвйта gubcruaculum имйеть форму углубленнаго челнока съ заостренными переднимъ и заднимъ концами: дно gubинасиит а въ передней своей части снабжено продольнымъ щелевиднымъ отверстіемъ; своими бортами gubernaculum чрезвычайно крбпко охватываетъ спикулы, давая имъ возможность скользить только въ одномъ, опредйленномъ направленіи.

\section{B. Сем. Ascaridae Cobbold 1864.}

Въ коллекціи проф. Догеля и Соколова имғлись представители этого семейства, относящіеся к’ь сль̆дующимъ родам'ь:

1. Ascaris L. 1758 (sens. lato)

2. Trispiculascaris gen. nor.

3. Orneorsectris g. n.

III. Родъ Ascaris L. 1758 (sens. lato).

Діагнозъ:

Крупныя или среднія нематоды, ротъ которыхъ окружень 3-мя губами: одиої дорзальної и двумя латеро-вентральными. Пище-

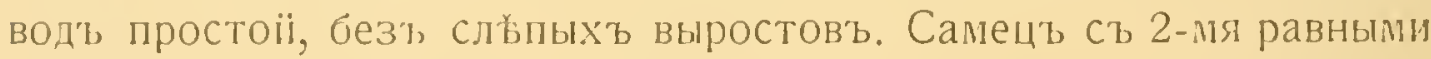
спикулами и многочисленными преанальными и постанальными сосочками. Gubcrnaculnm отсутствуеть. Vulva располагается кпереди отъ середины длины тъла. Мускулатура по типу Polymyarij, экскреторная система по типу Seccrnontes. Типъ: Ascaris lumbricoides L in né 1758.

Къ этому роду относятся 5 представителей коллекціи Догеля 
и Соколова: Ascaris euxina Linstow 1903, Ascaris filaria Dujald. 1845, Ascaris zebrae n. sp., Ascaris sp. и Ascaris sp.

\section{Ascaris euxina Linst. 1903.}

(Tаб.т. III, pнic. 12-14).

Linstow. Entozoa d. Zoolog. Museum d. Kaiserl. Akadem. der Wissenschaften zu St. T'etersburg. Ежегодникъ Зоологическаго Музея Импер. Академіи Наукъ въ Петербургов. 1903. томъ VIII. стр. 6. рис. 1: Ascaris euxina nov. sp. изъ желудка Pelecanus minor Rïpp.

Видъ этотъ до настоящаго времени былъ описанъ всего лишь 1 разъ Linstowымь изъ желудка Pelecanus minor R ii p p. Въ коллекціи Догеля и Соколова паразитъ этотъ оказался изъ новаго хсзяина--Phalacrocorax sp. (Enteble. 27 r).

Ротовое отверстіе окружено чрезвычайно типичныпи губами, снабженными высокими промежуточными губами, которыя доходятъ своимъ проксимальнымъ краемъ до верхняго края основныхъ губъ.

Къ краткому, но обстоятельному описаніг Linstow'a я, со своей стороны, прибавлю лишь размбръ спикулъ самца, которыя у изсльдованнаго мною экземпляра достигали $1,15 \mathrm{~mm}$., длины, при ширинъ $0,017 \mathrm{~mm}$. въ средней своей части. Спикулы слегка изогнуты въ вентральную сторону; кзади отъ середины своей длины спикулы имбютъ нео́ольшой крыловидный придатокъ, который постепенно сходитъ на нътъ. Концы спикулъ закругленные.

Число постанальныхъ папилль у самца, кікъ справедливо указалъ Lijstow, достигаетъ 12 паръ; однако, одна изъ этихъ папиллъ, расположенная наиболъе медіанно, является двойной, чего Linstow не отмбичаетъ въ своемъ описаніи.

Распредвлены сосочки такимъ оо́разомъ, какъ это изображено на моемъ рис. 13. Постанальные сосочки распредъияяются неправильно, безъ тенденціи выпрямиться въ рядъ; наоборотъ, преанальные сосочки образуютъ вначаль ломаную линію, которая вскорь выпрямляется. Число преанальныхъ сосочковъ около 40 паръ (по Linstow'y--50 паръ).

Какъ у самцовъ, такъ и у самокъ хвостовой конецъ имбетъ на своей вершинє небольшой заостренный отростокъ. 


\section{Ascaris filaria Dujardin 1845.}

Литература:

1. I) $\mathrm{j}_{\text {il }} \mathrm{l}_{\mathrm{d}} \mathrm{i}$. Histoire natur. Helminthes, Paris 18t5, p. 6533.

2. Diesing. Systema Helminth. II. 1851. p. 169.

3. Stossich. Il genere Ascaris L. Trieste 1896, p. 73, i. 155 .

4. Linstow. Parraten, meistens Hehminthen, aus Siam. Archir für mikroskop. Anatomie, Bd. 62. 1903. p. 108-109, Fig. 1-2. Ascaris infmatulicola n. sp. изь Python reticulatus. По мнднію Railliet et Hen ry. (1910) паразитъ этоть идентиченъ Ascris filaria D $11 \mathrm{j}$. 1 stj.

5. Ra illiet. et Henry: Sur quelques helminthes du "Python Sebae" (Gmelin). Bulletin de la Sinciété de Pathologgie Exntique, Séance 9. II. 1910. T. III. . \i 2. p. 95-96.

До настоящаго времени видъ этот’ь описанъ у слғдующихъ хозяевъ: 1). Astrophis tiyris

2). Python reticulatus,

3). Python Sebae.

Въ коллекціи Догеля и Соколова имбется этотъ видъ отъ новаго хозяина-Bitis gabonica.

Останавливаться на описаніи этого паразита я не нахожу ц блесообразнымъ. т. к. оно сдълано въ недавнсе время R a ill i e t " Н

5. Ascaris zebrae nov. spec.

(Tilü.t. III, pHIc. 15-1S).

Этоть новыї видъ паразитируетъ въь кншечникъ, зебры (Naіvashal 12 vil). Кутикула псчерчена въ поперечномъ направленіи; головной конецъ окруженъ 3-мя основными и 3-мя дополнительныли губами, длина которыхъ достигаетъ всего лишь ${ }^{1}{ }_{3}$ длины основныхт, губъ.

Губьі почти правильной, 4-угольноӥ формы со сльдани небольшоіі выемки какъ на переднемъ, такь и на боковыхъ краяхъ; перифернческіиі отдыл губы занимаеть прозрачная ньжная мембрана, окаймленшая зуббатымькраем’. Медіанная часть губысъ внут ренней стороны имъетъ довольно глубокое бороздчатое углубленіе, расииряющееся по направленію кпереди. Бороздка эта отдъ. ляеть другє отъ друга обь лопасти пульпы, которыя у этого вида не характеризуются ничьмъ достопримғчательнымъ. Чрезвычайно 
характернымъ для нашего вида зівляется наличность зубчиковидныхъ образованій, расположенныхъ на внутренней поверхности губъ въ области ихъ задней половины. Здъсь мы имъемъ выпуклое по направленію къ ротовому просвъту образованіе, верхній слегка вогнутый край котораго, равно какъ и боковые края усажены небольшини зубчиками съ остріями, направленными кпереди. Признак'ь этотъ можеть служить для отличія нашего паразита отъ другихъ родственныхъ формъ.

С аме цъ достигаетъ 150-180 mщ. длины при максимальной ширинъ 0,85-1,36 mm. Пищеводь сравнительно короткій, длиного всего лишь $6-7 \mathrm{~mm}$. Хвостовой конецъ закругленный съ небольшой пуговчатой вершиной. Отверстіе клоаки располагается на разстояніи 0,255 $\mathrm{mm}$. отъ хвостового конца. Въ области клоаки ширина тв́ла паразита достигаетъ $0,476 \mathrm{~mm}$., на уровн弚 же перехода пищевода въ кишечникъ -- 0,765 mm. Двь равныя, слегка искривленныя спикулы, простой конструкціи безъ какихъ либо крыловидныхъ расширеній, достигаютъ длины 4,08 іпm. Задній конецъ спикулъ ложечковидно закругленъ.

Распредъленіе папилль чрезвычайно своеобразно: преанальныхъ папилль я насчиталъ 48 паръ; изъ ихъ числа 6 паръ располагаются латерально, а 42 пары субмедіанно.

Латеральныя папиллы имъют’ь характеръ выпуклыхъ сосочковидныхъ образованій съ закругленной пуговчатой вершиной; субмедіанныя папиллы, наоборотъ, пмвюютъ видъ плоскнхъ, не возвышающихся надъ уровнемъ кутикулы, круглыхъ твлецъ, окруженныхъ овальнымъ ореоломъ, благодаря чему каждый сосочекъ въ отд’льности получаетъ характер’ какъ бы глаза, обрамленнаго контуромъ вък'ъ. Взаиморасположеніе сосочковъ мною точно зарисовано на прилагаемомъ рисункъ, къ которому и приходится отсылать читателя.

С амка. По странной случайности имйвшіяся въ моелъ распоряженіи самки этого вида были короче самцовъ, достигая 75-100 mщм. длины (въ половозр влом’ состояніи). ШШирина твла въь области anus'a доходила до 0,68 mm., въ средней части тъла-1,3-1,5 mm. Анальное отверстіе располагается на разстояніи 0,39 111и. отъ хвостового конца. Хвостъ закругленъ, и снабженъ небольшимъ коническимъ отросткомъ, длиною въ $0,034 \mathrm{~mm}$. Половое отверстіе располагается нбсколько кзади от’ь средины твлла. Яйца кругловато-овальной фс рмы, 0,085-0,09 mm. длины и 0,068--0,072mm. ширины. Скорлупа яицъ характеризируется ньъжной точечностью. Яйца находятся въ стадіи morula. 
До настоящаго времени въ кишечникв зебры была находима лишь обычная лошадиная аскршда-Ascaris megalocephala Cloquet 1824 .

\section{Ascaris spec.}

Молодая, неполовозрблая самка одного изъ видовъ Ascaris изъ кишечника змьи Bitis gabonica (Mabira). Длина тьла около $80 \mathrm{~mm}$. при ширинъ $1,75 \mathrm{~mm}$. Маленькая голова состоитъ изъ 3-хъ основныхъ и 3-хъ мапенькихъ дополнительныхъ губъ; позади головы кутикула образуетъ складку, равномърно охватывающую головку въ видъ воротника.

На каждой губъ по 2 круглыхъ сосочка. Зубчатый край отсутствуетъ. Пульпа состоитъ изъ двухъ закругленныхъ лопастеї, расположенныхъ параллельно переднему краю губы. Хвостовой конецъ конически заостренъ.

\section{Ascaris sp.}

Неполовозрғлая форма изъ кишечника птицы № 16 (11зъ Gallinaceae. Nabira 9 vı), безъ всякаго намека на развитіе половыхъ органовъ.

\section{Gen. Trispiculascaris gen. nov.}

Изученіе паразита Ascaris helicina Molin 1860, изъ кишечника крокодила, заставило меня выдълить его изъ рода Ascaris L. въ новый родъ, названный мною Trispiculascaris gen. nог.

Кардинальной особенностью этого новаго рода я считаю своеобразное строеніе хвостовой части твла салца. заключаюшееся: 1) въ наличности gub с 1 a c $11 \mathrm{l}$ m, который, обычно, у аскаридъ не встрбчается, 2) въналичности ограниченнаго количества преанальныхъ сосочковъ (всего 4 пары), каковые исчисляются у аскаридъ десяткамн и, 3) въ присутствіи крыловидныхъ расширенії кутикулы въ области хвостового конца самца. Эти признаки, въ связи со строеніемъ ротовыхъ органовъ (губъ) и. пищеварительнаго канала, опредъляяотъ нашелу новому роду совершенно точное

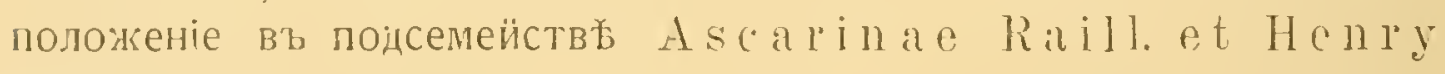
$\left.1912^{1}\right)$

Я предлагаю для этого рода сльдующіиі діагнозъ:

Мелкія аскариды, довольно крупныя губы которыхъ имбютъ

1) Railliet et Henry. Quelques Tematodes parasites des Repti les. Bulletin de la Sociéti de Pathologie Frotique, 1912, T. V, № 4. p. 256. 
по бокамъ ушковидные выросты; зубчатый край, равно какъ промежуточныя губы, имюются на лицо. Пищеводъ и кишечникъ простые, безъ слйпыхь выпячиваній. Хвостовой конецъ самца сильно скручен'ь, снабженъ широкими крыльями и весьма незначительнымъ количествомъ преанальныхъ и постанальныхъъ сосочковъ, располагающихся съ каждой стороны тьила въ 1 рядъ. 2 нбжныя тонкія спикулы равной величины. Имћется gubernaculnı. Хвостъ самки прямой, конически-заостренный. T'ulva располагается въ передней половинғ тъ́. Паразиты пищеварительнаго тракта рептилій. Типъ и пока единственный видъ: Trispiculascaris helicina (Moli n 1860) изъ кишечника крокодила.

\section{Trispiculascaris helicina (Molin 1860).}

(Тайл. IV, рис. 19-21).

Литература:

1. Molin. 30 Specie di Nematoidei. Sitzmngsericht d. Ii. Akadem. Wien XL, 1S60, "p. 337: Ascaris helicina n. sp. изъ желудка крокодила (Crocodilus acutus).

2. Diesing. Revision der Nematoden. Sitzungsbericht d. K. Akadem. Wien XLII, 1861. p. 658.

3. Drasche. Revision der in der Nematoden-Sammlung des K. K. Zoologischen Hofcabinetes befindlichen OriginalExemplare Diesing's und Molin's. Zoologisch--botanisch. Gesellshaft. Wien, 1883, XXXII, p. 130. Taf. IX, Fig. S-9.

4. Stossich. Il genere Ascaris Linné. Trieste 1896. XLVIII. p. 37 (43): Ascaris helicina Molin.

Къ сожальнію, въ. моемъ распоряженіи находились только 2 экземпляра этого интереснаго вида (1 самець и 1 самка), изъ крокодила (Jipe. 7/Vı), всльдствіе чего я не имблъ возможности изучить его вполнъ цетально; однако и тъ̆хъ признаковъ, которые выступили на первый планъ при изслбдованіи этого паразита, было вполнь достаточно для обоснованія новаго рода.

Ротовые органы Ascaris helicina подробно описаны въ работь J rasche (1883); однако посльдній почему то не упоминает'ь о зубчатомъ крағ на основныхъ губахъ этого паразита-признакъ в` систематикъ сем. A s c a l’ i a е весьма существенный-который былъ замътенъ на моихъ экземплярах'ь 'вполнь отчетливо. Отсутствіемъ у Drasche указанія на наличность у этого паразита зубчатаго края объясняется то обстоятельство, что Stossich въ своей монографіи 1896 года ошибочно отнесъ Ascaris helicina къкатегоріи видовъ «enzapiastre dentate e con labbra intermedie». 
Хвостовой конецъ самца С'ь 4 парами преанальныхъ и 5 парами постанальныхъ сосочковъ совершенно правильно описанъ и изображенъ въ работь l) rasche. Однако посльдній почему-то вовсе не упоминаетт, о хитиновыхъ частяхъ мужского полового аппарата-спикулахъ и ğиһерласиlım. 2 спикулы, равной величины,

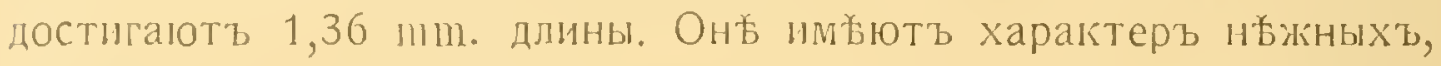
весьма тонкихъ, саблевидно-пзогнутыхъ, палочковидныхъ образованіи, передній конецъ которыхъ имьетъ видъ рукоятки и достигаетъ 0,02 шин. ширины; за рукояткой спикулы нысколько утолщаются (ширина 0,06 mш.), причель ихт, начинаетъ сопровождать нъжная прозрачная крыловидная мембрана, теряющаяся въ заднеій половинғ спикулъ. Наконецъ, позади этого расширенія спикулы снова утончаются, причемъ ширина ихъ доходитъ всего лишь до $0,014 \mathrm{~mm}$. Задняя часть спнкуль оканчивается закругленіемъ.

Наиболье интересної особенностью этого вида приходится

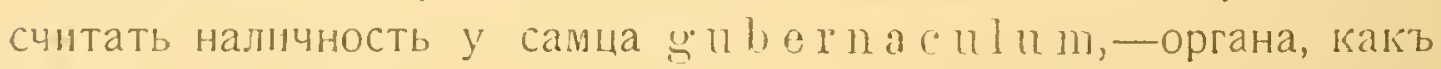
извъстно, у аскаридъ не встрбчающагося. Онъ ильеть форму остроугольнаго треугольника съ вершиной, направленной кзади; передняя его половина ильетъ, на вентральной поверхности желобокъ, служащій для скольженія по нему спикулъ. Длина ğubernaculum=0,22 mи. Точное изображеніе спикуль и gubernaculum дается лною на рис. 20 настоящей рабооты.

Изъ подробностеї строенія тъла самки отмбчу лишь размврь яицъ, не указанный въ литературныхъ источниках’ь; длина янць $=0,07$ mı., при ширинғ 0,052 шщ. Форма яицъ - кругловатоовальная

\section{V. Родъ Orneoascaris nov. gen.}

Вь кишечникъ амфиби-Bufo sl. -проф. Догелемъ и Соколовым была найдена одна аскарида, подробное нзученіе которой заставило выджлить ее въ новый родъ, названный мною Orneonscaris ก.

Основаніемъ для этого послужило строеніе хвостового конца самца, въ частности характеръ хвостовыхъ сосочковъ, спикулъ и наличность цшрокой хвостовой бурсы, наряду съ чрезвычайно сложнымъ. мсзаичнымъ, рисункомъ кутикулы на вентральной поверхности хвостового конца.

Діагноз' $\mathbf{6}$ :

Средней величины аскариды, ротовое отверстіе которыхъ окружено 3-мя крупными губами, снабженными зубчатымъ краемъ. 
Промежуточныя губы отсутствуютъ. Пищеварительный тракть простой, безъ сльпыхь выростовъ. Хвостовой конецъ самца снабженъ по бокамь широкой крыловидной бурсой; 2 равныя спикулы очень нбжнато строенія; gubernaculum отсутствуеть. Преанальныхъ сосочковъ небольшое количество (7 паръ). Всы они сидятъ на стебелькахъ, причемъ свободны конецъ ':х’ъ имъеть характеръ какъ-бы вынчика махроваго цвътка, т. к. состоитъ изъ цйлаго комплекса лепестковидныхъ лопастей. Постанальные сосочки сидячіе. Вентральная поверхность хвостового конца самца изборождена какъ въ продольномъ, такъ и въ поперечномъ направленіи цилымъ рядомъ извилистыхъ бороздокъ, образующихъ мелкую мозаичную съть. Съть эта переходитъ отчасти и на передній отдблъ бурсы. Половое отверстіе самки въ передней половинъ т总ла. Крупныя овальныя яйца. Паразиты пищеварительнаго тракта амфибій. Типъ и пока единствениый видъ: Orneoascaris chrysanthemoides 11. 2. 11. sp. "1зъ кишечника. Bufo sp.

9. Orneoascaris chrysanthemoides nov. sp.

(Табл. 11 : рис. 22-26).

Хозяннъ: Виғо sp.

Локализація: кишечникъ.

Тв̈ло цилиндрическое. слегка утончающееся у обопхъ концовъ. Кутикула нвъжн исчерчена въ поперечномъ направленіи. Головной конецъ снабжень тремя крупными губами, имғощими 6-ти угольную форлу съ двумя боковыми выемкали. Внутренняя поверхность губы характеризуется бороздковиднымъ углубленіемъ, выраженнымъ чрезвычайно рбъзо. Пульпа имъетъ закругленный передній край, причемъ правая и льввая ея лопасти соприкасаются другъ съ другомъ в"ъ области медіанной линіи. Зубчатый край имьется на лицо, сопровождая периферію губы на всемъ ея протяженіи; отде⿱丶万仒льные зубчики отличаются очень крупной величиной, всльдствіе чего на прилагаемомъ рисункє возможно было точно обозначить ихъ обцее количество и птносительный размвръ. Особенно крупной величины достигаютъ зубчики въ области переднихъ угловъ губъ. На наружной поверхности каждой губы располагаются по 2 крупныхь овальныхъ сосочка. Ширина дорзальной губы $=0,374 \mathrm{~mm}$., длина ея=0,221 mm. Пищеводъ простой, безъ всякихъ сльдов'ь какихъ-либо выростовъ.

Самецъ: 28-30 mm. длины прн максимальной ширин в 0,8 $11 \mathrm{~m}$. Длина пищевода $=5,1 \mathrm{~nm}$. (=1/6 часть длины товла). Ширина твла 
тотчась позади губъ достигаеть $0,34 \mathrm{~mm}$, въ области конца пищевода $=0,68 \mathrm{~mm}$., въ средней части тьла $=0,8 \mathrm{~mm}$., въ области anus'a (считая вмвств съ крыльями бурсы) $=0,85$ шн1. Хвостовой конецъ снабженъ по бокамъ слегка асимметричною бурсой, шириною=0,85 $\mathrm{mm}$. Бурса исчерчена въ поперечномъ направленіи нғжными полосками, къ которымъ въ передней части бурсы присоединяется мозаикообразная сътчатость, переходящая на крылья со стороны вентральной поверхности твла. Кутикула послъдняго въ области хвостового конца характеризуется чрезвычайно красивой структурой, состоящей изъ сложно переплетенной съти продольныхъ и поперечныхъ извитыхъ бороздокъ, пересъкаюцихъ другъ друга подъ разнообразными углами, вслғдствіе чего образуется поразительной красоты рисунокъ. состоящій какъ бы изъ отдъльныхъ звъздчатыхъ ячеекъ, распредъленныхъ въ видъ мозаики. Надъ общимъ хаосомъ этихъ сплетеній, однако, доминирують довольно правильно чередующіяся извитыя линіи, располагающіяся в’ь поперечномъ къ длинъ твла направленіи. Наибольшаго развитія это сплетеніе достигаетъ въ области расположенія самыхъ переднихъ преанальныхъ сосочковъ, причемъ, однако, по средней линіи располагается зона, незатронутая вышеохарактеризованнымъ рисункомъ. По направленію къ хвостовому концу эта причудливая структура кутикулы постепенно оттъсняется къ боковымъ краямъ тъла, причемт крайней задней ея границей является анальное отверстіе; посльднее расположено на разстояніи $0,17 \mathrm{~mm}$. оть хвостового конца.

Преанальныхъ сосочковъ 7 паръ; всь они стебельчатой формы, причемъ поверхность стебельковъ характеризуется структурой, одинаковой съ таковой боковыхъ краевъ тєла. Свободные концы папилль им ъютъ тоже чрезвычайно своеобразное строеніе, образуя собою какъ бы вбнчикъ махроваго цвътка, состоящій изъ цйлаго копплекса лепестковидныхъ лопастей, распредъленныхъ въ довольно правильные концентрическіе слои. Первые сосочки (считая оть клоаки) организованы наиболье просто и состоятъ изъ $1-2$ концентрическихъ слоевъ лепестковъ; по направленію-же кпереди характеръ сосочковъ постепенно усложняется, достигая своего апогея у 6-ой и 7-ой пары, такъ какъ на уровнғ ихъ расположенія сътчатый характеръ вентральной поверхности кутикулы тъла переходить, какъ я уже упоминалъ выше, на поверхность крыльевъ, въ результать́ чего получается такая картина, которая изображена на рнсункъ.

Постанальныхъ сосочковъ 4 пары; распредълены они нъсколько 
асимметрично, такъ какъ съ правой стороны латеральное положеніе принимаетъ второй сосочегъ, съ лғвой-же стороны-первый сосочекъ имъетъ аналогичное положеніе. Всъ постанальныя папиллы сидячія, лишенныя стебельковъ.

Спикулы 2, равной величины; длина спикулъ $=1,19$ шт. при ширинь основанія $=0,02$ пи!; ширина средней части=0,017 Такія нвжныя, хрупкія и тонкія спикулы являются исключеніемъ для аскаридъ, большинство которыхъ характеризуется мощными хитиновыми частями своего полового аппарата.

Gubernaculum-отсутствуетъ.

Самка: 48-51 mm. длины при максимальной ширинь $=1,2$ m॥. на уровнб полового отверстія.

Въ области задней части пищевода ширина тұла достигаетъ--

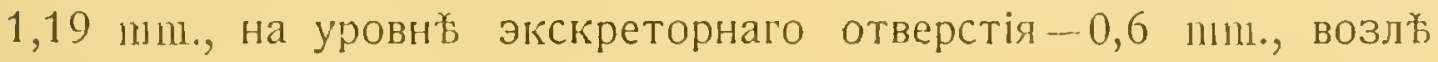
anus'a $=0,54 \mathrm{~mm}$. , позади губъ $=0,5 \mathrm{~m} 11$.

Пищеводъ достигаетъ $6,54 \mathrm{~mm}$. длины; экскреторное отверстіе располагается на разстояніи 1,0 피. оть головного конца, а половое отверстіе-въ передней половинь 17,5 $11 \mathrm{~m}$. отъ головы. Анальное отверстіе лежить почти терминально. Хвостовой конецъ тупо закругленъ. Яйца овальной Формы, довольно крупнаго размғра: 0,12 mı. длины и 0,085 $\mathrm{mm}$. ширины.

\section{C. Сем. Heterakidae Raill. et Henry 1914.}

Из'ь моего матеріала къ этому семейству относятся 2 формы, являющіяся представителями родовъ:

1) Subulura Mo lin 1860.

2) Strongyluris A. M ülle r 1894.

Посльдній родъ отнесенъ Railliet et He nl' у (въ работв 1914 г., напечатанной въ трудахъ IX зоологическаго международнаго конгресса въ Монако) къ подроду рода Heterakis $\mathrm{D}$ u.j. 1845, чего, на мой взглядъ, не сльвдовало-бы дъилать, такъ какъ вс⿱⺊口丂 представители Strongyluris характеризуются настолько типичными признаками, что ихъ вполнб сп справедливо было-бы отнести къ категоріи родовыхъ.

\section{VI. Родъ Subulura Molin 1860.}

Діагнозъ:

Нематоды семейства Heterakidae Raill. et Henry 1914. Ротъ въ ръдкихъ случаяхъ с`ъ 3-мя губами, иногда круглой формы, чаще овальной или шестиугольной, съ главной осью, 
расположенной въ дорзо-вентральномь направленіи. Ротъ переходитъ въ restibulum (ротовая капсула), на днғ которой находятся три зубца (входъ въ пищеводъ). Пищеводъ снабженъ ясно выраженнымъ бульбусомъ. На головъ 6 сосочковъ, въ большинствъ случаевъ ясно замытныхъ. Часто 2 боковыхъ крыла. Хвостовыя крылья самца слабо выражены или отсутствуютъ: спикулы равной величины (за рәдкимъ исключеніемъ = $=$. allodap Crepl. 1854); имъется subernaculum; веретенообразной формы преанальная присоска лишена хитиноваго кольца. Половое отверстіе самки возль середины дыны твла. Яйца кругловатой формы, почти всегда съ развитымъ зародышемъ. Паразитируютъ въ мышечномъ желудк各 или кишечникъ (по б. ч. Въ слбпыхъ кишкахъ) птицъ, а также въ кишкахъ (по б. ч. толстыхъ) млекопитающихъ (приматовъ, лемуровъ, хищныхъ, грызуновъ), Типичный видъ: Subulura acutissima. Mol. 1860 изъ желудка и кишечника Strix atricapilla и Cuculus melanoryphus.

Въ коллекціи проф. Догеля и Соколова находился одинъ видъ этого рода: Subuluru suctoria (Molin 1860).

\section{Subulura suctoria (Molin 1860).}

(Табл, V', рліс. 2T-29).

Литература:

1. Molin. Trenta specie di Nematodi. Sitzungsbericht. d. k. Akadem. Wien. 1S60. T. XL. p. $3+1$.

2. D rasche. Revision der in der Nematorlen-Sammlumg des K. k. zoologischen Hofkabinctes befindlichen OriginalExemplare Diesing's und Molin's. Trohandl. d. k. k. Zoolng. botanisch. Gesell. Wien, 1882, p. 119-120. Pl. I'H. Fig. j-10.

3. Ge ndre. Notes d'helminthologie alricane (3-me note). Extraits des Comptes Rend. des Séances de la Soc. Linnéenne de Bordeanx, 1909, р. LXXXI съ 1 pис.

4. Gendre. Sur quelques especes d'Heterakis du Dahomey. Extraits des Procis-Verbanx des Séances de la Société Linnéemne de Bordeaux 1911. p. 73: Heteralis suctoria Moliu.

5. Seurat. Sur un nouvel babitat et sur la morphologie du Subulura allodapa (Crepl.), C. Rend. Soc. Biologie, 20. T. 1914. T. ะ7. N 22. p. 154.

6. Railliet el Henry. Essai de classification des Heterakidae, IX Congrès internat. Zoologie, Monaco, 1914. p. 680: Subuluve suctoria Molin.

Видъ этоть, подробно изученный Drasche (1882 г.) и 
отграниченный за посльднее время отъ близкаго вида Subulura allodapa (Cr с p l. 1854), оказался въ коллекціи проф. Д огеля и Соколова, которые нашли его у новаго хозяина-Centropus superciliosus. До настоящаго времени видъ этотъ былъ onucaнъ y Caprimulgus campestris, Caprimulgus nacmula " Dicholophus marcgrafi Illig., а въ посльднее время удомашней курицы и цесарки (согласно данным’ Gend I’ ${ }^{1}$ ). У двухъ посльднихъ птицъ паразиты найдены на африканской территоріи.

Изсльдованные иною паразиты представлялись типическими Subulura suctoria M o 1 і п. Длина тьла самца доходила до 10-12 mm., при ширинъ $0,34-0,35 \mathrm{~mm}$. Пищеводъ чрезвычайно удлиненный (общая длина его вмьсть съ бъ бульусомь =1,5 mm.), выложенъ съ внутренней стороны хитинсвыми образованіями съ характерной поперечной исчерченностью. Ширина пищевода въ средней его части доходить до $0,085 \mathrm{~mm}$. Пищеводный бульбусъ, вооруженный зуо̆ныль аппаратомъ, достигаетъ $0,255 \mathrm{~mm}$. длины при ширинъ $0,22 \mathrm{~mm}$. На хвостовомъ конц务 11 паръ сосочковъ, изъ числа коихъ 5 паръ преанальныхъ и 6 паръ постанальныхъ. Распредълены сосочки (см. рис. 29) совершенно въ такомъ порядкћ, какъ то описано Drasche, Gendre и др. авторами. Удлиненно-овальная присоска располагается на разстояніи $0,85 \mathrm{~mm}$. отъ хвостового конца. Анальное отверстіе находится на разстоянін $0,272 \mathrm{~mm}$. отъ хвостового конца. 2 спикулы равной величины, дастигающія 0,90--0,93 $\mathrm{mm}$. длины при ширин古 основанія $=034 \mathrm{~mm}$. Онъ палочковидной формы и постепенно утончаются по направленію къ заднему концу. Кснцы спикуль закруглены. Возлћ аnия а располагается маленькій треугольный gubernaculum, лежащій не въ дорзальномъ къ спикуламъ направленіи, а въ вентральномъ. Внутренній желобъ gubernaculum а соотвътственно направленъ своей выпуклостью въ вентральную сторону (обычно, какъ изв бстно, бываетъ наоборотъ!). Ширина твла самца цостигала въ области пищеводнаго бульбуса 0,34 mm., на уровнь-же апus $a-0,15 \mathrm{~mm}$.

1) Gendre: Notes d'Helminthologie africaine (3-me nute). Extraits des Compt. Rend. des Séances de la Soc. Linnéenne de Bordeaux, 1909, p. LxXXl. однако можно предполагать, что Gendre имьль дыло не ст Subulura suctoria M o l., a ст Subulura allodapa (C r e p l. 185t), которая

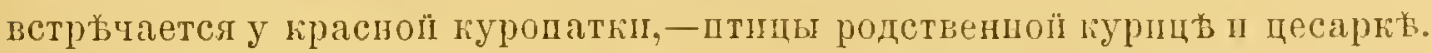
Единственнып̆ призпакъ, которынъ $S$. allodapa отличаетея отъ S. suctorîa-неравенство спикуль-соверііенно пе указань въ работь' Gendre, всльдствіе чего мы молемь тольго предлолагать, что Gendre пмйль дъво съ $S$. allodapa на основанін родс:ва хозяевъ его паразитовъ ст красной куропаткой-хозянномъ S. allodapa. 
Самка. 17,0 ши. длины при максимальной ширинь $0,51 \mathrm{~mm}$. (в’ь области расположенія rulv'ы). На уровнб пищеводнаго бульбуса ширина тйла доходила до $0.425 \mathrm{~mm}$, а возль апus`a $=0,06 \mathrm{~mm}$. Пищеводъ, длиною $1,87 \mathrm{~mm}$, снабженъ бульбусомъ, длина котораго достигала $0,34 \mathrm{~mm}$. при ширинь $=0.222 \mathrm{~mm}$. Ширина начальнаго отдела кишечника доходила до $0,357 \mathrm{~mm}$. Хвостовой конец’ь тонкіиі, заостренный. Anus открывается на разстояніи 0,17 $\mathrm{mm}$. отъ хвостсвого конца. Vulva располагается въ передней половинь тьла, на разстияніи 7,5 mm. отъ головного конца. Кругловато-овалығыя яіцца достигаютъ $0,055 \mathrm{~mm}$. длины при ширинь $0,04 \mathrm{~mm}$.

Ротовая капсула самки достигает’b $0,049 \mathrm{~mm}$. длины при ширин酋 0,051 m.

Vil Родъ Strongyluris A. Müller 1894.

Діагнозъ:

H e teraki da e, тәло которыхъ покрыто маленькими сосоч. ками, располагающимися преимущественно въ передней части. Ротъ изъ 3-хъ губъ. Пицеводъ снабженъ въ задней своей части бульбусомъ. Хвостовыя крылья самца короткія, поддерживаются стебельчатыми, чрезвычайно утолщенными сосочками, имъющими сходство съ ребрами хвостовой сумки Strongylidae. Спикулы равной величины, длинныя, тонкія; преанальная присоска отодвинута поо направленію к'b клоак заднемъ крағ выемкой, въ которой располагается непарная папилла. Половое отверстіе самки располагается кзади отъ середины длины твла. Влагалище направляется кпереди; матки расходятся въ противоположныя стороны; овальныя яйца, с’ь толстої скорлупой, заключаютъ сформированнаго зародыша. Паразиты желудка и кишечника рептилій.

Типичный видъ: Strongyluris brevicaudata A. M alle r 1894 изъ толстыхъ кишек's Agama colonumu.

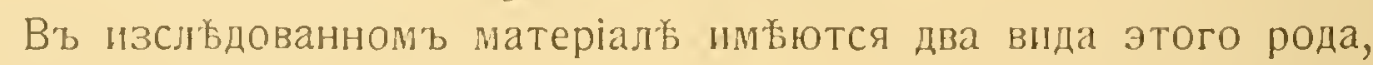
уже описанные изъ Африки.

11. Strongyluris brevicaudata A. Müller 1894.

(Синонимъ: Heteralis strongylura Gendre 1909.)

(Tani. I', pнu. 30-34).

Литература:

1. If ii l l e r. Helminthologische Beobachtungen an bekan- 
nten und unbekannten Entozoen. Arch. f. Naturgesch. 189t. Bd. I. p. $-116-117$, Taf. VII.

2. G e n dre. Notes d'Helminthologie africaine (2-me note). Extraits des Compt. Rend. des Séances de la Soc. Linnéemne de Bordeaux, 1909, p. XXXIX-XLI: Heteratis ornata? v. Li in st.-оть Agama colomurum Da ud. (съ 7 рисунками).

3. G e $n$ d re. Notes d'Helmint. africaine (3-me note), тамъже, стр. LIXV, въ примььчаніи. Авторъ указываетъ, что описанный имъ въ 1909 г. паразитъ подъ иленемъ Fleteralis ornatu? v. Linst. оть Agama colonulum является идентичнымъ паразиту, описанноліу Мïller’омъ въ 1894 г. подъ именемъ Strongyluris brevicaudata " предлагает'ь назвать его Heteralis strongylura (чтобы не сміғшать съ паразитопь рыбы-Heteralis brevicaudata R a tz. 1897.)

4. Ra 11 i e t e t H e n r y. Essai de classification des Heterakidae. IX Congris internation. de Zoolog., Monaco 1914. p. 677: Heteratis (Strongyluris) brevicandata. (.I ii l l. 1894)—какъ типъ подрода Strongyluris.

5. Gendre. Sur quelques espèces d'Hétérakis du Dahomey. Extraits des Procès-rerbanx des Séances de la Soc. Linnéenne de Bordeaux, 1911. p. 69: Heteralis strongylura Mïller (синонимъ: Strongyluris brevicaudata Mïller 1894.отъ Agama colonurum Daud.)

Видъ этотъ былъ найденъ проф. Догелемъ и Соколовымъ у трехъ экземпляровъ Agama: Agama № 2, Agama № 11 и Agama № 13.

Я считаю необходимымъ дополнить описаніе этого паразита, сдъланное вышеприведенными авторами, еще нижесльвдующими указаніями.

1). Ротовые органы этого вида, какъ указывають мои рисунки 30 и 31, состоять изъ трехъ равной величины губъ, на поверхности которыхъ располагаются по 2 торчащихъ сосочка. Съ внутренней стороны средней части каждой губы высовывается въ полость рта направленный своимъ остріемъ кпереди небольшой хитиновый копьевидный отростокъ.

2). Мощная присоска этого вида, при разсматриваніи ея въ профиль, характеризуется наличностью особеннаго мъшковиднаго придатка, находящагося въ соединеніи съ внутренней полостью присоски, какъ то видно на рис. 32

3). Внутреннія стбнки пищевода кзади отъ мьсторасположенія мышечныхъ сосочковъ глотки (о которыхъ упоминаетъ 
Gendre) выстланы хитиновыми образованіями, имбющими характерную равном зрную поперечную исчерченность.

\section{Strongyluris elegans Gendre 1909.}

(Taúi. VI, pric. $35-36$ ).

Литература:

1. Ge ndre. Notes d'helminthologie africaine (2-me note). Extraits des Comptes Rendus des Séances de la Société Linnéene de Bordeaux, 1909. p. XXXVI-XXXIX c’b 7 рисунками.

2. Ge n dre. Sur quelques espèces d'Hétérakis du Dahomez. Extraits des procés-rerbaux des Séances de la Société Linnéenne de Bordeaux 1911 г. p. 69.

3. Railli et et H en ry. IX Congrés international. Zoologie à Monaco 1914. p. 677.

Видъ, этот’ь, описанный G en dre'ом’ь изъ хамелеона, найденъ былъ проф. Догелемъ и Соколовымъ въ кишечник она (№ 21.)

Спикулы самца этого вида достигали $0,935 \mathrm{~mm}$. длины.

Я считаю полезнымъ дать рисунокъ этого вида, изображающіiі характеръ хвостовой бурсы самца и сдъланный при помощи рисовальнаго прибора Цейсса. На нем’ь, помимо распредъ̆ленія сосочковъ, замбтно характерное строеніе спикуль, неотльченное до сего времени въ литературь: спикулы въ своей передней половинь имғюють своеобразную выпуклую кольчатую поверхность, присутствіе которой обусловливает’ь характерную зубчатость боковыхъ краевъ спикупъ. У лъвой спикуль кольчатость эта начинается возлъ самаго ея основанія, у правой же, наоборотъ, близь основанія поверхность спикулы гладкая, средняя-же треть спикулы имғеть такую-же кольчатость, какъ и у львой.

Спикулы Strongyluris brevicandata M ii ll. 1894, повидимому, такой кольчатости не имъютъ.

\section{D. Сем. Oxyuridae}

В`ь изсль̆дованномъ матеріаль находились представители сльвдующихь родовъ этого семейства:

1. Oxyuris Rud. 1803 (sensu lato).

2. Oxysomatimm Raill. et Henry 1913 и

3. Isacis Lespes. 1856. 


\section{VIII Родъ 0xyuris Rudolphi. 1803.}

Родъ этотъ представленъ въ изслғдованномъ матеріаль наиболье богато, заключая въ себъ паразитовъ млекопитающихъ, рептилій, амфнбіиі и даже безпозвоночныхъ-многоножекъ. Объясняется это съ одной стороны твиъ обстоятельствомъ, что виды рода Oxyлиis вообще весьма распространены у амфибій и рептиліӥ (паразиты которыхъ занимаютъ главное мбсто въ разрабатываемой коллекціи). Съ другой стороны родъ Oxyuris R ud. является такой единицей въ современной систематикъ, куда относятьь паразитов'ь с'ь настолько разнообразными признаками, что будущему изсльдователю несомнынно придется раздробить его на нъсколько отдъльныхъ родовъ. Въдь, въ сущности говоря, Oxyлиris-это одинъ изъ тьъх немногихъ старыхъ родовъ, который со временъ Rudolph і почти не подвергался дифференціаціи. Зависить это обстоятельство главнымъ образомъ отъ того, что у большинства видовъ Oxyиl' is описаны одн方 лишь самки, строеніе которыхъ даетъ слишкомъ мало данныхъ для дифференціальной діагностики;-съ другой же стороны у представителей Oxyuris обычно чрезвычайно поверхностно изучалось строеніе ротовыхъ органовъ, каковые, однако, могли бы оказать большую услугу дйлу выясненія родственныхъ отношеній отдъльныхъ видовъ другъ, къ другу. Къ великому сожальнію, до настоящаго времени не нашлось изсльдователя, который бы взялъ на себя трудъ произвести такъ называемую «ревизію» рода Oxyиґіs работа эта въ настоящее время подь силу только западно-европейскому ученому, который можеть воспользоваться большими гельминтологическими коллекціями крупнййихъ университетскихъ и академическихъ музеевъ Европы, гдъ хранятся «типы» описанныхъ видовъ, русскій-же пзсльдователь не имветь подъ руками достаточнаго количества собраннаго матеріала, всльдствіе чего не имғетъ возможности принять на себя выполненіе этой задачи ${ }^{1}$ ).

Изъ вышесказаннаго станетъ совершенно понятнымъ, почему

1) Въ самое послиднее времл, когда пастоящая работа была уже закончена, появились запьти Railliet et Henry съ одной стороны и S е и т а l一сь другой, въ которыхь авторы дылагот пошытку раздройіть старый родт охуйіs Rud па дылый рядт салостоятельныхь повыхт

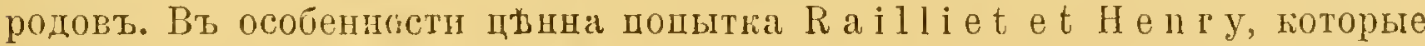
расцолагали псчершывающимь матеріаломт, а потиму і ввели в'ь свою спстему Ox у I I d a е почти всь оцисанныя формы. Работы вынеупомянутыхь авторовъ опублпкованы зъ первыхъ нолерахъ за 1916 годъ Cmpt. Rend. Soc. de Biologie, Paris. 
въ настоящее время нельзя дать точнаго діагноза роду Oxyинis $\mathrm{R} u \mathrm{~d}$, а приходится говорить лишь въ общихъ чертахъ о строеніи его представителей.

Во всяком’ь случаб современный изслбдователь, описывая паразитовъ рода Oxyuris Rud. 1803 (sensu lato). долженъ обращать особенное вниманіе на строеніе ротовыхъ органов’ чтобы твмъ самымъ подготовить матеріалъ, на основаніи котораго впосльодствін можно будетъ сдвинуть систематику этого рода с'ь мертвой точки.

Въ настоящей работьв я прнчисляю къ роду Oxyuris R u cl. (sensu lato) 7 видовъ коллекціи Догеля и Соколова. Огобеннаго вниманія заслуживаютъ 2 формы, найденныя въ кишечникъ одного экзелпляра многоножки Polyclesmus sp.; cb перваго взгляда оба паразита (самки) казались весьма близкими друг’ь к’ь другу, различаясь лишь положеніемъ vиlы и сравнительной величиной хвостового отростка. Подробное-же изученіе ротового аппарата, предпринятое мною, благодаря чрезвычайно палому размъру головы, при полощи масляной иммерсіи $(1 / 12)$, - выяснило вполн ясно и опредъленно, что это не только представители отдъльныхъ видовъ, но даже отдъльныхъ родовъ, т. к. ротовой аппарат`ъ ихъ устроенъ по совершенно различному типу.

Въ настояшее время я не счель возможнымъ обосновать новые роды для этихъ паразитовъ, т. К. въ моем'ь распоряженіи, къ сожальнію, не было самцовъ, и вынужденъ былъ отнести ихъ к’ъ роду Oxyuris Rud. (sensu lato).

\section{Oxyuris myriapodicola 11. sp.}

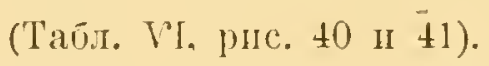

Въ моемь распоряженіи имғлись только самки, найденныя въ кишечникъ Polydesmus sp.

Длина твла достигала 2,48 шщ. при максимальной ширинж $0,187 \mathrm{~mm}$. на уровнғ голового отверстія. Въ области задняго отд‡ла иищевода твло достигало $0,153 \mathrm{~mm}$. ширины, на уровнъ же anus' $a=0,1 \mathrm{~mm}$.

Кутикула совершенно прозрачная, кольчатая. Кпереди от’ь пищеводнаго бульбуса тъло суживается, равно какъ и кзади оть уровня перехода средней кишки в’ь щелевидный reclum. Позади анальнаго отверстія располагается упругіiі, довольно массивный, гладкій хвостовой отростокъ, заостренныї на вершинт; и достигающій 0,4 mщ!. длины (около ' 
Переднее кольцо твла преобразовано въ ротовой орган'ь, будучи снабжено на своемъ переднемъ крағ 6-ю маленькими лопастями, играющими роль губъ. Круглое ротовое отверстіе ведетъ въ ръзко обособленную ротовую капсулу цилиндрической формы съ нбсколько расширеннымъ заднимъ отдъломъ. Хитинизирован-

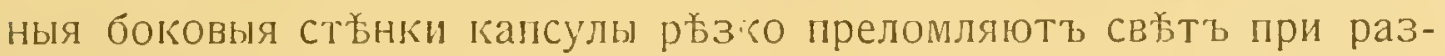
сматриваніи подъ микроскопомъ. Дно ротовой капсулы простирается приблизительно до уровня половины длины второго кольца тйла, которое длиннйе посльдующихъ колецъ (рис. 41).

Ротовая капсула какъ-бы вдавлена въ мышечный пищеводъ, который значительно шире ея. Обшая длина пищевода вмвстй съ бульбусовидныпъ его расширеніемъ достигаетъ 0,442 mли., что составляетъ около $\frac{1}{5.6}$ общей длины тьла.

Ширина цилиндрической части пищевода $=0,034 \mathrm{mlm}$., діаметръ -же бульбусовиднаго вздутія ${ }^{1}$ ) $=0,068 \mathrm{~mm}$. (длина) и $0,085 \mathrm{~mm}$. (ширина). Начальный отдълъ кишечника вздутъ, всльдствіе чего ширина его превызшетъ таковую бульбуса. Оканчивается кишечникъ щелевиднымъ ‘nus’omъ, расположеннымъ нъсколько кпереди отъ хвостового отростка, на разстояніи 0,5 $\mathrm{mm}$. отъ верцины хвоста.

Экскреторное отверстіе располагается на уровнъ передняго отдъла бульбуса пищевода. Vulva открывается почти въ серединь длины толла, на разстояніи 1,25 mm. отъ головного конца и $1,23 \mathrm{~mm}$. отъ конца хвоста.

Овальныя яйца достигаютъ 0,06-0,068 mm. длины при ширинъ 0,045 $\mathrm{mm}$. Vagina направляется кпереди отъ половой щели. Передняя граница яичниковъ не доходитъ до начальнаго отдъ́ла кишечника.

Своимъ ротовымъ аппаратомъ вышеохарактеризованный паразитъ напоминаетъ видъ, описанный L e i d у 2) въ 1850 г. подъ названіемъ Thelastomum labiatum (тоже изъ кишечника Polydes. mus virginiensis), у котораго „oral annulus inflated, six lobed at the margin"; однако другими признаками виды эти настолько отчетливо различаются другъ отъ друга (напр., хвостовой отдълъ самки нашего вида составляетъ 1/6 часть длины тбла, а у Thelastomum labiatum = ${ }^{2}$ 2), что видовая самостоятельность

1) Бульбусь шищевода пмћеть жевательный аппаратъ, состоянйї изъ 3-хь хитнновыхь кланановндныхь нластинокъ.

2) Le i d y. Procecd. Academ. Philadelpl. V. 1850. p. 101., 1851 p. 285 II 1856, p. 50., a также въ: Smithson. Contrib. I. 1853. p. 47. Tab. T'Il. fig. 13 
каждаго стоитъ внъв всякаго сомнънія. С’ другой стороны, нашъ паразитъ имбет’ь сходство с’ь Oxyuris pachyjuli P a r o n $\left.\mathrm{a}^{1}\right) 1896$ (изъ кишечника Tulus communis), который характеризуется одинаковымъ положеніемъ vulvы и экскреторнаго отверстія; отличается, однако, Oxyuris pachyjuli от’ь нашего вида как’ь ротовымъ аппаратом’ъ („bocca trilobata“), размъромъ пищевода, хвоста, такъ равно и величиною яицъ. Наконецъ, видъ нашъ до

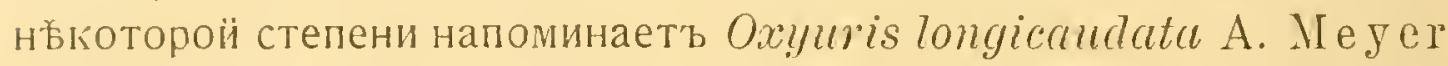
1896 (изъ кишечника цейлонскаго Iulus sp. $)^{2}$ ). Однако паразит’ этот’ь описан'ь такъ поверхностно, и работа Меуе г'а, послужившая ему докторской диссертаціей въ Базелғы, снабжена так'ъ небрежно выполненными рисунками, что чрезвычайно трудно оріентироваться въ точной зоологической характеристик古 его паразита. Не взирая на почти одинаковый размърьъ яицъ, на положеніе rulv'ы, Oxynris longicandata отличается отъ нашего паразита какъ общей длиной т各ла $(5,5-6,0 \mathrm{~mm}$.), такъ и длиною хвоста $(1,0 \mathrm{~mm}$.$) , хотя отношеніе длины хвоста къ общей длинъ$ тьла (около 1:6) остается для обоихъ паразитов'ь одинаковымъ. Описывая ротовую капсулу своего паразита, А. Меуег ничего не говорить о характерныхъ для нашего вида 6-ти лопастныхъ губныхъ образованіяхъ, окружающихъ снаружи ротовое отверстіе. Наконец’ъ, кишечник'ъ Oxyuris longicandata, какъ видно по рисунку 18 работы Меуег'а, значительно уже бульбусовиднаго расширенія пищевода, въ то время какъ у нашего паразита, наоборо'ть, кишечникъ гораздо шире бульбуса. Вышеприведенныя данныя я счита!о достаточными, чтобы ирнзнать за паразитомь Oxyиris myriapodicola видовую сапостоятельность.

Несомнбнно, однако, что будущій изсльдователь долженъ будетъ объединить виды O. longicaudata $\mathrm{Ney} \mathrm{(')} \mathrm{1896,} \mathrm{Thelas-}$ tomm labiatum. Leidy 1850, O. my:"iapodicola m i h i 11, вbроsтно, O. pachyjuli въ одинъ общіiі родъ, поставивъ во главу родового діагноза какъ строеніе рта, такъ и организацію лоловыхъ органовъ самца. Отсутствіе самцовъ лишает`ъ меня возможности выполнить это въ настоящей работь.

1) Parona. Di alcuni nematodi dei Diplopodi. Bolletino dei Musei di Zonlogia e Anat. Comp. della R. Lniversitil di Genora. 1596. № 4t. p. 2 Tab. I. fig. $1-3$.

2) A. Meyer. Nene Nematoden unter den Parasiten ceylonischer Süugetiere und eine Oxyuris, eine neue Sehmarotzerspecies in Iulus (Ceylon). Inaug. Diss. Basel 1896. p. 33-35. fig. 17-19. 
14 0xyuris leidyi nov. spec.

(Tабл. VI, pнс. 37-

Паразить этотъ быль найденъ совмвстно с'ь O. myriapodicola въ кишечникъ̌ Polydesmus sp.

Если ротовые органы O. myriapodicola чрезвычайно напоминали таковые Thelastommm labiatum L eіdy 1850, который, въ остальныхъ чертахъ своего строенія, ръзко разнился отъ O. myriapodicola, то нашъ новый паразитъ-O. leidyi n. sp., какъ разъ наоборотъ, имъетъ совершенно иное строеніе рта, чвмь у Thelastomun labiatum, въ остальномъ-же настолько сходенъ съ посльднимъ, что я первое время не рбшался выдълить его въ самостоятельный видъ.

Самцы неизвъстны.

Самки имжютъ веретенообразной формы тбло, снабженное чрезвычайно длиннымъ, упругимъ, б́чевиднымъ хвостовымъ отросткомъ, длина котораго лишь немногимъ меньше половины общей длины твла. Кутикула глубоко исчерчена въ поперечномь направленіи, образуя характерную кольчатость. Длина твла самки достигаетъ 2,465 mm. при максимальной ширинъ $=0,255 \mathrm{~mm}$. По бокамъ тьла тянутся крыловидныя расширенія кутикулы, начинающіяся на уровн务 шейки пищевода (т. е. мбста перехода цилиндрическаго отдйла пищевода въ бульбусъ) и доходящія до основанія хвостового отростка. Строеніе ротове'хъ органовъ этого паразита, для изученія которыхъ иришлось прибъгнуть къ содъйствію масляной иммерсіи, настолько своеобразно и интересно, что я остановлюсь, на немъ нбсколько попробнбе (см. рис. 38 и 39).

Разсматривая передній, суженный конецъ тйла, мы замйчаемъ, что первыя два его кольца рбззо отличаются отъ остальныхъ: переднее кольцо преобразовано въ спеціально ротовые органы губы, второе же кольцо образуетъ валикообразное вздутіе, отличаясь отъ посльдующихъ, однородныхъ колецъ какъ своимъ болье крупнымъ діаметром’ь, такъ и большею длиною (длина 2-ого

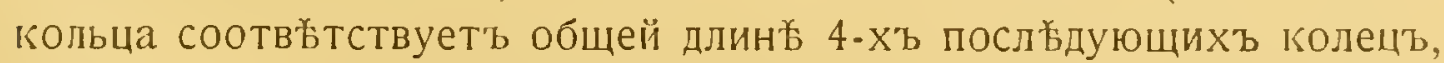
вмьсть взятыхъ). Переднее кольцо состоитъ изъ 3-хъ равныхъ губъ, между которыми располагаются 3 небольшіе кутикулярные выступа, образующіе своего рода рудиментарныя промежуточныя губы (какъ у многихъ аскаридъ). Каждая губа состоитъ изъ 2-хъ отдвловъ, расположенныхъ другъ надъ другомъ какъ-бы въ 2 этажа: задній (нижній) отдъ̆љ имъ̌еть форму выпуклаго прямоугольника, по сторонамъ котораго-располагаются 2 крупныхъ 
сосочка; передній отдұль губы значительно меньшаго размьра чвмъ задній, и имғетъ небольшую выемку въ области верхняго своего края; на наружной его поверхности располагается пара мапенькихъ сосочковъ, на внутренней же, обращенной къ ротовой полости поверхности, располагается небольшой гребень изъ мелкихъ хитногыхт зубчиковъ. Такимъ образомъ каждая изъ 3-хъ губъ этого паравита несеть по 4 сосочка, расположенныхъ в’ь 2 яруса. Вьпеуказанныя отпошенія отдаялныхь частей губъ другъ ќь другу иредставлены на рис. 38 и на схемғ (рис. 39), изображающей видъ ротовыхъ органовъ этого паразита при разсматриванін ихъ спереди.

Ротовое отверстіе переходитъ в'ъ пищеводъ, общая длина котораго достигаетъ $0,425 \mathrm{~mm}$. при ширин各 цилиндрическаго отдаяла $=0,04 \mathrm{~mm}$. Задній отдыль пшщевода преобразованъ въ шаровидный бульбусъ, діаметръ котораго догтигаетъ 0,085-0,09 $\mathrm{mm}$. На мвстћ перехода цилиндрическаго отдвла пищевода въ бульбусъ первый утончается, образуя какъ бы перетяжку. Бульбусъ снабженъ хитиновым'ь жевательнымъ аппаратомъ. Начальный отдълъ кишечника чрезвычаііно вздут'ь; анальное отверстіе открывается возль основанія хвоста, на разстояніи $1,105 \mathrm{~mm}$. отъ вершины посльвняго. Ширина твла на уровн各 апus'a достигаетъ всего лишь $0,085 \mathrm{~mm}$. Экскреторное отверстіе располагается на уровн古 передняго края пищеводнаго бульбуса. Половое отверстіе отодвинуто къ анальному отверстію, располагаясь нъсколько кпереди отъ посльдняго; отъ середины длины тәла половое отверстіе отодвинуто нь̆сколько кзади. Овальныя, сравнительно немногочисленныя яйца достигаютъ $0,085 \mathrm{~mm}$. длины при шириньъ $0,051 \mathrm{~mm}$.

\section{Oxyuris praeputialis nov. spec.}

(Табл. VI. рис. 42-44).

Этотъ новый видъ найденъ въ кишечникъ представителя селейства Bufonidae (Bufo № 10).

Самцы въ моемъ распоряженіи не нмълись. Тйло изсльдлованныхъ самокъ бълаго цвъта, цилиндрической формы съ нъсколько утонченнымъ передним' концомъ; задній конецъ снабженъ небольшимъ бичевиднымъ хвостовымъ придатком'ь. Кутикула чрезвычайно нбжно исчерчена въ поперечномъ направленіи, причемъ исчерченность эта запхтна лишь при большомь увеличеніи. На головномъ концт кутикула образует'ь складку, облекающую передній отдыль паразита на подобіе praеputium, причелъ 
головной конецъ у наткоторыхъ экземпляровъ этого вида былъ обнаженъ, у другнхъ-же, наоборотъ, прикрытъ, по бокамъ pracputial'ной складкой, изъ за которой виднълся лишь передній край губъ. Ротовое отверстіе окружено 3-мя равной величины удлиненными губами, на которыхъ располагаются по 2 довольно крупныхъ сосочка. У тьвъ экземпляров'ь, у которыхъ головка была обнажена отъ placputium'a, она высовывалась на пространствъ 0,05 mı, а далье кзади въ видъ; кольца обозначалось мвсто прикрвпленія рlacputial'ной складки.

Длина изсльдованныхъ самокъ қолебалась въ предълахъ 3,0-4,5 mı1. Щирина тила въ области пищеводнаго бульбуса доходила до $0,2-0,25 \mathrm{~mm}$., въ области расположенія полового отверстія $=0,238-0,275 \mathrm{~mm}$, на уровн古 апиз' $\mathrm{a}=0,153-0,17 \mathrm{~mm}$. Общая длина пищевода $=0,51-0,55 \mathrm{~mm}$. при ширинъ цилиндрическаго отдыла $=0,05-0,06 \mathrm{~mm}$, и ири діаметрж бульбуса $=0,136-$ $0,15 \mathrm{~mm}$. Посльдній снабженъ трехклапаннымъ хитиновымъ аппаратомъ. На уровнъ перехода цилиндрическаго отдъла пищевода въ бульбусъ или же нъсколько болъе кпереди, располагается экскреторное отверстіе. Кишечникъ, шириною почти равный ширинъ бульбуса или слегка шире посльдняго, оканчивается anus'oмъ на разстояніи $0,37-0,4 \mathrm{~mm}$. отъ хвостового конца. Задній отдълъ тьлыа снабженъ бичевиднымъ, заостреннымъ придатком'ь, длиною $0,28-0,32 \mathrm{~mm}$, составляя около $\frac{1}{10,5}$ части общей длины твла.

Половое отверстіе расположено почти по серединғ длины твла, будучи нъсколько сдвинуто кпереди: такъ, у самки длиною 4,5 m11. половое отверстіе помъщалось на разстояніи 2,20 $\mathrm{mm}$. отъ головного и 2,30 $\mathrm{mm}$. отъ хвостового конца.

Ни одна изъ изсльдованныхъ самокъ не содержала зрблыхъ яицъ. Половые органы выполняли своими извивами почти все твло паразита, начинаясь нъсколько позади бульбуса и доходя почти до основанія хвостового придатка.

16. Oxyuris megalocerca nov. spec.

(Табл. เіг, рпіс. 45, 46).

Этотъ чрезвычайно мелкій и изящный паразитъ былъ найденъ въ сль̆пой кишкъ ящерицы № 4 (изъ гекконовыхъ).

Общимъ своимъ характеромъ видъ этотъ чрезвычайно напоминаетъ описаннаго въ прошломъ году Oxyuris laevicauda Sell at 1914 (изъ кишечника африканскихъ рептилій Acan- 
thodactylus blanci Doum. и Scincus officinalis), отличаясь. однако, отъ посльдняго какъ цұлымъ рядомъ мелкихъ признаковъ, такъ, главнымъ образомъ, и наличностью крыльевъ, берущихъ свое начало отъ головного конца паразита и тянущихся до уровня anus'a (y Oxyuris lrevicaula крылья располагаются только въ задней трети длины твла). Самцы этого новато вида достигали 1,02-1,5 mm. длины, шри максимальной ширин $0,136-0,2 \mathrm{~mm}$. Твло состоитъ изъ двухъ ръзко обособлениыхъ частей: веретенообразной формь туловища и чеезвычайно длиннаго, тонкаго хвоста, длина котораго относится къ длиньв „туловнща“, какъ $3: 4$. Кутикула нжжно исчерчена въ поперечномъ направленіи, причемъ разстояніе между смежными полосками достигаетъ всего лишь 0,003 mm. По бокамъ твла располагаются широкія крылья, начинающіяся почти возль самаго головного конца " доходящія до уровня анальнаго отверстія. Пищеводъ, длиною $0,27-0,35 \mathrm{~mm}$,, снабженъ въ задней своей части бульбусомъ правильно шаровидной формы $\mathrm{cъ}$ діаметтромъ $=0,068-0,085 \mathrm{~mm}$. Въ центрь бульбуса располагается хитиновый аппаратъ, состоящій изъ 3-хъ клапановъ съ зазубренными краями. Кзади отъ бульбуса начинается кишечникъ; онъ чрезвычайно расширенъ въ своемъ нереднемъ отдйль, но постепенно суживается кзади, оканчиваясь анальныль отверстіемъ на разстояніи $0,46-0,51$ inm. отъ вершины хвостового отростка.

Кпереди отъ анапьнаго отверстія располагается 1 пара преанальныхъ, удлиненныхъ, направленныхъ кзади сосочковъ, которые имють болье вентральное положеніе, чћиъ 2 пары постанальныхъ сосочковъ. Изъ числа пссльднихъ одна пара, лежащая ближе къ отверстію клоаки, имьетъ направленіе спереди назадъ, другая-же пара, болъе отдаленная отъ клоаки, располагается своей осью перпендикулярно оси хвостового отростка.

Итакъ, по числу своихъ сосочковъ (1 пара преанальныхъ Һ 2 пары постанальныхъ) нашш новый видъ, сходенъ съ Oxyлris laevicauda Se ur at 1914. Хвостовой отросгокъ имъетъ характеръ упругаго бича, расlinреннаго у основанія и постепенно утончающагося по направленію кь вершинғ. Спикулы, не взирая на салые тщательные поиски, пнт обнаружить не удалось: въроятно, она такъ нъжна, что при изслғдованін сливается с’ь тканью окружающихъь ея органовъ. Экскреторное отверстіе располагается на разстояніи $0,187 \mathrm{~mm}$. оть головного конца. Ширина ть́ла въ области ай s’a доходить всего лишь до 0,04 111 . Самка этого вида значительно крупнъе самца, достигая 4 mm. 
длины при максимальной ширинє $0,34 \mathrm{~mm}$. ОБщая длина пищевода доходитъ до 0,6 mm., иричемъ діаметрь бульбуса $=0,17 \mathrm{~mm}$. Экскреторное отверстіе на разстояніи $0,34 \mathrm{~mm}$. отъ головного конца. Хвостовой конец’ь чрезвычайно удлиненный-достигаетъ $1,054 \mathrm{~mm}$. Половое отверстіе помғщается кпереди отъ середнны длины твла. Яйца удлиненно-овальної форлы, достигаютъ 0,17 $\mathrm{mm}$. длины при ширинғ, $0,055 \mathrm{~mm}$.

Ротовое отверстіе паразита круглое, безъ замұтно выраженныхъ губъ или аналогичныхъ имъ образованій. Нътъ, равнымъ образомъ, и намека на наличность какого-либо подобія ротовой капсулы.

Сравнивая нашего паразита съ другими видами Oxyuris, приходится считать его наиболье близкимъ виду Oxyuris laevicauda Seurat 1914 и отчасти Oxyuris spinicauda Dujardin 1845 , для отличія отъ которыхъ мною составлена нижесльдующая таблица ихъ сравнительной характеристики. Несомньнно будущій изсльдователь сем. 0 ху и гіdае выцвлитъ этихъ трехъ паразитовъ въ самостоятельный новый родъ. (Си. табл. стр. 68).

\section{Oxyuris spinicauda Dıjardin 1845.}

\section{Литература:}

Duja rdin. Hist. natur. d. Helminthes, Paris 1845 p. 143-144: Oxyuris spinicauda n. sp. oтъ Lacerta muralis.

2. Rudolphi. Synopsis, 1819, p. 47 " 287: Ascaris extenuata.

3. D i esing: Revision der Nematoden, 1861, p. 642: Pharyngodon acanthurus.

4. IV illem o es---s uh n. Uber einige Trentatoden und Nemathehn. Zeitschr. f. wiss. Zoologie XXI, 1870, p. 12. Taf. XII. Fig. $1-6,8$.

5. Li instow. Compendium d. Helminthologie, Hannover 1878. p. $192-194$.

6. Seurat. Sur un cas d'endotokie matricide chez un Oxyure. Compt. Rend. Soc. Biologie, Séance du 23. V. 1914. T. LXXVI, ำ 18. p. 850-852: Oxyuris spinicanda Duj. отъ Ptyodactylus Oudrii Latasta.

Хозяева паразита: Chryosolamprus ocellatus Fitz.

Lacerta muralis La $\mathrm{L} \mathrm{r}$.

Tejus nigropunctatus $\mathrm{W}$ ag $\mathrm{l}$.

Tejus teguixin Wagl. 


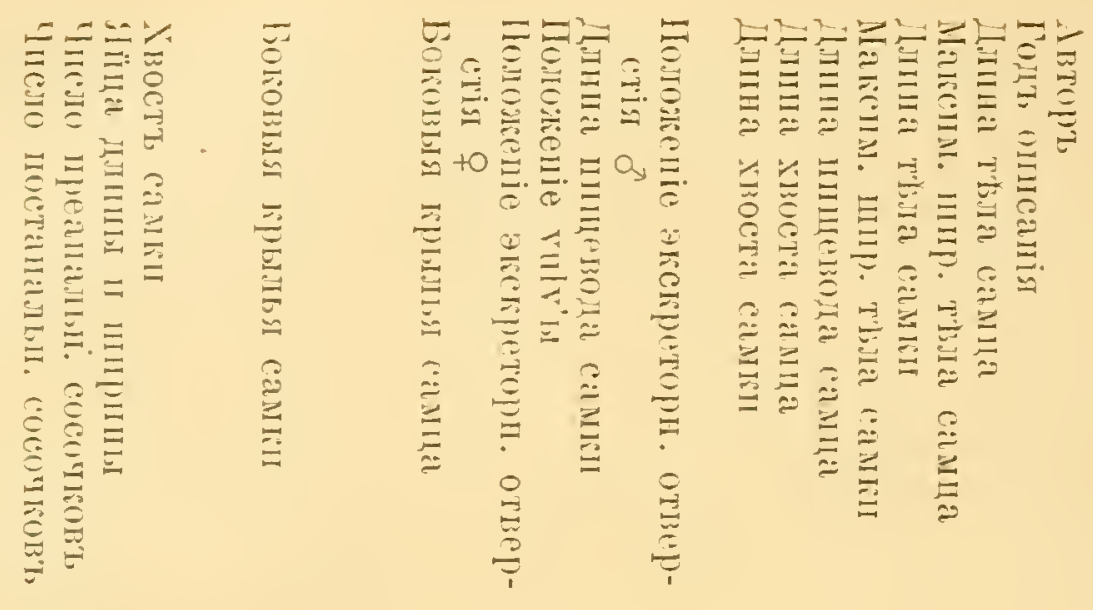

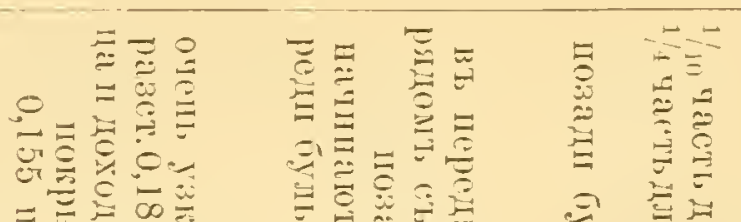

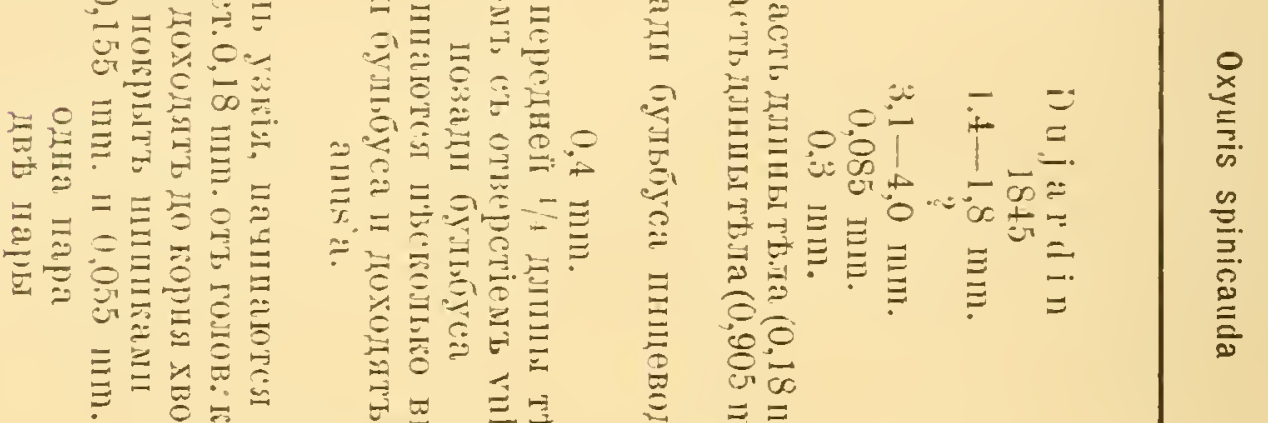
要

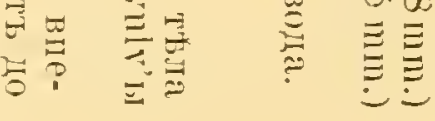

$\stackrel{8}{8}$

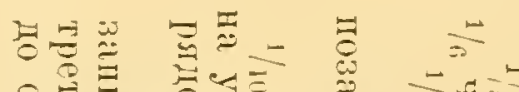

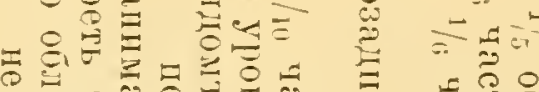

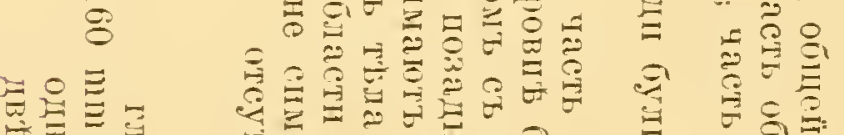

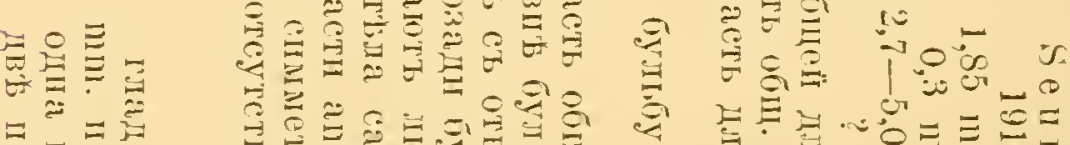

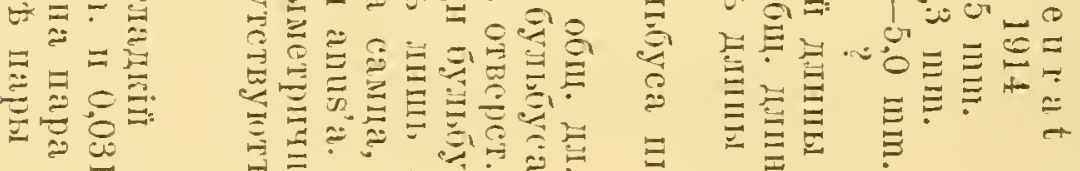

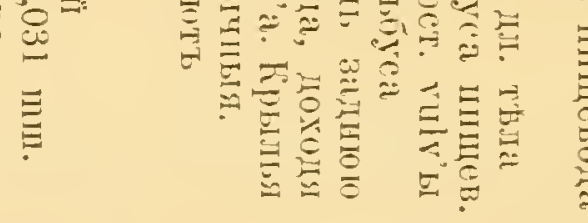

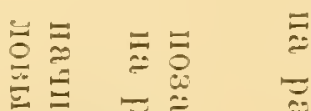

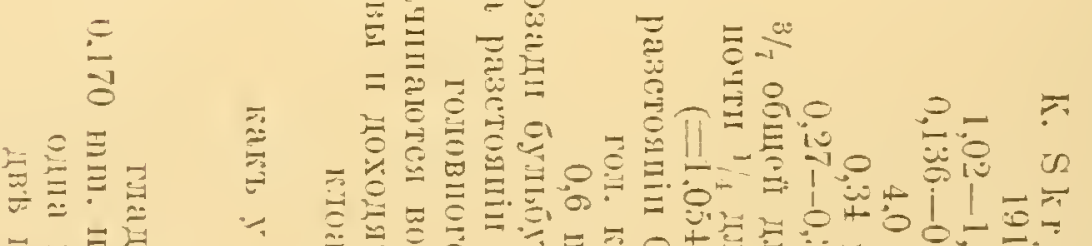

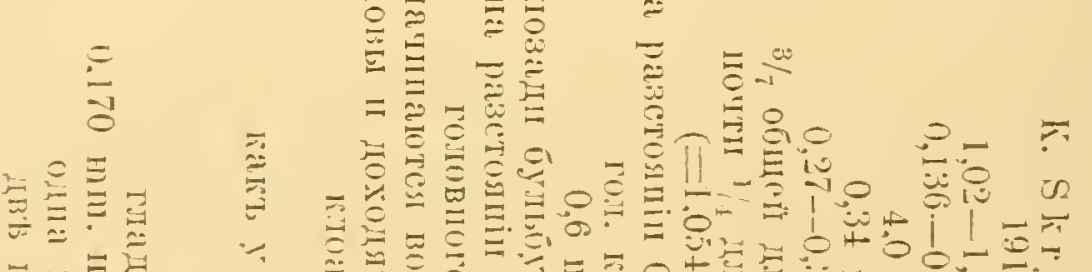

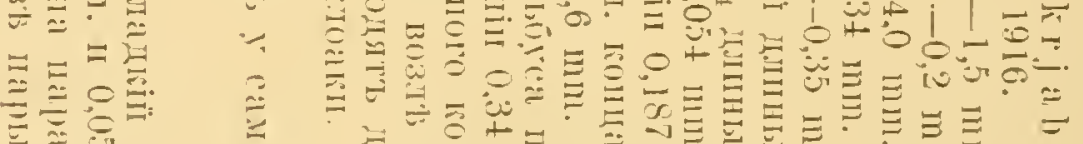

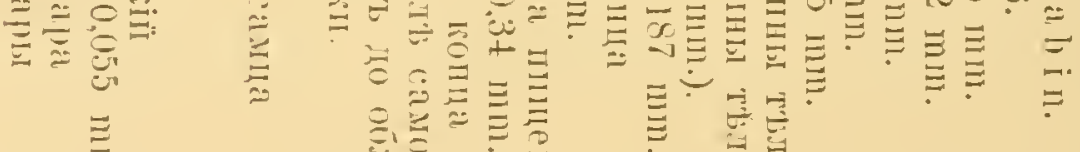

主

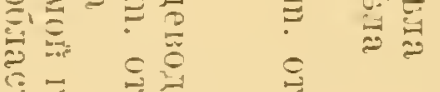

它要密 


\section{Ptyodactylus Oudrii Latast.}

Локализація: заднііі отдъљъ кишекъ.

Географическое распространеніе: Европа, Африка.

Видъ этотъ, недавно подробно описанный Se urat $(1914$ г.) пзъ кишечника аdриканскаго геккона Ptyodactylus Oudrii I a taste, оказался въ одной изъ пробирокъ коллекціи проф. догеля и Соколова съ этикеткой „Кишка геккона № 1 13/v“.

Самцы отсутствовали, нмйлись на лицо молодыя, незрғылыя самки, длиною $3,75 \mathrm{~mm}$. , съ хвостомъ вооруженнымъ шипиками и достигавшимъ $0,765 \mathrm{~mm}$.

\section{Oxyuris annulata Linst. 1899.}

(Табл. VIl, pнс. $47-51$ )

Литература:

Linstow. Nematoden ans der Berliner Zoolog. Sammlung, Mitteilung. aus der Zoolog. Sammlung. des Mus. f. Naturkunde in Berlin, 1899, Bd. I. H. 2. p. 21-22, Taf. V. Fig. 51.

К’ этому виду я отношу самокъ, найденныхъ въ задней кишкъв ящерицы № 6 (изъ сем. Scincidae). Самцовъ, къ сожап厹нію, въ моемъ распоряженіи не имълось. Въ виду того, что въ вышеуказанной работь Linstow'а характеристикъ самки этого вида посвящено всего 4 строчки и не дано ея изображенія, я хочу остановиться на ея описаніи нъсколько подробнғе и дать рисунки какъ ея общаго habitus'a, такъ равно и нбкоторыхъ ея отдъ́ььных'ь частей.

Описаніе вида.

Твло самки длиною 5,44-5,5 mm., бълаго цвъ̆та, цилиндрической формы, съ утончающимся переднимъ и, въ меньшей степени, заднимъ концомъ. Кутикула исчерчена въ поперечномъ направленіи, образуя рядъ колецъ, отдъленныхъ другъ отъ друга довольно глубокой бороздкой. Ширина этихъ колецъ достигаетъ 0,04-0,07 mm. Переднее кольцо снабжено 6-ью небольшими папиллообразными губами, окружающими ротовое отверстіе. Посльднее ведетъ въ чрезвычайно удлиненный и узкій пищеводъ, снабженный въ своей задней части бульбусомъ. Общая длина пищевода достигаетъ $1,7 \mathrm{~mm}$, что составляетъ $\frac{1}{3,2}$ часть общей длины төла. Ширина удлиненнаго отдвла пищевода доходитъ только до 9,085 mm.. Бульбусъ, длиною $0,255 \mathrm{~mm}$., при ширин各 0,3 mm., снабженный хитиновымъ аппаратомъ для перетиранія пищи, углубляется своимъ заднимъ отдъломъ въ полость кишечника, образуя т. Н. „желудочекъ“. Кишечникъ, 
почти одинаковоіі ширины на всемъ своемъ протяженіи, оканчивается anıs'oмъ на разстсяніи 0,34 mm. отъ хвостового конца. Посльдній снабженъ небольшимъ остроконечнымъ придаткомъ. длина котораго доходитъ до $0,15 \mathrm{~mm}$. Ширина телла варіируеть въ различныхъ своихъ частяхъ: такъ, в'ь области конца пищевода она доходитъ до 0,65 mm., въ области расположенія полового отверстія $=0,75-0,8 \mathrm{~mm}$, на уровнє-же an1s'а = $0,42 \mathrm{~mm}$.

Половое отверстіе располагается ньсколько кзади оть середины длины ть্љла, на разстояніи 2,9 mm. оть головного конца,

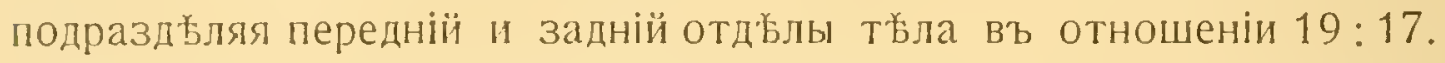
Зрғлыя яйца группируются исключительно въ задней половинь тьла, совершенно не заходя кпереди отъ полового отверстія. Форма яицъ чрезвычайно своеобразна: они трехтранной формы съ крышечкой на одномъ изъ полюсовъ. Грани скорлупы имъютъ параллельную исчерченность, поверхность-же скорлупы имъетъ мелкозернистый характерь. Длина яицъ 0,096-0,105 mm., при

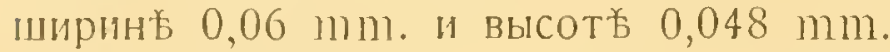

Не взирая на нбкоторое несовпаденіе вышеприведенныхъ измьреній съ цифровыми данными Linstow'a, я все таки отношу своего паразита къ виду Oxynris ammulatia Linst. 1899, и вотъ на какомъ основаніи. Linstow говоритъ о глубоко исчерченної въ поперечномъ направленіи кутикулъ съ шириною колецъ - 0,079 мm., о наличности 6 мало зам головь, о длинноль пищеводь, составляющемъ $\frac{1}{4,5}$ часть общей

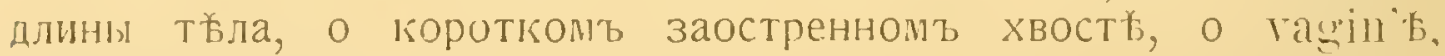
которая открывается въ задней половнны твла, двля посльднее въ отношеніи 13:10. Салка Linsto доходила до $5,57 \mathrm{~mm}$. длины, при ширинғ 0,71 mm. Всъ эти признаки чрезвычайно сходны съ вынеприведенным описаніемъ самокъ моихъ экземпляровъ. Наконец’ь, родственные хозяева паразитов'b [экзелпляры Linstow'a, были найдены у ящерицы Stellio vulgaris Latr. въ Египтћ (Торъ)], равно какъ и ихъ географическое распространеніе еше болье подтверждаетъ взглядъ объ ихъ зослогическоль тождествъ. Единственно. что бросается въ глаза--это разница въ размьрь янцъ, длина которыхь пго Linstow'y достигала 0,132 mm., прн ширинъ 0,067 mm., а согласно монмъ измъреніямъ: 0,096-0,105 $\mathrm{mm}$. длины и 0,06 $\mathrm{mm}$. ширины. Однако разницы этой недостаточно, чтобы выдғлить моего паразита въ отдъльныі видъ. Къ сожальнію, Linstow не даеть рисунка самки своего вида (рисунокь 51 его работы 
изображаетъ хвостовой конецъ самца) - тогда бы сходство этихъ обонхъ паразитов’ь вырисовалось еще рельефнъе.

Возможно, что паразить Oxymris ammulata Linst. 1899 является идентичнымъ виду, описанному Dujardin подъ именемъ Oxyuris brevicandatu Duj. 1845 изъ кишечника гекко (Platyductylus fascicularis). Къ сожальнію, Dијardin не даетъ рисунка опнсываемой имъ самки, длина которой доходила до 6-9 mm., при ширинъ $0,7 \mathrm{~mm}$. Утвержденіе его относительно "bouche ronde, nue"--можно объяснить твмъ, что Dujardin'y не удалось констатировать 6 сосочковидныхъ губъ вслғвствіе несовершенной въ то время методикъ изсльдованія. Единственнымъ крупнымъ доводомъ, говорящимъ противъ идентичности этихъ видовъ, служитъ положеніе у вида Oxyuris brevicandata vulv" „au quart antérieur de la longueur", хотя возможно, что Dujardill за fulvy принялъ экскреторное отверстіе, располагающееся у этого паразита какъ разъ въ этой части твйла.

\section{Oxyuris obvelata Zeder 1803.}

\section{Питература:}

1. Fröh lich. -Beiträge zur Naturgesch. der Eingeweidewürmer, 1791. Naturforscher, Stiick 25. 1791 p. 99: Ascaris vermicularis b. muris.

2. Zeder'. Anleitung zur Naturgeschichte der Eingeweidewiurmer, Bamberg, 1803, p. 108: Fusaria obvelata.

3. Rudolphi. Entozoor. s. rerminm intestinal. hist. natms. 1809. p. 155, ㄹ. 22. Ascaris obrelate.

4. Rudolphi. Entozoorum Synopsis, 1819, p. t4 и 280, 즈 32: Ascaris obvelata.

5. Nitzsch. Ascaris. Ersch. und Gruber's Encycloped: Ascaris oxyura.

6. Schmalz. XIX Tabula anatomiam Entozoorum illustrantes, 1831., pl. 17, Fig. 8-9: Ascaris oxyura.

7. Dujardin. Hist. natur. d. Helminthes, Paris 1845. p. 140-142: Oxyuris obvelata.

8. Linstow. Compendium der Helminthologie, Hannorer 1878 p. 19-25: Oxyuris obvelata Bremser.

9. Linstow. Helminthol. Studien. Arch. für Naturgesch. 45., 1879. p. 174. Fig. 19-21: O. ovelata Brem s.

10. Linstow. Helmintholog. Stidien. Arch. f. Naturgesch. Ig. 48 1882 p. 11. Fig. 17: Oxyuris obvelata Brem ser. 
11. Linstow. Parasitische Nematoden. Süsswasserfamna Jentshlands, herausgeg. ron Dr. Brauer, Iena 1909. Heft. 15, 1. 70: Oxymris obvelata Bremser.

Этотъ новый для АФрики видъ оказался въ одной изъ пробирокъ коллекціи проф. Цогеля и Соколова, изъ кишечника неопредъленнаго еще вида мышей (Nammalia ํo 22, 15/1·г 1914).

Ix. Родъ 0xysomatuim Raill, et Henry 1913

(Synonym: Oxysoma Schneider 1866", Gerrais 1849.)

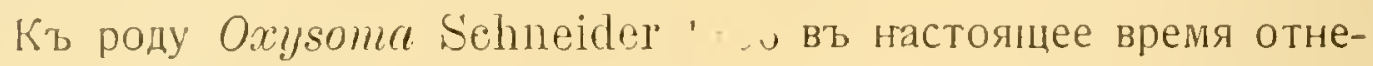
сено около 10 видовъ, которые, однако, настолько разнятся другъ отъ друга, что будущій изсльдователь несомньнно долженъ будетъ разбить ихъ на нъсколько отдъльныхъ родовъ. Не претендуя въ настоящей работь исчерпать вопросъ о систематическомъ положеніи отдъльныхъ видовъ Oxysoma и ихъ взаимоотношеніи другъ къ другу, я все же хочу совершить небольшую экскурсію въ систематику этого рода, чтобы твмъ самымъ сдълать попытку отдълить "настоящихъ“ представителей Oxysoma, которыхъ Railliet et Henry объединили въ родъ Oxysomatim, отъ твхъ видовъ, которые причислены къ этому роду по недоразумънію.

Уже основатель рода Oxysoma, A. Schneider, сдъ.лалъ въ 1866 году первую ошибку, объединивъ въ этотъ родъ трехъ нематодъ: Oxysoma brevicaudata Z e d. (отъ Rana temporaria), Oxysoma tentaculum R u d. (oт’b Didelphis), и Oxysoma leptumm Rud. (отъ Testudo mydas), которыя въ настоящее время должны считаться представителями трехъ различныхъ семействъ! Главный видъ, на которомъ Śchneide: построилъ свой родовой діагнозъ, Oxysoma brevicaudata Zed., является „типомъ“ рода Oxysomatium Raill. Ненly, всл前твіе чего къ этому роду должны быть относимы только тв нематоды, которыя объединены общими признаками съ паразитомъ Oxysoma brevicandate. Такихъ нематодъ, изъ числа описанныхъ подъ именемъ охуsoma, найдется однако очень немного: O.xysoma contortum Linstow $1906^{1}$ ) (oT̃ Bufo inlgaris) n Oxysomu perezi (iendle 1911 2) (оть Chamaelen) gracilis Hall). Этихъ парази-

1) Linstuw. Nematolen aus d. Zoulog. Museum in rönigrberg. Areh. f. Naturesech. 1906, Ig. 71. Bu. I J. 2256. Tal. Xllll. Fig. 17.

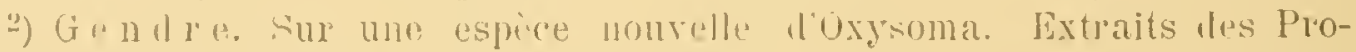

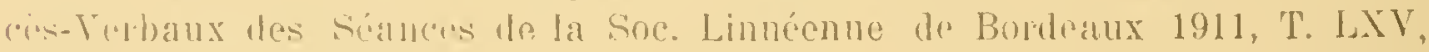
1. 4.)-97 aroce 6 ig. 
товь приходится считать истинными представителями рода Охулsomatium Raill. et Henry 1913.

Изъ числа другихъ описанныхъ въ. литературғы представителей рода O.rysoma Sch n. 1S66-Oxysoma gracitis Linstow 18991) (оть Firancolinus sp.) оказался представителемъ рода Subulura Molin. какъ на то указали Railliet et Henry въ 1914 году 2); Oxysoma falcatum. Limst. 1903 3) (от’b черепахи Nicoria trijuga), равно какъ и Oxysoma tuberculatum L in s tow 1903 4) (оть Megalophrys montana II a g.). благодаря своеобразному строенію спикуль и хвостовопу концу самца, должны быть тоже выдвлены изь рода Oxysoma s. Oxysomatium.

Разбираясь въ описаніяхъ видовъ близкаго къ Oxysomatium рода Nematoxys Schn. 1866, я наткнулся на одну форму-N'ematoxys unguiculutus Linst. $1906^{5}$ ) (отъ Bufo vividis). которая безулсловно долина быть перечислена въ родъ Oxysomatium, будучи чрезвычайно близкой виду Oxysoma contortum Linst. 1906 (отъ Bufo vulgaris). Читая описаніе этихъ 2-хъ формъ, сдъла̄нныхъ однимъ авторомъ, въ одномъитопъ-же году, больше того-вь одной и той-же работь и даже на смежныхъ страницахъ стр. 255 и 256), стдновится с овершенио непонятнымъ, что побудило Linstow'а причислить ихъ къ двумъ различнымъ родамъ (Oxysoma и Nematoxys)? Все различіе между этими формами зиждется на размърахъ отдъльныхъ органовъ, причемъ и колебанія в’ь величинь посльвднихъ приходятся по большей части на десятыя доли миллиметра!

Фагты эти являются краснор Бчивой иллюстраціей того, какъ трудно систематизировать представителей тұхъ нематодъ, родовые діагнозы коихъ еще не провұрены и не исправлены современными авторами и не установлены точно и опредъленно. Работа надъ подобнымъ „исправленіемъ“ діагнозовъ, сообразно современнымъ нашимъ представленіямъ о строеніи нематодъ,

1) Linstow: Nematoden aus der Berliner Sammlung. Nitteirung. aus d. Zoolog. Sammlung Nus. f. Naturliunde in Berlin, 1S99, Bu. I. H. 2. p. 20. Fig. $6 t--65$.

2) Railliet et Honl.y. Essai de la classification des Hetrabidae. I Congrés interuat. de Zoologie à Monaco, 1914, p. 679.

3) Linstow. Helminthes from the Colombo Musem. Spolia Cey. anica 1906, Bd. III. p. 169. Fig. 50-51.

4) Linstow. Parasiten, meistens Helminthen, aus Siam. Archiv fuir mikroskop. Anatomie, Bd. 62. 1903 p. $114-115$. Fig. 13.

j) Linstow. Nematorlen des Zoolog. Musenms in Königsberg. Arch. für Naturgesch. Ig. 71. 1906. 1). 255. Taf. X Ylll. Fig. 16. 
является одной изъ насущныхъ и очередныхъ задач'ь современной гельминтологін.

Итакъ, къ числу несомнънныхъ видовъ рода Oxysomatium Raill et Henry 1913, діагноз’ь коего мною будетъ приведенъ ниже, должны быть отнесены сльдующіе виды:

1. Oxysomatium brevicandatum Z e d. 1803. (типъ!).

2. Oxysomatium contortum Li in s to w 1906.

3. Oxysomatium unguiculatum (L in st. 1906).

4. Oxysomatium perezi Gend $\mathrm{d}$ e 1911.

Пятымъ представителемъ этого рода является новый видъ изъ коллекціи ироф. Догеля и Соколова:

5. Oxysomatium dogieli nov. spec.

діагнозъ рода Oxysomatium Raill. et Henry 1913.

Нематоды типа Мeromyarii и Secelnentes. Роть окруженъ 3-мя маленьқими губами (дорзальной и 2-мя латеровентральными), иногда слабо-замғтными. Пищеводъ оканчивается бульбусомъ, снабженнымъ зубнымь аппаратомъ. Хвость самца острсконечный, съ 3-12 парами преанальныхъ и $0-6$ парами постанальныхъ сосочковъ. 2 спикулы равної величнны, простыя, изогнутыя, значительно длиннье gubernaculum; gubernaculum маленыкій, челноковидной формы. T'ulvа располагается кзади отъ середины длины тбла. Яіцца заключаютъ готоваго зародыша, свернутаго колечкомъ. Паразиты пищеварительнаго тракта амфибiii и peптиліiі. Типичный видъ: Oxysomatium brevicaudatatum (7e el. 1803).

20 0xysomatium dogieli nov. spec.

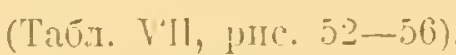

Хозяннъ: одинъ изъ представителей сем. Bufonidae.

Локализація: кишечникъ.

Тъло бълое, нажное, цилиндрической формы; утонченное у обоихъ концсвъ. Кутикула мслко исчерчена въ поперечномъ направленіи. Ротовой конецъ снабженъ 3-ля маленыкими губапи: одной дорзальной и 2-мя вентро-латеральными. На каждой губо̆ располагаются по 2 маленькихъ сосочка, образуя кругъ изъ 6 сосочковъ: 2-х`ъ латеральных’ь и 4 субмедіанныхъ, причемъ одна пара субмедіанныхъ приходится на дорзальную губу, а другая пара составляется изъ смежныхъ соспчковъ вентро-латеральных’ь губъ. Пищеводъ состонтъ изъ 3-хъ отд'вловъ: передняго мышечнаго vestibulum, длиною у самца $=0,085$ mm., средняго цилнндри- 
чески-удлиненнаго "з задняго-бульбуса. Средній отдылъ пищевода характеризуется хитинизированными внутренними стьнками, пр!челъ хитиновыя части распредълены въ 6 продольныхъ, параллельно расположенныхъ лентъ, которыя нъжно исчерчены въ поперечномъ, направленіи. Лишь самая передняя часть пищевода, vestibulum, лишена этихъ хитиновыхъ образованій. Задній отдълъ хитиновыхъ лентъ переходитъ въ зуобной аппаратъ третьяго отдйла пищевода-бульбуса. Въ полости бульбуса можно различить 3 неправильно-овальной формы раковиноподобныхъ образованія, поверхность которыхъ исчерчена параллельными рельефными полосками, а задній край которыхъ снабженъ мелкими зубчиками. За пищеводомъ сльдуетъ кишечникъ, начальный отдйлъ котораго нћсколько шире бульбуса. Экскреторное отверстіе, им бощее $0,05 \mathrm{~mm}$. въ діаметрғ и располагающееся на уровнб перехода цилиндрическаго отдйла пищевода въ бульбусъ, имбетъ чрезвычайно характерное строеніе. Оно окружено цилымт

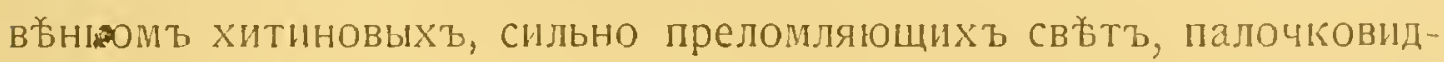
ныхъ образованій, которыя своими заостренными концами высовываются наружу (см. рис. 56). ППризнакъ этоть, не отмйченный до настоящаго времени у представителей рода Oxysomatim, заслуживаетъ быть подчеркнутымъ, такъ какъ благодаря епу намғчается родство рода Oxysomatium съ родомь Atractis D) u j. 1845, у ныкоторых'ь представителей котораго, какъ, напр., у вида Atractis cruciatr. Linst. $1902{ }^{1}$ ) $\mathrm{W}$ Atractis fasciolata Gendre 1909 2), экскреторное отверстіе характеризуется точно-такимъ-же строеніемъ.

Самецъ достигаетъ 5,1 mm. длины при ширинб твла: въ области пищеводнаго бульбуса $0,2 \mathrm{~mm}$., на уровн各 анальнаго отверстія $=0,15 \mathrm{~mm}$. Общая длина пищевода $=0,93 \mathrm{~mm}$; пнщевоцный бульбусъ достигает’ь 0,136 mm. длины при ширинъ $==0,12 \mathrm{~mm}$. Нервное кольно лежитъ на разстоянія 0,51 1пмл. оть передняго конца тьла, экскреторное-же отверстіе-на разстояніи 0,57 $\mathrm{mm}$. отъ головного конца. Хвостовой конецъ кзади отъ клоаки сильно заостряется и заканчивается тонкимъ остроконечнымъ жгутощъ. Хвостовыхъ папилль 1! паръ: 6 паръ преанальныхъ и 5 паръ постанальныхъ Первыя распредтлены съ каждой стороны тьлла

1) Linstow. Atractis cruciata und Oxymris manhyslera, zwei neue Vematoden aus Metopoceros comutus. Centralbl. f. Bakter. Parasitenkunde, 1902, Bd. 31. p. 29-30, Fig. 1-5.

2) Gendre. Notes d'Helminthologie africaine, Proc. Verb. Soc. Linnéenne Bordeaux, 1909, Vol. 63. p. XXX-XXXIII, 6 fig. 
въ одинъ рялъ н отстоят’ другъ отъ друга почти на одинаковомъ разстояніи; что касается постанальныхъ сосочковъ, то 5 пара лежить въ одномъ продотьомъ ряду съ преанальными, 4-ая же 1 3-ья пары сдвинуты къ средней линіи тьла, причемъ третья пара въ большей степени, чьмъ четвертая. Наконецъ, самые задніе сосочки-1 и 2 пары-располагаются на значительномъ разстояніи отъ остальныхъ, локализмуясь въ области утонченной части хвоста, недалеко отъ вершины посльдняго. Спикулы 2, равной величины, достигающія 0,238 мm., длины; онб загнуты въ вентральномъ направленіи, причемь цирина ихъ постепенио умменьшается от’ь слегка вздутаго основанія по направленію къ заднепу концу. Оканчиваются спикулы тонкої закругленноі вершиной. Поверхность спикулы имветъ поперечную псчерченность.

Дорзально и сзади примыкаетъ къ спикулаиъ небольшоіі gnbelnaculnm, который, какъ и у всьхь видовъ рода оxysomatimm, значительно меньшаго размьра, чғмь спикулы. Онъ характерной челноковидноі формы съ 2 бугорками въ своеіі передней части

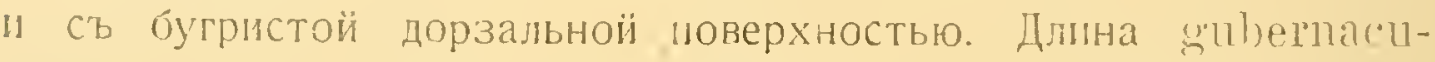
lım достигаеть $0.085 \mathrm{~mm}$. Отверстіе клоаки располагается на разстояніи 0,275-0,3 мm. оть хвостового гірнца.

С амка. Въ моенъ распоряженін имолся всего лишь одинъ экземпляръ неполовозрблой самки, длиною 7,5 11н., при максимальной ширин $=0,29$ mm. въ области расположенія полового отверстія. ПІирнна твла на уровнв пнщеводнаго бульбуса доходила до $0,27 \mathrm{mm.,} \mathrm{въ} \mathrm{области} \mathrm{же} \mathrm{аиия'а}=0,136 \mathrm{~mm}$. Длина пищевода достигала 1,2 mm. Хвостовой конецъ, въ отличіе отъ такового самца, не имељль характернаго для посльдняго жгутоподобнаго острія, а имъљъ форму конуса, постепенно суживающагося по направленію к’ь вершинь. Анальное отверстіе располагалось на разстоянін $0,17 \mathrm{~mm}$. отъ хвостового конца. Отверстіе vulvы польщалось въ задней половинь тьла, на разстояніи 4,2 11111. отъ головного конца.

Я іица у изсльдованнаго эгземпляра отсутствовали. Чтосы ярче дифы)еренцировать этотъ новый видъ отъ остальныхъ предсгавителей рода O.xysomatim, мною приводится таблица их'ь сравнитеньлої характеристики. (См. табл. стр. 77).

\section{Х Родъ Isacis Lespes 1856.}

Дiаннозь:

Мелкія нематоды, ротовое отверстіе конх\% о!раничено 3-пя плоскими губами, снабженными по краямъ и съ внутренней сто- 


\begin{tabular}{|c|c|c|c|c|c|c|c|}
\hline 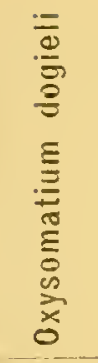 & 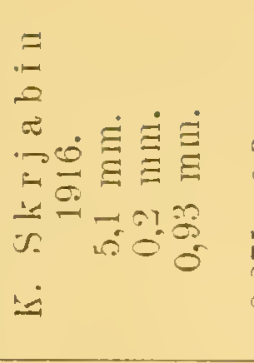 & 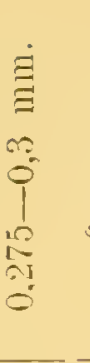 & 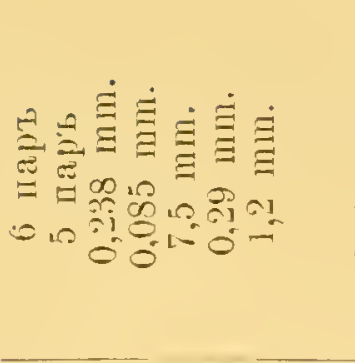 & 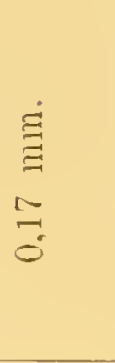 & 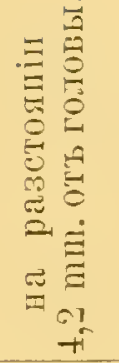 & 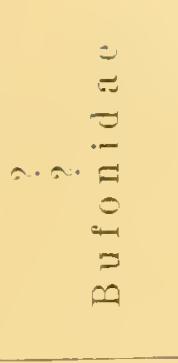 & 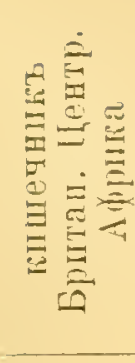 \\
\hline 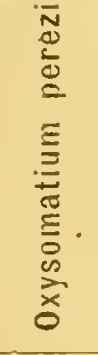 & 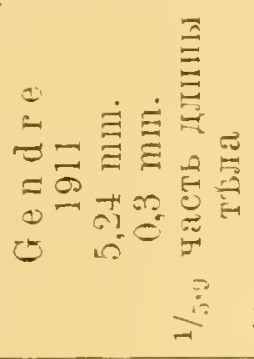 & 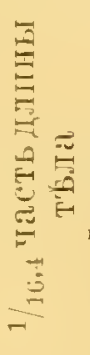 & 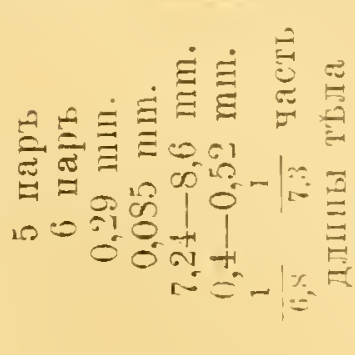 & 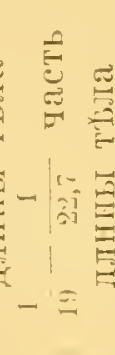 & 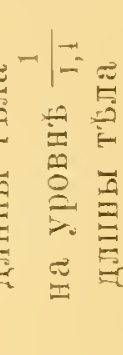 & 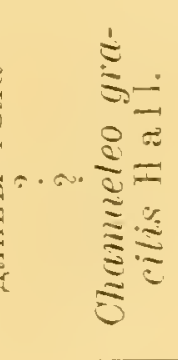 & 总 \\
\hline 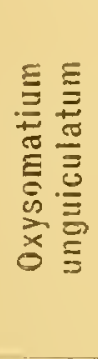 & 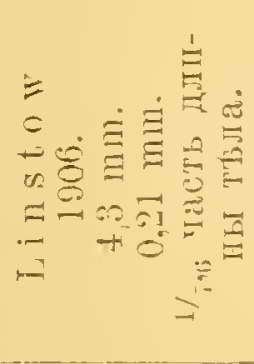 & 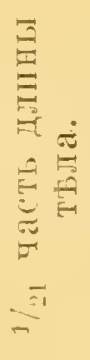 & 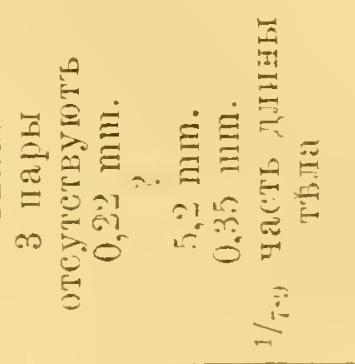 & 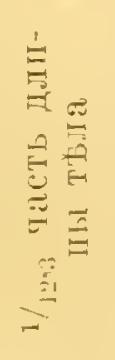 & 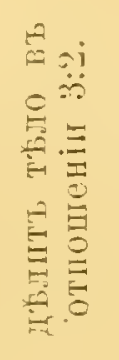 & 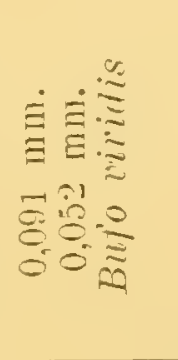 & 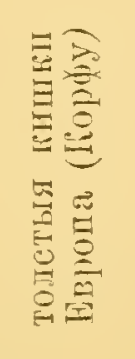 \\
\hline 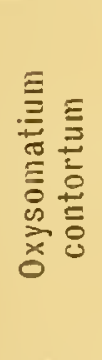 & 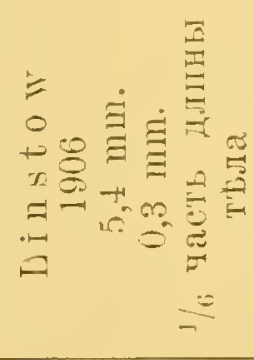 & 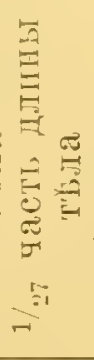 & 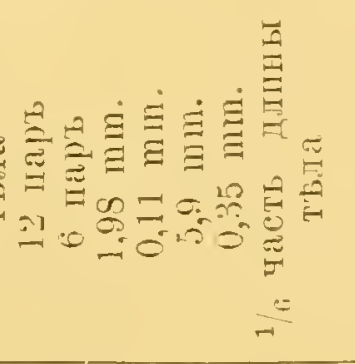 & 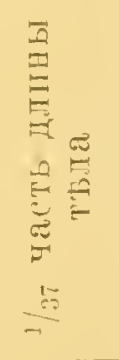 & 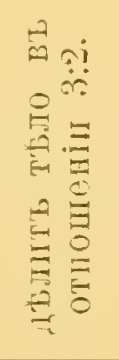 & 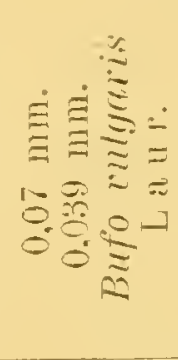 & 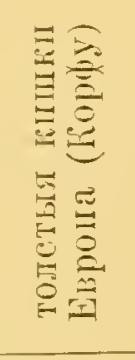 \\
\hline 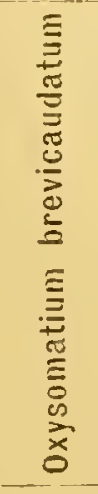 & 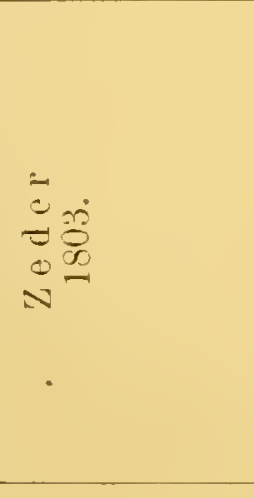 & & 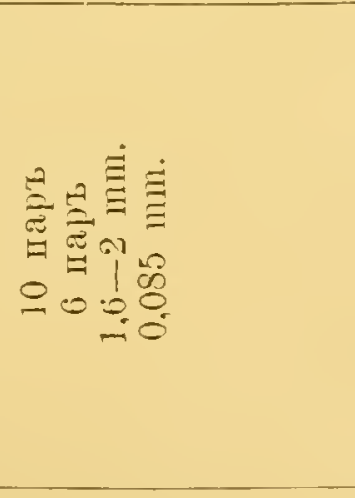 & 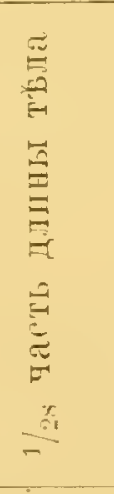 & & \multicolumn{2}{|c|}{ 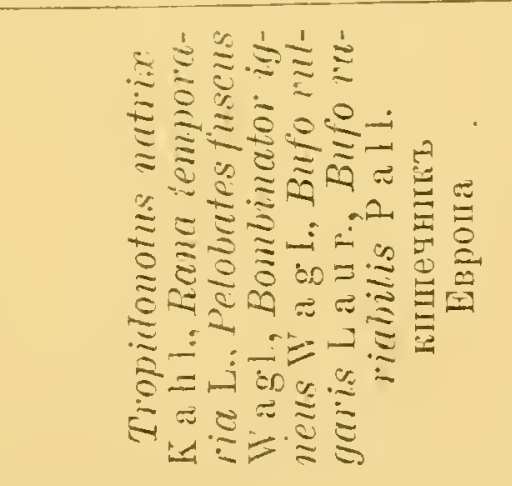 } \\
\hline $\begin{array}{l}\dot{0} \\
= \\
\infty\end{array}$ & 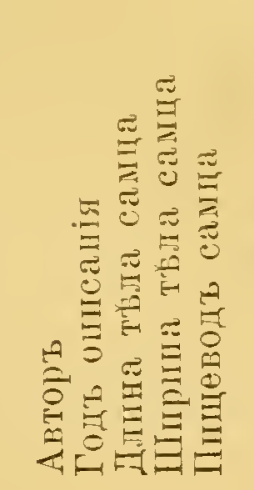 & 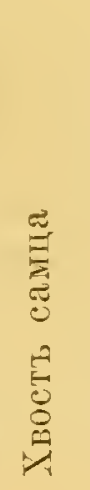 & 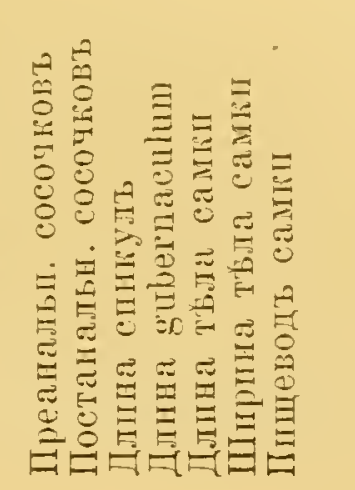 & 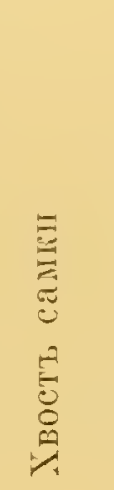 & 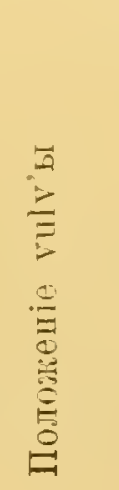 & 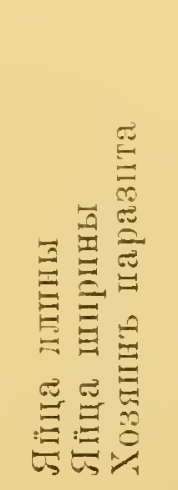 & 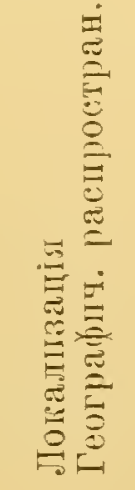 \\
\hline
\end{tabular}


роны зубчиками. Пищеводъ изъ 2 частей: передней цилиндрической расширенной въ задней своей части, и бульбуса съ хитиновымъ аппаратомъ. Ширина передняго отдъла пищевода не уступаетъ ıиринға бульбуса. Хвостовой конецъ заостренъ; 2 спикулы равной величины. Gubernaculum отсутствуетъ. Пре-постанальные сосочки въ количествђ ндсколькихъ паръ. Vulva возль середины ллины то̆ла. Яїнекладущія. Паразиты безпозвоночныхъ. Типъ: Isacis migrans Lespes. 1856.

\section{Isacis multipapillata nov. spec.}

(Табл. VIII, puc. 57-62).

Хозяинъ Iulus sp.

Локализація: задній отджљл кишечника.

Т‡ло цилиндрическое, бълаго цвъта, гладкое, безъ сльдовъ исчерченности, слегка суживающееся по направленію к'ъ обоимъ концамъ: передній конецъ тупо закругленъ, задній-заканчивается небольшимъ заостреннымъ отросткомъ. Ротовое отверстіе окружено 6 волнистыми кутикулярными образованіями, образующими неглубокую полость, на дне ъотороӥ располагаются 3 хитиновыхъ, неправильно треугольныхъ щитка, ограничивающих'ь входъ въ пищеводъ.

Строеніе щитковъ этихъ весьма своеобразно. Каждый изъ нихъ имъетъ наружный край-основаніе, которымъ щитокъ прикрбплен'є кь подлежащеі ткани, и внутренній, 'сводчатый выпуклый край, обращенный къ ротовону отверстію. Этотъ посльдній край усаженъ нбосклькими крупными, острыми хитиновыми зубцами и цвлымь рядомъ мелкихъ, прндаюоцихъ этому органу' видъ гребешка. Крупныхъ копьевндныхъ зубцовъ около 8 на каждой губъ, причемъ нькоторые изъ нихъ двузубчатые. Число мелкихъ зубчиковъ точно установить нельзя-ихъ нъскольо десятковъ, причемъ распредълены они въ нисколюо рядовъ. Это видно на рисункъ, сдъланномъ съ препарата, у котораго оцна губа снопмъ краемъ завернулась наружу, обнаживъ, такимт образомъ часть своей внутренней поверхности, усаженной зубчиками въ нћсколько (3-4) рядов'!.

Пищеволъ состоитъ изъ 2-хъ отдђловъ: болъе удлиненнаго передняго и шаровидно-сердцевиднаго задняго (бульбусъъ). Перелній отд основаніемъ. Задній отдъль, бульпусьь, сердцевндной формы, съ вершиной, обращенной къ кишечнику, какъ бы вставленной въ 
посльдній, образуя своего рода желулочекъ. Внутри бульбуса имъется хитиновый зубной аппаратъ, состоящій изъ трехъ пластинокь, передняя часть которыхъ имъеть шероховатую, полосчатую поверхность.

Кишечникъ въ своей передней части но̆сколько шире верхушки бульбуса, вслбдствіе чего онъ охватываетъ часть посльдняго, образуя какъ бы родъ футляра.

С а ме ц 'ь.

Общая длина самца $3,57 \mathrm{~mm}$, при максимальной ширин в $0,187 \mathrm{~mm}$. Общая длина пищевода $0,42 \mathrm{~mm}$, при ширинь- $0,14 \mathrm{~mm}$.

Пищеводный бульбусъ длиною $0,12 \mathrm{~mm}$, при ширинъ почти одинаковой съ таковой передняго отд‡ла. Хвостовой конецъ снабженъ остроконечнымъ придаткомъ, длина котораго дости. гаетъ $0,05 \mathrm{~mm}$. Длина хвоста (отъ задн. конца толла до anus'a)= $0,153 \mathrm{~mm} .2$ равной величины искривленныя спикулы съ острым'ь свободнымъ концомъ. Длина спикулъ въ вытянутомъ положеніи 0,408-0,41 плm. Преанальныхъ сосочковъ 9 паръ. Расположены они слғдующимъ образомъ. Первый и второй сосочекъ сближены другъ съ другомъ; въ нйкоторомъ отдаленіи отъ нихъ располагается группа изъ сосочковъ 3,4 и 5-аго, находящихся на равномъ другъ отъ друга разстояніи. Затвмъ уже располагаются сосочки $6,7,8$ и 9, въ свою очередь на равном'ь другъ отъ друга разстояніи.

Постанальныхъ сосочковъ 5 паръ; располагаются они симметрично сльдующимъ образомь: 1,3 и 5 сосочки сдвинуты ближе къ средней линіи твла, въ то время какъ 2,4 и 6 сосочки лежат’ь болье периферично Въ общемъ, соединивъ спежные сосочки прямыми линіями, мы получимъ довольно правыльную ломанную линію. Gubernaculum-отсутствуетъ.

С амка.

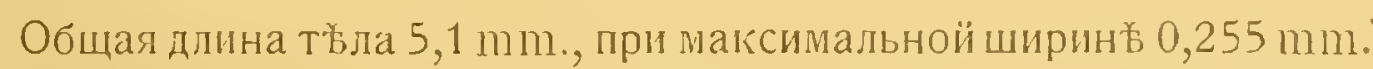
въ области матки. Огщая длина пищевода -0,476 $\mathrm{mm}$, при ширинд $0,17 \mathrm{~mm}$. Пющеводный бульбусъ длиною $0,15 \mathrm{~mm}$., при ширино $0,17 \mathrm{~mm}$. Хвостовой конецъ прямой, снабженный какъ и у самца остроконечнымъ отросткомъ. Анальное отверстіе располагается на разстояніи $0,18 \mathrm{~mm}$. отъ хвостового конца. Ширина тею́ла въ области пищеводнаго бульбуса достигаетъ 0,20,22 mm., въ области полового отверстія-0,24 mm., и, наконец'ь, въ области anus'a-0,12 mm. Половое отверстіе имєетъ видъ слабо замбтной поперечной щели, обрамленной 2 губами. Располагается половое отверстіе въ задней половинғ тйла, на 
разстояніи $2 \mathrm{~mm}$. отъ хвостового конца. Половыя железы занимаютъ среднюю треть длины тила, не заходя далеко ни кпереди, ни кзади.

Яйца очень крупныя, кругловато-овальной формы, длиною 0,102 mm., при ширинғ-0,08 m $\mathrm{m}$. Число яиць очень невелико: у изслћдованной самки было всего 22 яйца, находящихся на разныхъ стадіяхъ сегментаціи.

\section{E. Сем. Physalopteridae Leiper 1911.}

Въ коллекціи проф. Догеля и Соколова имвются 2 представителя этого семейства, относящіеся къ роду Physaloptera R ud. 1819.

\section{XI. Родъ Physaloptera Rud. 1819.}

Діагнозъ:

Роть окружен', 2-лия равными губами, расположенными латерально и снабженныли сосочками (по больш. частью 3-мя); края губъ вооружены зубчиами; позади губъ кутикула расширяется, образуя особаго рода капюшюнъ, надвинутый на головную часть паразита. Задній конецъ самца снабженъ болье или менъе широкої хвостовой бурсой, на которой располагаются двоякаго рода сосочкн. Одни, въ количествъ 4 паръ, инғютъ стебельчатый характеръ, располагаются возлю анальнаго отверстія и служатъ для поддерживанія бурсы; лругіе сосочки сидячіе, безъ стебельковъ,

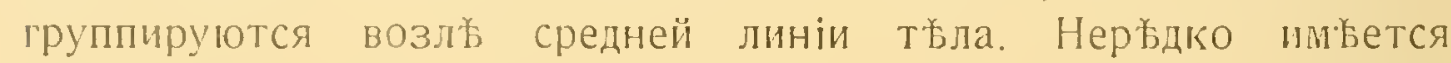
непарныї сосочекъ впереди апия'а. 2 спикулы неравной величины. Самки съ 2 янчникали. T'ulva открывается кпереди отъ середины длины тьлла. Яйцекладущія. Паразиты пищевар. органовъ млекопитающихъ, птицъ и рептилій.

Въ моемъ распоряженіи находились 2 вида этого рода; не взирая на отсутствіе самцовъ, я разсматриваю одинъ видъ, какъ Physaloptera abtreviata.Rud., другой же видъ признанъ мною новымь представителель рода Physaloptera. котораго я называю Physaloptera britanica spec. nova.

22. Physaloptera abbreviata Rud. 1819

(Тибл. 'भII, рніс. 63-65).

Литература:

1. Rudolphi. Entooz. Synops. 1819.

2. U u j a d i 11. Hist. nat. d. Helminthes, Laris 1Sto p. 176: Ascrivis fallax. 
3. D u j a d in. Ibid. p. 104: Spiroptera abbreviata.

4. Di e sing. Syst. Helminth. II. 1851. p. 235.

5. Molin. Wiener Sitzbericht. XXXIX., 1860, p. 646.

6. Schncider. Monographie d. Nematoden, 1866. p. 65. Fig. in 'Text.

7. Linstow. Compendium d. Helminthologie, 1878. p. 192.

8. L i n s to w. Arch. f. Naturgesch. Ig. 49, 1883. p. 281.282, Fig. $7-8$.

9. Л ин с т о в ъ. Путешествіе Федченко въ Туркестан'ъ. Москва 1886. стр. 6. Рис. 7-8.

10. Leidy. Proceed. Acad. Nat. Sc. Philadelphia, 1886, p. 312.

11. Stossich. Il Genere Physaloptera Rud., Trieste 1889. p. $7-8$, Fig. 9.

12. Se urat. Sur deux Physaloptères tétrahystériens des Reptils. Compt. Rend. Soc. Biolngie, Séance 31. VII. 1914. Tome LXXVII. N 27. p. 433-434. Fig. 2 et 3.

Паразитъ этотъ до настоящаго времени быль находимъ у сльдующихь хозяевъ:

1. Lacerta viridis L.-въ Европ占 (Вьна).

2. Chrysolamprus ocellatus Fitz.-вb Испаніи и Африк古 (S e r rat).

3. Phrynocephalus helioscopus K p.—-в` Русскомъ Туркестанъ (Фе д ч енко).

4. Phrynosoma regale-въ Америк方 (L e i d y).

5. Phrynosoma hernandezi-въ Америкь (L e i d y).

6. Tropidonotushydrus-въ Русскомъ Туркестань (Федченко).

7. Pseudopus palassii Cи v.-Въ Рус. Туркестань (Федченко).

$\mathrm{Bb}$ качеств псевдопаразита Linstow описалъ этого паразита изъ желудка бълаго аиста (Туркестанъ, сборъфедченко).

Въ одной из' пробирок'ь коллекціи Догеля и Соколова мною были обнаружены неполовозрғлыя самки этого вида изъ ящерицы Agama sp. ${ }^{1}$ ) Родъ Agama является новымъ хозяиномъ для этого ларазита.

Длина паразита доходила до $21 \mathrm{~mm}$., при максимальной ширинб $0,765 \mathrm{~mm}$. въь области конца пищевода. На уровны полового отверстія ширина тъла достигала $0,76 \mathrm{~mm}$., въ области расположенія шейныхъ сосочковъ-0,357 mm., и, наконецъ, на уровнъ аnия'а$0,255 \mathrm{~mm}$.

Цилиндрическіӥ пищеводъ достигал’ъ 3,4 mm. длины. Конически

1) ภщерпца ำ 12. 
заостренный и закругленный хвостъ $=0,51 \mathrm{~mm}$. длины. Половое отверстіе располагалось въ передней половинъ тъла, на разстояніи 2,9 im m. от’ь головного конца. На рцзстояніи $0,56 \mathrm{~mm}$. отъ головного конца располагаются заостренные шейные сосочки. На внутреннем'ь крағ обђихъ губъ многочисленные заостренные зубчики, причемъ по бокамъ средняго, самаго крупнаго зуо́ца, находится по одному маленькому, отличающемуся отъ всъхъ остальныхъ своей шириной (см. рис. 64).

23. Physaloptera britanica spec. nov.

(Тайл. IX, рис. 66-69).

Хозяинъ паразита: Agama sp.

Локализація: кишечникъ (задній отдълъ).

Самцы -отсутствуютъ.

Самки. Т६лло цилиндрическое, бълое, длиною $42 \mathrm{~mm}$,, при максимальной ширинғъ $0,6 \mathrm{~mm}$. въ области задняго отдыла пищевода. $\mathrm{Bъ}$ области расположенія полового отверстія ширина твла достигаетъ $0,51 \mathrm{~mm}$., въ областинахожденіяшейныхъсосочковъ=$0,425 \mathrm{~mm}$., на уровн' anus' $a=0,3 \mathrm{~mm}$. Хвостовой конець конически заостренный, закругленный, длиною $0,46 \mathrm{~mm}$. Цилиндрическіiі пицеводұ достигаетъ $5,44 \mathrm{~mm}$. длины.

На разстояніи $0,6 \mathrm{~mm}$. отэ головного конца располагаются шейные сосочки. По объимъ сторонамъ твла, начиная отъ головного конца, тянутся крылья, постепенно суживаюціяся по направленію ґзади.

Половое отверстіе находится въ передней половинғ тв́, на разстояніи 4,25 mm. от’ь головного конца. Изслйдованные экзелпляры были еще неполовозрблыми и не содержали яицъ.

Наиболье интересной частью паразита должна считаться его голова и вооруженіе ротовыхъ органовъ. Какъ у всъхъ видовъ Physaloptera, и у нашего паразита имьются на лицо 2 крупныхъ губы съ медіаннымъ большимъ зубцомъ на каждой. Однако, по объ стороны этого зубца у каждой губы имғется еще цылыі рядь болье мелкихъ зубчиковъ, располагающихся на внутренней поверхности губъ. Зубцы эти однако по своей формъ, характеру распредвленія, величины и количеству рьзко отличаются от’ъ таковыхъ вида Physaloptera abbreviata R ll d. У нашего вида на каждой губћ, по бокамь отъ главнаго медіаннаго зубца,

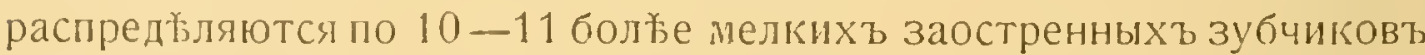
съ каждой стороны; что касается их'ь формы "І величины, то всъ они треугольной формы. причемъ рядом' съ самымз крупным, центральным зубцомъ раснолагаются 4 зубца значн- 
тельно меньшей величины, за которыми однако слддуют’ 2 болґе крупныхъ зубца; самые-же латеральные зубчики являются и самыми мелкими.

Мнғ удалось приготовить одинъ препаратъ и разслотрдть губної аппаратъ паразита сверху (см. рис. 68). Обнаружилась интересная картина: въ центрб препарата зіяла ротовая щель паразита, которая была ограничена съ объихъ сторонъ зигзагами вышеописанныхъ зубчиковъ.

По бокамъ каждой губы располагаются по 2 довольно крупныхь сосочка, имъющихъ своеобразное строеніе, позволяющее имъ, повидимому, уменьшаться и увеличиваться, сокращаясь на подоб́іе подзорной трубы.

Своеобразное устройство и распредбленіе зубчиковъ на губах`ъ этого паразита двллаеть возможнымъ отличать Physaloptera britanica sp. nov. от'ь другихъ представителей того-же рода.

\section{F. Cем. Filariidae Claus 1885.}

Изъ числа филярій в’ь коллекцін проф. Догеля и Соколова нашлись всего лишь 2 вида, относящіеся къ роду Diplotriaena Raill. et Henry 1909.

\section{XII Родъ Diplotriaena.Raill. et Henry 1909.}

Діагнозъ.

Крупные виды филярій, на наружной поверхности передняго конца пищевода которыхъ располагаются 2 небольшихь, латеральныхъ, хитиновыхъ образованія. Каждое изъ нихъ состоптъ изъ одного, направленнаго кпереди отростка, отъ котораго расходятся, направляясь кзади, 3 плоскія, слегка приплюснутыя вътви. Все это образованіе имћетъ видъ трезубца съ рукояткой. У самцовъ 2 неравныхъ спикулы, изъ коихь одна прямая, другая-же, меньшшая, имъет’ь форму спирали。 Паразиты полостей тблла воробьиныхъ птицъ (P asserifor m es), соколовъ '(по даннымъ Con п а l'я 1912) и зимородковъ (Скрябинъ 1916). Типичный видъ: Diplotriaena tricuspis (Fedtschenko 1874).

Въ изсльдованномъ мною матеріаль имьлись 2 представителя этого рода, изъ числа коихъ 1 видъ оказался новымъ.

24. Diplotriaena sokolowi spec. nova.

(Табл. IX, pнгс. $70-7 t)$.

Хозяинъ: синій зимородокъ (Halcyon senegaloides A. Smith) Локализація: брюшная полость. 
Описаніе вида.

Паразить съ длиннымъ, нитевиднымъ, молочно-бълаго цвъта твломъ, головной и хвостовой концы котораго слегка сужены 1 равномърно закруглены. Сльдовъ продольной и поперечной исчерченности кутикулы не замғтно. Головной конецъ не имъетъ ни губъ, ни сосочковъ. Круглое ротовое отверстіе ведетъ въ удлиненный, цилиндрическій пищеводъ, къ верхней части котораго, по бокамъ, грилегаютъ 2 хитиновыхъ трезубчатыхъ образованія, характерныхъ для рода Diplotricena. Каждое изъ нихъ состоитъ изъ рукоятки, располагающейся въ переднемъ отдълъ трезубца и 3-хъ удлиненныхъ цилиндрическихъ в守вей, имъющихъ направленіе кзади. Нервное кольцо (у самки) располагается на разстояніи $0,3 \mathrm{~mm}$. отъ головного конца.

Cап:ецъ; достигаетъ $27 \mathrm{~mm}$. длины.

Пищеводъ достигаетъ $3,82 \mathrm{~mm}$. длины при ширин务 основанія $0,085 \mathrm{~mm}$. Начальный отдълъ кишечника довольно широкій, достигаюцій $0,37-0,4 \mathrm{~mm} .2$ хитиновыхъ трезубца, располагающіеся по объимъ сторонамъ верхней части пищевода, прилегаютъ переднимъ краемъ своей рукоятки къ внутреннему слою головной части кутикулы [въ отличіе отъ н官оторыхъ другихъ видовъ Diplotriaena, у которыхъ трезубецъ отодвинутъ отъ головного отдъва паразита на сравнительно далекое разстояніе, какъ, напр., y Diplotriaena spemospizae (Linst. 1879)]. Длина трезубца достигаетъ 0,17 mm; длина рукоятки въ отдбльности доходитъ до $0,05 \mathrm{~mm}$. Отдйльныя в务ти трезубца неравной длины: у изсльдованнаго мною экземпляра самца одна боковая вътвь лъваго трезубца была длиннбе остальныхъ двухъ вътвей, въ то время какъ у праваго трезубца объ боковыхъ вътви были длиннъе средней.

Задній отдбль тбла самца нбсколько притупленъ и закруглен'ь. Изъ чнсла хвостовыхъ сосочковъ преанальные отсутствуютъ; постанальныхъ сосочковъ, 2 пары. располагающихся симметрично возлғ самаго хвостового конца, причемъ лежатъ сосочки въ поперечномъ къ иси те́лла направленіи, одна пара субмедіанно, другая-же латеральо.

С!икулы 2, перавной величины и неодинакової формы. Болъе круиная спикула, достигающая $0,714 \mathrm{~mm}$. длины при ширинж, оспованія 0,037-0,04 mm., имъетъ удлиненную форму, саблевидно-загнутую въ веитральномъ направленіи. Строеніе этой спикулы чрезвычайно своеобразно, причемь она состоить какъ бы изъ 2-х7, частей: рукоятки и саблевиднаго отдвла.

Pуколтка, составляющая ${ }^{3} ;$ часть осщей рлины спикулы 
имъетъ базальный, передній конецъ въ видъ шероховатаго бугра. служащаго для прикръпленія ретракторныхъ мышцъ. Тもло рукоятки цилиндрическое, сплющенное съ боковъ и имъющее на своей поверхности характерную скульптуру, которая состоитъ изъ мелкой, равномьрной исчерченности въ поперечномъ къ длинъ спикуль направленіи. По обоимъ краямъ тъла рукоятки эти параллельныя полоски образуютъ своеобразный пиловидно-зубчатый фестонъ, въ точности воспроизведенный на нашемъ рисункъ.

Въ задней своей части рукоятка какъ бы расщепляется на дв‡ вътви, которыя, продолжаясь, образуютъ собою задній саблевидный отдылъ спикулы. Одна изъ этихъ вй твей нъсколько короче другой. Объ эти вътви соединяются особой тонкой мембраной, которая въ видъ чехлика покрываетъ свободный задній конецъ спикулы. Благодаря тому, что объ вышеупомянутыя в бтви выпуклье соединяющей ихъ мембраны, посльдняя образуетъ своего рода желобовидное углубленіе, служащее, повидимому, для стеканія спермы въ женскій половой аппаратъ.

Меньшая спикула, имъющая спиралевиднсе очертаніе, достигаетъ 0,442 mm. длины при ширинъ базальнаго вздутія 0,05 $\mathrm{mm}$. Состоитъ эта спикула изъ основного, хитинового, спиралевидно изогнутаго тълла, которое на всемъ своемъ протяженіи сопровождается тонкой мембраной.

Взаиморасположеніе спикулъ тоже довольно своеобразно: своимъ переднимъ, базальнымъ отдъломъ маленькая спикула располагается справа отъ большой; затьмъ, приблизительно на уровнъ своей середины, маленькая спикула переходитъ дорзально отъ большой на львую сторону, гдъ и покоится своимъ задним'ь свободнымъ концомъ, прилегая къ львой сторонъ большой спикулы. Своимъ положеніемъ одновременно и справа и слъва отъ большой спикулы меньшая спикула обязана спиралевидной формъ своего тйла.

С амка достигает’ь $36 \mathrm{~mm}$. длины при максимальной ширинъ $0,7 \mathrm{~mm}$. въ области задней части пищевода. Ширина тъла въ области полового отверстія доходитъ до $0,34 \mathrm{~mm}$., в’ь области-же anus'a $=0,17 \mathrm{~mm}$. Пищеводъ цилиндрическій, безъ вздутія, длиною 5,1 mm. при ширинъ 0,09 mm. Хитиновый трезубецъ, расположенный возлъ начальной части пищевода, достигаетъ 0,19-0,2 $\mathrm{mm}$. длины, при длинғ рукоятки $=0,05 \mathrm{~mm}$. Хвостовой конецъ закругленъ; анальное отверстіе лежитъ на разстояніи 0,068 mm. отъ хвостового конца. Что касается полового отверстія, то оно располагается въ переднемъ отдъль тъла, на 
разстояніи 0,51-0,54 mm. отъ головного конца. Конечный отдълъ влагалища имғетъ характеръ мышечнаго образованія, достигающаго 0,17 mm. ширины. Половыя железы в’ь переднемъ отдылғ тұла простираются до уровня отверстія vuly'ы, въ задней же части тъла спиралевидно скрученныя железы находятся на разстояніи $0,55 \mathrm{~mm}$. отъ хвостового конца. Яйца достигаютъ $0,055 \mathrm{~mm}$. длины при ширинт $0,037 \mathrm{~mm}$., и заключаютъ сформированныхъ зародышей, скрученныхъ спиралью или колечкомъ.

\section{Diplotriaena 0zouxi Raill. et Henry 1909.}

Литература:

Henry et 0'zoux. La filaire du Foudi. Bullet. Societ. Patholog. Exotique. 1909. II. \ò 9, Séance du 10/Ix. p. 544-54т.

Видъ этотъ описанъ былъ до настоящаго времени всего только 1 разъ $\mathrm{R}$ a illi et et $\mathrm{H}$ en ry изъ брюшной полости Fandicis madagascariensis (B I i s s o n)-птицы сем. Ploc e id a e. Въ одной изъ иробирокъ коллекціи В. Догеля и Соколова отъ неопредбленной 'еще птицы № 7 (изъ сем. Ploce id a e) находились 2 самки этого паразита.

Не входя въ подробности описанія этого вида, которое мастерски сдълано авторами вышеупомянутой работы, я позволю себъ ограничиться приведеніемъ нбсколькихъ цифровыхъ данныхъ, выясняющихъ идентичность изсльдованныхъ мною экземпляровъ съ таковыми Railljet et Henry.

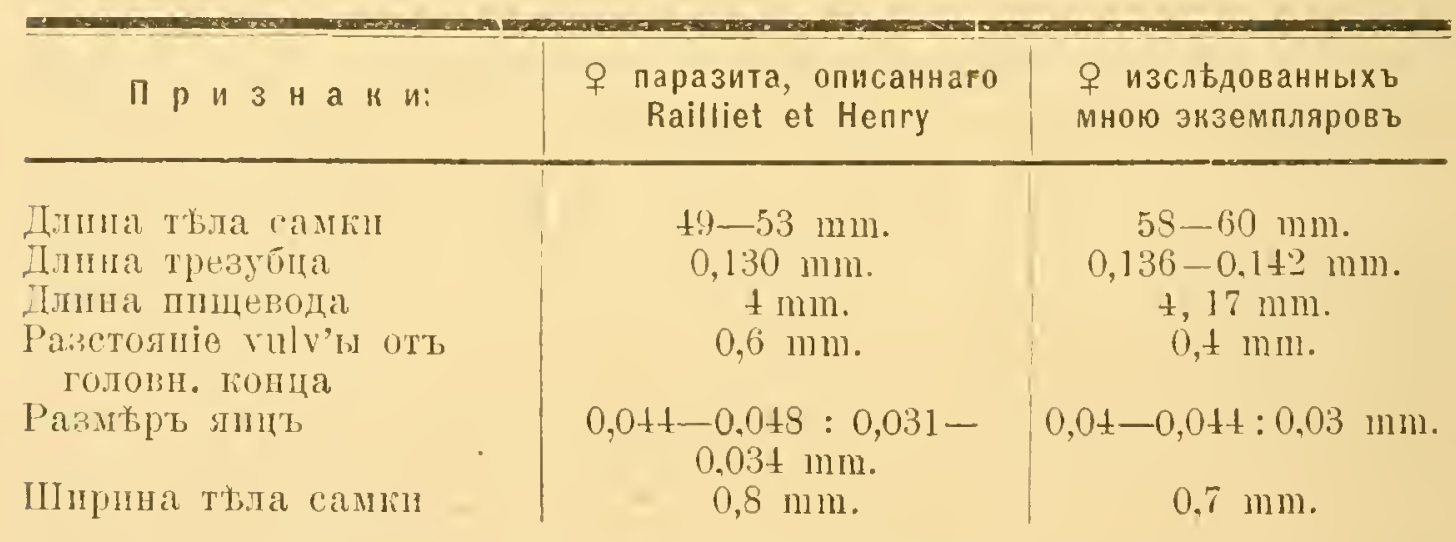

Не взирая на нюкоторое различіе между моими экземплярами $"$ паразитами, описанными Railli et et Henly, все же въ главныхъ признакахъ они настолько сходятся другъ съ другомъ, что отнести ихъ къ разнымъ видам'ь не имъется никакихъ основаній. Помимо морфологіи, родство ихъ подкрьпляется біологической особенностью:--паразитированіемъ обоихъ червей у птицъ одного семейства--Pl o c eida e (ткачики). 


\section{G. Сем. Angiostomidae.}

Изъ представителей этого семейства въ коллекціи проф. Догеля и Соколова имълся лишь одинъ видъ рода Angiostomum D и ј. 1845.

XIII Родъ Angiostomum Dujardin 1845.

Діагнозъ:

Нематоды типа Meromyarii и Resorbentes, характеризующіяся гетерогоніей, т. е. чередованіемъ несходныхъ покольній, развивающихся половымъ путемъ; гермафродитная, живородящая самка паразитируетъ въ легкихъ амфибій и рептилій, а ея дътеныши ведутъ свободный образъ жизни, пребывая или въ раздъльнополомъ, или же тоже въ гермафродитнопъ состояніи. Гермафродитныя паразитирующія формы характеризуются наличностью ротовой капсулы, на днв готорой или имъются зубчики, или отсутствуютъ. Пищеводъ вздувается въ своей залней части, образуя бульбусъ, не отграниченный, однако, отъ передняго отдъ́ға перетяжкой. Хвостовой конецъ заостренный, рғже закругленъ. Tulva располагается возль̈ середины длины тйла, чаще всего нъсколько кзади отъ нея. Живородящія. Паразиты легкихъ амфибій и рептилій. Типъ: Angiostomum nigrovenosum (Rud. 1819).

Изъ числа 9 описанныхъ по настоящее время видовъ, 1 видъ описан'ь у птицъ ${ }^{1}$ ), 4 вида у рептилій и 4 вида у амфибій. Въ коллекціи проф. Догеля имъется новый, десятый представитель этого рода изъ легкихъ хамелеона, названный мною Angiostomum chancieleonis n. sp. Въ Африкъ̌, до настоящаго времени, видовъ Angistomum обнаружено не было.

26. Angiostomum chamaeleonis nov. sp.

(Табл. IX, рис. 75, 76).

Хозяинъ: ящерица № 21 изъ Cham a c le o n t i d a e.

Локализація: легкія.

Описаніе вида: длина тб́ла гермафродитнаго покольнія достигаетъ $24 \mathrm{~mm}$. при максимальной ширин占=-1,0 $\mathrm{mm}$. Тъло цилиндри ческое, свернутое колечкомъ, суживающееся к'ь обоимъ концамъ;

1) Linstow. Helmintholog. Untersurhungen. Al'ch. fur Naturgesch 1880. Ig. 46 p. 46-47., Fig. 11: Angiostvinum sanguinolenta n. sp. изъ груди. п брюш. полості Strix flammea. Видт этоть, однако, врядь ли относится к' роду Angiostomum! 
цв Ћтъ твла - бъловатый, съ рђзко очерченнымъ буровато-чернымъ кишечникомъ. По объимъ сторонамъ твла располагаются крыловидныя расширенія кутшкулы, наиболъе широкія (до 0,068 $\mathrm{mm}$.) въ области головного конца, постепенно суживаюлціяся въ средней части тила и снова расширяющіяся близъ хвоста. Ротовое отверстіе круглой формы, безъ слєдовъ губъ и какихъ бы то ни было аналогичныхъ придатковъ, ведетъ въ небольшую ротовую капсулу, достигающую 0,02 mm. длины при ширинъ $0,034 \mathrm{~mm}$, за которой сльдуетъ мышечный пищеводъ, длиною 1,225 $\mathrm{mm}$. Посльдній имгегт цилиндрическую форлу, причемъ вт задней своей части постепенно образуетъ вздутіе, не отдвляющееся оть остального пищевода никакой перемычкой. Ширина цилиндрическаго отдтла пищевода=0,1 mm., вздутаго-же основанія его= $0,187 \mathrm{~mm}$. Анальное отверстіе располагается на разстояніи $0,34 \mathrm{~mm}$. отъ хвостового конца Посльдній загнутъ подъ тупымъ угломъ къ продольной оси тв̈ла и имъетъ форму коническаго, закругленнаго на вершинб придатка, окруженнаго крыловидным’ь кутикулярнымъ расширеніемъ. Ось хвостового придатка почти перпендикулярна оси твла (см. рис. 76). Въ своей задней части кишечникъ суживается, пріобрғтая характеръ небольшого щелевиднаго отверстія, по бокамъ коего располагаются анальныя железы. Половое отверстіе отодвинуто нбсколько кзади отъ середины длины твла, какъ у большинства видовъ Angiostomum. Переполняющія тьло гермафродита овальныя яйца съ сформировавшимся зародышемъ достигаютъ $0,136 \mathrm{~mm}$. длины и $0,076 \mathrm{~mm}$. ширины. Ширина тйла колеблется въ различныхъ отдълахъ: такъ, напр., въ области конца пищевода она достигаетъ $0,425 \mathrm{~mm}$, въ области полового отверстія $0,986 \mathrm{~mm}$., на уровн各 же anus'a $=0,17 \mathrm{~mm}$.

Для того, чтобы доказать видовую самостоятельность этого новаго паразита, я приведу таблицу сравнительной характеристики остальныхъ представителей рода Angiostomum D ujardin 1845. (См. стр. 90-91).

Кромъ вышеописанныхъ половозрълыхъ формъ паразитическихъ нематодъ, въ коллекціи проф. Догеля и Соколова имвлось нбсколько личинокъ, относящихся къ временному роду Agamospirura Raill. Henry et Sisoff 1912.

\section{XIV Родъ Agamospirura Raill. Henry"et Sisoff 1912.}

Родъ этотъ былъ обоснованъ Railliet, Henry et Sisoff для личиночныхъ формъ такихъ представителей подотряда Spirurata, половозрғлыя стадіи которыхъ еще не обнаружены. 
Въ коллекціи проф. Догеля и Соколова имъюются эти личиночныя формы от’ь слйдующихъ хозяевъ:

1) отъ рыбы сем. Сур rin idae (свободно в'ь кишечникь́).

2) отъ рыбы сем. Siluridae (рыба № 8)-въ цистахъ.

3) отъ птицы № 15 (Lavis sp.)一въ цистахъ на стьонкахъ кишечника.

\section{Дополненіе.}

Kiluluma n. gen.

Въ коллекціи Зоологическаго Музея Имп. Академіи Наукъ ии вется пробирка сь нематодами изъ желудка 2-хъ носороговъ, убитыхъ 26 и 28 Января 1912 г.,г. Сватошемъ на берегу р. Тана (Kiluluma). Въ виду того, что нематоды эти добыты изъ мъстности смежной съ территоріей, на которой работала экспедиція Догеля и Соколова, я счелъ умбстнымъ приложить описаніе этого паразита къ труду, посвященному разработкъ нематодъ, собранныхъ этими изсльдователями.

Изученіе экземпляровъ академическаго музея выяснило, что здъсь имблись на лицо тв самые паразиты, которые были описаны въ 1907 г. Linstow' ымъ подъ именемъ Deletrocephalus stylosus n. sp. отъ Rhinoceros africanus изъ Германской Восточной Африки.

Однако, подробное изученіе этихъ паразитовъ въ связи съ экскурсіей въ область литературы рода Deletrocephalus D ies. 1861 выяснило вполнб опредъ́ленно, что Deletrocephalus stylosus Linstow 1907 не долженъ быть относимъ, какъ то неправильно сдблано Linstow'ымъ, къ роду Deletrocephalus Dies., такъ какъ безусловно не имъетъ общихъ родовыхъ признаковъ съ типомъ этого рода-Deletrocephalus dimidiatus D i es. Родъ является типичнымъ представителемъ птичьихъ стронгилидъ, заключая въ себъ единственный видъ D. dimidiatus Dies. изъ чишечника Rhea americana, описанный какъ Diesing'омъ, такъ, въ послйдующее время, и Schneider'омъ. Паразитъ-же, фигурирующій въ литературь подъ именемъ Deletrocephalus stylosus Linst. 1907, несомнънно долженъ быть разсматриваемъ, какъ типъ спеціальнаго новаго рода, который я предлагаю назвать Kilulıma nov. g’ell. (названіе мÆстности, гдъъ найденъ паразитъ).

Въ литературб имъется описаніе нематоды Deletrocephalus brachylaimus Linst. 1901 изъ толстой кишки Heterohyrax 


\begin{tabular}{|c|c|c|c|c|}
\hline & $\begin{array}{l}\text { A. sanguino- } \\
\text { lentum }\end{array}$ & A. nigrovenosum & A. rubrovenosum & A. brachylaimus \\
\hline & & . & & \\
\hline Ізсльдователь & Linstow & $R u d \circ \operatorname{pl} \mathrm{i}$ & Schneider & Linstow \\
\hline Годт & 1850 & 1819 & 1566 & 1903 \\
\hline Длина твлла & $11 \mathrm{~mm}$ & $9-18 \mathrm{~mm}$ & $21015 \mathrm{~mm}$. & $8,8 \mathrm{~mm}$ \\
\hline Ширнна тьла & $1 \mathrm{~mm}$. & $0,5 \mathrm{~mm}$ & гц $0,4 \mathrm{~mm}$. & $0, \pm 8 \mathrm{~mm}$ \\
\hline Рот. капс. длины & $0.48 \mathrm{~mm}$ & $0,13 \mathrm{~mm}$ & $0,014 \mathrm{~mm}$ & \\
\hline$"$ ирины & $0,6 \mathrm{mu}$ & $0,06 \mathrm{~mm}$ & $0,015 \mathrm{~mm}$ & на головт 3 \\
\hline Дно рот. капсулы & ст S зубшпнами & безъ зубтиковъ & & Ма.тен. I \\
\hline Длина пищевода & $\begin{array}{l}\text { 1/12・2 длины } \\
\text { тьлла }\end{array}$ & $\begin{array}{l}\text { 1/21 часть дли- } \\
\text { ны тйла }\end{array}$ & & 1/15длшны тьБла \\
\hline Положеніе vulvы & $?$ & $\begin{array}{c}\text { позади середины } \\
\text { длины тьла (от- } \\
\text { нопеніе 8:7). }\end{array}$ & $\begin{array}{c}\text { кпереді отъ } \\
\text { середінын длі- } \\
\text { ны тьла (25:29). }\end{array}$ & $\begin{array}{c}\text { вт самой cepe- } \\
\text { дाн है длाшы } \\
\text { ть.та }\end{array}$ \\
\hline Хвость & $\begin{array}{l}\text { конически } \\
\text { заострешь }\end{array}$ & $\begin{array}{c}\text { конически заост- } \\
\text { ренъ. }\end{array}$ & заострепный & заостренъ \\
\hline Яйца длины & $0,072 \mathrm{~mm}$ & $0,09 \mathrm{~mm}$. & $0,13 \mathrm{~mm}$. & $0,12 \mathrm{~mm}$ \\
\hline п пширнны & $0,02 \mathrm{~mm}$ & $0,048 \mathrm{~mm}$ & $0,053 \mathrm{~mm}$ & $0,065 \mathrm{~mm}$ \\
\hline Хозлиньь & Strix flammea & $\begin{array}{l}\text { Anguis fragilis, } \\
\text { Bombinator igne- } \\
\text { us, Rana tempora- } \\
\text { ria, Rana esculen- } \\
\text { ta, Bufo vulgaris, } \\
\text { Bufo viridis, Bufo } \\
\text { cinerens, Pelobates } \\
\text { fuscus, Bufo vari- } \\
\text { abilis }\end{array}$ & $\begin{array}{c}\text { Bufo vulgaris, } \\
\text { Bufo viridis, } \\
\text { Pelobates fus- } \\
\text { cus. }\end{array}$ & $\begin{array}{l}\text { Bufo melanos } \\
\text { tictus Schneide }\end{array}$ \\
\hline & $\begin{array}{c}\text { брпит. и груд. } \\
\text { полость }\end{array}$ & легкія & легкія & легкія (?) \\
\hline & $\begin{array}{c}\text { Empona (Гep- } \\
\text { manis). }\end{array}$ & Еврона. & Европа. & Азія (Сіамъ) \\
\hline
\end{tabular}




\begin{tabular}{|c|c|c|c|c|c|}
\hline rotundatum! & A. entomelas & $\begin{array}{l}\text { A. macrosto- } \\
\text { mum }\end{array}$ & $\begin{array}{l}\text { A. fusco- } \\
\text { venosum }\end{array}$ & A. serpenticola & $\begin{array}{l}\text { A. chamae- } \\
\text { leonis }\end{array}$ \\
\hline instow & $D u j a r d i n$ & $\mathrm{~L}$ in stow & Railli et. & L in stow & K. Skrjabin \\
\hline 1906 & $18+5$ & 1875 & & $190 t$ & 1916 \\
\hline $6,0 \mathrm{~mm}$. & $4,4-4,5 \mathrm{~mm}$. & $3,3 \mathrm{~mm}$. & $3,4-6$ м & $4,49 \mathrm{~mm}$ & $24 \mathrm{~mm}$. \\
\hline $0,31 \mathrm{~mm}$. & $0,15 \mathrm{~mm}$ & $0, \pm \mathrm{mm}$ & $0,150,-19 \mathrm{~mm}$. & $0,24 \mathrm{~mm}$. & $1,0 \mathrm{~mm}$ \\
\hline$?$ & $0,036 \mathrm{~mm}$ & $0,12 \mathrm{~mm}$. & $?$ & & $0,02 \mathrm{~mm}$. \\
\hline$?$ & $0,0+\mathrm{mm}$ & $0,14 \mathrm{~mm}$ & $?$ & $\left\{\begin{array}{l}\text { Iптоск. рото- } \\
\text { вая кашсула }\end{array}\right.$ & $0,034 \mathrm{~mm}$ \\
\hline В зуб̆чІКовь & сь 3 зубчпками & $\begin{array}{c}\text { съ } 6 \text { зубчч1s- } \\
\text { камII }\end{array}$ & $?$ & - & \\
\hline длины тьлла & $\begin{array}{l}1 / 9,1 / 9,9 \text { длины } \\
\text { тьла(=0,48mm.) }\end{array}$ & 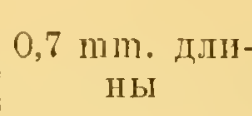 & $?$ & 1/15 длины тогла & $1,225 \mathrm{~mm}$ \\
\hline $\begin{array}{l}\text { гередп оть } \\
\text { едлны тьла; } \\
\text { ношеніе 4:5). }\end{array}$ & $\begin{array}{c}2.4 \mathrm{~mm} . \text { оть го- } \\
\text { ловн. конца }\end{array}$ & $\begin{array}{c}2,1 \text { mп. оть } \\
\text { хвостового } \\
\text { конца }\end{array}$ & $\begin{array}{c}\text { кшередш оть } \\
\text { середшны } \\
\text { длны тьла }\end{array}$ & $\begin{array}{c}\text { кшереді отт } \\
\text { середіны длі- } \\
\text { ны тьла }(7: 10)\end{array}$ & \\
\hline акругленъ & $\begin{array}{c}\text { заостренъ съ } \\
\text { ІггловІднымъ } \\
\text { концомь }\end{array}$ & заострень & короткій & $\begin{array}{c}\text { тонко заост- } \\
\text { рень }\end{array}$ & $\begin{array}{c}\text { коническій, } \\
\text { сь закруг- } \\
\text { лепной вер- } \\
\text { ппной. }\end{array}$ \\
\hline $0,097 \mathrm{~mm}$ & $0,12 \mathrm{~mm}$. & $?$ & $?$ & $0,065 \mathrm{~mm}$. & $0,136 \mathrm{~mm}$ \\
\hline $0,057 \mathrm{~mm}$. & $?$ & $?$ & $?$ & $0,049 \mathrm{~mm}$ & $0,076 \mathrm{~mm}$. \\
\hline 3ufo viridis & Anguis fragils & $\begin{array}{l}\text { Anguis } \\
\text { fragilis }\end{array}$ & $\begin{array}{l}\text { Tropidono- } \\
\text { tus natrix } \\
\text { Ru hl. }\end{array}$ & $\begin{array}{l}\text { Heterorlon pla- } \\
\text { tyilhinus Lath. }\end{array}$ & $\begin{array}{l}\text { представн- } \\
\text { тель Сем. } \\
\text { C ha m a e- } \\
\text { le o n t i- } \\
\text { d a e }\end{array}$ \\
\hline легкія & легкія & легкія & легкія & легкія & легкія \\
\hline $\begin{array}{l}\text { Eвpoпra (Kop- } \\
\phi y) .\end{array}$ & $\begin{array}{l}\text { Европа (Фран- } \\
\text { дія,Герман ія). }\end{array}$ & $\begin{array}{c}\text { Европа } \\
\text { (Германія). }\end{array}$ & $\begin{array}{c}\text { Европа } \\
\text { (Франція). }\end{array}$ & $\begin{array}{l}\text { Сьверная } \\
\text { Аперпка. }\end{array}$ & $\begin{array}{l}\text { Тропнч. } \\
\text { Афрнка. }\end{array}$ \\
\hline
\end{tabular}


mossambica Ptrs. 1), которую, повидимому, тоже приходится отнести къ поему новому роду Kiluluma, выдъливъ изъ рода Deletrocephalus; за это говоритъ какъ краткое описаніе Liustow'a, такъ и приложенный къ его работь⿱⺊口灬 рисунокъ хвостовой бурсы самца, распредъленіе реберъ которой въ своихъ главныхъ чертахъ соотвьтствуетъ таковому у filuluma stylosa (Lin s to w 1907).

Въ нижеслбдующихъ строкахъ я остановлюсь на подробной характеристик' вида Kiluluma stylosa (Linst. 1907), затъмъ приведу различія между моими данными и описаніемъ Linstow’a, и, наконецъ, дамъ діагнозъ своего новаго рода Fituluma n. gen.

Kiluluma stylosa (Linstow 1907).

(Табл. Х, рис. 76-82 п рле. С въ тексть̈).

Литература:

1. Linstow. Nematoden ans d. Zoologisch. Museum in

Berlin. Mitteilungen d. Zoolog. Museum in Berlin,

1907, III Bd. p. 254, Fig. 9-10: Deletrocephalus stylo-

sus n. sp. оть Rhinoceros africanus.

Хозяин'ь: Rhinoceros africanus.

Локализація: желудокъ.

Географическое распространеніе: тропическая Африка.

Описаніе вида.

Тъло цилиндрическое, желтовато-бураго цвйта, утончающееся по направленію къ обоимъ концамъ.

Кутикула исчерчена въ поперечномъ направленіи.

Головной конецъ построенъ чрезвычайно своеобразно, будучи сформированъ изъ цйлаго комплекса органовъ, которые можно подвести подъ категорію серій губъ: наружныхъ и внутреннихъ. (См. рис. С).

Наружныхъ (периферическихъ) губъ 4: двъ дорзальныхъ и 2 вентральныхъ. Каждая изъ этихъ губъ несет’ь по своеобразному сосочку, направленному кпереди и состоящему изъ утолщеннаго пуговчатаго основанія, на -котором'ь насаженъ болъе тонкій отростокъ съ закругленнымъ концомъ. Квнутри отъ 4-хъ наружныхъ губъ располагаются 6 внутреннихт: 2 дорзальныхъ, 2 вентральныхъ и 2 латеральныхъ. Изъ числа этихъ внутреннихъ

1) Linstow. Holmintlen ron den Lfern des Tyassa-Sers. Fenaische Zeitschrift für Naturwissensch. 1901. B1. 35. p. 410-411, Fig. 1-2. 
губъ латеральныя не несутъ на себъ никакихъ образованій; на каждой же изъ дорзальныхъ и вентральныхъ губъ располагаются по одному нитевидному образованію съ заостренной передней вершиной (см. медіально-расположенные сосочки на рис. 78). Вышеописанное строеніе ротовыхъ частей у этого паразита Linstow'ымъ оставлено безъ вниманія; единственно, о чемъ этотъ авторъ говоритъ въ своей работй-это о наличности, 4-хъ колбовидныхъ сосочковъ, квнутри отъ которыхъ располагаются 4 заостренныхъ образованія, сидящихъ на особыхъ закругленныхъ выступахъ“. Ротъ переходитъ въ мышечный короткій пищеводъ, колбовидновздутый въ своей задней части. Длина пищевода у самца $0,578 \mathrm{~mm}$. при ширинб $=0,238 \mathrm{~mm}$., у самки $=0,595$ mm. при ширинь

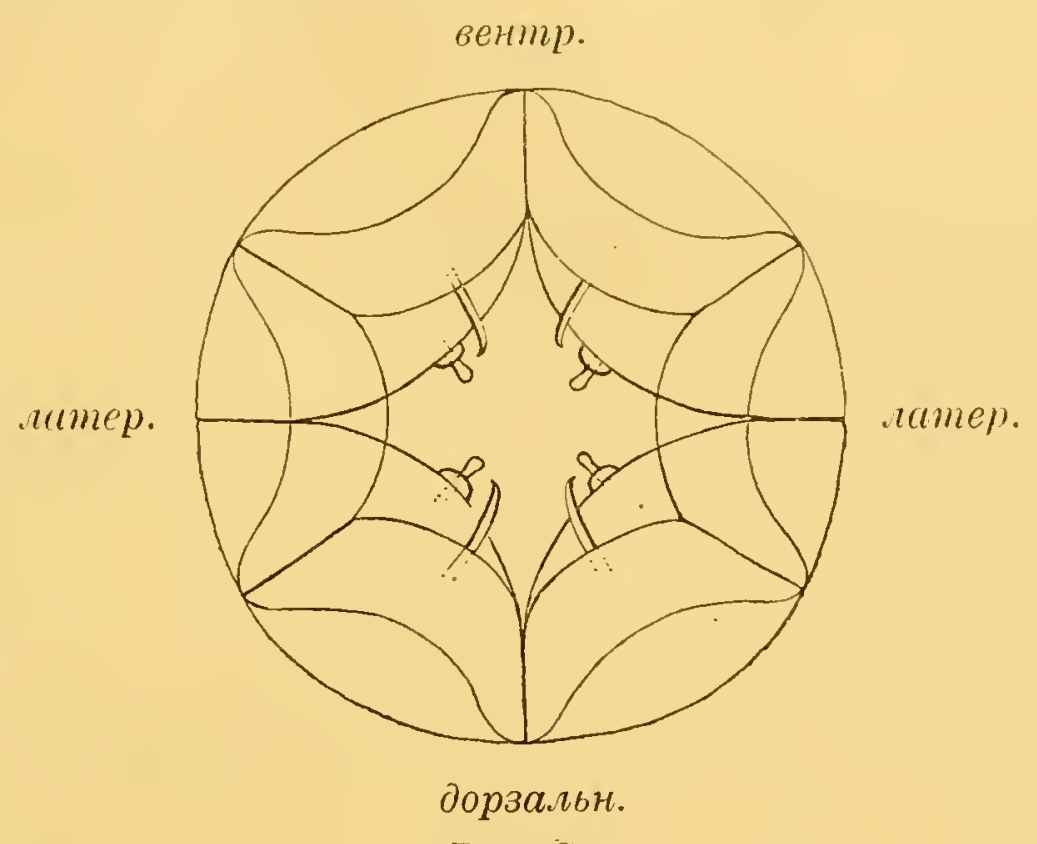

Piic. C.

Схема распредвленія наружныхъ п внутреінихъ губ́, у Kiluluma stylosa (L i in s t. 1907.).

0,255 mm. По бокамъ твла какъ самца, такъ и самки тянутся широкія крылья, суживающіяся постепенно по мә́рб приближенія къ хвостовому концу. На нъкоторомъ разстояніи отъ головного конца (у самца на разстояніи $0,85 \mathrm{~mm}$., у самки=0,952 $\mathrm{mm}$.) располагаются чрезвычайно своеобразные шейные сосочки, состоящіе изъ базальной части, имъъющей форму манжетки, изъ центра коей выступаетъ бичевидный, заостренный на концб отростокъ. Длина этого бичевиднаго отростка достигаетъ $0,051 \mathrm{~mm}$. (у самца) и $0,068 \mathrm{~mm}$. (у самки).

С аме цъ достигаетъ 19,0 mm. длины при ширинъ̆ $=0,935 \mathrm{~mm}$. въ средней части тьла. Въ области задняго конца пищевода 
ширина тв́ ла достигаетъ $0,52 \mathrm{~mm}$., въ области клоаки $=0,595 \mathrm{~mm}$. Длина двухъ равной величины спикулъ достигаетъ 2,72 $\mathrm{mm}$. при ширинь основанія =0,119 $\mathrm{mm}$. Форма спикуль чрезвычайно своеобразная: центральный отдълъ спикуль несетъ по объимъ сторонамъ поперечно-исчерченныя крылья, заднії-же отдълъ спикулъ итопорообразно скрученъ. Задній кончикъ спикулъ ложечко-образной формы, причемъ боковыя крылья располагаются на немъ, какъ то видно на рис. 82, не симметрично. Gubernaculum отсутствуетъ. Клоака располагается на разстояніи $0,32, \mathrm{~mm}$. отъ задняго конца твла.

Хвостовой конецъ самца имъетъ бурсу, состоящую изъ 3-хъ лопастей и несущую комплексъ своеобразно расположенныхъ реберъ, точное изображеніе коихъ приводится мною на рис. 80, сдђланномъ при помощи рисовальнаго прибора Abbé. Латеральныя лопасти бурсы отдълены лишь небольшой выемкой отъ средней, удлиненной. Costae posteriores состоять изъ средняго ствола, раздвоеннаго на концъ, къ передней части котораго прилегаютъ по бокамъ 2 болъе короткихъ ребра (по 1-му съ каждой стороны). Каждая изъ латеральныхъ лопастей поддерживается 7-ью ребрами, сгруппированными въ 4 отдвла: costa posterior externa одиночна, три costae mediae начинаются общимъ стволомъ, costae anteriores двойныя и, наконецъ, 4-ую группу составляетъ одиночная costa anterior externa. Нервное кольцо у самца располагается на разстояніи 0,2 mm. от́ головного конца.

Самка: 21,0 mm: длины при максимальной ширинъ $=1,12 \mathrm{~mm}$. в’ь средней части твла. Въ области задняго отдъла пищевода ширина тъла достигаетъ $0,612 \mathrm{~mm}$., въ области расположенія нервнаго кольца $=0,476 \mathrm{~mm}$, на уровнь экскреторнаго отверстія $=$ 0,68 mm.,-на уровнъ полового отверстія-0,51 mm., въ области anus'a $=0,37 \mathrm{~mm}$.

Нервное кольцо располагается на разстояніи $0,22 \mathrm{~mm}$. отъ головного конца; экскреторное отверстіе на разстояніи $0,88 \mathrm{~mm}$. отъ головы; діаметръ выводного отверстія экскреторной системы $=0,085 \mathrm{~mm}$. Хвостовой отдълъ заостренный, задніӥ кончикъ тупо закругленъ. Anus располагается на разстояніи $0,374 \mathrm{~mm}$. отъ хвостового конца.

Половое отверстіе лежитъ на разстояніи $0,52 \mathrm{~mm}$. отъ задняго конца тъла. Мускулистая vagina достигаетъ 0,187 $\mathrm{mm}$. ширины. Овальной формы яйца имъютъ въ длину 0,102 mm. при ширинъ $=0,055 \mathrm{~mm}$. 
Принимая паразита Kiluluma stylosa (Linst. 1907) изъ желудка Rhinoceros africanus за типъ своего новаго рода, я позволю себъ установить нижесльдующій ді агноз'ь рода Kilulıma: Средней величины стронгилиды, ротовое отверстіе коихъ обрамлено 4 периферическими и 6 внутренними губами, изъ числа коихъ первыя несутъ колбовидно вздутые сосочки, на внутреннихъ-же губахъ располагаются 4 игловидно-заостренныхъ сосочка. Пищеводъ колбовидно вздутъ въ задней своей части. Шейные сосочки имъютъ форму бичевиднаго отростка. 2 равныхъ спикулы, спиралевидно-изогнутыя въ своей задней части. Bursa самца трехлопастная; costae posteriores состоять изъ раздвоеннаго на концъ средняго стержня, къ основанію котораго съ каждой стороны прикрвплено по 1 короткому ребру. Боковыя лопасти поддерживаются 7-ью ребрами каждая, распредъленными въ 4 обособленныя группы: 1) 1 costa posterior externa, 2) 3 costae mediae, 3) 2 costae anteriores 4) 1 costa anteriol externa. Женское половое отверстіе близъ anus'a. По бокамъ тъ́ла располагаются кутикулярные крыловидные выросты. Паразиты пищеварит. органовъ млекопитающихъ. Типъ: Kiluluma stylosa (Linstow 1907) изъ желудка носорога. Второй въроятный видъ-Kiluluma brachylaima (L inst. 1901) изъ толстыхъ кишекъ Heterohyrax mossambica Ptrs.

Петроградъ 25. V. 1916.

\section{Объясненіе рисунновъ.}

\section{T A $\mathrm{B}$ II II I A I.}

Puc. 1. Lamreriella latoriporus n. g. n. sp.

Pirc. 2. Ganeo glottoides Klein 1905 var. africana n. var.

Pric. 3. Mesocoelium Sukolowi n. sp.

Puc. 4. Prosthogonimus dogieli nov. sp.

\section{Т А Б Л И Ц А II.}

PIIc. 1. Amphibiophilus a cant li o c irpatus n.g. n. sp. Общiй видъ $\delta^{\top}$ и 9 in copula (слабое увеличеніе).

Рис. 2. Головной конець того-же вида.

Рнс. 3. Хвостовой конецъ $\sigma^{7}$ того-же вида съ бурсой, 2-мя спнулами If gubernaculum. 
Pнс. 4. Задній конець спикуль того-же вида съ загнутыми крючечhaмir.

Piс. 5. Хвостовой нонецт самки ст апия'омт.

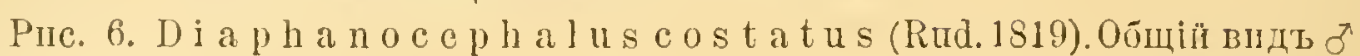
II q iu copula (увег. 6 разт).

Рис. ־. Головпой конець б того-же внда.

Рпс. 8. Хвостовая буреа самда того-же вида.

Pнс. 9. Обццій зидь б’ того-жіе внда.

Piсc. 10. Сппғулы того-ліе вида сь штонорообразно скрученными концами.

Pнс. 11. Челиоговпдный ğbernaculum тото-же вида.

T А Б II II Щ A III.

Pнс. 12. A s c a r is e $\mathrm{x}$ in a $\mathrm{L}$ ins $\mathrm{t}$. 1903. Головной понецъ.

Рiс. 13. Хеость бо того-љке віда.

Piлc. 14. Хвость ㅇ того-же відда.

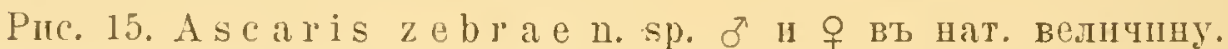

Pнс. 16. Хорзальная губа того-же вида.

Pнс. 17. Хвость б того-жіе внда, съ 2 спнкулами и дылымт рядомь сосочКов'

Pнс. 18. Участокь кутнкулы хвостового конца б ст боковыми и иъсколькнми субмедіанными сосочками.

\section{T A B II II II A IV.}

Pric. 19 Trispiculascar is helicina (Mol. 1860). Дорзатьная губ์a.

Pнс. 20. Хвость б сь сосочками, спикулами и gubernaculum

Рис. 21. Хвость 우 сь anus'onъ.

Pic. 22. Orneoascar is chrysanthemoides n. g. n. sp. o il 울 натур. величину.

Рнс. 23. Видь дорзальной губы снаружи.

Pнс. 24. Вндь дорзальной губы нзвнутріг.

Рнс. 25. Хвостовой конець самда сь паниллами, спиюлами и мозанчныит рисунголь на поверхности кутнкулы.

Рнс. 26. Часть кутикулы хвостового конда самда этого вида съ свободпымь конпомь передпей преанальной паппллы, пмьнющей видь махровато цвњьтка.

\section{T A $\mathrm{B}$ त II II A $\mathrm{T}^{\circ}$.}

Puc. 27. Subulura suctoria Molin 1860. Головной конедь сь иачальиой тастью пицевода (ठ).

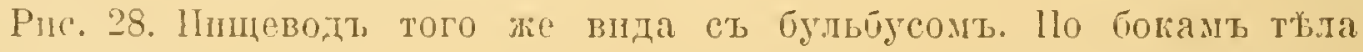

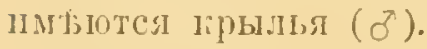

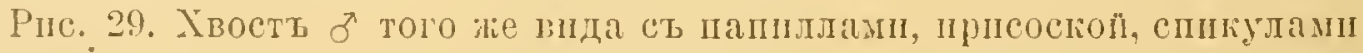
II guberilaculum.

Puc. 30. Strongyluris brevicaudata Mäl. 189t. Touobuon roпецт, паразита. Внд'ь свејху. 
Рнс. 31. Головной конецъ. Видт сбоку.

Pic. 32. Присоска па хвость самда.

Piлc. 33. Бурса салца. Вігды сбоку.

Piс. 34. 'Јасть pliaryx'а съ мышечными сосочками и начало пицевода съ хитнновыми пластннкалі.

\section{Т А Б Л ІІ Ц А V’.}

Pirc. 35. Strong y lut is e legan s Gend re 1909. Головной hoнець паразпта ст pharynхом, ппщеводомь, бульбусомь п началомь Iинечника.

Piс. 36. Хвостовал бурса самца съ паниллами, присоской и характерными спнкулан.

Pнс. .37. 0 x y u r i s le i d y i n. sp. Об́щiї видъ cankir.

Рис. 38. Передній конецъ головы самки этого вида съ`3-мя губами и рудиментамп промежуточныхъ губъ.

Рис. 39. Схена распредйленія гуйт у того-же вида.

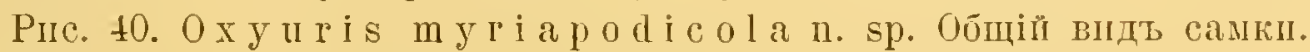

Рнс. 41. Головной конецт паразита съ ротовой капсулой.

Pнс. 42. Ox у и r i s p r a e put i a 1 i s n. sp. Обцій видъ самкі.

Ріс. 43. Головной копедт паразпта, покрытый кутикулярной складкой.

Рнс. 44. Обцаженшый головной конець царазпта.

T А Б Л Н Ц А ГI.

Piic. 45. Ox y uris megalocer ca n. sp.

Рис. 46. Хвостовой конедт самда этого вида

Pнс. 47. Ox y u r is a u n u l a t a L i s t. 1899. Общій впдъ самки.

Рис. 48. Головпой конедъ самки съ 6 панцллообразнымн губамп.

Рнс. 49. Яйцо этого вида.

Pirc. 50. Torie.

Ріс. 51. Расположеніе внутренннхт губъ этого внда.

Pıic. 52. Oxysomatium dogieli n. sp. Головной конедъ самда; e-экскреторное отверстіе.

Рнс. 53. Хвостовой конедъ самда того-же впда.

Рис. 54. Тоже. Видъ сбоку.

Рігс. 55. Хвостопой конецъ самкі того-же вида.

Piс. 56. Наружное экскреторное отверстіе того-же вида.

\section{T A B JI H}

Pıс. 57. Isacis multipapillata n. sp. Общіӥ видъ самда.

Рнс. 58. Обцій видъ самки того-ліе паразпта.

Рис. 59. Губы того-жіе паразита; видъ съ передией поверхности.

Ріс. 60. Передній отдыль тъла самда.

Ріс. 61. Хвостовой конедъ самда.

Ріг. 62. Тоже, видъ сбоку. 
Prc. 63. Phys a lo pte r a a b re vi a t R u d. Передній отдыль гыла. Рис. 64. Деталь головного конца.

Pıс. 65. Хвостовой понецъ самй.

\section{T A B J II II A IX.}

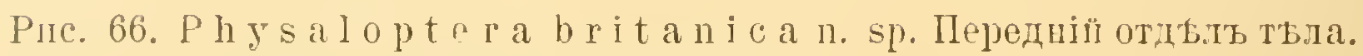

Ріс, 67. Головной гонецт того-же внда.

Pис. 6S. Видь губт наразита сь передней поверхности.

Pис. 69. Хвость самки.

Pirc. 70. D i plot r i e n a sokolow i n. sp. Головной конедь самк.

Ріс. 71. Хвостовой конедъ самки.

Pис. 72. Хвостовой копедт самца ст вентральной поверхности.

Рнс. 73. Хвостовой копецт самца. Боковой видъ.

Рис. 74. Хитнновый трезубедъ самца того-же вида.

Puc. 75. Angiostomum cham a eleou is n. sp. Гomobioñ конець паразита.

Ріс. 76. Хвостовой конецт паразита.

\section{T A B II II II A $\mathrm{X}$.}

Pinc. 77. Kiluluma stylosa (L i s st. 1907). Головной попедъ самца ст пицеводомъ, боковымп кірыльян, шейными сосочками п әкскреторпымь отверстіемь. Направо въ спльно увел. впды әкскреторное отверстіе въ впдь путовчатаго образованы сь радіальной псчерченностьо.

Рис. 79. Головной копець паразита съ губани и сосочками.

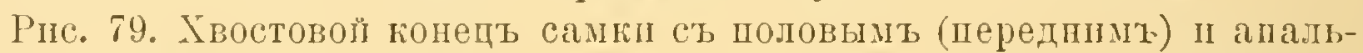
пымъ (задниъ) отверстіями.

Pис. S0. Хвостовая бурса самца съ лопастями и ребрами.

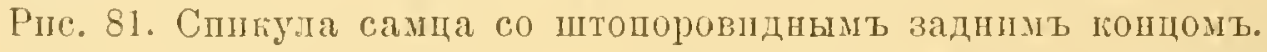

Pис. 82. Цеталь задияго конда спиулы съ аспмегрнчно расположеш-

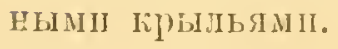




\title{
Parasitic Trematodes and Nematodes collected by the expedition of Prof. V. Dogiel and I. Sokolov in British East Africa.
}

\author{
K. I. Scrjabin.
}

In November of 1914 I was honoured by the proposal of Professor V. Dogiel to take part in the treatment of the collection of Trematodes and parasitic Nematodes taken by the expedition of V. Dogiel and I. Sokolor during the summer of 1914 in British East Africa.

The treatment of this collection, consisting of 10 species of Trematodes and 26 species of parasitic Nenatodes taken from 38 different hosts, promised to give interesting lesults, as the material was collected in a country which was hardly at all studied from the helmintho-famnistic point of vier.

\section{A. Trematodes.}

The Trematodes in the collection of prof. V. D o g i el and I. Sokolor belonged to 10 species taken from $\mathrm{S}$ different hosts.

These species represented 9 genera and 7 families. Amongst the hosts of the Trematodes there were representatives of all the classes of vertebrates, with the exception of Mammalia.

Three specimens of this collection are described by me as new species, one of them constituting a type of a new genus: Laureriella lateriporus nov. gen. nora spec., Mesocoelium soliolowi n. sp. and Prosthogonimus dogieli nov. sp.

The most interesting parasite of the collection of Trematodes is, of course, the new representative of the fam. Allocrea di d a e-Laureriella lateriporus n. gen. n. sp. (from the intestine of a chamaeleo); the Laurer's canal of this parasite is exceedingly long and opens not on the dorsal sur- 
face of the body, but on its right lateral edge,-a peculiari. ty which distinguishes this form from all other Trematodes known until now. It is also interesting to mention the affinity of this parasite with the genera of fam. Allocreadiidae which, with only one exception, are fornd in the intestine of fishes.

Mesocoelium sololonvi 11 . sp. (also from the intestine of a chamaeleo) is noteworthy in its being the second species of the genus Mesocoetium 0 dh ner 1911 from fam. Dicrocoeliidae), to which until recently only one parasite-Nesocuelium sociale (Lühe 1901) from Amphibia has been referred.

Prosthogonimus dogieli n. sp. Was found in the bursa Fabricii of the common swallow (Hirundo rustica) and, therefore, does not present a specific parasite of the African continent; this species will probably be discovered in due time in Europe as well.

The discovery of the parasite Ganeo glottcides Klein 1905 var. africance nova var. (from the intestine of a representative of Ranidae) in Africa is a very interesting fact, as this species had been. described only once until now in Rana hexadactyla from India.

And lastly, the species Nephrostomum ramosum (Sonsino 1895) (from the intestine of Ardea sp.) is interesting on account of the presence of 51 spines on the cephalic collar, the preceding authors having stated 46--49 spines (Sonsino, Dietz, odhner). This fact is remarkable, as it proves the rariation of the number of spines on the collar of Echinostomidae in the limits of one species, whereas most helminthologists consider the number of these spines a reliable criterion for distinguishing the species from each other.

I deeply regret my inability to give in the present paper the scientific nominations of some of the hosts of the parasites described, namely, of those the skins and conserved preparations of which had to be left on the African territory, on acconnt of military complications. In future, when the hosts of the parasites are accurately determined, I shall make a corresponding supplement to the present work

The arangement of the Trematodes from the col. lection of Prof. Dogiel and Sokolov in the zoological systèm. 
A. Fam. Paramphistomidae Fishoeder.

'I. Gen. Diplodiscus Diesing 1536.

1. Diploctiscus subclavatus Goeze 1782.

B. Fam. Allocreadiidae Odhner.

II. G e n. Lameriella gen. nov.

2. Laureriella lateriporus spec. nova.

C. Fam. Lecithodendriidae Odhner.

III. Gen. Ganeo IKle in 1905.

3. Ganeo glottoides Klein 1905 var. africana n. var.

D. Fann. Dicrocoeliidae Odhner.

IV. Ge n. Mesocoelium O d h u e r 1911.

4. Mesocoelium sokolowi sp. nova.

E. Fam. Lepodermatidae Odhner.

V. Gen. Prosthogonimus L üh e 1899.

5. Prosthogonimus dogieli spec. nova.

F. Fam. Echinostomidae Dietz.

VI. Gen. Echinoparyphium. Dietz. 1909.

6. Echinoparyphium volvulus $0 \mathrm{dhn}$ er 1911.

Vll. Ge n. Nephrostomum Dietz 1909.

7. Nephrostomum ramosum (S o n sin o 1895).

VIII. Gen. Mesorchis Dietz 1909.

8. Mesorchis denticulatus R ud. 1819.

G. Fam. Holostomidae Brandes.

IX. Gen. Diplostomum v. Nor d m.
9. Diplostomum sp.
10. Diplostomum sp.

Arrangement of the Trematodes from the collection of prof. Dogiel and I. Sokolov according to their hosts.
A. B ir ds:
Parasites.

I. Ciconiiformes.
1. Ibis sp.
Echinoparyphium volvulus
Odhn. 1911.
2. Ardea sp.
Nephrostomum ramosum (Sonsino 1895).

II. P a s s e rif or mes.

3. Hirundorustica L. Prosthogonimus dogieli sp. nova. 
III. L a i if o r m e s.

4. Larus sp. larra of Diplostomum sp.

B. Reptiles:

Mesorchis denticulatus ( $\mathrm{R} u \mathrm{~d}$. 1819).

IV. Chamaeleontidae.

5. ChamaeleoNo.18 Lauveriella lateriporus g. nov. sp. $n$.

6. Chamaeleo No. 8. Mesocoelium soliolowi sp. nova.

C. Amphibia:

V. Ranidae.

7. Bufo No.7. Diplodiscus subclavatus Goeze 1782.

D. Fis hes:

Ganeo glottoides Klein 1905.

VI. Cy prinidae.

8. Fish No. 6. Diplostomum sp.

A. Fam. Paramphistomidae Fischoeder.

I. Genus Dipiodiscus Diesing 1836.

1. Diplodiscus subclavatus Go eze 1782.

This species which is widely spread and thoroughly studied was found by Prof. Dogiel and I. Sokolor in the intestine of a large green frog of the fam. R a n i d a e (27/ri Kisumu).

\section{B. Fam. Allocreadiidae Odhner.}

Until present all the representatives of fam. Allocreadi dae $O d h n e r$ have been described as parasites of fishes. However, in his work of 1911, p. 72, ${ }^{1}$ ) $\mathrm{Odhner}$ says that he possesses specimens of a trematode from the intestine of a reptile-Lacerta vivipara (from the Museum of Copenhagen) which are typical representatives of Allocreadijdae. The parasite described by me below-Laureriella lateriporus $\mathrm{n}$. $\mathrm{g}$. $\mathrm{n}$. sp. from the intestine of a chamaleo is also a characteristic representative of this family. Thus, not only fishes, but also reptiles are to be considered as hosts of the Trematodes of fam. Allocreadiidae.

The new form of Trematodes which I named Laureriella

1) O d h n er. Nordostafrikanische Trematolen. Results of the Swed. Zool. Experlition to Egrpt... Part IV. 1911. p. 72. Note. 
Lateriporus gen. nov. sp. nova is characterized by an extremely elongated Laurer's canal which opens to the exterior not on the dorsal side, as usually, but on the right edge of the body.

\section{Genus Laureriella gen. nov.}

Diagnosis: Parasites of average size with a smooth cuticle. Oesophagus elongated, the intestinal trunks reach to the end of the body. The genital aperture is situated anteriorly to the ventral sucker, medially. The bursa cirri is small, not reaching the level of the middle of the ventral sucker. Pars prostatica is developed. The round testes are arranged medially one after another. The spherical ovary lies in the space between the anterior testis and the ventral sucker, medially. The vitelline glands are situated on both sides of the intestinal trunks. In the posterior part of the body the vitelline glands of the right side join those of the left side. Laurer's canal is extremely long and opens to the exterior on the right side of the body, not on the dorsal. The few convolutions of the uterus are arranged in the space between the anterior testis and genital aperture, the loops of the uterus passing a little beyond the lateral margin of the intestinal coeca. Parasitic in the intestine of reptiles. Type and meanwhile the only species: Laureriella lateriporus S krjabin 1915.

2. Laureriella lateriporus nova sp.

(Tab. 1, Fig. 1.)

Host: Lizard № 18 (from fam. Chamaeleontidae).

Occurence: Intestine.

Description of the species.

Body flat, equally rounded at both extremities. Length of the body reaches $6,12 \mathrm{~mm}$. at a maximum width-1,275 $\mathrm{mm}$. in the middle. A round-oval oral sucker the aperture of which is directed ventrally attains $0,476 \mathrm{~mm}$. in length, with a width of $0,51 \mathrm{~mm}$. The pharynx adjoining it has $0,30 \mathrm{~mm}$. in diameter. A rather long oesophagis, attaining 0,37-0,4 mm., is continued into the intestinal trunks reaching the posterior end of the body.

Two spherical testes, having $0,-1-0,5 \pm \mathrm{mm}$. in diameter, are situated medially one after another in the posterior part 
of the body. The testes are often adjacent with tbeir edges. The genital aperture is anterior to the rentral sucker, it lies on median line of the body, immediately behind the bifurcation of the intestine. Bursa cirri is very small, slightly overlapping the anterior edge of the ventral sucker with its posterior part (dorsally). The spherical even-edged orary is situated medially in the space between the anterior testis and the ventral sucker.

The vitelline glands are situated on the sides of the posterior part of the body. They commence at the level of the anterior margin of the anterior testis and continue backwards to the end of the body. They are arranged not only laterally to the intestinal trunks, but also merlially to the latter. The vitelline follicles are grouped in such a manner as to form 4 longitudinal bands rumning parallel to each other (2 bands on each side of the body). In the posterior end of the body the vitelline glands of the right side of the body join those of the left side so that the borders between the abovementio. ned bands are obliterated. Two vitelline ducts lead from the anterior portions of the vitelline ghands toward the median line of the body, where they unite to form the yolk reservoir.

The uterus is rery weakly developed: with its few convolutions it occupies the space between the posterior edge of the ovary and the external genital apertmre. Thus, part of the uterus is twisted dorsally to the ventral sucker, its loops in some places intersecting with the left intestinal trunk and projecting beyond its exterior margin. In none of the specimens investigated by me were there any eggs in the uterus, on account of which I can give no data on their form, or dimensions. As concerns the accessory genital organs, I may point out the presence of a receptaculum seminis which is of an irregular oval shape and situated with its long axis transversely with respect to the length of the body in the space between the ovary and the anterior testis.

The most characteristic organ of this parasite is its Laurer's canal, distinguished by its extreme length and original situation. It begins in the area of the median body-line behind the ovary and forms several convolutions running anteriorly and to the right body-margin of the parasite. Here, on the very margin of the body, at a distance of $2 \mathrm{~mm}$. from the anterior extremity the Laurer's canal opens to the exterior. 
This character which sharply distinguishes our parasite from the other Trematodes-in which, as it is known, the opening of Laurer's canal is situated on the dorsal surface of the body-was the chief reason for founding the new genus Laureriella. On the other hand, the character of structure and relations of all the other organs to each other (particularly the arrangement of the genital glands, the character of the uterus, vitelline glands etc.) guarantee the genus Lamreriella a firm position in the family Allocreadiidae.

\section{Fam. Lecithodendriidae Odhner.}

In the collection of Prof. Dogiel and Sokolov there is a single representative of the fam. Lecith odendri idae (subfam. Pleurogenetina e L.) belonging to the genus Ganeo Klein 1905 .

\section{Genus Ganeo Klein 1905.}

Diagnosis:

Small Trematodes with body of an elongated oval shape. The cuticle is covered with small spines in the anterior part of the body. The oral and ventral suckers are nearly equal in size. The latter is situated on the border of the anterior and middle thirds of the length of the body. The elongated oesophagus passes into the intestinal trunks which do not reach the end of the body. The genital aperture is situated on the left side of the body, and opens on its left edge into a deep cavity formed by the invagination of the cuticle (genital cloaca), and situated in the anterior part of the body at about the level of the middle of the vesophagus. The testes are arranged in the anterior third of the body, the foremost testis being situated anteriorly to the rentral sucker, and the posterior tes!is - with its posterior edge nearly at the same level with it; or the testes are arranged both anteriorly and posteriorly to the ventral sucker. The ovary is behind the testes. The pseud obur's a cirri is elongated, curved, and reaches the ventral sucker with its posterior edge. The vitelline glands are arranged near the lateral margins of the body in the area of its middle third. The uterus occupies the space between the ventral sucker and the intestinal trunks reaching the hinder end of the latter, or the very end of the body. The 
eggs are small, of an oral shape, with a dark-brown shell. Farasitic in the intestine of A mphibia. Typical species: Ganeo glottoides Klein 1905 ${ }^{1}$ ) from Rana hexadactyla (India).

In the collection of Prof. Dogiel and Sokolov there is one form of Trematodes, which is closely related to the species Ganeo glottoiaes Klein 1905. The resemblance between the African and Indian forms is so striking-even in such slight character's as, e.g., the length of the pharynx, the length of the oesophagus etc., to say nothing of the size of eggs that I had to refer the African form also to the species Ganeo glottoides Klein. The only character that distinguishes my parasite from that of $\mathrm{Kle}$ in is a difference in the position of the genital glands. This peculiarity justifies me in separating my parasite as a representative of a new variety of the species Ganeo glottoides Klein 1905 which I name var. africana $110 \mathrm{va} \mathrm{v}$ a r.

\section{Ganeo glottoides Klein 1905 var. africana nova var.}

(Tab. I, fig. 2.)

The new variety of Ganeo glottoides Klein 1905-var. africana nova. var., as mentioned above, is nearly in all details of its organization identical with the species described by Klein from India. I shall not give a detailed description of my variety, not wishing to repeat Kle in's masterful work, but shall point out those peculiarities in the structure of the African form which lead me to distinguish it as a new variety.

In comparing the African parasite with the Indian it is first of all noticeable that the intestinal trunks in the former nearly reach the hinder end of the body, whereas in the latter the blind extremities of the intestine are far from the end of the body (see fig. 6 in K le in's work). However, this character is of no specific value, as in several specinens of Ganeo glottoides $\mathrm{Kl}$ e i n observed a different length of the intetinal trunks. The difference in the arrangement of the genital glands is much more serious. In the Indian species the anteriol testis is situated immediately behind the bifurcation of the intestine, and the posterior testis lies anteriorly

4) Kle in. Neue Distomen aus Rana hexadactyla. Zool. Jahrbuch, Syst. Bd. 22, 1905, p. 72-78, lig. 6-7 (Taf. 5). 
to the rentral sucker; whereas in the African variety the anterior testis occnpies the same position like the posterior testis of Klein's parasite; as concerns the posterior testis of the African parasite, it is situated posteriorly to the rentral sucker. The ovary is also differently localized in both forms: in the Indian species the ovary is situated to the right from the ventral sucker, adjacent to the right trunk of the intestine (in the same position as the posterior testis in var. africana!), and in the African variety the ovary lies to the left from the median body-lime, posteriorly to the ventral sucker.

\section{Fam. Dicrocoeliidae Odhner.}

In the collection of Prof. Dogiel and S'okolov there is one representative of the stibfamily Dicrocoeliidae (from the intestine of a chamaeleo) belonging to the genus Mesocoelium Odhner 1911. Until present there was only one species-Mesocoelium sociale (Lïhe 1901) ${ }^{1}$ ) belonging to this genus. Thus, our parasite-Mesocoetium soliolowi n. sp. is the second species of this genus.

\section{Genus Mesocoelium Odhner 1911. \\ 4. Mesocoelium sokolowi nova spec.}

(Tab. I, fig. 3).

This species was found in the middle part of the intestine of one of the chamaeleos (요 8).

Body flat, linguiform, narrowing towards the hinder end. Length of body $3,7-4,335 \mathrm{~mm}$. at a maximum width $1,36-$ 1,70 $\mathrm{mm}$. In some specimens the anterior part of the body was widened, resembling the drawing of Distomum sociale in the work of $L$ ï he 1901. The surface of the cuticle is armed with small scale-like spines. The ventral sucker is arranged on the border of the first and second quarters of the length of the body, just as in Mesocoelium sociale. The dimensions of the ventral sucker are smaller than those of the oral. The oral sucker attains $0,4-0,45 \mathrm{~mm}$. in transverse section, the ventral sucker is $0,255-29 \mathrm{~mm}$. in length and $0,29-$ $0,32 \mathrm{~mm}$. in width. The spherjcal pharynx attains $0,17-0,20 \mathrm{~mm}$.

1) Lü h e. Zwei neue Distomen aus indischen Anuren. Centralbl. f. Bakt. Parasitenk. 1901, Bd. XXX Orig. p. 171-173, Fig. 5. 
in diameter. The oesophagus is altogether absent. The intestinal trunks reach the end of the body. The testes are arranged on both sicles of the rentral sucker, somewhat posteriorly to it, and projecting with their lateral margins beyond those of the intestinal trunks. The shape of the testes is irregular oral and slightly lobed. The spirally coiled bursa cirri is situated in the space between the pharynx and the rentral sucker, being localized dorsally to the latter with its posterior edge. I could not study the structure of this organ in detail on account of the limited quantity of material at my disposal. The ovary is of an irregular round shape, considerably smaller than the testes, and situated on the left side of the parasite adjoining to the posterior part of the interior edge of the left testis. The vitelline glands begin at the level of the posterior edge of the testes and reach the border of the third and hinder quarters of the body length. The vitellime glands are arranged not only on the sides of the intestinal trunks, but also dorsally to them, the main vitelline ducts fusing together in the median line at about the level of the middle of the body-length. The uterus is localized on the limit between the testes and the posterior end of the body. The convolutions of the uterus are arranged not only in the space between the intestinal trunks, but some portions of it cross the intestine and nearly reach the lateral edges of the body. The uterus is filled with eggs which are $0,032 \mathrm{~mm}$. in length, and $0,019 \mathrm{~mm}$. in width.

The genital aperture is situated medially, anteriorly to the ventral sucker.

\section{E. Fam. Lepodermatidae Odhner.}

\section{Gen. Prosthogonimus Lühe 1899.}

\section{Prosthogonimus dogieli spec. nova.}

(Tab. I, fig. 4).

Host: Hirundo rustica.

Occurence: bursa Fabricii.

Length of the body $=4,75 \mathrm{~mm}$., width $=3,65 \mathrm{~mm}$; this character alone places our parasite in a distinct position among the other species of the genus Prosthogonimus, as in the latter the width of the body forms a half of its length.

The surface of the cuticle is covered with spines pointed 
with their tips backwards; the length of the spines attains $0,029-0,030 \mathrm{~mm}$. The spines cover the entire surface of the body, the hinder part of it not excepted.

The suckers are strongly developed. The oral sucker may be $0,289 \mathrm{~mm}$. in length, with a width of $0,314 \mathrm{~mm}$. And again, contrary to what we find in the other species of Pro. sthogonimus, the width of the oral sucker in our parasite is greater than its length. The nearly spherical pharynx, $0,2 \cdot 2 \mathrm{~mm}$. long and $0,238 \mathrm{~mm}$. wide, passes into the oesophagus which attains $0,29 \mathrm{~mm}$. in length. The blind ends of the intestine which is filled with a black substance (food) run beyond the posterior margins of the testes, not reaching, however, the posterior end of the body.

The ventral sucker is situated on the border of the anterior and middle third of the body-length, being $0,85 \mathrm{~mm}$. long and 1,0 $\mathrm{mm}$. wide.

The oval testes are situated in the middle third of the body at the same level, being divided from each other by the convolutions of the uterus.

The bursa cirri is of an original retort-like shape, its bottom reaching the point where the oesophagus divides into the intestinal trunks; the length of bursa cirri is-0,883 $\mathrm{mm}$. It opens to the exterior by the male genital aperture which is situated in the left half of the body near the opening of the oral sucker, between the latter and the aperture of the female genital apparatus.

The ovary is multilobed, clustershaped, and is situated nearly medially, both posteriorly and dorsally to the ventral sucker. The vitelline glands, which are situated near both lateral margins of the body, begin at the level of the middle of the distance betwreen the anterior edge of the ventral sucker and the bifurcation of the intestine, and end somewhat anteriorly to the blind ends of the intestinal branches. In some specimens an asymmetrical arrangement of the vitelline glands has been observed: on the right they were more developed than on the left side. The vitelline glands consist of extremely small follicles which are not clustered into groups, as it is observed in the species Prosthogonimus pellucidus Linst., 1873 and $P$. putsckowstivi Skrjabin 1912. The length of the right vitelline gland in the specimen drawn by me reached $3,06 \mathrm{~mm}$., and that of the left-only $2,04 \mathrm{~mm}$. 
The convolutions of the nterus extend not only behind the ovaly, but also to the sides of the latter, and even in the part of the body anterjor to the rentral sucker there is a rather complicated portion of the loops of the uterus, which lie, howerer, only medially, and do not extend beyond the lateral margins of the intestinal trunks, as is the case in Prosthogonimus ovatus (Rud. 1803).

The numerous small ova filling the uterus have the following dimensions: 0,029-0,031 $\mathrm{mm}$. in length by $0,0174 \mathrm{~mm}$. in width.

\section{F. Fam. Echinostomidae Dietz.}

In the material investigated by me there were 3 representatives of this family, belonging to the genera: Echinoparyphium Dietz 1909, Nephrostomum Dietz 1909 and Mesorchis Dietz 1909.

\section{Genus Echinoparyphiım Dietz. 1909.}

\section{Echinoparyphium volvulus Odhner 1911.}

(Fig. A.).

The specimens studied by me were taken from the intestine of the black Ibis.

The number of spines on the collar $=33$. In one specimen there were only 29 spines.

VII. Gen. Nephrostomum Dietz 1909.

7. Nephrostomum ramosum (Sonsino 1895.)

(Fig. B).

This parasite present in the collection of Prof. Dogiel and Sokolov was taken from the intestine of a gray Heron-Arctea sp.

An interesting peculiarity in the specimens investigated by me is presented by 51 spines on the cephalic collar of the parasite. In his work Sonsino numbers 46 spines on the collar of Echinostomum ramosum described by him. Odhner found $47-49$ spines in his specimens; and, lastly, D i etz considers the number of spines in this parasite to be 48 . 
VIII. Gell. Mesorchis Dietz 1909.

8. Mesorchis denticulatus (Rud. 1819).

This species, which had been known a long time, is parasitic in the intestine of sea-gulls. It occured in the collection of Prof. Dogiel and Sokolov (from-Larus sp. killed on the lake Victoria-Nyanza) together with a larval form of Diplostomum sp.

\section{G. Fam. Holostomidae Brandes.}

\section{Gen. Diplostomum v. Nordm.}

\section{Diplostomum spec.}

This is a free larva from the intestine of Larus sp. It seems that the sea-gull was infected by this parasite through a fish, and the parasite did not yet develop into the adult stage in the organism of his final host.

The body is nearly round, flat, very tender, reaching $0,9 \mathrm{~mm}$. in length at a width of $0,05 \mathrm{~mm}$. The ventral sucker situated at a distance of $0,53 \mathrm{~mm}$. from the anterior end of the body (in its posterior half) is $0,068 \mathrm{~mm}$. in diameter. The oval pharynx is $0,05 \mathrm{~mm}$. long and $0,034 \mathrm{~mm}$. wide. Laterally to the oral sucker are arranged 2 small auricular invaginations. Unfortunately, it is impossible to determine the species of this parasite more definitely.

\section{B. Parasitic Nematodes.}

The parasitic Nematodes from the collection of Prof. V. Dogiel and I. Sokolov belonged to 26 species taken from 30 different hosts.

These species represented 14 genera and 7 families. Amongst the hosts of the parasitic Nematodes were representatives not only of all the classes of vertebrates but even two species of $\mathrm{my}$ riapods.

In the present work I am describing 12 new species of which two parasites represent two new genera. The folowing is a list of these parasites:-1) Amphibiophilus acanthocirratus $11 . \mathrm{g}, \mathrm{n}$. sp. (from a representative of fam. Ranidae); 2) Ascaris zebrae n. sp. (from the intestine of a $\mathrm{zebla}$ ); 3) Orneoascaris chrysanthemoides n. g. n. sp. (from the intestine 
of a representative of fam. Bufonidae); 4) Oxynris myriapodicola 1). sp. and 5) Oxyuris leidyi n. sp. (from the intestine of Polyclesmus); 6) Oxyuris praeputialis n. sp. (from the intestine of Bufo sp.): T) Oxyuris megalocerca n. sp. (from the intestine of Gecko); 8) Oxysoma dogieli n. sp. (from Bufo sp.); 9) Isacis multipapillata n. sp. (from the intestine of Iutus sp.); 10) Physaloptera britanica n. sp. (from Agama sp.): 11) Diplotriaena sokolowi n. sp. (from Halcyon senegaloides) and 12) Angiostomum chamaeleonis 11. sp. (from the lungs of Chamaeleo).

The detailed investigation of the parasite Ascaris helicina (Nolin 1860) from the intestine of a crocodile leads to the separation of this form from the old genus Ascaris L., and I am placing it into a new genus named by me Trispiculcuscaris, on account of the presence of a gubernaculum which, as it is known, is always absent in the typical Ascaridae.

One of the most remarkable parasites in the collection of Dogiel and Sokolor is the representative of a new genusAmphibiophitus acanthocirratus n. g. n. sp. from the intestine of an amphibian (fam. Ran id a e). The oral capsule of this parasite is built after the type of Amidostomm (parasitic in birds), while the bursa copulatrix of the male bears the character of that of Ankylostoma (parasitic in mammals).

The new genus of Ascaridae-Orneoascaris chrysanthemoides from the intestine of amphibia (fam. Bufon i$\mathrm{dae}$ ) is also interesting. It is characterized by the presence of broad alae, and, especially, by the structure of the cuticle at the candal end of the male, which is of a very complicated mosaic drawing; the caudal papillae of the male are of a queer form resembling the crown of a double flower.

The species of gemus Oxyuris were especially abundantly represented in the collection of Dogiel and Sokolor; nut of 7 representatives of them 4 parasites were separated by me into new species. In studying the Oxyuridae I paid special attention to the structure of the oral organs, as this character is to be of great importance in the systematic re-grouping of the representatives of this genus, which often differ from each other in generic, and not only specific characters.

It is necessary also to mention the new species of genus Isacis Lespes, Isacis multipapillata n. sp., the investigation of which gave the means for forming a diagnosis of 
this old genus which is hardly at all mentioned by modern helminthologists.

The study of the literature on the genus Oxysoma schneider 1866 made me re-group some of its representatives referring them to other genera of Nematodes, and, on the contrary, include into the genus oxysoma one of those parasites which was classified in literature as a representative of quite a different genus.

I paid much attention to drawings which often characterize certain species much clearer than the most detailed description of them.

I consider it necessary-before beginning the description of the separate representatives of Nematodes from the collection of Dogiel and Sokolov-to give the following tables: 1) table of their arrangement in the zoological system and 2) table of their arrangement according to the hosts.

Arrangement of the Parasitic Nematodes from the collection of Prof. Dogiel and Sokolov in the Zoological System.

A. Fam. Strongylidae Cobbold 1864 (s. lato).

I. G e n. Amplibiophilus gen. nov. 1. Amphibiophilus acanthocirratus n. sp.

II. G e n. Diaphanocephalus D i ez.

2. Diaphanocephalus costatus ( $\mathrm{R}$ u d 1819)

\section{B. Fam. Ascaridae Cobbold 1864.}

III. Gen. Ascaris Linné 1758 (s. lato).

3. Ascaris euxina Linst. 1903.

4. Ascaris filaria D u j a d. 1845 .

5. Ascaris zebrae nov. spec.

6. Ascaris sp.

7. Ascaris sp.

IV. Gen. Tripiculascaris gen. $n 0 \mathrm{v}$.

8. Trispiculascaris helicina (Molin 1860)

V. Gen. Omeoascaris gen. nov.

9. Orneoascaris chrysanthemoides spec. nov.

C. Fam. Heterakidae Raill. et Henry 1914.

VI. Gen. Subulura Molin 1860

10. Subulura suctoria Molin 1860. 
VII. Ge n. Strongyluris A. M ïll. 1894.

11. Strongyluris brevicaudata M ïll. 1894.

12. Strongyluris elegans G e nd re 1909.

D. Fam. Oxyuridae.

VIII. Gen. Oxyuris Rud. 1803 (s. lato).

13. Oxyuris myriapodicola n. sp.

14. Oxyuris leidyi nov. sp.

15. Oxyuris praeputialis n. sp.

16. Oxyuris megalocerca n. sp.

17. Oxyuris spinicauda D uj. 1845 .

18. Oxyuris annulata Lin st. 1899.

19. Oxyuris obvelata Zed. 1803.

IX. Gen. Oxysoma Schneider 1866 .

20. Oxysoma dogieli n. sp.

X. Gen. Isacis Lespes 18.

21. Isacis multipapillata nor. sp.

\section{E. Fam. Physalopteridae Leiper 1911.}

XI. Gen. Physaloptera Rud. 1819.

22. Physaloptera abbreviata R $\mathrm{d}$.

23. Physaloptera britanica n. sp.

\section{F. Fam. Filariidae Claus 1885.}

XII. Gen. Diplotriaena Raill. et Henry 1909.

24. Diplotriaena sokolowi nov. spec.

25. Diplotriaena ozouxi Raill. et Henty 1909.

\section{G. Fam. Angiostomidae}

XIII. Angiostomm D uj ard. 1845.

26. Angiostomm chamaeleonis nov. spec.

A special place is given to the larval forms of Nematodes united into

XlV. Gen. Agamospirma Raill. et Henly 1912. 
Arrangement of the parasitic Nematodes from the collection of Prof.

Dogiel and Sokolov according to their hosts.

Vertebrates.

A. Mammalia.

Perissodactyla.

1. Equus zebra Ascaris zebrae n. sp.

Rodentia.

2. Mus sp. Oxyuris obvelata Zed. 1803.

B. Aves.

Steganopodes.

3. Phalacrocorax sp. Ascaris euxina Linst. 1903.

Passeriformes.

4. Halcyon senegalo- Diplotriaena sokolorvi n. sp. ides A. Smith

5. Bird № 7 fr. fam. Diplotriaena ozouxi R a ill.

Ploceidae

Hen ry 1909.

6. Centropus siperci- Subulura suctoria Mol. 1860. liosus

L a r if orm es.

7. Larus sp. Agamospirura (in cysts).

Galliformes.

8. Bird ํㅛ Ascaris sp.

C. Reptilia.

L a certilia.

9. Scincidae № 6. Oxyuris ammulata Linst. 1899.

10. Agama № $13 . \quad$ Strongyluris brevicauda Müll. 1894.

11. Agama № 11. Strongyluris brevicauda Miill. 1894.

12. Agama № $2 . \quad$ Strongyluris brevicauda Müll. 1894.

13. Chamcieleo (lizard Strongyluris elegans Gendre - № 21). 1909.

Angiostomum chamcieleonis

n. sp.

14. Gecko (lizard № 4). Oxyuris megalocerca 11 . sp.

15. Gecko io 1. Oxyuris spinicauda Duj. 1845. 
16. Agama ำ 12.

\section{Crocodilia.}

17. Crocodilus sp.

Ophidia.

18. Bitis gabonica.

19. Snake s'ítr.

20. Snake A. 20/r'I. idem.

21. Snake o. 1. $6 / \mathrm{r}$. idem.

22. Suake io. 8. 22/ I.I. idem.

D. Amphibia.

23. Bufo ำ 8 .

24. Bufo ㅅ․ 10.

25. Bufo $15 / \mathrm{s}$.

26. Bufo.

\section{E. Pisces.}

Cyprin id a e.

27. Carp-fish.

Sil urid a e.

28. Fish 스 8. 28/to. Agamospirura.

\section{Invertebrates.}

\section{F. Myriapoda}

Diplopoda.

29. Julus sp.

30. Polydesmus sp.
Physaloptera britanica n. sp.

Physaloptera abbreviata Rud.

Trispiculascaris heticina

(Mol. 1860).

Ascaris filaria D u j. 1845.

Ascaris sp.

Diaphanocephatus costatus R ud. 1819.

Amphibiophilus acanthocirratus $\mathrm{n}$. g. n. sp.

Oxyuris praeputialis n. $\mathrm{sp}$.

Oxyuris praeputialis n. $\mathrm{sp}$.

Orneoascaris chrysanthemioides $n$. g. n. sp.

Oxysoma dogieli n. sp.

Orneoascaris chrysanthemoides $\mathrm{n}$.

$$
\text { g. In. sp. }
$$

\section{Agamospirura.}

Isacis multipapillata n. sp.

Oxyuris leidyi n. sp.

Oxyuris myriapodicola $11 . \mathrm{sp}$. 


\section{A. Fam. Strongylidae Cobbold 1864}

\section{Genus Amphibiophilus gen. nov.}

In one of the test-tubes of the collection of Prof. Dogiel and Sokolov were found some interesting Strongylidae (from the intestine of amphibia of fam. Ranidae) in which were curiously united characters belonging both to gen. Amidostomum Raill. et Henry 1909, and to gen. Ankylostomum Dubini 1St3. The cephalic end of these parasites was provided with a cup-like oral capsule, at the bottom of which sat a large triangular denticle with the sharp end directed anteriorly. This corresponds to the type of the cephalic end in Amidostomum. On the othel hand the caudal bursa of the male was provided with ribs arranged nearly in the same manner as in representatives of gen. Ankylostomum. I refer these parasites to a new genus of Nematodes belonging to fam. Strongylida e Cobbold 1864 which I name Amphi. biophilus nov. gen.

Diagnosis.

Tender, filiform Nematodes the male and female of which remain united in coitu for a long time, as is the case in gen. Syngamus v. Si eb. 1836 as well. The cephalic end is provided with an oral capsule-the structure of which is similar to that in Amidostomum Raill. et Henry 1909-at the bottom of which is situated a large triangular pointed denticle directed forwards. On the sides of the head are 2 lateral papillae. The oesophagus is short $(1 / 16-1 / 23$ part of body-length), gradually widening towards its posterior end. The caudal end of the male is provided with a bursa the ribs of which are arranged as follows: costae anteriores consist of 2 ribs originating by $\dot{0}$ common trunk; 3 costae mediae begin by a common trunk from which costa anterior externa parts separately, whereas costa lateralis media and costa lateralis posterior again have a common trunk. The costae posteriores externae are united with costa anterior into a common, very short trunk forming independent elongated ribs; costa posterior is dichotomically divided in the hinder quarter of its length, each of its branches forming at its end a trident. 2 spicula of equal length are composed of an anterior broad and flat part, and of a posterior-narrow, cylindrical part, provi- 
ded at the end with a small bent hook composed of 2 branches. The candal end of the female is thin, pointed. The vulva is situated in the hinder hall of the body, between the third and last quarter of its length. 2 oraries. Parasitic in the alimentary tract of amphibia. Type and until present the only species Amphibiophilus acanthocivratus nova spec. from the intestine of a representative of fam. $R$ a n i d a e.

\section{Amphibiophilus acanthocirratus n. sp.}

Host: a frog from fam. Ranid a e.

Occurence: intestine.

Description of the species.

Body thin, filiform, cylindrical, very tender. The male and female of all specimens investigated were in coitu, the male being so closely united with the female as to resemble the representatives of genl. Syngamus r. Si e bold.

II a le. Length of body reached 7,14-7,40 mm., at a width:$n$ the region of the hinder part of the oesophagus $=0,085 \mathrm{~mm}$., in the hinder part of the body $=0,1 \mathrm{~mm}$. and in the region of the anus $=0,09 \mathrm{~mm}$. The round mouth opening is continued into a cup-shaped oral capsule with a rounded bottom in the middle of which rises a conical denticle directed with the point forwards and reaching the upper edge of the capsule with its apex. The width of the oral capsule reaches $0,051 \mathrm{~mm}$. The mouth opening is surrounded by 6 papillae: 2 lateral and 4 submedian. The surface of the cuticle is slightly striated longitudinally. The nesophagus is short, occupying $1 / 16$ part of the body-length (length of oesophagus $=0,425-0,45 \mathrm{~mm}$.). At the commencement it is cylindrical, then it gradually widens forming at the posterior end of the oesophagus a club-shaped bulb. The caudal end of the male is provided with a bursa copulatrix supported by symmetrically arranged ribs. Costae anteriores are double with a common trunk for both. 3 costae mediae are united into a common trunk, the costa anterior externa being situated separately from the two hinder ribs, whereas costa lateralis media and costa lateralis posterior are fused into on e in their basal part. Costae posterjores externae are comnected with costa posterior by a short trunk from which, however, they soon depart, forming independent, thin, elongated ribs; 
costa posterior branches dichotomically in the posterior quarter of its length, each of its branches forming a trident at the end. As it is seen from this description, the caudal bursa of the male in this species is formed after the type of some Strongylidae parasitic in mammals-as, e.g., in Ankylostomum. Two spicula of equal size, 0,221 $\mathrm{mm}$. long, are of a very characteristic form: their anterior half is wide, flat with a granulated surface, whereas the hinder half is, on the contrary, cylindrical, filiform. The hinder end of the spiculum terminates by a dichotomous furca, forming a sort of a hook composed of two branches bent to the same side. With the spicula is connected a spindle-shaped gubernaculum reaching $0,09 \mathrm{~mm}$. in length.

The fem ale reaches $11,73 \mathrm{~mm}$. in length with a width of the body in the region of the end of the oesophagus = $0,136 \mathrm{~mm}$., in the region of the genital aperture $=0,136 \mathrm{~mm}$., at the level of the anus $=0,05 \mathrm{~mm}$. Oral capsule $0,07 \mathrm{~mm}$. wide. Oesophagus, of the same character as that of the male, occupies $1 /_{23}$ part of the body-length, reaching $0,51 \mathrm{~mm}$. in length. The caudal end is narrowed, conically pointed; the anus is situated at a distance of $0,22 \mathrm{~mm}$. from the caudal end. The vulva opens by an aperture between the third and posterior quarters of the body-length, at a distance of $2,9 \mathrm{~mm}$. from the candal end (in another female specimenat a distance of $2,3 \mathrm{~mm}$. from the caudal end). From the short vagina 2 uterj diverge to npposite sides, they contain a limited number of eggs arranged in one low and with their long axis either parallel, or perpendicular to the body length. The eggs are oval, 0,085 $\mathrm{mm}$. Iong, 0,05 $\mathrm{mm}$. wide, and contain a well formed embryo.

\section{Genus Diaphanocephalus Dies.}

The position of this genus in the suborder Strongylata is not yet fixed, and it is referred by the modern creator of the system of Strongylidae, prof. Railliet, to a group of "genres non encore classés“.

I propose the following diagnosis of this genus:

Middle-sized Nematodes the mouth opening of which has the character of a narrow dorso-ventral slit leading into the oral capsule consisting of 2 symmetrical, laterally arranged 
shields. Each shield presents a whole complex of chitinous filaments, in the spaces between these are arranged 3 parallel, elongated papillae which are continued to the mouth-opening. The tail of the male is provided with a bursa with the following arrangement of ribs: costae anteriores bifurcate slightly near their apex; costae mediae present 3 equal branches commencing by a common trunk; costae posteriores externae begin from the middle of the elongated trunk of costae posteriores; the latter are dichotomically divided in their posterior part, and anteriorly to their bifurcation they have a lateral branch, on account of which each costa posterior has a trilobed charactel. 2 equal spicula and a gubernaculum. The rulva is situated in the posterior part of the body. 2 uteri diverging in opposite directions. Parasitic in the alimentary organs of reptiles. Typical species: Diaphanocephalus galeatus (R u d. 1819) from Podinema teguixin in Brazil.

\section{Diaphanocephalus costatus Rud. 1819.}

The caudal bursa of the male is typical for the genus: costae anteriores slightly bifurcated near their apex; costae mediae present 3 branches of a common trunk; costae posteriores externae and costae posteriores begin by a common. trunk, the former departing from the middle of it; costae posteriores are composed of 3 lobes formed from the dichotomous bifurcation of the posterior part of the rib and frum the lateral branch which departs anteriorly to the point of this bifurcation. Length of spicules $=0,51-0,54 \mathrm{~mm}$; gubernaculum $=0,17-0,2 \mathrm{~mm}$. The rulva is situated in the posterior part of the body, dividing the latter into portions in the ratio $5: 3$.

The anal opening of the female is situated at a distance of $0,765 \mathrm{~mm}$. from the caudal end.

The structure of the spicula is very original: they consist of a basal corpus and an ala; the corpus is of a dark brown shade with more or less large tubercles on its surface; the transparent alae are transversely striated. The terminal part of the spicula is spirally coiled. The character of the spicula resembles that of the species described by Linstow in 1907 under the name Deletrocephalus stylosus (from the intestine of a rhinoceros). 
The straw-yellow gubernaculum has the shape of a deep canoe with the anterior and posterior ends pointed; the bottom of the guberuaculum is provided with a longitudinal slit-like opening in its anterior part; with its sides the gubernaculum tightly embraces the spicula allowing them to slide only in one definite direction.

\section{B. Fam. Ascaridae Cobbold 1864.}

\section{Genus Ascaris L. 1758 (sens. lato).}

\section{Ascaris euxina Linst. 1903.}

Until the present this species was described only once by Linstow from the stomach of Pelecanus minor $R u p p$. In the collection of Dogiel and Sokolov this parasite was taken from a new host-Phalacrocorax sp.

To the brief, but exact description of Linstow I shall add only the measurements of the spicula in the male. In the specimen investigated by me they were $1,15 \mathrm{~mm}$. long and $0,017 \mathrm{~mm}$. wide in their middle part. The spicula are slightly bent ventrally; posteriorly from the middle of their length the spicula are provided with a small alate outgrowth which gradually disappears. The tips of the spicula are rounded. The number of postanal papillae in the male reaches 12 pairs, as was shown by Jinstow; however, one of these papillae, situated most medially, is double. This was not mentioned by Linstow in his description.

\section{Ascaris filaria Dujardin 1845.}

Until the present this species was described from the following hosts:--

1) Astrophis tigris,

2) Python reticulatus,

3) Python sebae.

In the collection of Dogiel and Sokolov this species is taken from a new host-Bitis gabonica.

\section{Ascaris zebrae nov. spec.}

This new species is parasitic in the intestine of the zebra. The cuticle is transversely striated; the cephalic extremity is 
surrounded by 3 hasal and 3 accessory lips the length of which reaches only ${ }^{1}{ }_{3}$ of the length of the basal lips.

The lips are of nearly regular quadrangular form with traces of a slight groove both on the anterior and lateral edges: the peripheral part of the lip is occupied by a transparent fine membrane bordered by a dentated margin. The median part of the lip has a deep fissure on the interior side, the fissure widens anteriorly. The fissure divides both lobes of the pulp which has no remarkable features in this species. The most characteristic in our species is the presence of dentated formations situated on the interior surface of the lips in their posterior half. Here is a formation which is concave towards the oral lumen, its upper slightly concave edge, as well as its lateral edges, are corered with small denticles with their points directed anteriorly. This character distinguishes our parasite from other related forms.

The male reaches $150-180 \mathrm{~mm}$. in length, at a maximum width $0,085-1,36 \mathrm{~mm}$. The oesophagus is comparatively short, only $6-7 \mathrm{~mm}$. long. The caudal end is rounded, with a small knobbed tip. The aperture of the cloaca is situated at a distance of $0.255 \mathrm{~mm}$. from the cauclal end. In the region of the cloaca the width of the body of the parasite is $0,476 \mathrm{~mm}$., but at the level where the oesophagus passes into the intestine$0,765 \mathrm{~mm}$. Two equal, slightly curved spicula, of a simple structure without any alate diverticula, are 4,08 $\mathrm{mm}$. long. The posterior end of the spicula is rounded in the shape of a spoon.

The distribution of the papillae is very original: I counted 48 pairs of preanal papillae, of these 6 pairs are arranged laterally, and 42 pairs submedially. The lateral papillae have the character of concave formations with a rounded knobbed tip; the submedian papillae on the contrary, have the character of flat round bodies, not protruding above the surface of the cuticle, and surrounded by an oval ridge, on account of which each papilla resembles an eye surrounded by the contour of the eye-lids. The mutual arrangement of the papillae is exactly drawn in the figure 17 of the table III, to which I refer the reader.

F emale. By chance it happened that nearly all the females at my disposal were shorter than the males, the adult forms reaching $75-100 \mathrm{~mm}$. in length. The width of the body 
in the region of the anus was $0,68 \mathrm{~mm}$., in the niddle part of the body $-1,3-1,5 \mathrm{~mm}$. The anal aperture is situated at a distance of $0,39 \mathrm{~mm}$. from the candal end. The tail is rounded and provided with a small conical process, $0,034 \mathrm{~mm}$. long: The genital aperture is situated somewhat posteriorly to the middle of the body-length. The eggrs are round-oval, 0,085$0,09 \mathrm{~mm}$. in length and $0,068-0,072 \mathrm{~mm}$. in width. The egre shell in finely punctuated.

Until present only the common horse ascaris-Ascaris megalocephala Cloquet 1824-has been found in the intestine of the zebra.

\section{Gen. Trispiculascaris gen. nov.}

The investigation of the parasite Ascaris helicina Molin 1860 from the intestine of the crocodile led me to separate it from the genus Ascaris L. into a new genus named by me Trispiculascaris ge n. $110 \mathrm{v}$.

I consider the main peculiarity of this new genus to be the original structure of the caudal part of the body in the male, which is characterized by the following:-1) the presence of a gubernaculum usually not found in Ascaridae, 2) the presence of a limited number of preanal papillae (only 4 pairs), there usually being scores of them in Ascaridae, and 3 ) the presence of alate diverticula of the cuticle in the region of the caudal end of the male. Those characters, together with the structure of the oral organs (lips) and of the alimentary canal give our parasite quite a definite position in the sub-family Ascarinae Raill. et Hen r y 1912.

I propose the following diagnosis for this genus:

Small Ascaridae with rather large lips provided with auricular outgrowths on the sides; a dentated margin as well as intermediary lips are present. The oesophagus and intestine are simple, without blind diverticula. The caudal end of the male is strongly bent and provided with wide alae and very few preanal and postanal papillae arranged in one row on both sides of the body. 2 fine, thin spicula of equal size; guberna. culum present. The tail of the female is straight, conically pointed. The vulva is situated in the anterior half of the body. Parasitic in the alimentary tract of reptiles. Type and mean- 
while only species: Trispiculascaris helicina (Molin 1860) from the intestine of the crocodile.

\section{Trispiculascaris helicina (Molin 1860).}

The caudal end of the male provided with 4 pairs of preanal and 5 pairs of postanal papillae is quite correctly described and drawn in Drasche's work. However, the latter mentions nothing about the chitinous parts of the male genital apparatus-the spicula and the gubernaculum.

2 spicula of equal size, $1,36 \mathrm{~mm}$. long. They have the character of fine, rery thin, curved, rod-like formations the anterior end of which looks like a hilt and is $0,02 \mathrm{~mm}$. wide; after the hilt the spicules thicken slightly (width= $0,06 \mathrm{~mm}$.) and are accompanied by a tender transparent alate membrane which is lost in the posterior half of the spicula. Lastly, behind this dilatation the spicula narrow again, their width being only $0,014 \mathrm{~mm}$. The posterior part of the spicula terminates by a thin curvature.

The most interesting peculiarity of this species is the presence of a gubernaculum in the male-this organ, as it. is known, is not to be found in Ascaridae. It has the shape of an acute-angled triangle with the apex directed posteriorly; its anterior half is prorided with a furrow on its rentral surface which serves for the spicula to slide on it. Length of gubernaculum $=0,22 \mathrm{~mm}$.

\section{Genus Orneoascaris nov. gen.}

In the intestine of an amphibian (Bufo sp.) Prof. Dogiel and Sokolor found an Ascaris a detailed investigation of which leads to its separation into a new gemus named by me Orieoascaris n. g. The reason for that was the structure of the caudal end of the male, and particularly the character of the caudal papillae, spicula, and the presence of a wide caudal bursa, together with the rery complicated mosaic drawing of the cuticle on the rentral surface of the candal end.

Diagnosis:

A scaridae of middle size, the month opening of which is surrounded by 3 large lips provided with dentated margin. 
Intermediate lips are abseint. Alimentary tract simple, without coéca. The caudal end of the male is provided laterally with a wide alate bursa; 2 equal spicula of a very tender structure; gubernaculum absent. Preanal papillae are not numerous ( $\bar{r}$ pairs). They all sit on stalks, their free end having the character of a crown of a double-flower, as it consists of a whole complex of petal-shaped lobes. The postanal papillae are sedentary. The ventral surface of the caudal end of the male is marked both in Iongitudinal and in transverse directions with a series of furrows which form a fine mosaic network of stellate loops. This network partly passes to the anterior part of the bursa. The genital aperture of the female is in the anterior half of the body. Large oval eggs. Parasitic in the alimentary canal of Amphibia. Type and meanwhile only species: Orneoascaris chrysanthemoides n. g. n. sp. from the intestine of Bufo sp.

\section{Orneoascaris chrysanthemoides nova $s p$.}

Host: Bufo sp.

Occurence: intestine.

Body cylindrical, slightly narrowed at both extremities. Cuticle finely striated transversely. Cephalic end provided with three large lips of hexangular shape with two lateral furrows. The interior surface of the lip is characterized by a furrowed recess very sharply expressed. The pulp has a rounded anterior margin its right and left lobes adjoining each other in the region of the median line. The dentated margin is present, and follows the periphery of the lip on all its extent; some denticles are very large, on account of which it was possible to mark the number of all of them, and their relative dimensions. The denticles situated near the anterior angles of the lips are especially large. On the exterior surface of each lip are situated 2 large oval papillae. Width of dorsal lip $=0,374 \mathrm{~mm}$., its length $=0,221 \mathrm{~mm}$. The oesophagus is simple, without traces of any diverticula.

Male: 28-30 mm. long, 0,8 $\mathrm{mm}$.-maximum width. Length of oesophagus $=5,1 \mathrm{~mm}$. ( $=1 / 6$ part of body-length). Width of body immediately behind the lips reaches $0,34 \mathrm{~mm}$., in the region of the end of the oesophagus $=0,68 \mathrm{~mm}$., in the middle part of the body $=0,8 \mathrm{~mm}$., in the region of anus (together 
with the bursal alae)--0,85 $\mathrm{mm}$. The caudal end is provided at the sides with a slightly asymmetrical bursa, $0,5.5 \mathrm{~mm}$. in width. The bursa is finely striated in transverse direction, the stripes joining the mosaic network in the anterior part of the bursa, the netwrork passing unto the alae from the ventral surface of the body. The cuticle of the body in the region of the candal end is characterized by a very pretty structure consisting of a complex network of longitudinally and transversally winding grooves crossing each other at different angles; on account of all this the cuticle presents a beantiful drawing which seems to be composed of separate stellate alveoles arranged in the form of mosaic. Howerer, above this chaos of networks there dominate pretty regularly winding lines which are arranged in a transverse direction with regard to the body-length. This plexus attains its greatest development in the region, where the most anterior preanal papillae are situated, although on the median line there is a zone to which the aborementioned drawing does not extend. Towards the caudal end this original structure of the cuticle gradually becomes limited to the lateral edges of the body and disappears near the anal aperture; the latter is situated at a distance of $0,17 \mathrm{~mm}$. from the candal end.

There are 7 pairs of preanal papillae; they are all stalkshaped, the surface of the stalks being characterized by a structure similar to that of the lateral edges of the body. The free ends of the papillae are also of a very peculiar structure, having the form of a crown of a double-flower consisting of a whole complex of petal-shaped lobes arranged into more or less regular concentric layers. The first papillae (beginning from the cloaca) are organized most simply, and consist of $1-2$ concentric layers of petals; but towards the anterior end the character of the papillae gradually becomes more complicated attaining its greatest complexity at the 6 -th and 7 -th pairs, as at this level the reticular character on the ventral surface of the cuticle of the body passes, as I have mentioned above, to the surface of the alae, and, as a result, it presents the picture given in the figure.

There are 4 pairs of postanal papillae; they are somewhat asymmetrically arranged as on the right side the second papilla takes a lateral position, and on the left side-the first 
papilla has the same position. All the post-anal papillae are sessile, without stallis.

Two spicula of equal size; length of spicula=1,19 mun., at a width of the base $=0,02$ mm., width of middle part= 0,017 mm. Such tender, brittle and thin spicula are an exception in Ascaridae, most of which are characterized by strong chitinous parts of their genital apparatus.

Gubernaculum-absent.

Female: 48-õ $1 \mathrm{~mm}$. long, 1,2 mm. maximum width at the level of the genital aperture.

In the region of the posterior part of the oesophagus the width of the body reaches $1,19 \mathrm{~mm}$., at the level of the excretory opening- $0,6 \mathrm{~mm}$., near the anus $=0,54 \mathrm{~mm}$, behind the $\operatorname{lips}=0,5 \mathrm{~mm}$.

The oesophagus reaches $6,54 \mathrm{~mm}$. in length, the excretory opening is situated at a distance of $1,0 \mathrm{~mm}$. from the cephalic end, and the genital aperture-in the anterior half of the body at a distance of $17,5 \mathrm{~mm}$. from the head. The anal apertmre is nearly terminal. The caudal end is bluntly rounded. The egg's are oval, pretty large, 0,12 mm. long and $0,085 \mathrm{~mm}$. wide.

\section{Fam. Heterakidae Raill. et Henry 1914.}

In the material under investigation there belong to this family ' 2 forms which represent the following genera:

1) Subulura Molin 1860.

2) Strongyluris A. M ülle r 1894.

The latter genus is referred by prof. Railliet et Henry (in the paper of 1914 printed in the works of the IX Zoological International Congress in Monaco) to a subgenus of the genus Heterakis Duj. 1845, which I consider to be incorrect, inasmuch as all the representatives of Strongyluris are characterized by such typical characters that they may quite justly be taken for generic characters.

\section{Genus Subulura Molin 1860.}

In the collection there was only one species of this genus: Subulura suctoria (Molin 1860). 
This species, studied in detail by Drasche (1882) and recently separated from the allied species Subulura allodapa (Crepl. 185t)-(see Seurat's work, 1914), was found in a new host-Centropus superciliosus. Until the present this species has been described from Caprimulgus campestris, Caprimul. gus nacunda and Dicholophus maregrafi Illig., and recently from the domestic hen and from the guineafowl (according to Gendre's data ${ }^{1}$ ). However, it may be supposed that Gendre did not deal with Subulura suctoria Mol., but with Subulura allodapa (Crepl. 1854) which is found in the red partridge-a bird closely related to the hen and guineafowl. The only character by which $S$. allodapa differs from S. suctoria, namely the inequality of spicula, is not mentioned at all in the work of Gendre; therefore we may only make the supposition that Gendre dealt with S. allodapa, on account of the aflinity of the hosts of his parasites with the red partridgethe host of S. allodapa.

\section{Genus Strongyluris A. Müller 1894.}

In the material investigated there are two species, already described from Africa, belonging to this genus.

\section{Strongyluris brevicaudata A. Müller 1894.}

This species was taken from three hosts: Agama № 2, Agama № 11 and Agama № 13.

I consider it necessary to make some addition to the description of this parasite by Müller, Gendre, Railliet et Henry, as follows:

1) The oral organs of this species, as it is demonstrated by my figures 30 and 31 (tab. V.) consist of three lips of equal size; on the surface of eachofthem there protrude 2 tubercles. From the interior part of each lip a small chitinous spearshaped process is directed into the mouth-cavity with its point forwards.

2) The massive sucker of this species seen in profile is characterized by the presence of a special sac-shaped out-

1) Gendre. Notes d'Helminthologie africaine (3-me note). Extraits des Séances de la Soc. Linnéene de Bordeaux, 1909, p. LXXxi. 
growth which is in commection with the interior cavity of the sucker, as it is seen in fig. 32 .

3) The interior walls of the oesophagus posteriorly to the muscular suckers of the pharynx (about which Gendre mentions) are covered by chitinous formations which are characterized by a uniform transverse striation.

12. Strongyluris elegans Gendre 1909.

This species described by Gendre from Chamaeleo was found in the intestine of Chamaeleo No. 21.

The spicula of the male in this species reached $0,935 \mathrm{~mm}$. in length.

\section{Fam. Oxyuridae.}

In the collection we are treating there were representatives of the following genera of this family:

1. Oxyuris Rud. 1803 (sensu lato).

2. Oxysoma Railliet et Henry.

3. Isacis Lespes. 1856 .

\section{Genus Oxyuris Rudolphi 1803.}

In the present work I refer to the genus Oxyuris Rud. (sensu lato) 7 species belonging to the collection under treatment. Two of these forms are especially noteworthy. They were found in the intestine of one species of myriapods, Polydesmus. From the first aspect both parasites (females) seemed to be very near to each other differing only in the position of the vulva and the comparative size of the caudal process. However a closer examination of the buccal apparatus (for which purpose I had to use oil immersion [1/12], owing to the minute size of the head) proved clearly and definitely that these were not only representatives of different species, but even of distinct genera, their buccal apparatus being formed on quite different lines.

At present I did not consider it possible to establish the new genera for these parasites, as, unfortunately, I had no males at my disposal, and was obliged to refer them to genus Oxyuris Rud. (sensu lato). 
13. Oxyuris myriapodicola n. sp.

At my disposal there were only females taken from the intestine of Polydesmus sp.

The body was $2,48 \mathrm{~mm}$. long, at a maximum width $0,187 \mathrm{~mm}$. on the level of the genital aperture. In the region of the hinder portion of the oesophagus the body reached $0,153 \mathrm{~mm}$. in width, on the level of the anus--0,1 $\mathrm{mm}$.

The cuticle is quite transparent, annular. Anteriorly to the oesophageal bulb the body narrows, as well as posteriorly, to the point, where the midgut passes into the slitlike rectum. Posteriorly to the anal aperture begins the elastic, rather massive, smooth caudal process pointed on the apex and reaching $0,4 \mathrm{~mm}$. in length (about ${ }^{1} / 6$ of the entire body-length).

'The first ring of the body is modified into the buccal organ, being provided on its anterior edge with 6 small lobes which play the rôle of lips. The round month-opening leads into a sharply marked out oral capsule of cylindrical shape with a slightly expanded posterior portion. The chitinized lateral walls of the capsule show a high refraction of ligh when examined under the microscope. The bottom of the oral capsule extends to about the level of half the length of the second body ring which is longer than the succeeding rings. The oral capsule seems to be pressed into the muscular oesophagus which is considerably widel than the former. The entire length of the oesophagus together with its bulblike dilatation reaches $0,442 \mathrm{~mm}$., which makes about $1 / 5-1 / 6$ of the body-length. The width of the cylindrjcal part of the oesophagus is $0,03 t \mathrm{~mm}$., the diameter of the bulb-like dilatation $=0,068 \mathrm{~mm}$. (length) and $0,085 \mathrm{~mm}$. (width). The initial part of the intestine is swelled so that its width exceeds that of the bulb. The intestine terminates by a slitlike anus situated somewhat anteriorly from the base of the caudal process, at a distance of $0,5 \mathrm{~mm}$. from the apex of the tail.

The excretory aperture is situated on the level of the anterior part of the oesophageal bulb. The vulva opens nearly in the middle of the body-length, at a distance of 1,25 $\mathrm{mm}$. from the cephalic end (and 1,23 $\mathrm{mm}$. from the end of the tail). The oval eggs reach $0,06-0,068 \mathrm{~mm}$. in length at a width of $0,045 \mathrm{~mm}$. The vagina is directed forwards from the 
genital slit. The anterior linit of the orary does not leach the initial part of the intestine.

With its buccal apparatus the parasite characterized above resembles the species described by Leid y ${ }^{1}$ ) in 1850 under the name Thelastomm labiatum (also from the intestine of Polydesmus virginiensis) in which the „oral annulus is inflated, six lobed at the margin". However, in other characters these species differ from each other to such an extent (e. g. the caudal portion of the female in our species forms $1 / 6$ of the body-length, whilst in Thelastomum labiatum it is $1 / 2$ ) that the specific independence of each is doubtless. On the other hand, our parasite resembles Oxyuris pachyjuli $\mathrm{P}$ a $\mathrm{r}$ on a 1896') (from the intestine of Iulus communis) which is characterized by the similar position of the vulva and excretory aperture; the difference of Oxyuris pachyjuli from our species is in the buccal apparatus ("bocca trilobata"), the dimensions of the oesophagus, the tail as well as the size of eggs. Lastly, our species resembles Oxyuris longicaudata A. M e y e r ${ }^{3}$ ) 1896 to a certain degree (from the intestine of a Ceylon Julus sp.). However, this parasite is so superficially described, and N e y e r's work-which served him as dissertation for the doctor's degree-is supplied with such imperfect drawings that it is exceedingly difficult to form any accurate zoological characteristics of his parasite. Notwithstanding the nearly equal size of the eggs and the position of the vulva, Oxyuris longicaudata differs from our parasite both in the length of the entire body $(5,5-6,0 \mathrm{~mm}$.), and in the length of the tail $(1,0 \mathrm{~mm}$.$) , although the ratio of length of the tail to the length$ of the entire body (about 1:6) remains the same for both parasites. In describing the oral capsule of his parasite, A. Meyer mentions nothing about the 6-lobed labial formations peculiar to our species, which surround the mouth-opening from the exterior. And lastly, the intestine of oxyuris

1) L e i d y. Proceed. Academ. Philadelph. V. 1850. p. 101, 1851, p. 285 and 1856, p. 60, also in: Smithson. Contrib. V. 1853, p. 47. Tab. VlI. fig. 13.

2) Parou a. Di alcuni nematodi dei Diplopodi. Bolletino dei Musei di Zoologia e Anat. comp. della R. Università di Genova. 1896. № 44. p. 2. Tav. I. fig. $1-3$.

3) A. Me yer. Neue Nematoden unter den Parasiten ceylonischer Säugetiere und eine Oxyuris, eine neue Schmarotzerspecies in Julus (Ceylon). Inaug. Diss. Basel. 1896. p. 33-35. Fig. 17-19. 
longicandata, as seen in fig. 18 of $\mathrm{Me} \mathrm{ye} \mathrm{r's} \mathrm{work,} \mathrm{is} \mathrm{consi-}$ derably narrower than the dilatation of the oesophagus, whereas in our parasite the intestine is on the contrary much wider than the bulb. I consider the abovenamed data sulficient for establishing the specific independence of the parasite Oxyuris myriapolicola. It is, however, beyond doubt that the future investigator will have to unite the species 0 . Tongicaudata Meyer 1s96, Thelastomum labiatum Leidy 1850,.O. myriaporticola miln i and, probably. O. pachyjuli into one common genus, and place as a generic diagnosis both the structure of the mouth, and the organization of the genital organs of the male.

The absence of males prevents me from fulfilling this in the present paper.

14. Oxyuris leidyi nov. spec.

This parasite was found together with O. myriapodicola in the intestine of Polyctesmus sp.

Contrary to the buccal organs of O. myriapodicola which resemble those of Thelastomum labiatum Leidy 1850 so closely, although in other items of its structure differing sharply from O. myriapodicola,-our new parasite, O. leidyi n. sp., has quite a different structure of the mouth as compared with Thelastomum labiatum, being in the rest so similar to the latter, that for a long time I could not decide to separate it into an independent species.

Nales are unknown.

The females have a spindle-shaped body, provided with a very long, elastic, flagellated caudal process, the length of which is but slightly less than half the size of the entire body-length. The cuticle is deeply striated transversely producing the characteristic annulate aspect. The length of body of the female reaches $2,465 \mathrm{~mm}$. at a maximum width= $0,255 \mathrm{~mm}$. On the sides of the body are situated the alate dilatations of the cuticle which conmence on the level of the collar of the oesophagus (i. e. the point where the cylindrical portion of the oesophagus passes into the bulb) and extend to the base of the caudal process. The structure of the buccal organs of this parasite-for the study of which I was compelled to apply oil immersion-is so peculiar and interesting that I will describe it in fuller detail (see. fig. 38). 
In examining the anterior, narrowed end of the body we notice that its first two rings differ widely from the rest: the first ring is modified into special buccal organs-the lips; the second ring forms a swollen fillet, differing from the succeeding uniform rings both in its greater diameter, and greater length (the length of the 2-nd ring is equal to the length of the 4 succeeding taken together). The first ring consists of 3 equal lips between which are situated 3 small cuticular outgrowths which compose something like rudimentary intermediate lips (as in many Ascarids). Each lip is composed of 2 parts situated one above another in two stories: the posterior (lower) part has the form of a convex rectangle on the sides of which are situated 2 large papillae; the anterior part of the lip is considerably smaller than the posterior, and has a small groove in the region of its upper edge; on its exterior surface are situated a pair of small papillae, and on its interior surface directed into the buccal cavity is situated a small crest composed of minute chitinous denticles. Thus, each of the three lips of this parasite bears 4 papillae arranged in 2 stories. The abovenamed relations between the separate parts of lips are represented in fig. 38 and in the accompanying scheme (fig. 39) which shows the buccal organs of this parasite as seen from in front.

The mouth-opening passes intu the oesophagus the entire length of which reaches $0,425 \mathrm{~mm}$., the width of the cylindrical portion being $0,04 \mathrm{~mm}$. The posterior part of the oesophagus is modified into a spherical bulb, the diameter of which is $0,085-0,09 \mathrm{~mm}$. long. At the point where the cylindrical portion passes into the bulb, the former narrows so as to form a constriction. The bulb is provided with a chitinous masticating apparatus. The initial part of the intestine is very swollen; the anal aperture opens near the base of the tail, at a distance of $1,105 \mathrm{~mm}$. from the tip of the latter. The width of the body on the level of the anus is only $0,085 \mathrm{~mm}$. The excretory pore is situated on the level of the anterior edge of the oesophageal bulb. The genital aperture is replaced toward the anal aperture, being sitnated somewhat anteriorly to the latter. The oval eggs, comparatively few in number, are about $0,085 \mathrm{~mm}$. long, at a width $=$ $0,051 \mathrm{~mm}$. 


\section{Oxyuris praeputialis nova spec.}

This new species was found in the intestine of a representative of the family Bufonid a e (Bufo 스 10).

There were $n o$ males at my disposal. The body of the females examined is white, of a cylindrical form with a slightly attenuated anterior extremity; the posterior extremity is provicled with a small flagellated candal process. The cuticle is very linely striated transversely, this striation being visible only at high magnification. On the cephalic end the cuticle forms a fold which embraces the anterior portion of the parasite similarly to the praeputium. The cephalic extremity was in some specimens nucovered, whilst in the others it was covered on the sides by the praepntial fold ont of which only the anterior edge of the lips was to be seen. The mouth opening is surrounded by 3 elongated lips of equal size each of which is provided with 2 fairly large papillae. In the specimens the head of which was not covered with the praeputium the former protruded at a distance of $0,05 \mathrm{~mm}$. behind which the point of attachment of the praeputial fold ras marked in the form of a ring.

The length of the females examined varied between $3,0-4,5 \mathrm{~mm}$. The width of the body in the region of the oesophageal bulb reached $0,2-0,25 \mathrm{~mm}$, in the region of the genital aperture - 0,238 - 0,275 mm., on the level of the anus $=0,153-0,17 \mathrm{~mm}$. The entire length of the oesophagus= $0,51-0,55 \mathrm{~mm}$, the width of the cylindrical portion being $0,05-0,06 \mathrm{~mm}$., the diameter of the bulb-0,136-0,15 $\mathrm{mm}$. The latter is provided with a threevalved chitinous apparatus. On the level, where the cylindrical portion of the oesophagus passes into the bulb, or somewhat anteriorly, is situated the excretory pore. The intestine which is about as wide as the bulb, or a little wider, terminates by the anus at a distance of $0,37-0,4 \mathrm{~mm}$. from the caudal end. The posterior part of the body is provided with a flagellated pointed appendix, 0,28-0,32 $\mathrm{mm}$. long, and composing about $1 / 10^{-1 / 5}$ part of the entire length of the body.

The genital aperture is situated nearly in the middle of the body being slightly displaced forwards: thus in a female $4,5 \mathrm{~mm}$. long the genital aperture is situated at a distance of $2,20 \mathrm{~mm}$. from the cephalic end and $2,30 \mathrm{~mm}$. from the caudal. 
None of the females investigated contained any ripe eg'gs. The genital organs filled nearly the whole body of the parasite with their conrolutions beginning from a level somewhat behind the bulb and extending nearly to the base of the caudal appendix.

\section{Oxyuris megalocerca nova spec.}

This minute and elegant parasite was found in the coecum of lizard № 4 (Geckonidae).

In general characters this species resembles very much the species Oxyuris laevicauda Se ur at 1914¹), described last year (from the intestine of African reptiles Acanthodactylus blanci Doum., and Scincus officinalis), although differing from the latter in many small characters, and mainly in the presence of alae which originate at the cephalic end of the parasite and terminate on the level of the anus (in Oxyuris laevicauda the alae are situated only in the posterior third of the body).

The males of this new species reached $1,02-1,5 \mathrm{~mm}$. in length, at a maximum width of $0,136-0,2 \mathrm{~mm}$. The body consists of two distinct parts: a spindle-shaped body, and an extremely long, thin tail the length of which is in the ratio of 3:4 to the "body"-length. The cuticle is finely striated transversely, the distance between two striae being only $0,003 \mathrm{~mm}$. On the sides of the body are situated the wide wings which commence nearly exactly on the cephalic end and extend to the level of the anus. The oesophagus, 0,27-0,35 $\mathrm{mm}$. long, is provided in its posterior part with a bulb of a regular spherical form, 0,065-0,085 $\mathrm{mm}$. in diameter. In the centre of the bulb is situated the chitinous apparatus consisting of 3 valves with dentate edges. Posteriorly to the bulb the intestine begins. It is very wide in the anterior part which gra. dually narrows posteriorly terminating by the anal aperture at a distance of $0,46-0,51 \mathrm{~mm}$. from the tip of the candal process.

Anteriorly to the anus are situated one pair of preanal elongated papillae directed forwards, and arranged more ventrally than the two pairs of postanal papillae. Of the latter one pair lying nearer to the opening of the cloaca is directed backwards, the other pair which is further from the cloaca 
has its axis directed perpendicularly to the axis of the caudal process.

Thus, in the number of papillae (1 pair preanal, and 2 pairs postanal) our new species resembles Oxyuris laevicauda Sen rat 1914. The caudal process bears the character of an elastic flagellum widened at the base and gradually attenuating towards the apex. I did not succeed in finding any spiculum, notwithstanding the most careful examination; it is, probably, so fine that to the observer it becomes lost in the tissue of the surrounding organs. The excretory pore is situated at a distance of $0,187 \mathrm{~mm}$. from the cephalic end. The width of the body in the region of the anus reaches only $0,0 \pm \mathrm{mm}$.

The female of this species is much larger than the male its length being $4 \mathrm{~mm}$, and maximum width-0,34 $\mathrm{mm}$. The length of the entire oesophagus is about $0,6 \mathrm{~mm}$., the diameter of the $b u 1 b=0,17 \mathrm{~mm}$. The excretory pore is at a distance of $0,34 \mathrm{~mm}$. from the cephalic end. The caudal extremity is very elongated, leaching $1,054 \mathrm{~mm}$. The genital aperture is situated anteriorly to the middle of the body-length. The eggs are of a very elongated oval shape, the dimensions being $0,17 \mathrm{~mm}$. length, and $0,055 \mathrm{~mm}$. -width.

The mouth-opening of the parasite is round, without clearly expressed lips or formations analogons to them. There is likewise even no trace of anything similar to the oral capsule.

In comparing our parasite with the other species of Oxyuris, we are compelled to consider it as the nearest to the species Oxyuris laevicauda Seurat 1914 and partly to Oxyuris spinicanda Dujal in 1845 . There is no doubt that the future investigator of the fam. Ox y u r id a e will separate these three parasites into a new independent genus.

\section{Oxyuris spinicauda Dujardin 1845.}

18. 0xyuris annulata Linst. 1899.

To this species I refer the females taken from the hindgut of lizard $\lambda_{0} 6$ (from fam. Scincidae).

The body of the female, 5,44-5,5 mm. long, is of white colour, of cylindrical form with attenuating anterior extremity, and in a smaller degree posterior extremity. The cuticle is 
transversely striated forming a series of rings divided from each other by a fairly deep groove. The width of these rings reaches $0,04-0,07 \mathrm{~mm}$. The anterior ring is provided with 6 small papilliform lips. surrounding the month-opening. The latter leads into a very elongated and narrow oesophagus provided with a bulb in its posterior part. The entire length of the oesophagus reaches $1,7 \mathrm{~mm}$, which makes $1 / 3-1 / 2$ of the entire body-length. The width of the elongated part of the oesophagus reaches only $0,085 \mathrm{~mm}$. The bulb, 0,255 long and $0,3 \mathrm{~mm}$. wide, provided with a chitinous masticating apparatus protrudes with its posterior part into the cavity of the intestine, forming the so called "ventriculus". The intestine, which is of equal width throughout, terminates by the anus at a distance of $0,34 \mathrm{~mm}$. from the caudal end. The latter is provided with a small pointed appendix the length of which reaches $0,15 \mathrm{~mm}$. The width of the body varies in different parts: in the region of the end of oesophagus it is $0,65 \mathrm{~mm}$., in the region of the genital aperture0,75-0,8 mm., on the level of the anus-0,42 $\mathrm{mm}$.

The genital aperture is situated somewhat behind the mictdle of the body-length, at a distance of $2,9 \mathrm{~mm}$. from the cephalic end, dividing the anterior and posterior parts of the body in the ratio 19:17. The ripe eggs are found exclusively in the posterior half of the body, there being none anteriorly to the genital aperture. The form of the eggs is very peculiar: they are of a trilateral form with a lid on one of the poles. The sides of the shell are parallely striated, the surface of the shell is of a finely granulated character. The length of the eggs is $0,096-0,105 \mathrm{~mm}$. at a width of $0,06 \mathrm{~mm}$., and height-0,048 $\mathrm{mm}$.

Notwithstanding some disagreement which exists between the abovenamed measurements and those of Linstow, I still refer this parasite to the species Oxyuris annulata L i n st. 1899. The reason for this is the following: Linstow speaks of the cuticle being deeply striated transversely, the width of the rings being $0,079 \mathrm{~mm}$., of the presence of 6 minute papillae on the head, of a long oesophagus composing $1 / 4-1 / 5$ part of the entire body-length, of a short pointed tail, of the vagina opening in the posterior half of the body and dividing the latter in the ratio $13: 10$. The females of Linstow's specimens reached $5,57 \mathrm{~mm}$. in length and 
$0,71 \mathrm{~mm}$. in width. All these characters ar'e very similar to the description of my female specimens given above. And lastly, the affinity of the hosts of the parasites (Linstow's specimens were found in the lizard Stellio vulgaris La tr: in Egypt) as well as their geographical distribution givefurther support to the supposition of their zoologic identity. The, only striking difference is the dimension of the eggs which reach $0,132 \mathrm{~mm}$. in length, and $0,067 \mathrm{~mm}$. in width with Linstow, as compared with my measurements: 0,096$0,105 \mathrm{~mm}$. length, and $0,06 \mathrm{~mm}$. width. However, this difference is notsufficient to separate my parasite into a distinct species. Unfortmately, Linstow gave no drawing of the female of his species (fig. 51 of his work represents the candal end of the male); if he had-the resemblance between the two parasites would have been still moreobvious.

It is possible that the parasite Oxyuris anmulata Linst. 1899 is identical to the species described by Dujardin. under the name Oxyuris brevicaudata Duj. 1845 from the intestine of a lizard (Platydactylus fascicularis). Unfortmnately, Dujardin did not supply his description of the female, $6-9 \mathrm{~mm}$. long, and $0,7 \mathrm{~mm}$. wide, with a drawing.

His definition - „bouche ronde, nue"-may be explained by the imperfect methods of investigation at that time, which prevented $D$ ujardin from remarking the 6 papilliform lips. The only important fact that speaks against the identity of these species, is the position of the vulva in the species Oxyuris brevicaudata - ,au quart antérieur de la longueur", although it may be possible that Dujardin mistaked the excretory pore for the vulva, the former being also situated in the same part of the body.

\section{Oxyuris obvelata Zeder. 1803}

This species, which is new for Africa, was found in the intestine of a species of mice (Mammalia № 2) not yet defined.

\section{Genus 0xysomatium Railliet et Henry.}

The founder of the genus Oxysomatium-A. Schne ider made the mistake in 1866 of uniting into this genus the 
three Nematodes: Oxysoma brevicandata Zed. (from Rana temporavia), Oxysoma tentaculum Rud. (from Didelphis) and Oxysoma lepturum Rud. (from Testudo mydas) which are to be considered at present as representatives of three different families!

The chief species on which Sch ne i der fornded his generic diagnosis-Oxysoma brevicaudata Zed.--is the type of this genus, on account of which only such Nematodes must be referred to Oxysoma, which are united by common characters with the parasite Oxysoma brevicaudata.

There are but few of such Nematodes from the number described under the name Oxysoma; they are: Oxysoma contortum Linstow 1906 (from Bufo vulgaris) and Oxysoma perezi Gendre 1911 (from Chamaeleo gracilis Hall.). These parasites must be considered as the real representatives of the genus Oxysoma.

As concerns the other species-Oxysoma gracilis Linstow 1899 (from Francolinus sp.) came out to belong to the gemus Subulura Molin, as was shown by Railliet et Henry in 1914; Oxysoma falcatum Linst. 1903 (from the turtle-Nicoria trijuga), as well as Oxysoma tuberculatum Linstow 1903 (from Megalophrys montana Wag.) must also be separated out of the genus Oxysoma, on account of the peculiar structure of the spicula and caudal extremity of the male.

When looking through the descriptions of species of the gemms Nematoxys Schn. 1866, which is allied to Oxysoma, I came upon one form-Nematoxys unguiculatus L inst. 1906 (from Bufo viridis), which must absolutely be referred to the genus Oxysoma, being very closely related to the species Oxysoma contortum Linst. (from Bufo vulgaris). After reading the description of these two forms given by the same author in the same year, and even in the same work on adjoining pages (pp. 255 and 256), it is difficult to moderstand what induced the author to refer them to two different genera (Oxysoma and Nematoxys)? The only difference between these forms lies in the measurements of the different organs, though even these fluctuations in the size of the latter are found only in the tenth parts of a millimeter:

These facts serve as an eloquent illustration of how difficult it is to classify the representatives of those Nematodes, the generic diagnoses of which have not yet been re-exa- 
mined and corrected by modern authors, and determined exactly and definitely. The "correction" of such diagnoses, according to our modern views on the structure of Nematodes, presents one of the tasks of modern helminthology which requires immediate solution.

Thus, the following species must for certain be relerred to the genus Oxysoma Schneider 1866 the diagnosis of which is given below:-

1. Oxysoma brevicaudata Ze d. (type!)

2. Oxysoma contortum L in s tow 1906.

3. Oxysoma unguiculatum (Linst. 1906).

t. Oxysoma perezi Gendre 1911.

The fifth representative of this genus is a new species from the collection of lrof. Dogiel and sokolor:

\section{Oxysoma dogieli nova spec.}

Jiagnosis of the genus Oxysoma Schneider 1866.

Nematodes of the type of Meromyarii and Secernentes. Mouth surrounded by 3 small lips (dorsal and 2 lateroventral), sometimes undistinguishable. The oesophagus terminates by a bulb provided with a denticular apparatus. The tail of the male is pointed with $3-12$ pairs of preanal and $0-6$ pairs of postanal papillae. 2 spicula of equal size, simple, curved, much longer than the gubernaculum; the gubernaculum is small, canoe-shaped. The rulva is situated posteriorly from the middle of the body-length. The eggs contain a ready embryo curled into a ring. Parasitic in the alimentary tract of amphibia and reptiles.

Typical species: Oxysoma brevicaudata (Z e d. 1803).

\section{0xysoma dogieli nova spec.}

Host: a representative of fam. Bu fou idae.

Occurence: intestine.

Body white, tender, of cylindrical form, attenuated at both ends. Cuticle finely striated in transverse direction. Oral end provided with 3 small lips: one dorsal, and 2 rentrolateral. On each lip are arranged 2 small papillae forming a circle of 6 papillae: 2-lateral and 4-submedial, one pair of submedial papillae belonging to the dorsal lip, and the other pair composed of the adjoining papillae of the ventrolateral lips. The 
oesophagus consists of 3 parts: the anterior muscular--vestibulum, 0,055 mun. long in the male, the middle cylindrical elongated, and posterior-the bulb. The middle part of the oesophagus is characterized by chitinous interior walls, the chitinous parts being arranged in 6 longitudinal parallel bands which are finely striated in transverse direction. Only the most anterior part of the oesophagus-the restibulum-is devoid of these chitinous formations. The posterior part of the chitinous bands passes into the denticular apparatus of the second compartment of the intestine-the bulb. In the cavity of the bulb there can be distinguished 3 conchoidal formations of an irregular oval form, the surface of which is striated with parallel salient stripes, and the posterior edge of which is provided with small denticles. After the oesophagus follows the intestine the initial part of which is somewhat wider than the bulb. The excretory aperture which has $0,05 \mathrm{~mm}$. in diameter, and is situated on the level, where the cylindrical part of the oesophagus passes into the bulb, is of a very characteristic structure: it is surrounded by a crown of chitinous, highly refractive, rod-like formations, which protrude with their pointed ends outside (see fig. 52). This character, which had not yet been stated in any representative of the genus Oxysoma, deserves special attention, as it is owing to it that the affinity of the genus Oxysoma to the genus Atractis Duj. 1845 may be traced. Some lepresentatives of the latter, e. g. the species Atractis cruciata Linst. 1902 and Atractis fasciolata Ge n d re 1909, have excretory apertures characterized by the same structure.

The $\mathrm{m}$ a le reaches $5,1 \mathrm{~mm}$. in length, the width of the body being $0,2 \mathrm{~mm}$. in the region of the oesophageal bulb, and $-0,15 \mathrm{~mm}$. on the level of the anal aperture. The length of the entire oesophagus $=0,93 \mathrm{~mm}$, the oesophageal bulb reaches $0,136 \mathrm{~mm}$. in length at a width of $0,12 \mathrm{~mm}$. The nerve ring is at a distance of $0,51 \mathrm{~mm}$. from the anterior end of the body, the excretory aperture-at a distance of $0,57 \mathrm{~mm}$. from the head end. The caudal end becomes sharpened posteriorly to the cloaca, and terminates by a thin, pointed flagellum. There are 11 pairs of caudal papillae: 6 preanal pairs, and 5 postanal. The former are arranged in one row on each side of the body, and are divided from each other by the same distance; concerning the postanal papillae, the 5-th pair 
lies in one longitudinal row with the preanal, whereas the 4-th and 3-rd pairs are replaced towards the medial bodyline, the third pair to a greater extent, than the fourth. And lastly, the most posterior papillae-the 1-st and 2-nd pairsare sitnated at a considerable distance from the rest, being placed in the region of the attenuated part of the tail not far from the apex of the latter. There are 2 spicula of equal size, reaching $0,238 \mathrm{~mm}$. in length; they are bent ventrally, their width gradually decreasing from the slightly swollen base towards the posterior end. The spicula terminate by a thin round apex. The surface of the spiculum is transversely striated. Dorsally and posteriorly a small gubernaculum adjoins the spicula, the former being of a much smaller size than the spicula, as in all the species of the genus Oxysoma. It has a characteristic canoe-shape with two tubercles in the anterior part, and with a tuberculated dorsal surface. The length of the gubernaculum reaches $0,055 \mathrm{~mm}$. The opening of the cloaca is situated at a clistance of $0,275-0,3 \mathrm{~mm}$. from the caudal end.

The female. At my disposal there was only one specimen of an immature female $7,5 \mathrm{~mm}$. long, at a maximum width $=0,29 \mathrm{~mm}$. in the region of the genital aperture. The width of the body on the level of the oesophageal bulb reached $0,27 \mathrm{~mm}$., in the region of the anus=0,136 mm. The length of the oesophagus reached $1,2 \mathrm{~mm}$. The caudal end, mlike that of the male, was not of the pointed flagellum form of the latter, but had the form of a cone gradually attemating towards the apex. 'The anal aperture was situated at a distance of $0,17 \mathrm{~mm}$. from the caudal end. The opening of the vulva was in the posterior half of the body, at a distance of $4,2 \mathrm{~mm}$. from the cephalic end.

The specimen investigated was devoid of eggrs.

\section{Genus Isacis Lespes.}

Diagnosis:

Small Nematodes the month-opening of which is limited by 3 flat lips, provided at the edges and from inside by denticles. The oesophagus consists of two parts: the cylindrical part, widened in its posterior half, and the bulb with the chitinous apparatus. 'The width of the anterior part of the oesophagus is not smaller than that of the bulb. The caudal end 
is pointed. Two spicula of equal size. Gubernaculum is absent. Several pairs of preanal and postanal papillae present. Vulva near the middle of the body. Oviparous. Parasites of Invertebrates. Type: Isacis migrans L e spes.

\section{Isacis multipapillata nova spec.}

Host: Iulus sp.

Occurence: posterior part of intestine.

Body cylindrical, of white colour, smooth, without any traces of striation, slightly narrowing towards both ends; the anterior end bluntly rounded, the posterior-terminating by a small pointed appendage. Mouth-opening surrounded by 6 mndulating cuticular formations which constitute a shallow carity, at the bottom of which are arranged 3 chitinons irregular triangular plates surrounding the entrance to the oesophagus. The structure of these plates is very peculiar: each has an exterior edge, the base by which the plate is attached to the underlying tisues, and an interior convex edge turned towards the oral aperture. This latter edge is covered with several large, sharp chitinous denticles, and a whole series of minute ones, which give this organ the aspect of a comb. There are about 8 spear-shaped processes on each lip, some of them being bidentate. It is impossible to state exactly the number of minute denticles--there are some scores of them and they are arranged in several rows, as it is seen in the figure drawn from a preparation in which the edge of one lip was turned outwards, thus opening part of its interior surface, which is covered with several rows (3-4) of denticles. The oesophagus consists of 2 parts: a more elongated anterior and a posterior part (the bulb). The anterior part has the form of - a truncated cone with a wide base. The posterior part-the bulb-is cordiform with the apex directed to the intestine and inserted in the latter, forming a kind of ventriculus. Inside the bulb there is a chitinous denticular apparatus, composed of three plates the anterior part of which has a rough, striated surface. The intestine is somewhat wider than the apex of the bulb in its anterior portion, on account of which it envelopes part of the bulb in the form of a case.

The male. Entire length of male $3,57 \mathrm{~mm}$, at a maximum width-0,187 $\mathrm{mm}$. The length of the entire oesophagus 
is $0,4 \cdot 2 \mathrm{~mm}$., at a width of $0,14 \mathrm{~mm}$. The oesophageal bulb is $0,12 \mathrm{~mm}$. long, and nearly as wide as the anterior part. The caudal end is provided with a pointed appendix which reaches $0,05 \mathrm{~mm}$. in length. The length of the tail (from the posterior extremity of the body to the anus) $=0,153 \mathrm{~mm}$. Two bent spicula of equal size with a pointed free end. The length of spicula, when stretched out,--0,4-0,41 $\mathrm{mm} .9$ pairs of preanal papillae. They are arranged in the following way: the first and second papillae are close to each other; at some distance from them is situated a group composed of the 3-rd, 4-th and 5-th papillae, which are at the same distance from each other. Further are situated papillae 6, 7, 8 and 9, also at equal intervals from each other.

There are 6 pairs of postanal papillae; they are arranged symmetrically in the following way: 1, 3 and 5 papillate are displaced nearer to the medial body-line, whereas the 2,4 and 6 papillae lie more peripherally. Gubernaculum is absent.

'T'he female. General body-length- $5,1 \mathrm{~mm}$., at a maximum width $0,255 \mathrm{~mm}$. in the region of the uterus. The length of the whole oesophagus $-0,476 \mathrm{~mm}$. at a width$0,17 \mathrm{~mm}$. Oesophageal bulb $0,15 \mathrm{~mm}$. long, $0,17 \mathrm{~mm}$. wide. The caudal end is straight, provided, as in the male, by a pointed outgrowth. The anal aperture is situated at a distance of $0,18 \mathrm{~mm}$. from the caudal extremity. The width of the body in the region of the oesophageal bulb reaches $0,2-0,22 \mathrm{~mm}$., in the region of the genital aperture-0,24 $\mathrm{mm}$. and, lastly, in the region of the anus- $0,12 \mathrm{~mm}$. The genital aperture is in the form of a minute transverse slit limited by 2 lips. The genital aperture is situated in the posterior half of the body, at a distance of $2 \mathrm{~mm}$. from the caudal extremity. The genital glands occupy the middie third of the body without extending far both anteriorly, and posteriorly. The eggs are very large, of a round-oval shape, 0,102 mm. long; and $0,08 \mathrm{~mm}$. wide. The number of eggs is very small: in the female investigated there were only 22 eggs in different stages of cleavage.

\section{E. Fam. Physalopteridae Leiper 1911.}

In the collection there are 2 representatives of this family belonging to the genus Physaloptera R ud. 1819. 


\section{Genus Physaloptera Rud. 1819.}

There vere ' 2 species of this genus at my disposal. Notwithstanding the absence of males, I regard one species as Physaloptera abbreviata $\mathrm{Rud}$., and the other I consider to be a new representative of the genus Physaloptera to which I give the name Physaloptera britanica spec. nova.

\section{Physaloptera abbreviata Rud.}

In the material investigated I found immature females of this species from a lizard-Agama sp. The genus Agama presents a new host for this parasite.

The length of the parasite reached $21 \mathrm{~mm}$., at a maximum width of $0,765 \mathrm{~mm}$. in the region of the end of the oesophagus. On the level of the genital aperture the width of the body reached $0,76 \mathrm{~mm}$, near the papillae of the neck- $-0,357 \mathrm{~mm}$. and, lastly, on the level of the anus $-0,255 \mathrm{~mm}$.

The cylindrical oesophagus reached $3,4 \mathrm{~mm}$. in length. The conical, pointed and rounded tail-0,51 $\mathrm{mm}$. in length. The genital aperture is situated in the anterior half of the body, at a distance of $2,9 \mathrm{~mm}$. from the cephalic end. At a distance of $0,56 \mathrm{~mm}$. from the cephalic end are arranged the pointed neck papillae. On the interior edge of both lips are numerous pointed denticles; on each side of the middle, largest denticle is one small one, which differs from all the rest in its width (see fig. 64).

\section{Physaloptera britanica spec. nova.}

\section{Host: Agama sp.}

Occurence: intestine (posterior portion).

$\mathrm{M}$ a $l$ e s absent.

F e m a le. Body cylindrical, white, $42 \mathrm{~mm}$. long at a maximum width-0,6 mm. in the region of the posterior portion of the oesophagus. In the region of the genital aperture the width of the body reaches $0,51 \mathrm{~mm}$., in the region of the neck papillae- $0,425 \mathrm{~mm}$, on the level of the anus$0,3 \mathrm{~mm}$. The caudal end is conically pointed, rounded, $0,46 \mathrm{~mm}$. long. The cylindrical oesophagus reaches $5,44 \mathrm{~mm}$. in length. 
At a distance of $0,6 \mathrm{~mm}$. from the cephalic end are situated the neck papillae. On both sides of the body, beginning from the cephalic end, are situated alae which narrow towards the posterior end.

The genital aperture is in the anterior half of the body, at a distance of $4,25 \mathrm{~mm}$. from the cephalic end. The specimens investigated were not yet mature, and contained no eggs.

The most intelesting features of this parasite are its head and the armament of its buccal organs. Like in all species of Physaloptera in our parasite there are also present '2 large lips with a large medial denticle on each. However, on both sides of this denticle in each lip there are a whole series of smaller denticles arranged on its interior surface. These denticles differ greatly from those of the species Physcloptera abbreviata $R u d$. in their form, mode of distribution, size and number. On each lip of our species, laterally to the main medial denticle, are arranged 10-11 smaller pointed denticles on each side; concerning their form and size, all of them are of a triangular form, and situated so, that near the largest, central denticle there sit 4 denticles of conside. rably smaller size, these are followed by 2 larger denticles; the most laterally situated denticles heing the smallest.

I sncceeded in making a preparation in which the labial apparatus could be viewed from above (see fig. 68). It revealed the following interesting picture: in the centre of the preparation was the opening of the month of the parasite lined on both sides by zigzags of the abovenamed denticles.

On the sides of each lip are arranged 2 large papillae of pecinliar structure which, probably, allows them to become shorter or longer by contracting, after the principle of a telescope.

The peculiar structure and arrangement of the denticles on the lips of this parasite make it possible to distinguish Physaloptera britanica sp. n. from other representatives of the same genus.

\section{F. Fam. Filariidae Claus 1885}

In the collection investigated there were only 2 species of Filariidae, belonging to the genus Diplotriaena Raill. et Henry 1909. 


\section{Genus Diplotriaena Raill. et Henry 1909.}

\section{Diplotriaena sokolowi spec. nova.}

Host: blue martin (Halcyon senegaloides A. S m it h).

Occurence: ventral cavity.

Description of the species:

Parasite with long, filiform, milk-white body, the cephalic and caudal extremities of which are slightly narrowed and uniformly rounded. No traces of longitudinal and transverse striation of the cuticle are noticeable. The cephalic end has neither lips, nor papillae. The circular mouth-opening leads into an elongated, cylindrical oesophagus, to the upper part of which from the sides are attached 2 chitinous tridentate formations characteristic for the genus Diplotricena. Each of them consists of a manubrium situated in the anterior part of the trident, and 3 elongated cylindrical branches directed backwards. The nerve-ring (in the female) is situated at a distance of $0,3 \mathrm{~mm}$. from the cephalic end.

$\mathrm{M}$ a le: $27 \mathrm{~mm}$. long.

The oesophagus reaches $3,82 \mathrm{~mm}$. in length, the width at the base being $0,085 \mathrm{~mm}$. The initial part of the intestine is rather wide, reaching $0,37-0,4 \mathrm{~mm}$. 2 chitinous tridents arranged on both sides of the upper part of the oesophagus are adjacent by the anterior edge of their manubrium to the interior layer of the cephalic part of the cuticle (unlike some other species of Diplotriaena in which the trident is replaced from the cephalic part of the parasite on a comparatively great distance, as e. g. in Diplotriaena spermospizae (Linst. 1879)). The length of the trident is $0,17 \mathrm{~mm}$., length of manubrium separately reaches $0,05 \mathrm{~mm}$. The separate branches of the trident are of unequal size: in the male specimen investigated by me the lateral branch of the left trident was longer than the other two branches whilst in the right trident both lateral branches were longer than the middle one.

The posterior part of the body of the male is somewhat blunt and rounded. From the number of caudal papillae, the preanal ones are absent; there are 2 pairs of postanal papillae arranged symmetrically near the very caudal extremity and lying in a transverse direction with respect to the body-axis: one pair submedially, and the other-laterally.

There are 2 spicula of unequal size and different form. 
The large spiculum reaching $0,714 \mathrm{~mm}$. in length, and $0,037-$ $0,04 \mathrm{~mm}$. in width at the base, is of an elongated form, and bent ventrally in the shape of a sabre. The structure of this spicnlum is very peculiar: it seems to consist of 2 parts, the manubrium and the sabre-shaped part.

The manubrimm, composing $1 / 3$ part of the length of the whole spiculum, has a basal anterior end in the form of a rough tubercle which serves for the attachement of the retractor muscles. The body of the manubrium is cylindrical, flattened on the sides, and bears a characteristic sculpture on its surface which is uniformly striated in a transverse direction to the spiculum. On both edges of the body of the manubrium these parallel striae form a peculiar denticulated festoon, which is exactly represented in our drawing (fig: 72 and 73$)$.

In its posterior portion the manubrium is split into two branches the continuation of which forms the posterior sabreshaped portion of the spiculum. One of these branches is somewhat shorter than the other. Both these branches are united by a special thin membrane which covers the free posterior end of the spiculum in the form of a case. Owing to the abovenamed branches being more convex than the membrane connecting them, the latter forms a kind of channel which apparently serves to allow the sperm to flow into the female genital apparatus.

The small spiculum which forms a spiral, reaches $0,442 \mathrm{~mm}$. in length, and $0,05 \mathrm{~mm}$. in width at the basal swelling. This spiculum consists of a basal chitinous body bent spirally, and accompanied on all its course by a thin memtrane.

The mutual arrangement of the spicula is also peculiar: the basal portion of the small spiculum is situated to the right from the large one; further, in the middle of its length, the small spiculum passes on the dorsal part of the large one to the left side, where it remains adjacent to the left side of the large spiculum with its free posterior extremity. Its position on the right and left side of the large spiculum at the same time is due to the spiral winding of its body.

$\mathrm{The}$ fe $\mathrm{male}$ leaches $36 \mathrm{~mm}$. in length at a maximum width-0,7 $\mathrm{mm}$. in the region of the posterior part of the oesophagus. The width of the body in the region of the ge- 
nital aperture reaches $0,34 \mathrm{~mm}$., in the region of the anus$0,17 \mathrm{~mm}$. The oesophagus is cylindrical, withont any bulb, $5,1 \mathrm{~mm}$. long, and $0,09 \mathrm{~mm}$. wide. The chitinous trident near the initial part of the oesophagus reaches $0,19-0,2 \mathrm{~mm}$. in length, the manubrium being $=0,05 \mathrm{~mm}$. The caudal extremity is rounded, the anal aperture lies at a distance of $0,065 \mathrm{~mm}$. from the candal end. As concelns the genital aperture, it is situated in the anterior part of the body, at a distance of $0,51-0,5 \pm \mathrm{mm}$. from the cephalic end. The terminal portion of the vagina has the character of a muscular formation reaching $0,17 \mathrm{~mm}$. in width. The genital glands extend to the level of the opening of vulva in the anterior part of the body, whereas in the posterior part the spirally twisted glands are at a distance of $0,55 \mathrm{~mm}$. from the caudal extremity. The eggs reach $0,055 \mathrm{~mm}$. in length, and $0,037 \mathrm{~mm}$. in width, and contain developed embryos twisted spirally, or into a ring.

\section{Diplotriaena ozouxi Raill. et Henry 1909.}

This species was described only once till the present by Railliet et Henry from the ventral cavity of Faudias madagascariensis ( $\mathrm{Br}$ is so $\mathrm{n}$ )-a bird of the fam. Ploce i d a e. In the collection investigated there were 2 females from a bird not yet determined-入i 7 (from fam. Plocei d a e).

\section{G. Fam. Angiostomidae.}

From this family there was only one species representing the genus Angiostomum D u j. 1845 in the material investigated.

\section{Genus Angiostomum Dujardin 1845.}

Out of the 9 species described until present, 1 species is described from birds ${ }^{1}$ ), 4 species from reptiles and 4 species

1) Linst o w. Helmintholog. Untersuchungen; Arch. für Naturgesch. 1880. lg. 46, p. 46-47, Fig. 11: Angiostomum sanguinolenta 11. sp. from the thoracal and ventral carities of Strix flammea.

This species, however, does not seem to belong to this genus! 
from amphibia. In the collection of Prof. Dogiel there was a new, tenth reptesentative of this genus from the lungs of a chanaeleo, named by me Angiostomum chamcleonis n. sp.

Until the present no species of Angiostomum had been discorered in Africa.

\section{Angiostomum chamaeleonis nova $s p$.}

Host: lizard No 21 from the fam. Chamaeleontidae. Occurence: lungs.

Description of species: length of body in the hermaphrodite generation reaches $24 \mathrm{~mm}$. at a maximum width $=1,0 \mathrm{~mm}$.

Body cylindrical, twisted into a ring, narrowing towards both extremities; colour of body-whitish with the sharply marked brownish-black intestine. On both sides of the body are sitnated alate dilatations of the cuticle, widest (about 0,068 $\mathrm{mm}$.) in the region of the cephalic end, gradually narrowing in the middle portion of the body and again widening near the tail. The mouth-opening is circular, without any traces of lips, or any analogous appendages, and leads into a small oral capsule reaching $0,02 \mathrm{~mm}$. in length at a width of $0,03+\mathrm{mm}$, after which follows the muscular oesophagus, 1,225 $\mathrm{mm}$. long. The latter is of cylindrical form, gradually passing into a swelling which is not divided from the rest of the oesophagus by any constriction. The width of the cylindrical part of the oesophagus is $0,1 \mathrm{~mm}$., of the base of the swelling-0,187 $\mathrm{mm}$. The anal aperture is situated at a distance of $0,34 \mathrm{~mm}$, from the candal extremity. 'The latter is bent at an obtuse angle to the long axis of the bocly, and has the form of a conical outgrowth rounded at the apex, and surrounded by the alate cuticular dilatation. The axis of the candal process is nearly perpendicular to the body-axis (see fig. 76). In its posterior portion the intestine narrows, and bears the aspect of a narrow slit-like aperture, on the sides of which are arranged the anal glands. The genital aperture is placed somewhat posteriorly to the middle of the body-length, as in most species of Angiostomum. The oval eggs which fill the body of the hermaphrodite are $0,136 \mathrm{~mm}$. long; and 0,076 mm. wide, and contain dereloped embryos. The width of the body varies in the different parts: thus, in the region of the end of the oesophagus it reaches $0,425 \mathrm{~mm}$, 
in the region of the genital aperture-0,9\$6 $\mathrm{mm}$., on the le. vel of the anus $0,17 \mathrm{~mm}$.

Besides the mature forms of parasitic Nematodes described above, there were several larvae in the material taken by prof. Dogiel and Sokolor belonging to the provisional genusAgamospirura Raill., Henry et Sisoff 1912.

\section{Genus Agamospirura Raill. Henry et Sisoff 1912.}

1) From a fish of fam. Cyprinidae (freely in the intestine).

2) From a fish of fam. Siluridae (fish No. 8)-in cysts.

3) From bird No. 15 (Larus sp.)-in cysts on the walls of the intestine.

\section{Supplement.}

Amongst the collections of the Museum of the Imp. Academy of Sciences at Petrograd there is a test-tube with Nematodes from the stomach of 2 rhinoceros killed on the 26 - th and 2s-th of January 1912 by Svatosh on the bank of river Tana (Kiluluma).

The investigation of the specimens proved that they were the same parasites which had been described in 1907 by Linstow under the name of Deletrocephalus stylosus n. sp. from Rhinoceros africanus out of German East Africa.

However, a detailed study of these parasites in connection with a perusal of the hiterature on the genus Detetrocephalus Dies. 1861 showed quite clearly and definitely that Deletrocephalus stylosus Lin stow 1907 from rhinoceros ought not to be referred, as it was erroneosly done by Linstow, to the genus Deletrocephalus Dies., as it has absolutely no common generic characters with the type of this genus-Deletrocephalus dimidiatus Dies. The genus Deletrocephalus is a typical representative of the birds' Strongylidae, containing the only species $D$. dimidiatus Dies. from the intestine of Rhea americana, described both by Diesing, and recently by Schneider. The parasite which stands in the literature under the name Deletrocephalus stylosus Linst. 1907, must without doubt be regarded as a type belonging to a special new genus which I propose to name Kiluluma n. gen. (name of the locality where the parasite was discovered). 
In the literature there is a description of a nematode $D e$ Tetrocephalus brachylaimus Linst. 1901 from the large intestine of Heterohyrax mossambica Ptrs which must, probably, also be referred to my new genus Kilutuma, and separated from the genus Deletrocephalus: the facts speaking in favour of this are both the brief description by Linstow, and the drawing attached to his work, representing the caudal bursa of the male, the arrangement of the ribs in which corresponds in the main features to that in Kilutuma stylosa (Linsto W 1907).

\section{Kiluluma stylosa (Linstow 1907).}

Host: Fhinoceros africanus.

Occurence: stomach.

Geographical distribution: tropical Africa.

Description of species:

Body cylindrical, of a yellowish brown colour, attenuating towards both ends. Cuticle transversely striated. The cephalic extremity is very peculiarly composed of a whole complex of organs which may be considered under the category of a series of lips: exterior and interior. There are 4 exterior (peripheral) lips: 2 dorsal and 2 ventral. Each of these lips bears a peculiar papilla directed forwards and consisting of a thickened knobbed base on which a thinner process with a rounded tip is fixed. Interiorly to the 4 exterior lips are situated 6 interior ones: 2 dorsal, 2 rentral and 2 lateral. Out of this number of interior lips the lateral ones bear no appendages, whereas on each of the dorsal and rentral lips is situated one filiform formation with a pointed anterior apex (see the medially arranged papillae in fig. 78 and text-figure). The abovementioned structure of the buccal parts in this parasite was left without attention by Linstow; in his work the author only mentions about the presence of "4 club-shaped papillae, interiorly to which are situated 4 pointed formations sitting on special rounded processes". The mouth passes into the short muscular oesophagus, swollen in the shape of a club in its hinder part. The length of the oesophag'us in the male $=0,578 \mathrm{~mm}$., at a width $=0,238 \mathrm{~mm}$., in the female $=0,595 \mathrm{~mm}$., and $0,255 \mathrm{~mm}$. width. On the sides of the body both of the male and female run wide alae gradually narrowing towards the 
caudal extremity. At some distance from the cephalic extremity (in the male at a distance of $0,85 \mathrm{~mm}$. , in the female$0,952 \mathrm{~mm}$.) are situated very peculiar neck papillae composed of a basal portion, which has the form of a cuff, from the middle of which projects a flagellate outgrowth pointed at the tip. The length of this flagellate outgrowth reaches $0,051 \mathrm{~mm}$. (in the male) and $0,068 \mathrm{~mm}$. (in the female).

The male reaches $19,0 \mathrm{~mm}$. in length, at a width $=0,935 \mathrm{~mm}$. in middle portion of the body. In the region of the posterior end of the oesophagus the width of the body reaches $0,52 \mathrm{~mm}$., in the region of the cloaca $=0,595 \mathrm{~mm}$. The length of the two equal spicula is $2,72 \mathrm{~mm}$, the width of the base being $0,119 \mathrm{~mm}$. The form of the spicula is very peculiar: the central portion of the spicula bears on either side transversely striated alae, whilst the posterior portion of the spicula is spirally coiled. The posterior end of the spicula is spade-shaped, the lateral alae being arranged on them asymetrically, as it is seen in fig. 82. Gubernaculum is absent. Cloaca is situated at a distance of $0,32 \mathrm{~mm}$. from the posterior end of the body.

The caudal extremity of the male is provided with a bursa composed of 3 lobes and bearing a complex of peculiarly arranged ribs, the exact aspect of which is given by me in fig. 80 made with the help of Abbé's camera lucida. The lateral lobes of the bursa are divided from the elongated middle one by a small groove. The costae posteriores are composed of a median trunk bifurcated at the end, to the anterior part of which are adjacent on the sides 2 shorter ribs (one on each side). Each of the lateral lobes is supported by 7 ribs grouped into 4 parts: costa posterior externa is single, three costae mediae commence by a common trunk, costae anteriores are double, and lastly the 4-th group consists of the single costa anterior externa. The nerve-ring in the male is situated at a distance of $0,2 \mathrm{~mm}$. from the cephalic end.

The female: $21,0 \mathrm{~mm}$. long, at a maximum width $=$ $1,12 \mathrm{~mm}$. in the middle portion of the body. In the region of the posterior portion of the oesophagus the width of the body reaches $0,612 \mathrm{~mm}$., in the region of the nerve-ring = $0,476 \mathrm{~mm}$., on the level of the excretory pore $=0,68 \mathrm{~mm}$, on the level of the genital aperture $=0,51 \mathrm{~mm}$., in the region of the anus $=0,37 \mathrm{~mm}$. 
The nerve-ring is situated at a distance of $0,22 \mathrm{~mm}$. from the ceplalic extremity; the excretory pore is at a distance of $0,88 \mathrm{~mm}$. from the head; the diameter of the efferent aperture of the excretory system is $0,085 \mathrm{~mm}$. The caudal portion is pointed, the posterior end being rounded. The anus is situated at a distance of $0,374 \mathrm{~mm}$. from the caudal end. The genital aperture lies at a distance of $0,52 \mathrm{~mm}$. from the posterior end of the body. The ragina, which is very muscular, reaches $0,187 \mathrm{~mm}$. in width. The oval eggrs are $0,102 \mathrm{~mm}$. long, and $0,055 \mathrm{~mm}$. wide.

Diagnosis of the genus Kiluluma: Strongylidae of middle size, the mouth-opening of which is bordered by 4 peripheral and 6 interior lips, the former bearing club-shaped swelled papillae, the interior lips being set with 4 needle-pointed papillae. The oesophagits is swelled in the posterior portion in the shape of a club. The neck papillae have the form of a flagellate outgrowth. 2 equal spicula spirally coiled in the posterior portion. Bursa of the male 3-lobed; costae posteriores consist of a median trunk bifurcated at the end, to the base of which are attached ? short ribs, one on each side. Each of the lateral lobes is supported by 7 ribs, arranged into 4 distinct groups: 1) costa posterior externa, 2) 3 costae mediae, 3) 2 costae anteriores, and 4) 1 costa anterior externa. The female genital aperture is near the anus. On the sides of the body are situaled cuticular alate outgrowths. Parasites in the alimentary organs of Mammalia. Type: Kiluluma stylosa (Linstow 1907) from the stomach of rhynoceros. The second probable species-Kiluluma brachylaima (Linst. 1901) from the large intestine of Heterohyrax mossambica P trs.

\section{Explanation of Figures.}

T A B L E I.

Fig. 1. Lanteriella lateriporus n. g. n. sp.

Fig. 2. Ganeo glottoides Klein 1905 var. africana nov. var.

Fig. 3. Mesocoelium soliolowi n. sp.

Fig. 4. Prosthogonimus dogieli n. sp.

T A B L E II.

Fig. 1. Amphibiophilus acanthocirratus n. g. n. sp. General view of $\delta^{*}$ and $q$ in copula (low magnification). 
Fig. 2. Cephalic extremity of the same species.

Fig. 3. Candal extremity of $\delta^{\pi}$ of the same species with bursa, 2 spicula and gubernaculum.

Fig. 4. Posteriol cnd of spicula of the same species with bent hooks.

Fig. 5. Candal extremity of female with anus.

Fig. 6. Diaphanocephahes costatus (R u (1. 1819). General view of $\sigma$ and ㅇ in copula (nagnif. $\times 6$ ).

Fig. 7 . Ceplualic extremity of $\sigma^{\pi}$ of the same species.

Fig. 8. Caudal bursa of lliale of the same species.

Fig. 9. General view of $\delta^{\pi}$ of the same species.

Fig. 10. Spicula of the same species with spipally twisted ends.

Fig. 11. Canoe-shaped guberuaculum of the same species.

\section{T A B L E III.}

Fig. 12. Ascaris euxina Linst. 1903. Cephalic extremity.

Fig. 13. Tail of $\delta$ of same species.

Fig. 14. Tail of o of same species.

Fig. 15. Ascaris zebrae n. sp. $\delta$ and $q$ in natur. size.

Fig. 16. Dorsal lip of same species. pillae.

Fig. 17. Tail of $\delta$ of same species with 2 spicula and a series of pa-

Fig. 18. Portion of cuticle of the caudal extremity of $\sigma^{-7}$ with a lateral and several submedial papillae.

\section{T A B L E IV.}

Fig. 19. Trispiculascaris helicina (M ol. 1860). Dorsal lip).

Fig. 20. Tail of $\delta$ with papillae, spiculae and gubernaculum.

Fig. 21. Tail of 우 with anus.

Fig. 22. Orneoascaris chrysanthemoides n. g. n. sp. o and 우 in natul'. size.

Fig. 23. View of dorsal lip from the exterior.

Fig. 24. Ticw of dorsal lip from the interior.

Fig. 25. Caudal extremity of male with papillae, spicula and mosaic drawing on the surface of the cuticle.

Fig. 26. Part of the cuticle of the caudal extermity of the male with the free end of the anterior preanal papilla, which has the aspect of a double-flower.

\section{T A E E V.}

Fig. 27. Subulura suctoria Mo li n 1860. Cephalic extremity with initial part of the oesophagus $\left(\sigma^{\pi}\right)$.

Fig. 28. Oesophagus of same species with bulb. On the sides of the body there are alae $\left(\sigma^{\circ}\right)$.

Fig. 29. Tail of $\delta^{\star}$ with papillae, sucker, spicula and gubernaculum.

Fig. 30. Strongyluris brevicaudata Miill. 1894. Cephalic extremity of the parasite. View from above. 
Fig. 31. Cephalic extremity. View from the side.

Fig. 32. Suclier on the tail of the male. Detail.

Fig. 33. Bursa of male. Lateral riew.

Fig. 34. Part of pharynx with muscular papillae, and the beginning of the oesophagus with chitinous plates.

\section{T A B L E VI.}

Fig. 35. Strongyluris elegans Gendre 1909. Cephalic extremity of the parasite with pharynx, oesophagus, bulb, and beginning of the intestine.

Fig. 36. Caudal bursa of male with papillae, sucker and characteristic spicula.

Fig. 37. Oxyuris leidyi n. sp. General view of female.

Fig. 38. Anterior end of the head of female of this species with 3 lips and rudimentary intermediate lips.

Fig. 39. Scheme of distribution of lips in the same species.

Fig. 40. Oxyuris myriapodicola n. sp. General view of female.

Fig. 41. Cephalic extremity of the parasite with the oral capsule.

Fig. 42. Oxyuris praepulialis n. sp. General view of female. fold.

Fig. 43. Cephalic extremity of the parasite covered by the cuticular

Fig. 4t. Uncovered cephalic extremity of the parasite.

\section{T A B L'E VII.}

Fig. 45. Oxyuris megatocerca n. sp.

Fig. 46. Caudal extremity of male.

Fig. 47. Oxyuris annulata L in st. 1899. General view of female.

Fig. 49. Cephalic extremity of female with 6 papilliform lips.

Fig. 49. An egg of this species.

Fig. 50. Idem.

Fig. 51. Arrangement of the interior lips in this species.

Fig. 52. Oxysoma dogieli n. sp. Cephalic extremity of the male. excretory aperture.

Fig. 53. Caudal extremity of the male of the same species.

Fig. 54. Idem. Side riew.

Fig. 55. Caudal extremity of female of the same species.

Fig. 56. Excretory pore of the same species.

\section{T A B L E Vill.}

Fig. 57. Isacis multipapillata n. sp. General view of male.

Fig. 58. General view of female of the same parasite.

Fig. 59. Lips of the same parasite; view from the anterior surface.

Fig. 60. Anterior portion of body in the male.

Fig. 61. Caudal extremity of the male.

Fig. 62. Idem. Side view.

Fig. 63. Physaioptera abbreviata $\mathrm{R} u \mathrm{~d}$. Anterior portion of body. 
Fig. 64. Detail of cephalic extremity.

Fig. 65. Caudal extremity of female.

\section{T A B L E IX.}

Fig. 66. Physaloptera britanica n. sp. Anterior portion of body.

Fig. 67. Cephalic extremity of same species.

Fig. 68. View of lips of the parasite from anterior surface.

Fig. 69. Tail of female.

Fig. 70. Diplotriaena sokolowi n. sp. Cephalic extremity of female.

Fig. 71. Caudal extremity of female.

Fig. 72. Caudal extremity of male from ventral surface.

Fig. 73. Caudal extremity of male. Side view.

Fig. 7t. Chitinous trident of male of the same species. parasite.

Fig. 75. Angiostomum chamaeleonis n. sp. Cephalic extremity of the

Fig. 76. Caudal extremity of the parasite.

\section{T A B L E X.}

Fig. 77. Kululuma stylosa (L in st. 1907). Cephalic extremity of male with oesophagus, lateral alae, neck papillae and excretory pore. On the right is the excretory pore highly magnified in the form of a knobbed formation radially striated.

Fig. 78. Cephalic end of the parasite with the lips and papillae.

Fig. 79. Caudal extremity of female with genital (anterior) and anal (posterior) apertures.

Fig. 80. Candal bursa of male with lobes and ribs.

Fig. 81. Spiculum of male with spiral posterior end.

Fig. 82. Details of posteriol end of spiculum with asymmetrically arranged alae. 



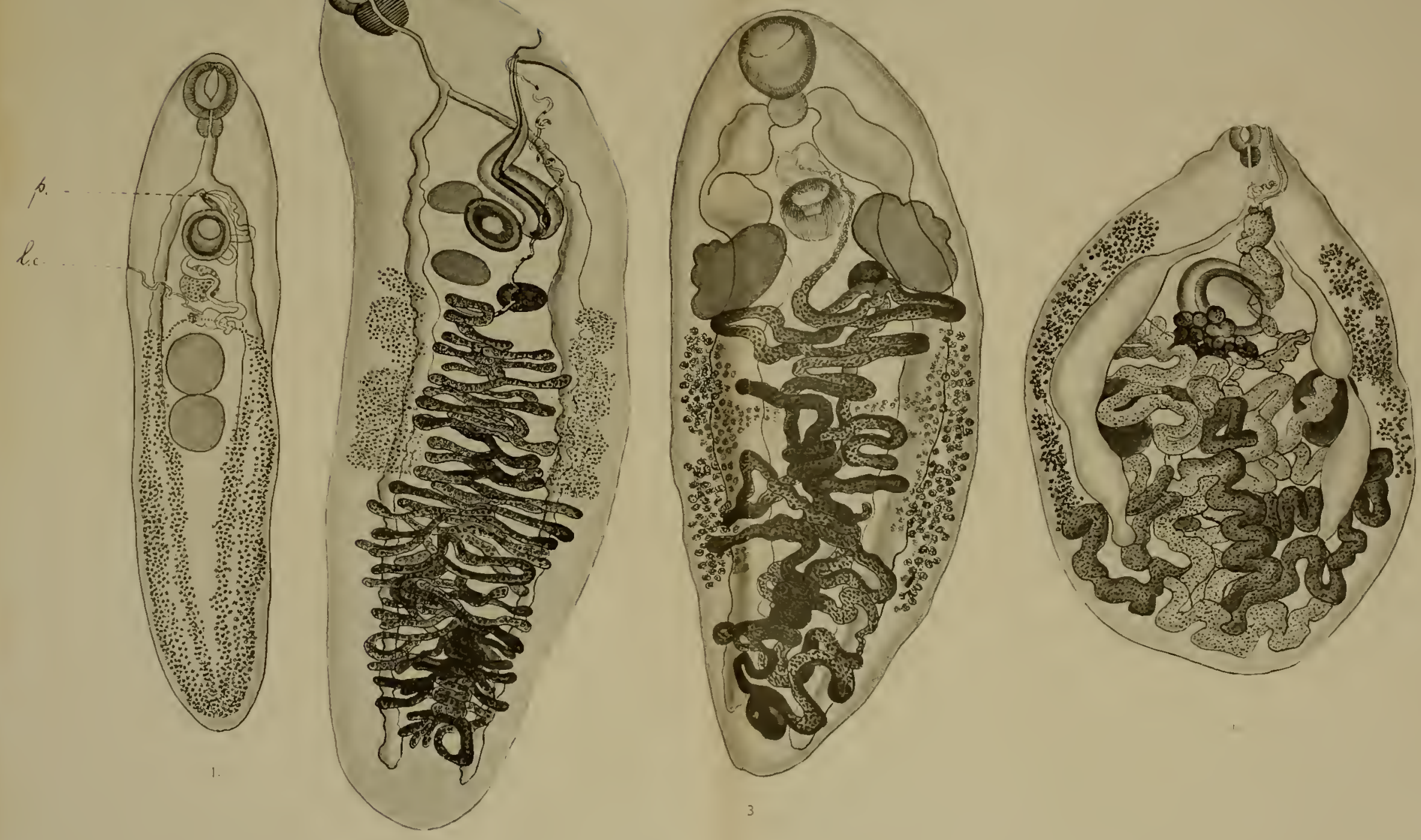





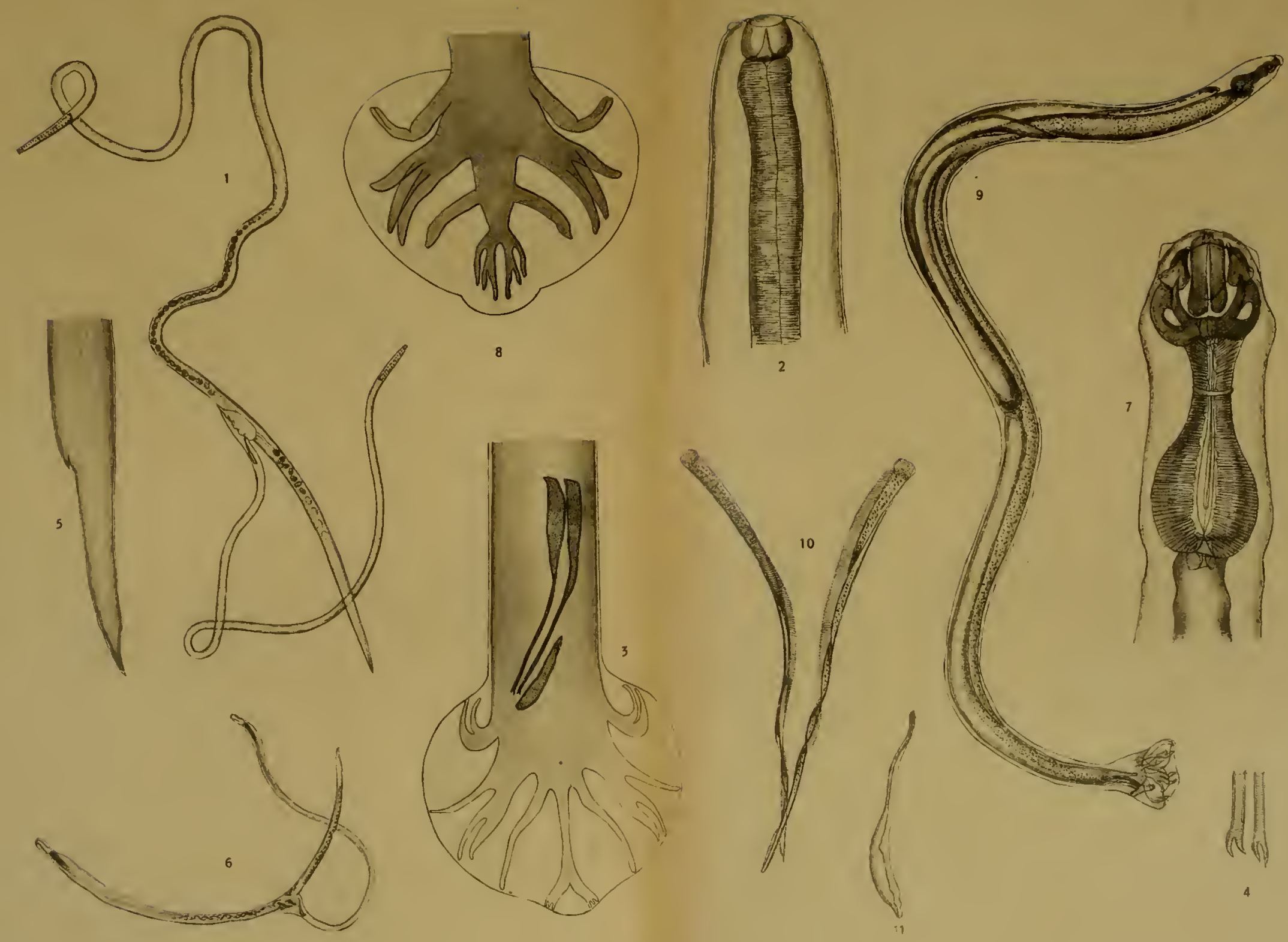






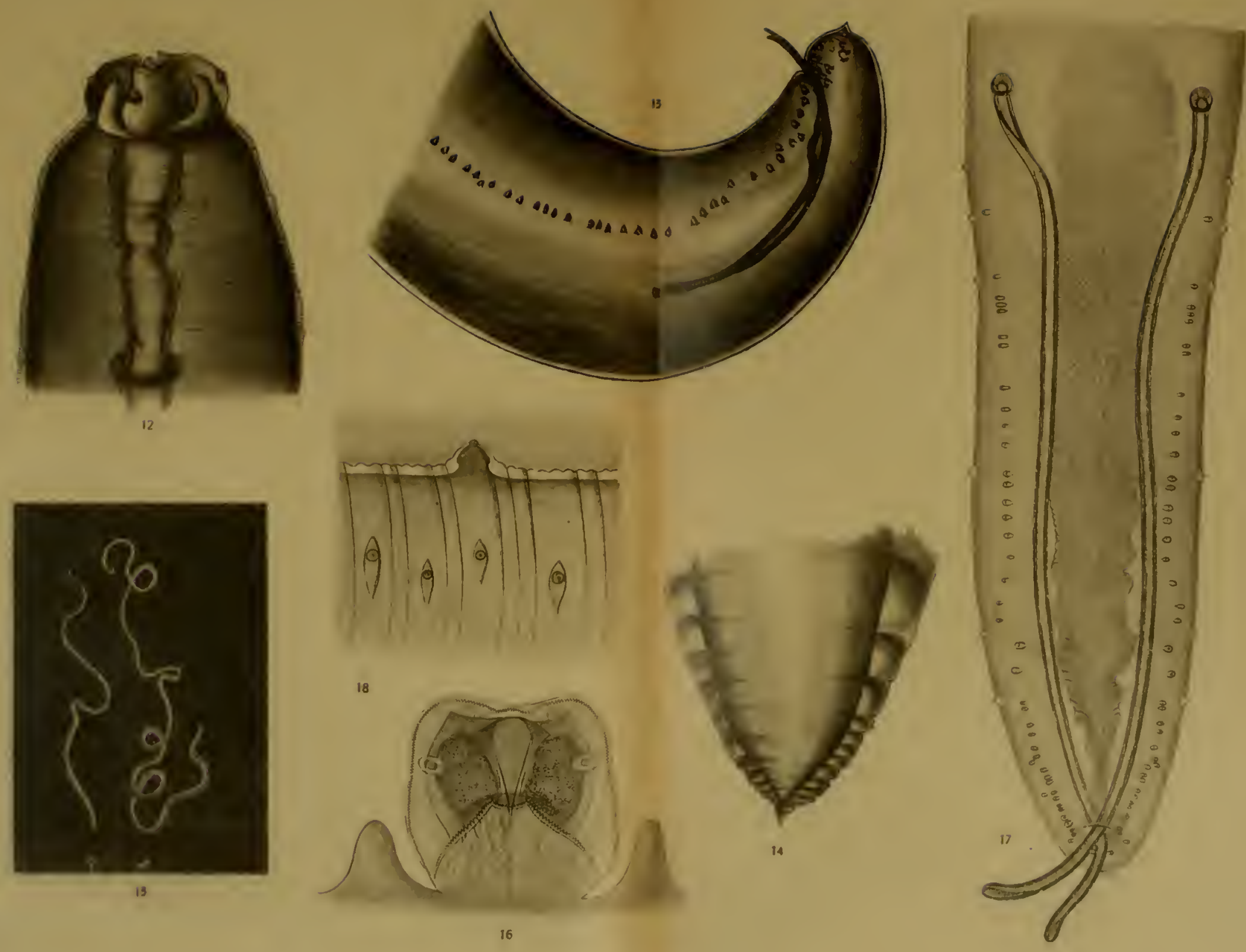



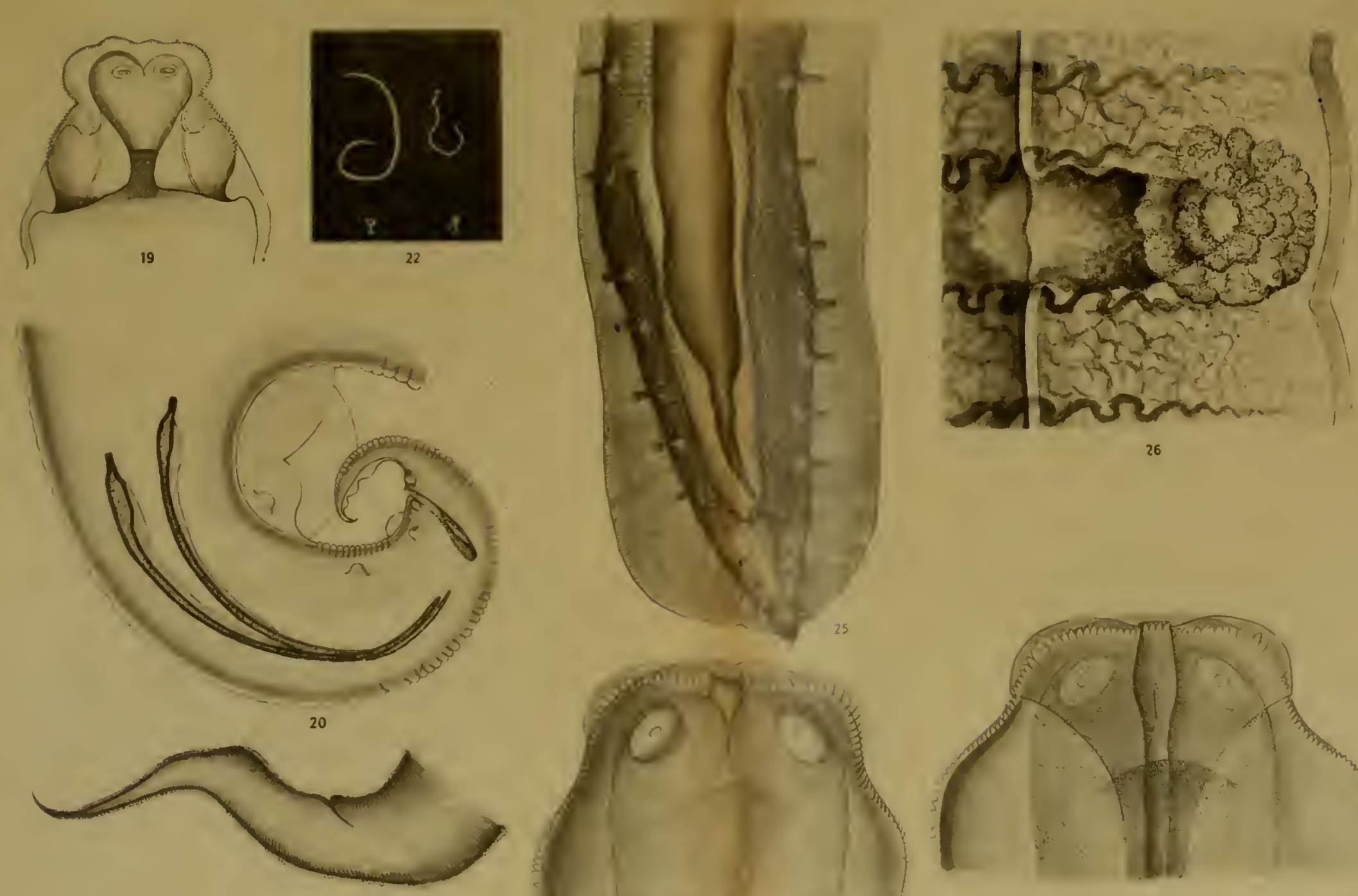

26

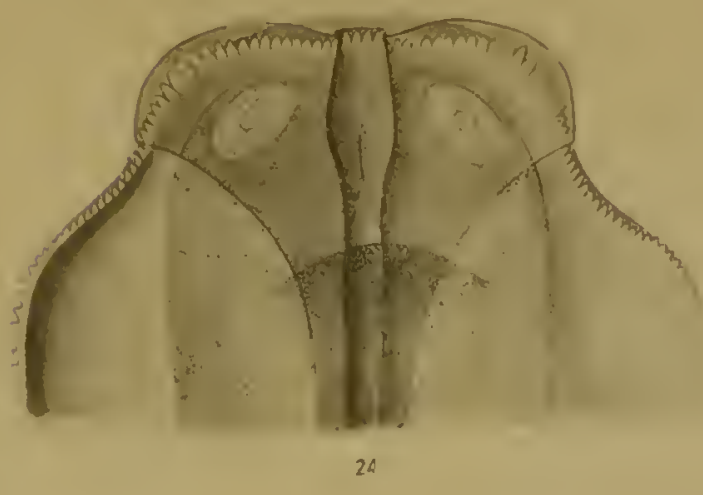






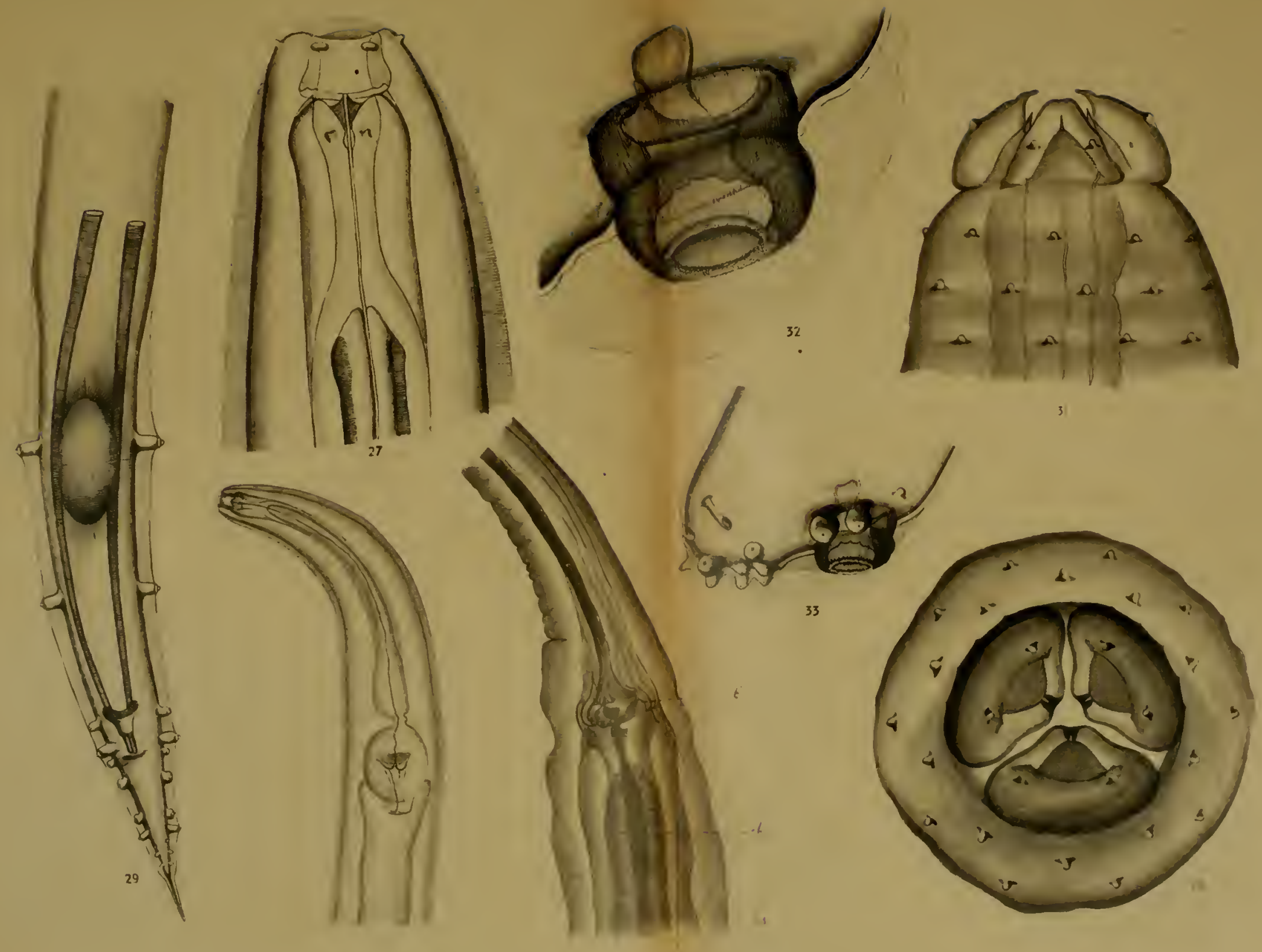




К. Скрябинъ. „Trematodes и Nematodes."

Табл. Vl.
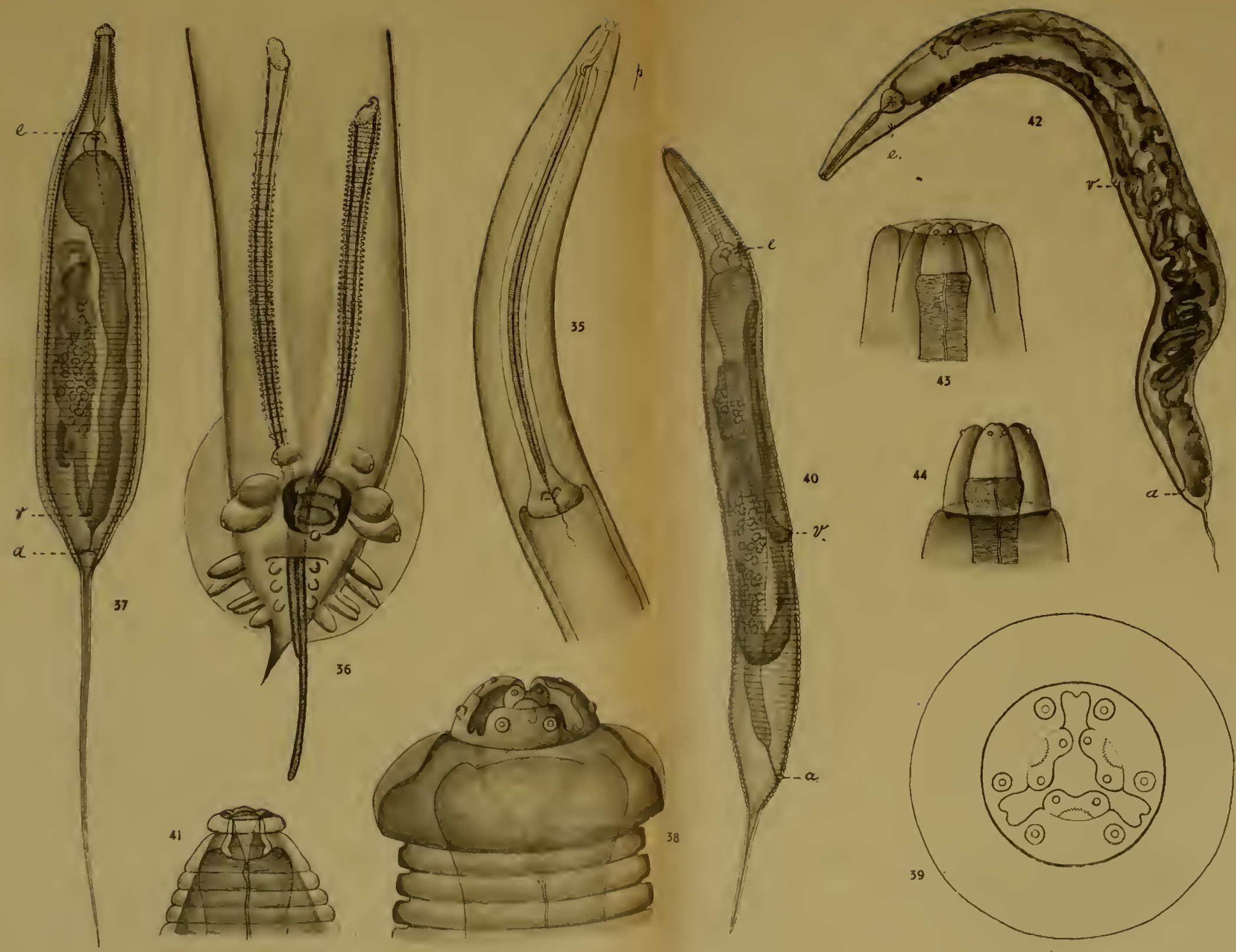





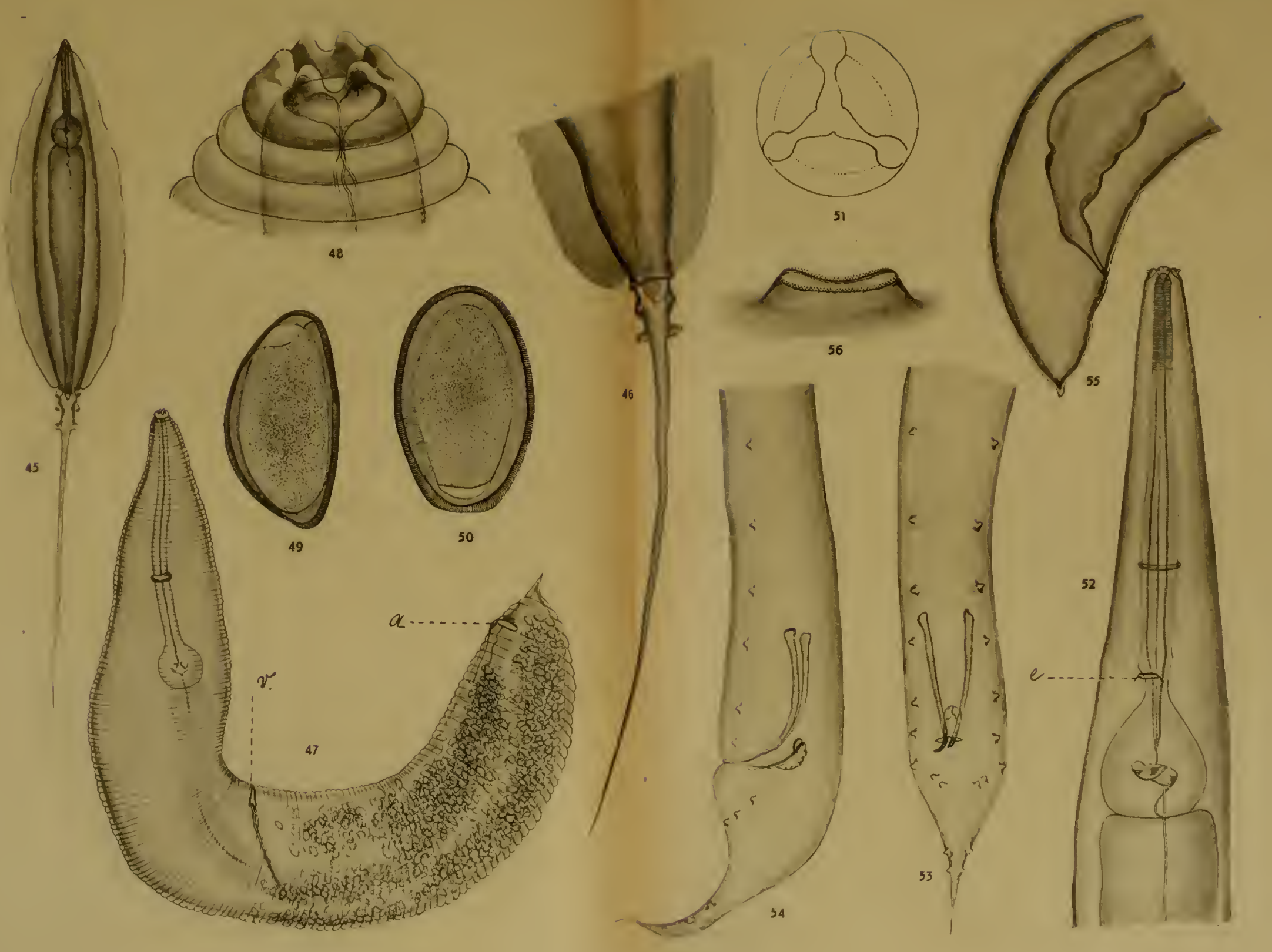






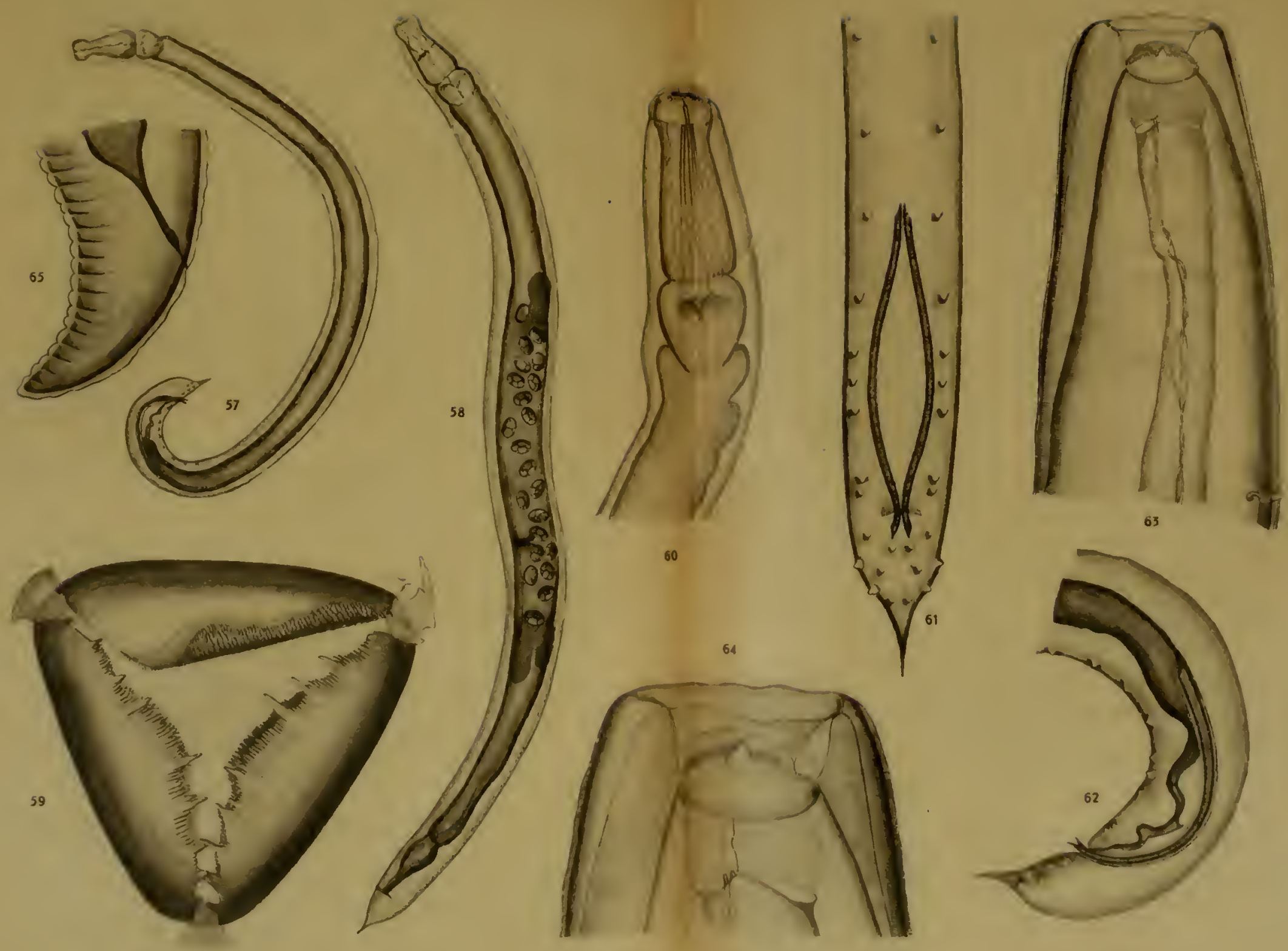




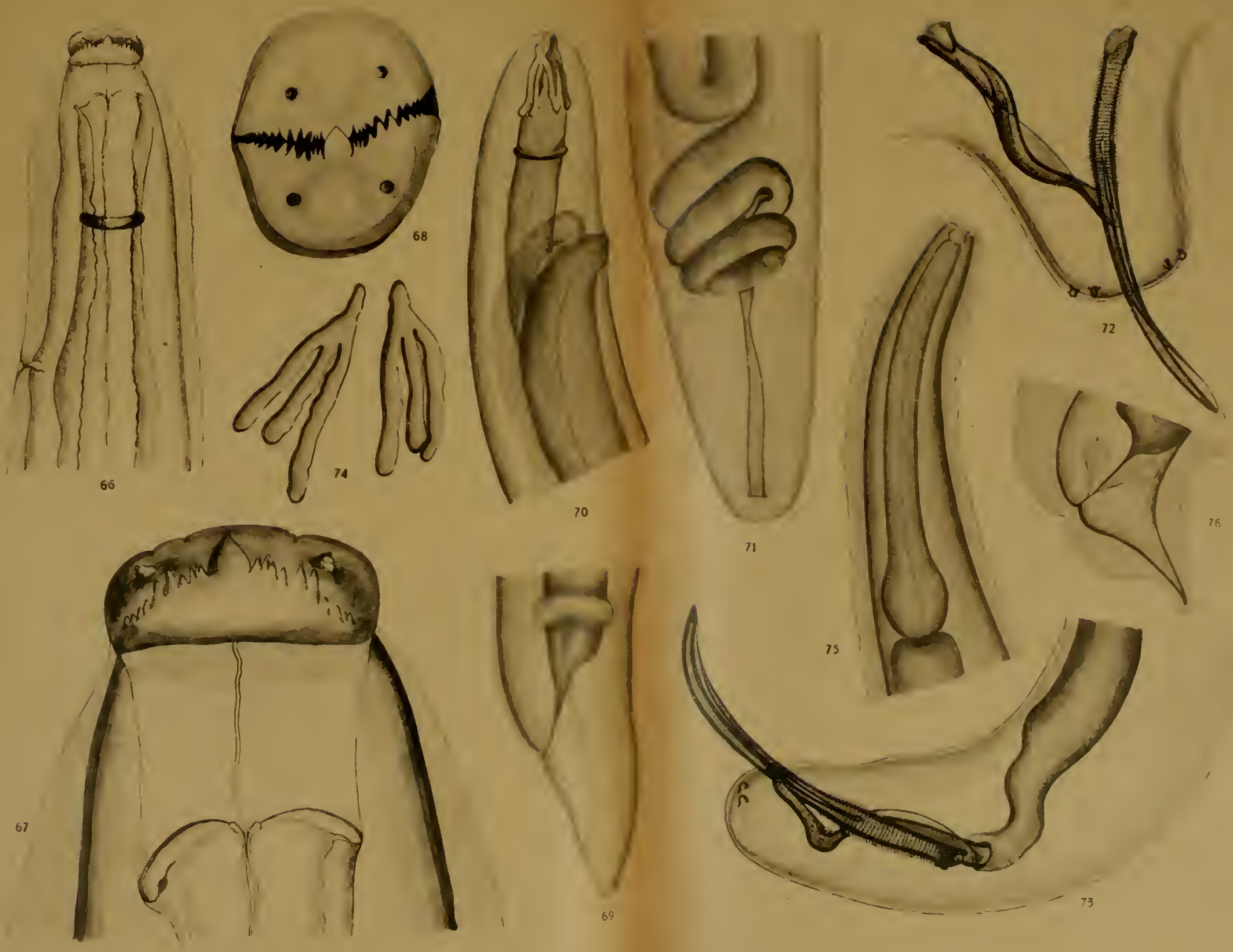




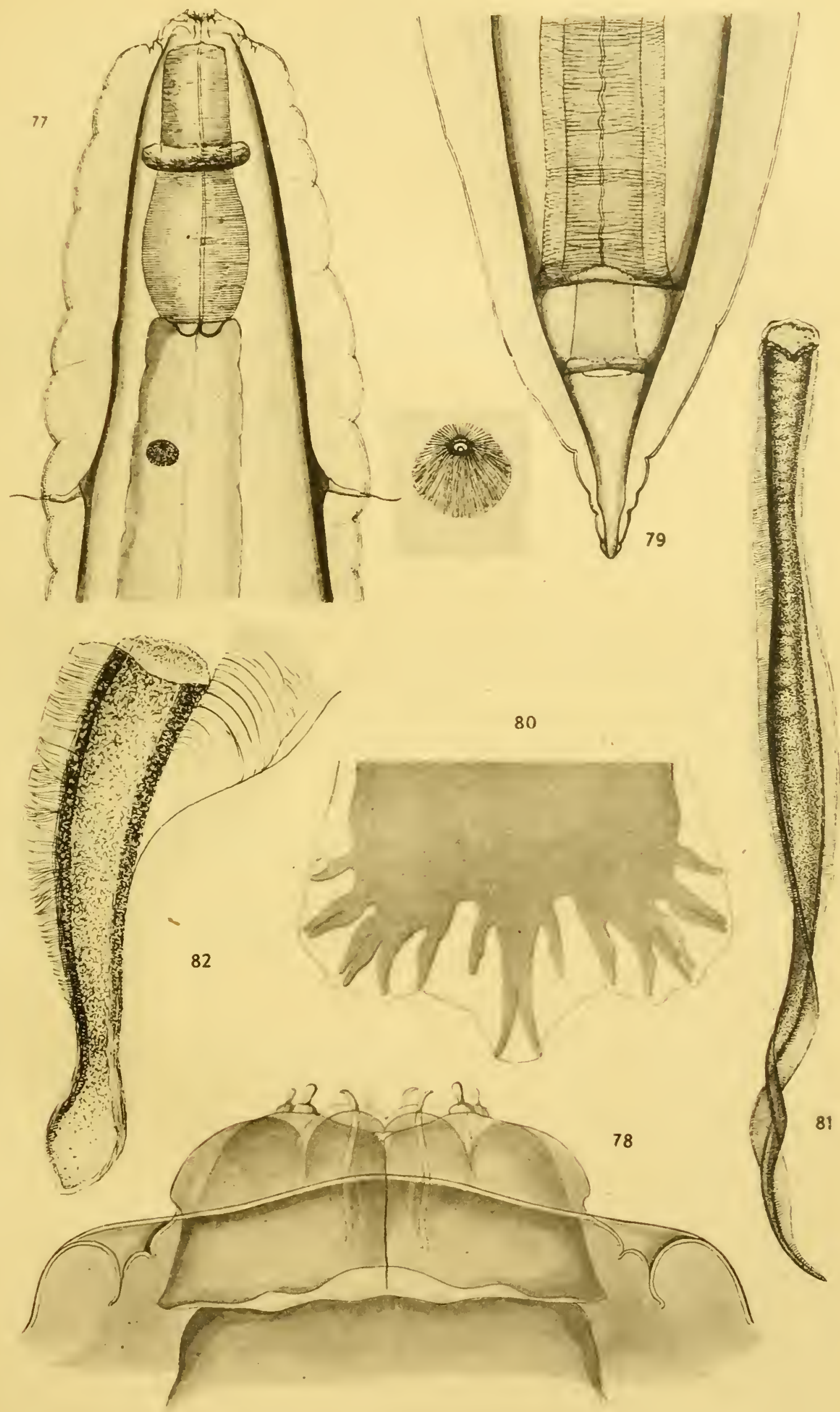



$$
\text { № } 5 .
$$

Ньсколько данныхъ по фаунь Entomostraca Центральной Африки.

$$
\text { Г. Ю. ВЕРЕЩАГИН }
$$

\section{Some remarks on the fauna of Entomostraca of Central Africa,}





\title{
Нжсколько данныхъ по фаунњ Ento- mostraca Центральной Африки.
}

\author{
Г. Ю. ВЕРЕЩАГИНъ.
}

Матеріаломъ для настоящей статьи послужили 10 пробъ планктона, любезно переданныхъ мнъ на обработку В. А. Д оге ле м ъ. Собраны онъ были во время поъздки его въ Центральную Африку льтомъ 1914-го года. Большинство пробъ собрано въ непосредственной близости оз. Викторія-Ніанца или въ самомъ этомь озеръ. Фауна Entomostraca этой мьстности неоднократно подвергалась болье или менће тщательному изученію, и въ обширной работь Daday'я $^{1}$ ) дана полная сводка всъхъ прежде опубликованныхъ свъдъній о микроскопическомъ населеніи какъ центральной Африки, такъ и вообще этой части свъта. Посль вышеназванной работы Daday`я появился цъзлый рядъ работ’b, затрагивающихъ фауну Entomostraca Африки, которыя, однако, лишь незначительнымъ образомъ пополнили наши о ней свбдъ̆нія.

1) G ur ll ey. On some freshwater Entomostraca from Egypt and the Soudan. London. Ann. a. Illagaz. of Nat. Hist.; Ser. 8. 1911, p. 25-33, Tab. 2.

Brehm, U. Cla d o cera. Wissensch. Ergebnisse d. Dentsch. CentralAfrica Expedition 1907-8. Bd 3; Lief. 5; 1911; p. 167-174.

Brehm, U. Beiträge zur ausseremropäischen Entomostrakenfauna. Archiv f. Hytrob. u Planktonk. B(t. 6; 1911. p. 486.

Methuen. Transwaal-clustacea. Pretoria Ann. Transv. Museum 1911; p. $253-256$.

G. O. Sars. Zoological Results of the Third Tanganaika Expedition. Report on the Copepoda. Proc. of the Zool. Soc. of London 1909. p. 31.

II ethuen. On a collection of freschwater Crustace from the Transwaal. Proc. of the Zool. Soc. of London; $1910 ;$ p. 148.

V an Douve. Copepoden des ostafrilianischen Seengebietes. Wissensch. Ergebn. d. deutsch. Central-Africa Expedit. 1907-08 Bd. 3; Lief. 15; 1912; p. $487-496$.

Van Douve. Copepoden in L. Schultze. Zoologische u. anthropol. Ergebnisse d. Forschnngsreise nach Südafrica Bd. 5, Lief. 1; p. $21-32$.

1) Daday E. v. Die Süsswasser. Mikrofauna Deutsch-Ost-Afrikas. Zoologica. Bd 23; Heft 39; 1910. 
Van Douve. Ost-Africanische Süsswasser-Copepoden. Zool. Iahrb. Abth. f. Syst. Bd. $33 ;$ p. $1-8$.

Gurney. On the Fresh-water Crustacea of Algeria and Tunisia. Journ. R. Hicr. Soc. 1909; p. 273.

Не имвя возможности достать нбкоторыхъ работъ, нужныхъ для изученія фауны Сореро а центральной Африки, я ограничиваюсь пока разработкой Cladocera, откладывая до ближайшаго будущаго разработку Copepoda изучаемаго матеріала.

Ниже я привожу краткія свъдънія объ изсльдованныхъ водоемахъ и даю общую характеристику собраннаго въ нихъ планктона.

\section{№ 1}

Яма, наполненная водой, въ окрестностяхъ г. Энтеббе (Entebbe); густо поросла травой. Изъ нея взята одна проба планктона (№ 1) Мюллеровской съьтю. 22. V. 1914 г.

Въ пробъ оказалось порядочное количество органическаго детрита, въ которомъ можно было различить части растеній. Небольшое количество зеренъ песка. Въ пробъ оказалось относительно много личинокъ насъкомыхъ: 1 экз. личинокъ Odonata; 3 экз. Ephemeridae и нисколько экз. Ditisc id a e. Встрбчено небольшое количество экземпляровъ Osta. coda, болынинство готорыхъ были сильно мацерированы. Въ большомъ количествв встрвиченъ Simocephalus serrulatus Koch. Порядочное количество экземпляровъ этого вида оказалось съ eplippium'ами. Въ единичномъ количествъ экземпляровъ встрбччены самцы его и самки съ субитанными яйцами; остальное, довольно значигельное число экземпляровъ состояло изъ стерильныхъ самокъ; молодыя формы встрбчались очень рғдко; такъ же рбдки были и отдвлившіеся ерhірpiиm'ы.

Въ довольно большомъ количествъ встрбчены были Cyclops sp.

\section{№ 2.}

Озеро Чала (Chala). Это довольно большое (около 2·хъь квадратныхъ верстъ) озеро лежитъ въ воронкъ широкаго кратера потухшаго вулкана. Берега озера обрывисты и покрыты льсомъ; въ прибрежной области совершенно отсутствуютъ заросли макрофитовъ; глубина озера значительна, но осталась невыясненной. Изъ этого водоема взята одна проба планктона (№ 2) 3. VIII. 14. Мюллеровской съткой возлғ берега.

Въ этой пробъ оказалось очень малое количество неорганическаго детрита; незначительное количество нитчатыхъ водорос- 
лей и по нбсколько экземпляровъ Cyclops sp. и Diaptomus sp. Большинство этихъ экземпляровъ были мертвы въ моментъ фиксаціи. Clad o cer a не оказалось ни одного экземпляра.

№ 3.

О3. Найваша (Naivasha.) Озеро расположено въ вулканической мбстности. Размъры его около 100 квадратныхъ верстъ; берега густо заросли папирусом'ъ.

Изъ озера взята въ іюль 1914 г. лишь одна планктонная проба Мюллеровской сътью изъ прибрежной его области.

Въ пробъ оказалось немного органическаго детрита и порядочное количество болъе крупныхъ остатковъ макрофитовъ; сине-зеленыя водоросли им блись в'ь небольшомъ количествь, зато нитчатокъ оказалось много. Неоднократно попадалась Arcella sp.; довольно много обрывковъ хитина, которые принадлежатъ, повидимому, какимъ то личинкамъ наськомыхъ. Изъ Cla d o cera встрбчена лишь Alona pulchella King: въ одномъ экземплярь, изъ Сорероda же порядочное количество Cyclops sp. и Diaptomus sp?

№ 4.

Озеро Накуру (Nakuru). Солоноватое, мелкое, небольшое озеро, площадью около 25 кв. верстъ. Берега его топкіе и сплошь заросли ситникомъ; заросли эти заходятъ далеко въ озеро. Изъ озера взяты 2. VII. 14. двь пробы планктона (№ 4 и № 5) въ мъсть свободномъ отъ зарослей, но мелкомъ, шагахъ въ двадцати отъ берега.

Характеръ объихъ пробъ оказался тождественнымъ, а потому я буду разсматривать ихъ вмъсть. Въ нихъ оказалось порядочное количество хлопьевъ органическаго детрита, среди которыхъ попадалось немало и болће крупныхъ остатковъ макрофитовой растительности; встрбчено незначительное количество нитчатокъ; въ порядочномъ количествъ встрбчены гладыши (Notonecta sp.) и ньсколько пустыхъ створокъ Ostracoda. Изъ Entomostraca встрбиченъ въ большомъ количествь лишь Diaptomus sp.

№ 5.

Оз. Викторія.-Ніанца. Изъ этого озера въ разныхъ частяхъ его взято 5 пробъ планктона. Въ виду того, что три разныхъ мъста, гдъ были взяты эти пробы, носятъ совсъмъ различный характеръ, необходимо дать краткія свъдънія о нихъ порознь.

Проба № 6 взята въ пелагической области противъ пристани города Entebbe; проба бралась Мюллеровской сътью съ поверх- 
ности озера, саженяхъ въ 100 отъ берега (30. V. 14). Въ пробъ оказалось небольшое количество нитчатокъ, немного Peridineae, единичные экземпляры личинокъ Corethra sp., немного обрывковъ хитина и органическаго детрита. Преобладали въ планктонъ Entomostraca, изъ которыхъ встрбиены сльдующія формы:

Diaphanosoma excisum G. O. S. ед. экз.

Ceriodaphnia rigandi Rich. поряд.

" cormuta G. O. S. поряд.

" quadrangula var. hamata. G. О. ऽ. ед. экз.

Moina hartwigi Welt. ед. экз.

Bosmina longirostris m. cornuta Gur. немн.

Alona rectangula var. rectangula ед. экз.

var. uncobensis ед. экз.

Chydorus barroisi Rich. довольно много.

Chydorus sphaericus O. F. М. много.

Изъ Сорерода встръчалось порядочное количество Cyclops sp. и Diaptomus sp.

Проба № 7, № 8 и № 9 взяты также въ окрестностяхъ Entebbe въ заливъ озера, черезъ который сдълана переправа. Всь эти пробы взяты также съ поверхности воды Мюллеровской сむтью на серединб залива, въ пелагической его области 29. V. 14 г. Составъ этихъ пробъ оказался почти тождественнымъ. Во всъхъ было значительное количество нитчатокъ и сине-зеленыхъ водорослей и небольшое количество Peridineae. Въ незначительномъ количествъ встрбчены остатки макрофитовъ, обрывки хитина и органическій детритъ. Cladocera были распредълены по пробамъ слғдующимъ образомъ:

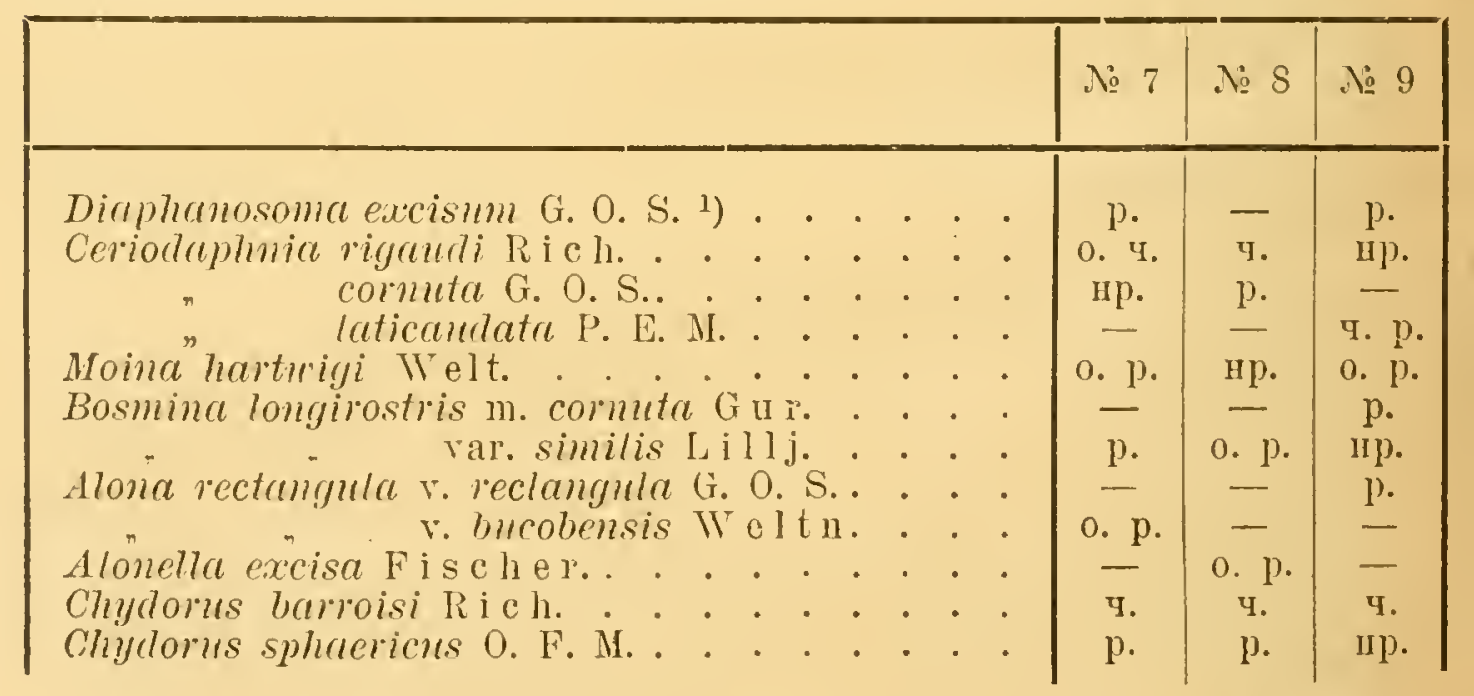

1) Буквы, обозначаюпія частоту нахожденія, какъ въ этой, такъ и въ сльдующей таблиць, употреблены ит сльдующемъ смыслъ: „о. ч.“-

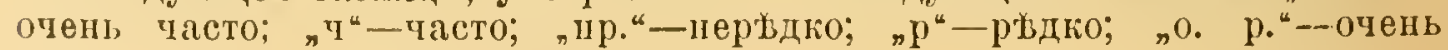
ридко; пч. р. “-чрезвычайно ридко. 
1 экземпляръ Chydorus barroisi въ “пробъ № 7 встрғзченъ былъ съ ертірріит'омъ.

Изъ Сорероda встрбчены Cyclops въ большомъ количествъ " Diaptomus sp. в’ъ небольшомъ числғ, экземпляровъ.

Проба № 10 взята у восточнаго берега Викторія Ніанца, въ одной из'ь бухтъ Кавирондскаго залива; взята во время переъззда черезъ эту бухту на лодк' ческой области, съ поверхности воды Мюллеровской сб̆ткой.

Въ пробъ оказалось много пыльцы цвътковыхъ растеній, много сине-зеленыхъ водорослей, нитчатокъ и Peridineae; сравнительно въ небольшомъ количествй присутствоваль органическій детритъ.

Животный планктонъ этой пробы состоялъ по преимуществу изъ Entomostraca. Vзз Cladocera встрғчены въь немъ:

Diaphanosoma excisum G. O. S. нерьдко.

Ceriodaphia rigaudi Rich. рвдко, среди экземпляровъ преобладаютъ полодыя формы.

Moina hartwigi. У многихъ экземпляровъ выводковая камера туго набита партеногенетическими яйцами.

Bosmina longivostris var. cormuta Jur. очень рьдко.

Alona rectangula var. bucobensis Weltu.- рәьдко.

Изъ Соре poda встрғччено было большое количество Сyclops sp. и Diaptomus sp.

Переходимъ теперь къ описанію отдъльныхъ видовъ, имъюцихся въ нашемъ распоряженіи Entomostraca.

Diaphanosoma excisum G. O. S.

Извъстная до сихъ порь лишь изъ Австраліи, откуда она была описана Сарсомъ, 1) и изъ Африки, гдъ она была указана рядомъ авторовъ, форма эта ръзко отличается отъ другихъ видовъ рода благодаря характерному строенію брюшного края створокъ, загнутыхъ во внутрь.

Найденные экземпляры приближаются къ var. longiremis, описанной Экманомъ ${ }^{2}$ ) изъ Египта. Характернымъ призна-

1) G. O. S a rs. On some Australian Cladocera etc. Christiania Videnskabs Selskabets Forhandlingar 1885; № 8; p. 13-18.

2) Ekin an. Cladoceren u. freilebende Copepoden aus Ägypten und dem Sudan. Results of the swed. zool. Exped. to Egypt and the White Nile. Pt. 1; № 26; 1903; p. 1-2. 
комъ этого варіетета является длина антеннъ 2-ой пары, которыя должны превосходить длину створокъ. Среди пересмотрънныхъ мною экземпляровъ, однако, встръчены всъ переходы между основной формой, у которой длина антеннъ не превосходитъ створокъ, И var. longimanus Ekm., что указываетъ на то обстоятельство, что признакъ длины антеннъ находится въ предб̈лахъ индивидуальныхъ колебаній и врядъ-ли можетъ считаться имбющимъ значеніе для выдєленія особаго варіетета.

Экманъ (Ekman) указываетъ на рядъ мелкихъ шипиковъ возл各 спинного края салы $а$, присутствующихъ у африканскихъ экземпляровъ этого вида, выдъляемыхъ имъ въ var. longimanus. Я могу подтвердить это его наблюденіе на бывшихъ въ моемъ распоряженіи экземплярахъ. Если эти шипики дъйствительно отсутствуютъ у австралійскихъ типичныхъ экземпляровъ, то этотъ признакъ быть можетъ, дъйствительно, оправдываетъ таксономическую самостоятельность африканскихъ экземпляров'ь.

Однимъ изъ характерныхъ признаковъ Diaphanosoma exci$s u m$ является присутствіе на нижне-заднемъ углу ея створокъ, съ брюшной стороны, нћсколькихъ зубчиковъ. Какъ удалось наблюдать на просмотрбьнныхъ мною экземплярахъ, число и относительное расположеніе этихъ зубчиковъ подвержены сильнымъ колебаніямъ. Я наблюдалъ у взрослыхъ самокъ отъ 5 до 11 зубчиковъ, причемъ число ихъ на правой и на лћвой створкъ у одного и того же экземпляра можетъ быть различнымъ. Фигура А и В рис. 1-го представляютъ правую и львую створку одного

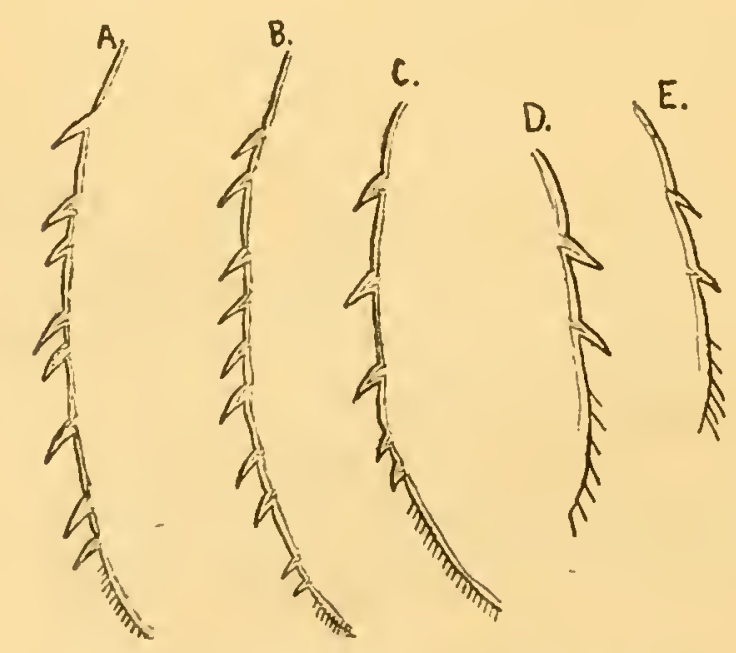

Puc. 1. Diaphanosoma excisum. у велпч. 530. экземпляра, и мы видимъ на одной изъ нихъ 8 , а на другой 10 зуобчиксвъ. Расположены зубчики ммгутъ быть либо одиночно (фиг. С рис. 1), либо группами (фиг. А рис. 1), причемъ это расположеніе точно также варінруетъ даже на разныхъ створкахъ одного и того же экземпляра (фиг. А и В рис. 1).

У молодыхъ экземпляровъ число зубчиковъ бываетъ гораздо меньше (до 2), какъ это изображено на фиг. D и Е рис. 1.

Въ обработанномъ матеріалъ видъ этотъ попадался исклю- 
чительно въ заливахъ оз. Викторія-Ніанца, въ пелагической его области; особенно часто онъ встрєчался въ бухть К Кавирондскаго залива. Вс'в экземпляры были партеногенетическія самки, въ выводковой камерь которыхъ находилось отъ 3 до 7 яицъ ипи эмбріоновъ.

\section{Simocephalus sermulatus K och.}

По справедливому замбчанію Ш тин ге ли на (St in ge lin) $\left.{ }^{1}\right)$ за посльднее время описано слишкомъ много новыхъ видовъ этого рода, которые, по всей въроятности, являются лишь варіететами уже прежде описанныхъ видовъ.

Встрбченные въ ямъ, наполненной водой, у Энтеббе (№1) экземпляры безусловно относятся къ виду serrulatus Koch, причемъ тщательное сравненіе экземпляровъ со среднеевропейскими не обнаружило замбтныхъ отличій отъ типичной формы. Среди большого количества партеногенетическихъ самокъ встрбчено (22. V. 14,) порядочное количество самокъ съ эфиппіями и единичные экземпляры самцовъ.

Видъ этотъ уже былъ встрбченъ въ Африкъ.

\section{Ceriodaphnia cornuta G. O. Sars.}

Видъ этотъ былъ уже неоднократно находимъ въ Африкъ, 2) кромъ того, онъ найденъ въ Австраліи, южной Азіи, южной Америкє, Новой Гвинеъ и др.

Что касается до нахожденія вида Ш т и н ге л и но м ъ на Явъ̆, ${ }^{3}$ ) то принадлежность встрбченныхъ имъ эКземпляровъ къ этому виду сомнительна.

Найденные мною въ порядочномъ количествъ въ заливахъ Викторія-Ніанцы экземпляры имъютъ всъ неп̆арный выростъ на головъ. Въ непарности этого выроста можно было ясно убћ̆диться при разсматриваніи экземпляровъ en face, какъ показываетъ рис. 2.

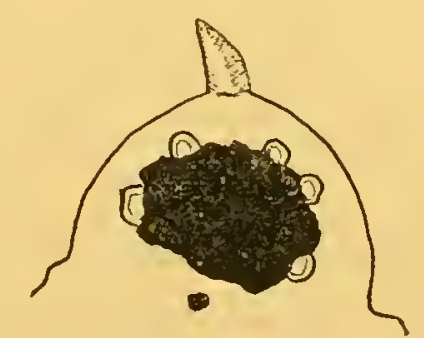

Pis. 2. Ceriodaplinia cornuta en face; У Вел. 530.

1) Stingelin. Cladocera. Voyage d' exploration scientifique en Colombie. Mémoires d. I. Soc. Neuchâteloise des sciences naturelles. Vol I: 1913. p 611.

2) D a d a y loc. cit. p. 144-145.

3) Stingelin. Untersuchungen über die Cladoceren-fauna von Hinterindien, Sumatra u. Jawa. Zool. Iahrbüch. Abth. f. System. 1904. 
Это обстоятельство и заставляетъ меня сомнћваться въ идентичности съ этимъ видомъ экземпляровъ, описанныхъ Ш тингели н о ґ съ о-ва Явы, у которыхъ онъ констатироваль выростъ въ видъ парнаго образованія. Размкры разсматриваемаго выроста у Cer. cornuta могутъ сильно 'колебаться, но экземпляровъ съ рудиментарнымъ выростомъ, каковые можно встрбтить среди Scapholebris mucronate mph. cornuta Jur., гдъ имъется аналогичный выростъ, я не наблюдалъ, и литературныя указанія на нахожденіе подобныхъ переходныхъ формъ мнъ также не извъстны. Въ вицу этого мнъ казалось-бы преждевременнымъ соединять этотъ видъ съ Cer. rigalli $\mathrm{Rich}$, хотя характеръ отличительнаго признака (рогъ на головъ) по аналогіи съ таковымъ у Scapholebris mucronata заставляеть считать таксономическое значеніе его очень невысокимъ. Небольшая разница между Cer. cornute и C. rigandi замьтна въ формь зубовиднаго выроста на форниксахъ; выросты эти особенно хорошо видны при разсматриваніи животнаго съ брюшной стороны. У Cer. cornuta вырост’ болье толстый и массивный, чвмъ
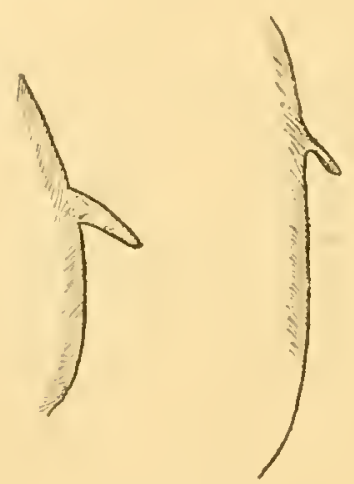

PIIc. 3. C. commata. C. rigandi. Увел. 530.

\section{у Cer. rigandi. (см. рис. 3 и 4).}

Возможно, однако, что отличія эти находятся в’ь предълахъ индивидуальной измънчивости.

Строеніе задне-верхняго угла створокъ у Cer. cornuta и Cer. rigandi является вполнъ аналогичнымъ. Сарсъ ${ }^{1}$ ), Штингелинъ2) и Дадай³) опиPнге. 4. сывають, что створки на этомъ углу раздвоены и выпячиваются свободными крыльями. Между тємъ, какъ это ясно видно изъ рис. 5, сдъланнаго для Cer. rigaudi, на самомъ двл官 створки вовсе не раздваиваются, а на углу ихъ стоятъ два зубовидныхъ выроста, которые

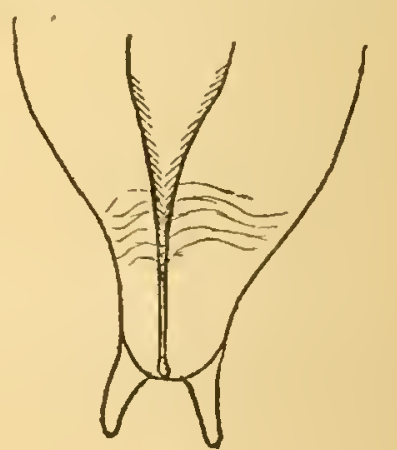

PuIc. 5.

Ceriod. Rigandi en face. Увелич. 530. при разсмотръніи сбоку можно принять за раздвоенность. Выросты эти аналогичны тьмъ, которые имбются на головъ Cer.

1) S a l. s loc. cit. p. 26-28.

2) Stingelin loc. cit. $9-10$. p.

3) Daday loc. cit. p. 144 . 
cornuta. Насколько мнъ удалось замътить, у молодыхъ экземпляровъ обоихъ видовъ выросты на верхнезаднемъ углу створокъ меньше, чъмъ у взрослыхъ формъ, но у ньсколькихъ взрослыхъ экземпляровъ Cer. comuta и Cer. rigaudi выросты эти даже совсьмьь отсутствовали.

Въ отличіе отъ описанія Дадая ${ }^{1}$ ), на встрұченыхъ мною экземплярахъ я не наблюдалъ волосковъ на створкахъ, даже вдоль спиннаго ихъ края, гд⿱⺊口) они согласно описанію Дадая должны бы быть особенно хорошо замътны.

Всъ́ встрбченные экземпляры были партеногенетическія самки, число яицъ въ выводковой камеръ которыхъ не превышало трехъ.

\section{Ceriodaphnia rigandi $\mathrm{R}$ i $\mathrm{ch}$.}

Эта почти повсембстно распространенная подъ тропиками форма встрбчена въ большомъ количествъे въ изсльдованомъ матеріаль.

Значительное разногласіе въ описаніяхъ этого вида, сдъланныхъ Р иш ар омъ для Тонкина ${ }^{2}$ ), С а рсом ъ ${ }^{3}$ ) для южной Африки, Э кман о м ъ $\mathbf{b}^{ \pm}$) для Египта., Да да е м ' $\mathrm{b}^{5}$ ) для централіной Африки, заставляло ¿̀ priori сдълать два предположенія: либо видъ этотъ подверженъ чрезвычайно сильной индивидуальной изм Ђнчивости, либо онъ представленъ въ различныхъ мъстностяхъ различными варіететами, неизвйстнаго таксономическаго значенія.

Желая приблизиться къ разрбшенію вопроса о качеств морфологическихъ особенностей различныхъ описаній, я предпринялъ сравнительное изсльдованіе найденныхъ въ обрабатываемой коллекціи экземпляровъ, которое заставляет'ь меня склониться ко второму изъ вышевысказанныхъ предположеній, а именно, что видъ этотъ въ различныхъ мыстахъ образуетъ разные варіететы.

При просмотръ взрослыхъ экземпляровъ постоянными признаками оказались сльдующіе:

1) Роговидный непарный выступъ на лбу (клювъ).

2) Форма и строеніе саиdа.

1) D a d a y. loc. cit. p. 144-145.

2) R iclu ard. Sur quelques animaux inférieurs des eaux douces au Tonkin. Mémoires d. 1. Soc. Zool. de France. Vol 7; 1894; p. 239-241.

3) S a r s. On Some South-african Entomostraca raised from dried mud. Skrifter udgivne of Vedenskab Selskab. Christiania. 1895; № 8; p. 1-56.

4) Ekm a n loc. cit. p. 5-6.

5) D a d a y loc. cit. p. 145. 
3) Число шиповъ на ея спинномъ краю.

4) Зубовидный отростокъ на форниксъ.

Непостоянными признаками при измбреніи 10 экземпляровъ оказались: 1) Размъръ глаза. Измъреніе вмбсть съ линзами, перпендикулярное общей длинъ т各ла, оказалось колеблющимся между $0,04 \mathrm{~mm}$. и $0,0512 \mathrm{~mm}$.

2) Длина клюва. Измъренный отъ пигментнаго пятна до его конца, онъ оказался отъ 0,0256 до $0,032 \mathrm{~mm}$.

3) Высота головы. Измьренная отъ наивысшей точки до передняго края створокъ, она оказалась колеблющейся отъ 0,056 до $0,06 \pm \mathrm{mm}$.

4) Отношеніе общей длины тбла къ наибольшей ширинғ его колебалось отъ $\frac{11}{8}$ до $\frac{13}{8}$.

5) Абсолютные размъры тйла колебались слбдующимъ образомъ: общая длина-отъ $0,355 \mathrm{~mm}$. до $0,126 \mathrm{~mm}$.

Наибольшая ширина-отъ 0, $269 \mathrm{~mm}$. до 0,291 $\mathrm{mm}$.

6) Шиповидные выступы на задне-верхнемъ углу створокъ оказались изъ 23 экземпляровъ болье или менъе развитыми у 17 и отсутствовали у 6 экземпляровъ.

По присутствію на форниксахъ зубовиднаго отростка встръченные мною экземпляры ближе всего подходятъ къ описанію, данному для Cer. rigaudi Д а д а е м ъ.

Однако, какъ отъ этого, такъ и отъ всъхъ иныхъ описаній они отличаются отсутствіемъ какой бы то ни было скульптуры створокъ; не имъютъ они также и волосковъ на поверхности створокъ, которые констатируетъ Дадай дия своихъ экзепіпляровъ.

Въ изсльдованномъ матеріалғ Cer. rigaudi встръчена была лишь въ заливахъ Викторіи Ніанцы, въ пелагической ихъ области, въ большомъ количествъ, причемъ всь⿱⺊口) изслбдованные экземпляры были партеногенетическія самки, число яицъ въ выводковой камерб которыхъ колебалось отъ 2 до 5.

Ceriodaphnia quadrangula var. hamata G. O. Sars.

Нъсколько экземпляров’ь этой формынайдены въ оз. Викторія Ніанца, возль Энтеббе. Отъ средне-европейскихъ экземпляровъ найденные отличаются болъе тупымъ верхне-заднимъ угломъ створокъ; послбдніе проксимальные зубчики на заднемъ краю cauda оказались двойными. Отличія эти, однако, такого характера, что не даютъ повода выдълить обладающіе ими экземпляры въ особый варіетегъ. Ceriodaphnia quadrangula въ типичной своей форм⿱⺊口丂 уже встрбчена въ Африкъ, а именно въ Египтъ 
Gurn e y, 1911). ') Var. же hamata G. O. Sar's является новой для африканской фауны.

Ceriodaphnia laticaudata P. E. M.

Въ пробъ планктона, взятой противъ пристани у Энтеббе въ оз. Викторія-Ніанца, встръченъ лишь одинъ экземпляръ вида, который, благодаря характерному строенію своей caudla и антеннъ 1 -ой пары, несомнънно принадлежитъ къ Cer.laticaudata Р. Е. М. Сравненіе съ европейскими экземплярами вида, однако, показываетъ ныкоторыя отличія: прежде всего шестигранная скульптра створокъ въ противоположность европейскимъ экземплярамъ выражена едва замбтно, далъе, голова не столь сильно вытянута.

На африканскомъ материкъ видъ этотъ еще встрбченъ не былъ, хотя онъ извъстенъ съ Мадагаскара 2).

\section{Moina hartwigi Weltn.}

Экземпляры, встрбченные въ большомъ количествъь въ оз. Викторія Ніанца, по своеобразному строенію caud儿 несомнбнно

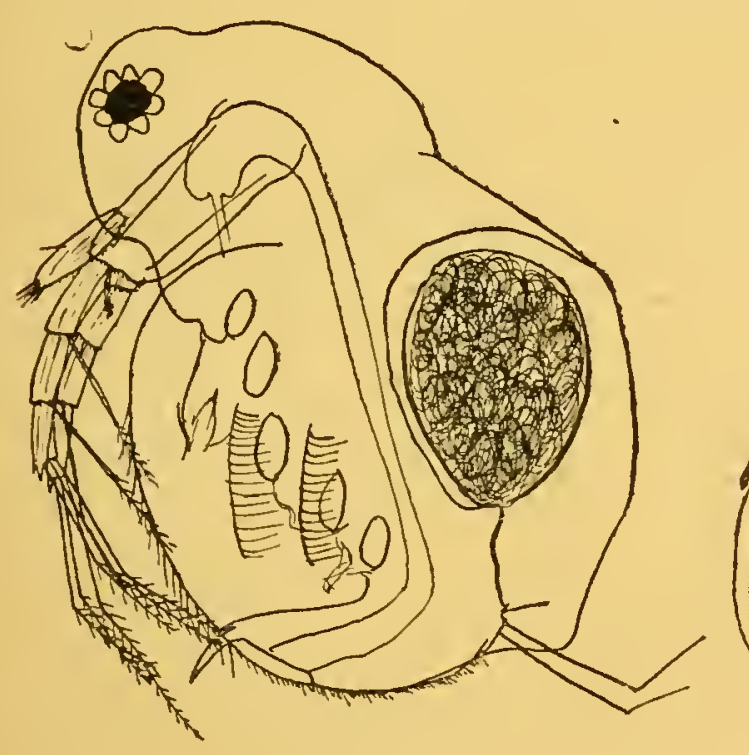

PiIc. 6.

Moina hartwigi. У велігч. 125.

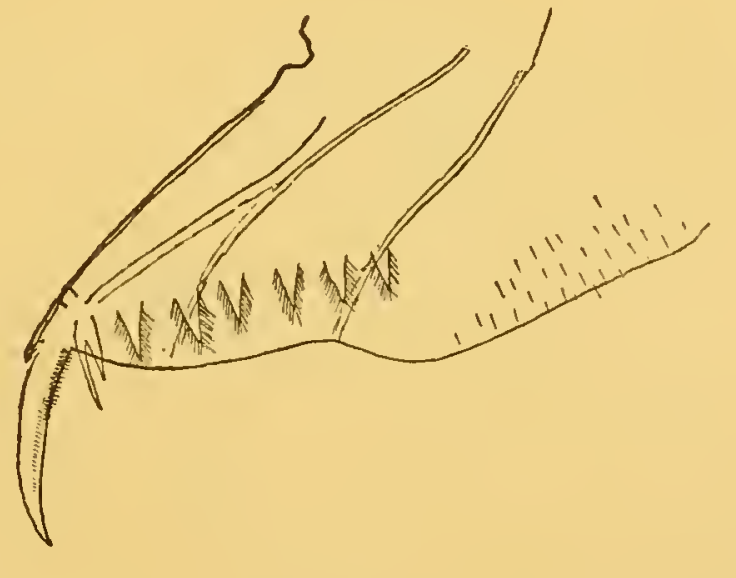

Pirc. 7.

Moince hartwigi. Увелич. 530.

относятся къ $M$. llartwigi Weltn.; тьвм не менъе, они имъютъ нбкоторыя особенности, отличающія ихъ отъ описанія, даннаго

1) Gurney. On some Freshwater Entomostraca from Egypt and the Soudan. Annals a. Magazine of Nat. Hist. Ser. 8; Vol. 7; 1911. p. 27.

2) Richard et de-Guerne. Sur quelques Entomostracés d' eau douce de Madagascar. Bul. d. l. Soc. Zoolog. de France Vol. 16; 1891; p. 223. 
Вель тнер ом ъ ${ }^{1}$ ). Прежде всего, число треугольныхъ шиповъ на заднемъ краю caиdа равно 5-8, а Вельтнер в указываетъ число 7-9. Далье, болье проксимальная, расииренная часть canda усажена не столь длинными и не столь густыми волосками, какъ по даннымъ Вельтнера. На антенныхъ 2-ой пары между ихъ развйтвеніями сидитъ характерная двучленистая шетинка, которая указывается также и В ель тн е ром ъ. Задній край створокъ усаженъ группами очень мелкихъ волосковъ.

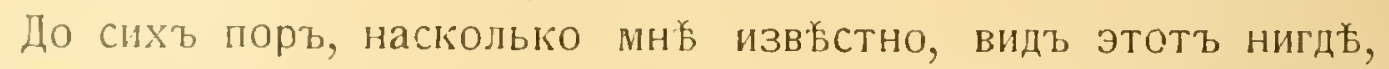
кромъ Африки, найденъ не былъ. Всъ встрбченные мною экземпляры были партеногенетическія самки, снабженныя 2-3 яйцами въ выводковой камерв.

\section{Bosmina longirostris.}

Представители этого широко распространеннаго вида были уже нбсколько разъ находимы въ Африки; встрьтились они въ не особенно большомъ количеств ь̌ и въ изсльдованномъ матеріалғ.

Сльдующіе варіететы были представлены:

a) morpha restivalis cormuta Ju i экземпляры были встрбчены въ заливахъ оз. Викторія-Ніанца

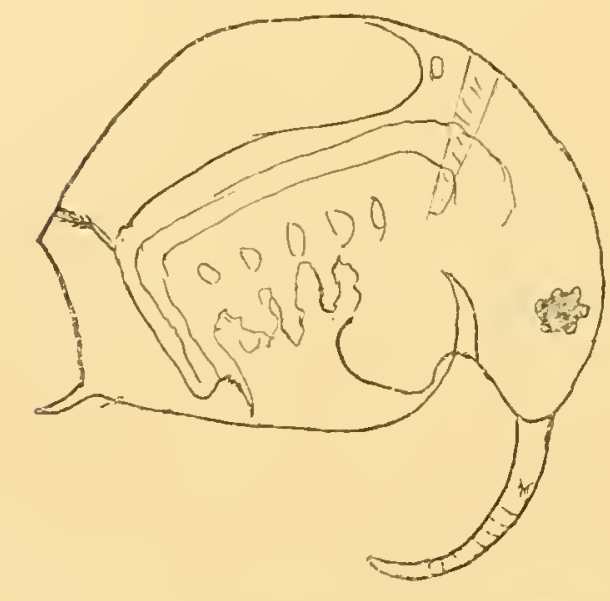

Pirc. S. Bosm. Iongir. m. cormuta Yेелпу 125. вмъст娄 со слғдующимъ варіететомъ. Характерная форма антеннъ 1-ой пары не позволяетъ сомнъваться въ принадлежности изображенныхъ на рис. 8 экземпляровъ къ разсматриваемой породь.

b) var. similis Lillj. $\mathrm{Bъ} 1898$ году Вельтне р ъ2) описалъ изъ Викторія Ніанца новый видъ, Bosmina stuhlmanni, назвав'ь его въ честь указавшаго впервые для озера эту форму, но не давшаго ей названія Ш тульмана ${ }^{3}$ ). Самостоятельность этого вида, однако, весьма сомнительна, и уже

1) W e l t ner. Ostafrikanische Clatoceren, gesammelt von Herm St IIhl ma n n 1888 und 1889.

Mitteilungen a. d. Naturhistorischen Museum in Hamburg Jahrg. 15; 1898; p. $135-170$.

2) 11 eltner loc. cit. p. $6-7$.

3) St u hl m a n n. Beiträge zur Fauna centralafrikanischer Seen. I. Süd. creek des Victolia-Niansa. Zoolog. Jahrbücher. Bd. 5; 1891; 5-me palt. p. 925 
Дадай ${ }^{1}$ ) отнесъ его къ синонимамъ Bosmina longirostris, присоединивъ его к’ъ варіетету similis Ijillj. Имъя въ распоряженін много зкземпляровъ формы, несомнънно описанной В ел ьтн еромъ какъ $B$. stuhlmanni, я тщательно сравнилъ ее съ var. similis Lillj., и могу лишь подтвердить мнъніе Дадая объ идентичности этихъ формъ.

Какъ мнь приходилось указывать еще раньше, ${ }^{2}$ ) характернымъ для var. similis признакомъ является закругленность лобнаго края съ одной стороны и, сравнительно, небольшая выемка у основанія первыхъ антеннъ съ другой стороны. Какъ разъ эти признаки и являются характерными для Bosm. stuhlmanmi. Указанное Вельтнеромъ отличіе отъ иныхъ Bosmina, а именно очень короткія антенны 2-ой пары, несущественно: во первыхъ, самое сужденіе объ относительныхъ къ переднему краю rostrum'a размърахъ антеннъ зависитъ въ большой степени отъ положенія экземпляра на препарать⿱⺊口), а, во вторыхъ, длина эта можетъ колебаться въ предълахъ чисто индивидуальной шзмьнчивости, что видно, какъ изъ рисунковъ 9-10, сдъланныхъ по препаратамъ обрабатываемаго матеріала, такъ и изъ сравненія рис. 12 и 14 на таблиць 31 в’ъ работь Lilljeborg'a 8).

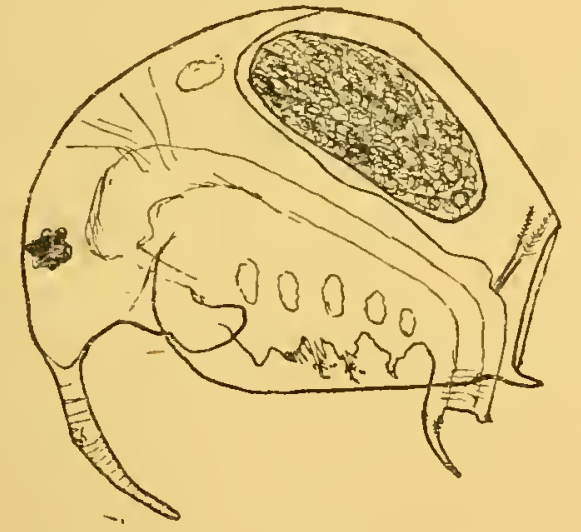

PIIc. 9.

Bosm. longir. v. similis. у велич. 125.

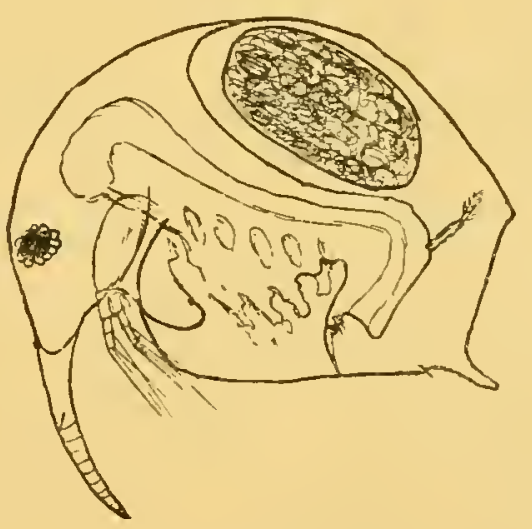

Puc. 10.

Bosm. Longir. r. similis. Увелич. 125.

Какъ видно изъ сравненія рисунковъ 9 и 10, размъръ углубленія у основанія антеннъ первой пары, а также и форма лба

1) Daday. loc. cit. p. 141-142

2) Веред агинъ. Планктонъ водоемовь пол-ва Я-мала. С I a ncera. Ежегодникъ Зоолог. Музея Император. Академін Наукъ; т. 18; 1913; стр.193.

3) Lilljeborg. Cladocera Sueciae. Nova Acta Reg. Societatis Scientiarum Upsaliensis. Ser. UII; Vol. 19; 1901. 
могуть немного калебаться у разныхъ экземпляровъ варіетета; подвержена измбненіямъ также отчасти и общая конфигурація тъла, Шестигранная скульптура створокъ, какъ на это уже указываетъ Дадай미, можетъ быть выражена различно ясно и, даже, отсутствовать.

Bc各 встрбченные экземпляры оказались партеногенетическими самками съ 1-2 яйцами въ выводковой камерь.

\section{Alona pulchella Ki in g.}

ЦҺ́лый рядъ описанныхъ въ разное время, по преимуществу экзотическихъ формъ Дадай объединиль въ одинъ разсматриваемый нами теперь видъ. Онъ не различаетъ въ этомъ видъ даже отдћльныхъ варіететовъ.

Нътъ сомнънія, что видъ этотъ со временемъ будетъ разбитъ на цълый рядъ низшихъ таксономическихъ единицъ, причемъ возможно, даже, что онъ не сохранитъ такого широкаго объема, который ему придаль Дада й ${ }^{2}$ ). Къ сожалънію, я лишен'ь возможности сдълать таксономическій анализъ варіететовъ вида, такъ какъ въ моемъ распоряженіи имъется лишь одинъ изъ нихъ, и то лишь въ нъсколькихъь экземплярахъ, изъ озера Найваша. Варіететъ этотъ ближе всего подходитъ къ описанію и изображенію, данному Дад а ем в для экземпляровъ, найденныхъ въ болоть Bura (tab. VI fig. 32 и 33).

Отличіе моихъ экземпляровъ составляетъ отсутствіе скульптуры на створкахъ.

Брюшной край створскъ моихъ экземпляровъ покрытъ довольно длинными волосками односторонне дистально оперенными.

Обращаясь къ систематическому положенію вида Al. pulchella ling, мы видимъ, что если принимать во вниманіе самокъ, то ближайшимъ видомъ будетъ Al. guttate G. O. S $\mathbf{S}$, съ которымъ и сближаетьь его на основаніи формы саиdа и общаго habitus'a. Дада іi 3 ). Если же принять во вниманіе данное Г. О. Сарсомъ ${ }^{4}$ ) описаніе самцовъ и изображеніе саиdа у самца Дадая 5 ), то форма саида самцовъ рьзко отличается отъ таковой у самцовъ

1) D a d a y loc. cit. p. 142.

2) D a d a y loc. cit. p. 128-130.

3) G. O Sars. Additional notes on Australian Cladocera. Vidensk. Selsk. Forhandling. in Christiania. 1888; № 7; p. 53-59.

4) D a d a y loc. cit. tab. 7 fig. 4.

5) D a d a y loc. cit. p. 130. 
Al. guttata и значительно приближается къ cauda самцовъ Alona rectangula G. O. S a r s. C ъ этимъ видомъ сближаетъ $A l$. pulchella также и способность образовать много различныхъ варіететовъ. Изъ всего этого сльдуетъ, что вопросъ о систематическом'ь положеніи Al. pulchella нужно считать еще неопредъленнымъ.

\section{Alona rectangula G. O. S a r.}

Представители этого чрезвычайно богатаго разнаго рода варіететами вида были встрбчены неоднократно в’ь изсльдованномъ матеріаль.

Сильное варьированіе признаковъ въ этомъ видъ очень затрудняетъ какъ возможность разграничить между собой отдұльные варіететы, такъ и возможность отнести тотъ или иной экземпляръ къ опредъленному варіетету, съ одной стороны, и опредълить ихъ таксономическое значеніе, съ другой стороны.

До т娄ъ поръ, пока систематика этого вида не будетъ разработана на основаніи обширнаго матеріала, нужно, мнъ кажется, провизорно относя формы къ уже установленнымъ варіететамъ, тцательно отмбчать всъ особенности строенія и отличія отъ прежнихъ описаній у встрбчаемыхъ формъ.

Въ изслғдованномъ матеріалъ были встръчены представители сльдующихъ варіететовъ:

a) Var. rectangula G. O. Sars встрбчена въ единичныхъ экземплярахъ въ Викторія-Ніанца возл Entebbe. Характерная cauda изображена на рис. 11.

Согласно опредълительной таблицй, данной Вейгольдомъ ${ }^{1}$ ) для группы видовъ rectangula, разсматриваемые экземпляры слбдовало-бы отнести къ Alona intermedia G. O. S a s по тому признаку,

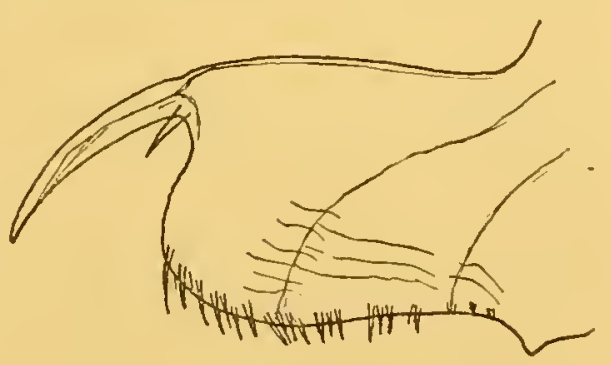

Puc. 11. Alona rectangula v. rectangula. У веліч. 530. что cauda у него слегка расширяется дистально; однако, считая для Alona intermedia наиболье характернымъ не форму cauda, а расположеніе на ней шипиковъ

1) We ig o ld. Biologische Studien an Lyncodaphniden und Chydoriden Iuternat. Revue d. ges. Hydrob. u. Hydrogr. Biolog. Supplem. zu Bd. III $1910 ;$ p. $21-27$. 
въ 2 ряда ${ }^{1}$ ), мы должны по характеру вооруженія саиda отнести разсматриваемые экземпляры къ $A$. rectangula var. rectangula.

б) Tar. bucobensis $1 \mathrm{t}$ eltn. Варіететъ этотъ встрбченъ въ небольшомь количествъ экземпляровъ въ оз. Викторія-Ніанца. Если соглашаться съ систематикой, предложенной В е й г о л д о м ъ

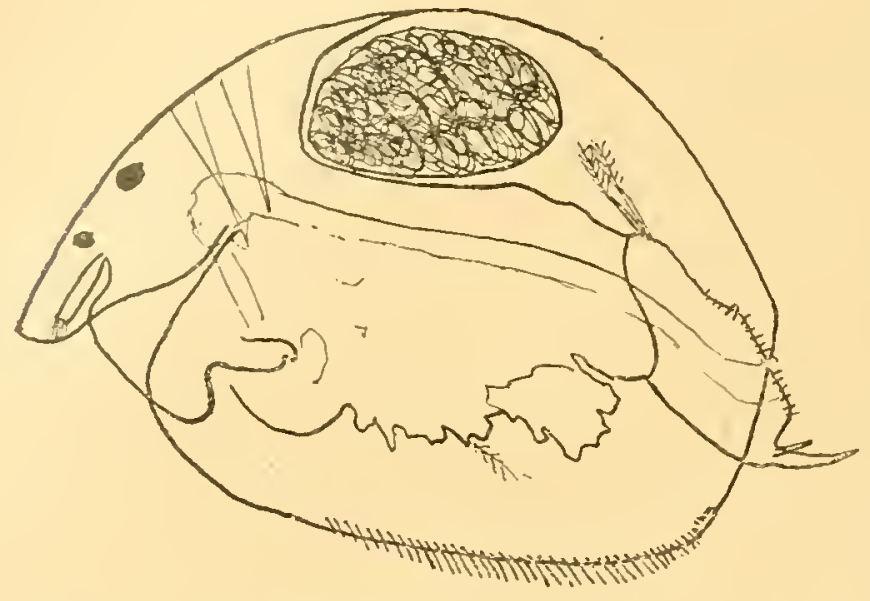

Puc. 12. Alona rectangula v. bucobensis. Уелич. 125.

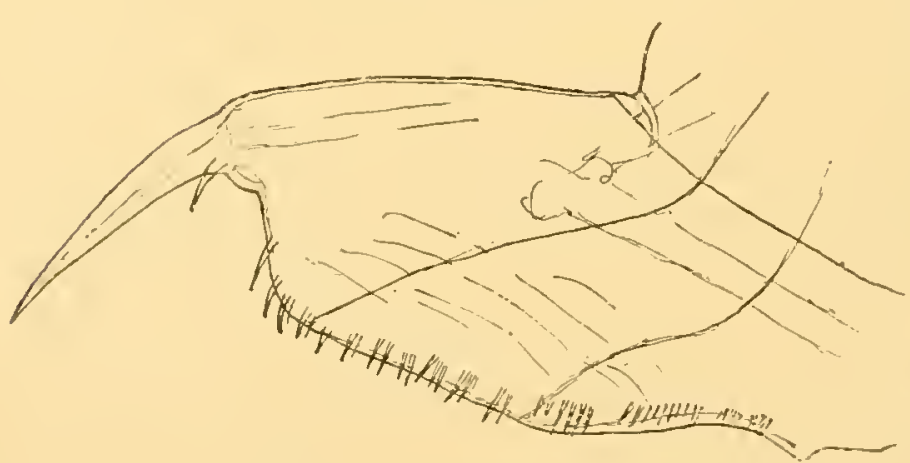

Pre. 13. Alona rectangula var. bucovensis. угелич. 5.30. для видовъ группы rectangula, то варіететъ этотъ близокъ по суживающейся к’ь дистальному концу формғ cauda $\mathrm{kъ}$ var. weltneri (Keilhack); однако, система Вейгольда опирается при различеніи единицъ на признаки врядъ-ли имғющіе существенное таксономическое значеніе, а потому, впредь до выясненія системы этой группы видовъ, я оставилъ за найденными экземплярами ихъ названіе таr. bllcobensis, отмитивъ рисунками характерныя особенности варіетета.

Alonella excisa Fi s cher.

Нъсколько экземпляровъ этого вида встрғчено было въ оз. Викторія-Ніанца, въ мъсть переправы возль Entebbe (лроба № 8). Экземпляры эти ничғмъ не отличаются отъ европейскихъ. До сихъ поръ видъ этотъ встрбченъ былъ въ Африкъ лишь Даца ем ъ 2) въ окр. оз. Викторія-Ніанца.

1) В е р ец а г и ъ. Cladocera Скутарійскаго озера (Черногорія).Работы лабораторіи зоологическаго кабинета II. Вариавскаго Уинверситета за 1912 г., стр. 16.

2) D a d a y loc. cit. $p-123$. 


\section{Chydorus barroisi (Rich.).}

Описанный Richard'омъ подъ именемъ Pleuroxus barroisi, видъ этотьь отнесенъ быль впосльдствіи Сарсом'ь ${ }^{1}$ ) къ роду Chyclorls, куда " относятъ его съ тъхъ поръ систематики. Характерный выростъ на нижне-заднемъ углу створокъ, очень небольшіе размъры т年ла, а также форма canda самца, описаннаго Сарсомъ, 2) сближають, мнғ кажется, скоръе этотьь видъ съ представителями рода Alonella, тьй, больье что сходство по образу жизни уже отмъчено Сарсомъ. ') Однако, въ виду отсутствія точнаго разграниченія родовъ Alona, Alonella, Chydorms и Plenroxus, я провизорно оставляю описываемый видъ въ родъ Chydorus.

Хотя видъ этотъ описывался уже нйсколько разъ ${ }^{4}$ ), однако, въ виду нъкоторыхъ разногласій и неполностей въ его описаніяхъ, я описываю его еще разъ.

Общая форма тьла слабо овальная, почти круглая. Спинной край створокъ равномърно закругленъ; задній край ихъ, образуя со спиннымъ ясно выраженный тупой уголь, самъ по себъ совсъмъ прямоӥ. $\mathrm{C} ъ_{ъ}$ брюшным з краем’ь задній образуетъ закругленный угол 'ь; брюшной край в’ь дистальной своей части почти прямой, въ проксимальной же равномғрно закругленъ. На нижнемъ краю

1) Rich ard. Cladocères, receuillis par M-eur Barrois en Syrie et en Egypte. Révue Biolog. du Nord d. l. France. Tume T'I; p. 16.

2) S a rs. On some South-African Entomostraca raised from dried mud. Tidenskabs—Selskabets Skrifter. I Math.--naturh. Klasse; 1895; № 8: p.25-28.

2) Sars. 1oc, cit. tab. 4; f. 12-13.

3) Sars. loc. cit. p. 28.

4) R i c h a r d. loc. cit.

Sars. loc. cit. 25-28; tab. 4; f. 9-13.

Sars. Contributions to the knowledge of the fresh-water Entomostraca of South-America as shown by artificial hatching from dried material. Archiv for Mathematik og Naturvidenskab. Christiania. Vol. 23; 1901; № 3; tab. XI, f. $1 \mathrm{a}-\mathrm{b}$. 
створокъ, возль нижне-задняго ихъ угла находится шиповидный отростокъ, размғры котораго колеблятся отъ едва замғтнаго до равнаго, приблизительно, половинб длины ungues caudales. У одного экземпляра отростокъ этотъ совершенно отсутствовалъ. Дистальная часть нижняго края створокъ усажена, немного отступя отъ края, рядомъ довольно длинныхъ, но не очень частыхъ, неоперенныхъ волосковъ; проксимальная часть нижняго. края створокъ и передній ихъ край вовсе лишены волосковъ. Поверхность створокъ гладкая, лишена всякой скульптуры.

Rostrum не длинный и довольно тупой.

Антенны 1-ой пары цилиндрическія, немного расширены у основанія, раза въ 3 длиннъе свосй максимальной ширины.

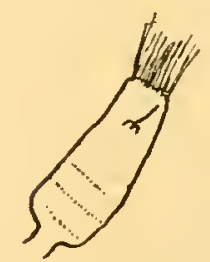

Prсc. 15. Chydorus barroisi. Увел. 540.

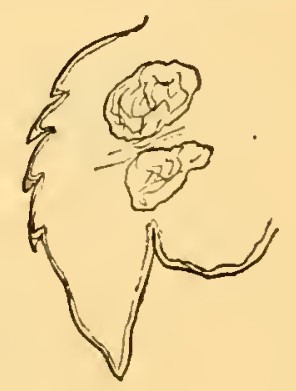

PiIc. 16. Chydorus barroisi. увеліг. 530.

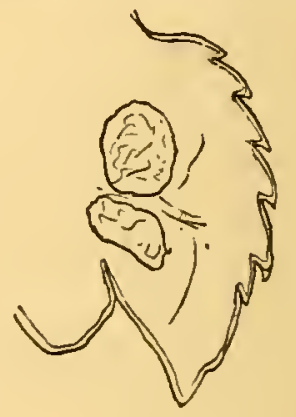

Puc. 17.

Chydorus barroisi. Увелич. 530 .

Чувствительная щетинка находится недалеко отъ дистальнаго конца антенны (рис. 15); антенны не достигаютъ конца rostrum'a. Labrum является характернымъ: оно вытянутое, заостренное на концъ; передній выгнутый край его зазубрен'ь; число зазубринъ

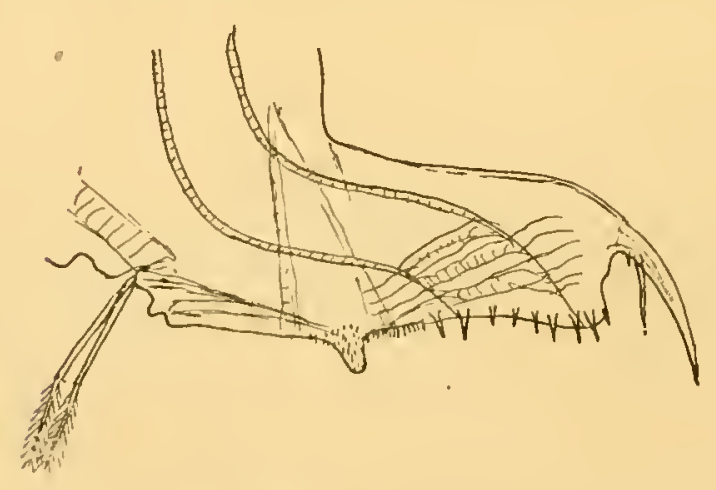

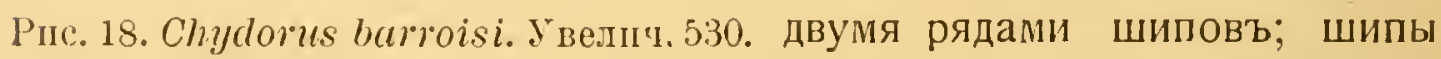
эти узки и остры; число ихъ съ каждой стороны отъ 8 до 10. Ближайшіе къ концу саида шипы крупные, по мъръ же отдаленія отъ конца дълаются мельче; почиваясь съь возрастом'ь; оно равно отъ 4 до 6 (рис. 16 и 17).

Cauda (рис. 18) вытянута, средней ширины, съ ръзко выраженным'ь постабдоминальнымъ угломъ

Задній край вооруженъ по бокамъ анальнаго отверстія

мєняется, повидимому увели- 
сльдніе два шипа, сидящіе дальше всего отъ конца саиda, снова крупные, равные, приблизительно, по размърамъ тьъмъ, которые сидятъ ближе всего къ концу саиda. За рядомъ шиповъ сльдуюют по направленію къ постанальному углу мелкія щетинки, которыя покрываютъ и самъ постанальный уголъ. Каудальные коготки длинные, слегка и равномърно загнутые; у основанія ихъ расположены два базальныхъ шипа, изъ которыхъ дистальный, очень тонкій, достигаетъ $1 / 3$ длины самых'ъ каудальных’ъ коготковъ, проксимальный же очень коротокъ.

Каудальныя щетинки коротки, двучленисты; дистальный членикъ ихъ двусторонне оперенъ. Въ выводковой камерғы находятся $1-2$ партеногенетическихъ яйца. Большинство экземпляровъ были вполнъ̆ прозрачны и только нъкоторые были окрашены въ слабожелтый цвътъ. Кишечникъ набитъ желтовато-зеленой массой, въ которой не удалось различить форменныхъ элементовъ.

Наибольшая длина твла взрослыхъ самокъ колебалась отъ 0,27 по 0,24 mm.; наибольшая высота тйла отъ 0,21 по 0,19 mm. Видъ этотъ встрбченъ въ большомъ количествъ̆ въ оз. ВикторіяНіанца въ окрестностяхъ Энтеббе. Среди большого количества партеногенетическихъ самокъ быль встрбченъ въ пробъ № 7 отъ 29. V. 14 г. одинъ экземпляръ съ эфиппіемъ.

\section{Chydorus sphaericus O. H. M.}

Этотъ широко распространенный и уже прежде не разъ констатированный въ Африкъ́ видъ встрбченъ въ обрабатываемой коллекціи въ оз. Викторія-Ніанца въ окрестностяхъ Энтеббе.

Вс各 встрбченные экземпляры были овальной формы, близкой къ m.-ab. alexandronvii Pog., и огличались сво̆тло-желтымъ цвътомъ своихъ створокъ. Число шипиковъ на заднемъ краю cauda колебалось отъ 6 до 8; у основанія коготковъ находилось 2 базальныхъ шипа, большой проксимальный и меньшій дистальный.

Сльдующая табличка показываетъ распредъдленіе C I a d o c e r a по взятымъ пробамъ планктона. (См. стр. 22).

Бросая общій взглядъ на фауну Cladocera просмотрънныхъ пробъ планктона, мы не можемъ не отмьтить сравнительное ея богатство какъ въ качественномъ, такъ и въ количественномъ отношеніи въ области оз. Викторія-Ніанца. Формъ общихъ съ европейской фауной оказалось сравнительно много; таковыми являются:

Simocephalus serrulatus Ko ch. 


\section{Ceriodaphinia quadrangula}

"var. hamata G. O. S.

Ceriodaphinia laticandata P. E. M.

Bosmina longirostris cum var.

Aloma rectangula r. rectangula G. O. S.

Alonella excisa Fischer.

Chyctorus sphaericus O. F. M.

\begin{tabular}{|c|c|c|c|c|c|c|c|}
\hline №№ водоемовъ. & $\therefore 1$ & o 3 & & & . 5 & & \\
\hline №№ проб́ь планктона & $\therefore 1$ & di 3 & $\therefore 6$ & 으 7 & No & № 9 & . 10 \\
\hline $\begin{array}{l}\text { Diaphanosoma excisum } \\
\text { G. O.S. . . . . }\end{array}$ & 一 & - & p. & p. & 一 & $\mathrm{p}$. & ฯ. \\
\hline $\begin{array}{l}\text { Simocephalus sermalatus } \\
\text { Koch h } \\
\text { Ceriodaphia commita G. }\end{array}$ & Ч. & - & 一 & 一 & - & - & - \\
\hline $\begin{array}{l}\text { Ceriodapmia rigaudi } \\
\text { C. }\end{array}$ & - & 一 & нр. & нр. & p. & - & - \\
\hline Reriodaphmia laticanda- & - & - & ч. & ०. ૧. & ษ. & нр. & нр. \\
\hline 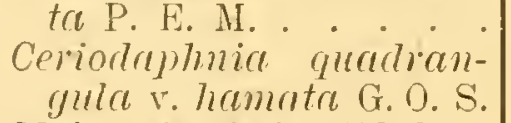 & - & 一 & o. p. & - & - & $\begin{array}{l}\text { ч.p. } \\
-\end{array}$ & - \\
\hline $\begin{array}{l}\text { Moina hartuigi Weltn. } \\
\text { Bosmina longirostris m. }\end{array}$ & - & $=$ & p. & o. p. & нр. & o. p. & ч. \\
\hline $\begin{array}{l}\text { cormuta Jur. } \\
\text { Bosmina longirostris var. }\end{array}$ & - & 一 & нр. & -- & - & - & o. 1 . \\
\hline similis Lillj. & 一 & - & o. p. & $\mathrm{p} \cdot$ & o. $\mathrm{p}$. & нр. & - \\
\hline $\begin{array}{c}\text { Alona rectangula vai. } \\
\text { rectangula G. O. S.. }\end{array}$ & - & - & o. p. & - & - & p. & - \\
\hline $\begin{array}{l}\text { Alona rectangula var. } \\
\text { bucobensis Weltn. }\end{array}$ & - & - & o. p. & - & - & - & $\mathrm{p}$. \\
\hline Alonella excisa Fisch. & - & 一 & - & -- & o. p. & - & - \\
\hline $\begin{array}{l}\text { Chydorus barroisi Rich. } \\
\text { o."F. II. }\end{array}$ & - & - & Ч. ๆ. & $\begin{array}{l}\text { ч. } \\
\text { p. }\end{array}$ & $\begin{array}{l}\text { ч. } \\
\text { p. }\end{array}$ & $\begin{array}{l}\text { ч. } \\
\text { нр. }\end{array}$ & - \\
\hline
\end{tabular}

Формы эти составляютъ больше половины общаго числа найденныхъ въ коллекціи. Эндемичной для Африки является:

\section{Moina hartwigi IV e 1 t.}

Остальныя формы имъютъ болъе или менъе широкое распространеніе въ экзотическихъ странахъ; таковы:

Diaphanosoma excisum G. O. S.

Ceriodaphnia cormuta G. O. S.

"rigandi Rich. 
Alona pulchella Ki ing.

Alonia rectangula var. bucobensis $\mathrm{W}$ e $\mathrm{lt}$.

Chydorus barroisi R i ch.

Для сужденія о распредђленіи формъ по различнымъ водоемамъ и ихъ участкамъ обрабатываемый матеріалъ слишкомъ недостаточенъ; однако, можно указать на одну особенность этого распредъленія. Пробы изъ Викторія - Ніанца взяты вСъ изъ пелагической его области и, тьмъ не менъе, въ нихъ присутствуютъ въ значительномъ количествъ представители рода Moina, всъ европейскіе виды котораго обитаютъ исключительно либо въ прибрежной области озеръ, либо, даже, въ небольшихъ мелкихъ водоемахъъ.

Встрбченные въ пелагической же области Викторія-Ніанца европейскіе виды

Cerioctaphnia laticaudata,

Alona rectangula $и$

Alonella excisa

были найдены лишь въ нъсколькихъ экземплярахъ, а потому ихъ нахожденіе въ необычной для нихъ въ, средней Европъ пелагической области можетъ быть объяснено случайнымъ ихъ сюда заносомъ.

Фактъ перехода въ пелагическую область на югъ тбхх формъ, которыя въ среднихъ широтахъ пріурочены къ прибрежной области, уже мною отмБчался въ одной изъ предыдущихъ работъ ${ }^{1}$ ), и въ этихъ новыхъ данныхъ онъ находитъ себъ лишь новое подтвержденіе.

Половой періодъ, констатированный для Simocephalus serrulatus $\mathrm{K}$ o ch въ ямъ, наполненной водой, въ окрестностяхъ Энтеббе, свидъ̆тельствуетъ, повидимому, о полициклическомъ состояніи этого вида въ изслъдованной мб̆стности. Единичное же нахожденіе эФиппіальной самки Chydorus barroisi Rich. никакихъ заключеній дълать не позволяетъ.

1) Г. Ю. В е р е щ а г и н ъ. Къ вопросу о распред'вленіи планктонныхъ организмовъ по водоемамъ и ихъ участкамъ. Протоколы 0-ва Естествоиспытателей шри Имш. Варшавскомъ Унив-ть́ за 1914 г. 


\title{
Some remarks on the fauna of Ento- mostraca of Central Airica.
}

\author{
G. VERESTCHAGIN.
}

During his journey in Central Africa, Professor V. Dogiel has taken several (10) samples of plancton from the lake Victoria Nyanza, and some other places. He was so kind as to put this material at my disposal for the purpose of investigating the Entomostraca to be found there.

In the present paper I am giving the description of Cladocera which were found in these samples; the material was taken from the following localities.

Sample 1. A small water pit corered with regetation in the neighbourhood of Entebbe (22. V. 1914).

"2. Lake Chala. The lake occupies abont 2 sq. miles, and presents the crater of an extinct vulcano. The sample was taken in the littoral zone (3. VIII. 1914).

"3. Lake Naivasha. The lake occupies about 100 sq. miles; its banks are covered with vegetation (papyrus). The sample was taken in the littoral zone (July, 1914).

"4. Lake Nakuru. Small (ab. 25 sq. m.) and shallow lake with banks covered with regetation; the water is brackish. The sample was taken in the littoral zone (2. VII. 1914).

Sample 5. Lake Victoria Nyanza.

n 6. Lake Victoria Nyanza. The sample was taken on the surface of the water opposite the town Entebbe (30. V. 1914).

"7,8,9. Lake Victoria Nyanza. The sample was taken in the ricinity of Entebbe in crossing a narrow bay of the lake (29. V.1914). 
Sample 10. Lake-Victoria Nyanza. The sample was taken in the Kavirondo Bay, in the vicinity of the town Kisumu (June, 1914).

All the samples from Victoria Nyanza were taken in the pelagic zone.

The following forms of Cladocera were discovered in the samples named above.

Diaphanosoma excisum G. O. S. resembles more closely its variety'longimanus Ekm. amongst the specimens of which are found transitory forms to the typical $D$. excisum, on account of the length of the 2-nd pair of antennae. The number and arrangement of denticles on the postero-inferior angle of the valves is variable (fig. 1).

Simocephalus serrulatus Koch. In sample No.·1 were found females with the ephippium, as well as males.

Ceriodaphnia cornuta G. O. S. The cephalic spine is single (fig. 2), not double, although it is analogous to the spine of Scapholebris mucronata. No transitory forms between C. cormuta and Cer. rigaudi $\mathrm{R}$ i ch. were discovered. The ralves do not diverge in the postero-dolsal angle, but there are two spines (fig. 5) which were by some authors taken for the free edges of the valves. Sometimes these spines are absent.

Ceriodaphnia rigaudi $\mathrm{R}$ i ch. Disagreements of authors in the description of this species are caused by the fact that it is found in several varieties. Some of the morphological characters in the specimens investigated by me proved to be constant. Such are: 1) the frontal spine; 2) the form and structure of cauda; 3 ) the number of denticles on the dorsal edge of cauda; 4 ) the denticles on the fornix. Other characters are variable, as, e. g. the measurements of the eye, the frontal spine, the height of the head, the absolute size of the body, the ratio between the length of the body and its width.

Ceriodaphnia quadrangula v. hamata G. O. S. differs from the European species by a more obtuse postero-dorsal angle of valves and several double spines on the dorsal margin of the cauda.

Ceriodaphnia laticaudata P. E. M. The specimens investigated by me differed from the European ones by the less elongated head. The reticulation of the head is badly expressed. 
Moina hartwigi Weltn. The number of denticles on the dorsal margin of the canda is $5-8$.

Bosmina longirostris m. cornuta Jur. presents a typical form. The rariety similis is identical to Bosmina stuhlmanni which was described by Weltne from the lake Victoria Nyanza. The form of the 1--st pair of antennae, the hollows on the forehead at the bases of the antennae, and the form of the valves vary (fig. 9-10).

Alona pulchella King is nearer to $A$. vectangula than to $A$. guttata, especially if to compare the males of these forms.

Alona rectangula var. rectangula G. O. Sars is found in the typical form. The variety bucobensis Veltn. presents a very insufficiently studied form.

Alonella excisa is quite similar to the European form.

Chydorus barroisi. $\mathrm{Rich}$. This form resembles the genus Alonella but we are leaving it provisionally in the genus Chydorus.

Chydorus sphaericus 0 . S. M. All the specimens that were at my disposal were elongated, and coloured yellowish.

It must be marked that in the pelagic. zone of Victoria Nyanza was found one species of the genus Moina; whereas all the European representatives of this genus inhabit the littoral zone and small basins. 


\title{
№ 6 .
}

\section{Новые и мало извђстные виды семейства Diopsidae Британский Восточной Африки,}

\author{
Ф. 0. ЭГГEРСЪ.
}

On some new and incompletely known species of the family Diopsidae from British East Africa.

F. 0. EGGERS. 



\title{
Новые и мало извжстные виды се- мейства Diopsidae Британской Bo- сточной Африки.
}

\author{
Ф. 0. ЭГГЕРСЬ.
}

Ізъ Зоотомпескаго кабннета Нмператорскаго Петроградскаго Университета.

Благодаря любезности проф. В. А. Догеля, я получилъ для научной обработки небольшую коллекцію Diopsidae, „рогатыхъ мухъ“, собранныхъ имъ и И. И. Соколовымъ во время ихъ экспедиціи въ Британскую Восточную Африку льтомъ 1914 года.

Матеріалъ былъ большей частью фиксированъ и консервированъ по новъйшимъ методамъ, и проф. В. А. Догель предложилъ мн市 взяться за гистологическое изслғдованіе оригинальныхъ глазъ этихъ животныхъ, пока еще вовсе не изученныхъ.

Посль того, какъ я познакомился съ очень разбросанной литературой для опредъленія изсльдованныхъ животныхъ, оказалось, что значительное число имъвшихся у меня Diopsidae пока еще не извъстно. Поэтому я счелъ полезнымъ дать систематическую обработку полученнаго мною матеріала, которая и составляетъ предметъ настоящей статьи.

Въ отношеніи Diopsidae до сихъ поръ лучше всего изсльъдованы Зондскіе острова въ работахъ Meijere и ran der Vulpa. Въ Африкъ во многихъ мбстностяхъ, особенно въ центральныхъ и восточныхъ ея частяхъ, D i opsidae вообще еще не были собираемы. Лишь изъ Германской Восточной Африки въ 1912 году Speiser'oмъ были описаны 3 новыхъ вида, добытые экспедиціей Sjöstedt’a на Килиманджаро и Меру. Британская Восточная Африка относительно данной группы еще совершенно не изсльдована.

Настоящій матеріалъ былъ собранъ въ двухъ мйстахъ; вопервыхъ, въ Мабирскомъ льссу (Mabira), километрахъ в’ 50-ти съвернъе Викторіи Ніанцы. Это сырой лғсъ, гдъ́ Di ops idae 
встръчаются на растеніяхъ вдоль льсныхъ тропинокъ. Здъсь онъ были пойманы въ серединғ іюня. Другое мъсто нахожденія представляють берега р. Луми (Lumi) близъ озера Чала (Chala), восточнъе Килиманджаро, гдъ сборы производились въ началғ августа, т. е. въ сухое время года. Въ виду этого мухи были найдены исключительно у самой воды, сидящими на поверхности камней и листьевъ, иногда по нъсколько десятковъ сразу. Сльдующая табличка даеть перечень изслғдованныхъ видовъ съь обозначеніемъ мғасть нахожденія и числа экземпляровъ.

1. Diopsis ichneumonea L. Mabira $1 \sigma^{\pi}$

2. " finitima n. sp. " , $1 \sigma^{\pi}$

(?) 3. " $\quad$ fumipennis Tistw. " 1 ㅇ

4. " tenuipes Wstw. Chala. $2 \sigma^{\pi}$

5. $\quad$ thoracica W I tw. , $1\left(\sigma^{*} ?\right)$

6. " sulcifrons Bezzi Mabira 1 우

7. Diasemopsis varians n. sp. Chala 2 o $\sigma^{7} 4$ 우

8. $" \quad$ silvatica n. sp. Mabira 1 ㅇ

9. $\quad$ incerta n. sp. " $2 \sigma^{7}$

10. " pulchella u. sp. " 1 के 1 ㅇ

Изъ этого перечня явствуетъ, что значительное большее разнообразіе формъ имъется въ Мабиръ.

Переходя къ описанію имъющися у меня формъ, я считаю пріятнымъ долгомъ выразить проф. В. А. Догелю сердечную благодарность не только за разрґшеніе пользоваться лабораторіей Зоотомическаго Кабинета и за предоставленіе мнъ матеріала, но и за цұнные совъты и интересъ къ моимъработамъ.

\section{1) Diopsis ichneumonea $L$.}

B i gra a Ins., 5, Amoen. Acad., V'lil. 307 (1775).

F iissly Archir. Ins. I tab. VI p. 19 (1781).

Gmelin. Syst. Nat. Tom. I pars Y, p. 2829.

O I i vi e r. Encycl. métl., VI., 276. (1789).

D $0110 \mathrm{v}$ a n Epit. N. Hist.. IX pl. 2. (1803).

F a br i c i us. Syst. Autl. p. 201.

Isatreille, Dict. hist. nat. Deterv, XXIV, 435, tab. 12, f. 6-7. 1804.

Hist. nat. Gen. XW 1. 376, tab. 14., f. 6-7 (1805).

Gen. Crust. et Ins. IN p. 353 (1809).

lígn. anim. Col. I IX, p. 477, pl. D, f. 5, 6. III p. 650.

dourn. Soc. Med. et hist. nat. Bordeaux I (1796). p. 77.

L a m a rk. Animals sans vertibres IH, 370.

D a $1 \mathrm{~m}$ a n. Vet. Acad. Handl. XXXVIII, 211. (1817). 
Okens Isis V. (1820) p. 502.

Dalman. Anal. ent. (1823) p. 3-..4.

Wiedemann. Auss. Zweifl., II. 5 57. 1. (1830).

We s tw o od. Trans. linn. Soc. XVIl. p. 292., tab. IX, f. 1. (1835).

S l) a w. Gen. Zool. lus. II p. 104.

II a c q u a ret. Suites ì Buff. II. 485. 1. 1835;

B l a n c ha de Hist. nat. Ins. IlI. 622. (1840).

Bigot. Anu. Soc. entom. France. LX. 366. (1891).

I ii 11 e r. Verl. Ges. dentsch. Naturf. LV. (2). p. 133 (1894)

B ezzi. Bull. soc. entom. ital., XXXIIl. 23. 36. (1901).

Rond a ni. BuII. soc. entom. itaI. 39, p. 167. (1907).

Это первый сдълавшійся извьстнымъ видъ Diopsidae, описанный уже Линнеемъ. Къ сожалбнію, описаніе и рисунокъ Линнея недостаточны, чтобы характеризовать опредъленный видъ и нбъкоторые признаки этого вида различными авторами истолковываются по своему, что вызываетъ рядъ недоразумъній. Уже Вествудъ (W e stw o o d) упоминаетъ, что ему пришлось сдвлать тщательный анализъ данныхъ Линнея, такъ какъ отъ этого зависъвла квалификація одного или двухъ его собственныхъ видовъ. Найденные впосльдствіи въ другихъ мъстностяхъ Diорsidae были опредъляемы нғкоторыми авторами (Bigot, Bezzi и Rondani), какъ D. ichneumonea L., безъ описанія экземпляровъ, а потому вопросъ оставался открытымъ, тождественны ли эти формы, даже если они и соотв宩ствуютъ описанію Линнея. Этот”ь пробълъ особенно остро чувствуется въ зоогеографическихъъ вопросахъ. Напримъръ, въ перечнъ Diopsidae Африки Рондани (Rondani) называетъ мъстностями нахожденія D. ichneumonea L. Гвинею, Сенегалъ, Абиссинію и Эритрею, какъ на основаніи собственныхъ данныхъ, такъ и данныхъ выше названныхъ авторовъ. Пока тождественность встрбчающихся тамъ формъ не доказана, мнғ кажется, что къ этимъ даннымъ нужно относиться съ осторожностью.

Въ моемъ матеріаль также есть форма, которую можно отнести к'ь D. ichneumonea L. На основаніи выше-сказаннаго я считаю необходимым'ь дать описаніе ея.

Длина 7 мм. Голова красновато-коричневатая, вооруженная зубцомъ по объимъ сторонамъ рта. Хоботъ свътло-сърый, щупики свътло-коричневые. Лобъ выпуклый, съ широкой, черной linea arcuata, продолжающейся тонкой линіейна рога до основанія усиковъ. Рога одного цвътта съ головой, относительно немного расходящіеся; длина ихъ равна длинь груди. М官сто прикрьлленія щетинки, къ сожальвнію отломанной, ближе къ глазамъ, чь̆ыъъ къ головъ. 
Усики желтовато-коричневатые, основная часть ихъ щетинки къ дистальному концу темнъе. Грудь черная, съ слабымъ матовосърымъ отливомъ. Шейка (prothorax) и щитокъ черные. Боковые шипы заднегруди желтые, короткіе; шипы щитка длинные, почти прямые, желтые съ чернымъ кончикомъ. Ляшки коричневато-красныя, одного цвъта съ брюшкомъ. Бедра, особенно сильно вздутыя переднія бедра свътлће брюшка, желто-коричневыя. Конечные шипы у посльднихъ паръ бедерұ имъются, но слабо развиты. Переднія и заднія голени темно-коричневыя, среднія голени одного цвъта съ бедрами. Лапки коричнево-желтыя, покрытыя маленькими черными щетинками. Три среднихъ членика переднихъ лапокъ темнъе остальной ихъ части, темно-коричневые. Жужжальца бъловатыя. Крылья до своей конечной четверти со слабо буроватымъ налетомъ. Конечная четверть стекловидно прозрачна и имбетъ характерное пятно перецъ верхушкой между 2 и 4 продольной жилкой ( $\mathrm{R} 2+3$ и M), которое немного переходитъ черезъ посльднюю. Жилки у основанія коричневыя, къ концу темнъе.

Брюшко, равномърно расширяющееся кзади, покрыто у основанія немногими бълыми волосками. Первый болъе длинный членикъ безъ темно окрашенной наръзки, указывающей на составъ его изъ нбсколькихъ сросшихся члениковъ, а имъется лишь слабое вдавленіе на этом'ь мъст方. Отсутствіе яснаго надръза замғчается также и на рисункъ Линнея. Цвътъ этого болье длиннаго членика темно-буровато-красный; вентрально онъ свътлъе; основной конецъ, также какъ и дистальный-черные. Остальные членики черные.

Отличія моего экземпляра отъ типа Линнея состоять т: обр. въ болье темныхъ усикахъ, въ черномъ цвът各 обоихъ концовъ перваго, длиннаго членика брющка и въь буроватомъ налеть на крыльяхъ. Эти признаки настолько незначительны, что они никакъ не могутъ служить достаточнымъ основаніемъ къ обособленію новаго вида; в`ъ крайнемъ случаъ мы имћемъ дйло съ мъстной разновидностью. Зато, если считать данную форму идентичной съ линнеевской $D$. ichneumonea. L., мы можемъ установить т各 признаки, не упомянутые Линнеемъ, относительно которыхъ спорили Вествудъ съ Дальманомъ, а именно: черную шейку, буровато-красный первый членикъ брюшка и бъловатыя жужжальца.

Единственный экземпляръ, повидимому самецъ, изъ Мабиры 12 VII. 


\section{Diopsis finitima n. sp.}

(Фиг. 1).

Этотъ видъ очень близокъ къ D. apicalis Dalm., но по н务оторымъ особенностямъ отличается отъ всъхъ представителей той группы трудно различимыхъ Diopsidae, которые вс6 такъ гохожи на типъ apicalis Dalm.

Длина 7 мм., ширина головы съ глазными стебельками $6 \frac{1}{3}$ мм., длина крыльевъ $5 \frac{1}{4}$ мм.

Голова, равномбрно суживающаяся ко рту, желто-коричневаго цвъта. Лицо свътлъе темени. На лбу, выше linea arcuata, большое, рбзко ограниченное черное пятно; ниже ея-другое пятно, меньше перваго. По объимъ сторонамъ рта по одному нбжному зубцу. Хоботъ съровато-желтый, щупики св втло-желтые. Глазные стебельки длиннъе головы и груди вмъсть взятыхъ, при основаніи ръзко отграничены отъ головы благодаря иной окраскъ. Ихъ цвътъ коричневый или бурый; ближе къ дистальному концу, ч६ вато-коричневые, съ черной щетинкой. Глаза темно-коричневые. Грудь черная, со слабымъ матово-сърымъ оттвнкомъ. Длинная шейка и щитокъ черные. Боковые шипы короткіе, желтаго цвъта. Щитковые шипы длинные, острые, гораздо менъе расходящіеся, чьзъ у всъхъ другихъ видовъ группы apicalis D a l m.

Жужжальца бълыя. Ляшки свьтло-желтыя. Переднія бедра вздутыя, коричнево-желтыя; остальныя бедра немного свйлле. Объ послбднія пары бедеръ со слабо развитыми конечными шипами. Переднія голени коричневыя, среднія голени коричнево-желтыя; заднія также коричнево-желтыя, но по бокамъ близко къ основанію и у дистальнаго конца съ темно-бурыми, продолговатыми пятнами, такъ что, если смотрбть сбоку, онб кажутся темно коричневыми, съ широкой свътлой лентой въ серединъ. Переднія лапки болће темно-коричневыя, чймъ остальныя.

Крылья стекловидно-прозрачныя, со слабо-бурымъ налетомъ въ серединъ, по объимъ сторонамъ верхней поперечной жилки, и съ пятномъ того-же цвъта на концб 3-ей продольной жилки (R $4+5$ ).

Брюшко кзади расширяется (abdomen clavatum), вентрально немного вогнуто. Первый, болъе длинный членикъ до поперечнаго надръза, остатка границы двухъ сросшихся члениковъ, чернаго цвъта. Остальная часть его красно-коричневая. По бокамъ, на высоть́ надръза этотъ членикъ свъ̆тлье (см. фиг. 1). Нижняя, вентральная сторона членика бурая, у обоихъ концовъ темнъе. 
Н务оторыя части т臬ла покрыты бблыми нбжными волосками, а именно, спинная часть брюшка, особенно у основанія, и лицо. Бедра, за исключеніемъ передней пары, имъюютъ слабый волосистый покровъ. Голени и лалки покрыты нғжжными щетинками.

Признаки, отличающіе этоть видъ оть apicalis Dalm., заключаются въ слабо расходящихся щитковыхъ шипахъ, въ черномъ цв片 основной части брюшка, въ мало развитомъ конечномъ пятнђ крыла и въ налет各 на серединь грыла.

1 экз. љ, изъ Мабиры.

\section{Diopsis tenuipes Wstw.}

Westwood. Trans. Linn. Soc. XVII p. 298, tab. IX, f. $5 \delta^{\text {T }}$ (1835).

" $"$ aynart. Dipt. exot. $1842^{*}$ p. 395

p. 545, tab. XXVIII f. 5 ㅇ․

Farsch. Berl. Ent. Zeitschr. XXXI. 1887 p. 380.

Два самца, въроятно, относятся к’ этому виду. На головь, ниже linea arcuata находится небольшое черное пятно, зато другое пятно, выше названной линіи, имғюющееся у D. finitima m., отсутствуетъ. Брюшко широкое, плоское, свьтло-коричневатокраснаго, почти кирпично-краснаго цвъта, какъ у thoracica IV stw. Имъющіеся у меня экземпляры изъ Узумбуры темнъе. Бока брюшка, а также лицо и переднія бедра покрыты волосками. Крылья имъютъ относительно слабый, бурый налетъ. Переднія лапки почти черныя.

2 б $\sigma^{\pi}$ съ озера Чала 2 VIII, высушеные экземпляры.

\section{? Diopsis fumipennis Wstw.}

Westwood. Trans. Linn. Soc. XVII p. 302, tab. IX, f. G (1835).

Одинъ экземпляръ, далеко не въ безупречной сохранности, на первый взглядъ напоминаетъ tenuipes Wistw. Но онъ отличается окраской брюшка, снабженнаго тремя шпрокими темнобурыми поперечными полосами у задняго края переднихъ двухъ члениковъ и у насъчки перваго, болъе длиннаго членика. Кромь того, у этого экземпляра ноги отличаются болье свътлой, желтоватой окраской. Голова, къ сожальнію, взята для гистологическихъ изслғдованій, такъ что нельзя установить, чернаго ли она цвъта. Общій цвътъ экземпляра пострадалъ отъ фиксировки пикриновой кислотой. Но, по общему облику и главнымъ образомъ по выше- 
упомянутымъ двумъ признакамъ этотъ экземпляръ очень похожъ на нъсколько экземпляровъ изъ Узумбуры, которые я принимаю за разновидность fumipennis, съ поперечно-полосатымъ брюшкомъ.

1 q изъ Мабиры 12 VI.

\section{Diopsis thoracica. Wstw.}

Trans. Linn. Soc. Lond. XVII 1837 p. 306-307, Tab. IX., f. 15.

Кромь одного экземпляра отъ проф. Догеля, передо мною имъется еще 8 экземпляровъ коллекціи.Ш таудингера изъ Сомалиланда и Занзибара, которые всъ совершенно сходны другъ съ другомъ и несомнънно относятся къ виду thoracica W stw. Только въ одномъ важномъ признакъ они не соотвьтствуютъ описанію В ествуда, а именно. въ присутствіи конечных'ь шиповъ на среднихъ бедрахъ. Этоть признакъ имъетъ значеніе, но мнб̆ кажется нужно принять въ соображеніе то обстоятельство, что типъ Вествуда, какъ онъ самъ говоритъ, не былъ въ безупречной сохранности, а потому возможно, что названные шипы у него были отломаны.

Лобъ окрашенъ въ основной цвєтъ животнаго, красноватый, не переходящій въ черный. Въ медіанномъ направленіи онъ является немного бороздчатымъ. Лицо немного свътльље лба, желтоватое. Усики, которые были отломаны у типа Вествуда, немного свътлыъе цвъ̆та глазныхъ стебельковъ. Боковые шипы цвъта твла, а не желтые. Щитковые шипы, также отломанные у типа Вествуда, въ концевой части немного загнуты вверхъ, (въ спинномъ направленіи). Боковыя пластинки, за исключеніемъ пластинокъ среднегруди, съ съроватымъ отливомъ. Такого же отлива и основная часть брюшка, въ видъ матовой поперечной ленты. Почти все тъло, за исключеніемъ глазъ и глазныхъ стебельковъ, покрыто волосками. Крылья прозрачныя, но съъ желтымъ оттбнкомъ.

1 экз. съ рбки Луми 2 VIII.; 8 другихъ экземпляровъ изъ Занзибара и Сомалиланда.

\section{Diopsis sulcifrons Bezzi.}

Ann. Soc. Ent. Belgique 52. 1908, p. 387.

Одинъ изъ моихъ экземпляровъ въ главныхъ признакахъ соотвб̆тствуетъ описанію $D$. sulcifrons Bezzi, отличаясь, главнымъ образомъ, отсутствіемъ коричневыхъ пятенъ на груди, а 
также присутствіемъ чернаго конечнаго пятна на крылъ. Такъ какъ описаніе Бецци довольно кратко и не совсъмъ детально, то необходимо дать болъе подробныя данныя относительно этого вида.

Длина $8^{1} / 2$ м. Ширина головы съ глазными стебельками $63 / 4 \mathrm{mm.}$ Голова у моего экз. отръзана и, можетъ быть, принадлежала другому экз., почему на ней и не останавливаюсь. Она отличается отъ головы sulcifrons Bezzi болъе темнымъ черно-бурымъ цвътоољ.

Грудь и шейка черныя, спинка груди съ блескомъ, боковыя пластинки съ матово-сърымъ отливомъ, щитокъ коричневый, щитковые и боковые шипы свбтло-коричневые, также и ляшки. Щитковые шипы на концб черные. Переднія бедра сильно вздуты, свбтло желто-коричневыя. Остальныя бедра немножко темнъе, на дистальномъ конць снабжены шипами. Переднія голени чисто коричневыя, среднія голени такого-же цв бта, какъ и соотвбтствующія бедра, заднія голени тоже желто-коричневыя, за исключеніемъ боковыхъ сторонъ ихъ концовъ, окрашенныхъ въ черно-коричневый цвътъ. Лапки цвћта соотвътствующихъ голеней (заднія лапки желто-коричневыя).

Крылья прозрачныя, желтоватыя съ черноватымъ, неотграниченнымъ ръззко конечнымъ пятномъ между 2 и 4 продольными жилками. (Rr-3 и M). Жужжальца бъловатыя.

Форма брюшка широкая, плоская, съ сильно укороченными задними члениками, почти какъ у thoracica. Цвьть брюшка грязно красно-бурый, темнъе чъмъ у thoracica Wstw. Тъло покрыто волосками, но слабъе, чъмъ у thoracica. Насъчка на первомъ, длинномъ членикъ отсутствуетъ.

Такъ какъ у меня имъется еще 3 экземпляра Diopsis Императорской Академіи наукъ изъ Узумбуры, не совсъмъ соотвйтствующіе описанію sulcifrons $\mathrm{Bezzi}$, но и не совсъиъ тождественныя съ вышеописаннымъ, то я предполагаю, что видъ этотъ нбсколько варіируетъ, смотря по мъсту обитанія. Выше описанный экземпляръ-самка (типъ B сzzі былъ самецъ изъ Ирингуи въ Конго?) изъ Мабиры. $12 \mathrm{VI}$.

\section{Genus Diasemopsis Rond.}

Rondani. Ann. Mus. Cir. Gen. VII, 1875, p. 442.

Bi got. Ann. S. Ent. Fr. (5) X. 80, p. 91.

Прежде чъ̆ъ перейти къ описанію сльдующихъ видовъ, относящихся къ роду Diasemopsis R oud., мнъ хочется вставить 
нъсколько общихъ замъчаній относительно этого рода. Рондани въ 1875 году раздълилъ родъ Diopsis L. на нъсколько новыхъ родовъ, изъ которыхъ насъ здъсь интересуютъ два новыхъ рода: Teleopsis и Diasemopsis. Первый родъ, съ типомъ Teleopsis syliesii W stw. отличается главнымъ образомъ присутствіемъ особой пары грудныхъ шиповъ у мъста прикрълленія крыльевъ. Родъ же Diasemopsis, съ типомъ D. aethiopica $\mathrm{R}$ ond., на концй щитковыхъ шиповъ имъетъ еще по особой щетинкъ.

Въ моемъ матеріаль приблизительно половина видовъ не. относится къ типичному роду Diopsis, обладая щетинкой на концъ щитковыхъ шиповъ. Я отношу эти виды къ Diasemopsis Roud. несмотря на то, что у всъхъ нихъ встрћчается еще щетинка на спинкъ, медіально отъ мъста прикрєпленія крыльевъ, которая могла бы указывать на принадлежность ихъ къ Teleopsis Rond. Хотя у меня и нътъ Teleopsis для сравненія, я полагаю, что названная щетинка не гомологична шипу у Teleopsis Rond. Я это полагаю потому, что, по крайней мърғ, у одного изъ видовъ, D. varians m., имъется еще вторая щетинка, передъ мъстомъ прикръпленія крыльевъ, которая скоръе соотвътствуетъ шипу Teleopsis, такъ какъ ванъ-деръ-Вульпъ у Teleopsis sykesii ясно высказываетъ, что шипъ находится пе ре д ъ мъстомъ прикрғпленія крыльевъ. Также, кромъ того, у разныхъ видовъ Teleopsis, судя по рисункамъ Вествуда и ванъ-деръ-Вульпа мы имъемъ дъло съ сильно развитыми шипами, обыкновенно особо окрашенными, а не съ щетинками, почему мнъ и кажется, что $D$. varians m. нужно отнести къ Diasemopsis R ond.

Щетинка, расположенная на спинъ болъе медіально отъ мъста прикрђпленія крыльевъ, встръчается у всъхъ моихъ экземпляровъ Diasemopsis, и поэтому странно, что она не упоминается другими авторами. Правда эти щетинки легко отламываются, также какъ и щитковыя щетинки. Онь имблись, можетъ быть, и у нбкоторыхъ ранъе описанныхъ видовъ, но тамъ о нихъ не упоминается въ видовомъ діагнозъ. Поэтому теперь нельзя съ точностью установить, которые изъ ранъе описанныхъ видовъ относятся къ Diasemopsis Rond. и какіе родовые признаки, кромъ щитковыхъ щетинокъ, присущи еще этому роду. У моихъ экземпляровъ есть еще одинъ общій признакъ-это отсутствіе зубцовъ по бокамъ рта. У всъхъ экземпляровъ боковые шипы короткіе и тупые, щетинки же на глазныхъ стебелькахъ, за исключеніемъ $D$. varians m., сильно развиты. Конечные шипына заднихъ бедрахъ отсут- 
ствуютъ, ясно выраженъ половой диморфизмъ въь окраскъ брюшка. у самокъ обыкновенно на брюшкъ преобладаетъ или, по крайней

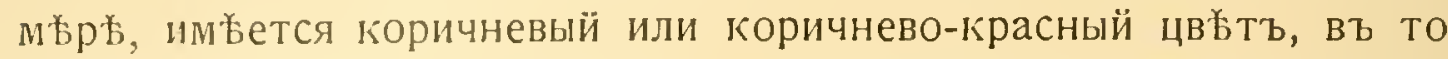
время какъ самцы обыкновенно совершенно черны. Различіе въ цв各т考 доходитъ до того, что въ нъкоторыхъ случаяхъ трудно установить, относятся ли вообце эти животныя къ одному и тому-же виду, или къ различнымъ.

Изъ Diopsidae, описанныхъ до установленія рода Diasemopsis, только у двухъ упоминается присутствіе щетинокъ на шитковыхъ шипахъ: это D. macrophthalma D a $1 \mathrm{~m}$. и D. signata D a 111 . Ихъ, значитъ, сльдуетъ относить теперь къ p. Diasemopsis Rond. Всъ до сихъ поръ извьстные виды Diasemopsis найдены въ Африкъ. Изъ фауны Зондскихъ острововъ лишь въ посльднее время описанъ любопытный видъ Teleopsis rubicunda r. d. Vulp., имъющій короткія щетинки на щитковыхъ шипахъ, но который по среднегруднымъ шипамъ и всему облику нужно отнести къ p. Teleopsis Rond.

Здъсь сльдуетъ отмътить что къ чиспу родовъ, имъющихъ родственныя отношенія къ Diasemopsis, прежде относился еще родъ Hexechopsis Rond. (типъ Diopsis beccarii изъ Эритреи) на основаніи присутствія у него щетинокъ щитковыхъ шиповъ. Этотъ родъ впосльдствіи былъ принятъ Остенъ-Сакеномъ за синонимъ Sphyracephala Gray, рода совершенно обособленнаго, характернымъ признакомъ котораго является присутствіе алюлы. Самъ Рондани съ этой перестановкой, въроятно, согласился, такъ какь въ его перечнғ Diopsid a e 1907 года мы находимъ D. beccarii подь названіемъ Sphyracephala beccarii Rond. Родъ Hexechopsis слъдовательно можно считать лишнимъ. Родъ Sphyracephala представленъ въ африканской фаунъ еще однимъ видомъ, Sphyracephala africana Karsch изъ Восточной Африки. Другіе роды Diopsidae, кромъ упомянутыхъ, въ африканской фаунъ̆ не встрђчаются.

\section{Diasemopsis varians $\mathrm{n}$. sp.}

(Фиг. 2 а и с 우, 2 b $ठ^{\pi}$ ).

К’ этому виду я отношу нъсколько экземпляровъ, которые до нъкоторой степени различны, но соединены между собою переходными формами, такъ что между ними нельзя провести рбзкой границы. Полы также различаются между собою. Но, нбкоторые признаки этого сильно варіирующаго вида повторяются, указывая на видовое родство описываемыхъ животныхъ. 
Длина $\sigma^{7} \sigma^{1} / 2-7$ мм., 우 $4 \frac{3}{4}-6 \frac{1}{4}$ мм. Ширина головы съ глазными стебельками у б’ 5-8 мм., у क $3^{1 / 2}-6$ мм.

Видъ близокъ къ $D$. aetliopica $\mathrm{R}$ ond. Голова безъ зубцовъ, темно коричневая. Лобъ темно-черно-коричневый; по объимъ сторонамъ глазковъ находится по пятну. Лицо шоколадно-бураго цвъта съ темнымъ мазкомъ ниже широкой черной дугообразной линіи. Посльдняя продолжается въ видъ болъе тонкой линіи вдоль глазныхъ стебельковъ. Другая, еще болъе тонкая линія проходитъ параллельно первой и беретъ начало у лица. Глазные стебельки темнаго цвъта, какъ лобъ, только на передней сторонъ, тамъ гд⿱ проходятъ параллельныя линіи, стебельки св бтлье. Глазные стебельки сильно варіируютъ въ длинъ и особенно длинны у самца. Они достигаютъ, по крайней мърғв, длины головы и груди вмъстъ взятыхъ, но у самца они еще длиннъе. Щетинка на серединь глазныхъ стебельковъ прикрьплена немножко ближе къ головъ, ч६мъ къ глазамъ, и очень мала. Щупики коричневожелтые, съ черной щетинкой.

Грудь черная, со слабымъ сърымъ отливомъ. Шейка и щитокъ черные. Щитокъ довольно сильно суживается кзади. Его шипы небольшіе, немножко длиннъе его самого, мало расходящіеся, чернаго цвъта. Боковые шипы короткіе, тупые, черно-коричневаго цвъ̆та. На среднегруди находятся двъ пары нбжныхъ, черныхъ щетинокъ. Передняя пара меньше и находится передъ мъстомъ прикрвпленія крыльевъ, у латеральнаго конца надръзовъ среднегруди. Эти щетинки направлены латерально. Вторая пара щетинокъ находится. немного позади и медіально отъ мъста прикрђпленія крыльевъ. Эти щетинки приблизительно вдвое длиннъе первыхъ и направлены кзади. Наконецъ, щитковые шипы также снабжены щетингами, которыя немножко длиннъе ихъ самихъ, но нъсколько меньше заднихъ среднегрудныхъ щетинокъ.

Ляшки буро-желтыя; переднія немного темнъе двухъ остальныхъ паръ, довольно свътлыхъ. Общій цвътъ бедеръ одинаковъ съ цвътомъ ляшекъ, у самцовъ немного темнъе, чьмъ у самокъ. Переднія бедра вздуты, коричнево-желтаго или почти коричневокраснаго цвъьта (посльдд. у фиг. 2-с), съ двумя параллельными рядами маленькихъ черныхъ шиповъ на задней сторонъ. Остальныя бедра болъе или менъе свътло-красно-желтыя, а дистальная половина ихъ черно-коричневая. У экземпляра фиг. 2·с объ посльднія пары бедеръ у основанія немного темнъе, дистальная же часть ихъ свьтлъе. У всъхъ экземпляровъ темная полоса вытянута по бокамъ бедеръ лентообразно по направленію къ 
основанію, а у заднихъ бедеръ почти до самаго основанія бедеръ. Голени немного расширены къ дистальному концу. Передняя пара голеней темно черно-коричневая, средняя пара свътлъе, такогоже цвъта, какъ и дистальная часть бедеръ. Заднія бедра такого-же цвъта, какъ среднія, только у нихъ средняя треть свЄтлъе, въ вид看 св臬тпой ленты. Лапки однообразно красно-бурыя, только первый членикъ переднихъ лапокъ немного темнбе остальныхъ.

Крылья стекловидно прозрачны, съ слабымъ затемн务іемъ на гонць. Жужжальца бъловатыя.

Очень различны форма и основной цвътъ брюшка у $\sigma^{\pi}$ иं Основной цвътъ варіируетъ также и у одного и того-же пола, и лишь нъкоторые опредъленные элементы рисунка, напримъръ, пятна голубоватаго налета, повторяются (фиг. 2 a, b и с).

Форма брюшка у самки (фиг. 2 а и с) продолговато-овальная и плоская. Задніе края посльднихъ брюшныхъ члениковъ строго перпендикулярны къ оси тъла, посльдній членикъ съ короткимъ яйцекладомъ. У самца (фиг. 2 b) брюшко продолговатое, цилиндрическое; оба предпослғдніе членика на заднемъ краю имъютъ небольшія щетинки или сильно развитые волоски.

Основной цвътъ брюшка у самца черный. Изъ двухъ экземпляровъ у большаго (фиг. 2 b) брюшко было совершенно чернымъ, у другого экземпляра медіальная часть перваго, болҰе длиннаго членика была темно-каштаново-бураго цвєта.

У самки основной цвъ́тъ брюшка либо однообразно темнобурый (фиг. 2 с), или вдобавокъ съ болъе или менъе правильно распредьленными свътло-коричневыпи пятнами (1 экз.), или, наконец'ь, эти пятна увеличиваются въ размьрахъ и болье ръзко отграничены отъ тенныхъ частей, такъ что брюшко получаетъ характерный рисунокъ (фиг. 2 а). Этотъ рисунокъ состоитъ прежде всего изъ свътлаго пятна на каждой сторон学 брюшка, передъ насъчкой перваго длиннаго членика. За этой насъчкой почти вся поверхность перваго членика св各тло-коричневая. На сльдующемъ, второмъ членик年 имбются два маленькихъ свбтлыхъ пятна, отдбленныхъ другъ отъ друга болье темной медіальной полосой.

Въ то время, какъ основной цвътъ сильно варіируетъ, распредъленіе пятенъ, похожихъ на голубой налетъ, повторяется. Эти пятна распредълены сльдующимъ образомъ. У основанія брюшка находится широкая поперечная полоса. Немного далъе кзади на каждой сторонъ имъется по пятну, закругленному медіально. Впереди и позади насъьки перваго, длиннаго членика, на каждомъ боку имъется по пятну, соприкасающемуся съ пятномъ той-же 
стороны. Пятно передъ насъчкой распространяется довольно далеко въ медіальномъ направленіи и кзади закруглено. Пятно же за насъчкой не такъ широко и закруглено кпереди. Передній край второго членика имєетъ съ каждой стороны по большому, округлому спереди пятну. Соотвбтствующее пятно, но менышей величины, имћется и на переднемъ крағ третьяго членика. У чернаго самца (фиг: 2 b) пятна имбютъ-видъ темно-голубого налета, въ то время какъ у бурыхъ самокъ они имъютъ болье бъловато-фіолетовый оттънокъ. Нижняя, брюшная сторона брюшка грязно-съроватая, причемъ темный цвътъ спинной стороны переходитъ у задняго края каждаго чпеника на брюшную сторону въ видъ треугольниковъ, съ тупымъ внутреннимъ угломъ, 6 экземпляровъ (2 ठ⿱宀 и 4 우) съ ръки Луми 4 VIII.

Одна самка замъчательно малыхъ размъровъ. Самцы на нижней сторон古 брюшка и на ногахъ мъстами обросли грибками изъ семейства Laboulbeniaceae.

\section{Diasemopsis silvatica $11 . \mathrm{sp}$.}

(Фиг. 3 ㅇ).

Длина 6 мм. Ширина головы съ глазными стебельками $51 / 4 \mathrm{mм.}$

Видъ близок'ь къ D. concolor W stw. Голова безъ зубцовъ. Основной цв‡тъ головы и глазныхъ стебельковъ красно-коричневый. Щупики желто-горичневые, хоботъ сьро-желтый. Јобъ черноватый, между основаніемъ стебельков' съ $V$-образнымъ рисункомъ. Черная дугообразная линія продолжается на переднеиі сторонъ глазныхъ стебельковъ до огнованія усиковъ. У основанія глазъ глазные стебельки чернаго цвъта. Щетинка на серединб глазныхъ стебельковъ, длинная и толстая. Усики желто-коричневые, съ черной щетинкой.

Грудь, шейка и щитокъ черные, спинная сторона груди съ буроватымъ, боковыя пластинки съ сұроватымъ отливомъ. Медіально отъ мъста прикрбпленія крыльевъ находится щетинка, загнутая кзади. Она немного длиннъе щетинки глазныхъ стебельковъ. Боковые шипы короткіе, тупые, черные. Щитокъ относительно короткій. Щитковые шипы хорошо развиты, приблизительно вдвое длиннъе щитка, немного длиннъе грудныхъ шетинокъ, расходятся кзади, немного загнуты медіально. Они коричневаго цвъта, съ черными концами, Щетинки этихъ шиповъ у единственнаго, къ сожальнію, экземпляра отломаны. 
Ляшки свътло съро-желтыя, цвъ̆та хобота. Бедра желтокоричневыя, у основанія св бтлбе, дистально темнъе, у дистальнаго конца совершенно коричневыя. Переднія бедра сильно вздуты. Переднія голени черно-коричневыя, среднія голени желто-коричневыя, заднія голени черно-коричневыя съ широкой свъ̆тлой лентой по серединъ. Лалки желто-коричневыя, первый членикъ переднихъ лапокъ черно-коричневый, второй свътлъе, остальные еще болће свбтлы.

Крылья стекловидно прозрачны и имбютъ на конц' третьей продольной жилки $(\mathrm{R} 4+5)$ маленькое, но ръзко ограниченное коричневатое пятно. Жужжальца бъловатыя.

Брюшко широкое, плоское, у основанія покрыто бъловатыми волосками. Основной цвбтъ брюшка черный, кзади переходящій немного в` буроватый. Мъстами брюшко имъетъ голубоватый налетъ, особенно на боковыхъ коричневыхъ пятнахъ у задняго края члениковъ

Коричневыя мъста являются въ видъ двухъ поперечныхъ лентъ, медіально сильно суженныхъ; первая у насъики перваго длиннаго членика, вторая у задняго края того-же членика. Притомъ коричневая окраска переходитъ немного на передній край сльлующаго членика. Передняя лента у боковых'ъ краевъ

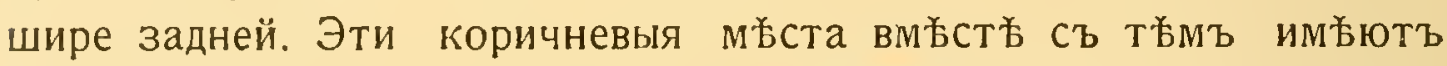
и фіолетовый налетъ. Налетъ въ видъ поперечной ленты имъется также и у основанія перваго членика.

Послъдніе три членика короткіе, широкіе и вооружены на заднемъ краю нъсколькими мелкими щетинками.

Нижняя, брюшная сторона брюшка съро-желтая. Темный цвътъ верхней стороны переходитъ на нее въ видъ черныхъ треугольниковъ съ основаніемъ у задняго края каждаго членика.

На глазныхъ стебелькахъ и на ногахъ моего экземпляра находится нъсколько грибковъ изъ Laboulbeniaceae.

Одинъ экземпляръ, о, из'ь Мабиры.

Diasemopsis incerta n. sp.

(Фиг. 4 ठ

Длина 5-53/4 мм. Ширина головы съ глазными стебельками $4-63 / 4$ мм.

Видъ близокъ къ только что описанному silvatica m., отъ котораго онъ отличается главнымъ образомъ отсутствіемъ пятна на концб крыла, меньшей величиной и бол务е темнымъ цвъ̆томъ. Можетъ быть это самецъ предыдущаго вида? 
Голова безъ зубцовъ, черно-коричневая. Глазные стебельки темно-коричневые. Лобъ, темя и дистальные концы глазныхъ стебельковъ черноватые. Дугообразная линія продолжается въ видъ тонкой черной линіи на глазныхъ стебелькахъ до основанія усиковъ. Глазные стебельки у бо́льшаго изъ обоихъ экземпляровъ довольно длинные, особенно въ сравненіи съ малой головой. Щетинки на серединб глазныхъ стебельковъ, сравнительно длинныя. Усики желто-коричневые, съ тонкой черной щетинкой. Глаза темно-коричневые. У дистальнаго края глазныхъ стебельковъ, дорзально, имъется загнутая вбокъ щетинка (отломанная у большого числа экземпляровъ другихъ видовъ). Грудь, шейка и щитокъ черные, съ съроватымъ отливомъ. Шейка слегка уже, ч各ъъ у silvatica $m$. Медіально и дорзально отъ мъсть прикрбпленія крыльевъ имъется по щетинкъ, загнутой кзади. Боковые шипы короткіе, тупые, черно-коричневые. Шипы щитка сильно расходящіеся, вдвое длиннъе самаго щитка, крбпкіе, прямые, коричневые. Щетинка на концъ шиповъ тонкая и нбжная, почти достигаетъ длины гшиповъ.

Ляшки свђтло съро-желтыя. Вздутыя переднія бедра у основанія почти такъ-же свътлы, какъ и ляшки, дистально переходятъ постепенно въ темный, желто-коричневый цвътъ. Остальныя бедра въ основныхъ двухъ третяхъ почти такъ-же свбтлы, лишь немного желтъе ляшекъ. Дистальная треть чернокоричневая. Переднія гопени черно-коричневыя. Среднія голени коричневожелтыя, по бокамъ черновато-коричневыя. Заднія голени такъ-же коричнево-желтыя, во второй и посльдней четверти по бокамъ коричнево-черныя. Лапки свътло коричнево-желтыя; первый членикъ переднихъ лапокъ коричнево-черный.

Крылья стекловидно прозрачны, со слабымъ буроватымъ затемнбніемъ въ серединъ. Жужжальца бъловатыя.

Брюшко расширяется кзади (clavatum), черное, блестящее. На первомъ, длинномъ членик占, въ незначительномъ разстояніи отъ основного конца, имъется голубоватый налетъ въ видъ поперечной ленты. Эта лента блестящая, зато самое основаніе брюшка матовое. Передъ насъчкой перваго членика, на каждой сторонъ по голубоватому, закругленному кзади пятну. За насъцкой, у бокового края брюшка по одному красно-коричневому, слабо отграниченному пятну. Посльдніе три членика снабжены на заднемъ краю нбсколькими маленькими щетинками.

Нижняя, брюшная сторона брюшка имьетъ широкую, бурую, кофейнаго цвћта медіальную продольную ленту, которая на 
границъ члениковъ прерывается сърымъ основнымъ цвбтомъ брюшной стороны. Черный цвътъ спинной стороны переходитъ также на брюшную сторону брюшка въ видъ треугольниковъ, съ острымъ внутреннимъ угломъ; изъ нихъ передній внутреннимъ своимъ угломъ достигаетъ медіальной ленты, другіе близко к’ъ ней подходятъ.

Два ð из Мабиры 12 VI (фиксированы по Джильсону). Можетъ быть фиксировка измънила нбсколько окраску ногъ, которая вброятно должна быть желтъе.

Diasemopsis pulchella in. $s p$.

(Фиг. 5 \%).

Длина 5-51/2 мм. Ширина головы съ глазными стебельками приблизительно $3 \frac{1}{2}$ мм.

Это граціозный видъ съ сильно развитыми, сидящими отчасти на стебелькахъ щетинками, и густымъ покровомъ волосковъ. Половой диморфизмъ имъется.

Голова безъ зубцовъ; голова и глазные стебельки желтокоричневые. Дугообразная линія слабо очерчена, но продолжается въ вид务 ясной, черной линіи вдоль глазныхъ стебельковъ. Подъ дугообразной линіей грязно-бурый мазокъ. Хоботъ съро-бълый, щупики съро-желтые. Короткіе 'глазные стебельки тонки; ихъ щетинка мощная и длинная, сидитъ вертикально на короткомъ коричневомъ стебелькъ и немного загнута кзади. Глаза, къ сожальнію, обработаны гистологически, но судя по ранће сдъланному мною наброску, не представляютъ ничего особеннаго.

Грудь черная, блестящая. Боковыя пластинки у самки немного переходятъ въ коричневатый цвътъ. Передняя часть среднегруди отливаетъ сърымъ или буроватымъ цвьтомъ. Шейка темно красно-коричневая. Короткій, довольно сильно приподнятый цитокъ черный, или коричнево-черный. Щитковые шипы у основанія стоятъ почти вертикально, загнуты въ дистальной половинъъ назадъ, и расходятся, какъ обыкновенно. Шипы не особенно мощные, острые, въ основной половинъ черные, въ дистальнойгоричнево-желтые. Щетинка на конц в шипа тонкая, нъъная, достигаетъ двухъ третей длины шипа. Щетинка, расположенная медіально отъ мъста прикрбипленія крыльевъ, мощная и длинная; она направлена почти вертикально и прикрфплена къ короткому, широкому, черному стебельку.

Переднія ляшки темно коричнево-красныя, остальныя ляшки 
съро-желтыя. Переднія бедра вздуты не сильно и у самца не сильнғе развиты, чғмъ у самки; желто-коричневыя. Остальныя бедра въ основныхъ двухъ третяхъ коричнево-желтыя (свьтлье, чь̆ъ въ фиг. 5), въ дистальной трети и по обоимъ бокамъ черно-коричневыя.

Голени свътло коричнево-желтыя; у посльъднй пары голеней, по объимъ сторонамъ каждой, одинъ участокъ, начиная почти у самаго основанія и въ дистальной четверти-черновачый, такъ что голени, если смотрбть сбоку, кажутся снабженными двумя св ғтлыми лентами. Лапки вс年 свътло коричнево-желтыя, у самца немного темнъе, первый членикъ заднихъ лапокъ съ маленькимъ выпячиваніемъ у основанія.

Крылья стекловидно прозрачныя, немного буроватыя. Нd переднєй поперечной жилкъ (по объимъ сторонамъ ея) находится небольшой буроватый мазокъ. Базально отъ задней поперечной жилки имъется неръзкая поперечная лента, достигающая лиць второй продольной жилки $(\mathrm{R} 2+3)$ и не доходящая до передняго края. Наконецъ, на конц'ь третьей продольной жилки ( $\mathrm{R} 4-\uparrow 5)$ находится слабое, буроватое пятно.

Брюшко имъетъ сильно суженную у основанія форму, какъ y Ichneumonidae. Цвътъ брюшка у обоихъ половъ различный. Самецъ чернаго цвъта. У самокъ первый, длинный, и у этого вида очень вытянутый членикъ черный, за исключеніемъ дистальнаго конца, имъющаго красно-коричневую поперечную ленту. Эта лента переходитъ также на проксимальную часть второго членика. Такимъ образомъ, у самки имъется лента по объимъ сторонамъ границы перваго и второго членика. Передній край этой ленты медіально имъ̌тъ прямоугольную выемку; задній край имьетьь соотвоьтствующій выступь.

Остальные членики черно-коричневые. Мъста съ голубымъ налетомъ у самки и самца распредәлены одинаково и состоятъ, прежде всего, изъ ленты въ нъкоторомъ разстояніи от’ь основного конца брюшка у самаго узкаго мвста его, гдъ оно немного

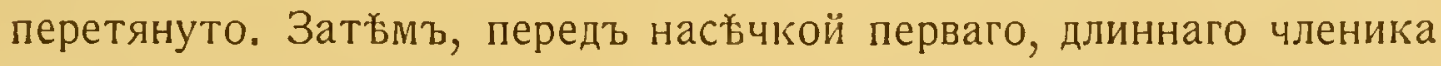
находятся два загнутых'ь назадъ пятна. Наконец’ь, у задняго края перваго членика, по обоимъ бокамъ находится по большому пятну и у передняго края второго-по маленькому.

Брюшная сторона брюшка у самки до насьчки перваго членика-сърая, начиная оттуда, дистально, бғлая. Медіально брюшная сторона самки имъетъ широкую, желтую продольную полосу съ коричневой каймой. Кайма имъетъ на второмъ и 
третьемъ членикъ по три маленькихъ щетинки. Между насъчкой

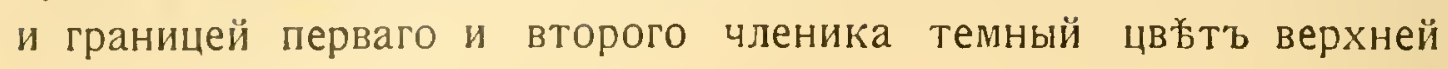
стороны переходитъ въ видъ остраго угла на брюшную сторону, но не достигаетъ брюшной продольной полосы. У самца рисунокъ брюшной стороны такой же, но основной цв各тъ не бълый, а сърый, и продольная полоса грязно свбтло-коричневая. Все тә́ло довольно густо покрыто крбпкими волосками, которые можно даже назвать щетинками. Волоски особенно сильно развиты на спинной сторонғы

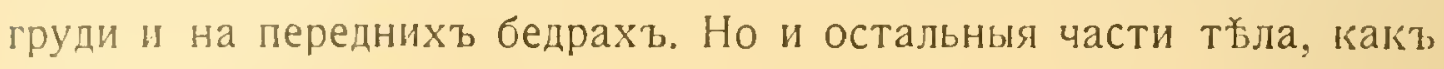
голова и брюшко, довольно обильно покрыты волосками.

\section{Объясненіе рисунковъ.}

Животныя зарисованы при помощи бинокулярнаго микроскопа Цейса и рисовальнаго прибора Аббе. Увеличеніе всъхъ фигуръ одинаково-8 разъ. Рисованіе осложнялось т各ъ обстоятельствомъ, что животныя были погружены въ алкоголь и оттого нбкоторые оттьини были нбсколько замаскированы. Нъкоторые цвъта можетъ быть отчасти пострадали отъ дбйствія фиксирующей жидкости; у экземпляровъ, фиксированныхъ пикриновой кислотой, это стоитъ вн各 сомн务нія. Зато консервированныя такимъ образомъ въ жидкости животныя обладали т各ъ преимуществомъ, что форма ихъ хорошо сохранилась и экземпляры остались несморщенными, что бываетъ обычно у сухого матеріала.

Фиг. 1. Diopsis finitima n. sp. 七 $^{*}$.

"2-a Diasemopsis varians $\mathrm{n}$. $\mathrm{sp}$. 우.

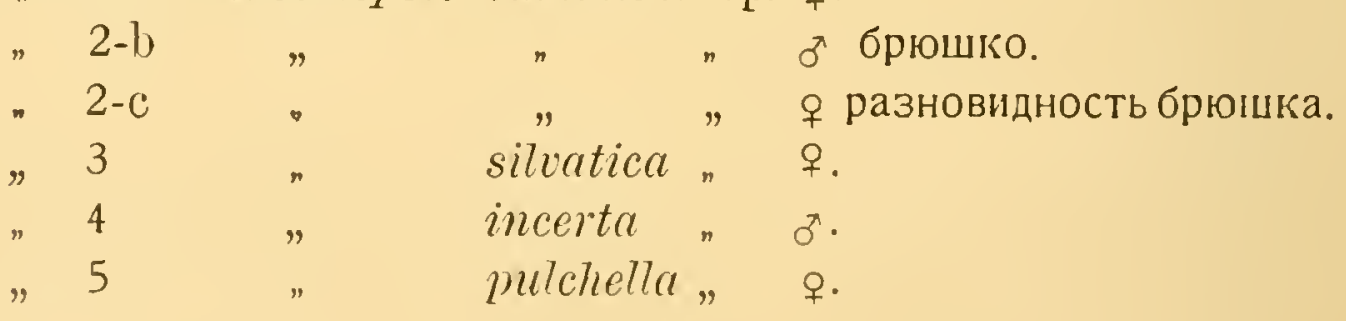




\title{
On some new and incompletely known species of the family Diopsidae from British East Africa.
}

\author{
F. 0 . EGGERS.
}

(From the Zootomical Laboratory of the Imperial University of Petrograd).

Owing to the kindness of Prof. V. A. D o g i e I I received for scientific research a small collection of Dio psida e, or "horned flies", which were taken by him and I. I. Sokolor during their expedition to British East Africa in the summer of 1914 .

With respect to Diopsidae, until the present the Sunde islands were more fully investigated in the works of Meijere and van der Wulp. In Africa, in many places, especially in its central and eastern parts, Di opsidae had not been taken at all. British East Africa remains entirely unexplored as far as concerns this group.

The present material was taken from two places: firstly, in the Mabira forest, about 50 kilometres north of Victoria Nyanza. This is a damp forest, and the flies are to be found on plants, lining the foot-paths. They were caught here in the middle of June. The second place, where they were to be found, were the banks of the river Lumi, near lake Chala, to the east of Kilima-Njaro, where captures were made in the beginning of August i. e. in the dry season. That is the reason why the flies were found near the very water exclusively, sitting on the surface of stones and leaves, sometimes scores at a time. The following table gives a list of the species investigated together with the places of capture and number of specimens.

1. Diopsis ichneumonea L. Mabira $1 \sigma^{\pi}$

2. " finitima n. sp. " $1 \sigma^{\pi}$ 
(?) 3. Diopsis fumipenmis Wstw. n 1 우

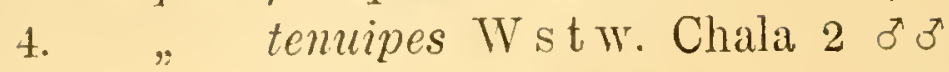

5. " thoracica Wstw. " 1 (ठ??)

6. " sulcifrons B ezzi. Nabila 1 우

7. Diasemopsis varians 11 . sp. Chala 2 ơ 4 우우

8. " silvatica 11. sp. Mabira 1 우

9. $\quad$ incerta $11 . \mathrm{sp}$. $\quad 2 \quad 2 \sigma^{\pi}$

10. $"$ pulchella $11 . \mathrm{sp} . \quad$ " $10^{\pi} 1$ 우

Diopsis ichneumonea L.

This is the first species of Di o p s i d a e that became known, and was already described by Linnaeus. Unfortunately, the description and drawing of Linnaens are not sulficient for characterising the given species and some characters of this species are interpreted by different authors in their own way which leads to many misunderstandings.

In my material there is a form which may be referred to D. ichneumonea L. On account of what was said above, I consider it necessary to give its description.

My specimen differs from the type of Lin n a e u in .darker antemnae, in the black colour of both ends of the first, long abdominal segment, and in a brownish tint on the wings. These characters are so insignificant, that they cannot in any way serve as a basis sufficient for distinguishing this form as a distinct species; in the most, we may be dealing with a local variety. On the other hand, if we consider the given form as identical with $D$. ichnemmonea of $\mathrm{Linn}$ a eus, we shall be able to state those characters not mentioned by Linnaens, which led to disputes between $\mathrm{T}^{\mathrm{T}} \mathrm{estw}$ ood and Dalman, viz.: the black neck, brownish-red first abdominal segnient and whitish halteres.

The only specimen is evidently a male, from Mabira, 12. VII.

Diopsis finitima n. sp.,

(Fig. 1, $0^{\top}$ ).

This species is very near to $D$. apicalis $\mathrm{D}$ alm., but in certain peculiarities it differs from all the representatives of that group of D i o p si d a e which are so difficult to distinguish one from another and which all resemble the type apicalis D a $1 \mathrm{~m}$. so much.

Length $7 \mathrm{~mm}$., width of head with eyestalks $6 \frac{1}{3} \mathrm{~mm}$., length of wings $5^{1 / 4} \mathrm{~mm}$. 
The head narrows regularly towards the mouth, of yellowbrown colour. The face is lighter than the occiput. On the front above the linea arcuata is a large, sharply outlined black spot; below it is another spot of smaller size. From both sides of the month there is one frail spine. The proboscis is grayishyellow, the palps-light yellow. The eye-stalks are longer than the head and thorax taken together, and are sharply distinguishable from the head owing to different coloration. They are light or dark-brown; nearer to the distal extremity than to the head a small seta is attached. The antemnae are yellowish-brown with a black seta. The eyes are dark-brown. The thorax is black with a weak dullgray tint. The long: neck and scutellum are black. The lateral spines are short, of yellow colour. The scutellar spines are long, sharp, and much less divergent than in all the other species of the group apicalis $\mathrm{D}$ alm. The halteres are white. The coxae are lightyellow. The fore femora are swollen, brown-yellow; the remaining femora are slightly lighter. Both hind pairs of femora are provided with slightly developed distal spines. The fore tibiae are brown, the middle brown-yellow, the hind-also brown-yellow, but on the sides near the base and at the distal end-with dark-brown, elongate spots; so that when they are seen from the side, they seem dark-brown with a wide light band in the middle. The fore tarsi are darker brown than the rest. The wings are transhucent with a slight brown tinge in the middle, on either side of the upper transverse vein, and with a spot of the same colour on the end of the 3-rd longitudinal vein $(\mathrm{R} 4+5)$. The abdomen widens posteriorly (abdomen clavatum), ventrally slightly concave. The first, longer segment, is black up to the transverse groove which represents the remnant of the border between two segments that have grown together. The remaining part of it is redbrown. On the sides. on the level of the groove this segment is lighter (see fig. 1). The lower, ventral side is brown, darker at both extremities. Some parts of the body are covered with white tender hairs, namely: the dorsal part of the abdomen, especially at the base, and the face. The femora, except the fore pair, have a slight hairy covering. The tibiae and tarsi are covered with tender setae.

The characters that distinguish the species from apicalis Dalm. are the slightly diverging scutellar spines, the black 
colour of the basal part of the abdomen, the small development of the distal spot on the wing and the tinge in the middle of the wing.

1 specim. $\sigma^{x}$, from Mabira.

Diopsis tenuipes Wstw.

Westwood. Trans. Linn. Soc. XYII, p. 29S, tab. IX, f. 5 o (1835).

Two males probably belong to this species. The abdomen is wide, flat, of a light brownish-red, nearly brick-led colour, as in thoracica Wstw. The specimens that I have from Usumbura, German East Africa, are darker.

$2 \sigma^{\pi} o^{\pi}$ from Chala, 2. VIII.

? Diopsis fumipennis Wstw. var.

Westwood. Trans. Linn. Soc. XVII, p. 302, tab. IX, f. 9 (1835).

One specimen which is far from being preserved in a good state reminds tenuipes Wstw. from the first glance. But it differs in the colour of the abdomen which is provided with three wide dark-brown transverse bands. Besides, in this specimen the leg's differ in a ligther, yellowish colour. In the general aspect and chiefly in the abovementioned two characters this specimen strongly resembles the several specimens from Usumbura which I consider as a variety fumipennis with a transversely striped abdomen.

1 o from Mabira, 12. TI.

\section{Diopsis thoracica Wstw.}

Trans. Linn. Soc. Lond. XIII. 1837, p. 306-307, T'ab. IX, f. 15.

Besides the single specimen from prof. Dogiel, I have before me 8 specinens more collected by Standinger in Somaliland and Zanzibar, which all resemble each other fully and without doubt belong to the species thoracica N stw. Only in one important character they do not correspond to W c stwood's description, viz. in the presence of distal spines on the middle femora. This character is important, but

think it must be taken into consideration that Westwood's type was not quite intact, as he himself asserts, therefore, it is possible that the spines named had fallen off in his case. 
The antennae which were broken in Westwood's type are a little lighter than the colour of the eyestalks. The lateral spines are of the colour of the body, and not yellow. The scutellar spines, also broken off in Westwood's type, are slightly bent upwards in their distal part (i. e., dorsally).

1 spec. from river Lumi, 2. VIII.

$s$ other specimens from Zanzibar and Somaliland.

\section{Diopsis sulcifrons B e z i.}

Ann. Soc. Ent. Belgique. 52. 1908. p. 387.

One of my specimens in its chief characters corresponds to the description of $D$. sulcifrons $\mathrm{B}$ e zz $\mathrm{j}$ and differs mainly in the absence of brown spots on the thorax, and in the presence of a black apical spot on the wing as well.

Length $8^{1 / 2} \mathrm{~mm}$. Width of the head with eyestalks $6^{3 / 4} \mathrm{~mm}$.

The form of abdomen is wide, flat, with greatly shortened posterior segments, about the same as in thoracica. Colour of abdomen-dingy red-brown, darker than in thoracica Wstw.

\section{Genus Diasemopsis Ron d.}

Ann. Mus. Cir. Gen. VII, 1875, p. 442.

B i g o t. Ann. S. Ent. Er. (5) X. 80 p. 91.

Before proceeding with the description of the following species belonging to the genus Diasemopsis Rond., I should like to make some general remarks concerning this genus. In 1875 Rondani divided the genus Diopsis L. into several new genera, of which two new genera-Teleopsis and Diasemopsis-are of interest to us. The first genus with its type Teleopsis sykesii. W stw. is distinguished chiefly for the presence of a special pair of thoracic spines on the points of attachment of the wings. As concerns the genus Diasemopsis with its type $D$. aethiopica Rond., it is provided with special setae at the extremity of the scutellar spines.

In my material about half the species do not belong to the typical genus Diopsis as they possess a seta on the extremity of the scutellar spines. I attribute these species to Diasemopsis Rond. notwithstanding the fact that in all of them there is also a seta on the notnm medially from the 
point of attachment of the wings, which character might be in farour classing them with Teleopsis Rond. Although 1 have no Teleopsis for comparison, I consider the seta named not to be homologous to the seta in Teleopsis Rond. The reason why l hold this opinion is that in one of the species, $D$. varians $m$, at least, there is yet a second seta situated anteriorly to the point of attachment of the wings, and which more probably corresponds to the seta of Teleopsis, as Tan der Trulp clearly states that in Teleopsis sykesii the seta is placed anteriorly to the point of attachment of the wings. Besides, in different species of Teleopsis, according to drawing's of Westwood and $\mathrm{V}$ an der W $\mathrm{Wlp}$, we are dealing with strongly developed spines, usually distinctly coloured, and not with setae; that is why I consider it necessary to classify $D$. varians $\mathrm{m}$. with Diasemopsis Rond.

The seta situated on the notum more medially from the point of attachment of the wings occurs in all my specimens of Diasemopsis, it is, therefore, unexplainable why it is not mentioned by other authors. It must be admitted, however, that these setae easily break off, just as the scutellar setae do. They might have been present in species described before as well, but they are not mentioned in the specific diagnosis. It is, therefore, impossible to state correctly which of the species described before belong to Diasemopsis Rond., and what generic characters, except-scutellar setae, appartain to this genus. In my specimens there is one more general character-the absence of spines laterally to the mouth. In all the specimens the lateral spines are short and blunt, but the setae on the eyestalks, excepting $D$. varians m., are strongly dereloped. Distal spines on the hind femola are absent. Sexual dimorphism is clearly expressed in the colour of the abdomen. In females the predominant colour, or the colour that is, at least, present, is usually brown or brown-red, whereas the males are usually quite black. The difference in colour in some cases is so striking that it is sometimes difficult to decide whether these insects belong to the same species, or to different ones.

Amongst the Diopsidae described before the genus Diasemopsis was established only in two cases is the presence of setae on the scutellar spines mentioned: these are D. macrophthalma Dalm. and D. signata Dalm. They must now be 
refered to g. Diasemopsis $\mathrm{R}$ on d. All the species of Diasemopsis that are known until the present were found in Africa.

From the fauna of the Sunde islands only recently an interesting species, Teleopsis rubicunda V. d. W u I p., was described; it has short setae on the scutellar spines, but for its mesothoracic spines and general aspect it must be referred to g. Teleopsis $\mathrm{R}$ o $\mathrm{nd}$.

It must be here mentioned that in the number of genera related to Diasemopsis the genus Hexechopsis Rond. (type Diopsis beccarii from Eritrea) was also named on account of the setae of scutellar spines - being present in it. This genus was afterwards taken to be synonymous to Sphyracephala Gray by Osten-S a k ken, this genus being altogether distinct and characterized by the presence of alulae.

It appears that Rondani himself consented to this trans. position, as in his list of Diopsidae of 1907 we find $D$. bec. carii under the name of Sphyracephala beccarii $\mathrm{R}$ ond. The genus Hexechopsis may, therefore, be considered as superfluous. The genus Sphyracephala is represented in the African fauna by one more species Sphyracephala africana Karsch from East Africa. Other genera of D i o p si d a e, except those mentioned, are not met with in the African fauma.

\section{Diasemopsis varians $n$. $s p$.}

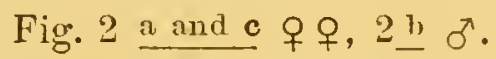

To this species I refer several specimens which, although being somewhat unlike, are comnected with each other by transitory forms, so that a strict demarkation cannot be drawn between them. The sexes also differ from each other. But several characters of this very variable species are repeated which points to a specific relationship between the insects described.

Length of $\sigma^{\pi} \delta^{x} 5^{1 / 2}-7 \mathrm{~mm}$. 우 우 $4^{3} / 4-6^{1 / 4} \mathrm{~mm}$.

Width of head with eye-stalks in $\sigma^{\pi} 5-8 \mathrm{~mm}$., in ${ }^{\circ} 3 \frac{1}{2} \mathrm{~mm}$.

The species is related to $D$. aethiopica Rond. Head without spines, dark brown. Frons-dark, black-brown. The eyestalks are of a dark colour as the front. The eyestalks vary greatly in length and are especially long in males.

Thorax black, with a slight gray tint. Neck and scutellum black. The scutellum exceedingly narrow posteriorly. Its spines 
are small, not much longer than itself, slightly diverging, of black colour. The lateral spines are short, blunt, of blackbrown colour. On the mesothorax there are two pairs of tender, black setae. The anterior pair is smaller and situated anteriorly to the point of attachment of the wings, laterally to the fissure of the mesothorax. The second pair of setae is a little behind and medially from the point of attachment of the wings. Lastly, the scutellar spines are also provided with setae which are somewhat longer than the former, but shorter than the posterior mesothoracic setae.

The coxae are brown-yellow. The general colour of the femora is like that of the coxae. The fore femora are swollen. The fore pair of tibiae is dark black-brown, the middle pair is lighter; the hind femora are of the same colour as the middle only the middle third is lighter, in the shape of a light band. The tarsi are of a uniform red-brown colour, only the first segment of the fore tarsi is a little darker than the rest.

The wings are translncent with a slight obscurity at the tips.

The shape and ground-colour of the abdomen is very different in $\delta$ and $q$. The ground-colour varies also in the same sex, and only certain definite elements of the drawing, e. g., spot of a bluish tint, are repeated (fig. 2).

The ground-colour of the abdomen in the male is black. In the female the ground-colour is either monotonous dark brown (fig. 2c), or it is in addition spotted more or less regularly with light brown (1 spec.); or, lastly, these spots expand and become more sharply limited from the dark parts, so that the abdomen obtains it characteristic drawing (fig. $2^{a}$ ). The lower, ventral side of abdomen is dusky gray-yellow and the dark colour of the dorsal side passes at the posterior margin of each segment to the ventral side in the shape of triangles with an obtuse interior angle.

6 specimens, $2 \sigma^{\pi}$ and 4 우, from river Lumi, 4 . VIII.

\section{Diasemopsis silvatica n. sp.}

Fig. 3 q.

Length $6 \mathrm{~mm}$. Width of head with eyestalks $5^{1 / 4} \mathrm{~mm}$.

The species is related to $D$. concolor $\mathrm{W}_{\mathrm{s}} \mathrm{tw}$. The ground colour of the head aud eyestalks is red-brown. The front is 
blackish with a wide V-form drawing between the bases of the stalks. The black arcuate line continues on the anterior side of the eyestalks to the bases of the antemnae.

The thorax, neck and scutellum are black. Medially to the point of attachment of the wings there is a seta bent backwards. The scutellum is relatively short. The scutellar spines are well developed, about twice longer than the scutellum, slightly longer than the thoracic setae, diverging backwards, slightly bent medially. They are brown with black tips. The setae on these spines are, unfortunately, brocken off in the single specimen.

The coxae are light gray-yellow. The femora are yellowbrown, lighter at the basis, darker distally. The fore femora are exceedingly swollen. The fore tibiae are black-brown, the middle tibiae-yellow-brown, the hind tibiae are black-brown with a wide light band in the middle. The tarsi are yellowbrown, the first segment of the fore tarsi black-brown.

The wings are translucent and have at the end of the third longitudinal vein $(\mathrm{R} 4+5)$ a small, but distinctly linited brown spot.

Abdomen wide, flat, at the base covered with whitish hairs. The ground-colour of the abdomen is black, passing into brownish towards the back. In some places the abdomen has a bluish tint, especially on the lateral brown spots at the posterior margin of the segments.

The brown spots appear in the shape of 2 transverse bands, medially very narrow; the first is near the groove of the first long segment, the second-at the posterior margin of the same segment.

The lower, ventral side of the abdomen is gray-yellow. The dark colour of the upper side passes into it in the shape of black triangles with the kase at the posterior margin of each segment.

One specimen, $q$, from Mabira.

\section{Diasemopsis incerta n. sp.}

Fig. 14 우.

Length $5-5^{3} / 4 \mathrm{~mm}$. Width of head with eyestalks $4-6^{3} / 4 \mathrm{~mm}$.

This species is very near to silvatica $m$. described above, and differs from it chiefly in the absence of a spot at the 
tip of the wing, in its smaller size and darker colour. May be this is the male of the preceding species?

The eyestalks are dark-brown. The front, occiput and distal ends of the eyestalks are blackish. The eyes are darkbrown. At the distal margin of the eyestalk there is dorsally a seta bent laterally. The thorax, neck and scutellum are black with grayish tint. The seta at the end of the spines is thin and tender, almost as long as the spines.

The wings are translucent with a weak brownish obscurity in the middle.

The abdomen widens towards the back, black, shining.

Anteriorly to the groove of the first segment there is on either side a light blue spot rounded behind.

Behind the groove, near the lateral margins of the abdomen there is a pair of red-brown weakly outlined spots.

The lower, ventral side of the abdomen possesses a wide, brown, coffee-coloured median longitudinal band, which is interrupted at the border-line of the segments by the gray ground-colour of the ventral side. The black colour of the dorsal side passes also to the rentral side of the abdomen in the form of triangles with an acute interior angle, of which the anterior triangle reaches the median band with its interior angle, whilst the other's do not approach it near.

Two $\sigma^{x}$ from Mabira, 12. VI.

\section{Diasemopsis pulchella n. sp.}

Fig. 5, ㅇ․

Length $5-5^{1 / 2}$ mm. Width of head with eyestalls about $3^{1 / 2} \mathrm{~mm}$.

This is a graceful species with strongly developed setae sitting partly on stalks and with a dense corer of hairs. Sexual dimorphism is present.

The head and eyestalks are yellow-brown. The arcuate line is weakly outlined, but is continued as a clear, black line along the eyestalks. Under the eyestalks there is a duskybrown smear. The short eyestalks are thin, their seta is strong and long, sits vertically on a short brown stalk and is slightly bent backwards.

Thorax black, shining. The pleurae in the female gradually pass into a brownish colour. The short, rather elerated scutel- 
lum is black, or brown-black. The scutellar spines are raised nearly vertically at the basis, and in their distal half are bent behind, and diverge as usual. The seta at the extremity of the spine is thin, tender, reaching two thirds of the spine in length. The seta situated medially to the point of attachment of the wings is strong and long; it is directed nearly vertically and attached to a short, wide, black stalk.

The fore coxae are dark brown-red, the rest of coxaegray-yellow. The fore femora are not much swollen, and are not stronger developed in the male than in the female; yellow-brown. The remaining femora are brown-yellow (lighter than in fig. 5) in their basal two-thirds, and are blackbrown in their distal third and on both sides.

The tibiae are light brown-yellow; in the last pair of tibiae, on either side of each, there is a place beginning nearly at the base and in the distal quarter that is blackish, so that the tibiae seem to be provided with two light bands; if looked at from the side. The tarsi are all brown-yellow.

The wings are translucent, slightly brown. On the anterior transverse vein (on either side of it) there is a small brownish smear. Basally to the posterior transverse vein there is an undistinct transverse band, reaching only the second longitudinal vein $(\mathrm{R} 2+3)$ and not approaching the anterior margin. Lastly, at the end of the third longitudinal rein $(\mathrm{R} 4+5)$ there is a weak, brownish spot.

The abdomen is very narrowed at the base, like in Ichneumonidat. The colour of the abdomen is in both sexes different. The male is black. In the female there is a band on both sides of the border-line between the first and second segments.

The spaces with a light bline tint are distributed alike in male and female and consist, first of all, of a band at some distance from the basal end of the abdomen at its narrowest point, where it is slightly constricted. Further, anteriorly to the groove of the first, long segment there are two spots bent backwards.

The ventral side of the abdomen in the female is gray up to the groove of the first segment, and beginning from it, distally-white. Medially the rentral side of the female has a broad yellow longitudinal stripe with brown hems. The hem has three small setae on the second and third seg- 
ments respectively. Between the groove and border of the first and second segment the dark colour of the upper side passes in the shape of an acute angle to the rentral side, but does not reach the rentral longitudinal stripe. In the male the drawing of the ventral side is the same, but the ground-colour is not white, but gray and the longitudinal stripe is dusky light-brown. All the species is rather thickly coreled with strong hairs which may even be called setae.

2 specimens, 1 o and 1 of from Nabira.

13. VI., 10. VI.

\section{Explanation of drawings.}

The animals were sketched with the help of a binocular microscope of Zeiss and camera lucida of Abbé. The magnification of all the figures is the same $\times 8$.

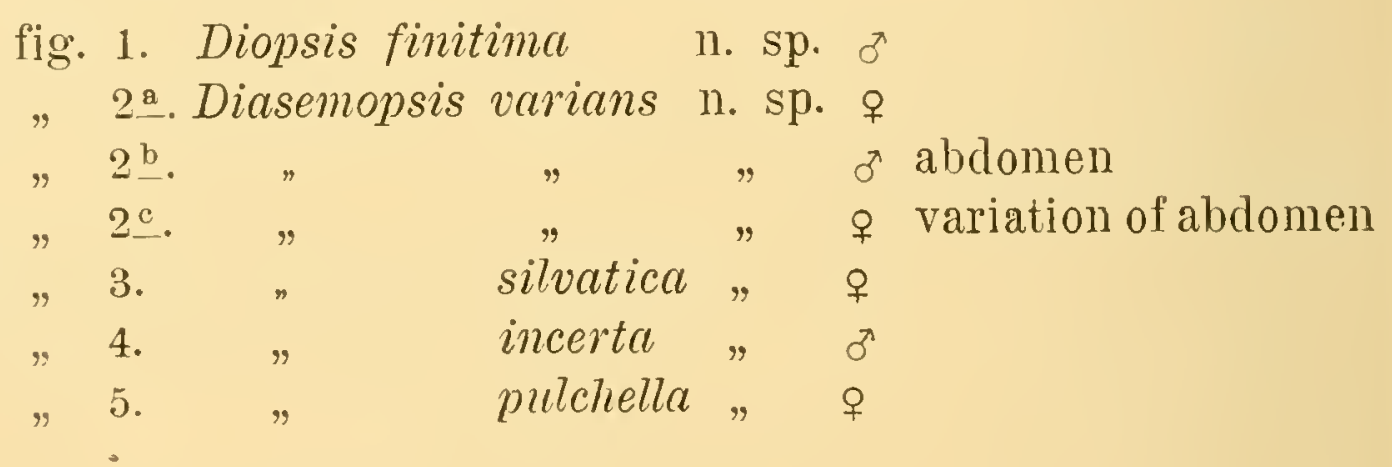


Ф. Эгересо. Cucmenamuna Diopsidne.
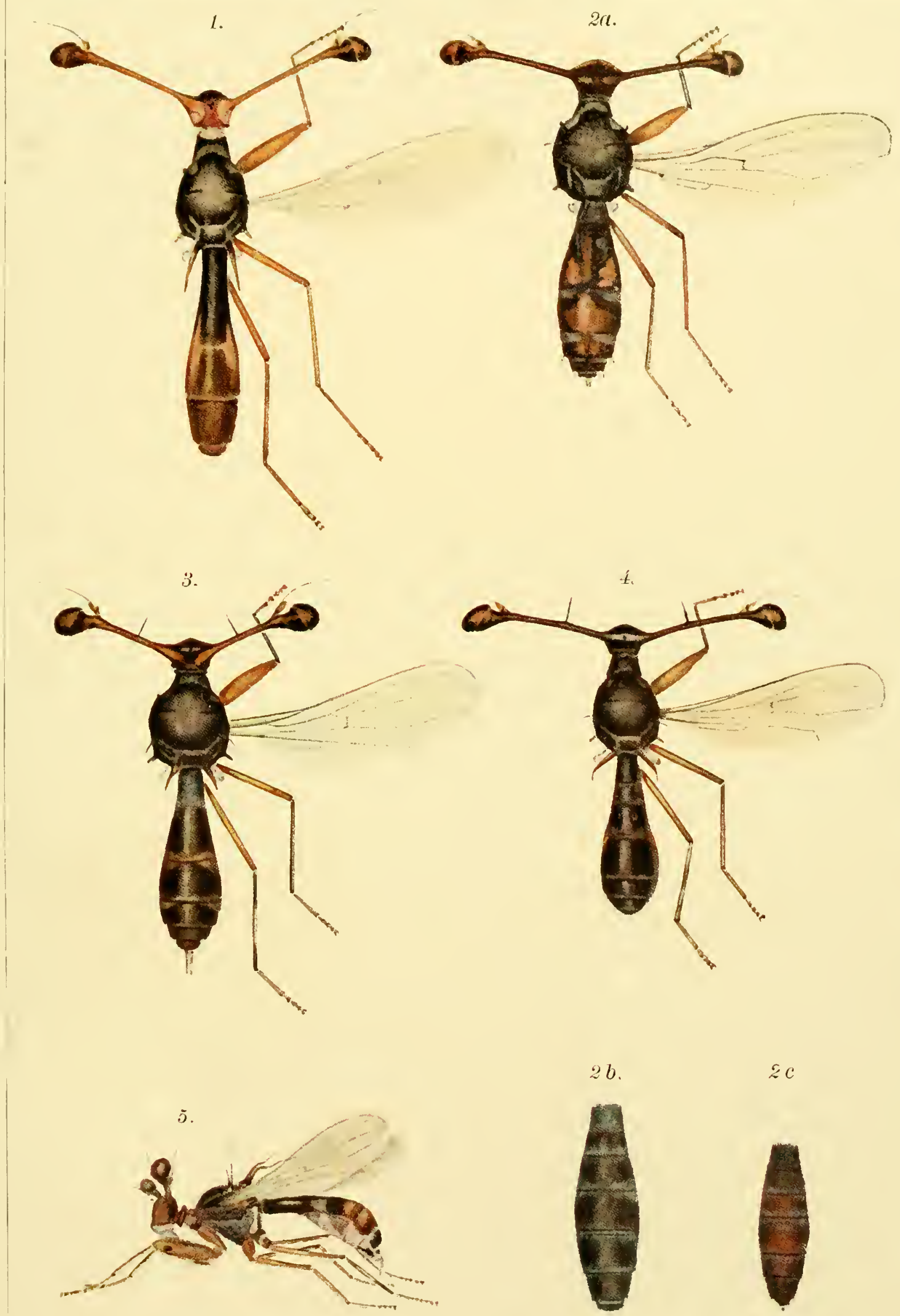



$$
\text { № } 7 \text {. }
$$

\section{0 строеніи стебельчатыхъ глазъ Diopsidaе.}

$$
\text { Ф. 0. ЭГГЕРC В. }
$$

On the structure of the stalked eyes of Diopsidae.

F. 0. EGGER S. 



\title{
О строеніи стебельчатыхъ глазъ Diopsidae.
}

\author{
Ф. 0. ЭГГЕРСЪ.
}

(Пзъ Зоотомическаго Кабинета Петроградскаго Университета).

Профессоръ В. Догель и И. Соколовъ, во время своей побздки л各томъ 1914 г. въ Британскую Восточную Африку, собрали небольшой матеріалъ по анатоміи Diopsidae, который и передали мн各 для обработки. Матеріалъ быль фиксированъ главнымъ образомъ смъььью Жильсона, сулемой съ уксусной к. и пикриново-азотной смбсью, и консервированъ въ спирту. Систематическую обработку полученныхъ мною Diopsidae я даю въ другой статьђ. Что касается до настоящей работы, то она содержитъ описаніе своеобразныхъ глазъ этихъ мухъ, гистологическое изсльдованіе которыхъ я предпринялъ по совъту профессора В. Догеля.

D j opsjdae, a также еще одно семейство, Achi asida e (Cyclorapha, Acalyptera), представляютъ собою тропическихъ мухъ, отличающихся глазами, сидящими на длинныхъ стебелькахъ. Подобное устройство глазъ мы, среди насъкомыхъ, встрбчаемъ только у нихъ. У Achiasidae стебельчатые глаза являются половымъ признакомъ, который свойственъ только самцамъ. Напротивъ того, у Diopsida e стебельчатыми глазами (рис.

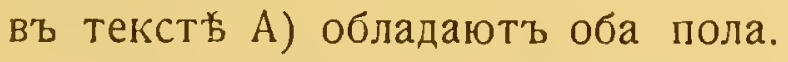

Ach i asidae принадлежатъ исключительно индо-австралійской фаунъ, преимущественно встръчаясь на Зондскихъ о-вахъ; Diopsidae, кромб того, распространены почти по всей Африкь и Аравіи, исключая съверную часть африканскаго континента.

Стебельки, на которыхъ помб́щаются глаза двухъ вышеупомянутыхъ семействъ D i ptera, являются боковыми выростами головы и достигаютъ у многихъ видовъ двухъ третей длины. всего твла. Глаза находятся на дистальныхъ концахъ стебельковъ. 
у Achiasidae только самые глаза удалены оть головы, усики же остаются сидъть на головъ. Усики D i o psida e смъщаются вмбств съ глазами къ концу стебельковъ и прикръпляются нбсколько впереди основанія глазъ (рис. А. и рис. 1,2).

Подробное изсльдованіе фасеточныхъ глазъ Diptela предпринято въ посльднее время Дитрихомъ (Dietrich 1909). Хотя работа его касается только европейскихъ Diptera, она все же успвла показать, какое огромное разнообразіе наблюдается въ гистологическомъ строеніи глазъ даже у близкихъ между собою семействъ и у различныхъ половъ одного и того же вида. При этомъ варіаціи въ гистологическомъ строеніи глазъ могутъ затрагивать самые разнообразные элементы, какъ то: діоптрическій аппаратъ, число, положеніе и форму рабдомныхъ кльтокъ, развитіе пигмента и т. д. Половой диморфизмъ фасеточныхъ глазъ, встръчающійся главнымъ образомъ у 0 rthorrapha, состоитъ въ образованіи у самцовъ такъ называемыхъ ,двойныхъ глазъ“ (кромғ Em pidae, у которыхъ двойными глазами обладаютъ оба пола).

Для многихъ изъ перечисленныхъ модификацій глаза Дитрихъ даетъ физіологически-біологическое объясненіе, исходя изъ той мысли, что своеобразіе глазъ стоитъ въ связи съ жизненными условіями, при которыхъ существуетъ каждый данный видъ.

Весьма въроятно, что и образованіе стебельчатыхъ глазъ у Diopsidae имъетъ извъстную біологическую подкладку. Прежде всего при этомъ возникаетъ вопросъ, ограничивается ли приспособленіе глаза Diopsidae къ извъстнымъ особымъ функціямъ образованіемъ стебелька, или же рука объ руку съ этимъ происходятъ и измъненія въ гистологическихъ элементахъ глаза. Выясненію этого вопроса и посвящена главныльъ образомъ данная работа.

Имъвшійся въ моемъ распоряженіи матеріалъ былъ консервирован'ь, какъ я уже упоминалъ, различными фиксирующими жидкостями. у нокоторых'ь экземпляровъ Diopsidae голова или глаза обрбзывались при фиксированіи для лучшаго прониканія въ нихъ консервирующей жидкости. Наиболъе благопріятные результаты дали объекты, консервированные сулемой съ уксусной кислотой. Заливаніе объектовъ производилось черезъ кедровое масло, причемъ они помғщались затбмъ на сутки въ смъсь кедроваго масла съ парафиномъ и уже оттуда переносились въ тугоплавкій чистый парафинъ. При ръзаніи въ тугоплавкомъ парафинғ легко удавалось получать серіи србзовъ въ $3 \varphi$ 
толщиной. Лучшіе результаты въ смысль окраски препаратовъ давалъ гематоксилинъ съ эозиномъ. При этомъ я сначала держаль сръзы около трехъ сутокъ въ сильно разбавленномъ растворъ гематоксилина Деляфильда, а затьмъ оставлялъ ихъ еще на сутки въ эозинъ. Кромю г гематоксилина мною примънялись и другія краски.

Для лучшаго об́наруженія извъстныхъ деталей я примънялъ различные методы депигментированія. Полнъе всего пигментъ удаляется смъсью Дитриха (1 часть глицерина, 20 ч. 80\% спирта и 1 ч.соляной кислоты). Однако, при слабомъ развитіи пигмента въ глазу Diopsidae, депигментированіе не является настоятельно необходимымъ. Между тъмъ, депигментирующія смъси всегда оказываютъ нбкоторое разрушительное дъйствіе на плазматическія структуры, почему я вскорб и оставилъ этотъ методъ.

$\mathrm{Bъ}$ заключеніе пользуюсь случаемъ выразить профессору В. Догелю мою искреннюю благодарность, какъ за предоставленіе матеріала, такъ и за помощь при выполненіи работы.

\section{Вньшняя морфологія глаза.}

Фасеточные глаза Diopsidae находятся на дистальномъ конц各 длинныхъ, неподвижныхъ стебельковъ, которые представляютъ собою выросты головы, отходящіе по бокамъ отъ лба (рис. А).

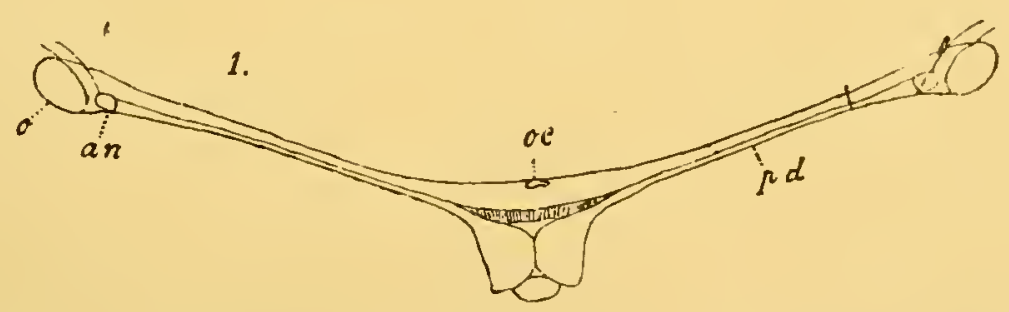

Pис. А. Голова Diasemopsis varians m. $\sigma^{\pi}$ спереді. an-успк; oглазъ; ос-одиночные глазкі; $p$-глазной стебелекъ. Fig. A. The head of Diasemopsis varians m. of, front view; an-antennae; o-eye; ocsimple eyes (ocelli); $p$ d-eye-stalk.

Для сравненія у меня имълось нъсколько видовъ изъ родовъ Diopsis L. и Diasemopsis Rond. Развитіе стебельковъ нъсколько варіируетъ у различныхъ видовъ. У однихъ видовъ стебелекъ коротокъ и широкъ, не превосходя своей длиной ширины головы (напр., Diopsis ornata Wstw.). У большого числа видовъ стебелек'ъ, однако, длиннъе головы и груди, вмбстб̈ взятыхъ 
(напр., Diasemopsis varians, рис. А), и тогда онъ всегда очень тонок'ь. Обыкновенно, сильно дивергирующіе глазные стебельки, направлены нъсколько кверху, дорсально. Однако, при наклоненной головь, стебельки могут’ь быть направлены и нбсколько впередъ. ${ }^{1}$ )

Такъ какъ, при подвижности головы, трудно точно установить разныя направленія, то я принимаю за нормальное положеніе головы такое, при которомъ стебельки глазъ расположены перпендикулярно къ длинной оси тъ̆ла.

При такомъ положеніи усики находятся на передней сторонъ стебельковъ. Уголъ, образуемый стебельками, не вполнъ постояненъ, что, однако, не зависитъ отъ длины стебельковъ. У отдъльныхъ видовъ оба стебелька находятся почти на одной и той же горизонтальной прямой линіи.

Обыкновенно, у видовъ съ длинными глазными стебельками голова имъетъ относительно меньшій объемъ, чъмъ у видовъ съ короткими стебельками. Получается впечатльнје, что въ первомъ случағ развитіе стебельковъ происходитъ за счетъ матеріала, идущаго на образованіе головы. Длина стебельковъ варіируетъ, между прочимъ, и въ предълахъ одного вида, особенно у разныхъ половъ, причемъ у самца стебельки нъсколько длиннъе, чъмъ у самки; всльдствіе этого прежде авторы въ сомнительныхъ случаяхъ основывались на длинъ стебельковъ при опредъленіи пола. Въ поперечномъ разръзъ стебельки являются неправильно округлыми, часто съ острымъ переднимъ краемъ. На дистальномъ концъ, на которомъ помъщается глазъ, каждый стебелекъ значительно утолщается; въ этом'ъ утолщеніи расположенъъ зрительный ганглій.

Фасеточный глазъ (рис. 1 со спинной стороны, рис. 2--съ брюшной) устроенъ у изсльдованныхъ мною видовъ весьма однообразно. При этомъ онъ имъетъ одинаковое строеніе у обоихъ половъ и, внбшнимъ образомъ, не обнаруживаетъ никакой дифференцировки въ двойной глазъ, кромъ увеличенія числа или величины фасетокъ на передней сторонб глаза.

Форма глаза очень неправильная, приблизительно яйцевидная. Дистальная наружная поверхность („Angenmittelfeld“) глаза является наиболъе выпуклой. Стебелекъ прикрвпляется къ глазу

1) У пеб́ольшой грушшы D i o p s i a e, близкихт къ, D. ichnemmonea. L., стебельии глазт п при нормальномъ положеніп головы наклонены, иовидимому, нсколько киереди. 
сзади и со спинной стороны, такъ что наибольшая свободная поверхность глаза находится на его передней и нижней сторон官. Такой оріентировкъ глаза отвъ́чаетъ отчасти и степень развитія фасетокъ: самыя крупныя фасетки помьщаются на передней поверхности глаза, тогда какъ остальныя части глаза, особенно задняя, снабжены гораздо меньшей величины фасетками. Передняя, крупно-фасеточная часть глаза простирается дальше всего проксимально и является ньсколько уплощенной въ данномъ направленіи.

Впереди, передъ основаніемъ глазъ находятся трехчлениковые усики, съ большимъ, плоскимъ концевымъ членикомъ, несущимъ длинную, тонкую концевую щетинку. Начиная съ основанія усиковъ, передняя сторона глазного стебелька, подъ которой проходитъ оптическій нервъ, является нбъсколько приподнятой. Спинная граница этой выпуклости проходигъ, обыкновенно, въ видъ тонкой линіи вдоль стебелька (рис. А) и переходитъ на головъ въ такъ называемую linea arcuata; посльддняя им ъетъ характеръ широкой, большею частью черной линіи, отдъляющей лобъ отъ лица. На лбу находится дорзально три глазка (ocelli, рис. A, ос.).

Передъ основаніемъ самыхъ глазъ сидятъ нбсколько тонкихъ щетинокъ, самая задняя изъ которыхъ достигаетъ значительной величины, превращаясь у одного изъ изсльдованныхъ видовъ, Diopsis acanthophthalma m., въ настоящій шипъ. Цвъ́тъ консервированныхъъ въ спирту глазъ темно-бурый.

\section{Роговица.}

Роговица представляетъ собою кутикулу глаза, которая дифференцировалась въ шестиугольныя фасетки такимъ образомъ, что на каждый омматидій приходится по одной фасетк夆. По направленію кнаружи фасетки выпуклы и закруглены, как’ъ это можно видбть изъ рис. 10, на правой сторонб котораго разръзъ задблъ поверхность фасетокъ. Въ продольномъ разръзъ (рис. 3, С) фасетки кажутся плоскими или плосковыпуклыми. Форма и величина фасетокъ варіируютъ въ различных'ъ участкахъ поверхности глаза; при этомъ, вопреки тому, что наблюдается у большинства насъикоых, самыми крупными являются фасетки не спинной, а передней стороны глаза (рис. 4 и 5). Форма фасетокъ измъняется въ зависимости отъ ихъ размьров'ъ. Рисунки 6 и 7 изображаютъ фасетки, взятыя изъ одного и того же поперечнаго разръза глаза, но принадлежащія двумъ различнымъ частямъ 
посльдняго. Фасетки передней площади глаза (рис. 6) велики, плоски и вогнуто-выпуклы, со слабо выпячивающейся внутренней стороной. Фасетки задней поверхности (рис. 7), при той же толщинғ, что и вышеупомянутыя, наполовину уже ихъ, съ сравнительно сильно выпуклой наружной стороной. Однако, между этими двумя формами есть цълый рядъ переходныхъ ступеней, не позволяющихъ внбшнимъ образомъ установить обособленія глаза на двъ различныхъ части, какъ это мы находимъ въ такъ называемыхъ двойныхъ глазахъ.

По направленію къ заднему краю глаза фасетки измъняются ецце сильнъе, становясь, при малой величинъ̆, двояковыпуклыми (рис. 8).

\section{Псевдоконусъ.}

Псевдоконусомъ называется образованіе, свойственное спеціально глазу Diptera. Онъ состоитъ изъ болье или менъе жидкаго вещества, расположеннаго подъ фасетками (рис. 3, 9 и 11, psc.). На границъ съ фасетками псевдоконусъ является еце шестиугольнымъ (рис. 11, сльва), далъе же вглубь онъ постепенно округляется, утончается и принимаетъ коническую форму; въ такой формь вещество псевдоконуса удерживается двумя окружающими его главными пигментными клғтками (P'). Проксимально, т. е. далъе вглубь, передъ вершиной псевдоконуса находятся четыре кльтки хрустальнаго конуса, ядра которыхъ (Семперовскія ядра) всегда хорогшо замбытны на моихъ препаратахъ (n. s.). Напротивъ того, самъ лсевдоконусъ плохо сохранился на моих'ь препаратахъ-онъ сильно съёживается и состоитъ, повидимому, изъ очень нестойкой, жидкой массы. На передней поверхности глаза, гдъ фасетки крупнъе, и исевдоконусъ имъетъ значительные размғры (рис. 4 и 5).

Происхожденіе псевдоконуса до сихъ поръ еще толкуется различными авторами различно. Гренахеръ разсматриваетъ его, какъ продуктъ выдғленія четырехъ хрустальнохъ клътокъ, т. е. какъ гомологъ хрустальнаго конуса прочихъ насыкомыхъ. Между тұмъ Карь ер ь (Сarrière) приходить къ тому убъжденію, что псевдоконусъ сльдуетъ считать за часть роговицы. Къ этому взгляду примкнулъ въ новъйшее время и Дит рихъ. Его привело къ этому наблюденіе, что у нъкоторыхъ видовъ, напримъръ, Simnlium и Chrysogaster, отсутствуетъ ръзкая граница между фасеткой и псевдоконусомъ, ибо складчатость первой изъ упомянутыхъ частей продолжается непосредственно во вторую. 
На моихъ препаратахъ я не могъ подмғтить связи между псевдоконусомъ и роговицей. Роговица, обыкновенно, отдълялась отъ псевдоконуса, не увлекая при этомъ вмъсть кусочковъ послбдняго, и сморщенные остатки псевдоконуса всегда оставались при хрустальныхъ клғткахъ. Хотя, такимъ образомъ, мои наблюденія не согласуются со взглядомъ Дитриха на происхожденіе псевдоконуса, однако у меня но̆тъ никакихъ серьезныхъ возраженій, которыя я могъ бы привести противъ этого воззрьнія.

Въ томъ случаъ, если мы будемъ считать псевдоконусъ составною частью роговицы, мы должны принимать, что онъ, подобно посльдней, образуется корнеагенными кльтками. Особыя корнеагенныя кльтки имбются въ фасеточномъ глазу ракообразныхъ и низшихъ насъкомыхъ (Apterygota, Ephemeridae, Periplaneta). у прочихъ, высшихъ насъкомыхъ эти кльтки отсутствуютъ и, поэтому, раньше думали, что ихъ роговица образуется насчетъ кльтокъ хрустальнаго конуса, которыя въ эвконномъ глазу выдъляяютъ якобы въ дистальномъ направленіи - роговицу, а въ проксимальномъ-хрустальный конусъ. Въ настоящее время это воззрьніе поколеблено, съ тъхъ поръ какъ Гессе (1901) обратиль вниманіе на тотъ фактъ, что вмъсто двухъ корнеагенныхъ клътокъ у высшихъ насъкомыхъ появляются двъ главныя пигментныя кльтки, отсутствующія у низшихъ. Это наблюденіе дълаетъ весьма въроятнымъ гомологичность обоихъ упомянутыхъ родовъ кльтокъ другъ другу. Впрочемъ, Гессе

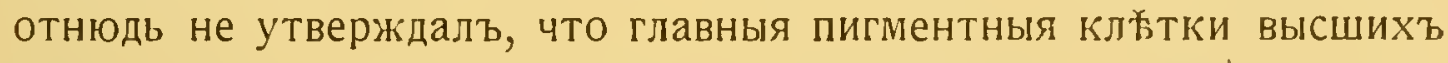
насъиомыхъ сохранили функцію корнеагенныхъ клътокъ; эту функцію онъ, скоръе, приписывалъ попрежнему кльткамъ хрустальнаго конуса. Новыя эмбріологическія изсльдованія Бер лезе надъ глазомъ Polistes gallica показали, однако, что у высшихъ насъкомыхъ роговицу выдъляютъ главныя пигментныя клғтки, которыя лишь впосльдствіи, при дальнъйшемъ развитіи, превращаются въ пигментныя клбтки; что же касается кль̆токъ хрустальнаго конуса, то онъ не принимаютъ участія въ образованіи роговицы.

Если мы, такимъ образомъ, ръшимъ считать псевдоконусъ D iptera составною частью роговицы, то отсюда логически вытекаетъ, что и онъ долженъ быть продуктомъ выдъленія главныхъ пигментныхъ кльтокъ-спғдствіе, которое въ видъ предположенія было высказано уже Дитрихомъ.

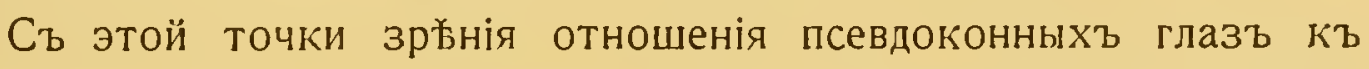
прочимъ фасеточнымъ глазамъ являются значительно измънен- 
ными по сравненію съ твмм, какія принимались раньше. По Дитриху псевдоконный фасеточный омматидій является модифицированнымъ аконнымъ; поскольку четыре хрустальныхъ кльтки не непосредственно прилегаютъ къ фасеткъ, но отдъляются отъ нея большею частью мягкимъ, частью же плотнымъ processus corneae (=pseuducomus). Мнъ представляется, однако, еще болъе существеннымъ сльдующее различіе: тогда какъ въ псевдоконномъ глазу функціонирующая въ качествъ хрустальнаго конуса свътопреломляющая среда, или "стекловидное

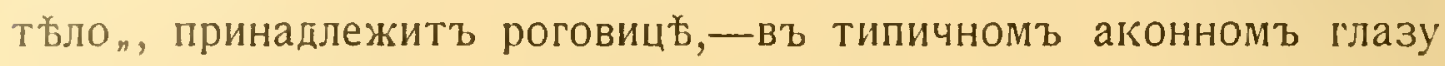
она представлена хрустальными кльтками ${ }^{1}$.)

Несмотря на все это, провести ръзкую границу между псевдоконными и аконными глазами очень трудно, ибо въ природъ имъется цйлый рядъ переходовъ отъ однихъ къ другимъ. Мы часто находимъ въ аконныхъ глазахъ, напримъръ, у водяныхъ клоповъ, присутствіе въ фасеткахъ processus corneae, который съ одинаковымъ правомъ могъ бы именоваться псевдоконусомъ. Мы только потому привыкли давать особое названіе processus corneae y Diptera и обозначать его, какъ псевдоконусъ, что до сихъ поръ посльдній считался имъющимъ иное происхожденіе, ч各мъ processus corneae. Поэтому я считаю праздной попытку Іонаса (Iohnas), который въ своей работғ о фасеточныхъ глазахъ бабочекъ старается свести эвконные глаза нъкоторыхъ Rhopalocera, всльдствіе присутствія въ нихъ processus corneae, къ псевдоконному типу. Правда, въ морфологическомъ отношеніи processus corneae нъкоторыхъ Rhopalocera (а также жуковъ) можетъ, какъ составная часть роговицы, быть равноцбннымъ псевдоконусу Diptera. Но, въ генетическомъ отношеніи, его никакъ нельзя производить отъ псевдоконуса двукрылыхъ. Мы могли бы скоръе свести его къ processus corneae нъкоторыхъ аконныхъ глазъ, хотя и это кажется мнб мало въроятнымъ, ибо первичныя, наиболъе примитивныя формы эвконныхъ глазъ (напр., у Machilis и Periplaneta) не имбють processus colneae. Въ лицғ processus corneae бабочекъ и жуковъ мы, въроятно, имғемъ дәло со вторичнымъ приспособленіемъ къ спеціальнымъ физіологическимъ функціямъ. Данныя Гессе, приводимыя Іонасомъ въ защиту своего воззрънія, по которымъ псевдоконный глазъ

1). Эвконный глазь приблнаетея кіь аконному В'т томъ отношеніп, что его хрустальный конуст предетавляеть собою шродукте хрустальныхь клтокт. Къ псевдоконноу глазу әвконный пе имьеть дикакихъ близихь отпопеній. 
Bibionidae обладаетъ маленькимъ хрустальнымъ конусомъ и такимъ образомъ представляетъ собою переходъ къ эвконному типу, не были подтверждены Дит рихомъ.

\section{Ретинулы (сьтчатка).}

Регинулы (рис. 3 и 9 ret) образуютъ чувствительный аппаратъ фасеточнаго глаза. У Diptera каждая ретинула имъетъ характеръ трубки, лежащей проксимально отъ хрустальныхъ клътокъ. Стънки трубки состоятъ изъ 7 вытянутыхъ въ длину и соприкасающихся своими краями рабдомныхъ клътокъ. На внутренней своей сторонь каждая такая кльтка несетъ по чувствительной палочкъ, или рабдомеру (рис. 9 и $12 r h$ ), которая вдается въ центральный просвьтъ ретинулы. Въ проксимальномъ направленіи ретинулы подстилаются базальной мембраной $(m b)$.

Во всъхъ частяхъ глаза ретинулы устроены приблизительно одинаково, за исключеніемъ передней его поверхности, гдъ онъ нйсколько отличаются отъ общаго типа. Для сравненія я даю три рисунка $(3,4$ и 5). На рис. 3 продольный разръзъ прошелъ не черезъ передній участокъ глаза, вслбдствіе чего здъсь всъ ретинулы приблизительно одинаковы, и только на краю срединной площадки онъ нъсколько крупнъе, какъ это обыкновенно бываетъ въ фасеточномъ глазу. Передняя часть глаза попала на поперечный разръзъ на рис. 5, а на продольный-на рис. 4. На поперечномъ разръзъ замътно, что ретинулы передней площади глаза $(a)$ почти вдвое длиннъе ретинулъ прочихъ частей его $(d$, $v$ и $p$ ), всльдствіе чего относящійся къ передней поверхности участокъ базальной мембраны является плоскимъ, а не выпуклымъ. На рис. 4, гдъ ретинулы разръзаны поперекъ, можно видъть, что ретинулы передней площади глаза (ret.v.) разставлены гораздо дальше другъ отъ друга, чъмъ ретинулы спинной поверхности глаза, которыя непосредственно соприкасаются другъ съ другомъ своими стънками. Кромъ того, даже при примъненномъ въ данномъ случаъ слабомъ увеличеніи бросается въ глаза, что осевой просвътъ спинныхъ ретинулъ гораздо шире просвъта переднихъ.

Всл务дствіе только что приведенныхъ признаковъ вся совокупность относящихся къ передней площади глаза ретинулъ можетъ быть на поперечномъ разръзъ черезъ глазъ довольно ръзко отграничена отъ прочихъ. 
Всъ эти факты заставляютъ насъ заключить, что передняя площадь глаза имъетъ своеобразно устроенную ретину и поэтому заслуживаетъ отдбльнаго описанія.

Обратимся сначала къ гистологическимъподробностямъ строенія твхъ ретинулъ, которыя не принадлежатъ передней площади глаза. На продольномъ разрьъз черезъ омматидій (рис. 9) мы видимъ, что ретинулы (ret.) отходять въ проксимальномъ направленіи отъ ядеръ хрустальныхъ клғтокъ (n. s.). Дистально ретинулы становятся шире и здъсь находится большинство крупныхъ, пузырьковидныхъ ядеръ (n. ret. 1-6) рабдомныхъ клғтокъ. По направленію къ базальной перепонкъ $(m . b$. $)$, т. е. проксимально, ретинулы постепенно суживаются. Проксимально же отъ средины ретинулъ удается разсмотрьъть еще одно, седьмое ядро (n. ret. 7) одной изъ рабдомныхъ кл卷токъ. Плазма этихъ клғтокъ свьтлая. Наружная поверхность ретинулы покрыта слоемъ мелкозернистаго пигмента (P. ret.). Внутренній, осевой просвътъ ретинулы весьма широкъ; но довольно ръзко суживается въ дистальномъ направленіи, наконецъ совершенно замыкаясь; въ проксимальномъ направленіи просвбтъ суживается весьма постепенно и доходитъ до базальной перепонки. По стйнкамъ осевого

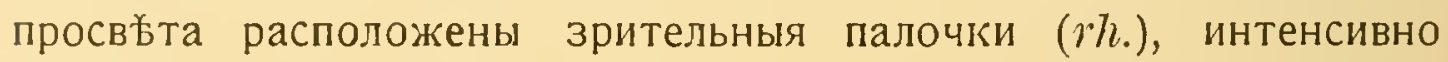
окрацивающіяся эозиномъ. Діаметръ посльднихъ наиболъе великъ на дистальномъ концъ, такъ что получается впечатлғніе, что онъ вдвигаются своими концами между клғтками хрустальнаго конуса.

Изображенныя отношенія хорошо иллюстрируются рисунками поперечныхъ разръзовъ, проведенныхъ черезъ ретинулы на различныхъ уровняхъ (рис. 11-14); при этомъ рис. 14 сдбланъ при нйсколько бо́льшемъ увеличеніи, чбъмъ остальные.

На рис. 11 самый правый изъ омматидіевъ изображенъ на уровн各 хрустальныхъ клғтокъ. На этомъ мвст年 омматидій ограниченъ толстымъ слоемъ пигмента, принадлежащаго главнымъ пигментнымъ, кльткамъ, и охватывающаго собою хрустальныя кльтки. Видны границы четырехъ хрустальныхъ кльтокъ, но Семперовскія ядра незамътны, такъ какъ они маскируются сближенными темными концами рабдомеровъ ( $/ h$.).

На рис. 12 представленъ разръзъ черезъ два омматидія, проведенный на уровнъ дистальныхъ ядеръ (n. ret. 1-6) рабдомныхъ кльтокъ. Рабдомныя кльтки расположены на разрбзб въ видб вънчика, причемъ 6 изъ нихъ приблизительно одинаковой величины и формы, седьмая же очень тонка и какъ бы вклинена 
среди другихъ. Ядра (n. ret. 1-ij) лежатъ приблизительно на одномъ уровнъ, так'ъ что иногда, как'b, напримър'ь, на правомъ омматидіи нашего рисунка, всъ 6 ядеръ больъе крупныхъ рабдомныхъ клғтокъ оказываются на одномъ разрьзб. Отсутствуеть только ядро седьмой, тонкой кльтки. Какъ мы увидимъ впосльдствіи, посльднее идентично съ тьмъ ядромъ (n. ret. 7), присутствіе котораго проксимально отъ средины ретинулы мы установили на продольных'ь разръззах’ь (рис. 9). Какъ по направленію кнаружи, такъ и къ осевому просвбту всь кльтки, кромъ седьмой, являются нбсколько выпуклыми. Тонкая седьмая кльтка выдается лишь въ сторону осевого просвъта, но зато сильнье прочихъ, наружная же ея поверхность оказывается вогнутой. Рабдомеры $(r h$.$) въ поперечномъ разръзъ́⿱丶万仒 округлы и наполовину выдаются$ свободно в’ь осевой просв Һ̌тъ. Рабдомеръ 7-ой кльткки тоньше прочихъ. Ретинулы окружены снаружи мелкозернистымъ пигментомъ. Мъстами онъ соприкасаются между собой, мъстами отдълены другъ отъ друга неправильными ходами трахей.

Рисунокъ 13 изображаетъ поперечный разрћзъ, проведенный нбсколько болье проксимально черезъ пять омматидіевъ. Омматидіи имъютъ здъсь, приблизительно, видъ звъзды. Можно замътить, что у трехъ верхнихъ омматидіевъ этого разрғза тонкая седьмая кльтка направлена книзу, тогда какъ у двухъ нижнихъ омматидіевъ эти кльтки расположены как'ь разъ наоборотъ; такимъ образом’ь три верхнія ретинулы представляют' собою какъ бы зеркальное отраженіе нижнихъ. Какъ первымъ показаль это у D iptera Д и т р и 'ь, у многихъ насъкомыхъ черезъ глазъ можно провести плоскость симметріи, которая дълитъ его на спинную и брюшную половины. При этомъ въ каждой изъ половинъ ретинулы, въ смыслъ расположенія рабдомныхъ кл卆токъ, являются зеркальнымъ изображеніемъ ретинулъ другой половины глаза. На рис. 13 верхнія и нижнія ретинулы расположены именно по объ стороны отъ только что упомянутой плоскости симметріи. Осевой просвътъ ретинулы достигаетъ на разсматриваемомъ разръзъ своего максимума. Ретинальный пигментъ лежитъ очень тонкимъ слоемъ на поверхности ретинулъ. Посльднія мъстами соприкасаются другъ съ другомъ, ограничивая между собою, приблизительно, шестиугольныя трахейныя пространства (Ti.).

Сльвдующій рисунокъ (рис. 14) изображаетъ разрьзъ черезъ 5 омматидіев’ изъ области седьмого ретинальнаго ядра и даетъ н务сколько своеобразную картину. Узкая, седьмая рабдомная кльтка

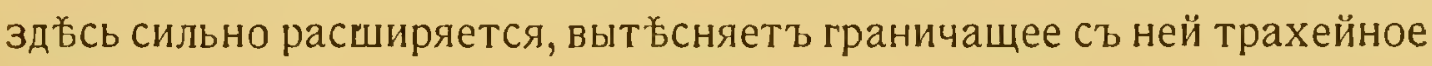


пространство и тб́сно прикладывается к’ наружнымъ ст бнкам'т, сосъдних'ь ретинулъ. Вслбдствіе этого контуры седьмой кльтки становятся неправильными. Ядро ея (n. ret. 7) довольно слабо выдъ́ляется среди окружающей плазмы. Прочія кльтки ретинулы суживаются по сравненію съ рис. 13, такъь что осевой просвъть и здғсь еще весьма великъ. Трахейныя пространства на изображаемомъ уровн各 сильно сужены и со всъхъ сторонъ охватываются стьнками ретинулъ, утрачивая сообщеніе между собой. Остальное тоже, что и на рис. 13 (отмбтимъ только, что на рис. 14 омматидіи перерьзаны нысколько вкось).

Менъе подробно удалось мнъ изучить строеніе ретинульь передней площади глаза. Какъ можно видъть на рис. 5, общій принципъ строенія этой части глаза таковъ же, какъ и прочихъ его отдығлов’ь.

Отличающіяся своей бо́льшей длиной ретинулы передней площади такъ же постепенно суживаются въ проксимальномъ направленіи. Большинство ихъ ядеръ такъ же располагается въ дистальной половинбъ кльтокъ, тогда какъ одно, очевидно, седьмое ядро помғщается въ проксимальной половинғ. Эти седьмыя ядра всь⿱⿱亠䒑女口‘ ретинулъ лежатъ на одномъ общемъ уровнъ.

Поперечный разръзъ (нбсколько увеличенный) черезъ ретинулу (рис. 16) передней площади, проведенный на уровнъ̆ разрбза, представленнаго на рис. 13, обнаруживаетъ уже знакомое намъ расположеніе рабдомныхъ кльттокъ: 6 одинаковыхъ, болье крупныхъ, и одна узкая, вклиненная между ними. Однако, осевой просвбтъ ретинулъ передней площади глаза значительно уже, чьмъ въ ретинулахъ остального глаза, такъ что рабдомеры почти соприкасаются между собой. Ретинальный пигментъ развитъ сравнительно сильн安е и расходится лучеобразно во всъ стороны, достигая иногда сосъднихъ ретинулъ. Посльднія раздылены другъ отъ друга обширными трахейными пространствами. Хотя ретинулы передней площади вдвое длиннъе ретинулъ другихъ частей глаза, діаметръ ихъ таковъ же.

Позволимъ себъ теперь сдълать нъсколько общихъ замћчаній относительно плана строенія ретинуль D i op sidae. По изсльдованіямъ Д и т р и а, сдъланнымъ надъ многочисленными видами D i p t e ra, ретинулы посльднихъ отличаются вполнь⿱ постояннымъ асимметричнымъ построеніемъ (см. рис. В,-копію $\mathrm{cъ}$ рисунка Дитриха, рядомъ съ которымъ, на рис. С, представлена схема ретинулы Diopsidae). По Дитриху оказывается, что рабдомеры 1-3 всегда расположены по одной прямой линіи и обращены къ медіанной линіи твла;рабдомеры 3-5 тоже образуютъ 
прямую линію, лежащую подъ острымъ угломъ къ первой, "während die Verbindungslinie von 5 mnd 6 der von $1-3$ parallel laüft. Das siebente Rhabdomer schiebt sich zwischen I und 6 nach dem inneren Lumen zu vor"

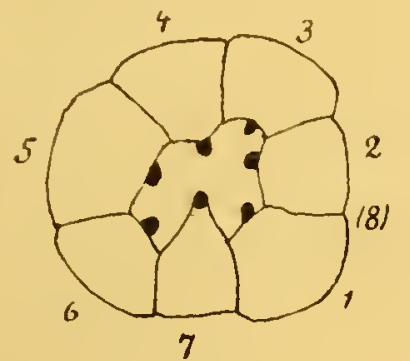

Pис. B.

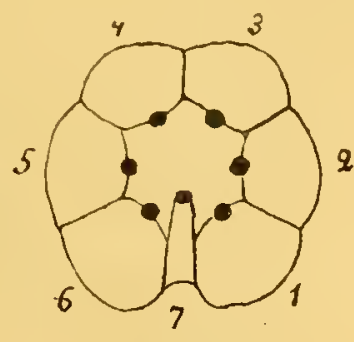

PIIC. C.

Далье, Ди т рих ъ на. ходитъ между 1-ой и 2-ой ретинальными кл в тк а м и еще одну, рудиментарную восьмую клюेтку или, по крайней мъ̌ръ, ея ядро.

У Diopsidae я не нахожу подобнаго асимметрическаго строенія ретинулъ. Напротивъ того, ретинула Di opsidae (рис. С) является строго билатерально-симметричной. Рабдомеры $1-6$ расположены въ видъ вънчика, а между 1-ой и 6-ой кльтками вставлена крайне узкая 7-ая ретинальная кльтка. Плоскость симметріи проходитъ между 3-ей и 4-ой кльтками, раздћляя

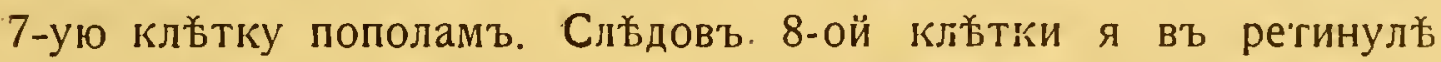
D i p sidae обнаружить не могъ. Возможно, однако, что остатки 8-ой кльтки имы̆ются въ дистальной части ретинулы, такъ какъ мнб кажется, что здъсь правильность расположенія кл务токъ до извистной степени нарушается всльдствіе сближенія 7-го рабдомера съ 1-ымъ. Вообще же расположеніе рабдомеровъ (рис. С) таково, что рабдомеръ 7-ой находится въ мьсть скрещиванія двухъ прямыхъ, изъ которыхъ одна соединяетъ между собою 1-й и 5-й рабдомеры, а другая 2-й и 6-ой. Это общее правило, находящее себъ подтвержденіе, повидимому, и въ рисункахъ Дит риха (рис. В).

Подобно Дитр иху я долженъ отмбтить составъ глаза изъ двухъ частей, представляющихъ одна зеркальное отраженіе другой (см. сказанное раньше объ рисункъ́ 13).

\section{Пигменть.}

Пигментъ обволакиваетъ омматидіи Diopsidae со всъъхъ сторонъ, на подобіе влагалища; онъ не простирается на оптическіе гангліи, по ту сторону базальной мембраны. Какъ у насъикомыхъ вообще, такъ и у Diopsidae можно различать "пигментъ ириса" и „пигментъ ретины“. Пигментація ириса обусловлена главными и лобочными пигментными кльтками. Каждому омматидію при- 
надлежатъ двь главныя пигментныя клбтки, которыя обхватываютъ псевдоконусъ и образуютъ вокнугъ него какъ бы толстую оболочку (ср. рис. 9 " 11, $P^{\prime}$ ). На рис. 11 сръзъ прошелъ черезъ омматидіи нб́болько госо, благодаря чему пигментныя клғтки здъсь видны на различной высоть: слғва онъ находятся ближе къ фасеткъ, справа-ближе къ кль̆ткамъ хрустальнаго конуса.

У краевъ фасетки главныя пигментныя клбтки, взятыя вмъстй, имъютъ гексагональную форму, но въ проксимальномъ направленіи он古 округляются и въ области кльтокъ хрустальнаго конуса являются совсъ̆м круглыми. Здъсь же онъ достигаютъ своей наибольшей толщины, а нъсколько проксимальнъе оканчиваются. Ядра главныхъ пигментныхъ клғттокъ $\left(n . P^{\prime}\right)$ находятая на половинной высот务 псевдоконуса и, такъ как'ь они спрятаны въ густомъ пигмент占, то ихъ не всегда легко обнаружить. Пигментъ главныхъ клйтокъ имъетъ темно-коричневую окраску.

Немного болъе проксимально отъ клбътокъ хрустальнаго конуса находится нбсколько побочныхъ пигментныхъ клбтокъ. Количество этихъ кл各токъ у различныхъ семействъ двукрылыхъ весьма измғнниво; у Diopsidae на каждый омматидій приходится по меньшей мъръ по четыре побочныхъ клътки. Всћ онғ вклиниваются между омматидіями на границ в между псевдоконусомъ и ретинулой (Рис. 9. n. $P^{\prime \prime}$ ), въ томъ моғст年, гд各 омматидіи сильнъе всего перетянуты. Структура пигмента какъ главныхъ, такъ и побочныхъ пигментныхъ кл各токъ представляется грубозернистой.

Пигментъ ретины (Рис. 9, 12 и 13, P. ret.) покрываетъ въ видъ тонкаго нъжнаго слоя наружную поверхность ретинулъ. Онъ составленъ изъ мелкихъ зернышекъ, видимыхъ лишь при сильномъ увеличеніи. Ретинулы передняго глазного поля имъ̆ютъ нъсколько болъе сильно развитой ретинальный пигментъ, который входитъ въ трахейныя пространства и мбстами слабо соединяетъ отдঝльныя ретинулы. Цвӧтъ этого пигмента-желто-коричневый. Относительно происхожденія ретинальнаго пигмента существуютъ пока разногласія. Дитрихъ считаетъ, что онъ образуется особыми кльтками, хотя ему и не удалось обнаружить ядеръ, которыя могли бы принадлежать этимъ клъткамъ.

\section{Оптическіе гангліи.}

Фасеточный глазъ D i opsida e можно сравнить съ полымъ полушаровиднымъ образованіемъ, ограниченнымъ снаружи роговицей, а извнутри базальной мембраной. При этомъ оказывается, 
что объемъ образованной глазомъ внутренней полости является сравнительно небольшимъ (ср. рис. 3). У другихъ двукрылыхъ, обладающихъ точно такъ же сильно выпуклыми глазами, какъ, напр., у Microchrysa, Chrysopilus, Chrysogaster и мн. др., внутренняя полость настолько сильно развита, что въ ней помъщаются не только наружный и внутренній оптическіе гангліи, но обычно лежатъ еще, внутри выступа базальной мембраны, и довольно значительныя трахеальныя полости.

y Diopsidae полость внутри глаза занята лишь наружнымъ оптическимъ гангліемъ (рис. $3, G$. о.е.), а большія трахеальныя полости вовсе отсутствуютъ. Что же касается внутренняго оптическаго ганглія, то онъ лежитъ въ расширенномъ дистальномъ конци глазного стебелька. Съ морфологической точки зр£нія вполнъъ понятно, что фасеточный глазъ не сидитъ прямо на узкомъ стеблъ, а что посльдній постепенно расширяется, чтобы этимъ самымъ дать глазу болье надежную опору. Понятно также, что полость этого расширенія-при другихъ обстоятельствахъ излишняя-использована для помєшенія внутренняго оптическаго ганглія. Зато труднъе объяснить, какія модификаціи въ положеніи или въ формъ омматидіевъ могли обусловить уменьшеніе внутренней полости глаза, въ которой заключенъ наружный оптическій ганглій.

Если мы будемъ сравнивать совокупность омматидіевъ глаза Diopsidae cъ таковой другихъ Diptera, то мы замътимъ сльдующія двъ особенности. Во-первыхъ, внутренняя полость глаза Diopsidae мала не только въ отношеніи къ объему оптическихъ гангліевъ, но и въ отношеніи толщины глаза, измъряемой длиной омматидіевъ. Если принять за масштабъ глазной полости средній половинный діаметръ кривизны базальной мембраны, то этотъ половинный діаметръ будетъ у большинства D i ptera значительно длиннъе омматидіевъ; у Diopsidae онъ, наоборотъ, короче ихъ. Слєдовательно омматидіи Diорsidae придвинулись ближе, чъъъ таковые другихъ Diptera, къ своему идеальному центру, изъ котораго они расходятся, или же, что менъе въроятно, они проксимально удлиннились. Первая возможность повлекла бы за собой значительное суженіе омматидіевъ, вторая--по крайней мърғъ суженіе ихъ проксимальныхъ канцовъ. Но тутъ выступаетъ особый моментъ, который позволяетъ имъ сохранить свою первоначальную ширину: это сильное уменьшеніе числа омматидіевъ въ глазъ Diopsidae. у всъхъ остальныхъ Diptera cъ сильно выпуклыми 
глазами число омматидіевъ довольно значительно. Такъ, напр., на рисункахъ Дитриха, на продольномъ сръзъ черезъ глазъ Microchrysa можно насчитать у самца 97, у самки 92 омматидія, тогда какъ на моемъ рисункъ аналогичнаго разръза (рис. 3) видно всего 53 омматидія при приблизительно одинаковой выпуклости глаза. Сходныя числовыя отношенія получаются и при сравненіи со многими другими Diptera. Несомнънно, что такое небольшое количество омматидіевъ въ глазу D i o psida e позволяетъ имъ занимать упомянутое положеніе, безъ того, чтобы они замбтно отъ этого суживались. Если бы количество омматидіевъ при данныхъ условіяхъ увеличилось, то ихъ проксимальные концы постепенно настолько бы сузились, что не осталось бы мвста даже для прохода нервныхъ волоконъ. Данное же число омматидіевъ позволяетъ пом ъститься внутри глазной полости лишь одному ганглію и при томъ относительно небольшой величины; весьма возможно при этомъ, что небольшому количеству омматидіевъ соотвътствуетъ и небольшой объемъ обоихъ оптическихъ гангліевъ.

Заспуживаетъ вниманія такъ же и нъсколько уклоняющаяся форма омматидіевъ у Diopsidae, обусловленная, въ связи съ сильной выпуклостью глаза, ихъ небольшимъ числомъ. Если сравнивать отдъльный омматидій съ клиномъ, который направленъ своимъ острымъ концомъ внутрь глаза, то у Diopsidae онъ заканчивается болье тупо, т. е. его стъннки дивергируютъ сильн台е, ч悉ъ у остальныхъ Diptera. При половинномъ числь омматидіевъ, каждый изъ нихъ, при равныхъ условіяхъ, будеть обладать вдвое большимъ внутреннимъ угломъ, ч各мъ при полномъ числь ихъ. Въ связь съ обусловленной такими обстоятельствами формой отдъльныхъ омматидіевъ Diopsida e мнъ хотвлось бы поставить еще то явленіе, что ихъ ретинулы и рабдомеры прогсимально явственно суживаются, что у другихъ Diptera не та́к’ замътно, и что, за исключеніемъ узкаго седьмого ядра ретинулы, всъ ядра ретинулы расположены дистально.

Въ наружномъ оптическомъ гангліи Diopsidae мы находимъ т古 же слои гангліозныхъ кльтокъ и волоконъ, какъ и у других' двукрылыхъ (ср. схематическ. рис. D). Съ базальной мембраной граничитъ „Nervenbündelschicht“ Бергера, который состоитъ изъ пучковъ нервныхъ волоконъ(fibres postrétiniennes V iallan es, рис. $3 f$.p.).

Промежутки между отдбльными пучками заполнены межкльточнымъ веществомъ съ рбдкими ядрами, по всей въроятности 
гэмолимфой, и содержатъ, кромъ того, очень мелкія трахеи. Нервныя волокна отходятъ отъ омматидіевъ наподобіе продолженій клбтокъ рабдомовъ и вступаютъ въ сльдующій, зернистый слой-„Körnerschicht" Б е р ге ра (Рис.

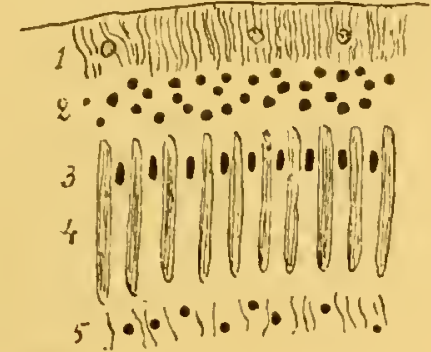

PIIC. D.

1. Слой нервныхъ пучковъ.

2. Зернистый слой.

3. Однорядный слой узкихъ ядеръ.

4. Молекулярный слог̆.

5. Слой гангліозныхъ кльстокъ.
3. st.gr.). Этотъ слой составленъ изъ гангліозныхъ кльтокъ, и въ немъ нервныя волокна, повидимому, разсыпаются и перегруппировываются. Кльтки названнагослоя расположены весьма тъсно и снабжены круглымъ, маленькимъ ядромъ и небольшимъ количествомъ протоплазмы. Слбдующій слой, „Molekularschicht“ Бергера (Рис. 3. st. m.), отличается весьма правильной структурой, имъющей отношеніе къ структуръ ретины.

При слабомъ увеличеніи, какъ на рис. 3 и 5, можно видъть что молекулярный слой состоитъ изъ цйлаго ряда ппалочекъ", расположенныхъ параллельно другъ другу, которыя по количеству отвЪчаютъ количеству омматидіевъ. Направленіе "палочекъ“ не совсъмъ соотвътствуетъ направленію омматидіевъ, такъ какъ онъ менъе дивергируютъ, чвъмъ посль⿱㇒㠯中ніе. Вблизи зернистаго слоя, въ дистальной части молекулярнаго слоя находится однорядный слой удлиненныхъ ядеръ гангліозныхъ кльтокъ; ядра располагаются между темно-окрашенными „палочками“. О такомъ однорядномъ слоъ ядеръ не упоминается ни у одного изъ другихъ D iptera, и я потомъ вернусь къ этому вопросу.

"Палочки“ молекулярнаго слоя представляются на поперечныхъ срғзахъ (ср. рис. 15, сильн. увел.) въ видғ пучка изъ семи, приблизительно, темно-окрашенныхъ волоконъ, которыя располагаются въ кругъ. Микроскопическія картины были, правда, не

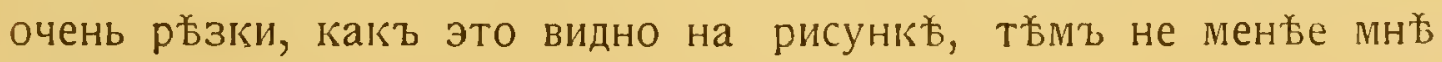
думается, что 7 здъсь-постоянное число.

Дитрихъ, который прослбдиль наиболье подробно путь нервныхъ волоконъ въ наружномъ оптическомъ гангліи двукрылыхъ, представляетъ себъ этотъ путь у нбкоторыхъ видовъ слғдующимъ образомъ. Прежде всего, онъ различаетъ двоякаго рода волокна: волокна ретинуль ( Retinulafasern“) и волокна гангліозныя ( Ganglienfasern“). Ди трихъ мог”ь съ несомнбнностью установить, что у многихъ формъ выше зернистаго слоя нервныя воло- 
кна, а именно волокна ретинулъ, соединяются по сели въ одну группу. Ниже этого слоя, въ слоъ молекулярнаго вещества, онъ находитъ то же число, но сгруппированнымъ вокругъ меньшаго количества гангліозныхъ волоконъ; эти посльднія берутъ свое начало, каждое отъ одной гангліозной кльтки зернистаго слоя. Но, принадлежатъ ли эти ретннулярныя волокна тйлъ же самымъ группамъ, или же здъсь произошла перегруппировка ихъ въ межлежащемъ зернистомъ слоъ въ томъ смыслъ, что ретинулярныя волокна одного омматидія распредбляются на различные сосбдніе нервные узлы, какъ это было описано Радлемъ для Squilla,一Дитрихъ не могъ ръиить. На моемъ рис. 15-омъ 7 нервныхъ волоконь одной „палочки“ соотв悉тстуютъ, очевидно, ретинулярнымъ волокнамъ Дитриха. Внутри этихъ ретинулярныхъ волоконъ по Дитриху должно еще проходить нұсколько гангліозныхъ волоконъ, коихъ число колеблется у различныхъ видовъ. На моихъ препаратахъ мньь ихъ не удалось обнаружить.

Болье глубокаго проникновенія въ эти детали можно достичь лишь при помощи спеціальныхъ методовъ. Несомнъннымъ, однако, является то,-и это подчеркивалось цйлымъ рядомъ авторовъ,что расположеніе волоконъ въ наружномъ оптическомъ гангліи представляетъ въ грубыхъ чертахъ повтореніе расположенія кльтокъ рабдомовъ въ омматидіи. Лоунъ (Lowne) впервые установилъ, что молекулярный слой составленъ изъ палочекъ, обычно соединенныхъ въ пучки, которые соотвьтствуютъ отдбльным'ь омматидіямъ. Это соотвътствіе въ строеніи наружнаго оптическаго ганглія съ таковымъ же ретины заставило многихъ изсльддователей разсматривать первый, какъ составную часть ретины, а не одинъ изъ гангліевъ. Къ этому же взгляду лримыкаетъ и Дитрихъ, такъ какъ „ріs zu diesem Ganglion hin die Reizleitung in den "Retinulafasern" geschieht und die unmittelbare Leitung nach dem Gehirn erst hien beginnt".

Изученіе строенія наружнаго оптическаго ганглія діопсидъ заставило меня сдълать предположеніе, что и между ядрами этого ганглія и ядрами ретинуль можетъ быть связь въ ихъ расположенін. Въ ретинъ мы находимъ дистально густой слой ядеръ 1-6 рабдомныхъ кльтокъ, а далће проксимально--однорядный слой удлиненныхъ ядеръ клътки 7. Сходное распредъленіе повторяется и въ ядрахъ гангліозныхъ кльтокъ наружнаго оптическаго ганглія: дистально находятся густо расположенныя ядра зернистаго слоя, болье проксимально-отдъльный однорядный слой удлиненных'ъ ядеръ, соотвътствующихъ видимо ядрамъ 
7-ой кльтки ретины. Во всякомъ случаъ бросается въ глаза, что у цругнхъ двукрылыхъ, гд⿱⺊口 часто встрбччаются однорядные слои ядеръ въ ретинъ, не наблюдается такого повторенія въ распредъленіи ядеръ наружнаго оптическаго ганглія.

Всъ до сихъ поръ упомянутые слои являются выпуклыми и простираются параллельно кривизнъъ базальной мембраны.

Проксимально отъ молекулярнаго слоя, въ бълом'ь мозговомъ веществй, мы находимъ еще отдыльныя разсъянныя ядра гангліозныхъ кльтокъ, которыя, въроятно, соотвътствуютъ посльднему слою наружнаго оптическаго ганглія-слою гангліозныхъ кльтокъ ("Ganglienzellenschicht“) Бергера. Три посльднихъ слоя наружнаго оптическаго ганглія разсматриваются Віалланомъ (Viallanes) совмьстно, какъ, lame ganglionnaire", и въ ней отличаются, соотвьтственно слоямъ Бе рге ра: „couche externe“, "couche moléculaire" и „couche interne". Эта номенклатура болъе точная, чъмъ у Бергера, но она какъ-то не привилась

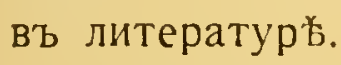

За наружнымъ оптическимъ гангліемъ сльдуетъ перекрестъ нервныхъ волоконъ- chiasma“ (Рис. 3, Ch), который соединяетъ другъ съ другомъ наружный и внутренній оптическіе гангліи.

Во внутреннемъ оптическомъ гангліи (Рис. 3, G. o. i) лежатъ два, расположенныхъ поперекъ, полулунныхъ комплекса гангліозныхъ кльтокъ: одинъ дистально, другой-въ серединь ганглія. По периферіи же этого ганглія гангліозныя кльтки распредълены чрезвычайно густо. Между упомянутыми полулунными комплексами гангліозныхъ кльтокъ можно различить три слоя мозгового вещества. Болъе подробный анализъ строенія оптическаго ганглія выходитъ за предьлы моей задачи.

\section{0 двойныхъ глазахь.}

Какъ мы уже видъли въ предыдущихъ отдълахъ, одна часть глаза діопсидъ, а именно передняя, подверглась особому измъненію въ составляющихъ ее элементахъ. Эта часть отличается сльдующими особенностями отъ остального глаза. Омматидіи передняго глазного поля выдаются своей особенной величиной, почти вдвое превосходящей остальные омматидіи; они располагаются почти параллельно и ихъ основаніе, базальная мембрана, не выпуклое, а плоское. Въ діоптрическомъ аппаратъ, какъ фасетки, такъ и псевдоконусы увеличены. Форма фасетки роговицы широкая и плоская, вогнуто-выпуклая, а не плоско- 
выпуклая. Рёцепторный аппарат’ тоже увеличенъ. Ретинулы съ рабдомерами значительно удлиннены, но не являются при этомъ соотвътственно болье широкими; всльдствіе этого он古 отстоятъ дальше другъь отъ друга и соприкасаются лишь при помощи пигментныхъ мостиковъ ретинальнаго пигмента. Ретинулы переднягаглазного поля отличаются еще особенно узкой аксіальной полостью, въ которой рабдомеры тъсно прикладываются другъ къ другу. Ихъ ретинальный пигментъ развитъ сильнъе.

Вс各 эти отличія въ достаточной мъръ доказываютъ, что здъсь мы имъемъ т. наз. „дифференцировку въ двойной глазъ“. Какъ показали изсльдованія Д и т р и а, такая дифференцировка имъется въ болъе или менъе ръзко выраженной степени у очень большого числа представителей Diptera. Какъ правило, двусторонне дифференцированный глазъ бываетъ присущъ только самцу, причемъ именно дорсальная часть глаза, т. наз. "Dorsalauge“, испытываетъ это вторичное измънненіе. Лишь у Empidae мы находимъ двойные глаза у обоихъ половъь, а у нбкоторыхъ видовъ ихъ, напр., у Tachydromia minuta, по Дитриху, болье дифференцирована вентральная часть глаза. У діопсидъ мы имбемъ такимъ образомъ „передній глазъ “ съ уклоняющимся развитіемъ. Впрочемъ, уклоненія въ строеніи одной части глаза отъ другой въ сущности настолько незначительны, что здъсь слишкомъ смйло говорить о какомъ-нибудь особомъ „глазъ“... Вся суть въ томъ, что одна часть глаза, въ данномъ случаъ передняя, отличается отъ остального глаза своимъ гистологическимъ строеніемъ и приспособлена къ особой дъятельности, о чемъ будетъ рбъь въ сльдующемъ отдильь.

Мн古 хотьлось бы еще остановиться на вопросъ, не имбло ли глазное поле, находящееся въ настоящее время спереди, раньше иного положенія? Я считаю допустимымъ, что на той стадіи, когда глазной стебелекъ еще находился in statu nascendi, обособленная часть глаза была направлена дорсально. Постепенно, по мъғъғ развитія стебля, онъ могъ завернуться спирально вокругъ своей оси такимъ образомъ, что первоначально лежавшая дорсально часть глаза, теперь оказалась спереди. Отсюца дифференцировка въ двойной глазъ будетъ явленіемъ первичнымъ, образованіе же стебля-вторичнымъ. Такое предположеніе я основываю съ одной стороны на томъ, что у діопсидъ, поскольку я могу судить на основаніи одного препарата, плоскость симметріи ретинуль дълитъ глазъ не на дорсальную и вентральную части, какъ у остальныхъ двукрылыхъ, но на заднюю и переднюю. 
Направленіе же плоскости симметріи у двукрылыхъ является несомнънно первичнымъ и измьненіе этого направленія должно было произойти вторично. Съ другой стороны, за закручиваніе стебля говорятъ наблюдаемыя и въ настоящее время непостоянство и измбнчивость посльдняго; это выражается въ томъ, что длина и ширина глазного стебля въ предълахъ одного и того же вида колеблются, и матеріалъ его, такъ сказать, обладаетъ большой пластичностью.

Если я въ своемъ допущеніи и предположилъ, что дифференцировка въ двойной глазъ у діопсидъ должна была совершиться очень рано, то изъ этого вовсе не сльдуетъ, что теперешняя с ту ге н ь гистологическаго строенія глаза была достигнута еще до образованія глазныхъ стебельковъ. Во время развитія стебельковъ могъ произойти рядъ вторичныхъ измъненій въ омматидіяхъ и ихъ группировкъ, какъ, напр., симметричное расположеніе кльтокъ рабдомовъ въ ретинуль діопсидъ.

\section{Физіолого-біологичесное значеніе стебельчатыхъ глазъ.}

Въ литературъ нельзя найти почти никакихъ указаній относительно значенія глазного стебля діопсидъ. О жизни діопсидъ мы знаемъ очень мало и, во всякомъ случағ, ничего особеннаго, что могло бы служить объясненіемъ причудливаго развитія стеблей. Діопсиды живутъ частью вдоль тънистыхъ береговъ ручьевъ

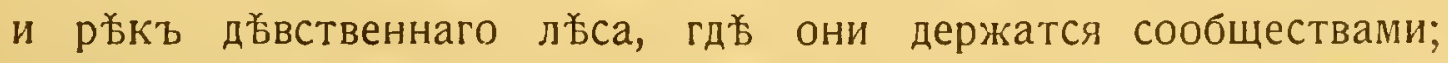
частью обитаютъ въ трав лучей солнца. Не подлежитъ сомнънію, что мы имъемъ здъсь дъло съ ясно выраженными хищными насбкомыми. На такой нравъ этихъ мухъ указываютъ сильныя хватательныя переднія ноги, утолщенныя бедра которыхъ вооружены на внутренней поверхности зубцами и предназначены для ловли живой добычи ${ }^{1}$ ). Сходное устройство переднихъ лапок'ъ имъется у другой извъстной хищной мухи-у Ochtera mantis.

Мнъ думается, что развитіе стебельчатыхъ глазъ у діопсидъ нужно скоръе всего поставить в’ь связь с'ъ ихъ хищническим'ь образомъ жизни. Предположеніе же, что эти глаза могутъ имъ̆ть значеніе въ половой жизни, врядъ ли будетъ въроятнымъ, такъ

1) У одного изъ имьввшихсл въ моемъ распоряженіи әкземпляровъ я нашелъ во рту оторванную голову муравья, что указываетъ на родъ дсбычи. 
какъ мы здъсь не имъем’ь дейа съ мужскимъ вторично-половымъ признакомъ, который служилъ бы для отыскиванія самки.

Какъ уже было сказано, фасеточный глазъ діопсидъ построенъ не однородно, но его передняя часть обладаетъ особымъ строеніемъ, Исходя изъ теорій мозаичнаго зръннія, какъ онъ были подробно развиты Экснеромъ, такому глазу нельзя приписывать сильной остроты зрғнія. Выпуклая поверхность передней части глаза обусловливаетъ большое поле зрбнія, но малое количество фасетокъ оказывается недостаточнымъ, чтобы изъ отдъльныхъ картинъ составить детальную общую картину. Выпуклость передней части глаза вызвана, по крайней мърғ отчасти, удлиненіемъ ея омматидіевъ наружу. Но то обстоятельство, что базальная мембрана на этомъ мисть представляется не выпуклой, а плоской, указывает”ь на удлиненіе омматидіевъ въ передней частй глаза и квнутри. При этомъ процессъ оптическіе гангліи, понятно, оказывали сопротивленіе, которое было однако преодольно, причелъ (ср. рис. 5) наружный оптическій ганглій испыталъ деформацію, сдблался плоскимъ. Наружу для удлиненія переднихъ омматидіевъ не представлялось никакого сопротивленія; но, тотъ фактъ, что, тъмъ не менъе, ихъ удлиненіе произошло и въ направленіи квнутри, заставляетъ насъ принять, что этимъ самымъ нужно было изббгнуть слишкомъ сильнаго выпячиванія передней части поверхности глаза и зависящаго отъ этого уменьшенія остроты зрънія.

Но, какая выгода достигалась увеличеніемъ переднихъ омматидіевъ, если это не имъетъ отношенія къ остротъ зрънія? Какъ я полагаю, эту выгоду нужно усматривать въ полученіи возможности передней частью глаза видъть на болъе далекое разстояніе. Какъ извъстно, насъкомыя не обладаютъ этой способностью. Сфера яснаго видънія у мухи не превышаетъ нъсколькихъ сантиметровъ. По опытамъ Плато комнатная муха можетъ различать движеніе человъчческаго тьла или руки лишь на разстояніи, не превышающемъ 40-70 ст., а Musca vomitoria на разстояніи въ $100-150$ ст.

По теоріи мозаичнаго зръннія каждый омматидій воспринимаетъ лишь лучи, идущіе, приблизительно, параллельно его длинной оси; косо падающіе лучи либо отражаются, либо приводятся къ боковому пигменту. Благодаря этому малый предметъ даже ири не очень большомъ разстояніи воспринимается лишь однимъ омматидіемъ. Чъмъ больше омматидій и его фасетка, твмъ болье свътовыхъ лучей попадаетъ въ него и тъмъ сильнбе 
будетъ свъ̆товое дъйствіе предмета. При ме́ньшихъ омматидіяхъ и фасеткахъ той же формы и при равномъ разстояніи предмета, пучекъ пучей, исходящій отъ послбдняго, распредълится, правда, на нбсколько омматидіевъ; но, такъ какъ они сильно дивергируютъ, то лишь средній изъ нихъ уловитъ идущіе параллельно его оси лучи, а эти посльдніе, благодаря ихъ незначительному голичеству, не будутъ въ состояніи подъйствовать раздражающе на зрительный аппаратъ. Въ природъ предметъ становится, въроятно, видимымъ лишь тогда, когда онъ попадаетъ въ поле зрғннія нъсколькихъ омматидіевъ. Если эти омматидіи и ихъ фасетки велики и всльдствіе этого имъются въ небольшомъ числь, то они обусловят'ъ тьмъ не менъе, какъ указываетъ Э к с н е ъ, хотя и диффузныя, но какъ болъе интенсивныя, такъ и болғе экстенсивныя св бтовыя впечатльнія. Оба эти обстоятельства, какъ интенсивность, такъ и величина свбтовыхъ впечатлбній и могутъ, по моему мнънію, сдълать возможнымъ зръніе на большее разстояніе. Дальность зрьнія, т. е. разстояніе, на которомъ нас务комое видитъ, является несомнънно факторомъ, который стоитъ въ прямомъ отношеніи

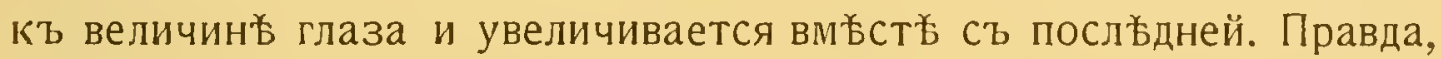
принимая во вниманіе небольшое количество фасетокъ у діопсидъ, здъсь не можетъ быть достигнуто ясное видъніе формъ; но фасетированные глаза, вообще, мало приспособлены къ воспріятію формы предметовъ, а скоръе къ воспріятію ихъ движенія. Различеніе движущейся добычи или самки играетъ въ жизни насғакомыхъ значительно бо́льшую роль, чъъмъ различеніе покоющихся предметовъ. И если обыкновенно у насъкомыхъ болъе высоко дифференцированная часть глаза, которая приспособлена къ такому зрбнію, лежитъ дорсально, или спереди, какъ у діопсидъ, то это намъ совершенно понятно, такъ какъ здъъсь мы имъемъ дъло какъ разъ съ тұлми направленіями, въ которыхъ насъиомое можетъ наиболғе быстро проявить свою активность, чтобы поймать добычу. Если насъкомое выходитъ изъ своего покоющагося положенія, ползаетъ или взлетаетъ, то это происходитъ почти ${ }^{1}$ ) всегда въ направленіи вперед’ или кверху, и

1) Нькоторое псключепіе представляють водныя насъкомыя, обладающія способностьо нырять. Такъ, напр., у Gyvinus, по C a r i ère, боковой глазъ подњленъ соотвытственно на двъ части: одну нгжнюю и одну верхнюю. Нижній глазъ предназначается къ зрънію въ водъ, верхній же-къ зрънію въ воздухъ. 
какъ разъ въ этихъ направленіяхъ хищное насъкомое можетъ наибопье быстро поймать свою добычу. Въ нашшемъ случаъ, у діопсидъ, достаточно установить, что по всъмъ видимостям飞 наибольшая активность животныхъ проявляется въ направленіи впередъ, такъ какъ въ этомъ направленіи фасетированные глаза развиваются наиболъе сильно.

Какъ относится къ такому результату развитіе глазного стебля? Какъ уже указывалось, эти стебли направлены въ сторону и немного дорсально, а также и ныскколько кпереди. Если бы стебель былъ направленъ сильно впередъ, то можно было бы думать, что это имъетъ смыслъ въ перембщеніи глаза возможно ближе къ разсматриваемому предмету. Но въ томъ направленіи, въ какомъ эти стебли на самомъ дълъ развиты, фасетированный глазъ не является вовсе выше организованнымъ, или приспособленнымъ къ болъе усиленному функціонированію. Направленіе стеблей болье совпадаетъ съ направленіемъ глазныхъ нервовъ, какъ это вообще имъетъ мъсто у мухъ. Получается впечатльніе, что у діопсидъ глазной нервъ удлиннился въ томъ направленіи, какое онъ имъль съ самаго начала. Результатомъ такого удлинненія глазныхъ нервовъ было то, что глаза другъ отъ друга удалились и широко раздвинулись. Такъ какъ при данныхъ обстоятельствахъ предметъ, находящійся спереди на опредъленномъ разстояніи, видится не только одним'ь, но обоими глазами, то здғсь несомньнно имъется возможность бинокулярнаго зръинія въ том'ь смысл各, что видимый объектъ отождествляется дважды. Въроятность такого рода зрънія увеличивается ещет что фасеточный глазъ направленъ въ своей передней и медіанной части нбсколько медіанно и несетъ здбсь наиболбе крупныя фасетки. Если принять наличность бинокулярнаго зрънія, то станетъ понятнымъ, что чьмъ сильнъе расходятся оба фасеточныхъ глаза, тұмъ болъе тълесными и рельефными становятся видимые объекты, Бинокулярное зръніе ограничивается, правда, только направленіемъ впередъ, тогда какъ сверху или снизу или сзади выпуклость глаза слишкомъ слаба, чтобы какой-нибудь предметъ могъ въ этихъ направленіяхъ попасть въ поле зрънія обоихъ глазъ одновременно.

Возможность бинокулярнаго зрънія у мухъ уже ранће разбиралась Дитрихомъ. Онъ относится, правда, къ принятію такого зрънія отрицательно, но его аргументы мало убъдительны. Мнъ думается, что у діопсидъ именно допущеніе бинокулярнаго зрънія 
является единственнымъ достаточнымъ объясненіемъ для явленія развитія глазныхъ стеблей I).

\section{Главньйшіе результаты.}

1) Фасетированный глазъ діопсидъ является дифференцированнымъ въ двойной глазъ, причемъ передняя часть глаза выказываетъ уклоняющееся гистологическое строеніе. Передніе омматидіи значительно крупнъе остальныхъ; ихъ фасетки слабо вогнутовыпуклыя; узкія ретинулы имъюютъ узкую же аксіальную полость; отдйльные омматидіи отдъдены другъ отъ друга большими трахеальными полостями.

2) Количество рабдомеровъ въ одномъ омматидіи равно 7-ми; изъ нихъ одинъ, седьмой, расположенъ ближе къ продольной оси и уже остальныхъ.

3) Ретинулы обнаружкиваютъ, въ противоположность остальнымъ двукрылымъ, типичную симметричную группировку кльтокъ рабдомовъ, причемъ узкая, седьмая кльтка рабдома находится въ плоскости симметріи.

4) Сильно выпуклый глазъ обладаетъ относительно небольшой внутренней полостью, въ которой умъщается одинъ лишь наружный оптическій ганглій. Малый размъръ этой полости становится возможнымъ благодаря

5) небольшому, сравнительно съ другими двукрылыми, количеству омматидіевъ, которые подходятъ ближе къ центру глаза, не становясь изъ-за этого уже.

6) $\mathrm{Bъ}$ наружномъ оптическомъ гангліи въ дистальной части молекулярнаго слоя, находится однорядный слой продолговатыхъ ядеръ гангліозныхъ клбтокъ, которыя располагаются между палочками и своимъ числомъ вполн务 согласуются съ числомъ омматидіевъ.

7) Боковое направленіе глазныхъ стеблей въ связи съ болъе высокой дифференцировкой п е р е д н е й части глаза, дьллаетъ

1) Присутствіе глазныхъ стеблей можетъ навести на мысль, что они имьють особое біологическое значеніе, одновременно какъ приспособленіе къ защить и при нападеніц. Такъ, можно предположнть, что діопспды шрячутся въ кустахъ, между листьями п т. п., и что, незамњтныя для врага или для ддобычи, выставляютъ оттуда лишь свон стебельки. Однако, такое предположеніе до сихъ поръ не подтверждается наблюденілми. Проф. До гель находиль животныхъ большими сообцествами всегда на незащищеншыхъ мъстахъ. 
весьма вьроятнымъ, что глазные стебли имъютъ значеніе для осуществленія хорошаго бинокулярнаго зрььнія по направленію впередъ.

\section{Литература.}

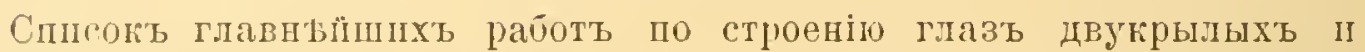
друтихт наськомыхъ можпо найти y $\mathrm{D}$ i e tr i cli. Die Facettenaugen der Dipteren. Z. พ. Z. Bd. 92. 1909 pg. 465-539. Здысь әтотъ списокъ допол-

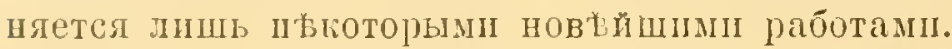

B e d a 11. 1911. Das Facettenauge der Wasserwanzen. Z. w. Z. Bd. 97.

B e r l es e. 1909. Gli Insetti. Milano.

G r ï tz n e r. 1907. Über das Selien der Insekten. Jahresb. Ver. Vaterl. Naturk. Württemberg. Jg. 63.

I o li n as. 1911. Das Facettenange der lepidopteren. Z. w. Z. Bd. 97.

Ii i c h h of e r. 1910. Die Entwicklung des Komplexauges nebst Ganglion opticum ron Dermestes rulpinus G. Arch. f. Naturg. Bd. 76.

Lore l 1. 1910. The color sense of the Honey Bee. Can Bees distinguish colors? Amer. Natural. Vol. 44.

Rád 1. 1912. Neue Lehre vom centralen Nervensystem. Leipzig. Engelmann. (м. пр. полемика протнвь Дитріха стр. 161.).

Strohm. 1910. Die zusammengesetzte Augen der $\sigma^{\pi} \sigma^{\pi}$ von Xenos rossii. Zool. Anz. Bd. 36.

Vigier. 190t. Sur la présence d’un appareil d'accomodation daus les yeux composés des Insectes. C. R. Acad. Sc. Paris. T. 138.

$\mathrm{V}$ i a $l$ l a n es. 1892. Recherches anatomiques et physiologiques sur l'oeil composé des Arthropodes. Aun. Sc. Nat. (7) Zool. T. 13. № 6.

X a m bese. 1906. Organes. visuels des coléoptères carernicoles. Bull. Soc. Entom. France.

Z a vrel. 1907. Die Augen einiger Dipterenlarven und-puppen. Zool. Anz. Bd. 31 .

З а в а р з н и. 1913. Гистологнческія изсльдованія чувствительной первної системы и оптическихъ гангліевъ наськомыхъ. С.-Петербургъ.

\section{Объясненіе таблицы рисунковъ.}

an. антениа.

c. роговіца.

f. p. слой нервныхтыучковт. пой кльткі.

G. о. е. наружиый оптическій ганглій.

G. o. i. внутрепиій оптическй raแrлin̆. m. b. базальная мембрана.

n. $P^{\prime}$. ядро главной пнтмент-

л. $P^{\prime \prime}$. ядро побочной плгмент-

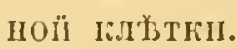

r. ret. ядро ретпнулы.

n. S.' лдро Семпера. 
nv. vet. ретикулярное волокно.

o. глазъ.

ос. глазокъ.

$P^{\prime}$. главная пигментная

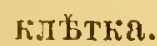

$P^{\prime \prime}$. побочная пигментная клвтка. p. . глазной стебель.

psc. псевдоконуст.

ret. ретннула.

$v$. рабдомер'ь.

st. gr. зернистый слой.

st. m. молекулярный слой.

Tr. трахея.

Рисункі 1 п 2 относятся къ Diasemopsis varians m., ठ; остальные рисунки относятсл къ Diasemopsis pulchella m., ठð, II Diopsis ichnenmonеа Z., б; первый видъ быль фнксированъ сулемой ст уксусной юпслотой, посльдній пикрнново-уксусной смьсью. Прниьнялсл мпкроскопь Цейсса сь пммерсіями Лейца 1/12" п Зейберта 1/16". Рисунки сдьланы съ помощью больпого рисовальнаго прибора Аббэ. Увеличенія, об̈означенныл при рисункахъ, указаны цриблизительно.

Рис. 1. Конецъ праваго глазного стебля съ глазомъ Diasemopsis varians, дорсальный видъ. Рисовано съ помощью бинокулярнаго микроскопа. $30 / 1$.

Рис. 2. Тоже, вептральный вндъ.

Рис. 3. Правый глазь D. pulchella. Сагиттальный разрьзъ сверху и сзади (dp) кнпзу и напередъ (va). Приблпзительное направленіе срьза обозначено на рисункъ поперечнаго срвза (рис. 5) днфрами 3-з. Окр. гематоксилинъ Делафильда, эозинъ. 195/1.

Рис. 4. Разръзъ черезъ тотъ же об̆ъектъ, параллельно предыдущему разръзу, но ближе къ передней и дорсальной поверхности глаза. Направленіе срьза обозначено на рис. 5 цифрами 4-4.Окр. та ж九е. ${ }^{195} / 1$.

Рис. 5. Поперечный разрьзъ черезъ правый глазъ D. ichnemonea на уровнь хіазмы, которал видна посрединь рисунка въ видь удлиненнаго бълаго овала, а-передъ, р-задъ, d-дорсально, v-вентрально. Нашравленіе срьза обозначено на рис. 3 цифрами 5-5. Депнгментировано. Окр. та же+пикриновал кислота. 105/1.

Pнс. 6. Четыре фасеткі вентральной часті допер. разрьза рис. $5.32 \%$.

Ріс. 7. Плть фасетокъ дорсальной часті того же разрьза. $320 / 1$.

Рнс. 8. Три фасетки пошеречнаго разрљза, дорсально, вболзи глазного стебля того же объекта, какъ и рис. 6 и $7.320 \%$.

Рис. 9. Три омматидія изъ средней части сагиттальнаго разрьза puc. 3. $785 / 1$.

Рис. 10. Поперечный разрьзъ фасетокт дорсальной части льваго глаза D. pulchella. Справа срьзомъ затронуть лишь верхній слой басетокъ. $785 / 1$.

Pпс. 11. Пошеречный разрьзъ черезъ шесть омматпдіевъ D. pulchelic, Справа задъты кльткі хрустальнаго конуса. Тотъ же объектъ, какъ на pнe. 3. $1390 / 1$.

Рис. 12. Поперечный разръзъ черезъ два омматидія дорсальнаго глазного поляна уровнь ретинулярныхъ ядеръ 1-6. Тотх же объектъ. 1390/,

Рис. 13. Поперечный разрьзъ черезъ пять дорсальныхъ омматидіевъ проксимально отъ ретинуллрныхъ ядеръ 1-6 и дистально оть ядеръ 7. 
Верхніе омматндіи рисунка находятея сь одной, нижніе омматидін ст, другой сторопы плоскости снметрін, дьлящей глазь иа двь равныя части. Тоть же прешарать, какъ и па рис. 3. 1390/.

Pис. 14. Поцеречный разрьзт черезъ пять дорсальныхъ омматидіев' ша уровны ретннулярныхъ ядеръ 7 . Тоть же объектъ. ${ }^{1510 / 1}$.

Рпс. 15. Поперечный разрьзъ черезъ рядъ , палочекъ молекулярнаго

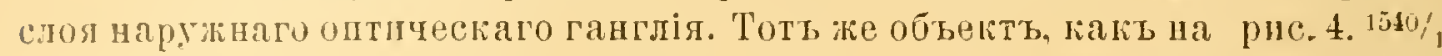

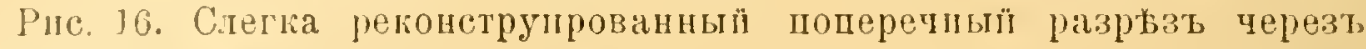
вентратьиый омматидій того же объекти, какь на рис. 3 и на томь же уровнъ. какь в'ь рнс. 13. ${ }^{1390 / 1}$. 


\title{
On the structure of the stalked eyes in Diopsidae.
}

\author{
F. 0. EGGERS.
}

(From the Zootomical Laboratory of the University of Petrograd).

\section{Introduction.}

During their journey in British East Africa in the summer of 1914 Professor V. Dogiel and I. Sokolor have collected some material on the anatomy of Diopsidae which they delivered to me for investigation. The material was fixed chiefly with Gilson's mixture, corrosive sublimate and acetic acid and with picric-nitric mixture, and preserved in alcohol.

Concerning the present work, it contains a description of the peculiar eyes of these flies, the histological investigation of which I undertook by the advice of Professor V. Dogiel.

Diopsidae, as well as another family, Achiasidae (Cyclorrapha, Acalyptera), are tropical flies distinguished by their eyes sitting on long stalks. Amongst insects we find such an arrangement of the eyes only in these forms. In Achiasidae the stalked eyes are a sexual character, being peculiar to males only. Whereas in Diopsidac both sexes possess stalked eyes (text-fig. A).

The stalks on which the eyes of the two abovenamed families of Diptera sit present lateral processes of the head, and in many species attain the length of two thirds of the whole body. The eyes are situated at the distal ends of the stalks. In Ach i as id a e the eyes alone are removed from the head the antennae remaining on the head. The antennae of Diopsi$\mathrm{d}$ a e are displaced together with the eyes to the end of the stalks and are attached somewhat anteriorly to the bases of the eyes (fig. A and figs. 1,2).

A detailed investigation of the facetted eyes of Diptera was recently undertaken by Dietrich (1909). Although his 
work bears on European Diptera only, it was successful in demonstrating the great variety existing in the histological structure of the eyes even in families closely related to each other, and in the different sexes of the same species. The variations in the histological structure of the eyes may concern the most different elements: e. g., the dioptric apparatus, the number, position and form of rhabdom cells, the development of pigment etc. The sexual dimorphism of the facetted eyes, fonnd chiefly in Orthorrapha, consists in the formation of so called "double eyes" in the males (except in Empidae, in which both sexes possess double eyes).

Djetrich provides a physiological explanation for many of the named modifications of the eye, his point of view being that the form of the eyes is in connection with the conditions of life to which each given species is subjected.

It is quite probable that the formation of stalked eyes in Diopsidae has also a certain biological foundation. First of all, the question arises whether the adaptation of the eye of Diopsidae to certain special functions is confined to the formation of the stalk, or together with this there take place also changes in the histological elements of the eye. The present work is deroted chiefly to the solution of this question.

\section{External morphology of the eye.}

The facetted eyes of Diopsidae are situated on the distal ends of long immobile stalks which present outgrowths of the head arising from the sides of the forehead (fig. A).

For comparison I had some species of the genera Diopsis L. and Diasemopsis Rond. The degree of development of the stalks varies slightly in different species. In some species the stalk is short and broad, not exceeding the width of the head in length (e. g., Diopsis ornata Ws tw.). In a great number of species, however, the stalk is longer than the head and thorax taken together (e. g., Diasemopsis varians, fig. A), in this case it is always very thin.

Generally, in the species with long eye-stalks the head is of a relatively smaller volume, than in the species with short stalks. This gives an impression that in the latter case the stalks are developed at the expense of the material used for the formation of the head. 
The length of the stalks varies also in the limits of one species especially in different sexes, the male possessing somewhat longer stalks than the female. On account of this, the authors formerly used to base their determination of the sex in doubtful cases on the length of the stalks. At the distal end, on which the eye sits, each stalk thickens considerably, in this thickening the optic ganglion is situated.

The facetted eye (fig. 1-dorsal view, fig. 2-ventral view) in the species investigated by me is very uniformly organized. It has the same structure in both sexes, and exhibits no other external differentiation into a double eye, except an increase of facets in the anterior part of the eye.

The shape of the eye is very irregular, nearly oviform. The distal external surface of the eye ("Augenmittelfeld") is the most convex. The stalk is attached to the eye from behind and by the dorsal side, so that the largest free surface of the eye is situated on its anterior and lower part. The degree of development of the facets partly corresponds to this orientation of the eye: the largest facets are situated on the anterior surface of the eye, whereas the remaining parts of the eye, and especially the posterior possess facets of a much smaller size.

Anteriorly to the bases of the eyes are attached the threejointed antennae with a large, flat terminal joint, carrying a long, thin terminal seta. Beginning from the base of the antennae, the anterior side of the eye-stalk under which the optic nerve passes is slightly raised. The dorsal border of this prominence usually passes as a thin line along the stalk (fig. A), and is continued on the head into the so-called linea arcuata; the latter bears the character of a vide, mostly black line, dividing the forehead from the face. On the forehead there are three ocelli situated dorsally (fig. A, oc).

\section{The Cornea.}

The cornea presents the cuticle of the eye, which became defferentiated into hexagonal facets in such a way that one facet corresponds to each ommatidium. 'Towards the exterior' the facets are convex and rounded, as it may be seen from fig. 10, on the right side of which the section has passed through the surface of the facets. In longitudinal section 
(fig. 3, C) the facets seem to be plane, or plano-convex. The lorm and size of the facets vary in different parts of the sirface of the eye; the largest facets being those of the anterior side of the eye, and not of the dorsal as is the case in most insects (ligs. 4 and 5). The form of the facets de pends on their size. Figures 6 and 7 represent facets taken from the same transverse section of the eye, but belonging to two different parts of the latter. The facets of the anterior surface (fig. 6) are large, plane-and concavo-convex, with the interior side slightly convex. The facets of the posterior surface (fig. 7) having the same thickness as the abovementioned, are twice smaller with a comparatively vely convex external surface. However, between these two forms there is a whole series of gradations, which do not allow to distinguish an external differentiation of the eye into two different parts, as is the case in the so-called double eyes.

Towards the posterior edge of the eye the facets undergo a still greater change, becoming with a small size biconvex.

\section{The Pseudocone.}

Pseudocone is the name given to a formation especially peculiar to the eyes of Diptera. It consists of a more or less fluid substance lying under the facets (fig. 3, 9 and 11 , psc.). Where it borders with the facets, the psendocone still lemains hexagonal (fig. 11, on the left), but deeper it gradually rounds, becomes thinner, and assumes a conical shape in this form the substance of the psendocone is maintained by the two chief pigment cells surrounding it $\left(\mathrm{P}^{1}\right)$. Proximally, i. e. deeper inside, in front of the apex of the pseudocone there are four crystalline cells the nuclej of which (Semper's nuclei) are always clearly visible in my preparations (n. s.). On the contrary, the psendocone itself is badly preserved in my preparations-it shrinks very much and, probably, consists of a very viscous, fluid mass. On the anterior surface of the eye the facets are larger, and the psendocone is of a considerable size (fig. 4 and 5 ).

The origin of the psendocone is still interpreted by different anthors in a diflerent manner. Gre n a che considers it to be the prodnct of secretion of the four crystalline cells, i. e. as homologons to the crystalline cone of other insects. 
Carrière, on the other hand, comes to regard the pseudocone as part of the cornea. In recent times D i etrich also joined to this point of view. He was lead to this conclusion by observing that in some species, e. g., Simulium and Chrysogaster, there is no sharp demarcation between the facet and psendocone, as the folds of the former pass minterupted into the latter.

I rid not succeed in noticing any comnection between the psendocone and cornea in my preparations. The cornea usually became separated from the pceudocone without carrying along with it any pieces of the latter, the shrivelled remmants of the pseudocone always remaining with the crystalline cells. But, although my observations do not agree with Dietrich's views on the origin of the psendocone, I have no serious objections which I could put against this view.

\section{The Retinulae (Retina).}

The retinulae (fig. 3 and 9 , ret) form the sensory apparatus of the facetted eye. In Diptera each retinula has the character of a tube lying proximally to the crystalline cells. The walls of the tube are composed of 7 rhabdom cells which are elongated and are adjacent with their edges. On the interior side each of these cells bears a sensory rod, or rhabdomere (fig. 9 and 12, rh), which protrudes into the central lumen of the retinula. In the proximal direction the retimulae are underlaid by the basilar membrane (bm).

In all parts of the eye the retimulae are built nearly alike, excepting its anterior surface where they differ somewhat from the general type. For comparison I am giving three figures (3, 4 and 5). In fig. 3 the longitudinal section did not pass through the anterior portion of the eye, on account of that all the retinulae are about the same there, and only on the edge of the middle area they are somewhat larger, as it is usual in the facetted eye. The anterior part of the eye is represented in transverse section in fig. 5 , and in longitudinal-in fig. $t$. In the transverse section it is seen that the retimulae of the anterior surface of the eye $(a)$ are nearly twice longer than the retinulae of its other parts $(d, v$ and $p)$, on account of 
which the portion of the basilar membrane belonging to the anterior surface is plane, not convex. In fig. 4, where the retinulae are cut transversely, it is seen that the retinulae of the anteriol area of the eye (ret. $v$.) are placed much farther from each other, than the retinulae of the dorsal surface of the eye, which are closely adjacent to each other with their walls. Besides, eren with low power as applied in this case, it is noticeable that the axial lnmen of the dorsal retinulae is much wider than the lumen of the anterior ones.

According to the characters just set forth all the retinulae belonging to the anterior area of the eye may be sharply enough delimited from the others in transverse sections through the eye.

All these facts bring us to the conclusion that the anterior area of the eye possesses a peculiarly built retina, and therefore deserves special treatment.

The shall first tmm to the histological particulars of those retimulae that do not belong to the anterior area of the eye. In a longitudinal section through the ommatidia (fig. 9) we see that the retinulae (ret.) depart in a proximal direction from the nuclei of the crystalline cells (n. s.). The distal retinnlae become wider and here are sitnated most of the large vesicular nuclei (n. ret. $1-6$ ) of the rhabdom cells. Towards the basilar membrane $(m . b)$, i. e. proximally, the retinulae narrow gradually. Proximally from the middle of the retinulae it is possible to distinguish another, serenth mucleus (n. ret. $r$ ) of one of the rhabdom cells. The plasm of these cells is light. The exterior surface of the retimula is corered by a layer of finely granulated pigment (p. ret.). The interior axial lnmen of the retinula is very wide bnt narrows rather sharply distally, finally obliterating altogether; in the proximal direction the lumen narrows very gradually and reaches the basilar membrane. Along the walls of the axiat lumen are arranged the visual rods $(r h$.) intensely stainable with eosin. The diameter of the latter is greatest at the distal end, so that it seems-as if they wedge in with their ends between the crystalline cells.

The relations described are clearly illnstrated in the drawings of transverse sections made throngh the retinulae on different levels (fig. 11-14). Figure 14 was taken at a higher magnilication than the rest. 
In fig. 11 the ommatidium furthest right is shown on the level of the crystalline cells. In this place ommatidiun borders with a thick layer of pigment belonging to the chief pigment cells and embracing the crystalline cells.

In fig. 12 is represented a section through two ommatidia passing on the lerel of the distal nuclei (n. ret. $1-6$ ) of the rhabdom cells. The rhabdom cells are arranged in the section in the shape of a crown, six of them being about the same size and form, whereas the seventh is rery thin and seems to be wedged in between the others.

Both towards the ontside, and towards the axial lumen all the cells, except the seventh, are somewhat convex. The thin serenth cell protrudes only towards the axial lumen, but more than the rest, its exterior surface being concave.

Figure 13 represents a transverse section passing more proximally through five ommatidia. It is noticeable that in the three upper ommatidia of this section the thin seventh cell is directed downwards, whereas in the two lower ommatidia these cells are arranged contrarywise. Thus, the three upper retimulae present the mirror reflection of the lower. As it was first shown in Diptera by Dietrich; in many insects it is possible to draw a plane of symmetry which divides it into a dorsal and ventral halves. In such cases in each half the retimulae present, with respect to the arrangement of the rhabdom cells, the mirror reflections of the retinulae of the other half. In fig. 13 the upper and lower retinulae present this arrangement on both sides of the plane of symmetry just spolien of. The axial lumen attains its maximum in this section.

The next figure (fig. 14) represents a section through 5 ommatidia in the region of the seventh retinal nucleus and presents a somewhat peculiar picture. The narrow seventh rhabdom cell widens considerably in this place, displaces the tracheal space bordering with it, and becomes closely adjacent to the exterior walls of the neighbouring retinulae. On account of this, the contours of the seventh cell become irregular. The tracheal spaces in this section are very narrowed and embraced from all sides by the walls of the retinulae, thus losing connection with each other.

The structure of the retinulae of the anterior area of the eye was studied by me in less detail. As.it may be seen from 
fig. 5, the general principle of structure is in this part of the eye the same, as in its other portions. The retinulae of the anterior area. distinguished by their greater length, also narrow gradually in the proximal direction. Most of their nuclei are also arranged in the distal half of the cells, whereas one mucleus, evidently the seventh, is situated in the proximal half. Those seventh nuclei of all the retimulae lie at one general level.

The transverse section (somewhat enlargened) through a retinula (fig. 16) of the anterior area, passing at the level of the section represented in fig. 13, reveals the arrangenent of the rhabdom cells already familiar to us. Only the axial.lumen of the retinulae of the anterior area of the eye is considerably narrower than in the retinulae of the rest of the eye, so that the rhabdomeres nearly touch each other. The retinal pigment is comparatively stronger developed and diverges radially to all sides, sometimes reaching the neighbouring retinulae. The latter are separated by large tracheal spaces. Although the retinulae of the anterior area are twice longer than the retimulae of the other parts of the eye, their diameter is the same.

We shall now make some general remarks on the plan of structure of the retimulae in Diopsidae. According to Dietrich's investigations made on numerous species of Dip ter a, the retimulae of the latter are distinguished by a constant asymmetric construction (see fig. B, a copy from Dietrich's drawing. near which, in fig. $C$, is represented a scheme of a retinula of Diopsidae). According to Dietrich, the rhabdomeres $1-3$ are always arranged along one right line and are directed toward the median body-line; the rhabdomeres $3-5$ also form a right line lying at an acute angle to the first, "wïhrend die Verbindungslinie von 5 und 6 der ron 1-3 parallel laïf. Das siebente Rhabdomer schiebt sich zwischen 1 und 6 nach dem inneren Lumen zu ror".

Further, D i e trich found between the 1 st and $2^{\text {nil }}$ retinal cells one nore, the rudimentary eigth cell, or, an any rate, its nucleus.

I rlo not see any such asymmetrical structure of the retimulae in Diopsidae. On the contrary, the retinula of Diopsidae (fig. C) is strictly bilateral-symmetrical. The rhabdomeres $1-6$ are arlanged in the form of a crown, and between the 
1.-st and 6 -th cells is placed an extremely narrow 7 -th retinal cell. The plane of symmetry passes between the 3 -rd and 4 -th cells, dividing the 7 -th cell on a half. I did not succeed in discovering any traces of the 8 -th cell in the retinnla of $\mathrm{D}$ i o p s idae. But it is possible that remunts of the 8 -th cell are to be found in the distal part of the retinula, as it seems to me that in this place the regularity of arrangement of the cells is to a certain degree interrupted, on account of the 7 -th and 1 -st rhabdomere converging together. In general, the arrangement of the rhabdomeres (fig. ()) is such, that the 7 -th rhabdomere is situated at the point of crossing of two right lines, of which one joins the 1 -st with the 5-th rhabdomere, and the other-the 2-nd and 6-th. This is a general rule, which seems to be supported by Dietrich's drawings as well (fig. B).

I must also, in accordance with $\mathrm{Dietrich}$, state that the eye is composed of two parts, each representing the mirror reflection of the other (see what was said above with regard to fig. 13).

\section{The Pigment.}

The pigment surrounds the ommatidia of Diopsidae from all sides like a sheath; it does not extend into the optic ganglia, on the other side of the basilar membrane. Both in insects generally, and in Diopsidae there are to be distinguished "the pigment of the iris“, and "the pigment of the retina". The pigmentation of the iris is due to the chief and accessory pigment cells. T'o each ommatidium belong two chief pigment cells which embrace the pseudocone and form a sort of thick membrane around it (cp. fig. 9 and 11, $P$,). In fig. 11 the sec. tion passed through the ommatidia somewhat obliquely, on account of which the pigment cells are seen on different heights here: on the loft they are nearer to the facel, on the right-nearer to the cells of the crystalline cone. At the edget of the facet the chief pigment cells taken together have a hexago, .1 shape, but they become rounder in the proximal direction, and in the region of the cells of the crystalline cone they are quite round. It is here that they attain their greatest thickness, and further proximally they terminate. The nuclei of the chief pigment cells $\left(n . P^{1}\right)$ are situated in the middle of the height of the psendocone. 
A little more proximally from the cells of the crystalline cone there are several accessory pigment cells. The number of these cells is rery rariable in the different families of Diptera; in Diopsidae to each ommatidium correspond at least four accessory cells. All of them wedge in between the ommatidia on the border between the pseudocone and retinula (fig. 9. n. P) at the point, where the ommatidia are most constricted.

The pigment of the retina (figs. 9, 12 and 13, P. ret.) covers the exterior surface of the retinulae in the form of a very thin layer. It is composed of fine granules seen only at high magnification. The retimulae of the anterior area of the eye are provided with more developed retinal pigment which passes into the tracheal spaces, and in some places slightly connects the separate retinulae.

\section{Optic ganglia.}

The facetted eye of Diopsid a may be compared with a hollow hemispherical formation limited from the exterior by the cornea, and from the interior by the basilar membrane. It appears that the rolume of the interior carity of the eye is comparatively small (cp. fig. 3). In other D ip te r a also provided with very convex eyes, e. g. Microchrysa, Chrysopilus, Chrysogaster and many others, the interior cavity is so strongly developed that it not only contains the exterior and interior optic ganglia, but inside the outgrowth of the basilar membrane there are large tracheal carities.

In Diopsidae the cavity inside the eye is occupied only by the exterior optic ganglion (fig. $3, G$.o.e.), and large tracheal carities are altogether absent. As concerns the interior optic ganglion, it is situated in the widened distal end of the eje-stalk.

If we compare the ommatidia of the eye of Diopsidae as a whole, with those of other Diptera, we shall notice the following peculiarities. Firstly, the interior cavity of the eye of Djopsidae is small not only with regard to the volume of the optic ganglia, but also in relation to the thickness of the eye measured by the length of the ommatidia. If we take as a scale of the cavity of the eye the average half diameter of the curve of the basilar membrane, this half diameter will 
in most Diptera be much longer than the ommatidia, whereas in Diopsidae it is, on the contrary, shorter than they are. Consequently the ommatidia of $\mathrm{D}$ i o p s i d a e have moved nearer to their ideal centre from which they start than those of other Diptera, or, which is less probable, they have elongated proximally. The first case would result in a considerable narrowing of the ommatidia, the second-at least in the narrowing of their proximal ends. But here we meet with a special adaptation which allows them to preserve their primary width: that is a great diminution of the number of ommatidia in the eye of Diopsidae. In all the other Diptera with strongly convex eyes the number of ommatidia is considerable. Thus, e. g., in D i e tr i c h's figures, on a longitudinal section through the eye of Microchrysa there can be counted 97 ommatidia in the male, and 92 -in the female, whereas in my figure of an analogous section (fig. 3) only about 53 ommatidia are seen at about the same convexity of the eye. Similar numerical relations are also to be found in comparing with many other Diptera. Evidently, such a small number of ommatidia in the eye of Djopsidae allows them to occupy the position named without perceptibly narrowing from that. If in the conditions given the number of ommatidia were increased, their proximal end would gradually narrow to such an extent that there would remain no place even for the passage of the nerve-fibres. The existing number of ommatidia gives room only for one ganglion of relatively small size inside the cavity of the eye. Besides, it is quite possible that the small number of ommatidia corresponds to the small volume of both optic ganglia. It is also noteworthy that the form of ommatidia in Diopsidae deviates somewhat; this is caused by the small number of them in connection with the great convexity of the eye. If we compare a separate ommatidium with a wedge directed with its pointed end inside the eye, then in Diopsidae it terminates more bluntly, i. e. its walls diverge stronger than in the other Diptera. When the number of ommatidia is reduced to a half, each of them-all conditions being equal-possesses an interior angle twice-greater than when their number is complete. In connection with the form of separate ommatidia of Diopsidae evoked by such circumstances, I should like to mention another fact, that is that their retinulae and 
rhabdomeres are visibly narrowed proximally, which is not so evident in other Diptera.

In the exterior optic ganglion of Diopsidae we find the same layers of ganglion cells and fibres as in other D i p tera (cp. schematic ifg). D To the basilar membrane is adjacent "Nervenbindelschicht" of Berger which consists of bundles of nerve fibres (,fibres postretiniennes" of Viallanes, Fig. $3, f . \quad p$.). The spaces between separate bundles are filled with an intercellular substance with few nuclei, probably with haemolymph, and, besides, contain very minute tracheae. The nerve fibres are directed from the ommatidia like the continnations of the rhabdom-cells, and pass into the next layer- "Körnerschicht" of Berger (Fig. 3, st. $g r$.$) . This layer is composed of ganglion cells where the nerve$ fibles seem to be dispersed and arranged into new groups. 'The cells in this layer are very closely arranged, and are provided with a round, small nucleus and a small quantity of protoplasm. The next layer-the "Molekularschicht" of Berger (fig. 3, st. m.) is distinguished by a very regular structmre which is in connection with the structure of the retina. At small magnification, as in figs. 3 and 5 , it is to be seen that this layer consists of a row of "rods" arranged parallel to each other, their number corresponding to that of the ommatidia. The direction of the rods does not exactly correspond to that of the ommatidia, as they diverge less than the latter. In the distal part of the molecular layer, near the granular eayer there is a single-rowed layer of elongated nuclei of ganglion cells (cp. fig. D ); the nuclei are arranged between the dark-coloured „rods“. Nothing has been mentioned about such a single-rowed layer of nuclei in any of the other Diptera. I shall return to this question again.

The "rods" of the molecular layer are seen in transverse sections (cp. fig. 15, highly magnif.) as a bundle of about seven dark-coloured fibres arranged in a circle. It is true that the microscopical pictures are not rery convincing, as it is seen from the figure; however, 1 suppose that 7 -is a constant number here.

D i e trich, who had traced the course of the nerve fibre, in the exterior optic ganglion of Diptera in greatest detail considers this comrse in some species to be as follows. First of all, he distinguishes two sorts of fibres: the fibres of the re- 
tinulae ("Retinulatasern") and ganglion fibres ("Ganglienfasern"). Dietrich stated without any doubt that in many forms above the granular layer seren nerre fibres (the fibres of the retinulae) join into one group. Below this latyer, in the layer of molecular substance, he finds the same $110 \mathrm{mber}$, but grouped around a smaller number of ganglion fibres; each of the latter begins from one gangion cell of the gramular layer. But Dietrich could not decide whether these retimular fibres belong to the same groups, or there has been a regrouping of them in the interlaying granular layer in the sense that the retinular fibres of one ommatidium are distributed among different neighbouring nerre nodes, as it was described by $\mathrm{R}$ adl for Squilla. In my fig. 15 the 7 nerve fibres of one "rod" evidently correspond to D i e tri c h's retinular fibres. According to D i e trich, inside these retinular fibres there must also pass some ganglion fibres the number of which is rariable in different species. I did not succeed in discovering them in my preparations. Further details may be revealed only with the help of special methods. However, it is certain-and confirmed by many anthor's-that the arrangement of the fibres in the exterior optic ganglion is a rough repetition of the arrangement of the rhabdom cells in the ommatidium. L o w n e was the first to state that the molecular layer is composed of rods usually united into bundles which correspond to a separate ommatidium. This correspondence in structure between the exterior optic ganglion with that of the retina lead many investigators to regard the former as a component of the retina, and not as one of the ganglia.

The study of the structure of the exterior optic ganglion in $D$ i o p s id a e lead me to suppose that there may be a comnection between the arrangement of the nuclei of this ganglion and the nuclei of the retinulae. In the retina we find distally a thick layer of nuclei of $1-6$ rhabdom cells, and further proximally - a one-rowed layer of elongated nuclei belonging to the 7 -th cell. A similar arrangement of the nuclei is repeated in the ganglion cells of the exterior optic ganglion: distally are situated the densely arranged nuclei of the granular layer, more proximally - a separate one-rowed layer of elongated nuclei, probahly corresponding to the nuclei of the 7 -th retina cell. At any rate, it is remarkable that in other 
D ipter a, where one-rowed layers of nuclei are often found in the retina, such a repetition in the distribution of the nuclei of the exterior optic ganglion is not to be observed.

All the layers mentioned till here are convex and extend parallel to the curve of the basilar membrane.

Proximally to the molecular layer, in the white cerebral substance we still find separate dispersed nuclei of the ganglion cells which, probably, correspond to the last layer of the exterior optic ganglion-- the layer of ganglion cells ( Ganglienzellenschicht") of Berger.

After the exterior optic ganglion follows crossing of the nerve fibres-the "chiasma" (fig. 3, ch), which joins tog'ether the exterior and interior optic ganglia.

In the interior optic ganglion (fig. 3. $G$ o. $i$.) are situated two transversely arranged, semilunar complexes of ganglion cells which are not densely distributed: one-distally, the other-in the middle. On the periphery of this ganglion the ganglion cells are very densely arranged. A more detailed analysis of the structure of the optic ganglion would be beyond my task.

\section{The Double Eyes.}

As we have seen in the preceding paragraphs, one part of the lateral eye of Diopsidae, namely-the anterior, has undergone a special modification with respect to the elements composing it. This part is distinguished from the rest of the eye by the following pectliarities. The ommatidia of the anterior area of the eye are nearly twice larger than the remaining ommatidia, they are arranged nearly parallel and their base, the basilar membrane, is not conrex, but plane. In the dioptric apparatus both the facets, and the psendocones are enlarged. The form of the facet of the cornea is wide and flat concaro-convex, and not plano-convex. The receptive apparatus is also increased. The retinulae with the rhabdomeres are considerably elongated, but are not accordingly wider; on account of this, they are further from each other and are adjacent only by means of pigment bridges of the retinal pigment. 'The retinulae of the anterior area of the eye are also distinguished by a specially narrow axial cavity in which the rhabdomeres are set very close to each other. Their retinal pigment is developed stronger. 
All these distinctions clearly prove that here we are dealing with the so called "dilferentiation into a double eye“. As was shown by Dietrich's investigations such a differentiation is to be found in different degrees in a very great number of representatives of Diptera. As a rule a bilaterally dilferentiated eye is peculiar only to the male, this secondary change taking place only in the dorsal part of the eye, in the, so called, "Dorsalange“. It is only in E in pidae that we find "double eyes" in both sexes, and in some of them, e. g. in Tachydromia minuta, according to Dietrich, the most differentiated part of the eye is its ventral part. Thus, in Diopsidae the "anterior eye" deviates in development, the term here having a relative meaning. The deviation in the structure of one part of the eye from the other is, as a matter of fact, so insignificant, that it is hardly advisable to

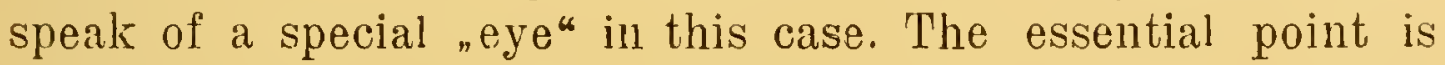
that one part of the eye, the anterior in our case, differs from the other part of the eye in its histological structure and is specialized for a special function, which will be treated in the next paragraph.

\section{The physiological and biological Significance of the stalked Eyes.}

In literature there are hardly any data concerning the significance of the eye-stalk in Diopsidae. We know rery little of the life of $\mathrm{Di}$ opsidae, and, at any rate, nothing that could be of value in explaining the curious development of the stalks. The Diopsidae live partly aloug the shadowy banks of streams and rivers in virgin forests, and partly inhabit the grass of the plains, where they are exposed to the sun. There is no doubt, however, that these insects are rapacious. Such a nature of these insects is evident on account of their strong anterior legs adapted to grasp, the broad femora of which are provided from the interior surface with denticles and destined for catching live prey ${ }^{1}$ ). A similar structure of the anterior legs is found in another well known rapacious fly-Oethera mantis.

I think that the development of stalked eyes in Diopsi-

1) In one of the specimens I had at my disposal I found a torn head of an ant, which points to the character of its prey. 
d a e is more likely to be connected with the rapacious mode of life. Whereas the supposition that these eyes may be important in their sexual life can hardly be justified, as in this case they are not a male secondary sexual character which serves for finding the female.

As was described above, the facetted eye of Diopsidae is not miformly constructed its anterior part possessing a special structure. According to the theories of mosaic vision, as they were exponnded by Exner, such an eye cannot possess an acute sense of sight. The convex surface of the anterior part of the eye affords a wide field of view, but the small number of facets is insufficient to compose a detailed general picture from the separate pictures. The convexity of the anterior part of the eye is, at least in part, evoked by the elongation of its ommatidia to the exterior. But the fact that the basilar membrane in this portion is not conrex, but plane, points to the elongation of the ommatidia in the anterior part of the eye to the interior as well. In this process the optic ganglia necessarily afforded a resistance, which was, however, overcome.

The distinguishment of the moving prey, or female plays a greater rôle in the life of insects then the distinguishment of immobile objects. And if usually the most highly differentiated part of the eye in insects, adapted to that form of vision, lies dorsally, or anteriorly, as in D io psid a e,-this is quite understandable, as in this case the eye is adapted to those directions which are most important in quickly attracting the activity of the insect in order to catch its prey. When the insect begins to walk or fly it nearly always moves either forward, or upward, and it is just in these directions that the insect can attack its prey more speedily. In the case of $\mathrm{D}$ i o p s i d a e it must be concluded that the insect shows the greatest activity in the forward direction, as in this direction the facetted eyes are most strongly dereloped.

How far does the development of the eye-stalk agree with these conclusions? As was mentioned above, these stalks are directed to the sides and somewhat dorsally, as well as a little anteriorly. If the stalks were strongly directed forwards, it might be supposed that this is essentila in order to move the eye as near as possible to the object of its vision. But in the direction in which the eyes are actually developed 
the facetted eye is not at all more highly developed, or adapted to a more intensire function. The direction of the stalks corresponds to the direction of the optic nerves, as it is usual in flies. It gives the impression that in Diopsidae the optic nerve has become elongated in the same direction that it had from the very beginning. The result of such an elongation of the optic nerves was that the eyes diverged from each other and became ridely separated. In the circumstances given the object which is at a certain distance in front is seen not only with one, but with both eyes, therefore it is quite possible that the insect is capable of binocular rision in the sense that the object seen twice is identified. The possibility of this kind of vision is still more supported by the fact that the facetted eye is directed in its anterior and median portions somewhat medially, and bears the largest facets here. If we assume the presence of binocular vision, it will be clear that the more both the facetted eyes diverge, the more plastic the vision becomes. It is true that the binocular vision is limited to the forward direction, whereas from above and from below, or from behind the convexity of the eye is too small to allow any object in these directions to fall into the field of view of both eyes simultaneously.

\section{Explanation of Figures on the Plate.}
a. antenna.
o. eye.
c. cornea.
oc. ocellus.
f. p. layer of nerve-bundles.
$\mathrm{P}^{\prime}$. chief pigment cell.
g. o. e. exterior optical ganglion
g. o. i. interior optical ganglion.
$\mathrm{P}^{\prime \prime}$. collateral pigment cell.
m. b. basilar membrane.
n. $P^{\prime}$. nucleus of chief pigment cell.
n. $\mathrm{P}^{\prime \prime}$. nucleus of collateral pig- ment cell.
n. ret. nucleus of retinula.
n. s. nucleus of, Semper.
nv. r e t. retinular fibre.
p. d. eye-stalk.
psc. pceudlocone.
r e t. retinula.
rlı. rhabdonere.
st. gr. granulous layel.
st. m. molecular layer.
Tr. trachea.

Fig. 1. End of right eye-stalk with eye of Diopsis variuns, lorsal aspect. Sketched with the lielp of a binocular microscope $30 / 1$

Fig. 2. The same, ventral aspect.

Fig. 3. Right eye of D. pulchella. Sagittal section from above and from behind (dp), downwards and forwards (va). The approximate direction 
of the section is denoted in the figure of the transverse section (fig. 5) by $3-3$. Stained with Delafield's haematoxylin, Eosin. ${ }^{195} / 1$.

Fig. 4. Section through the same object parallel to the preceding section, but nearer to the anterior and dorsal surface of the eyc. The direction of the section is denoted in fig. 5 by figures $4-4$. Stained as above. 195/1.

Eig. 5. Transverse section through the right eye of D. ichneumonea on the level of the chiasma which is seen in the midlle of the drawing in the shape of an elongated white oval. a-anterior aspect, p-posterior, d-dorsal, r-ventral. The direction of the section is denoted in fig. 3 by figures 5-5. Depigmentated. Stained as above + picric acid 105/1.

Fig. 6. Four facets of the ventral part of the transverse section of fig. 5. $320 / 1$.

Fig. 7. Five facets of the dorsal part of the same section $320 / 1$.

Fig. 8. Three facets of the transverse section, dorsal aspect, near the eye-stalk of the same object as in fig. 6 and $7.320 / 1$.

Fig. 9. Three ommatidia from the middle part of the sagittal section in fig. 3. $785 / 1$.

Fig. 10. 'l'ransverse section of the facets from the dorsal part of the left eye of $D$. pulchella. On the right side the sectiou has passed only through the upper layer of facets. $785 / 1$.

Fig. 11.' Transverse section through six ommatidia of D. pulchella. On the right the section has passed through the cells of the crystalline cone 'The same object as in fig. 3. 1390/1.

Fig. 12. 'Transverse section through two ommatidia of the dorsal eye region on the level of the retinular nuclei $1-6$. Same object. 1390/1.

Fig. 13. Transverse section through five dorsal ommatidia proximally to the retinular nuclei $1-6$ and distally to nuclei 7 . The upper ommatidia in the drawing are on one side, and the lower onmatidia-on the other side of the plane of symmetry dividing the eye in two equal parts with respect to the arrangement of the rhablom cells. The same preparation as in fig. 3. $1390 / 1$.

Fig. 14. Transverse section through five dorsal ommatidia on the level of the retinular nuclei 7. The same object. $1510 / 1$.

Fig. 15. Transverse section through the row of "rods" of the molecular layer of the exterior optical ganglion. Same object as in fig. $4 .{ }^{1510} / 1$.

Fig. 16. Slightly reconstructed transverse section through the ventral ommatidium of the same object, as in fig. 3 , and on tile same level as in fig. 13. $1390 / 1$. 

Ф. О. Эгrерсъ. Гистологія глаза Diopsidae.

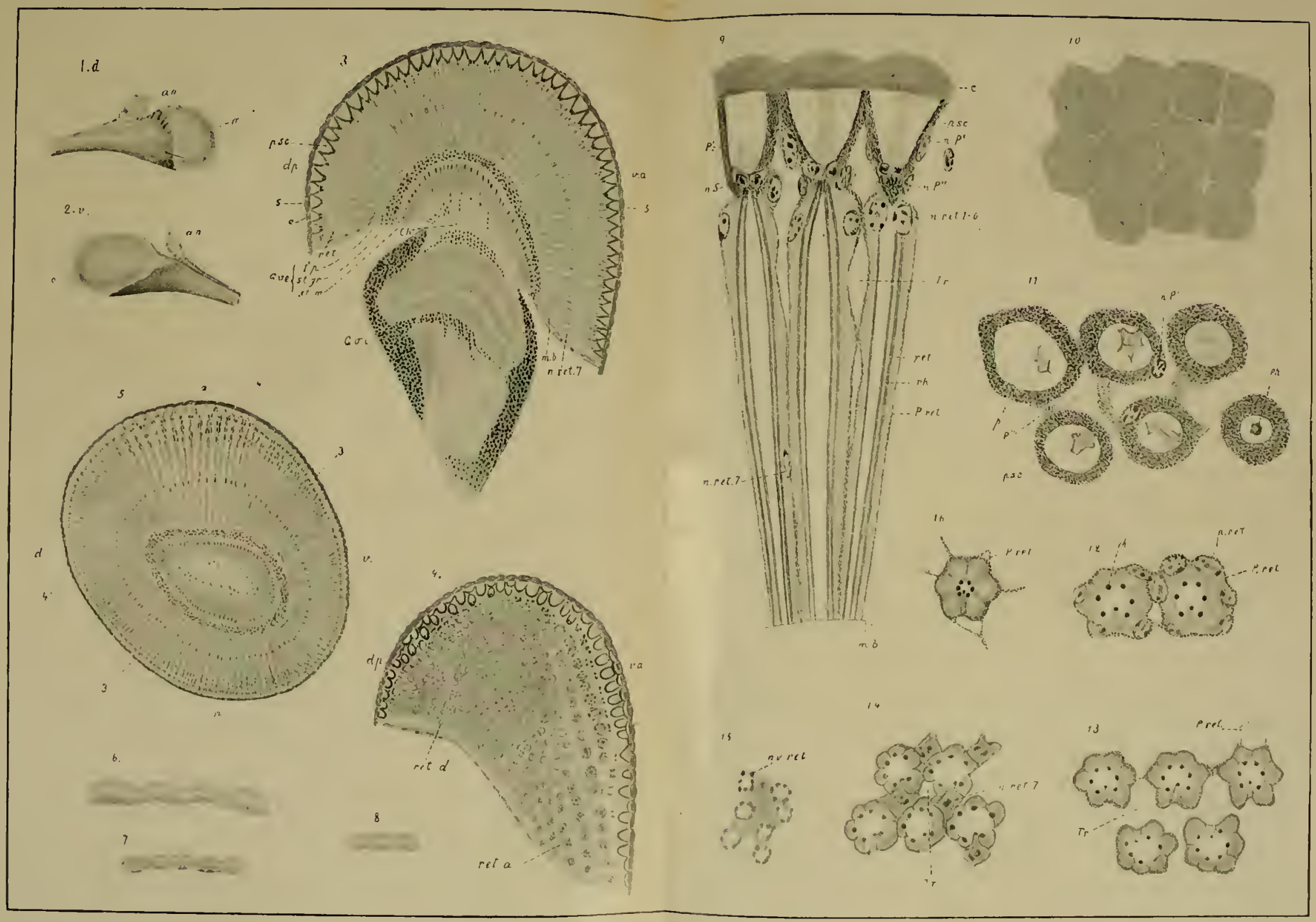

Puc. Эrrepcz. 

№ 8 .

\title{
Два новыхъ вида Sarcocystis изъ африканскихъ антилопъ.
}

\author{
B. А. ДОГЕЛ В.
}

\section{Two new species of Sarcocystis from African Antelopes,}

V. A. DOGIEL. 



\section{Два новыхъ вида Sarcocystis изъ африканских'ь антилон'ь.}

В. Догель.

Во время своей поъздки въ Британскую Восточную Африку я изсльдовалъ мышцы различныхъ африканскихъ животныкъ, а именно зебры, Placochoerls и нбкоторыхъ аңтилопъ на Sarcosporidia. Въ мышцахъ двухъ видовъ антилопъ мнб́ при этомъ, д屯йствительно, удалось обнаружить присутствіе многочисленныхъ мьшковъ Surcocystis. Въ данной замьткб я и намъренъ дать краткое описаніе найденныхъ мною видовъ, нъсколько подробнъе останавливаясь на строеніи эктоплазмы, ибо тонкая структура посльдней у Sarcosporidia до сихъ поръ различными авторами толкуется различно.

Въ моемъ распоряженіи были мъшки Sarcocystis, взятые изъ мышцъ конечностей (самыхъ молодыхъ и самыхъ старыхъ, встрбчающихся въ мышцахъ пищевода стадій у меня нътъ) и фиксированные сулемой съ уксусной кислотой. Перехожу теперь къ описанію обоихъ найденныхъ мною видовъ.

\section{Sarcocystis bubalis n. sp.}

Эта форма въ большомъ количеств各 встрғтилась мнғ въ мышцахъ двухъ изсльдованиыхъ мною экземпляровъ Bubalis cookei. Мєшки S. bubalis я находилъ исключительно внутри мышечныхъ волоконъ, очень толстыхъ у данной антилопы. Длина мұшковъ колебалась отъ $250 \mu$ до $2 \mathrm{~mm}$, тогда какъ ширина ихъ равнялась $65-200 \mu$. Вся внутренность мъшковъ равномърно набита спорами, которыя имъютъ характерную для споръ Sarcosporidia вытянутую и слегка бобовидно изогнутую форму. Длина споръ равна приблизительно $10 \mu$. На одномъ концъ споры явственно замътна крупная свътлая вакуоль. Какъ я уже замътилъ, группового расположенія споръ въ мбшкахъ описываемой формы 
не встрбчается; въ связи съ этимъ отсутствуетъ и система перекладинъ основного вещества, которыми у многих'ь Sarcosporidia содержимое мъшка разбивается на камеры. Въ этомъ отношеніи S. bubalis напоминаеть виды S. lindemanni (R i volt a) и S. muris Blanchard, у которыхъ вышеупомянутыя перекладины развиты слабо и очень нбжны и тонки.

Находясь внутри мускульныхъ волоконъ, мъшки S. bubalis слғдуютъ за всбли измғненіями формы мышечнаго волокна. Въ т各хъ случаяхъ, когда мускульная кльткка сокращается и дълаетъ многочисленные волнообразные изгибы, мы находимъ соотвъ́тственные изгибы и на мъшкъ Sarcocystis (см. табл. рис. 3). Заслуживаетъ вниманія строеніе оболочки, в’ь котором’ь мнъ̆ удалось довольно хорошо разобраться. Несмотря на наличность довольно большого числа работъ, касающихся Sarcosporidia, вопрос'ъ о строеніи ихъ оболочки еще не можетъ считаться рбшеннымъ. Такъ, еще въ посльднемъ изданіи (1911 г.) большого руководства по протистологіи Дофлейна говорится, что наружный слой оболочки Sarcopsoridia „состоитъ изъ многочисленныхъ параллельныхъ палочекъ, поствленныхъ перпендикулярно къ поверхности тьла, или же, быть можетъ, правильнъе оболочка пронизана многочисленными канальцами, что и даетъ на сръзахъ картину исчерченности или ръсничнаго покрова“. Мъжду тъъмъ со времени выхода цитируемой книги никакихъ новыхъ данныхъ относительно строенія оболочки Sarcosporidia не появлялось.

На основаніи моихъ изсльдованій надъ S. bubalis я могу категорически утверждать, что болъе правильнымъ является первое предположеніе и что о пористости оболочки у Sarcosporidia не можетъ быть ръчи. Наружная оболочка Sarcocystis состоить изъ палочекъ, или ромбическихъ призмъ, расположенныхъ въ вполнь опредъленномъ порядкь, а именно діагональными по отношенію къ продольной оси мъшка рядами. Расположеніе упомянутыхъ призмъ лучше всего видно на поверхностныхъ продольныхъ сръзахъ черезъ мышокъ. Такъ, рисунок'ъ А в’ъ тексть изображаетъ нбсколько косо прошедшій черезъ мәшокъ S. bubalis поверхностный разр‡зт; въ верхней части рисунка разръзъ задћль самый мұшокъ, набитый спорами и окруженный исчерченной оболочкой; въ нижней части рисунка разръзомъ затронута только наружная оболочка мъшка, палочки которой переръзаны поперекъ. Ясно замғтно расположеніе палочекъ діагональными рядами, причем'ъ каждая палочка въ разрбзъ даетъ фигуру ромба. Между палочками находится, повидимому, какое то слабо красящееся 
вещество. Только что описанная картина встрбчается наиболье часто и я считаю ее нормальной. Гораздо рбже попадаются мбшки Sarcocystis, укоторыхъ палочки, или призмы, наружной оболочки располюжены не діагональными, но продольными, совпадаюшими съ длинной осьюм ышка рядами (рис. 4). На поперечныхъ разръзахъ палочки такихъ мъшковъ кажутся сплющенными въ направленіи продольной оси.

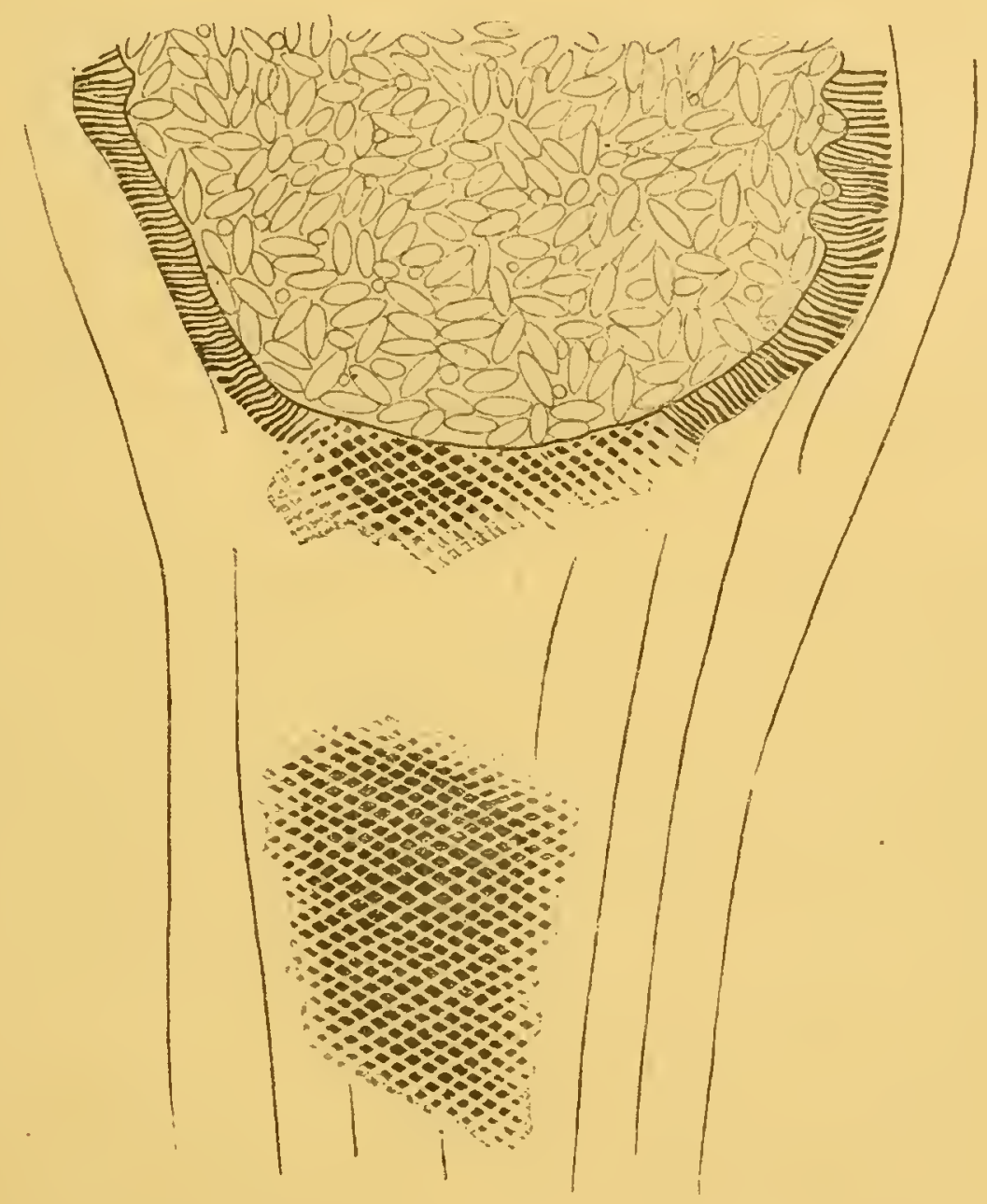

Рис. А. Поверхностный сръзъ черезъ мњшокъ S. bubatis.

Изложенныя наблюденія я склоненъ толковать сльдующимъ образомъ. Я полагаю, что палочки оболочки Sarcosporidia являются съ одной стороны довольно мягкими, съ другой стороны въ значительной мғръ упругими; форма палочек'ь и расположеніе ихъ мъняются въ зависимостти от’ь различной степени сокращенія мускульной кльтки, въ которой помъщается паразитъ. При среднемъ сокращеніи мускульной кльтки палочки, или призмы, имъютъ ромбическую форму и расположены нормально, т. е. діагональными рядами. При сильномъ сокращеніи мышечнаго 
волокна, мұшокъ паразита испытываетъ сдавливаніе по направленію продольной оси. Вслєдствіе этого палочки испытываютъ нбкоторое смъщеніе, образуя продольные ряды, а каждая палочка изъ болъе или менъе правильной ромбической призмы превращается въ узкую пластинку, плоскія стороны которой обращены къ концамъ мұшка. При ослабленіи сокращенія мышечной кльтки палочки должны занять прежнее положеніе и вернуться къ своей нормальной формъ. Такимъ образомъ форма и расположеніе палочекъ оболочки представляютъ какъ бы функцію степени сокрашенія мышечной кльтки животнаго хозяина.

Изъ всъхъ предыдущихъ изсльдователей наиболъе близкое къ моему и наиболье правильное толкованіе оболочки Sarcosporidia даетъ Вилье мен ь (Vuillemin 1902), работавшій надъ Sarcocystis tenella. Къ сожальннію, его небольшая статья прошла совершенно незамбченной, в броятно именно всльдствіе своей краткости и отсутствія въ ней рисунковъ. Вильеменъ тоже находитъ, что наружный слой оболочки Sarcosporidia cocтонтъ изъ призматнческихъ палочекъ, но ему не удалось подмғтить описанныхъ выше измғненій въ ихъ расположеніи и формъ. В и ль ем ен ъ считаетъ палочки неправильно угловатыми, хотя и отм‡чаетъ, что он各 сидятъ болъе или менъе правильными рядами. Изъ позднъйшихъ авторов'ь только Ферре (Ferret, 1904), спеціально изучавшії строеніе оболочки Sarcosporidia, цитируеть статью Вильемена, Однако, Ферре не только не пополниль наблюденій упомянутаго изсльдователя, но даже не могъ замьтить правильнаго рядового расположенія палочекъ оболочки.

Судя по совпаденію нбкоторыхъ данныхъ моихъ и В и ль е м е н а оболочка нмъетъ только что описанное строеніе у всъхъ вообще Sarcosporidia, но только $S$. tenella $и$ S. bubalis являются наиболье удобными объектами для ея изученія.

\section{Sarcocystis woodhousi n. sp.}

Встрғчается въ мышцахъ Gazella granti. Этотъ видъ названъ мною въ честь г. Вудгауза, помощника завъдывающаго департаментомъ охоты въ Британской Восточной Африкъ. Г. Вудгаузъ первый предупредилъ меня, что въ газели Гранта часто попадаются какія то Sarcosporidia.

Длина и толщина мвишовъ S. woodhousi колебалась въ сльдующихъ пред务лахъ: длина $=250 \mu-1^{1} / 2 \mathrm{~mm}$., ширина $=$ $60-80 \mu$. 


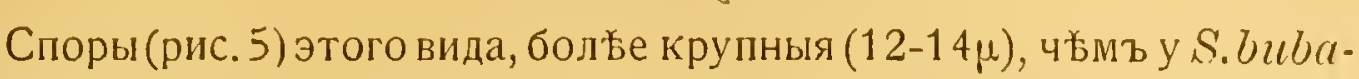
lis, расположены группами, въ видъ болье или менъе правильныхъ шариковъ (рис. 7 и 8), тбсно прилегающихъ другъ къ другу. Каждый такой шарикъ содержитъ болъе десятка споръ. Между группами споръ, у периферіи мъшка замътны перекладины промежуточнаго вещества, которыми мъшокъ разбивается на камеры (чего нељьзя замлтить у $S$. bubalis).

Наружная оболочка $S$. woodhousi значительно тоньше, чъммь у предыдущаго вида, вслйдствіе чего радіальная исчерченность ея очень плохо выражена. Внутренняя оболочка даетъ отъ себя вглубь мышка вышеупомянутыя перекладины промежуточнаго вещества.

Въ противоположность предыдущему виду, я находилъ мұшки S. woodhousi не только внутри мускульных'ъ клғтокъ, но и въ межмышечной соединительной ткани. Весьма вброятно, что раннее выхожденіе паразита изъ мышечныхъ кльтокъ связано съ меньіней толщиной посльднихъ у газели Гранта, по сравненію съ мускульными кльтками Bubalis cookei.

Межкльточные экземпляры мошшовъ Sarcocystis окружаются тонкой соединительно-тканной капсулой (рис. 6 и 8). На всемъ протяженіи посльдней разбросаны ядра соединительно-тканныхъ кльтокъ. Эти ядра скопляются въ особенномъ изобиліи на концахъ мъшка, гд⿱ 口 они образуютъ какъ бы два явственныхъ колпачка. По грисутствію подобныхъ колпачковъ сразу, даже пользуясь слабымъ увеличеніемъ микроскопа, можно отличить, имъемъ ли мы двло съ внутрикльточными, или же съ межкльточными стадіями паразита.

\section{Объясненіе рисунковъ таблицы.}

Puc. 1. Sarcocystis bulbalis. Oc. 6; obj. Reiclsert № 3.

Puc. 2. idem, ciropa. Oc. 6; obj. Zeiss Imm. $2 \mathrm{~mm}$.

Piгc. 3. idem, длинный менок внутри сократпвшагося мышечнаго вилокна. Oc. 6; орj. Zeiss $32 \mathrm{~mm}$.

Pнс. 4. idem, расположеніе палочегъ оболочки в'ъ сократившемея мちнкъ. Oc. 6 ; obj. Zeiss Imm. $2 \mathrm{~mm}$.

Puc. 5. Sarcocystis woodhousi. Criopa. Oc. 6; obj. Zeiss Imm. $2 \mathrm{~mm}$.

Pic. 6. idem, мьшокь цљъ межмышечной соединительной ткапн. Ос. 6; obj. Reichert № 3.

Puc. 7. idem, конецъ ввутри-мускульнаго мишка. Oc. 6; obj. Zeiss 4 mm.

Рис. 8. idem, конецъ мъшка пзъ межмыненой ткани, сь колпачкомт ядерт, соединительно-ткашныхт кльтокъ. Oc. 6; obj. Zeiss $4 \mathrm{~mm}$. 



\title{
Two new species of Sarcocystis from African Antelopes.
}

\author{
BY V. DOGIEL.
}

During my voyage in British East Africa I investigated the muscles of different African animals, viz. Hippotigris, Phacochoerus and some antelopes for Sarcosporidia. And indeed, in the muscles of two species of antelopes I succeeded in discovering numerous sacs of Sarcocystis. In the present paper I intend to give a brief description of the species found by me, and shall treat the structure of the ectoplasm in greater detail, as the fine structure of the latter in Sarcosporidia is interpreted differently by the various authors.

I had at my disposal the sacs of Sarcocystis taken from muscles of the limbs (I have not got the youngest and oldest stages, which are to be found in the muscles of the oesophagus), and fixed by corrosive sublimate with acetic acid. I shall now pass to the description of the two species found by me.

\section{Sarcocystis bubalis n. sp.}

This form was found in great quantities in the muscles of the two specimens of Bubalis cookei investigated by me. I have found the sacs of $S$. bubalis embedded in muscle fibres which are very thick in the antelope named. The length of the sacs varied from $250 \mu$ to $2 \mathrm{~mm}$., wheareas their width was $65-200 \mu$.

The whole interior of the sacs was uniformly filled with spores which have the elongated and slightly bean-shaped form characteristic for the spores of Sarcosporidia. The length of the spores is about $10 \mu$.

At one end of the spore a large light vacuole is plainly visible. As I have already noticed, the arrangement of spores 
into gromps in the sacs is not to be found in the species described. In comnection with this is the absence of the system of strands of the basal substance by means of which in many Sarcosporidia the contents of the sac are divided into chambers. In this respect $S$. bubalis resembles the species S. lindemami (Rivolta) and S. muris B lanchard, in which the strands named are weakly developed and are rery thin and tender.

Being imbedded in the muscle-fibres the sacs of S. bubalis follow all the changes in the form of the muscle-fibre. In the cases, when the muscle cell contracts and is corered with nndulated folds, we find corresponding folds on the sac of Sarcocystis (fig. 3) as well. The structure of the membrane-which I sncceeded in revealing pretty well-also deserves attention. Notwithstanding the many works relating to Sarcosporidia, the question of the structure of their membrane - has not yet been solved. For instance, eren in the latest edition (1911) of Doflein's large text-book on Protistology it is said that the exterior layer of the membrane of Sarcosporidia "consists of numerous parallel rods set perpendicularly to the surface of the body, or, it may be more correctly, the membrane is pierced by numerous canals, which in section give the appearance of striation or of a ciliated tegument.

Since the book quoted was published, there have not appeared any new data concerning the structure of the membrane in Sarcosporidia.

On account of my own investigations on $S$. bubalis I can positively affirm that the first point of view is more correct, and that porosity of the membrane in Sarcosporidia is to be denied. The exterior membrane of Sarcocystis consists of rods, or rhombic prisms arranged in definite order, namely, in diagonal rows with respect to the long axis of the sac. The arrangement of the prisms mentioned is best seen on superficial longitudinal sections through the sac. Thus, fig. A on the page 5 represents a superficial section that has passed somewhat obliquely through the sac of $S$. bubalis; in the upper part of the drawing the.section passes through the sac itself filled with spores and surromnded by a striated membrane; in the lower part of the drawing the section passes only through the exterior membrane of the sac, the rods of which are cut transversely. The arrangement of the rods in diagonal rows 
is plainly visible, each rod being seen as a rhomb in the section. Between the rods there seems to be some kind of a weakly stainable substance. The picture just described is most frequently met with, and l consider it as normal. Very rarely there are to be found sacs of Sarcocystis in which the rods, or prisms, are arranged not diagonally, but in longitudinal rows, parallel to the long axis of the sac (fig. 4). In transverse sections the rods of smeh sacs seem to be flattened in the direction of the long axis.

1 am inclined to regard the observations described in the following manner. I suppose that the rods of the membrane of Sarcosporidia are on the same time pretty soft, and very elastic; the shape of the rods and their arrangement rary and depend on the different degrees of contraction of the muscle cell in which the parasite is imbedded. At an average degree of contraction of the muscle cell the rods, or prisms, have a rhombic shape, and are arranged normally, i. e. in diagonal rows. At a strong contraction of the muscle fibre the sac of the parasite is pressed in the direction of the long axis. On account of this, the rods are displaced, and become arranged into longitudinal rows, and the more or less regular rhombic prism, or rod, is transformed into a narrow plate the flat sides of which are directed to the ends of the sac. When the contraction of the muscle cell is relaxed, the rods again return to the same position and assume their normal shape. Thus, the form and arrangement of the rods of the nembrane present a sort of function of the degree of contraction of the muscle cell in the host.

Out of all the preceding investigators the most correct interpretation which is the nearest to my own of the membrane in Sarcosporidia was given by Vuillemin (1902) who studied Sarcocystis tenella. But, unfortunately, his brief paper passed quite unnoticed, most probably on account of its briefness and absence of drawings. V u i $11 \mathrm{e} \mathrm{m}$ i n also states that the exterior layer of the membrane in S a r cos p o r i d i a consists of prismatic rods, but he did not succeed in revealing the changes in their arrangement and shape as described above. $\mathrm{V}$ uille min considers the rods to be irregularly angulous, although he remarks that they are set into more or less regular rows. Of the mole recent authors only Fer ret (1904), who made a special study of the structure of the membrane in 
Sarcosporidia, quoted V'uillemin's paper. However, Ferret not only added nothing to the observations of the latter author, but did not even notice any regular arrangement of the rods of the membrane into rows.

Judging from the coincidence of some of my data and those of Tuillemin, the membrane has the structure just described in all Sarcosporidia generally, S. tenella and $S$. bubalis being only the most convenient objects for its study.

\section{Sarcocystis woodhousi n. S.}

Occurs in the muscies of Gazella granti.

This species is named by me in honour of M-r Woodhouse, Assistant Game- Warden in British East Africa. M-r Woodhouse was the first to turn my attention to the frequent occurence of some kind of Sarcosporidia in Grants gazelle.

The length and thickness of the sacs of $S$. woodhousi valied in the following limits: the length $=250 \mu-1 \frac{1}{2} \mathrm{~mm}$; the thickness $=60-80 \mu$.

The spores of this species, which are larger than those of S. bubalis are arranged in groups forming more or less regular balls closely adjoining each other. Each of these balls contains more than ten spores. Between the groups of spores, on the periphery of the sac are seen strands of the interme. diary substance which divide the sac into chambers (which is not to be found in $S$. bubalis).

The exterior membrane of $S$. woodhousi is mush thimmer than in the preceding species, on account of which the radial striation is very slightly expressed on it. The interior membrane produces the strands of intermediary substance mentioned, which pass from it into the middle of the sac.

Contrary to what is found in the preceding species, I found sacs of $S$. woodhousi not only inside the muscle cells, but in the intermuscular comnective tissue as well. It is quite probable that the early escape of the parasite out of the muscle cells is due to the latter being thinner in Grant's gazelle, as compared with the muscle cells in Bubalis cookei.

The intermuscular sacs of Sarcocystis are surrounded by a thin connective-tissue capsule (fig. 8). On all the surface of the latter are dispersed the nuclei of connective-tissue cells. These nuclei are especially abundant at the ends 
of the sac, where they seem to form two distinct hoods. From the presence of such hoods we may at once, even at low power of the microscope, distinguish whether we have before us the intracellular or intercellular stages of the parasite.

\section{Explanation of figures on the plate.}

Fig. 1. Sarcocystis bubalis. Oc. 6; obj. Reichert № 3 .

Fig. 2. The spore of the same species. Oc. 6; obj. Zeiss. Imın. 2 mm.

Fig. 3. A long sac of $S$. bubalis inside of a contracted muscle-fibre. Oc. 6; obj. Zeiss $32 \mathrm{~mm}$.

Fig. 4. The arrangement of ectoplasmatic rods on the surface of a contracted sac of S. bubalis. Oc. 6; obj. Zeiss Imm. $2 \mathrm{~mm}$.

Fig. 5. The spore of Sarcocystis woodhousi. Oc. 6; obj. Zeiss Imm. $2 \mathrm{~min}$.

Fig. 6. A sac of $S$. woodhousi lying in the intermuscular connective tissue 0c. 6; obj. Reichert № 3 .

Fig. 7. One of the ends of an intramuscular sac of S. woodhousi. Oc. 6; obj. Zeiss $4 \mathrm{~mm}$.

Fig. 8. One of the ends of an intermuscular sac of S. woodhousi. Oc. 6; obj. Zeiss $4 \mathrm{~mm}$. 

Д. Догель. Sarcosporidia.

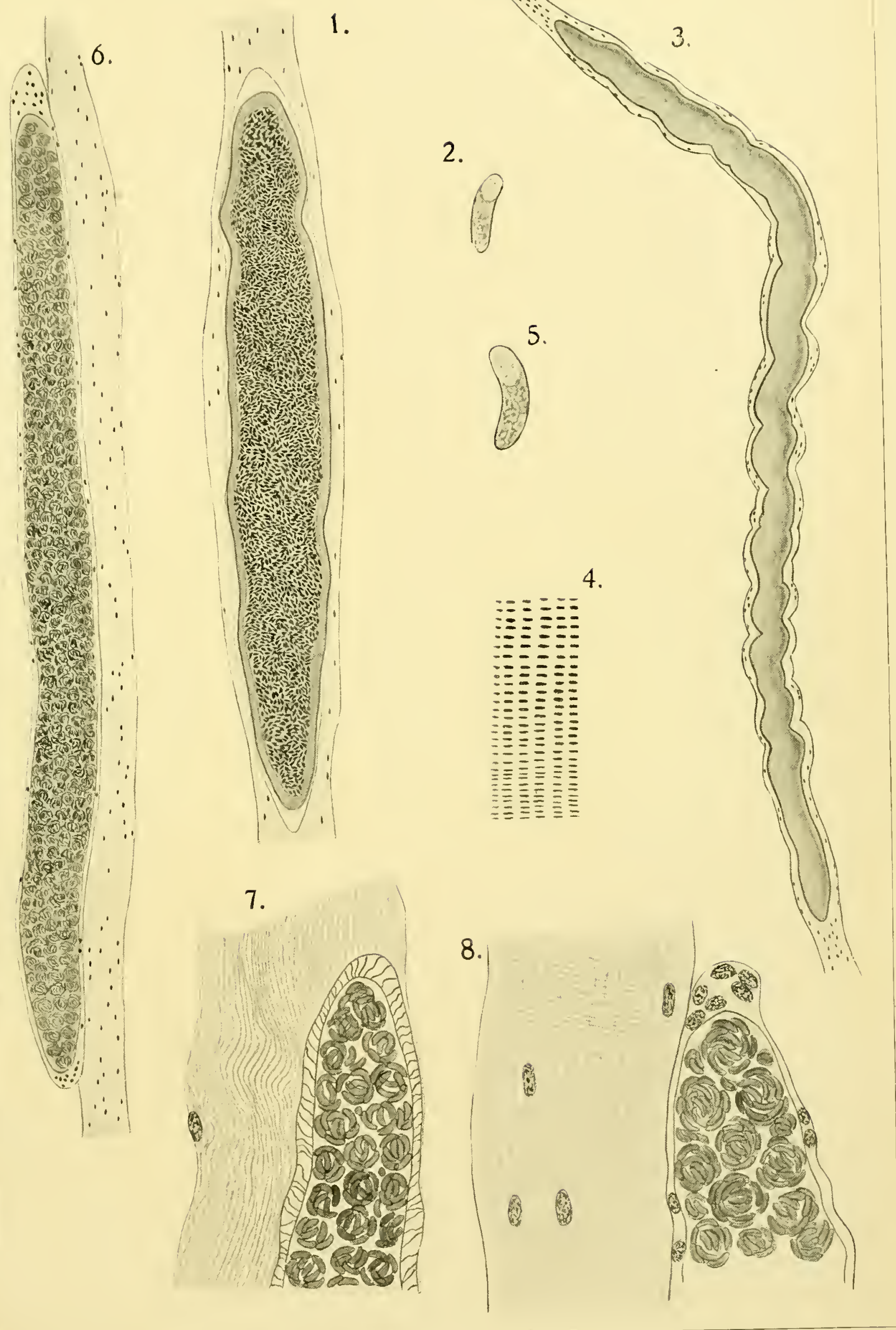

Рис. В. Догель. 

№ 9.

Обзоръ фауны скорпіоновь Британской Восточной Африки,

А. А. БиРуля.

A general list of the Scorpions of British

East Africa,

By

A. A. BIRULA. 



\title{
Обзорт фауны скорпіоновъ Бри- танской Восточной Африки.
}

\author{
А. А. Бируля.
}

(Зоологическій Музей Нмшер. Академіп Наукъ)

Въ теченіе трехъ посльднихъ льтъ я имғль возможность ознакомиться съ систематическимъ составомъ скорпіофауны Британской Восточной Африки по двумъ небольшимъ сборамъ русскихъ экспедицій въ эту область чернаго материка, вообще до сихъ поръ не посъщщавшуюся русскими съ научными цълями: всъимъ, что было извбстно до сихъ поръ о фаунъ этой части Африки, наука обязана преимущественно англичанамъ, и въ частности въ отношеніи скорпіофауны, бывшему завъдующему отдъленіемъ паукообразныхъ Британскаго Музея Р. І. Пококу. Обработанныя ${ }^{1}$ ) мною коллекціи были собраны, одна С. Ф. С в а т оше мъ въ 1913 г., а другая проф. В. А. Догелемъ и И. И. Соколовымъ въ 1914 г.; объ экспедиціи работали почти въ одной и той же части страны, именно въ южной, вдоль и въ ближайшихъ окрестностяхъ жельзной дороги Момбаса-Викторія Ніанца. Собранныя ими коллекціи дали довольно полное, хотя и не исчерпывающее, представленіе о скорпіофаунб्ठ этой страны, такъ какъ въ нихъ не оказалось нъкоторыхъ видовъ, раньше найденныхъ въ странъ. Поэтому, получивъ отъ проф. В. А. Догеля предложеніе принять участіе въ публикуемыхъ имъ научныхъ результатахъ его путешествія въ Брит. Вост. Африку, я призналъ болье удобнымъ дать статью о мъстныхъ скорпіонахъ болъе исчерпывающаго характера, пользуясь которой каждый, ъдущій въ эту страну для зоологическихъ изсльдованій, могъ-бы опредълить встрбчающіеся ему виды скорпіоновъ. Поэтому въ настоящей статьъ мною даны-литературная сводка по скорпіофаунь Брит. Вост. Африки, краткій очеркъ внбшняго строенія скорпіоновъ, поскольку это нужно для

1) Ср. Ежег. Зоол. Муз. Акад. Наук', XIX, 1914, стр. 114, и Русск. Энтом. Обозр., ХТ, 1915, стр. 50. 
оріентировки въ опредблительныхъ таблицах'ь и описаніяхъ видов'ь, и, наконецъ, достаточно подробное описаніе всъхъ найденных'ь въ странъ видовъ скорпіоновъ съ указаніемъ на ихъ географическое распространеніе; въ заключеніе я счелъ необходимымъ дать также краткій зоогеографическій очеркъ страны в’ь отношеніи интересующаго насъ отряда.

Въ предғлахъ Британской Вост. Африки до сихъ поръ найдено 17 видовъ скорпіоновъ, относящихся къ 9 родамъ и двумъ характернымъ для Эфіопской фауны семействамь-Buthidae (11 видовъ) и Scorpionidae (8 видовъ); однако, съверная часть страны еще плохо изсльдована въ фаунистическомъ отношеніи, и въ ней могутъ быть открыты новые виды, съ другой стороны нбкоторые виды найдены близъ границъ области и со временемъ, очевидно, будутъ найдены " Въ предълахъ ея. Географическое распространеніе какъ найденныхъ въ области видовъ, такъ и такихъ, нахожденіе которыхъ въ ней возможно, видно изъ таблички въ конц лійскаго текста. Изъ этой-же таблички легко видвтьь, что южная часть Брит. Вост. Африки по видовому составу скорпіофауны близка къ сосъдней Германской Вост. Африкъ, тогда какъ въ съверной ея части появляются виды, свойственные съверовосточной Африкъ. Южноафриканскій элементъ въ лиц в характерныхъ для него родовъ Opisthophthalmus и Hadogenes вполнғ чуждъ всей вост. Африкт.

Экспедиціеї проф. В. А. Догеля и И. И. Соколова добыто всего 7 видовъ скорпіоновъ: Jomachus politus Pос. (q juv.Бура. 24-25 VII; q juv.-.Темба, 14 VIII: $\sigma$ semiad. и 4 우 ad.-pъка Тцаво). Uroplectes fischeri (K a l’s ch) ( o semiad.-Тавета, 1 VIII), Lroplectes xanthogrammus intermedius Tull. ( q semjad.-о3. Найваша, 11-13 VII, въ жилищъ), Lychas obsti Krp. (o ad.-Бура, 24-25 Vil), Lychas burdoi rugulosus 11. subsp. (2 o ad. fert.-Taвета. 31 Vill), Buthus emini Po c. (6. ad.fo ad.-Бура, 24-25 VIl; o semiad.-Тавета, 31 VIl; \% ad.to fert.t2 juv.-оз. Чала, 4 VIII; o semiad. to ad.оз. Цжипе, 7 VIII; 2 q fert.-p. Тцаво, 12-14 VIII; q ad.-Темба, 14 VIII), Parabuthus pallidus Poc. (o juv.+o semiad.-p. Тцаво, 12-15 VIII). 


\title{
A general list of the Scorpions of British East Africa.
}

\author{
By
}

A. A. Birula.

(Zoological Iruseum, Academy of Sciences of Petrograd).

On their return to Russia, Prof. V. A. Dogiel and Dr. I. I. Sokolow, members of a Russian Zoological Expedition to British East Africa, brought home a valuable series of zoologrical specimens for scientific, investigation. The scorpions came into my hands for determination and form the subjectmatter of a communication, which I published in 1915 under the title "Weitere Bemerkungen über die Scorpionenfamna Britisch Ost-Afrikas»'). As far as the present paper is concerned, it contains a synopsis of all the species of the order Scorpions known to occur in Britjsh East Africa.

\section{Index of the principal works.}

1879. Karsch, F. «Scorpiologische Beiträge. II»; Mitth. Münchener entom. Vereins, r. III, pp. 124-127. .

1888. Pocock, R. "On the African specimens of the genus Scorpio (Linn.) contained in the collection of the British Museum»; Ann. and Mag. nat. Hist., ser. 6, v. II, pp. $245-255$.

1890. id., "Descriptions of two new species of scorpions brought hy Emin Pasha from the inland parts of East-African; loc. cit., ser. 6, v. VI, pp. 98-101, pl. I.

-i d., "On some old-world species of scorpions belonging to the genus Isometrus»; Jour. Linn. Soc. London, v. XXIII, pp. $433-447, \mathrm{pl}$. II.

1) A. B irula. Rerue russe d'Entomologie, v. XV, 1915, p. 50. 
- i d., "A revision of the genera of Scorpions of the family Buthidae, with description of some south-african species»; Proc. Zool. Soc. London, pp. 111-144, pl. XIII-XIV.

- Simon, E. «Etudes arachnologiques. Mém. 22e. XXXV. Étude sur les Arachnides recueillis par M. L. von Höhnel, officier de la marine autrichienne, pendant l'expedition de M. le comte S. Téléki dans l'Afrique orientale equatoriale en 188718ss»: Ann. soc. entomol. France, p. 130.

1S95. l'ocock, R. «Supplementary note upon the Scorpions obtained in Egypt and the Soudan by John Anderson»; Journ. Linn. Soc. London, v. XXII, pp. 299-316, pl. IX.

1896. id. "On the Scorpions, Centipedes and Millipedes obtained by Dr. Gregory on his Expedition to Mount Kenia, East Africa»; Ann. and Mag. nat. Hist., ser. 6, v. XVII, pp. 425-444, pl. XVIII.

- Kraepelin, K. Nene oder weniger bekannte Scorpione»: Mitt. naturh. Mus. Hamburg, v. XIII, pp. 121-146, 1 Tal.

1898. Po cock. R. "On the Scorpions, Spiders and Solpugas collected by $\mathrm{Mr}$. C. Stuart Betton in British East Africa»; Proc. Zool. Soc. London, pp. 497-524, pl. XLI-XLII.

1912. L $\ddot{3} n n$ b e r g, E. «Scorpions, Solpugids and Ixodides collected by the Swedish Zoological Expedition to British East-Africa 1911»; Arkiv för Zoologie, v. VII, № 24, pp. 1-う.

1913. Kr a e p elin, K. "Neue Beiträge zur Systematik der Gliederspinnen. Il[»; Mitt. naturh. Mus. Hamburg, r. XXX, pp. $167-188$.

1914. Birula, A. "Miscellanea scorpiologica. X. Bemerkumgen über die Scorpionenfanna Britisch Ost-Afrikas»; Ann. Mus. Zool. Petrograd, r. XIX, pp. 114-124.

1915. i d., "Arachnologische Beiträge. V. "Weitere Bemerkungen über die Scorpionenfauna Britisch Ost-Afrikas»; Revue russe d'Entomologie, v. XV, pp. 50-65.

\section{An account of the external morphology of Scorpions.}

The scorpions may be characterized in detail as follows: the body is divided into three main regions-an anterior, or cephalothorax, a middle, or trunk (praeabdomen), and a posterior, or «tail» (postabdomen). The cephalothorax is covered by a dorsal shield, or carapace, which is unsegmented and furnished near its centre with a pair of large median eyes 
and on each of its anterolateral angles with two, three or five small lateral eyes. The rentral surface of the cephalothorax consists of four pairs of coxal plates, or coxa, two pairs of maxillary lobes and a median sternal plate or sternum. The cephalothorax is furnished with five pairs of appendages, of which the anterior pair, or mandibles are situated close together beneath the front edge of the carapace above the month; each of the mandibles is armed with two fingers, movable and immovable; the upper and lower edge of each finger are mostly dentate. The appendages of the 2-nd pair (palpi) are chelate and consist of four joints, which are named as follows from base to tip-trochanter, humerus, brachium and hand, which is armed with an immovable and with a movable digits. The digits are furnished with an armature of several rows of granules, or of small teeth arranged longitudinally and partly obliquely along their biting-edges. 'The remaining four pair's of appendages, or legs consist each of six segments-trochanter, femur, tibia, metatarsus, protarsus and tarsus; the last is provided with two claws at the tip. To the articular membrane between the matatarsus and the protarsus is attached a spur, and between the protarsus and the tarsus-two, or one (outside) tarsal spine; the upper side of the tarsal joint is generally produced at its distal end into a claw-lobe overhanging the base of the claws. The abdomen consists of twelve distinct segments, seven (praeabdomen) of which are covered from above by a tergal plate, or tergite each and from beneath by a stermal plate, or sternite. 'The last five segments are narrow, flexibly jointed together and constitute with the postanal segment "the tail» (postabdomen). The postanal joint, a veritable tail, consists of a usually globular basal portion, the vesicle, which contains a pair of poisonglands and a spiniform distal portion, the aculeus; all the joints of the tail are as a rule ornamented at the sides and below with elevated and usually granular lieels. The first four segments are furnished with eight or ten keels; the 5-th joint has only five complete keels. Behind the sternum of the cephalothorax, on the first abdominal somite is situated the genital aperture, which is corered by a single, or double movable lid, the genital opercula; the sternite of the 2-nd abdominal somite bears a pair of comblike appendages, the pectines; each of the following four abdominal sternites 
is furnished with a pair of respiratory stigmata; the last sternite usually only with lour keels.

A synoptical table of families, genera and species of scorpions.

'The scorpions of British East Africa are referable to 2 families, 9 genera and about 17 species, the characters of which may be tabulated as follows:

A. Sternum triangular, narrowed in lront; legs furnished with a pair of tarsal spines, one in front and one behind; hands of the palpi slender and rounded-fam. Buthidae.

a. 3rd and 4th leg's furnished with spurs.

$a_{1}$. No triangular tooth (or only a small tubercle) beneath the acnleus on the vesicle; immorable finger of mandible with two teeth below.

$a_{2}$. Carapace of the cephalothorax not crested: tergites furnished with only one median keel: no small tubercle beneath the aculeus on the resicle.

$a_{3}$. Tail posteriorly very distinctly incrassate; inferior keels of $1-3 \mathrm{r}$ l candal segments lorming on each segment a pair of posteriorly converging ridges; morable digit of palpi furnished with 11 -12 external sramules; pectinal teeth $27-25$ (q) or $33-34$ (১). . . . . . Parabuthus pallidus Poc. $b_{3}$. Tail posteriorly slightly incrassate: inferior keels of 1 -3 rd candal segments nearly parallel; morable digit of palpi furnished with 13-14 external gliat-

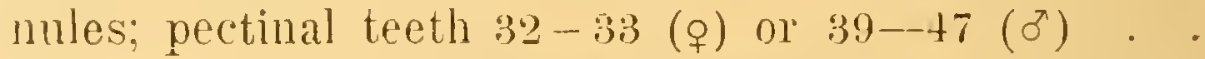

Parabuthus liosoma (H. et. E lı r.).

b2. Carapace of the cephalothorax distinctly crested: tergrites furnished with three (one median and two lateral) keels; a small tubercle heneath the aculeus on the vesicle (or only geniculate).

$a_{4}$. "Less coarsely gramular; tail thinner and lower height of 4 th segment barely hall its own length and distinctly less than length of 1 st; upper surfiace of candal segments much less strongly excavated"; superciliar crest of the ocular tubercle granular . . . . . . Buthus polystictus P oc. $b_{4}$. Nore coarsely gramular: tail thicker, its superior keels more strongly elevated; height of 4 th segment more than half its length and equal to length of 
1st"; superciliar crests of the ocular tubercle smooth. . . . . . . . . . Buthus emini Po c.

$b_{1}$. A strong triangular tooth on the caudal vesicle beneath the aculeus.

$a_{5}$. Immovable finger of mandible with two teeth or nuly one tooth below.

$a_{6}$. Immovable finger of mandible with two teeth below; digits of the palpi on external side with $2 \mathrm{Gr}^{\circ} 3$ rows of large granules. Odonturus dentatus kis ch. $b_{6}$. Immorable finger of mandible with only one tooth below; digits of the palpi on external side with one row of large granules.

$a_{i}$. Fourth sternite of abdomen nearly smooth; lifth sternite without distinct keels

Lychas burdoi (Si m.).

$b_{7}$. Fourth sternite of abdomen strongly granular; fifth sternite with distinctly developed keels.

.Lychas obsti Kr pl.

$b_{5}$. Immorable finger of mandib e unarmed.

is. Apical granula of all the rows at the movable digit of hand hardly enlarged and not separated from the rest; sulcus on upper side of all the segments of the tail granular; digits of the hand with 12 rows of granules. Uroplectes xanthogrammus Poc.

bs. Apical granula of the distal rows at the movable digit of the hand enlarged and distinctly separated from the rest; digits of the hand with 11 rows of granules; sulcus on upper side of all the segments of the tail smooth. Uroplectes fischeri lirsch.

b. Only 4th pair of legs furnished with spurs; immorable finger of mandible with two teeth below.

$a_{9}$. Last abdominal sternite smooth, without keels; keels of the tail exceedingly feeble, only minutely crenulate, lower median keels of the tail smooth. .

Babycurus centrurimorphus Kr $\mathrm{sch}$.

$b_{9}$. Last abdominal sternite with two or four distinct keels; all the normal keels of the tail well defined and coarsely granular.

$a_{10}$. Movable digits of the palpi, except two basal coalite rows and a distal rudimentary row, with eight rows of granules. Babycurus wituensis K r pl. 
$b_{10}$. Morable digits of the palpi, except two basal coalite rows and a distal pudimentary row, with six rows of granules. . . Babycurus jacksoni P oc.

B. Sternum pentagonal, parallel-sided; legs furnished with a single anterior tarsal spine, the posterior always absent; spurs absent; hands of the palpi flat and rery broad-fam. Ścorpioniclae.

$a_{11}$. Distal lateral edges of tarsal joint produced into a rounded lobe overlapping the base of claws and forming an acute angle with the base of the claw-lobe; tarsal joints furnished beneath with two lateral rows of spicules; body not flat.

$a_{12}$. Distal lateral lobes of tarsal joint with two spines on each side; apex of the lobe furnished with a stout spine. Upper surface of the hand in adult male conspicuously concave towards the base of the immorable digit; anterior margin of the hand smooth; width of the hand greater than length of cephalothorax .

Pandinus cavimanus (P oc.). $b_{12}$. Distal lateral lobes of tarsal joint with three or four spines on each side; apex of the lobe furnished with a bristle. Upper surface of the hand not distally concave; width of hand not greater than length of cephalothorax.

$a_{13}$. Colour a uniform olive-brown; legs dark reddish brown; hand of palpi paler reddish. digits deep blackish green: hand above distinctly punctured, ornamented with irregularly shaped, low, not isolated tubercles. . . Pandinus gregoryi (P oc.). $b_{13}$. Colour yellowish brown; leg's paler yellow; hand reddish brown, sometimes with black digits.

$a_{14}$. Hand punctured above and reticnlated with low ridges; 2 spines only on each tarsal lobe . .

Pandinus militaris Poc.

$b_{14}$. Hand not punctured abore, with distinctly isolated tubercles, 3 spines on cach tarsal lobe

- Pandinus pallidus (K $\mathrm{r} \mathrm{pl}$.).

$b_{11}$. Distal lateral edges of tarsal joint not produced into a lobate prominence overlapping the base of the claw, but straight and forming a right angle with the clawlobe. 
$a_{15}$. Tarsal joints furnished beneath with a median row of spicules; body flat... . . Jomachus politus Poc.

$b_{15}$. Tarsal joints furnished beneath with two lateral rows of spicules; body not flat

Opisthacanthus fischeri Kr p I.

Synopsis and description of species with notes on their geographical distribution.

\section{Fam. Buthidae.}

\section{Buthus (Hottentotta) emini Poc.}

1890. Buthus Eminii, Pocock, R., Ann. and Mag. nat. Hist., ser. 6, r. VI, p. 98, pl. 1, fig. 2 (loc. typ.: «south shore of Victoria Nianzas).

S y no n y ma: Buthus emini, P o c ock, R., l. cit. ser. 6, v. XVII, p. 425, 1896; id., I. cit. ser. 7, v. II, p. 430, 1898; id., Proc. Zool. Soc. London, p. 499, 1898; Buthus minax (partim), Kr a e p e li n, K., Mitt. naturh. Mus. Hamburg, v. IXX, pp. 168-171, 1913; Buthus emini, Birula, A., Ann. Mus. Zool. Petrograd, v. XIX, p. 121, 1914; i d., Revue russe d'Entomol., r. $\mathrm{XV}$, p. $60,1915$.

Colour of the body yellow or ochraceo-fuscous: kecls of the trunk above and of the tail beneath-black; trunk above with five longitudinal rows of black or fuscous patches; crests of cephalothorax well developed and marked with smooth and rounded granules; superciliar crests of the ocular tubercle smooth; tergites of the trunk with three strongly granular lougitudinal keels; sternites mostly smooth, sparsely punctured and hairy; the last sternite more coarsely granulated at the sides or shagreened, with four distinctly granular keels; tail powerful, nearly parallel-sided, deeply excavated above; the anterior four segments of tail furnished with ten well developed, granular keels; intercarinal spaces finely and closely granular; vesicle large and inflated, strongly granular and hairy below, with a small tubercle beneath the aculeus. Palpi and legs granular and carinate; hand of the palpi large and very finely and closely granular, much wider than the brachium; digits short, each furnished with a lobe and 12-13 rows of granules; pectines with $23-25$ ( $\left.\sigma^{*}\right)$ or $21-24$ (q) teeth; total length $45-50 \mathrm{~mm}$. 
D) is tribution. British East Africa: occuring in abundance in the basins of T'ana and Travo rivers: at Voi, Bura, Taveta, Chala- and Jipe-lakes, Temba (Birula 1914 and 1915), also at Ndara and on Athi-plains (Pocock, 1\&96, p. 425); thence spreading southwards into German East Africa and northwards into British Somaliland, Boran Country (Pocock, 1898, p. 499). A species belonging to the ethiopian section of the subgenus Hottentotta, of which the westafrican $B$. hottentotta (F a b r.) is the type ${ }^{1}$ ), and closely resembling $B$. (H.) minax (L. K o ch) from Erythraea and Abyssinia in size and colour, but differing in particulars 2).

A number of specimens of varions ages and both sexes was obtained by the members of the Expedition in several localities: Voi-Bura, o ad., \& ad., 24-25 VII-Tareta, 31 VII, \& semiad.-Chala-lake, 4 VIII., $\sigma^{*}$ ad., +9 ad. (fert.), 2 juv.-Jipe-lake, . VIII, o semiad., क ad.-Tzavo-river, 12-14 VIll, 2 q ad. (fert.)-Temba, 14 VIII., o ad.

\section{Buthus (Hottentotta) polystictus Poc.}

1896. Buttus polystictus, Pocock, R., Ann. and Mag.-nat. Hist., ser. 6, v. XVIII, p. 178, pl. XI, fig. 1 (loc. typ.: «Goolis Mountains inland of Berbera»).

Synonyma: Buthus polystictus, Pocock, R:, Proc. Zool. Soc. London. p. 57, 1900; Buthus emini polystictus, K r a e p el in, K., Zool. Jahrb., Syst., v. XVIll, p. 560, 1903; Butluus polystictus, Lönnberg, E., Ark. f. Zool., v. VII, № 24, p. 2, 1912 .

Coloul of body a clear Iemon-yellow, spotted with black; each tergite except the last with five transverse black spots, the three median of which are on the three keels; tail below, palpi and legs with black spots; in granulation and development of crests and keels the species comes near Buthus emini, but the superciliar crests of the ocular tubercle are granular; the upper surface of the segments of the tail is much less strongly excavated and the superior keels are neither so high, nor so coarsely granular; the vesicle is larger and sligthly genicnlate under the aculeus; pectinal teeth $18-20$ (o); total length circa $55 \mathrm{~mm}$.

1) A. B irula, Ann. Mus. Zool. Petrograd, v. XIX, 1914, p. 121.

2) A. B ir u la, op. cit., p. 123 . 
b jstributiou. This species was based upon a single female example from Berbera (NE. Africa), but recorded also from Sso-omadu, a locality on the caravantrack from Zeyla to Addis-Abbeba in Shoa (Kraepelin, 1903), and from the Kenia-district, whence only two specimens were hitherto obtained; they ware found sunder log's and dry palm leaves in the thornbush country north of Guaso Nyiro river at Njoron during a swedish zoological Expedition to British East-Africa 1911 (Lönnberg, 1912). B. polystictus is undoubtedly closely allied to $B$. cmini; the specific value of this form of scorpion is very doubtful.

\section{Parabuthus liosoma ( $H$. et Ehr.).}

1527. Androctonus (Prionurus) leiosoma, Hem prich, F. und Ehrenberg, Ch., Verh. Ges. naturf. Freunde, Berlin, v. I, p. 356 (loc. typ. «inl glikklichen Arabien bei Lochaje, an der Kiiste, ).

Syno y m a: Androctonus (Prionurus) leiosoma. H e m pl i ch, F. G. et Ehrenberg, Ch. G., Symbolae physicae. Animalia articulata; I. Arachnoidea, Scorpiones africani et asiatici, № 10 , tab. II, fig. 6, 1829--1834; Parabuthus liosoma, Kra e pelin, K., Mitt. naturh. Mus. Hamburg, v. XXX, p. 171, 1913; B il'ula, A, Rev. rus. d'Entom., v. XV, p. 62, 1915.

Colour of body a clear yellow, infuscate yellow, or fuscous above; the legs, palpi with the exception of the palely infuscate digits, and first three segments of the tail are pale yellow, but the 4th and 5th segments of the tail and the resicle are brown, or deep greenish black; cephalothorax granular throughout, except for a nearly smooth ol shagreened area on each side of the ocular tubercle; space between the principal eyes nearly doubly as large as diameter of the eyes; tergites nearly smooth (o), or granular $\left(\delta^{*}\right)$ with a median longitudinal keel; sternites smooth; the last is smooth (o), or at most finely shagreened $\left(\delta^{n}\right)$, with four granulated keels; tail nearly parallel-sided, with elongated joints; joints $1-3$ with 10 keels; the 5 th joint is just at the base of the vesicle not, or very slightly attenuated below and on each side sparsely granular; intercarinal spaces of first four caudal segments smooth, or only very sparsely granular; anal lobes bidentate; pectinal teeth $32-33$ ( $q)$, or $39-47\left(\sigma^{*}\right)$, of which 
the basal tooth is rery wide, equalling in width about $5-9$ of the remaining teeth together; movable digits of palpi with 13-14 rows of granules; total length about $90-118 \mathrm{~mm}$.

bistribution '). The typical form of this species occurs in SE-Arabia (Yemen, Hadramaut, Aden); an eastafrican subspecies, P. liosoma abyssinicus Poc., which differs from the typical arabian form in having the inferior lateral keels of the 5-th segment of the tail furnished posteriorly with distinctly enlarged teeth, extends from the RedSea littoral into NE. Africa (Somali, Harar, Galla and Ogaden) and thence is spread southwards to the mountain Kilimanjaro and Mianzine (Pocock 1895, p. 312) in British East Africa. This form occurs also in German East Africa (Moschi, Umbugwe and Meru, according to Krate pelin 1913, p. 172).

\section{Parabuthus pallidus Poc.}

1895. Parabuthus pallidus, Pocock, R., Journ. Limn. Soc. London, v. XXV, p. 312 (loc. typ. «Mombasa»).

Synon y ma: Parabuthus pallidus, Pocock, R., Ann. and Mag. nat. Hist., ser. 6, v. XVII, p. 425, 1896; id., Proc. Zool. Soc. London, p. 499, 1898; Kra e pejin. K., L. Schultzes Forschungsreise im westlichen und zentralen Siidafrica ausgeführt in den Jahren 1903-1905, Denkschr. med.-naturw. Ges. Jena, XIII, 1., p. 250 (48), p. 253 (43), 1908; Lönnberg E., Arkiv l. Zool., v. VII, № 24, p. 2, 1912; Kraepelin, K., Mitt. naturh. Mus. Hamburg, v. XXX, p. 172, 1913; Birula, A., Rev. russe d'Entom., v. XV, p. 60, 1915.

Colour of body pale yellow; carapace and tergites of the trunk darker, reddish, or brownish yellow; legs, palpi, tail and lower side of trunk entirely pale yellow; cephalothorax entirely covered, including the high ocular tubercle, with coarse granules; spaces on each side between the ocular tubercle and the lateral eyes nearly smooth; space between the principal eyes nearly as large as the diameter of the eyes; tergites also covered with coarse granules, which are hardly finer in the front half of each. Median keel mostly extending from the 2 -nd to the 6 -th tergit; sternites smooth

1) A. Birula, "Arachnologische Beiträge. VI. Uber die nordostafrikanischen Formen von Parabuthus liosoma (Hemp. et Ehr.)", Rev. russe d'Entom. v. XV, 1915, p. 131. 
and polished; the last at most finely shagreened and on each side gramulated, with the four weakly developed keels. 'Tail gradually expanding to the middle of the 4-th segment, with all the joints short and thick; joints $1-4$ with ten keels; the j-th joint is just at the base of the vesicle very distinctly attenuated, below and on the sides rery thickly and coarsely gramular; intercarinal spaces of the first four joints of the tail on the upper surface smooth and polished, but on the sides and below-gramular; the granulation becoming thicker on the posterior joints; anal lobes not dentute; pectinal teeth $27-28$ (q) or $32-34\left(\sigma^{7}\right)$ of which the basal tooth is moderately wide, equalling in width about $3-4$ of the remaining teeth together; movable digits of palpi with $11-12$ rows of. granules; total length about $65-66 \mathrm{~mm}$.

Distribution. This species was based upon two specimens from Mombasa; the other specimens were found at Geriama near Fuladoya (Pocock 1896, p. 425), in the Taru desert at Machmma (Pocock, 1898, p. 499), at Pokomonie and Wanga, on the coast of the Indian ocean (Kraepelin, 1913, p. 172), in the hasin of the Tzavo-river (B Irula, 1915 p. 60) and in the Kenia district at Njoro and at northern bank of Guaso Nyiro below Chanler Falls (L ö n $n$ berg, 1912, p. 2); according to Kraepelin (l. cit.) a specimen of this species was obtained at Kilimanjaro in German East Africa. This species differs markedly from $P$. liosoma in the uniform yellow colouring of the tail. Two specimens (o jur. and $\sigma^{*}$ semiad.) of the collection of the Expedition taken on the shore of Tzavo-river $12-15$ VIII.

\section{Odonturus dentatus Krsch.}

1879. Odonturus dentatus, Karsch, F., Sitzber. Gesellsch. naturf. Fr. Berlin, p. 119 (loc. typ. «Mombasa»).

S' y $n$ on y ma: Rhoptruris dentatus, Simon, E., Ann. soc. entom. France, p. 130, 1890; Karsch, F., Berl. entom. Zeitsch., v. XXX. p. 77, 1886; Pseudobuthus dentatus, Kraepelin, K., Nitth. naturh. Mus. Hammburg, v. XIII, p. 121, 1896; P 0c ock, R., Proc. Zool. Soc. London, p. 499, 1898; Odonturus centatus, Kr a e p el i n, K., Mitth. naturh. Mus. Hamburg, v. XXX, p. 172, 1913; B irula, A., Ann. Mus. Zool. Petrograd, v. XIX, p. 118, 1914 
Colour of body brownish yellow, abdomen with three longitudinal dark bands above, one in the middle and one on each side; palpi, legs and tail pale yellow, faintly spotted with blackish (the last below); carapace of the cephalothorax entirely granular, not crested or posteriorly with the weakly developed median crests; anterolateral angles of the carapace with three lateral eyes on each side; tergites with a median keel; tail gradually expanding to the 5-th joint, strongly keeled, with intercarinal spaces entirely granular; first joint of the tail with 10 keels, the $2-4$ joints with 8 keels; 5 -th joint with weakly dereloped inferior median keel; a denticle beneath the aculeus on the vesicle; movable finger of mandibles with two teeth on the inferior border; hand of the palpi without crests, smooth, a little wider than the brachium; its digits armed with 8 rows of granules; pectinal teeth $16-24$ ( 9 ) or $24-25\left(\sigma^{*}\right)$; basal tooth in adult female wide; total length circa $70 \mathrm{~mm}$.

Distribution. This species was originally described from Mombasa; it vccurs also in several other localities near the sea-coast and also farther inland, at Kibwesi, Pokomonie, Taita (Kraepelin, 1896, p. 121), Samburu, Machuma, Mbuyuni, Voi (Pocock, 1898, p. 499), near the mount PundaMilia between Fort Hall and Nairobi (Birula, 1914, p. 118) and in the basin of Tana-river (Kraepelin, Birula, 1. cit.); southwards $O$. dentatus extends from British East Africa into German Colony (Kraepelin l. cit., Usambara, Tanga, Massai, Morogoro).

\section{Babycurus centrurimorphus Krsch.}

1886. Babycurus centrurimorphus, Karsch, F., Berliner entom. Zeitsch., v. XXX, p. 78, pl. III, fig. 2 (loc. typ. «NW.Madagaskar»).

Synonyma: Babycurus pictus, Pocock. R., Ann. and Mag. nat. Hist., ser. 6, v. XVII, p. 426, pl. XVIH, fig. 1; id., loc. cit., ser. 7, v. II, p. 430, 1898; Babycurus centrurimorphus, Kra e pelin, K., Das Tierreich, Scorpiones, p. 63, 1899; id. Mitt. naturh. Mus. Hamburg, v. XXX, p. 182, 1913; Birula, A., Ann. Mus. Zool. Petrograd, r. XIX, p. 119, 1914.

Colour of body yellow; trunk above on the carapace and tergites (except on the seventh) with three longitudinal black bands, one in the middle and one on each side; tail pale 
yellow, below spotted with fuscous or blackish patches; palpi yellow, digits alone black in their basal half; legs yellow, faintly spotted with black; carapace not crested, finely granular throughout; ocular tubercle low, with smooth superciliar crests; tergites finely granular with a median distinctly granular keel; sternites smooth, punctured, the last with neither granules nor crests; tail almost parallel-sided, smooth with convex spaces; keels all very weak, smooth, or hardly grantulated; the lower surface of the third, fourth and fifth joints without visible keels; vesicle as wide as the 5 -th caudal joint; palpi almost smooth; the crests very wealily granular; hand smooth, a little wider than the brachium, not keeled; digits short, with 7 ( 1 bas $+5+1$ apic.) rows of granules, which are flanked with 7 larger external granules and 7 internal ones; pectinal teeth $18-19$ (q) or 19 (ఠ); total length $43--5 \mathrm{l} \mathrm{mm}$.

D istribution. This species has at first been described from Madagaskar, but afterwards was found in several localities ol East Africa and also in West Africa (Angola). In the British East Africa B. centrurimorphus occurs on the sea-coast (Mombasa), in the basin of Tana-river (Birula 1914, p. 119), near Eldama-river and in the district of the mount Kenia (Athi-plains, Pocock 1896, p. 426); the same species was procured also in many a locality of German East Africa (Victoria-Nyanza on the island Ukereve, Kavende, shores of the lake Tanganyika, Ukamba; Krae pelin 1913, p. 182 and P o c ock 1898, p. 430).

\section{Babycurus wituensis Krpl.}

1913. Babycurus wituensis, K r a e peli n, K., Mitt. naturh. Mus. Hamburg, v. XXX, pp. 180-181, 1913 (loc. typ. «o von Wanga, o von Pokomonie in Britisch Ost-Afrika».

Colour of body yellow; trunk with three very weak dark bands above; tail and legs pale reddish yellow; digits of palpi fuscous; carapace of cephalothorax sparsely and finely granular; tergites only in the posterior half of each sparsely granular; sternites not polished, the last with two or four smooth keels; tail gradually expanded to the 5 -th joint $\left(\sigma^{*}\right)$, or nearly parallel-sided ( + ). Keels of all the joints granular with the exception of the smooth inferior keels of the first joint; 5 -th joint parallel-sided $(q)$, or posteriorly attenuated $\left(\sigma^{\star}\right)$ 
resicle elongated and distinctly more slender than j-th candal joint, weakly granular below; spine beneath the aculeus withont dorsal granules; keels of brachium almost smooth; hand in the male wider than the brachium; digits of the hand in the male with distinct lobes; pectinal teeth $20-21$; total length about $45 \mathrm{~mm}$.

D istribution. Only two specimens are hitherto known: a male specimen was obtained at Wanga, another specimen, a female, recorded from Pokomonie.

\section{Babycurus jacksoni (Poc.).}

1590. Rhoptrurus jacksoni Pocock, R., Proc. Zool. Soc. London, p. 13s, pl. XII, fig. 1. (loc. typ. "at Taveita, Kilimanjaros).

Synonyma: Babycurus jacksoni, Krile pelin, K., Das. Tierreich, Lief. 8, Scorpiones, p. 62, 1899; id.. Mitt. natmrh. Nus. Hamburg, v. XXX, pp. 181-182, 1913.

Colour of body ochraceons; carapace of the cephalothorax and abdominal tergites above fusco-ochraceous; lateral margrins of the carapace and tergites dull black; digits of palpi infuscate, yellow only at the tips; legs, palpi, tail and lower surface of the trunk pale ochraceous; carapace of the cephalothorax almost wholly covered with coarse granulation; ocular tubercle with granular superciliar crests; tergites gramular throughout. with a median granular keel; the anterior three sternites smooth, the fourth slightly granular only at the sides, the fifth somewhat coarsely granular and bicarinate. in its posteriol half; tail parallel-siderl; all the caudal keels are strong and evenly granular; the first joint of the tail with ten keels, the second, third and fourth with eight keels; all the intercarinal spaces thickly and coarsely granulated; intercarinal spaces of the $3-r d-5$-th joints convex; resicle smooth above, coarsely and subserially granular below; palpi hairy; brachium granular and carinate; hand smooth, rounded, not carinate, nearly equalling the brachium in width; digits not lobate; pectinal teeth 20-24; total length about $76 \mathrm{~mm}$.

Distribution. This species originally recorded from Taveita. From British East Alrica B. jacksoni extends along the sea-coast southwards into Cieman Last Africa 
(Usambara, Mkata, Morogolo, the Gologolo-monntains. Daressalam. Lindi: Kirae pelin 1913, p. 182).

\section{Uroplectes fischeri (Krsch).}

1879. Lepreus fischeri Karsch, F., Mitth. Münch. Entom. Verein, v. III, p. 124 (loc. cit. „e Barawa Somali“).

Synonyma: Uroplectes fischeri var. nigrimanus, Pocock, R., Proc. Zool. Soc. London, p. 130, pl. XIV, fig. 2, 1890; Croplectes fischeri, Pocock, R., Anm. and Mag. nat. Hist., ser. 5. r. XVII, p. 387, 1896; id., Proc. Zool. Soc. London. p. 55, 1900; Krae pelin, K., Zool. Jahrb., Syst., r. XVII, p. 566, 1903; L ön n b e r g, F., Ark. för Zool., Bd. 7, 스 24, p. 3, 1912; Krate elin, K., Mitt. naturh. Mus. Hamburg, r. XXX, p. 178, 1913; Bilula, A., Amn. Mus. Zool. Petrograd, r. XIX. p. 116, 1914; id., Rerme russe d'Entomol., r. XV, p. 52, 1915 .

Colour of body yellow; trunk above of a greenish black or dull oliraceous colour; carapace of the cephalothoria ornamented with yellow patches mostly on the sides; all the tergites with three very narrow yellow longitudinal bands: seventh tergite paler than the preceding; trunk greenish, or olivaceo-testaceous below; palpi pale yellow except the hands. which are dark, almost greenish black, or piceous; the apical hall of digits hardly paler; the first three caudal joints are pale yellow, with black spots and short bands below, the fourth slightly reddish, the fifth and the resicle wholly reddish black; carapace without crests. almost wholly smooth and polished or finely and sparsely granular at the sides; tergites alsi) almost wholly smooth, polished, with a smooth median keel: the seventh tergite somewhat closely but finely granular; sternites wholly smooth, sparsely punctured; the fifth slightly pitted but not punctured; tail nearly parallelsided wholly withont keels below and with almost obsoletely granukar superior keels only on the last joint; first and second caudal joints furnished posteriorly on each side of the superior sulcus with one, or two large tooth-shaped granules; on the other joints each superior keel is represented by a row of pits; the upper surface of all the joints smooth and polished in the sulcus; the fifth joint posteriorly hollower; lower surface of all the joints thickly and coarsely pitted and 
between the pits finely punctured; in the male specimens the same surface is mostly only very minutely and sparsely pitted; vesicle pitted and punctured below, with a large triangular tooth beneath the acnleus; palpi with rounded, not carinate almost smooth joints; the brachium and hand sparsely punctured, weakly granular in front; digits long and curved; legs almost entirely smooth, not carinate; pectinal teeth $17-20$ (q) or 20 ( $\sigma^{\text {) }}$; basal pectinal tooth in female expanded; total length circa $40-49 \mathrm{~mm}$.

Distribution. Uroplectes fischeri originally was recorded from Barawa in Somaliland; but this species has a wide range in East Africa; it is obtained in several localities of British Somaliland (Turfa, Lummo, Berbera, Hargaisa-Pocock 1900, p. 55) and of East Shoa (Genir, Segirso, the Siban-mountains-Kraepelin 1903, p. 566 and Birnla 1914, p. 117); in British East Africa occurs in abmulance a melanistic varicty of the same species, $U$. fischeri var. nigrimanus, which has been recorded at first from Mombasa; it was found afterwards in the district of Mount Kenia on the northern side of Guaso Nyiro river (Lönnberg 1912, p. 3), in the basin of Tana river (Thibe river-B i r $n 1$ a 1914, p. 116), at Taveita near Kilimanjaro (Birula, 1915 p. 52) and also at Kibwesi and Taita (Kraepelin 1913, p. 178); according to Kraepelin (loc. cit, p. 178) the typical form $U$. fischeri fisheri was collected in several Jocalities of German East Africa (Massai, Moroyoro, Mikindani, Mulenda), but in other localities of the sane country a variety, $U$. fischeri nigrocarinatus Krpl., occurs, which differs from the typical form in having a black median keel on the trunk. A single specimen (o semiad.) taken by the members of the Expedition at 'laveta 1 VIII.

\section{Uroplectes xanthogrammus Poc.}

1897. Uroplectes xanthogrammus, l'ocock, R., Ann. and Mag. nat. Hist., ser. 6, v. XIX, p. 118 (loc. typ. „east shore of the lake Nyasa").

Synollyma: Uroplectes xanthogrammus, Pocock, R., Ann. and Mag. nat. Hist., ser. 7, v. II, p. 431, 1898; Uroplectes fischeri xanthogrammus, $\mathrm{Kr}$ a e pelin, K., Nitt. naturh. Mus. Hamburg, v. XXX, p. 179, 1913; Uroplectes intermerius T u $11 \mathrm{~g}$ r e n, A., Arachnoidea in: Wissensch. Frgeb. der Schwed. 
Exp. nach dem Kilimanjaro, dem Meru und der umgebenden Massaisteppe Dentsch Ost-Afrikas 1905-1906 unter der Leitung von Prof. Yngve Sjöstedt, v. 20, p. 2, pl. I, fig. 1a-b, 1907; Croplectes xanthogrammus intermectius, B irnla, A., Revue russe d'Entom., r. XV, p. 52, 1915.

Colour of body yellow or brownish yellow; trunk above resy dark: carapace of the cephalothorax blackish with a few yellow spots at the sides; tergites brownish black, yellow spotted; the first six tergites ormamented with small rounded pale yellow spots, the three of which together compose on each side of the median keel an insect-shaped figure; the remaining spots compose at each side of the tergite two angleshaped rows; lower surface of the trunk clear greenish yellow; tail brownish yellow, black spotted and banded below; 5 -th joint and vesicle greenish, or reddish black; hand of palpi with short blackish bands; diyits at the base fuscous; carapace and all the tergites thickly and coarsely granular; pectinal teeth 17 (o); basal tooth of the pectines in lemale specimens moderately expanded; total length about $41,5 \mathrm{~mm}$.

D) istribution. In British East Africa there occurs not a typical form of this species, which hatd at first been found in the northern part of German East Africa (Meru) and named by Dr. Tullgren Uroplectes intermedius; a female specimen of the same variety was found by Prof. Dogiel and Dr. So k o lo w near the lake Naivasha (Birula 19! 5, p. 53). The typical form of the species was recorded originally from the east shore of the lake Nyasa (P ocock 1898, p. 431).

\section{Lychas burdoi (Sim.).}

1882. Isometrus Burdoi, Sim o n, E., Bull. Soc. entom. Belgique, v. XXVI, p. LVIII (loc. typ. an unknown locality in the northern part of German East Africa).

S yn o n y m a: Isometrus Burdoi, Pocock, R., Jour. Linn. Soc., Zool., v. XXIII, p. 443, pl. XI, fig. 5, 1890; Archisometrus Burdoi, Poc ock, R., Ann. and Mag. nat. Hist., ser. 7, v. I, p. 309, 1898; id., loc. cit., v. II, p. 430, 1898; id., Proc. Zool. Soc. London, p. 500, 1898; Kra e pel in, K., Scorpiones in: "Das Tierreich“, p. 48, 1899; Lychas burdoi, H i r's t, S., Mem. and Proc. Manchester Lit. and Philos. Soc., r. LVI, pt. I, № 2, p. 4, 1911; L önn berg, E., Ark. f. Zool., v. VII, № 24, 1912; 
K r a e pelin, li., Mitt. naturh. Mus. Hamburg, r. XXX, p. 175 , 1913; Lychas burdoi rugulosus, B i rula, A., Revue russe d'Entom., r. XV, p. 57, 1915.

Colour of body clear testaceous or ochraceous yellow, rariegated with brownish black or fuscous patches, spots and lines; carapace of the cephalothorax with ncular tubercle and anteocular surface infuscate or blackish brown; the posterior portion of carapace dark spotted; upper surface of the abdomen with three longitudinal fuscous bands, one of which is median, the other two being situated laterally; sternal plates of the lower surface of the abdomen palely testaceous with blackish margins; the 5-th sternite spottel with black; upper surface of the tail mostly pale, sometimes with a median fuscous patch on each joint; the sides and inferior surface with fuscous, or black spots and lines; the 5 -th caudal joint, except the upper surface, uniformly fuscous; vesicle mostly fus. cous, with traces of pale lines; humerus of the palpi yellowish, with a median fuscous band above; brachim infuscate above and below; hand yellowish with fuscous digits; carapace. of the cephalothorax finely and closely granular throughout; ocular tubercle smooth, or only sparsely granular, with smooth superciliar crests; tergites granular throughout, with a median keel; sternites smooth, but not polished; the 5 -th sternite only at the sides sparsely granular, withont keels, or only with rery weak median keels; tail thicker at the base than at the apex; all the keels well developed and granular; all the intercarinal spaces finely and closely granular; the lirst caudal joint with ten keels, of which the inferior are weakly dereloped; the 2-nd-4-th joints with eight keels; superior and superolateral keels very strongly developed on each joint, with a large terminal tooth; the 5 -th caudal joint with all the keels well developed and gramular throughout; this joint above in the sulcus nearly smooth, at the sides and below coarsely granular; resicle very slender, smooth above, subserially granular below, with a strong tooth beneath the aculeus; brachium of palpi costate and very sparsely granular ahove, smooth behind and below; hand rounded and almost smooth, narrower than the brachium; legs granular and costate; pectinal teeth $13-15$ (q) or $16-17$ ( 3$)$; total length about $36 \mathrm{~mm}$.

D is tribution. In British East Africa occur's not quite a typical form, which has been described above; this variety 
Was found at, Taveita and at Voi near Kilimanjaro (P o cock 1890 , p. 443, Birnla 1915, p. 57); the same variety was probably obtained also by Lön $n$ ber $g(1912, p .3)$ in the district of the mount lienia on the northern side of Guaso Nyiro fiver below Chanler Falls. The typical form Lychas burdoi, which has originally been recorded from the northern part of German East Africa, differs from the variety rugulosus in some slight particulars: namely-the anterior lateral eye on each side of the carapace is not smaller than the posterior, and the median is slightly larger than the former; the keels on the 5 -th abdominal sternite and on the first caudal joint are altogether absent; the 5-th caudal joint above is smooth and at the sides and below only weakly granular; the second caudal joint is marked with ten keels, of which the lateral accessorial keels are almost fully developed, or representer only on the posterior half of the joint. The typical form of this species, L.burdoi burdoi, is widely distributed in the more southern parts of East Africa, in the German colonies from Kilimanjaro sonthwards to the lake Tanganyika, Nyasa and Zambesi river (Kr a e p e l in 1913, p. 175), in British Central Africa (Blantyre-Kraepelin l. cit.) and also in Rhodesia (Broken Hill-Kra e pe $\mathrm{i}$ n l.cit., Petauke-H i r's t 1911,p. 4). A single specimen of $L$. burdoi rugulosus (q semiad.) was obtained by the members of the Expedition at Naivasha-lake 11-13 VII.

\section{Lychas obsti Krpl.}

1913. Lychas obsti, Kr a e pelin, K., Mitt. naturh. Mus Hamburg, v. XXX, p. 175.

S'yllonyma: Lychas obsti, Birula, A., Ann. Mus. Zool. Petrograd, r. XIX, p. 120, 1914; id., Revue russe d'Entomol., r. XY. p. 56, 1915 .

Colour of body pale fulvous, variegated with deeply infuscate or black spots and bands and partly reticulated with fuscous lines; trunk above with five black longitudinal bands; the black median keel interrupted on each tergite with a yellow spot; sternites yellow, the 4-th with black lateral margines, the $\overline{0}$-th black spotted; tail spotted; the terminal part of each joint mostly infuscate; 5 -th caudal joint and vesicle infuscate throughout; humerus of the palpi spotted or reticulated; brachium and hand mostly deeply infuscate throughout, 
or partly reticulated; lligits pale; legs spotted; trunk with a median keel; the first three sternites finely granular at the sides, in the female a triangular roughened median spot with low transyersal ridges on the first and second sternites; 4-th and 5-th stemal plates coarsely granular mostly throughout; the o-th with four granular keels; tail in the male very elongated and slender, in both sexes with very strong and granular keels; the upper keels of the 2-nd and 3-td candal joints with a very enlarged terminal tooth; all the intercarinal spaces coarsely granular; vesicle almost cylindrical, narrow, with a tooth beneath the aculeus; brachium of the palpi with granular upper keels; hand narrow; pectinal tecth 15-18 (q), or $17-20()^{3}$; total length about $25-31 \mathrm{~mm}$.

Distribution. The typical specimen of this species has been recorded from Kilimatinde in German East Africa; in British East Africa the same species was found at first near the Mount Kenia (Kra e pelin 1913, p. 175), afterwards also in the basin of 'Tzavo river (at Magji and Madzura--B i ru I a 1914, p. 120, and at Voi and Bura-Birula 1915, p. 56); northwards Lychas obsti extends into South Somaliland (Rahanvin-Kraepelin l. cit.). A single specimen (q ad.) taken by the Expedition at Voi-Bura $24-25$ VIII.

\section{Fam. Scorpionidae.}

\section{Jomachus politus Poc.}

1896. Jomachus politus, Pocock, R., Ann. and Mag. nat. Hist., ser. 6, v. XVII, p. 317 (loc. typ. „Mombasa“).

Synonyma: Jomachus politus, Kraepelin, K., Mitt. naturh. Mus. Hamburg, v. XIII, p. 138, 1896; Pocock. R., Proc. Zool. Soc. London, p. 499, 1898; Kr a e pelin, K., Mitt. naturh. Nus. Hamburg, v. XXX, p. 187, 1913; B i r u la, A., Ann. Mus. Zool. Petrograd, v. XIX, p. 114, 1914; i d., Revue russe d'Entom., v. XV, p. 52, 1915.

Colom of body brown, or brownish yellow, abore blackish brown or greenish black; tail entirely dark; vesicle l'eddish; legs pale at the base; lower surface of the trunk fulvous, partly infuscate; carapace and tergites entirely smooth and polished; sternites of abdomen also very smooth; tail slender and very short; its 1 -4-th joints smooth and polished, not 
punctured, marked below with series of pores, withont distinctly developed keels; the inferior surface of the 5-th caudal joint scarsely granular, with weakly developed and hardly cranular keels; vesicle smooth and polished; palpi in male specimens very elongated; brachium smooth above, partly reticulated; its anterior crests granular and the basal anterior tooth prominent; liand flat, long and narrow, almost parallelsided; its upper surface reticulated, imer surface grammlar or denticulate; digits short, with a sharp basal tooth; tarsi with a median row of spicules and lateral rows of four bristles; pectinal teeth $7-8$ (क) or 8-9 (ङ); total length circa 50$65 \mathrm{~mm}$.

D istribution. This species has a very wide area of distribution, but only in East Africa; namely, it occurs in Uganda ${ }^{1}$ ), in the British and German east-african colonies, in Mozambique and Natal. Jomachus politus has been described from Mombasa, but afterwards it was obtained in several localities of the southern part of British East Africa: at Naziwa Milatu, Machuma, Mbuyuni, Samburu (Pocock 1898, p. 499), at Simba, Voi, Bura, Tembu and near the Tzavo river (Birula 1914 and 1915); according to $\mathrm{Kr}$ a e pelin (1913, p. 185) this species extends from British East Africa southwards along the sea-coast into German East Africa (from Tansa to Lindi and Mikindani); in the sonthern part of the same country it was obtained further inland at Livale, Barikiwa and Langenburg near the lake Nyasa. The Expedition obtained several specimens of various age and both sexes at Voi-Bura 24-25 VII (q jur.), Tembu 14 VIII (o juv.), and Tzaro 14-15 VIII ( $\delta$ semiad. and 4 o ad.).

\section{Opisthacanthus fischeri Krpl.}

1911. Opisthacanthus fischeri, Kraepelin, K., Nitt. naturh. Mus. Hamburg, v. XXVIII, pp. 74 and 79 (loc. typ. "Gebiet des Kilimandjaro-Ngurumin, Maragoja-Tembe»).

S yn on y ma:? Opisthacanthus asper, Si mo n, E., Ann. soc. entom. France, p. 130, 1890; Opisthacanthus fischeri, Birula, A., Revize russe d'Entomol., v. XV. p. 51, 1915.

Colour of body yellowish or reddish brown; tail brown;

1) E. Sim o n, Ann. Soc. entom. Belgique, LIII, p. 42-43, 1909: 
resicle and legs yellow; carapace of cephalothorax smooth, anteriorly on the frontal lobes punctured; all the tergites and sternites of abdomen mostly smooth, only punctured; 5 -th tergite in male specimens also weakly granular; joints of the tail almost smooth and punctured, near the dorsal keels hardly granular; the first four caudal joints with distinct inferior keels; its dorsal keels weakly granular; 4-th joint with denticulated dorsal keels; vesicle below with rows of denticles; the upper surface of the hand distinctly ( $\sigma^{*}$ or weakly (o) reticulated; femur of the 4 -th legs only punctured; tarsal joints of the 3 -d and 4 -th legs on each distal angle below with a bristle and on each lower edge with three, or two spines; pectinal teeth $8-9$; total length about $65-85 \mathrm{~mm}$.

T) istribution. This species was hitherto found only near the mount Kilimanjaro, at Ngurumin and at MaragojaTembe, in German East Africa (Kraepelin 1911, p. 79), but it will be found doubtless also in the souther'n parts of British East Africa; Opisthacanthus asper of Simon (1890, p. 130), several specimens of which "trouvés au pied du Kilimanjaro» during the rxpedition of pr. S. Téléki (1887-1888), is probably the same species.

\section{Pandinus cavimanus (Poc.)}

1888. Scorpio covimanus, Pocock, R., Ann. and Magaz nat. Hist., ser. 6, r. II, p. 247 (loc. typ. "Umyamuezi»).

Sy nonyma: Scorpio cavimanus, Pocock, R., Ioc. cit., sel. 6, v. XVII, p. 431, pl. XVIII, fig. 2, 2a, 1896;? Scorpio bellicosus, Pocock. R., Proc. Zool. Soc. London, p. 498, 1898; Pandinus cavimanus, Kra e pelin, K., Das Tierreich, Scorpiones, Lief. 8, p. 121, 1899; id., Mitt. naturh. Mus. Hamburg, v. XXX, p. 183, 1913.

Colonr of borly piceo-castaneous; hands castaneous, digits very dark green; legs and under surface of the trunk ochraceous; carapace of cephalothorax at the anterior margin with a median semicircular excision; the frontal lobes, the depressel area between the former, and the lateral and posterolateral regions of the carapace finely granular, the rest smooth; the central eyes nearer to the margin of the excision, than to the hind margin of the carapace; all the tergites of trunk granular, more coarsely so anteriorly than posteriorly; ster- 
nites entirely smooth; the last bearing four very weak keels; tail with well developed and gramular keels, except the inferior keels of two proximal joints; intercarinal spaces granular; vesicle with lows of sharp granules below, smooth above; hand in adult male specimens remarkably wide, convex from side to side proximally, but distinctly concave at the base of the immovable digits; its anterior margin rouncled and smootl, without denticles, or granules; the upper surface of the hand smooth and sparsely punctured, posteriorly granular, slightly roughened in the concarity; immorable digit. very wide at the base; femoria of legs outside finely granmlitr; pectinal teeth $13-14$ (q) ol $14-16\left(\sigma^{*}\right)$; total length circa. $100-110 \mathrm{~mm}$.

Distribution. This remarkable species of Pandimus has originally been described from Unyamuezi, a comntry in German East Africa; in the latter country this species is widely distributed, and was found in several localities: Mpapua, Ussagara, east shores of the lake Tanganyika, Ugogo, Tabora, west shores of the alke Victoria-Nyanza at Bukoba and near Kilimanjaro; from the latter locality the same spe cies extends into the southerm parts of British Eist Africa, but it is probably rare in this country; according, to I'ocock (1896, p. 431) P. cavimanus was hitherto obtained only at Kinani.

\section{Pandinus gregoryi (Poc.).}

1896. Scorpio Gregorii, Pocock, R., Ann. and Magaz. natur. Hist, ser. 6, v. XVII, p. 432, pl. XVIII, fig. 3, 3a (loc. typ. «Kimani»).

S y $n$ on y ll a: Scorpio gregorii, P oc ock, R., Proc. Zool. Soc. London, p. 498, 1898; Pandinus gregoryi, Krate e lin K., 7ool. Jahrb., Syst., v. XVIII, p. 568, 1903; id., Mitt. maturh. Mus. Hamburg, v. XXX, p. 183, 1913; Birnla, A., Ann. Mus. Zool. Petrograd, v. XIX, p. 115, 1914.

Colour of body a uniform olive-brown; legs dark reddish brown; hand of palpi paler reddish, digits deep blackish green; carapace of cephalothorax anteriorly with a semicircular excision, smooth towards the middle, sparsely pmuctired, distinctly granular at the sides; the principal eyes well behind the middle; tergites of the abdomen smooth, sparsely punctured; sternites smooth and polished, the last coarsely 
punctured on each side near the middle part, withont any traces of keels; tail narrowed posteriorly, above, in the sulcus, smooth, on the sides granular; its keels high and granular partly denticulate, except that the interior keels of first and second joints are smooth and weak; vesicle large, granular below; hand thick and large, moderately wide, ornamented externally abore and at the base of the digits with smootl, punctured, rounded, irregular-shaped low tubercles, which fuse into a reticulated pattern towards the imner edge; pectinal teeth 17--19; total length circa $117 \mathrm{~mm}$.

Distribution. The type-specimen of this species, a female, has been obtained at Kinani in British East Africa; the other specimens were found in several localities of the southern part of the same country: namely in basins of Athi river, near Tzavo river (P o cock 1898, p. 498), at Simba (B irula 1914, p. 115). The same species occurs doubtless also in East Abyssinia (Harar, Ginir-Krae pelin 1903, p. 569, Birula 1914, p. 115ّ).

\section{Pandinus pallidus (Krpl.).}

1894. Scorpio pallidus, Kraepelin, K., Mitt. naturh. Mus. Hamburg, r. XI, p. 60 (loc. typ. „vermuthlich Barawa in Somaliland").

Synonyma: Scorpio pallidus, Pocock, R., Ann. and - Mag. nat. Hist., ser. 6, v. XVII, p. 435, 1896; Pandinus pallidus Kraepelin, K., Das Tierreich, Scorpiones, p. 120, 1899; Pocock, R., Proc, Zool. Soc. London, p. 58, 1900; Kr a e peli in, K., Zool. Jahrb., Syst., v. XVIII, p. 571, 1904;? Pandinus pal. lidus, Lön n b e r g, E., Ark. f. Zool., v. VII, № 24, p. 3, 1912.

Colour of body yellowish, reddish, or dark brown; tergites of trunk of the same colour; tail and hands reddish brown; legs yellow, or brown; carapace of cephalothorax smooth above, granular laterally; median eyes behind the middle of the carapace; tergites almost smooth; abdominal sternites smooth, the latter without any trace of keels; tail short with strongly denticulated superior keels; sulcus of the 1-3-rd candal joints smooth, of the 4 -th-5-th weakly granular; vesicle granular below and on the sides; hand almost as wide, as the length of the movable digit; its inner and hinder edges rounded, smooth, or with a few tubercles; upper surface of the hand covered with mostly isolated, not punctured, poli- 
shed low tubercles; lower surface of the hand without rows of granules, entirely smooth; humerus smonth below; total number of spines on tarsal joints $6-9$ on the inner side and $t-6$ on the outer side; three spines being situated on each lateral lobe of tarsal joints; pectinal teeth 17-21; total length about $75 \mathrm{~mm}$.

Distribution. Pandinus pallidus has been originally recorded from Barawa in Somali maritima and was frequently obtained in several localities of Somaliland (NE. Africa), but during the Swedish expedition in 1911 to British East Africa a number of specimens of Pandinus were caught at Njoro in the Guaso Nyiro district "mostly on doume-palms under the dry adherent leafstalks", which were named $P$. pallidus by $K \mathrm{r}$ a e pe l in ( $\mathrm{L} \ddot{\mathrm{n}} \mathrm{n} \mathrm{n} \mathrm{b}$ er g; 1912, p. 3); according to L $\ddot{n} \mathrm{nberg}$ the general colour of the upper parts of these specimens was „a live dark green, or blackish green".

\section{Pandinus militaris Poc}

1900. Pandinus militaris, Pocock, R., Proc. Znol. Soc. London, p. 61 (loc. typ. „Aimola in the Boran country“).

Syno n y a: Scorpio bellicosus, Pocock, R., in Donaldson Smith's „Through Unknown African Countries“, p. 397, 1897.

Colour of body yellowish brown; legs paler yellow, hand reddish brown with black digits; carapace entirely smooth above, granular at the sides; median eyes near the middle of carapace; tergites of trunk finely granular laterally; the last abdominal sternite scarsely visibly crested; tail with superior and supero-lateral keels of all the joints granular, or weakly denticulated; its inferior keels on joints $1-3$ quite smooth, those of the 4 -th at most slightly rugose; sulcus of the 1-2-nd caudal joints weakly granular; humerus of palpi smooth beIow; brachium almost entirely smooth; its anterior side weakly granular above, more coarsely below; hand wide; its inner edge smooth, upper surface smooth, finely punctured and finely reticulated, with a few low tubercles just above the keel of the underhand and at the base of the immovable digit; lower surface of the hand finely punctured, granular distally, scarsely crested; total number of spines on tarsal joints 5 behind and. 3 in front; 2 spines only being situated on each lobe; pectinal teeth 12-15; total length circa $112 \mathrm{~mm}$. 
Distribution. This species has been obtained at first in the southern parts of Somaliland, Boran Country; afterwards the same species ras found in British East Africa at Ndi on the Weiss Road inland from Mombasa.

$P$. milituris and $P$. gregoryi are undoubtedly closely allied to $P$. mallidus and perhaps may prove to be only subspecies ol the last.

\section{An account upon the zoogeographical value of the scorpiofauna of} British East Africa.

At the present time we have more or less intimate knowledge of the scorpiofauna only on the sonthern parts of British East Africa; almost nothing is known of the scorpions, of the northern parts of the same comntry. In the limits of this British colony were found about 17 species of scorpions, six species of which are referable to the fam. Scorpionidae and the rest to the fam. Buthidae. The following table will show the differential features of the scorpiofamna of British East Africa and of the neighbouring countries:

\begin{tabular}{|c|c|c|c|c|c|c|c|c|c|}
\hline Index of species: & 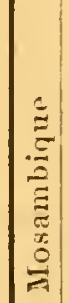 & 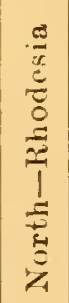 & 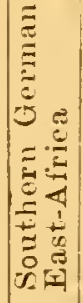 & 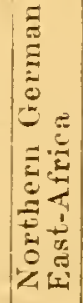 & 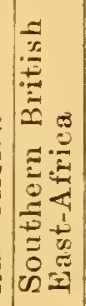 & 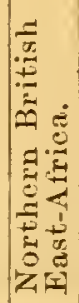 & 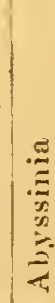 & & 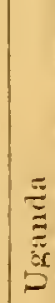 \\
\hline 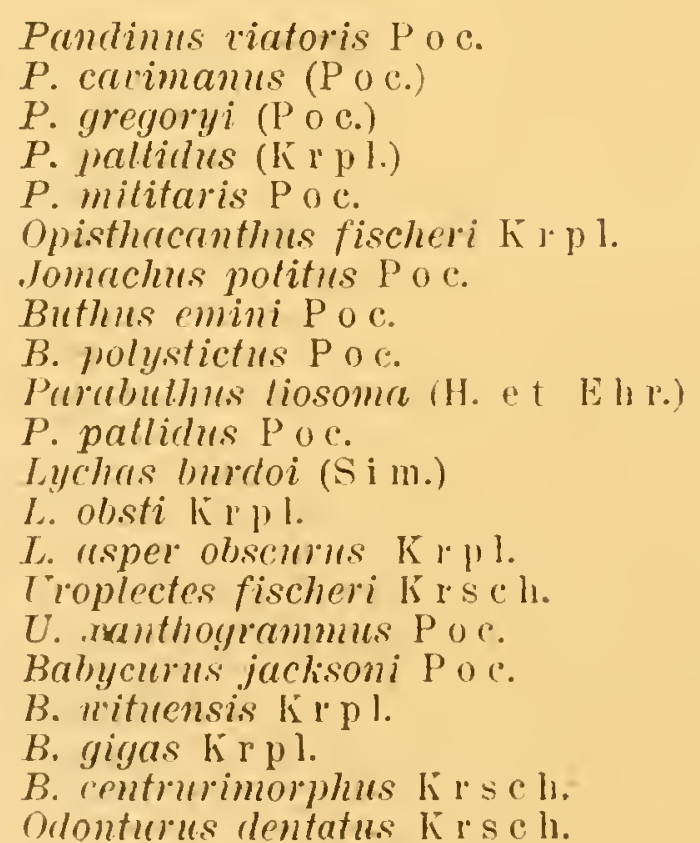 & + & $\begin{array}{l}t \\
+\end{array}$ & $\begin{array}{c}t \\
t \\
t \\
t \\
-t \\
t \\
t \\
t \\
t\end{array}$ & $\begin{array}{c}\frac{1}{1} \\
+ \\
+ \\
+ \\
+ \\
+ \\
? \\
+ \\
+ \\
+ \\
+ \\
+ \\
+ \\
+ \\
+\end{array}$ & $\begin{array}{c}? \\
+ \\
+ \\
+ \\
+ \\
? \\
+ \\
+ \\
\\
+ \\
+ \\
-1 \\
-1 \\
? \\
+ \\
+ \\
+ \\
+ \\
+ \\
+ \\
+ \\
+\end{array}$ & $\begin{array}{c}+ \\
+ \\
? \\
+ \\
+ \\
+ \\
+\end{array}$ & + & $\frac{\frac{1}{1}}{\frac{1}{1}}$ & + \\
\hline
\end{tabular}


The scorpiofama of British East Africa is closely allied to that of German East Africa and constitutes together with the falnna of the northern parts of the latter a transition to the fama of NE Africa, of Somaliland and of Abyssinia. The south-african genera and species are almost wholly absents in the scorpiofamna of this country; for instance, the genera Opistophthalmus and Hadogenes are not represented in the tauna of East Africa; Opisthacanthus is represented perhaps only by one species, O. fischeri, inhabiting the northern parts of German East Africa. Babycurus centrurimorplus and Lychas asper are species of a wide distribution and occur also in West Africa; several species are essentially northeast african, somalian, in their affinities: namely--Buthus polystictus, Parabuthus liosoma, Pandinus pallidus, and, perhaps also $P$. gregoryi. Uroplectes fischeri, Jomachus politus, Buthus emini, Lychas burdoi have a very wide area of distribution in East Alrica; several species are hitherto found only in British East Africa and partly in the neighbouring parts of the German colony, namely Porabuthus pallidus, Lychas obsti, Odonturus dentatus and Babycurus wituensis. 



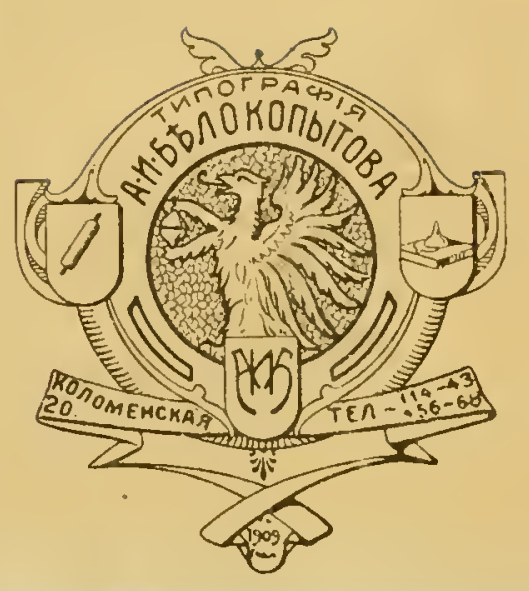

\section{Цちна 10 руб. Price $1 \mathrm{~L}$.}

Скпадъ изданія у проф. В. А. Догепя. Петроградъ, Зоопогическій Кабинеть Университета.

To be obtained from Prof. V. A. Dogiel. Petrograd, Zoological Laboratory of the University. 




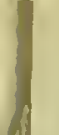



